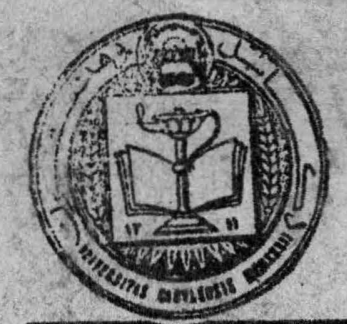

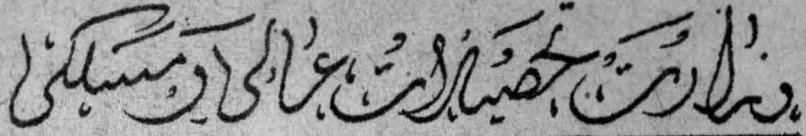
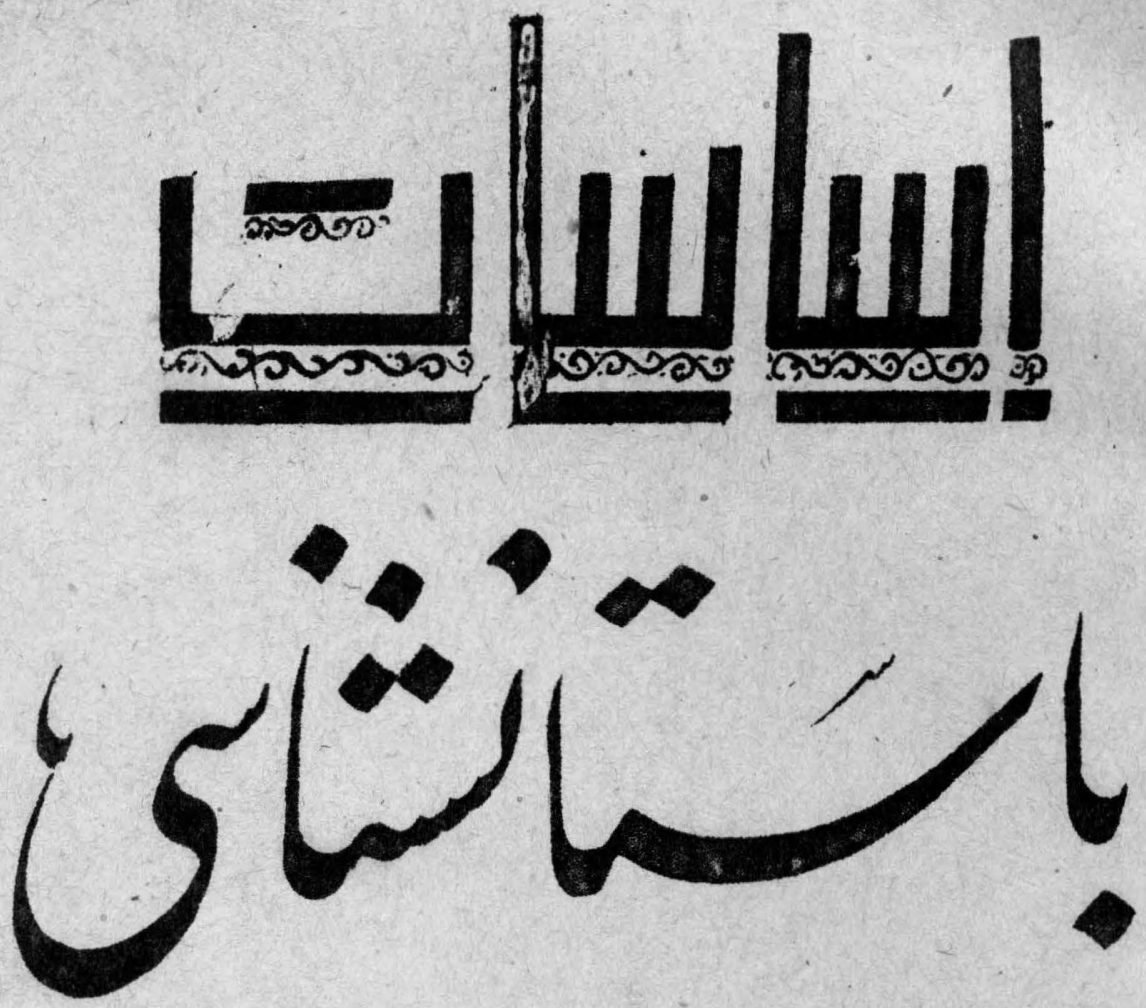

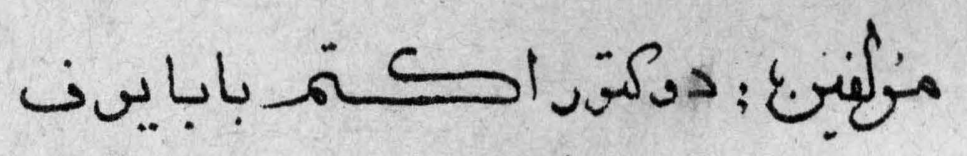

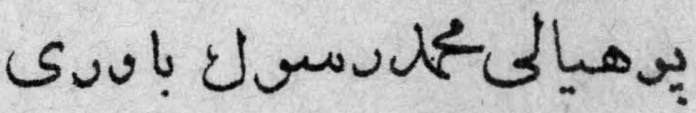

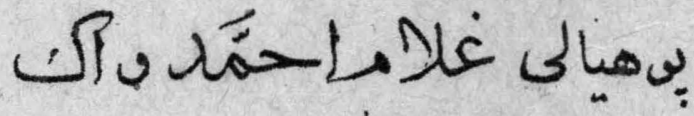

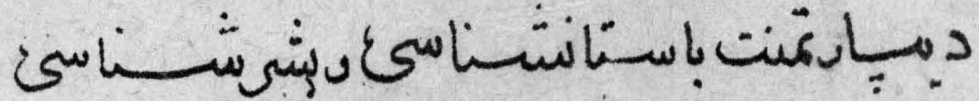

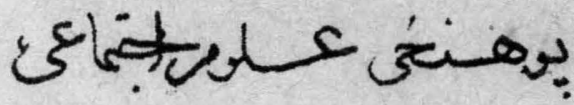

b.

$$
\text { Cli_mileil_ J }
$$




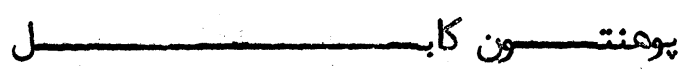

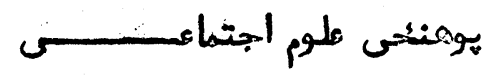
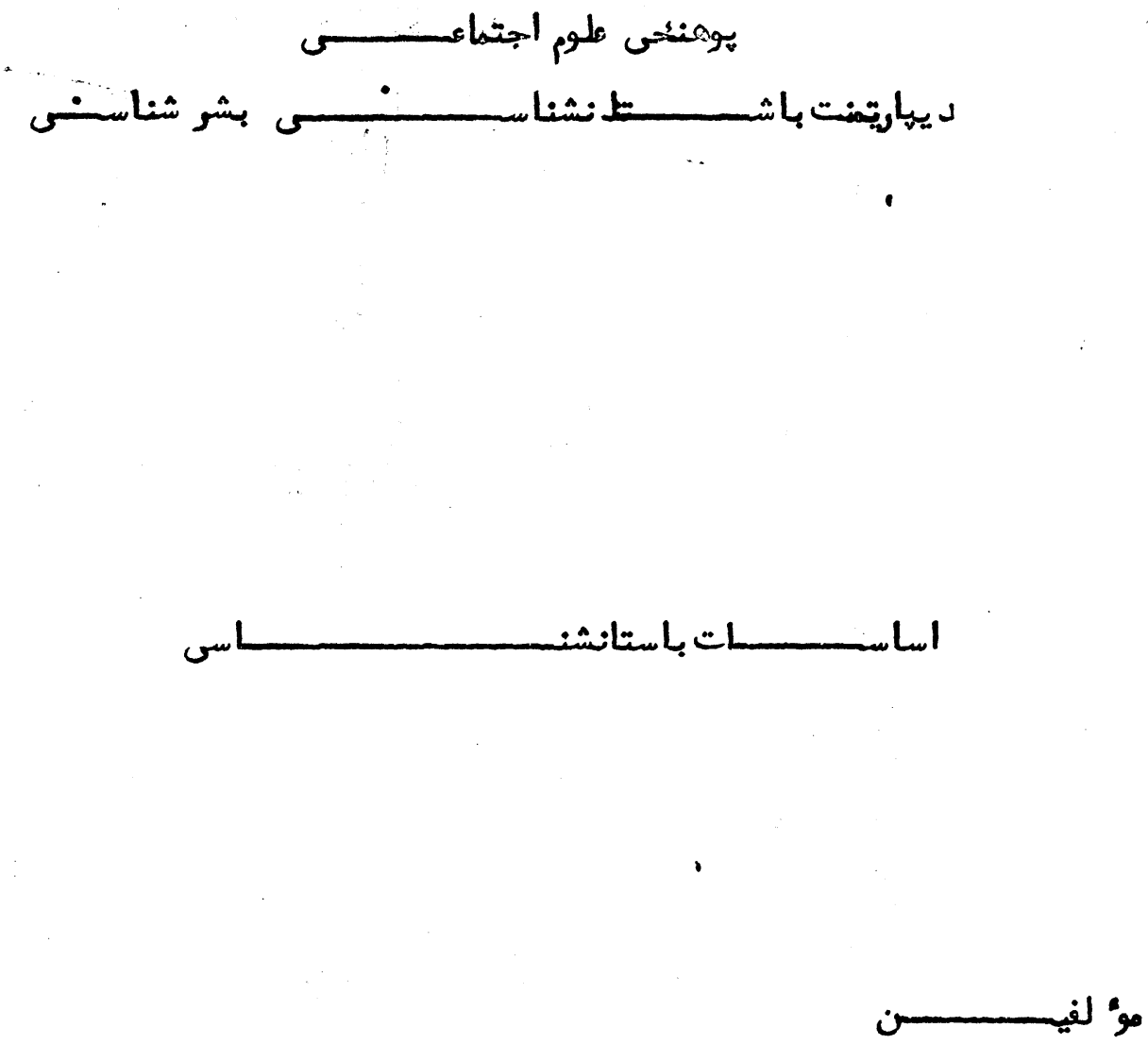

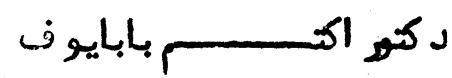

هوهيالى محمد رسول باهي

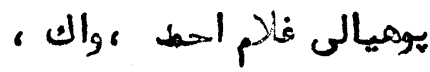

كابلاففانستان

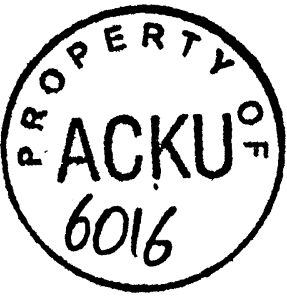




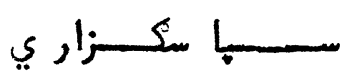

لدر تهييه وترتيباين كتاب محترم هوماند سيد سلتان شاه ملام ومتترم بومنوال دركتور الف شاه يحدران استادان ديارتمنت باستانشناسى و بشرشناس بوهنكى طوم اجتمانسي

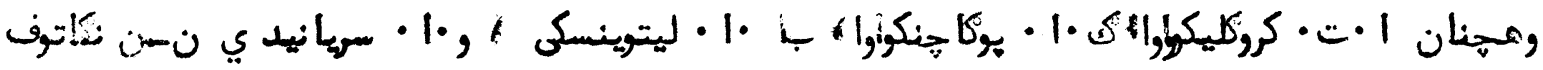

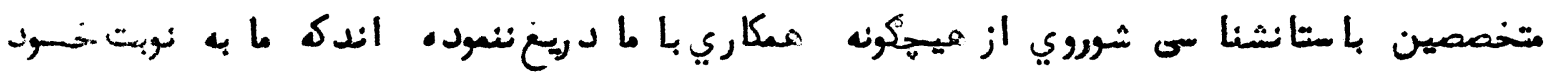

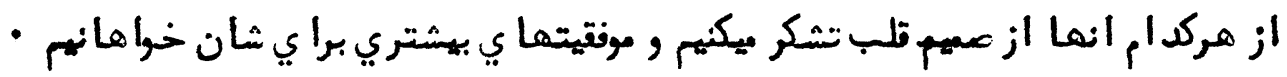

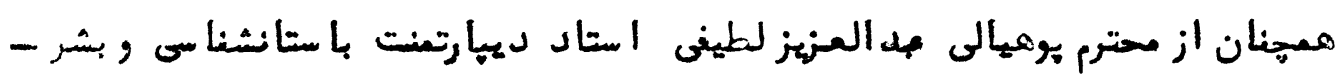

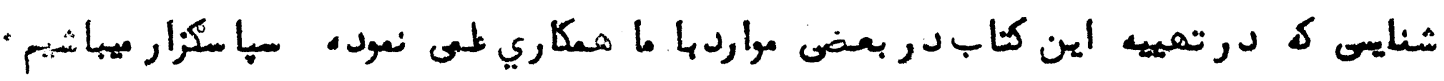

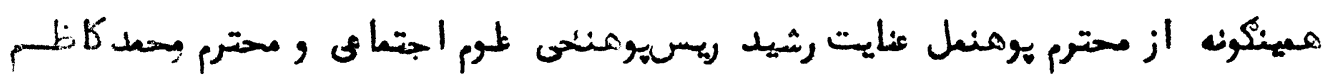

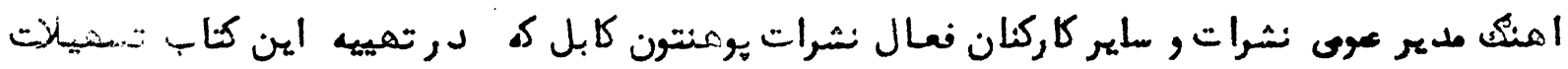
لازم را فرامم نموده و در زمهن تلبعان ممكاريكرد ماند عميمانه تشكر مى نمايم •

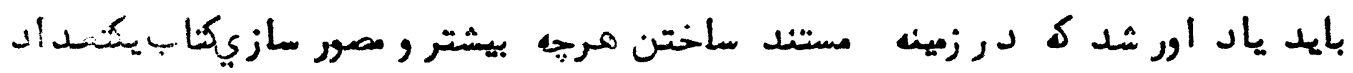
كسها وتماويري را در اخير كنابكنجانيده شده است به اجازه استادان كرانقد راتحاد ثـــور:ي كه در بالا ازانها نام برده ايم ازكنابماي اوشان كرفته شده استدر اخيدر بايد بكويم كه بمكار ي محترم مير احمل جوينده رئيسوسسه باستانشناسى ه عبد الظامر يوسفزي وديكر اغضاي لـدسى

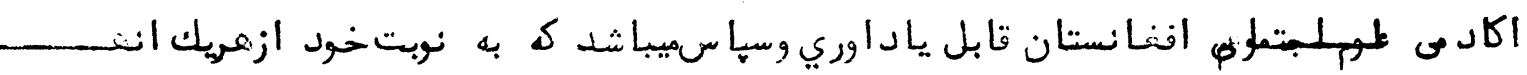
ازمميم قلب تشكر مينطيسم

$$
\text { دوكنــــو راكتــم بيابايوف }
$$

هوثيالي محمديوسف باروي

$$
\text { بونيالى غلام محمد والك }
$$


• الف

فهرست مند رجات

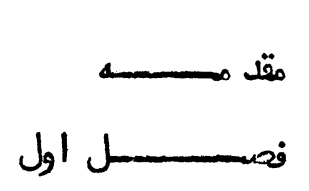

$-1$

$-r$

1 ب باستانشناسى جيست

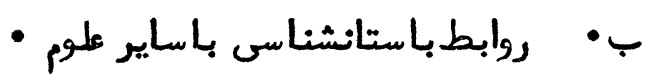

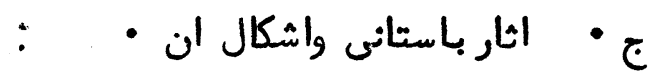

فمل دوم :

$-r$

• • امول حفريات

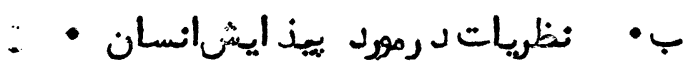

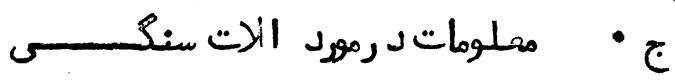

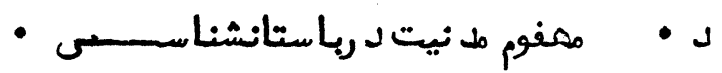

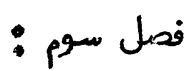

$-\alpha$

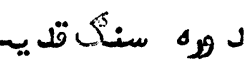

فمل تهـ

$-10$

لهوه سنك ميانه

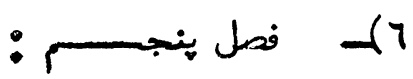

• 1

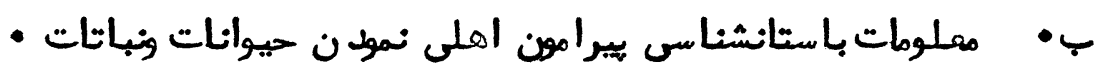




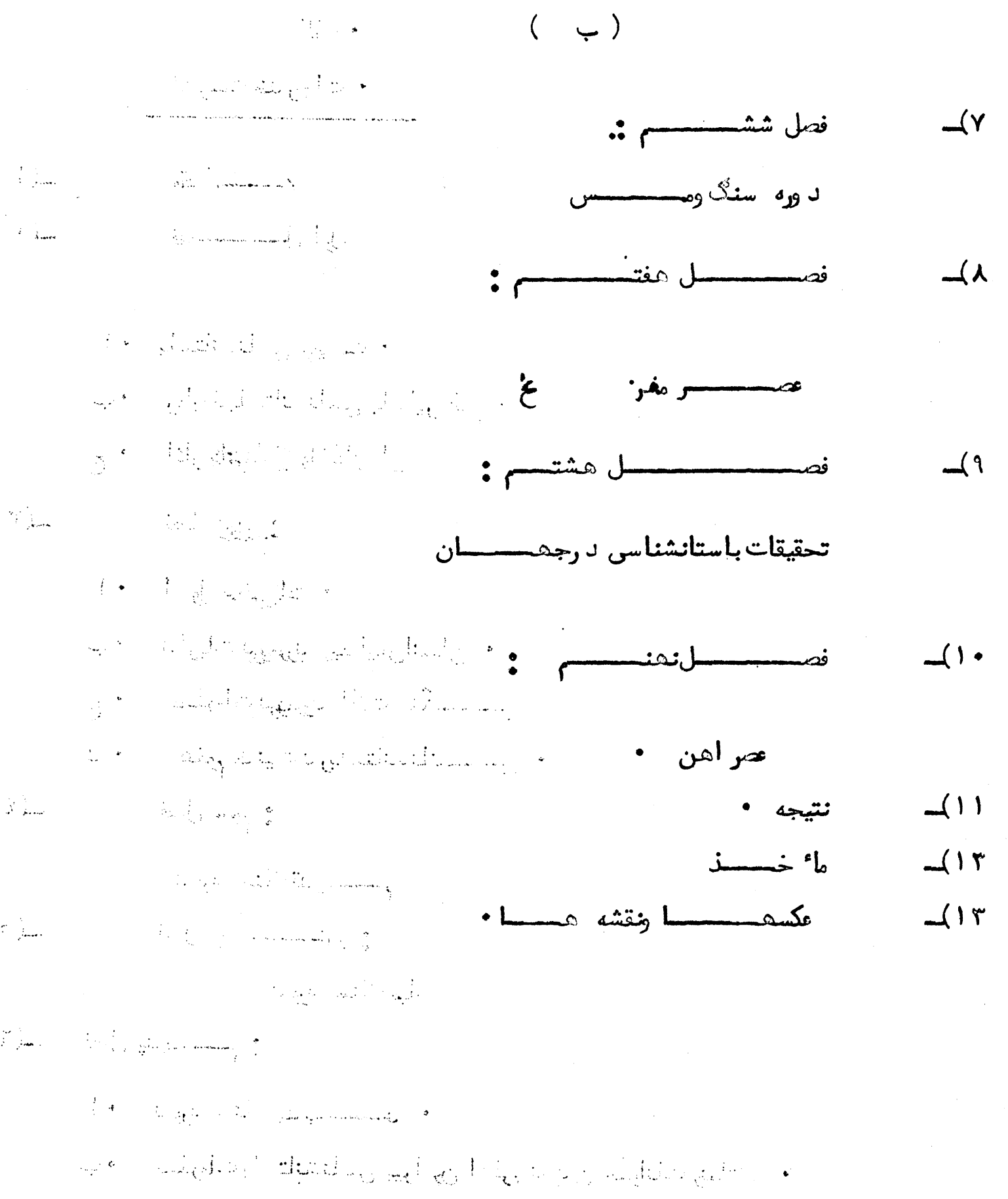




$$
\text { به بيشوازششين سالكُبرافتخاز انقلاب شكومند ثرا }
$$

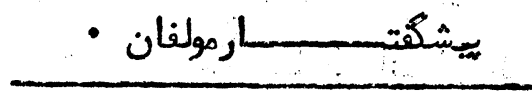

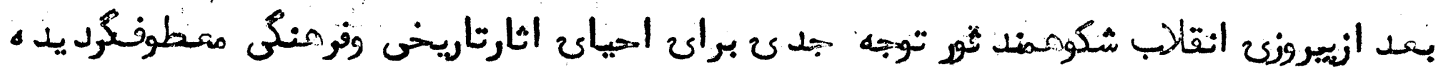

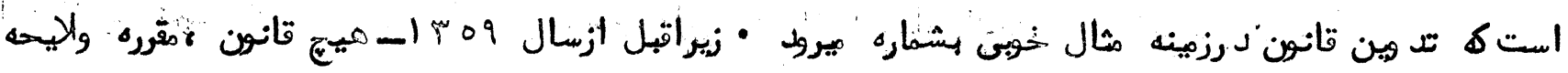

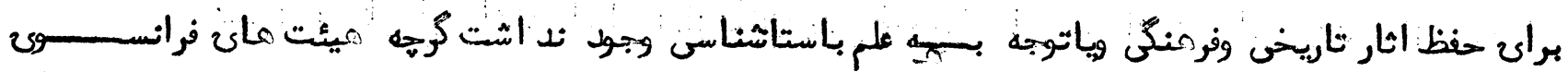

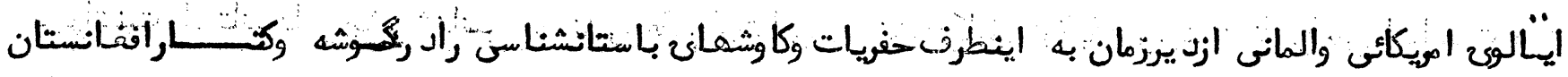

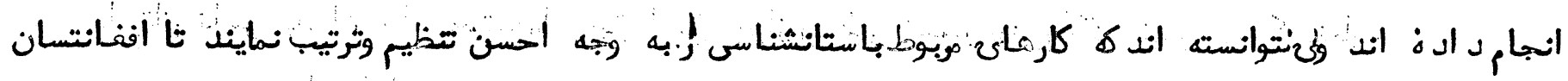

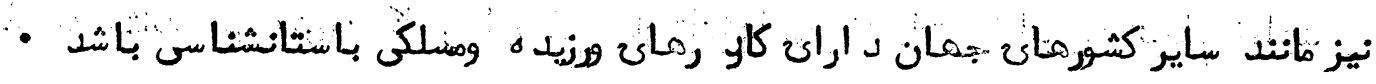

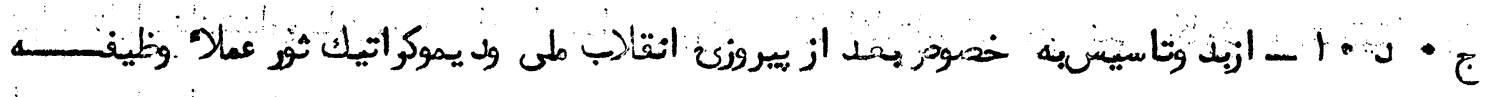

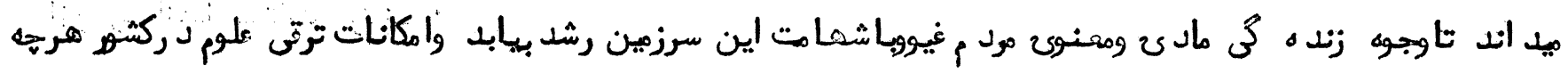

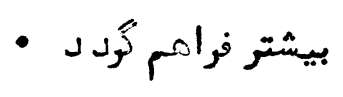

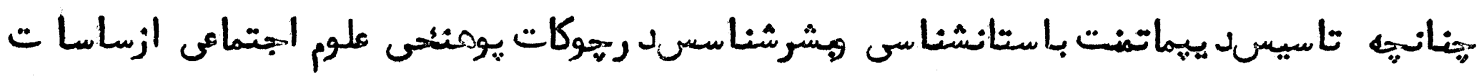

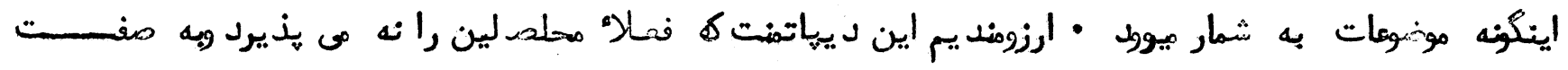

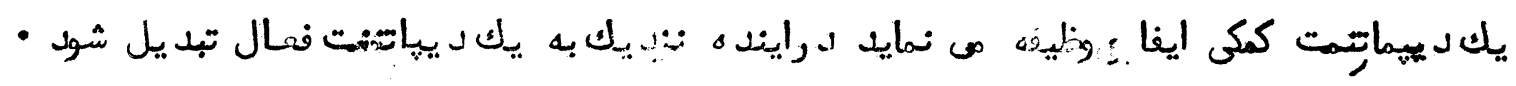

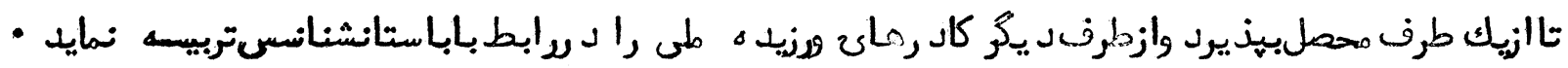

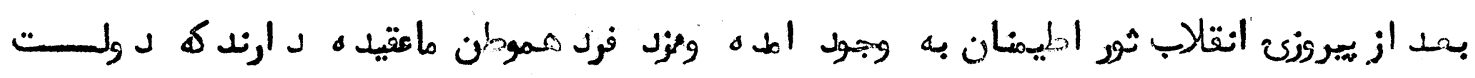

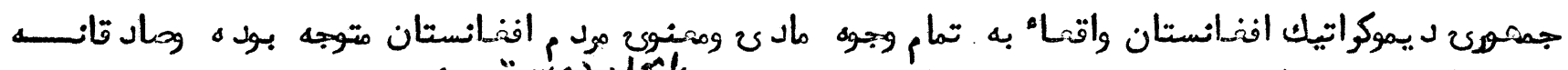

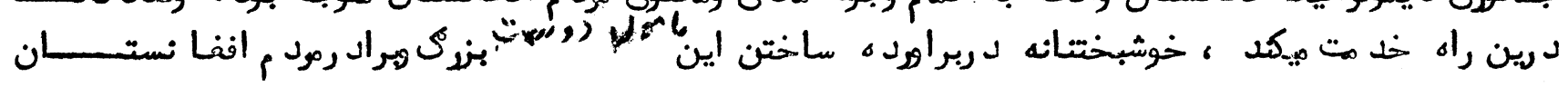

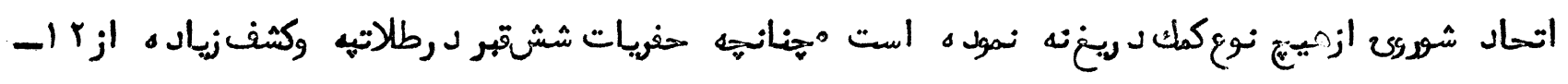

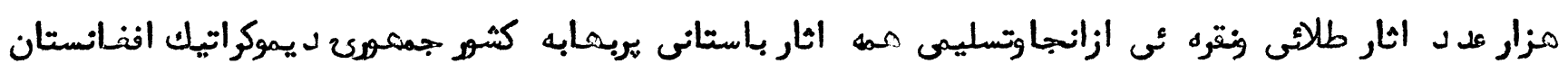

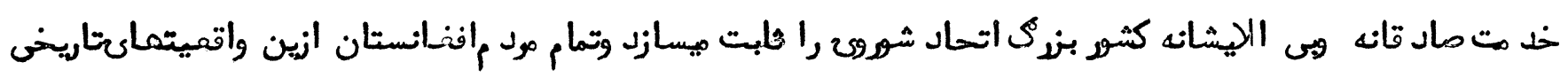


$-r-$

- به خوبى مطلحمستتد

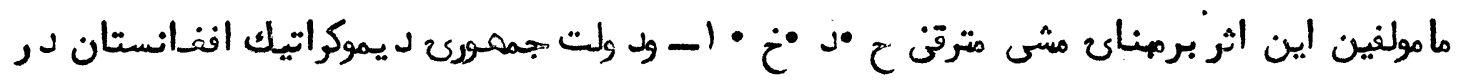

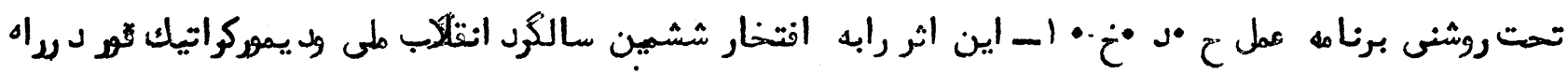

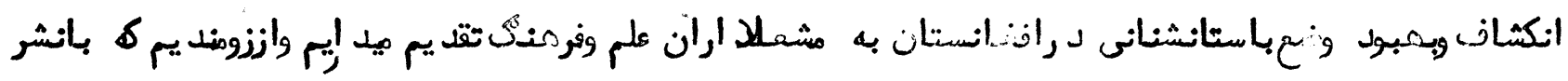

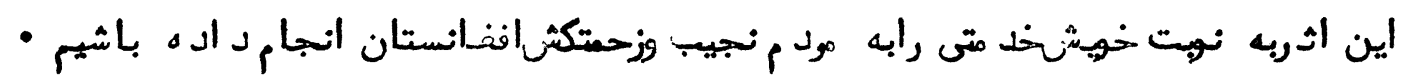

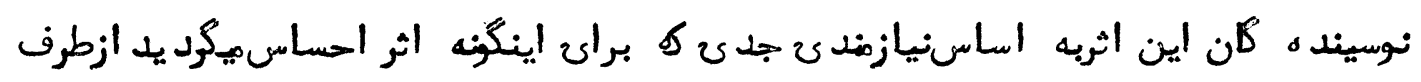

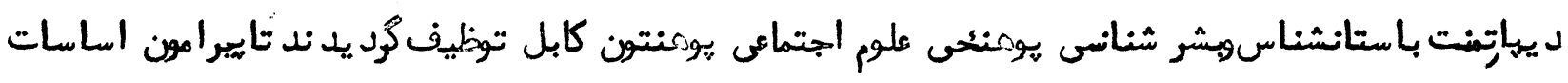

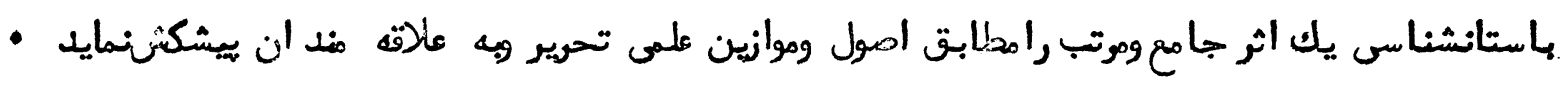

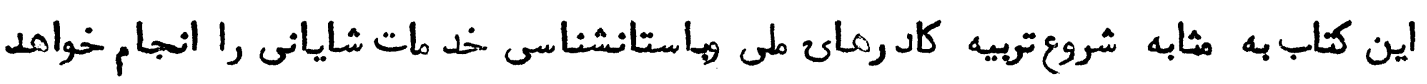

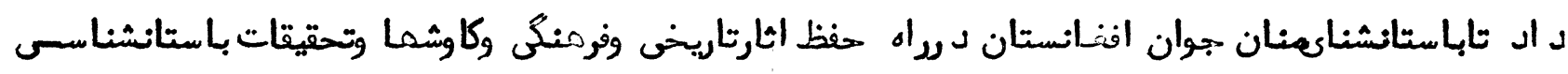

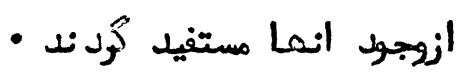


فمل اول

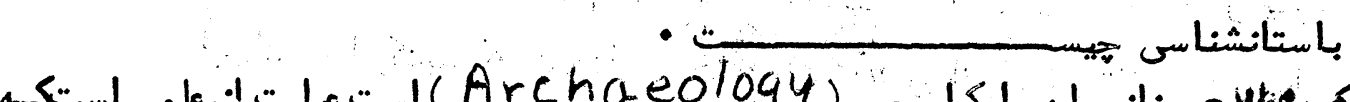

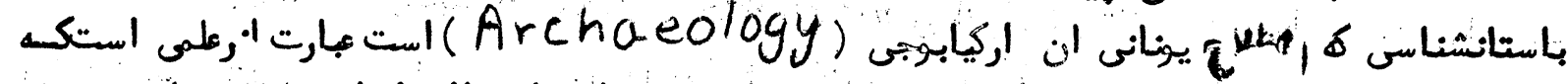

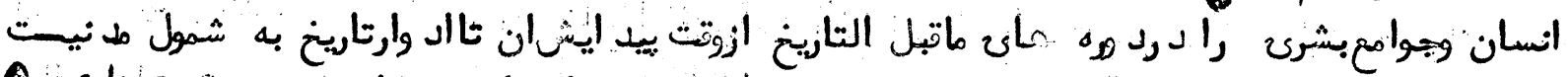

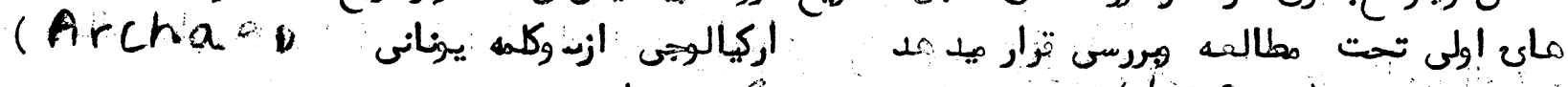

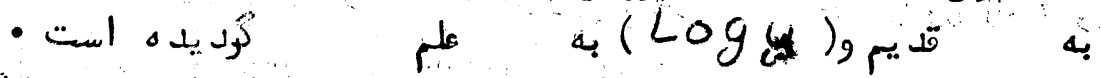

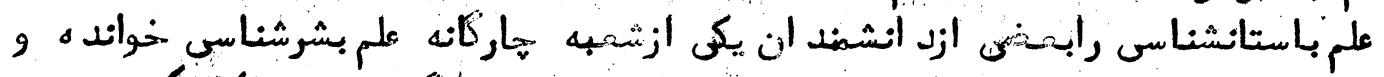

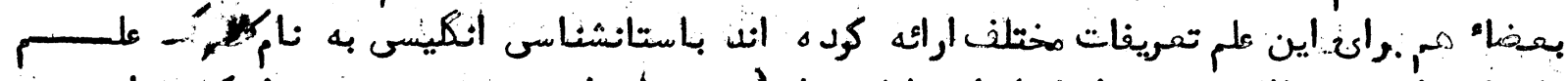

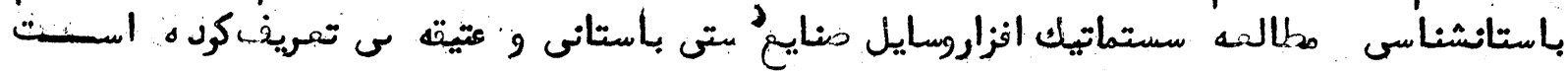

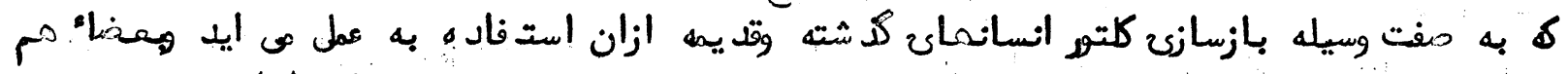

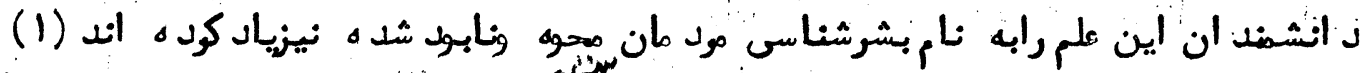

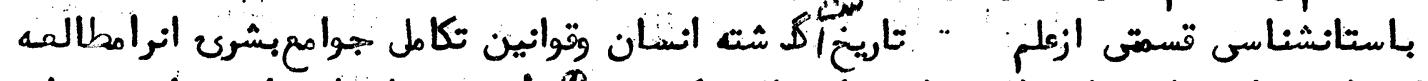

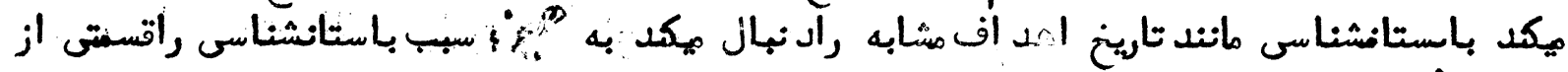

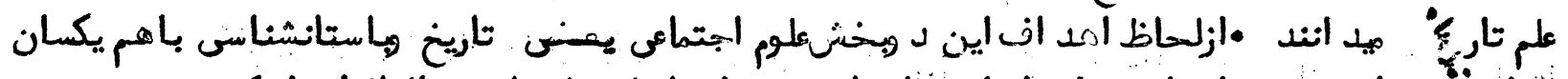

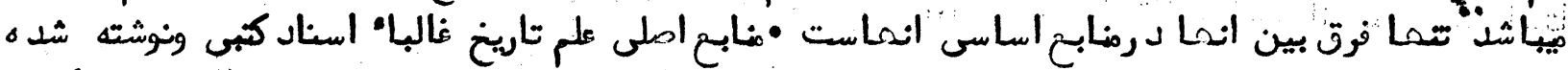

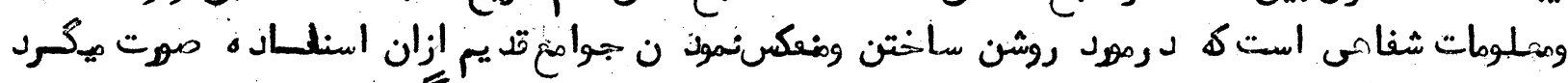

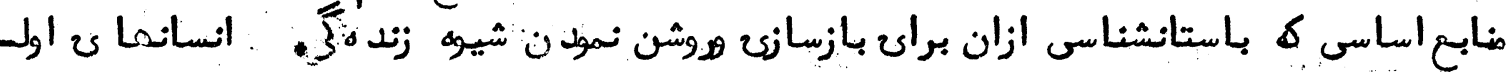

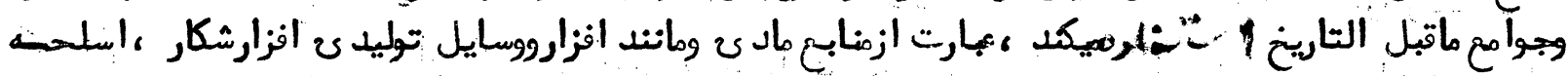

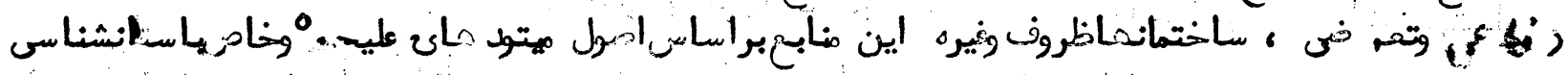

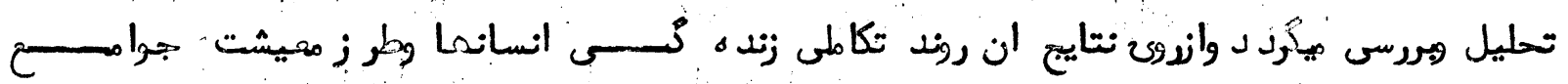

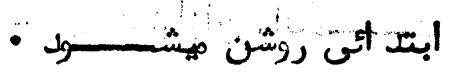

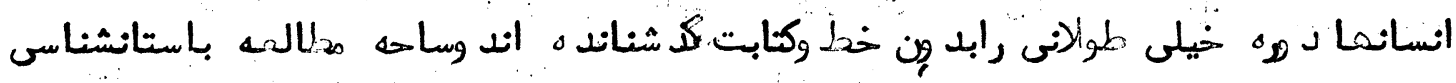

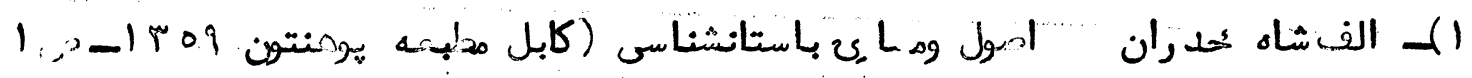




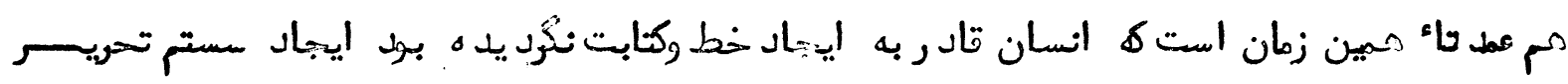

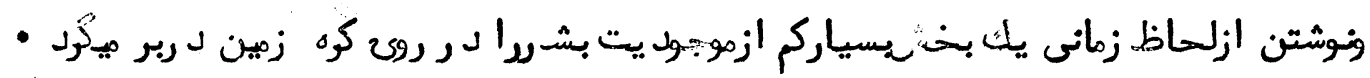

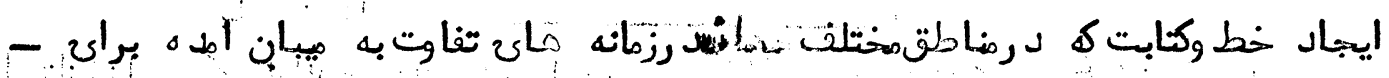

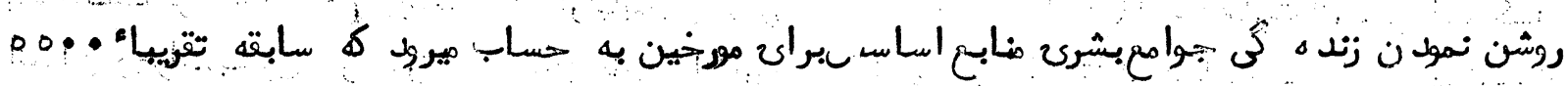

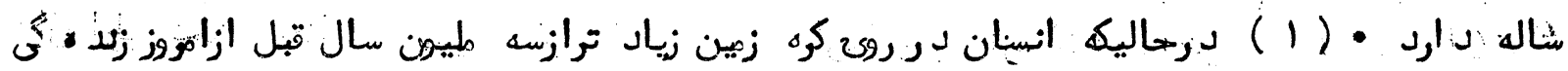

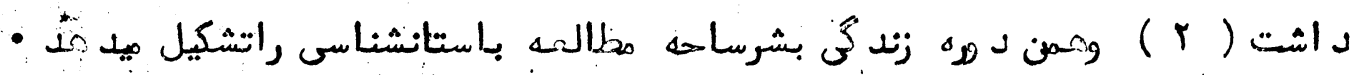

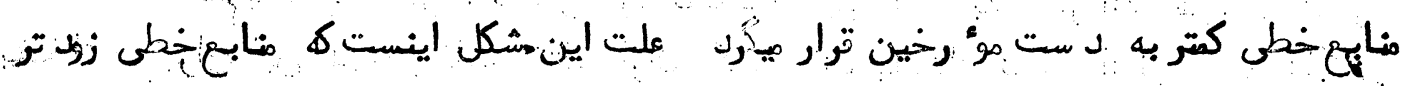

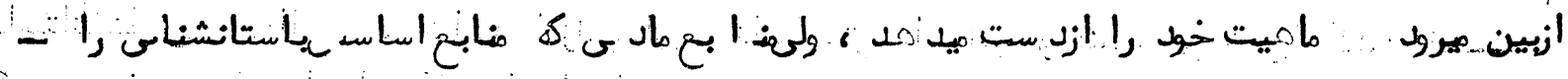

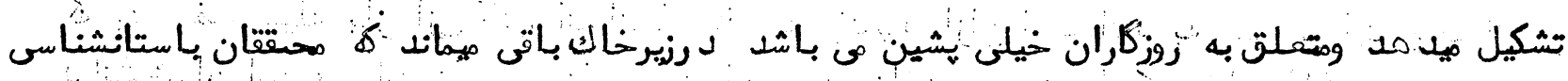

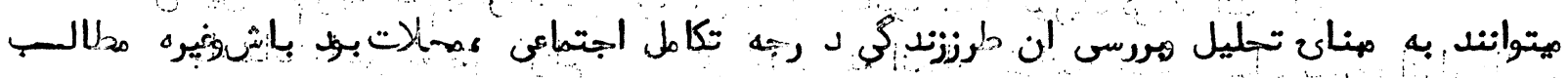

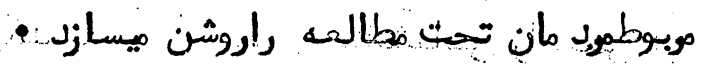

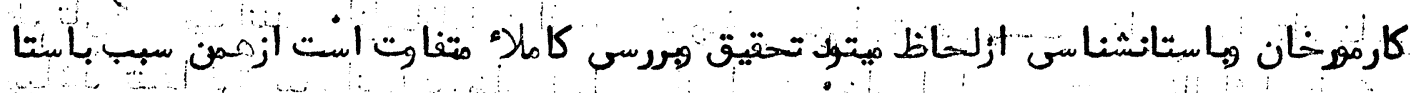

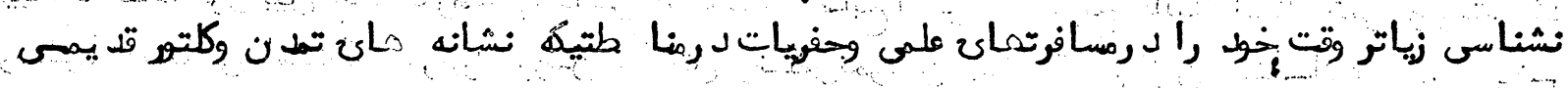

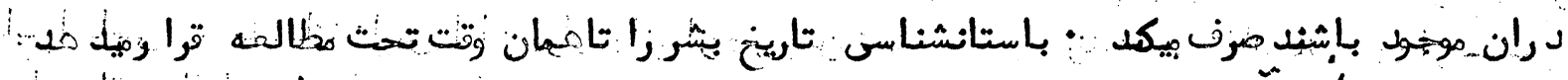

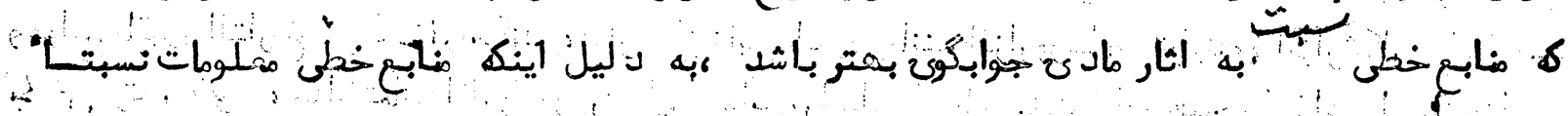

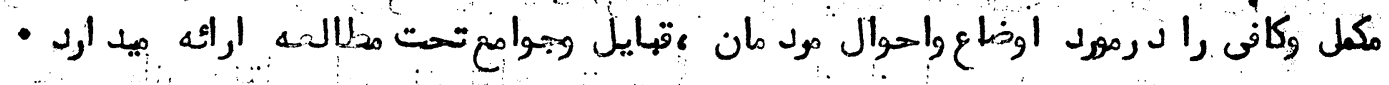

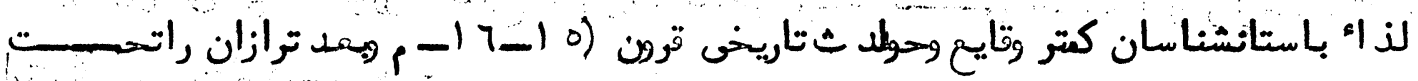

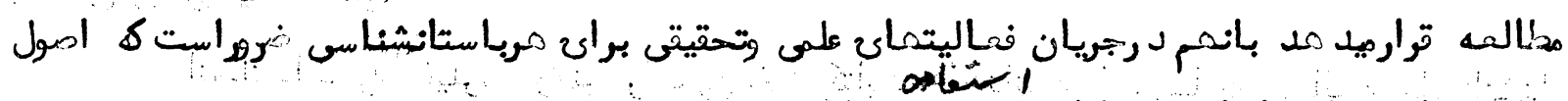

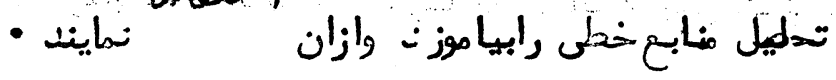

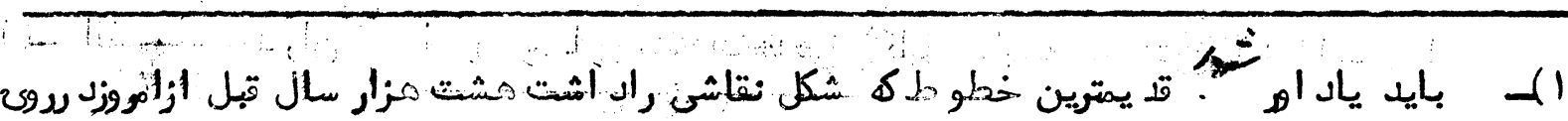

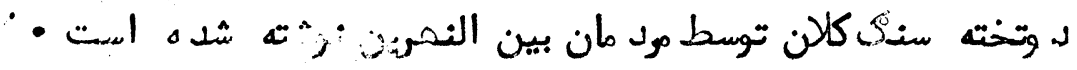

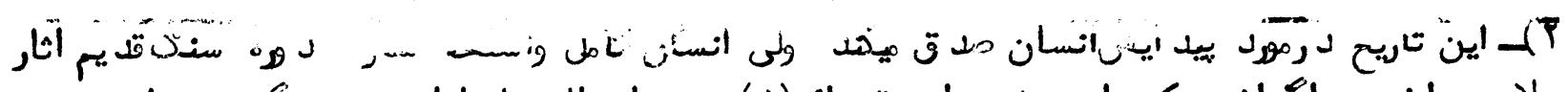

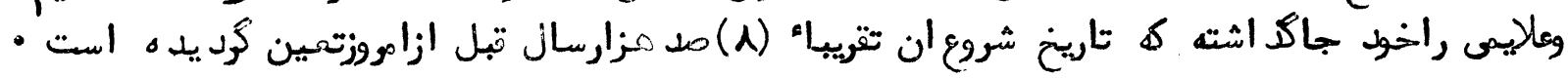




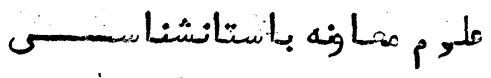

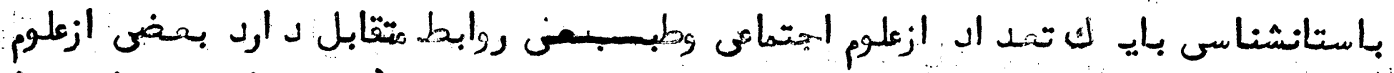

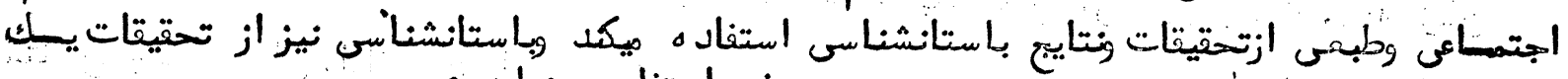

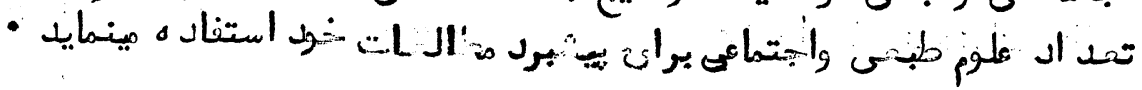

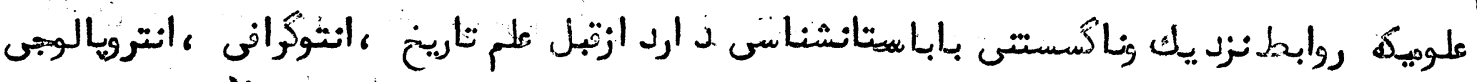

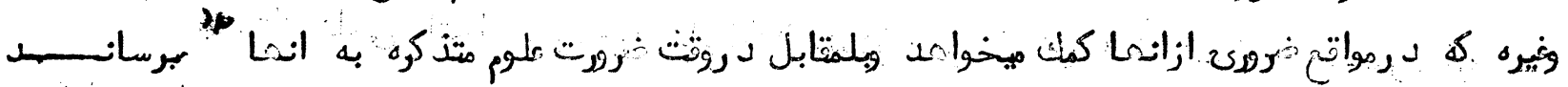

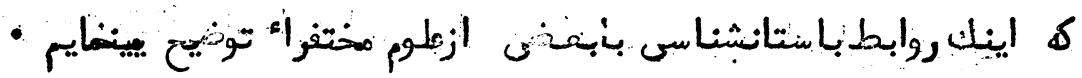

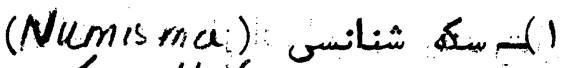

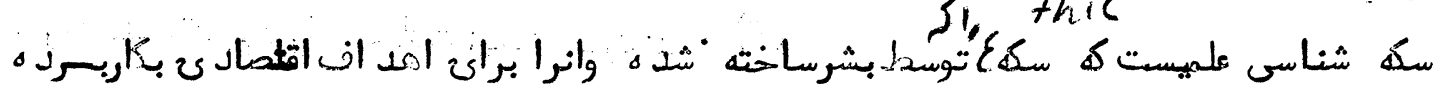

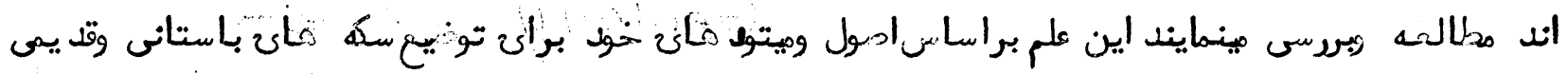

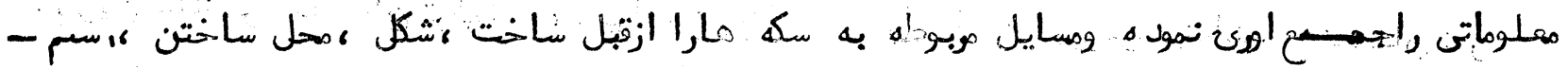

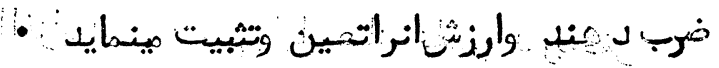

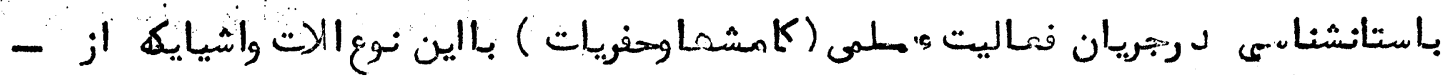

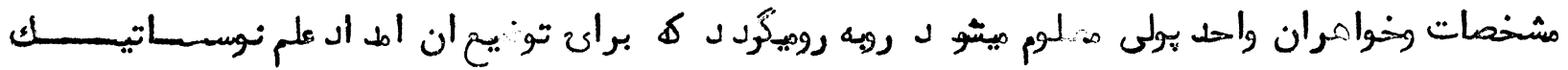

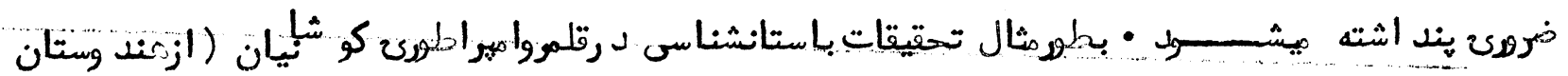

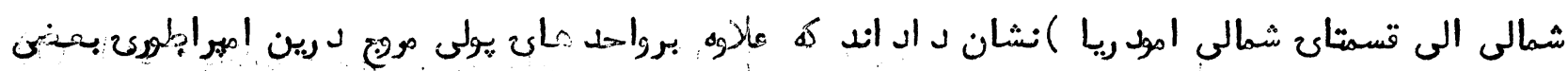

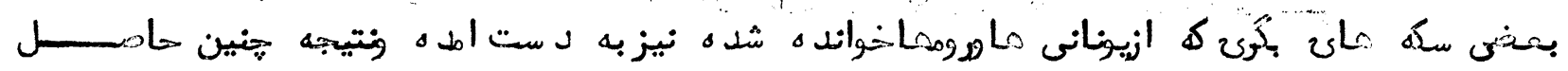

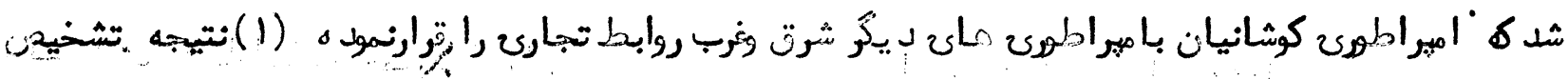

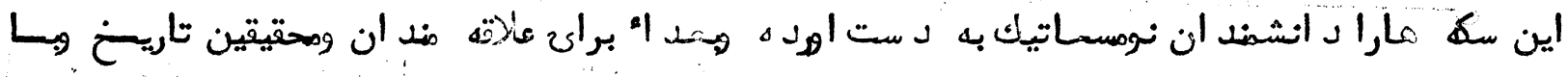
Anthropology) • •

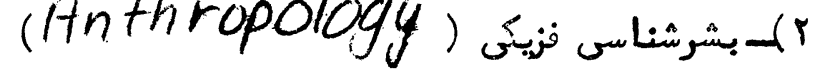

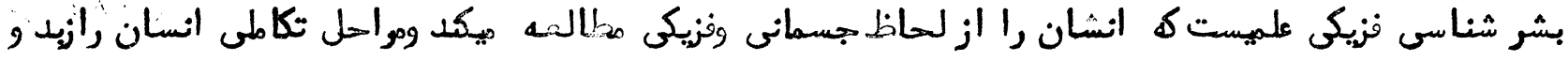

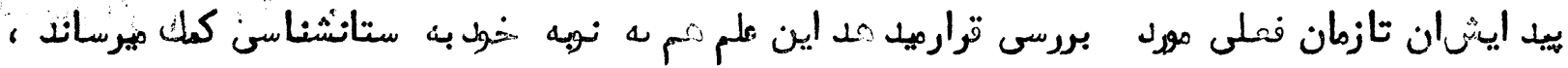


$-4-$

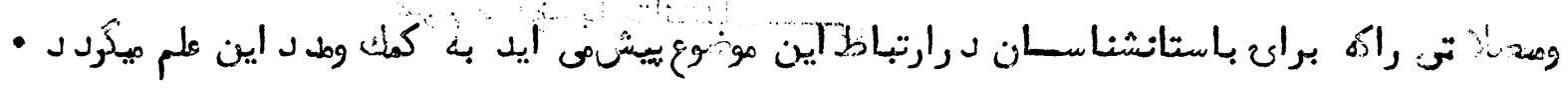

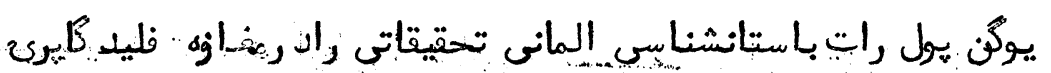

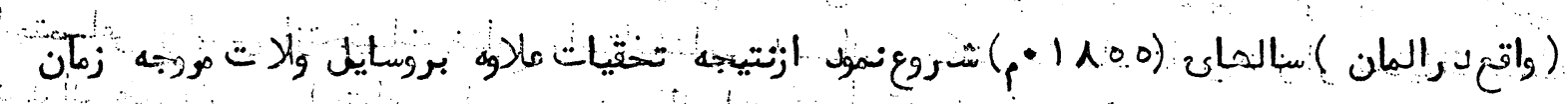

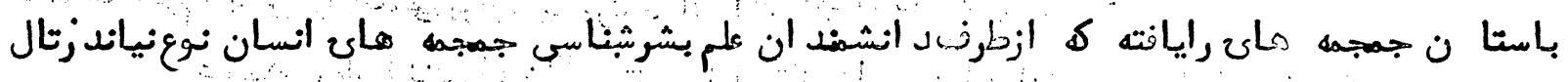

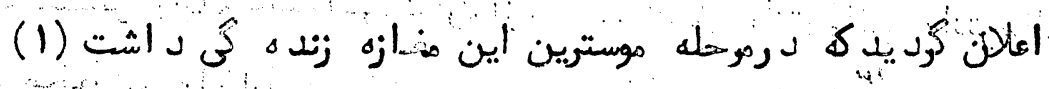

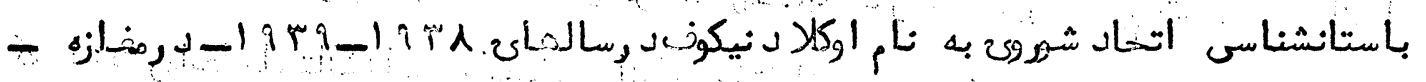

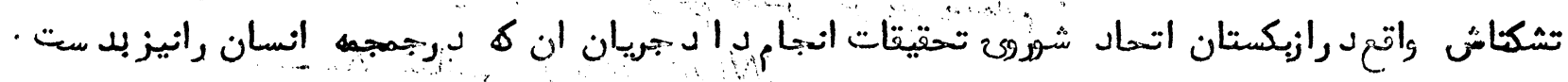

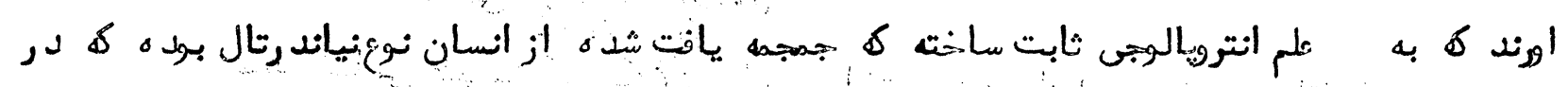

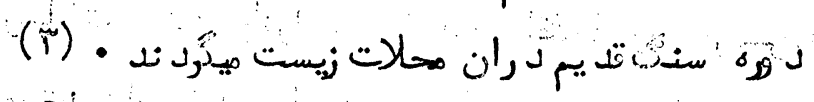

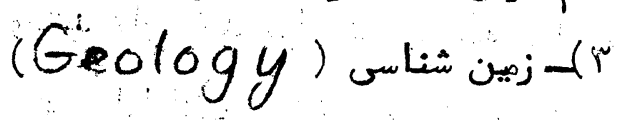

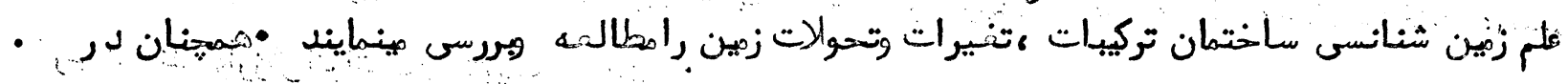

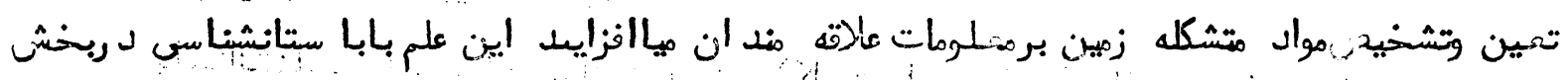
تمين مهد نى ؤزاعتى كه مول مان قدين

1

امول وتحقيقات باستانشناس

(ب)

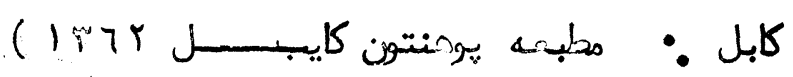

( rai o

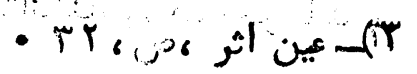




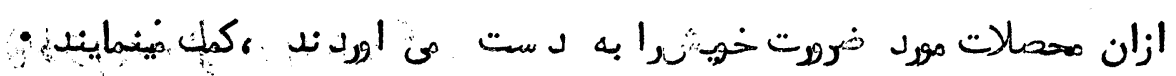

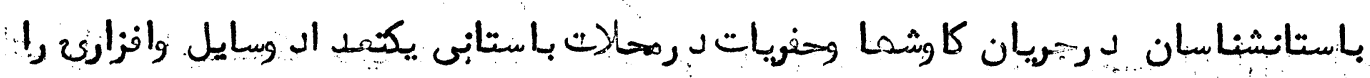

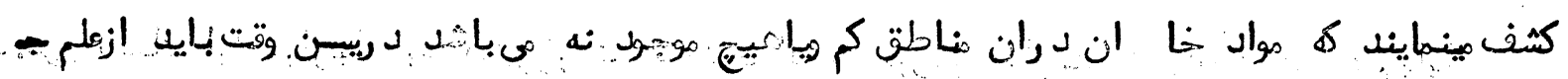

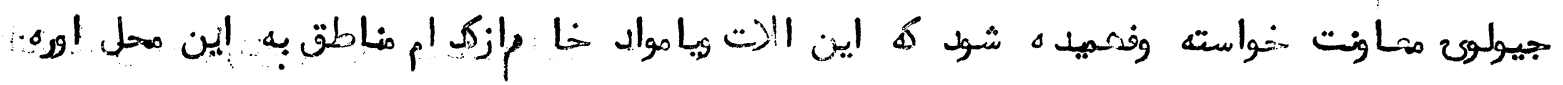

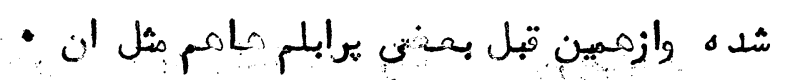

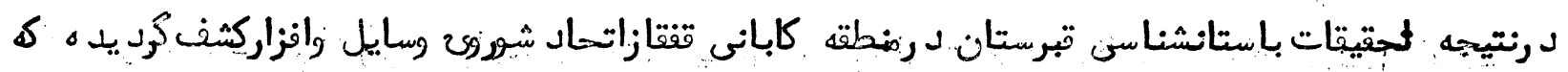

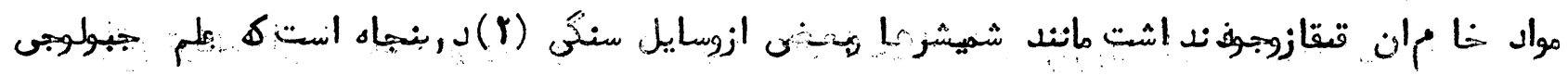

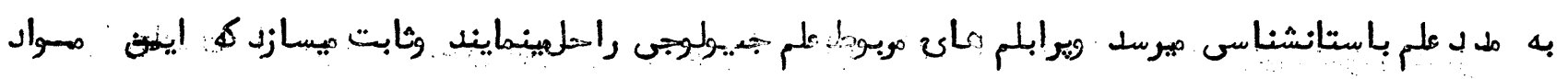

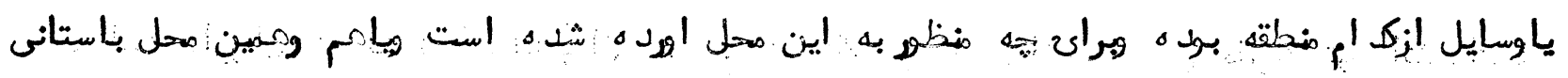

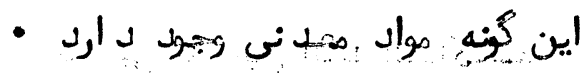

اسناسات باستانشنانسن " (كابل م-بنت

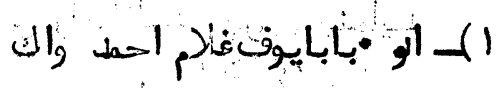




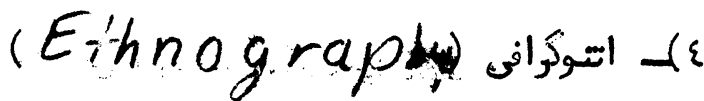

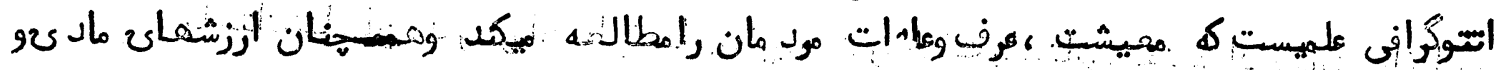

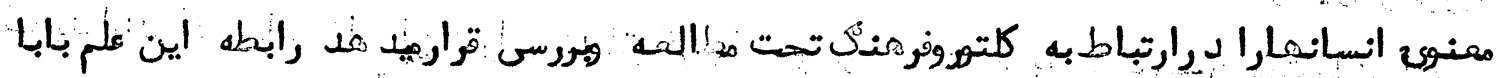

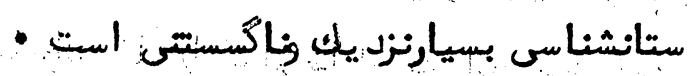

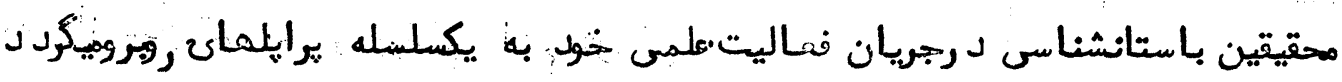

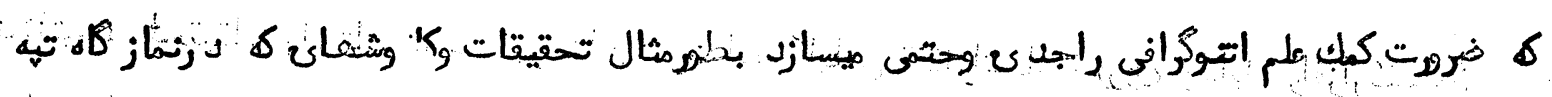

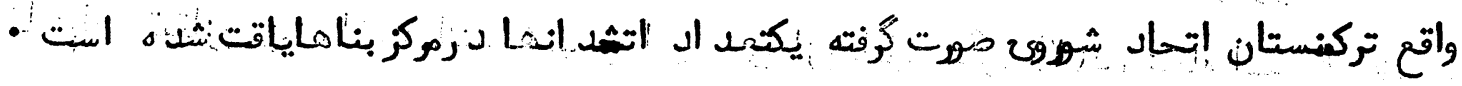

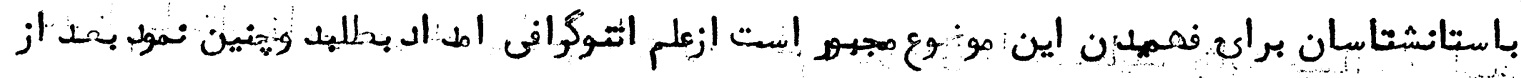

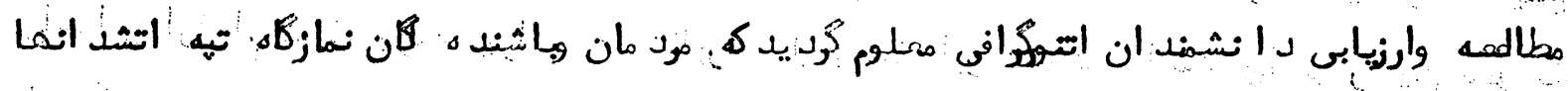

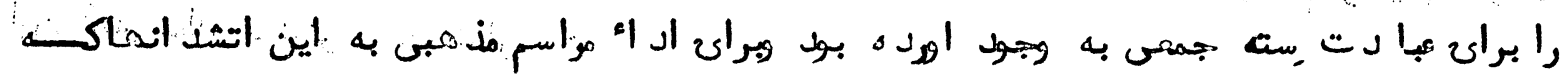

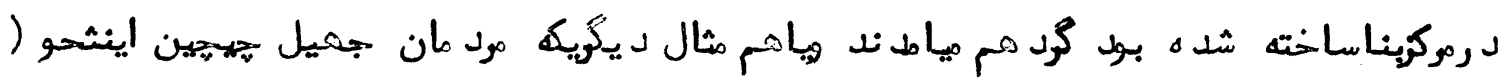
(Chichin et co

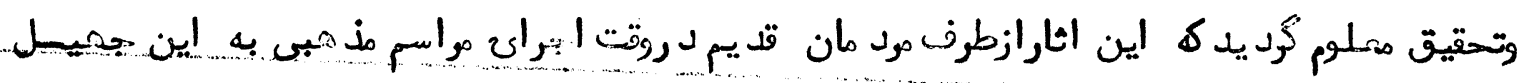

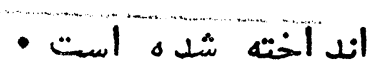
(Epigraphy) (مخط شناسى

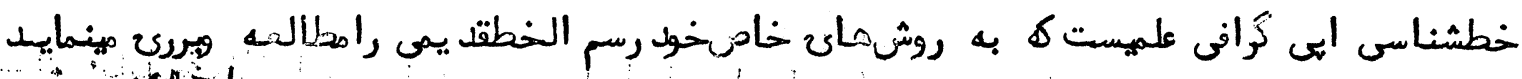

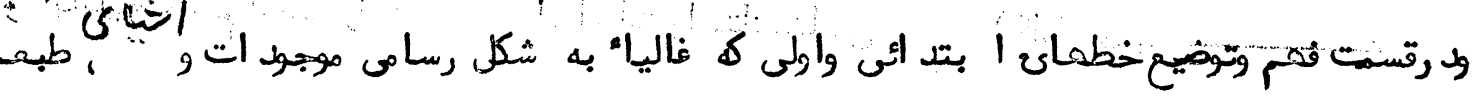
- بود مدالسه مينمايد

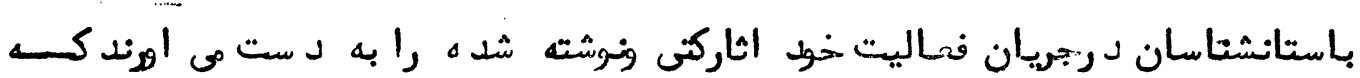

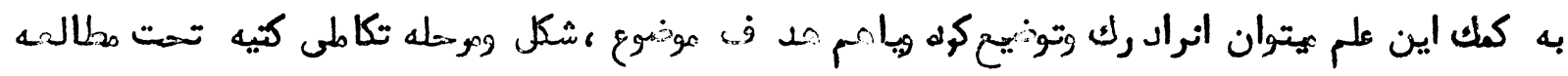

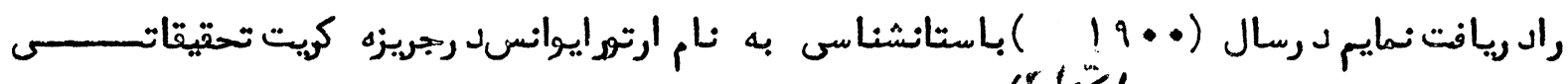

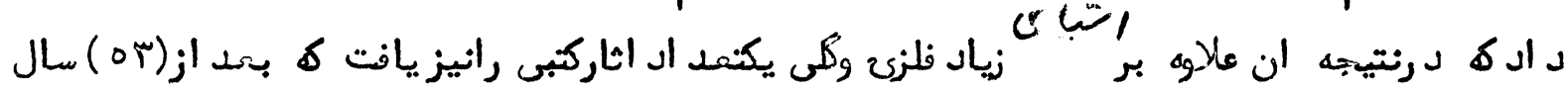

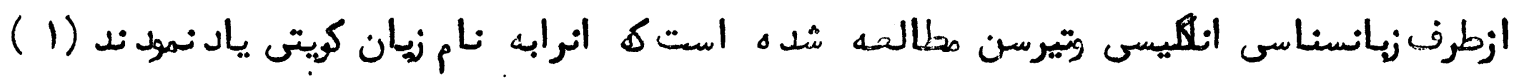

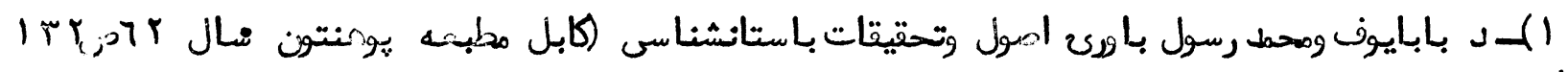


$-9-$

(Dendrology

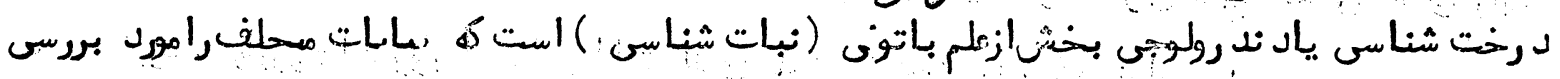

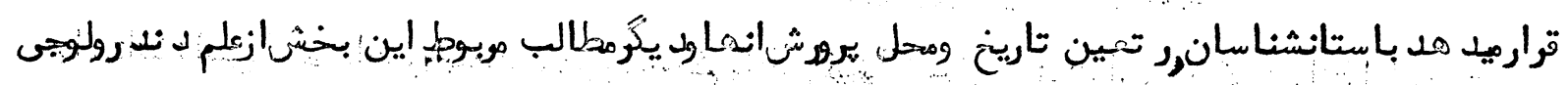

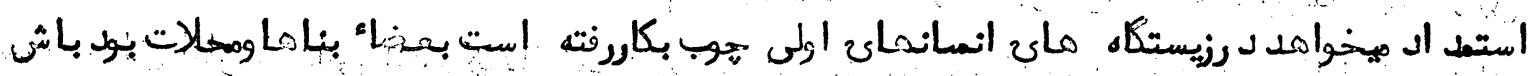

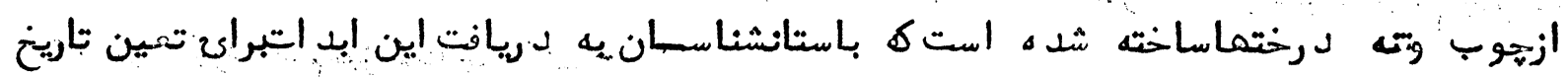

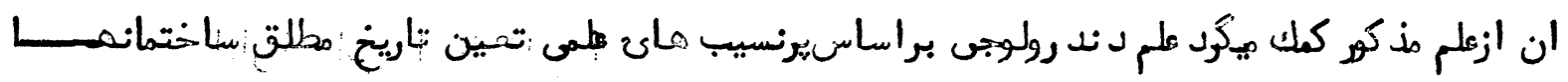

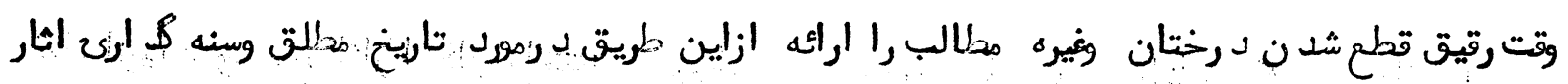

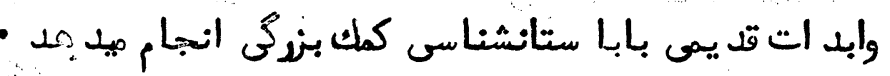

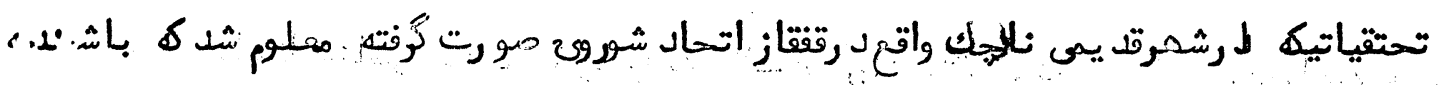

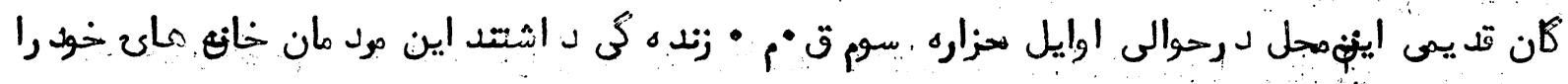

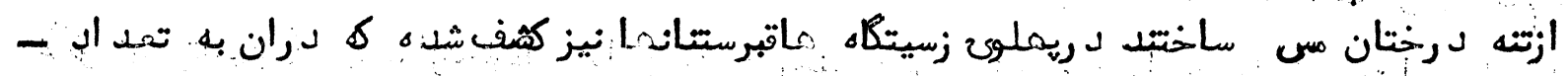

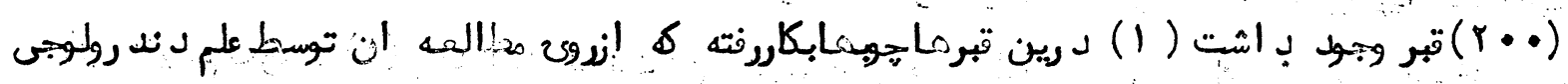

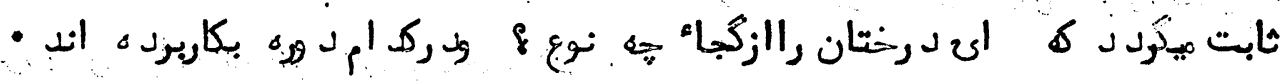

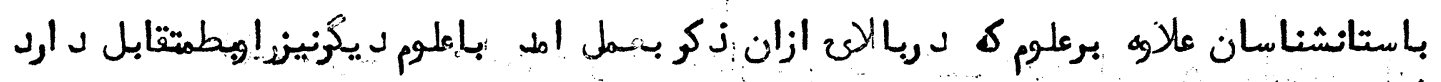

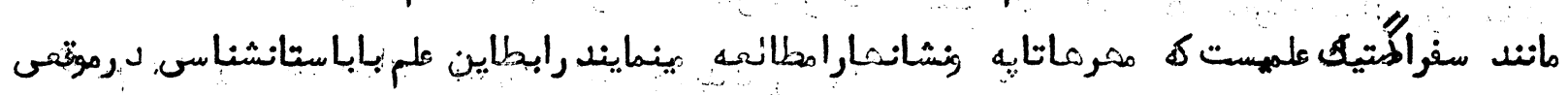

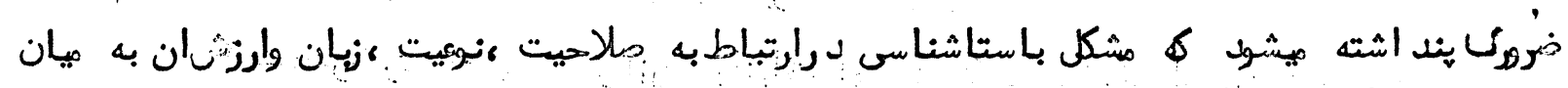

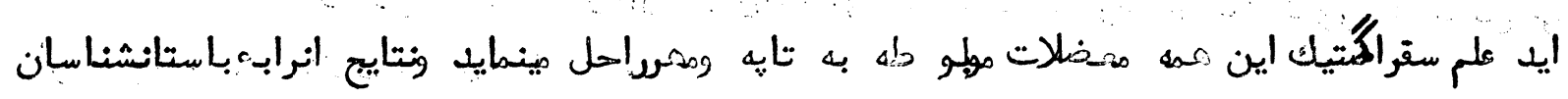

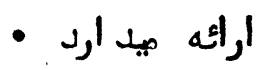

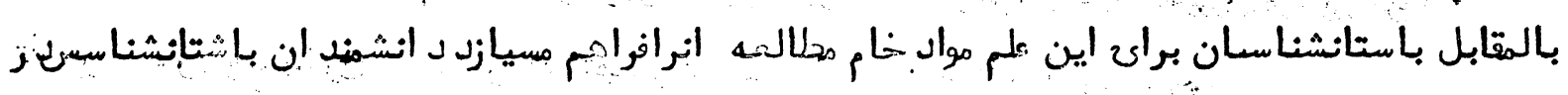

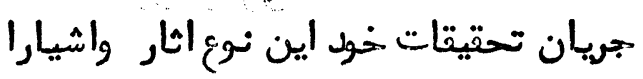

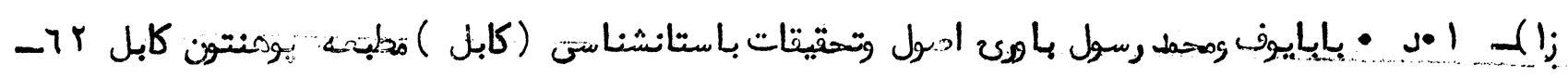
$-97-6$

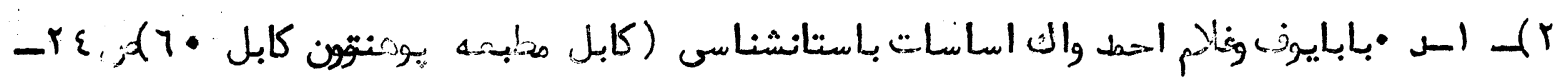




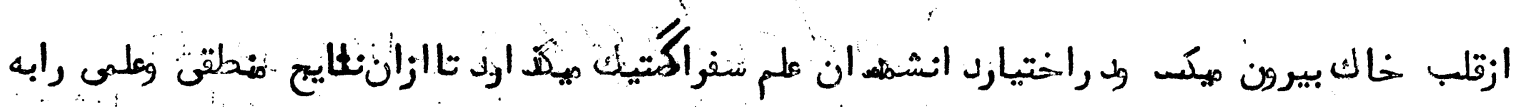

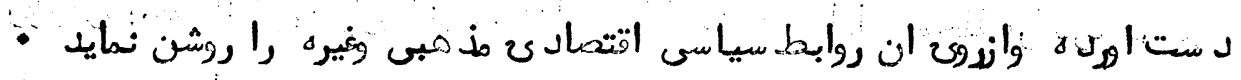

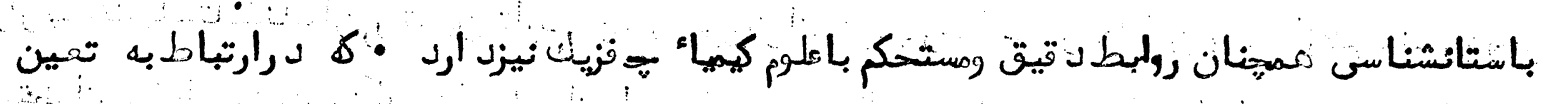

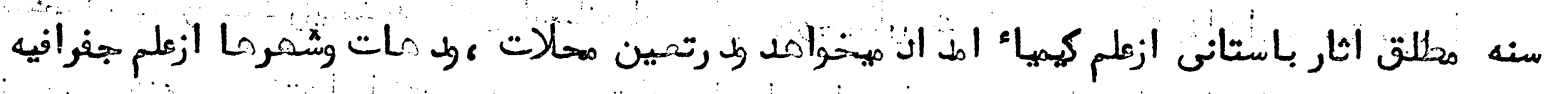

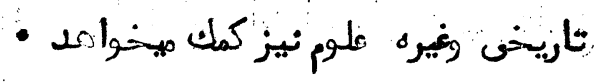

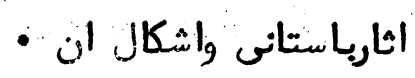

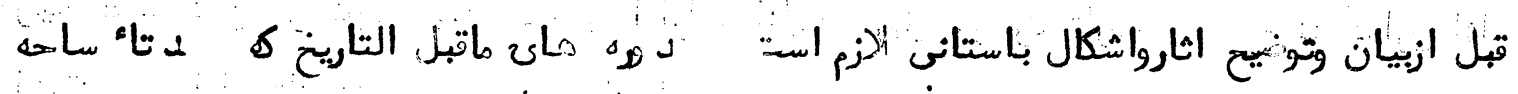

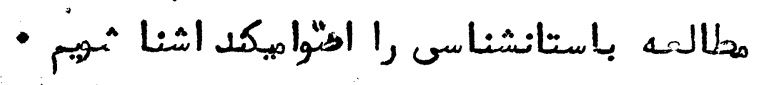

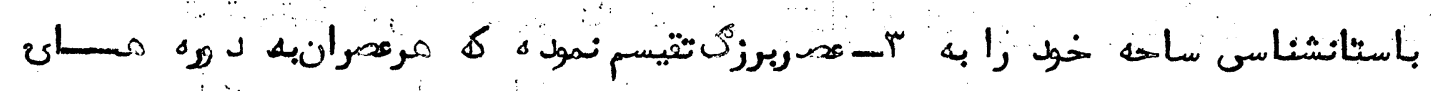

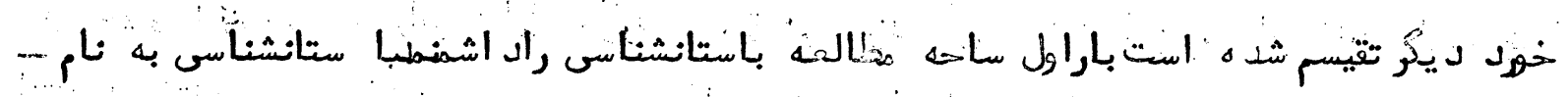

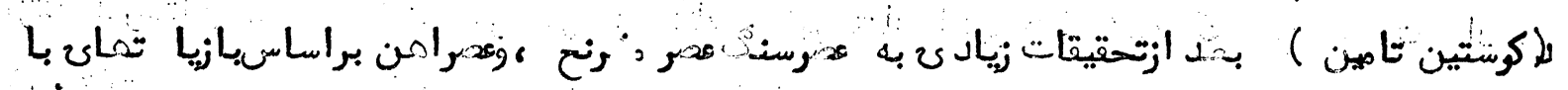

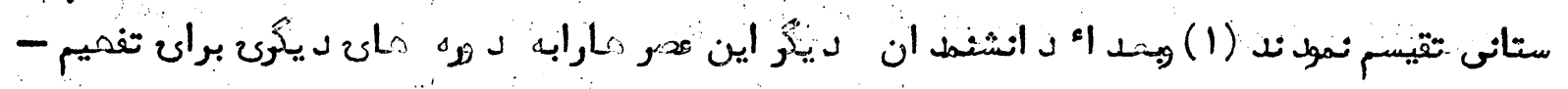

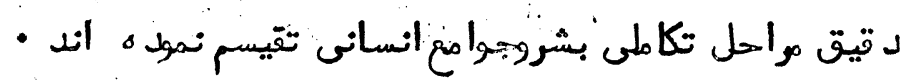

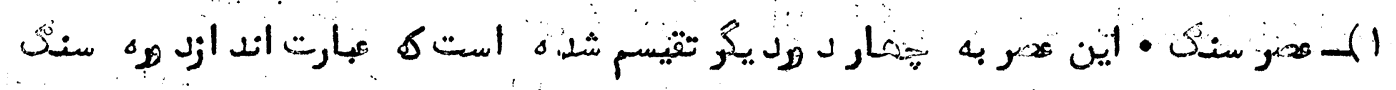

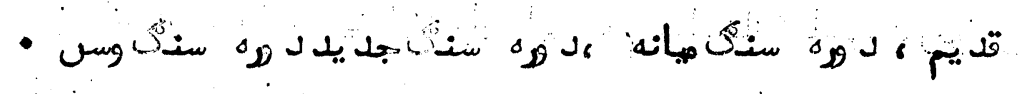

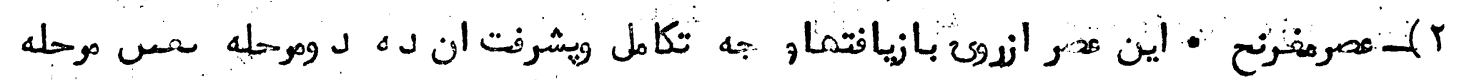

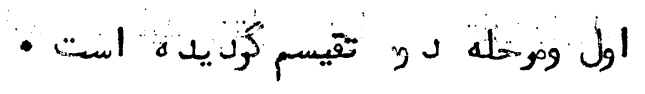

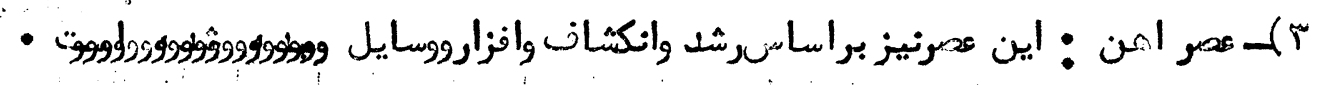

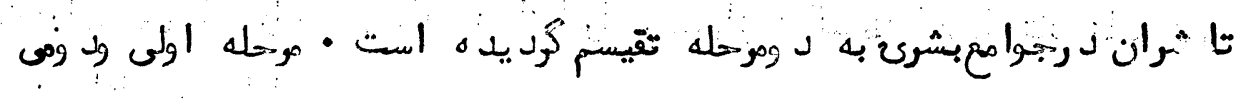

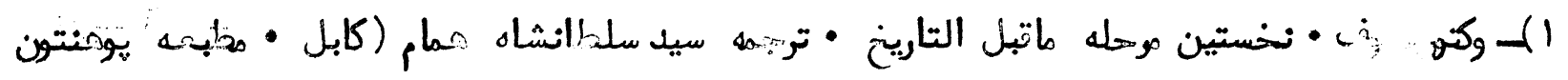
كابل 


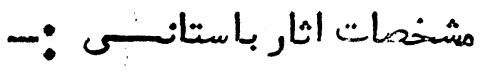

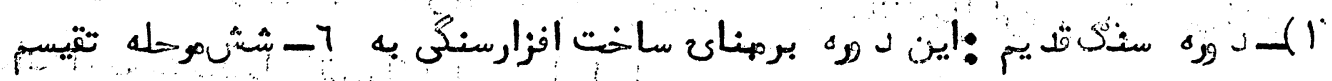

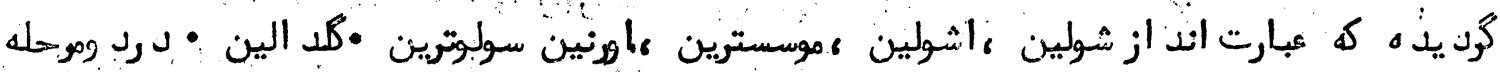

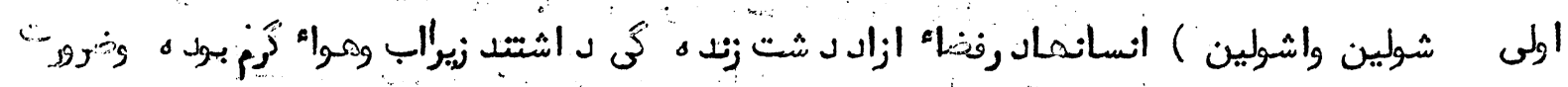

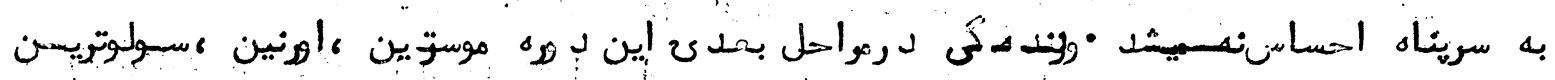

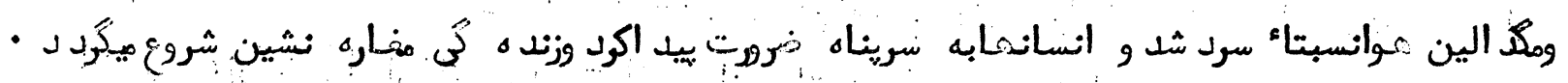

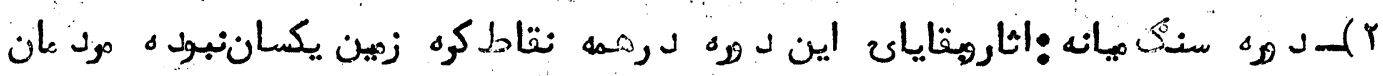

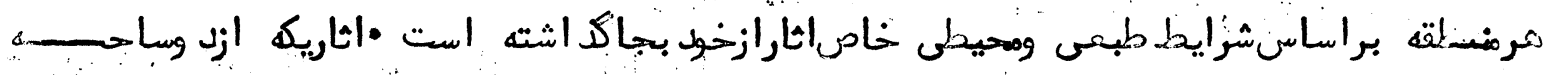

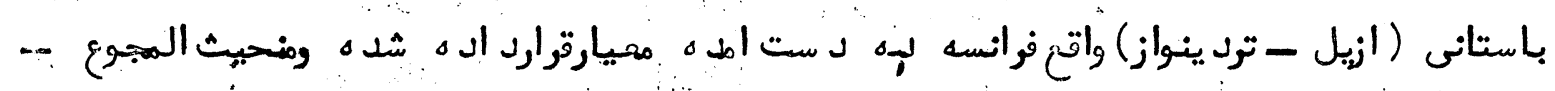

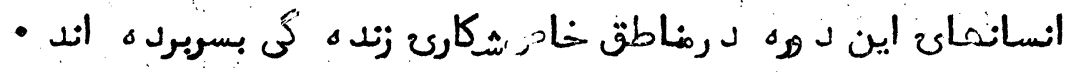

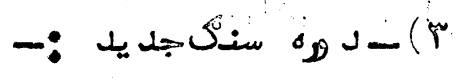

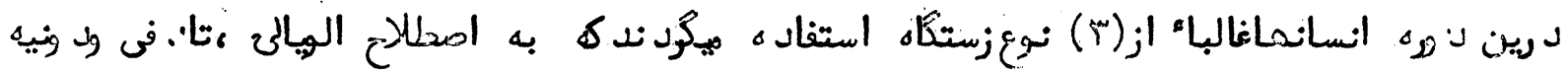

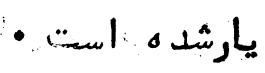

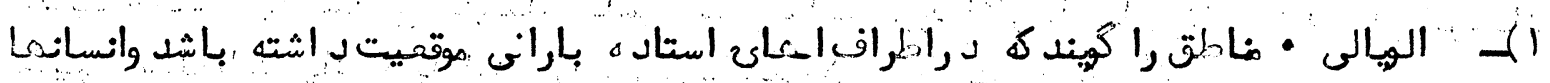

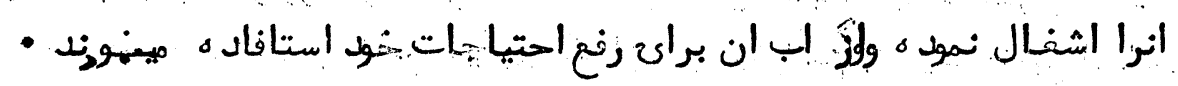

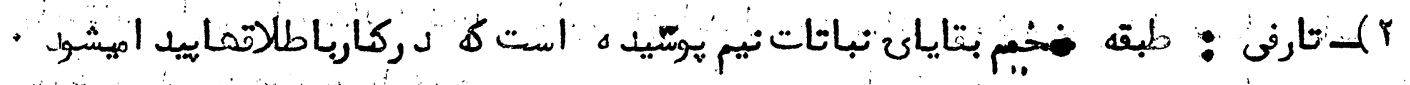

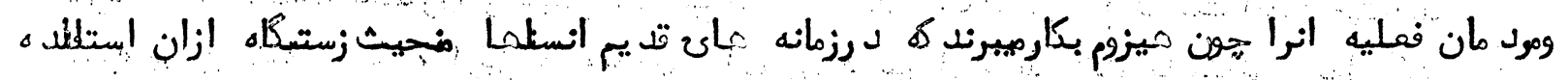

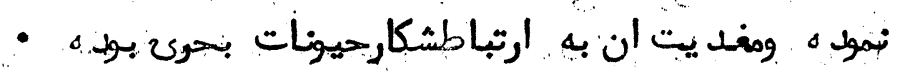

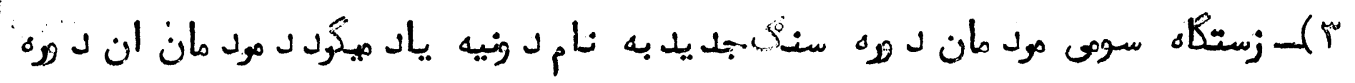

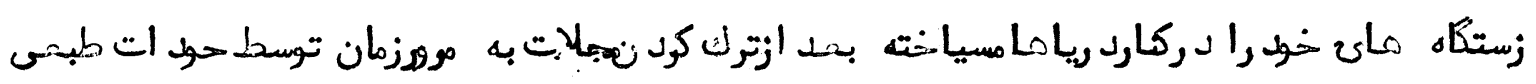

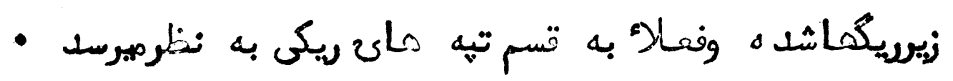




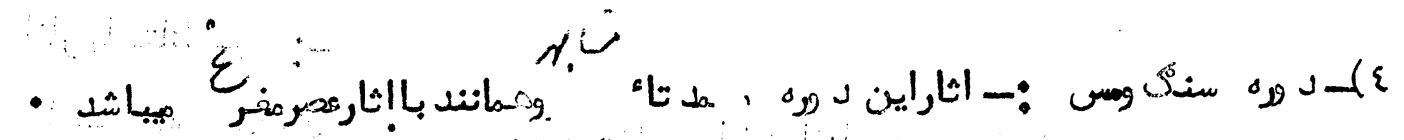

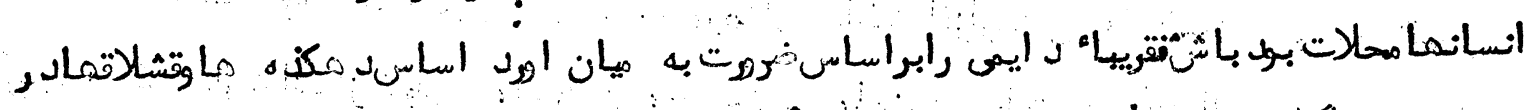

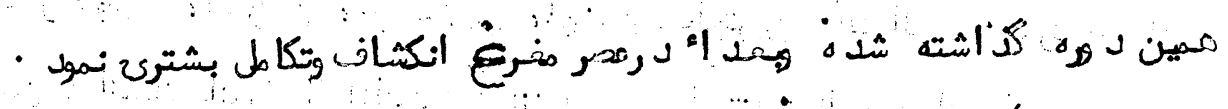

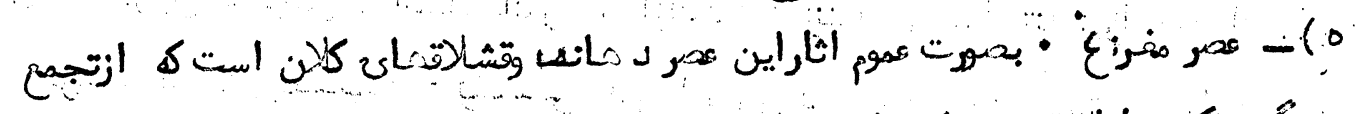

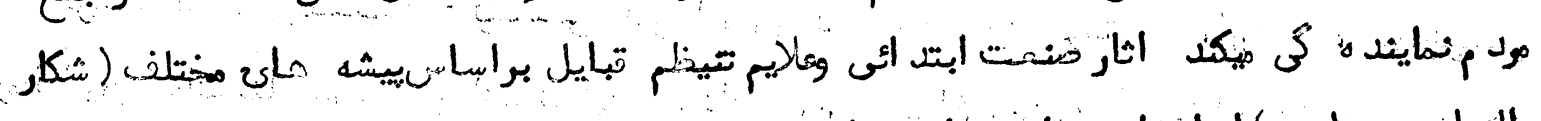

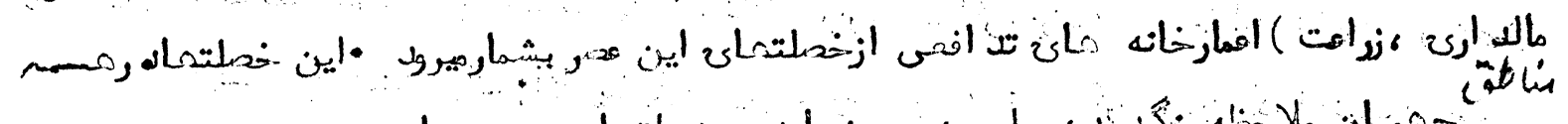

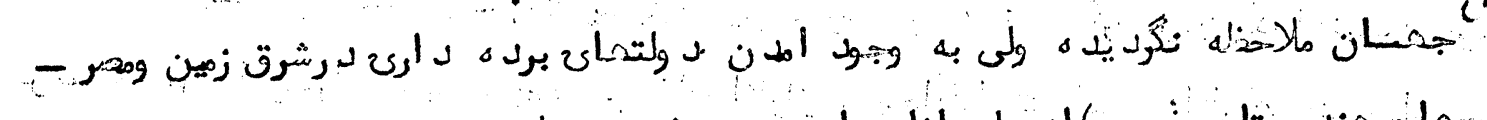

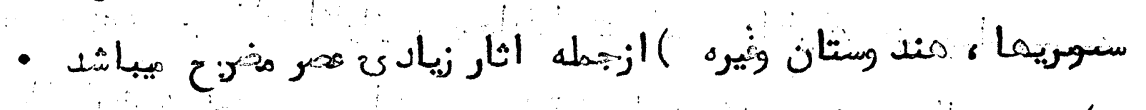

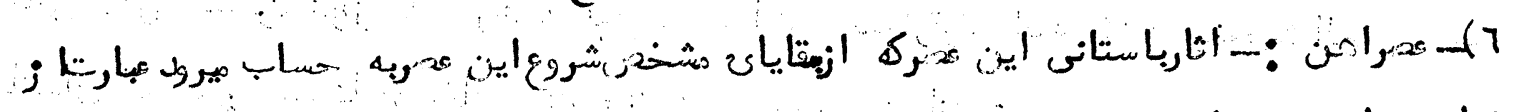

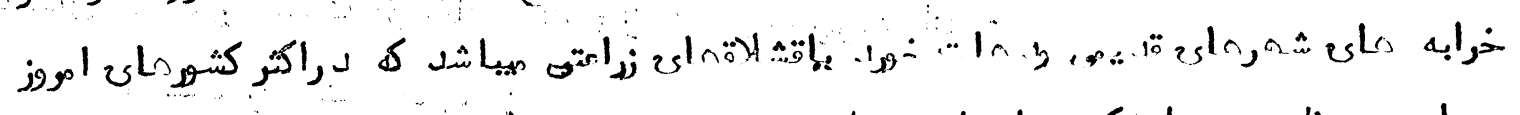

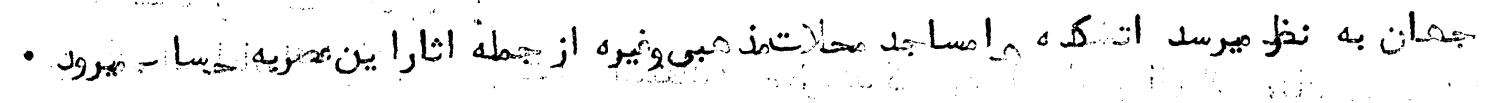

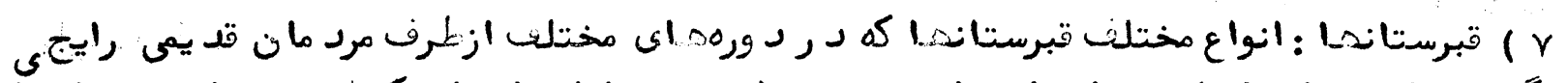

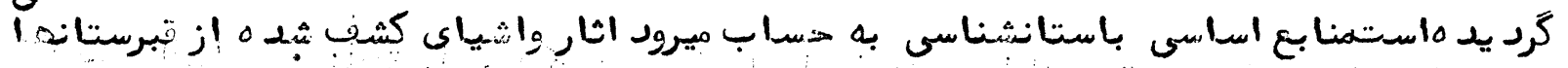

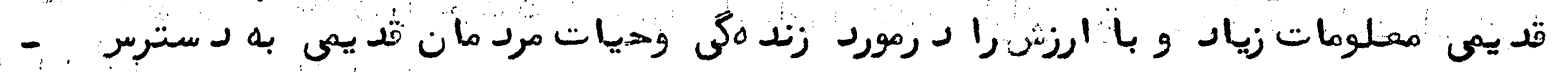

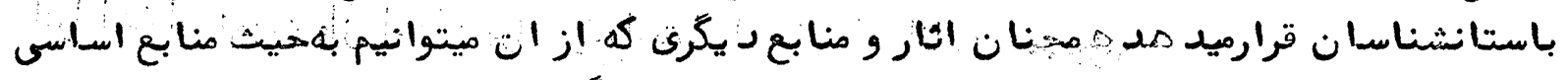

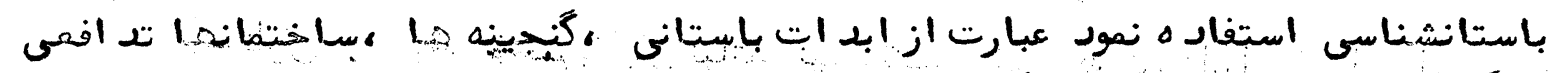

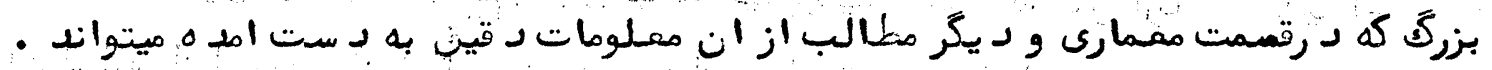

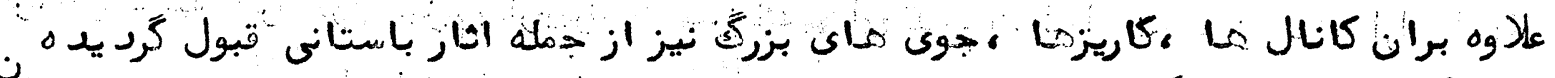

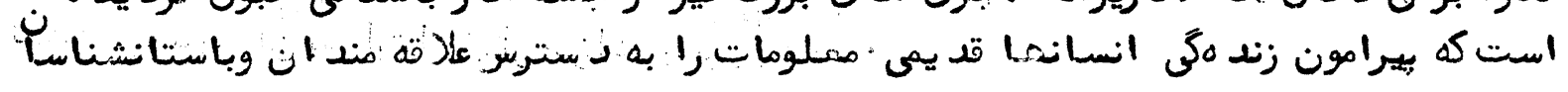

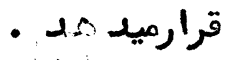


$-\infty$

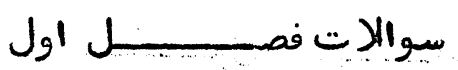

1-باستانشناسى جيست

ץ- منابع اسداسى باستانشناسى جيست ؟

r-رابطرعلم باستانشناسى بالنتروضالوجى توضيح نمايد ؟

؟- رابطه علم باستانشناسى باساير علوم متقابل است يايك جانبه ؟ 


$$
\begin{aligned}
& \text { فـ }
\end{aligned}
$$

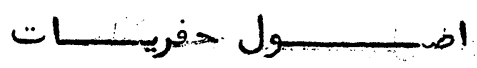

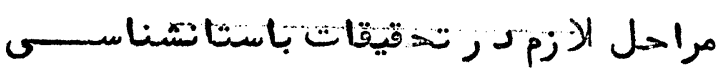

هـرعلم براى به د ست اورد ن اهد اف خدود از اصول و ميتود هاى خاص اسخفاده مينمايد -

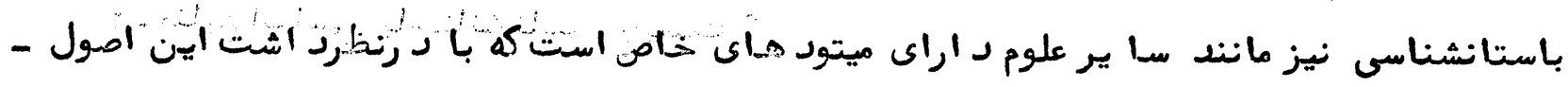

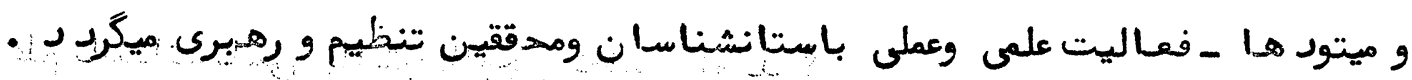

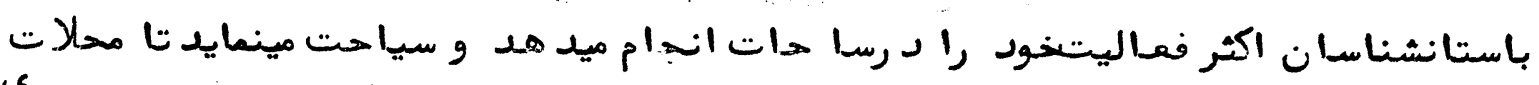

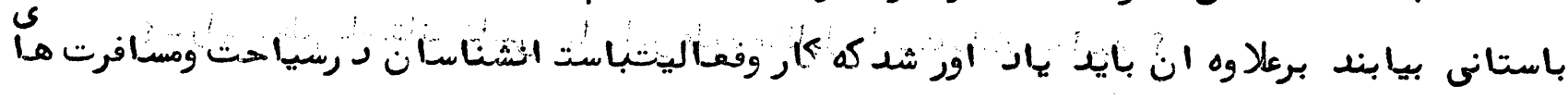

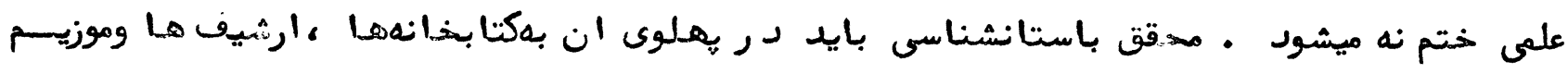

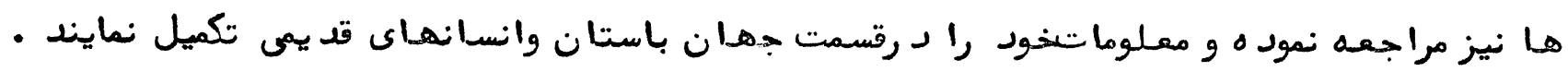

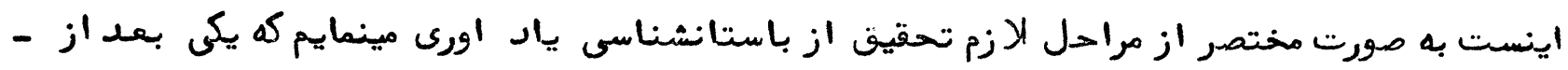

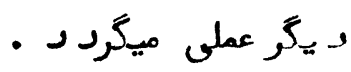

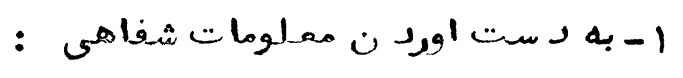

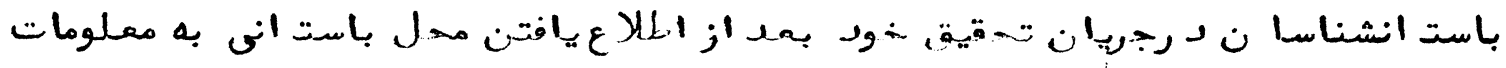

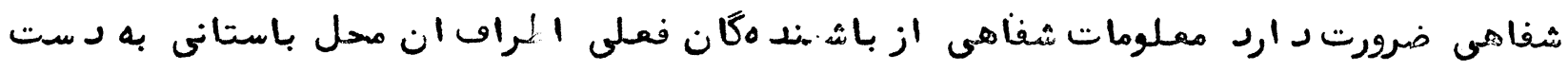

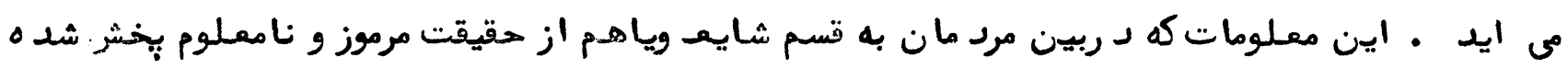
جمع اورى ميكرد د ـ كه بعد از تحقين وكاوش د رست بود ن وياغلط بود ن ان معلومات ثابت ميشود .

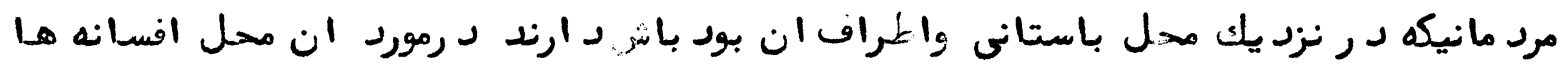

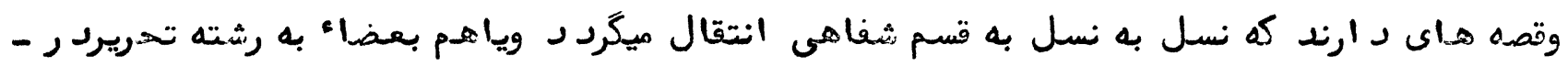

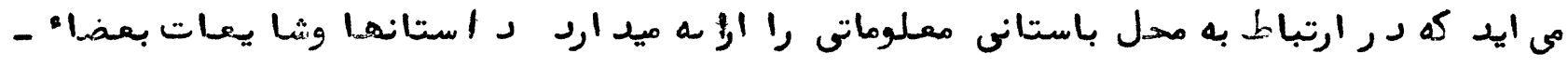
قصدى و عمدى سا خته شدهوياهـم بى محتواى واهل عينى دـ ربين مرد مان رايج گرد يده است بط بطور

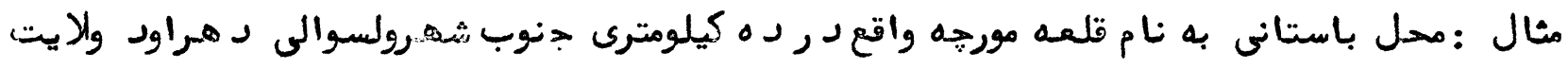




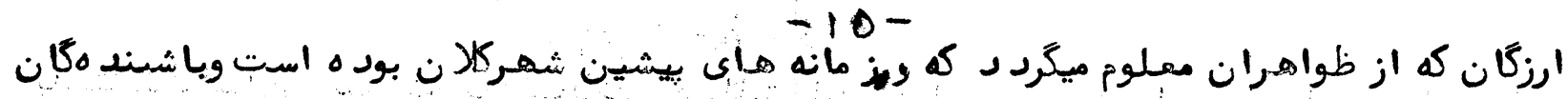

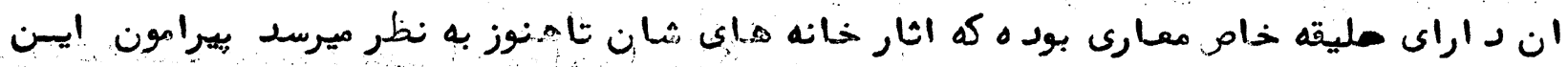

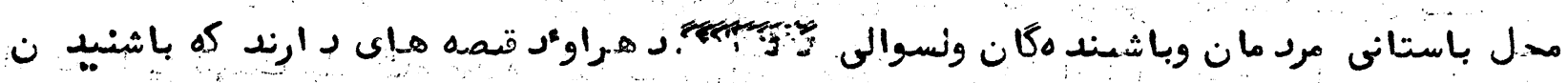

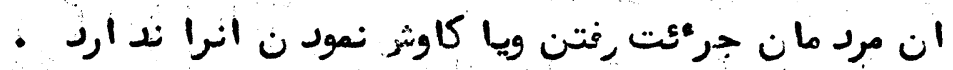

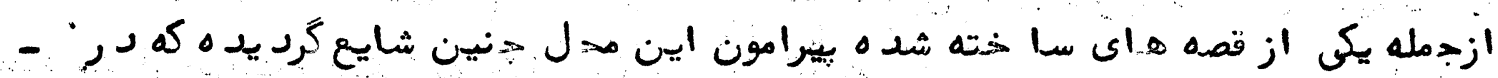

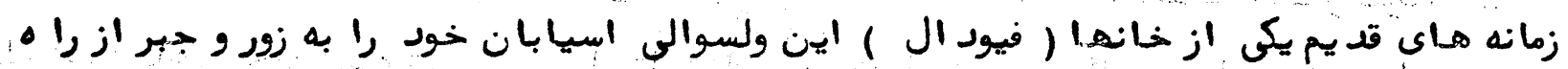

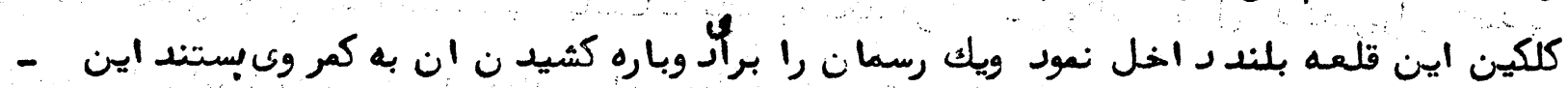

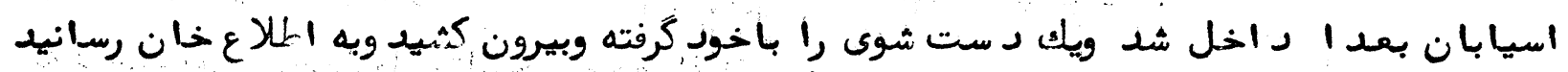

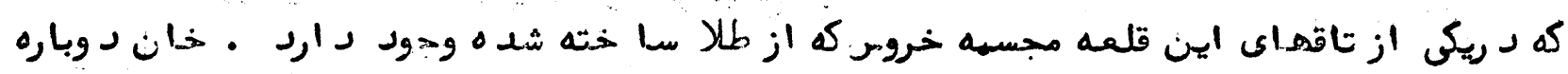

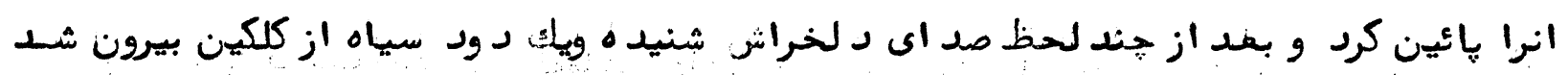

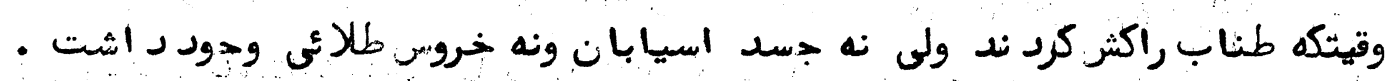

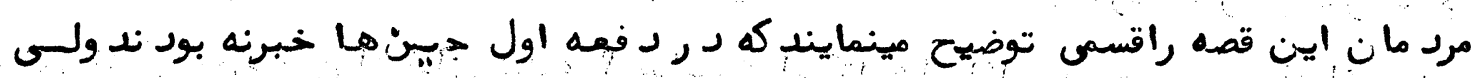

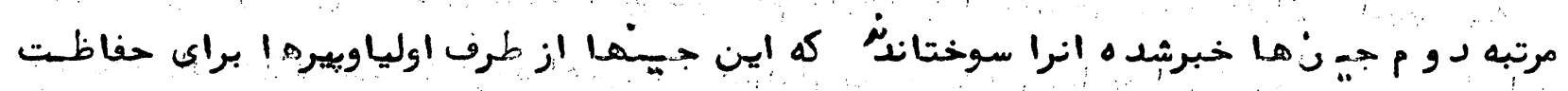

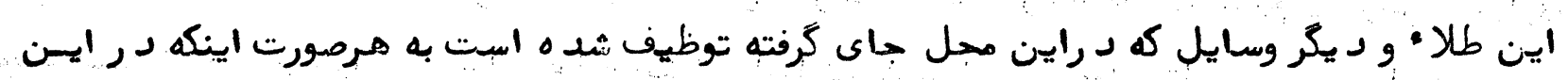

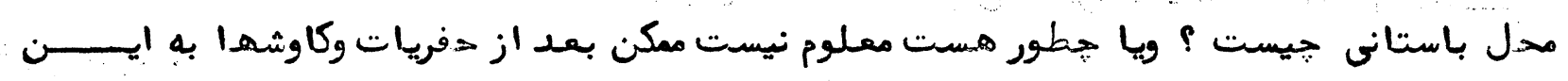

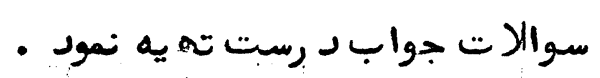

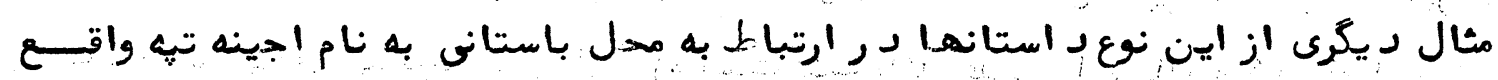

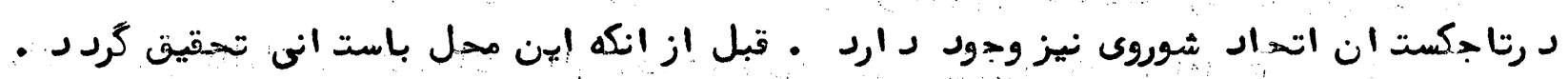

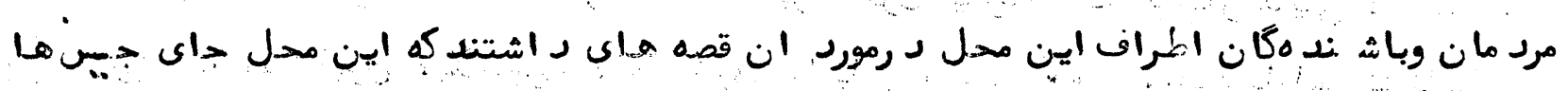

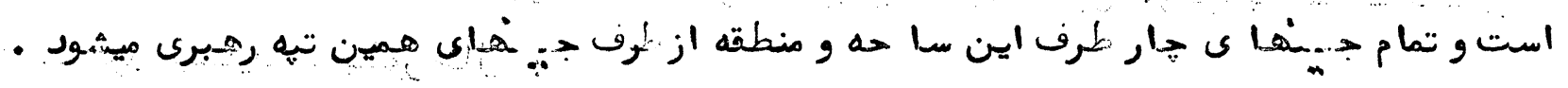

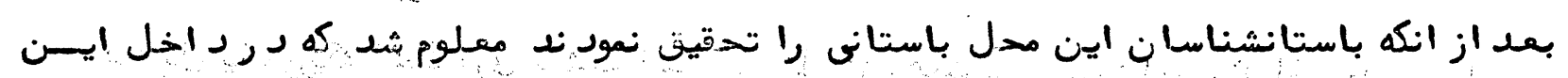

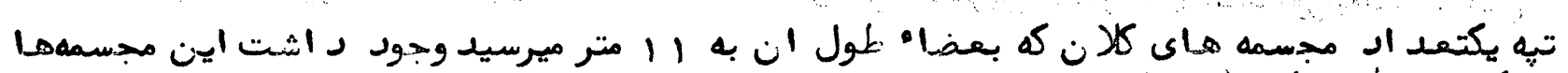
(1) (1)

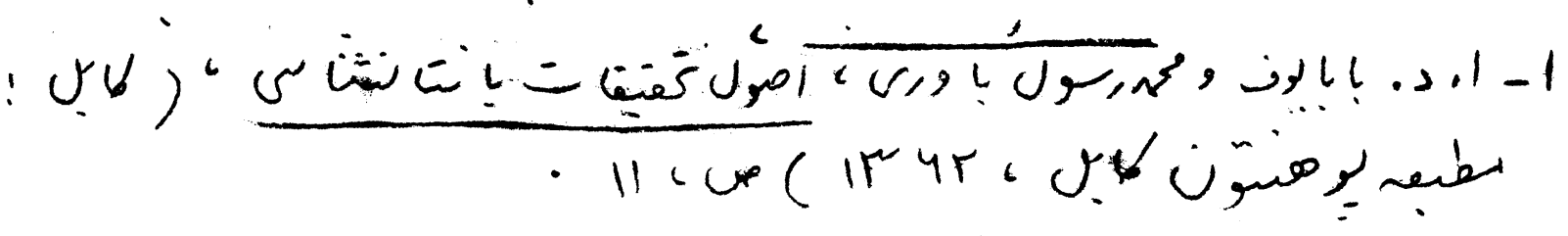




$$
-11-
$$

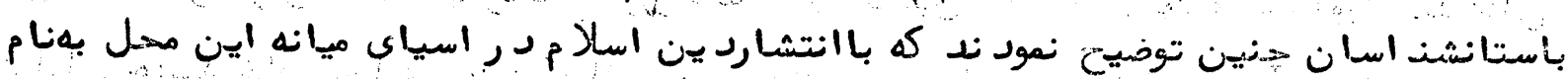

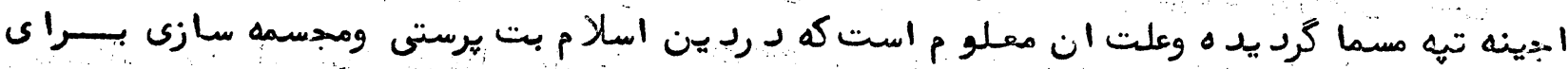

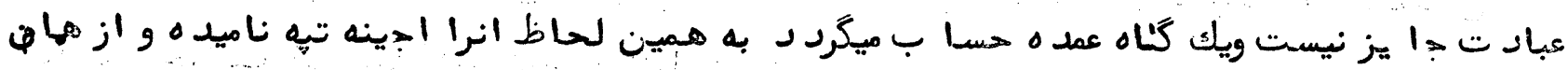

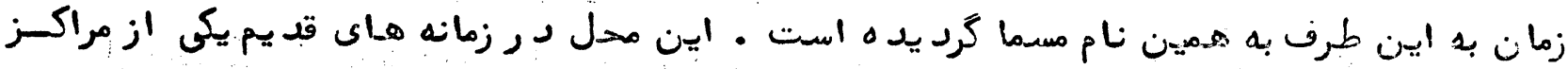

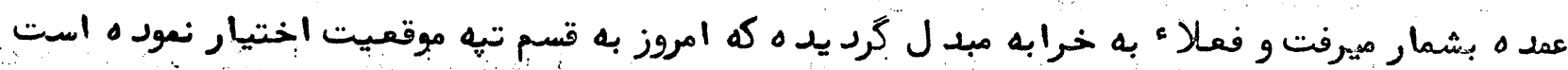

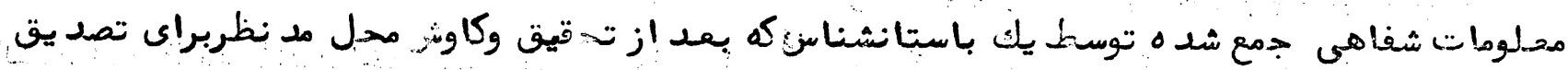
ويا ترد يد ان أبراز نظر ميكردد مواد خام و اولى مهقق شمرده ميشو د .

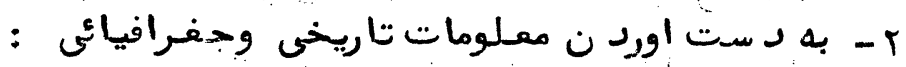

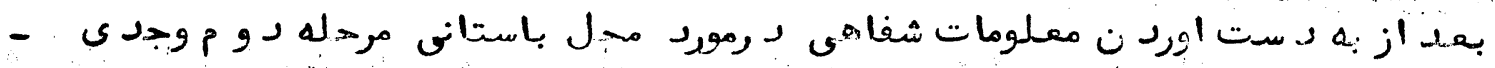

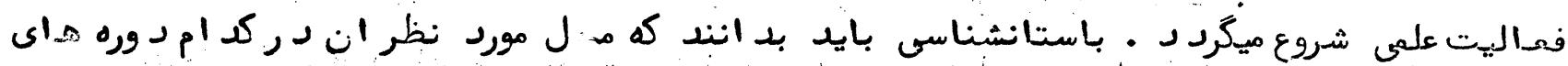

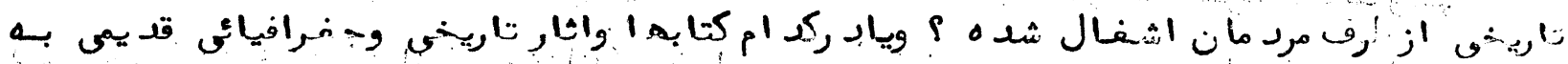

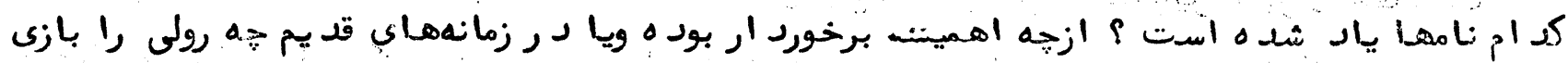

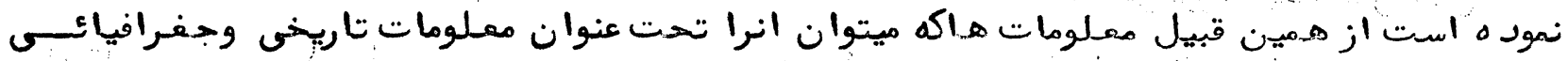
توضيح نمود

معلومات مذكور از اثار قد يمى نوسيند هأن ود انشم ند ان تاريخ وجغـرافيا وغيره ميتـوان د ربافت نمود - برأى بيشبرد اين كار الاز است كتب واثار قد يم را مطالعه كرد كه اين قسمت كار

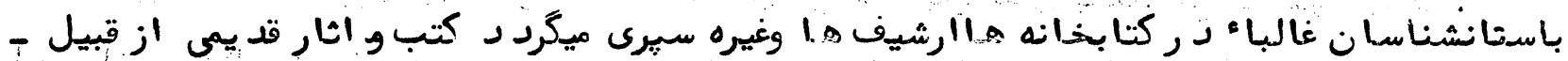
تاريخ هيرون وت هنسترابون ،بلاذورى ،اهلخرى ،اريان ،ابن خلهون ،وغيره باباستانشناسان

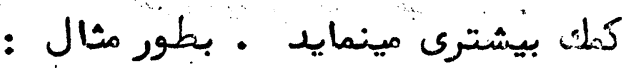
دارتل يالموريكه اهطخرى نوشته اند شهـرتل از مهمترين شهـرهاي زيند اور بوده ـ ـ اينن (1) 


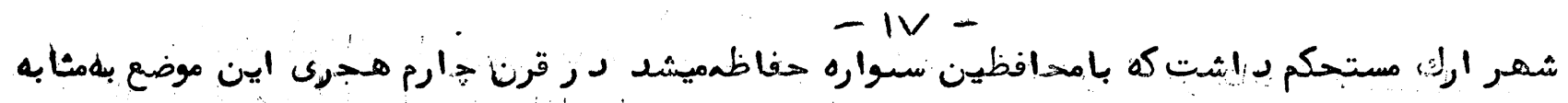

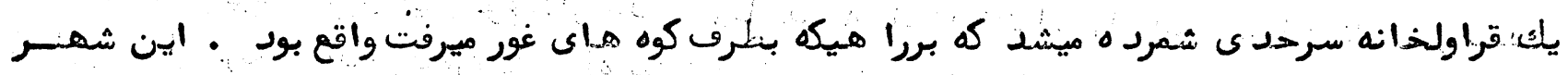

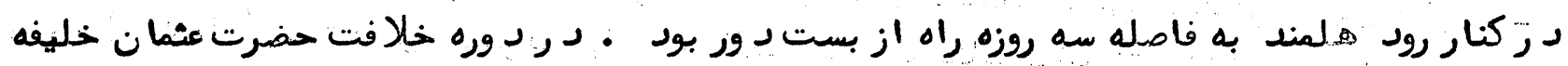

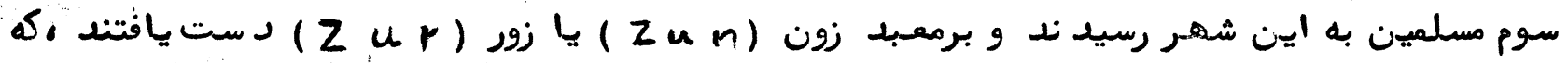

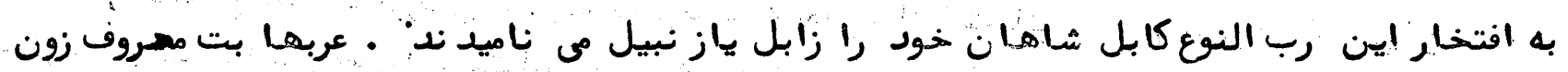

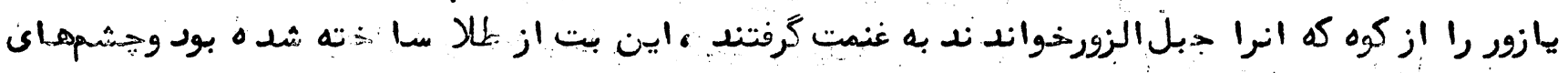

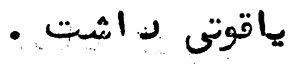

ماركوارت زمين د اور را زمين شخص عادل ليعنى زون خوانذه بيهقى خويند كه دـ زمين د إور

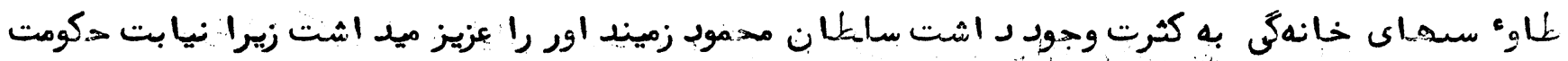

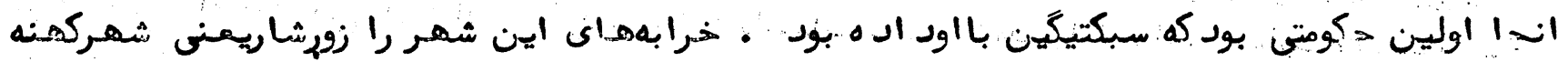

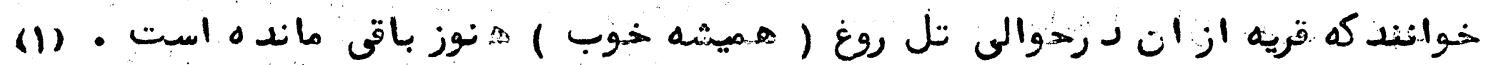

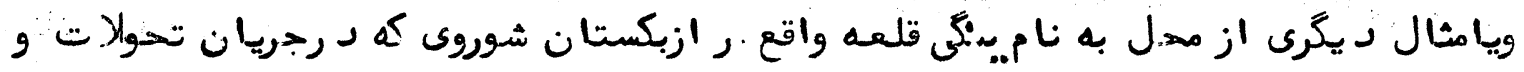

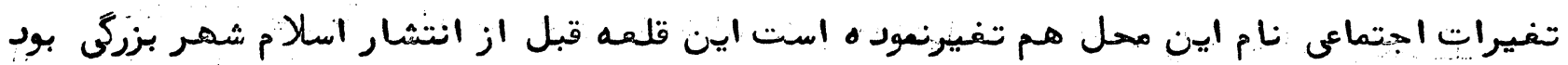

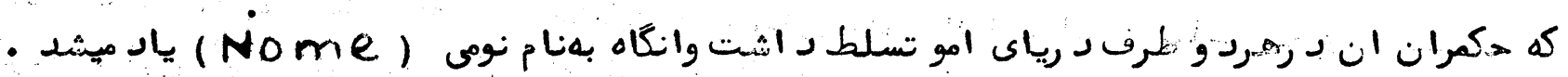

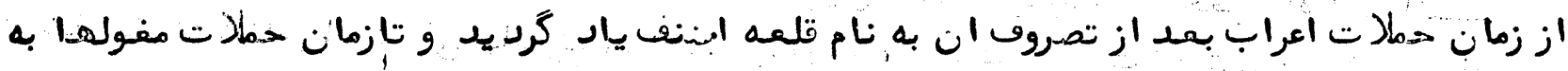

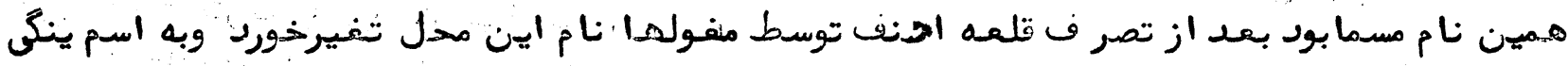

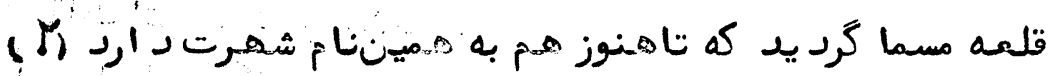
r- معلومات ماد ى :

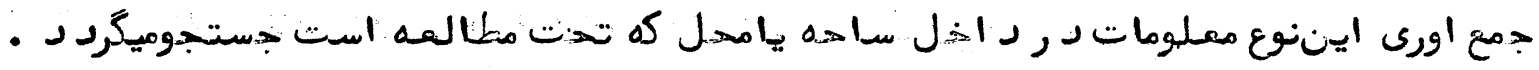

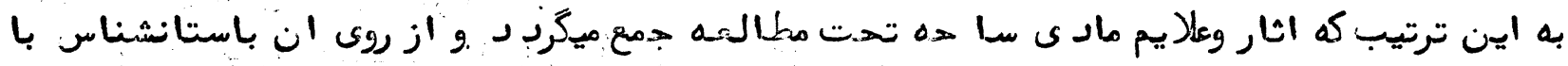

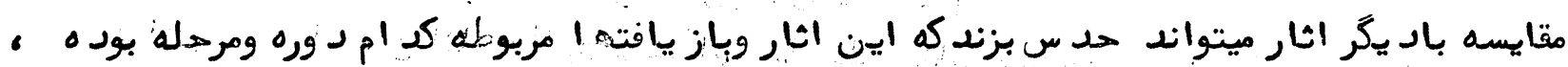

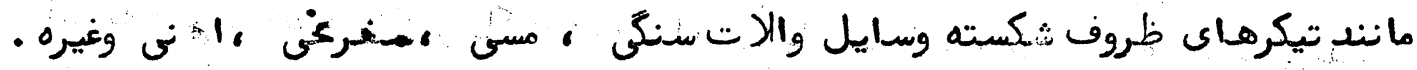

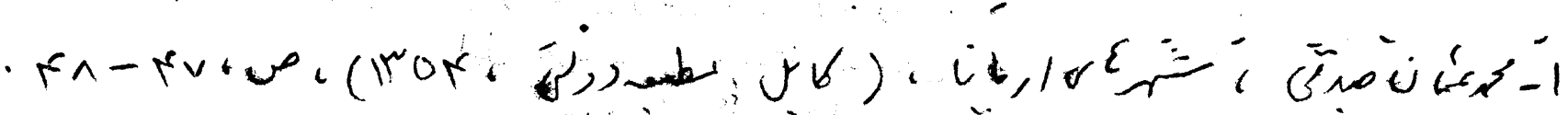
Wr- 
$-1 /$ -

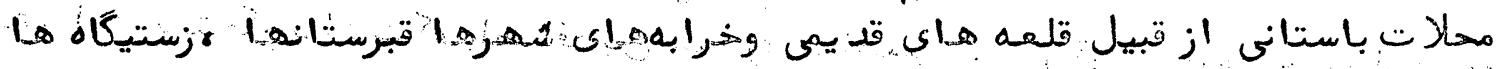

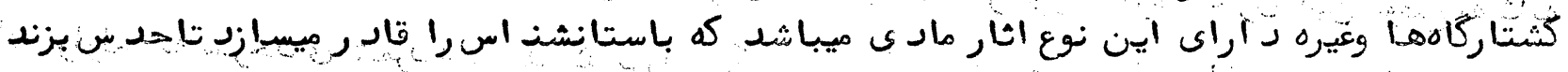

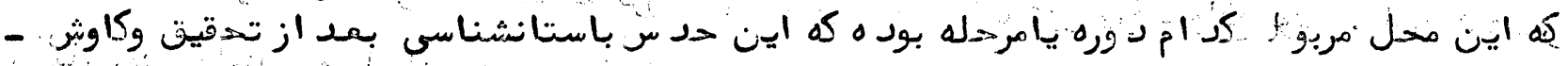

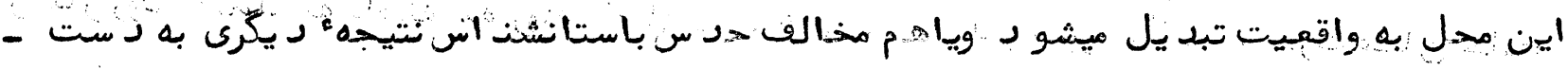

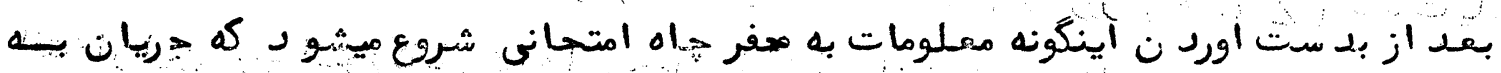

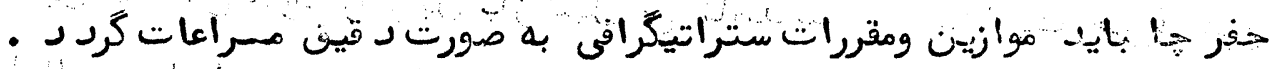

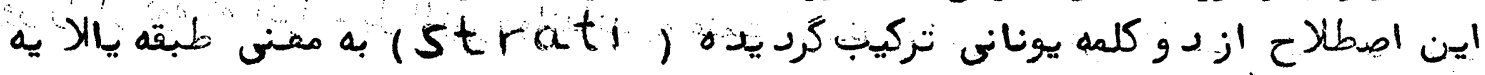

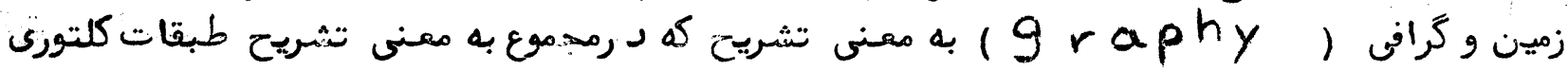

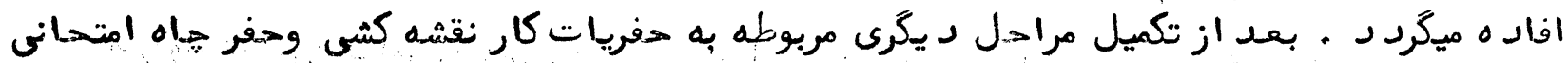

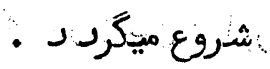

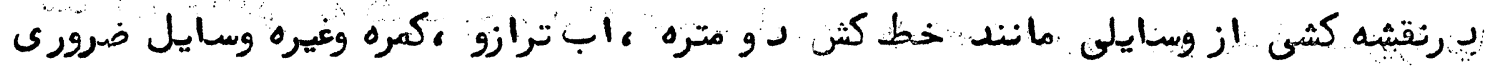

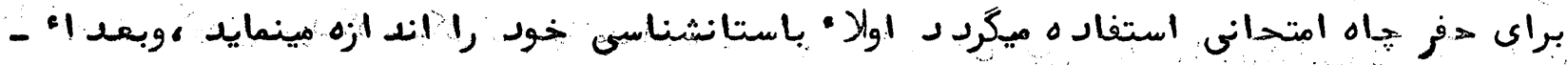

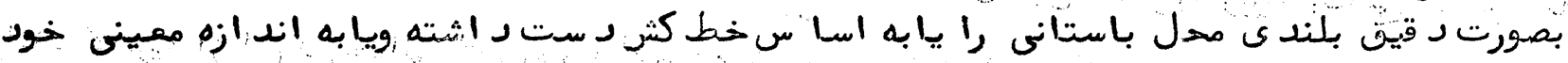

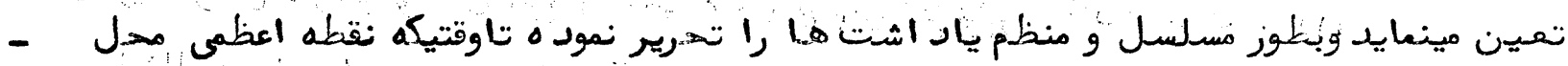

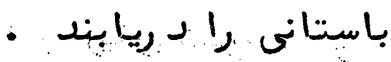

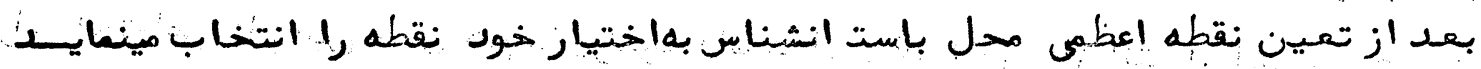

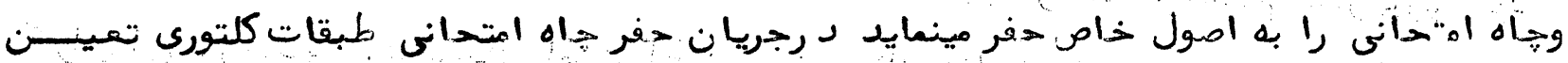

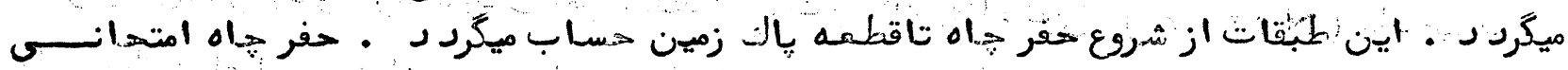

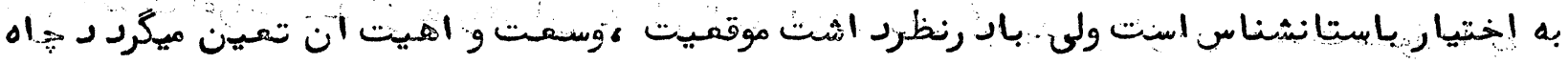

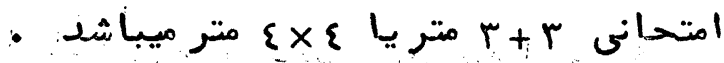

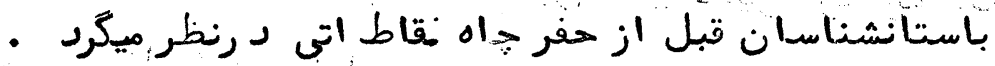

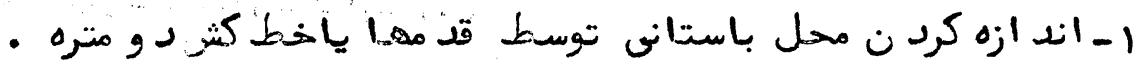

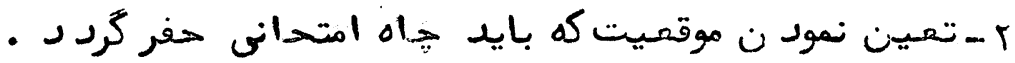

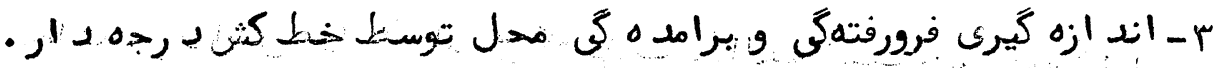

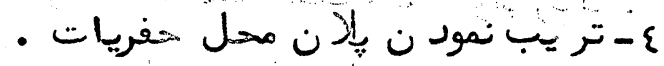

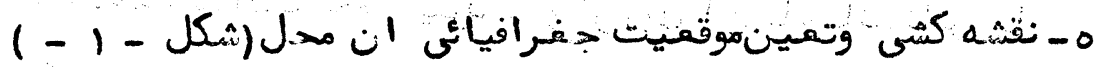

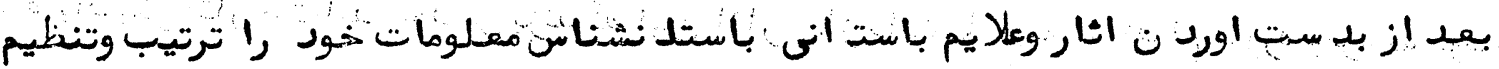

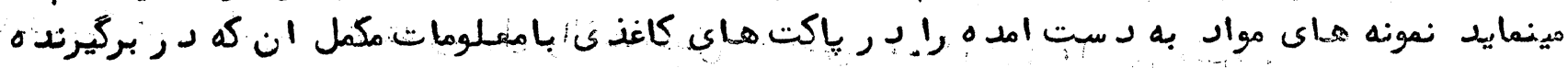

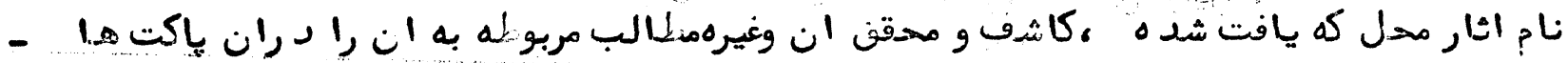

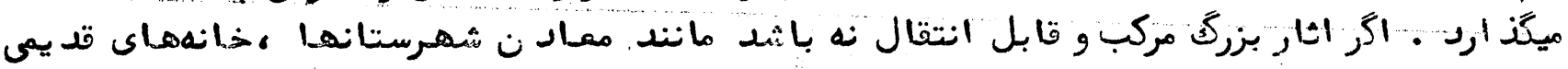

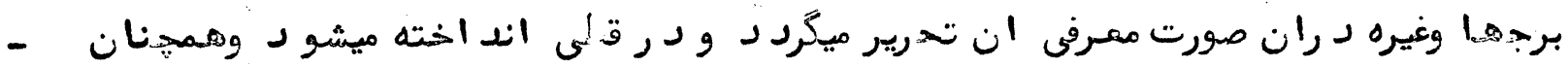

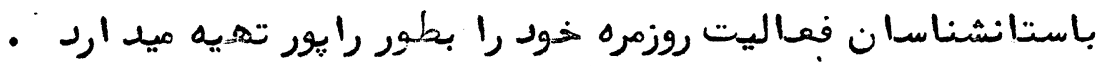

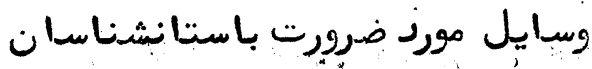

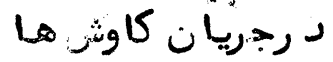

باستانشناسا ن قبل از شروع كاوثر وتحقيق وسايل ذيل راوثل را بايد’ اماده سـا زد . 
$-19-$

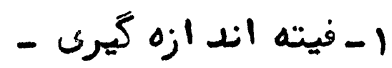

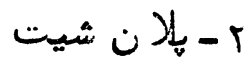

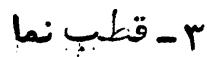

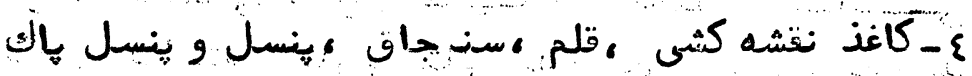

هـ - اب ترازو

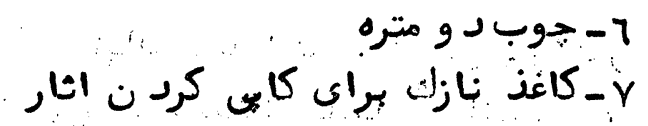

1-

?

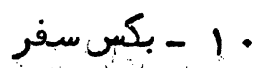

0 -il

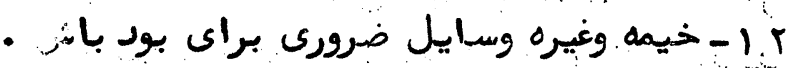

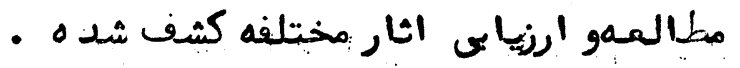

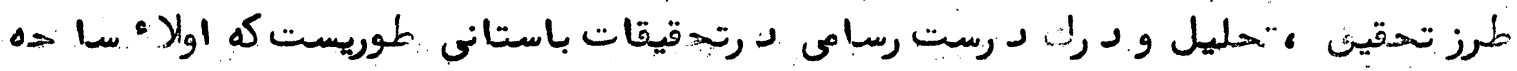

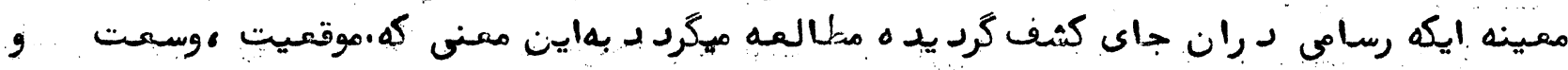

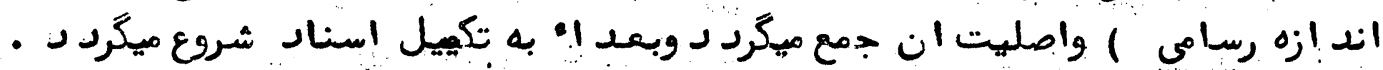

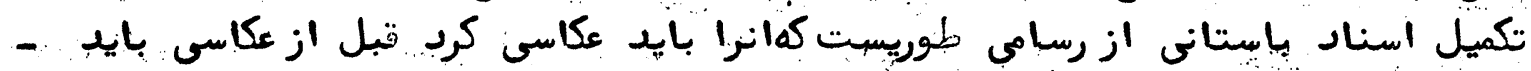

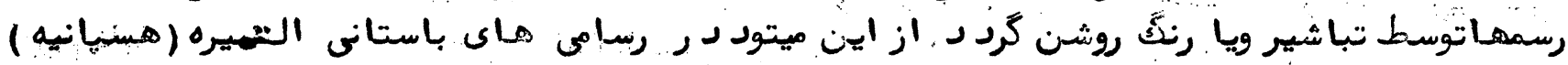

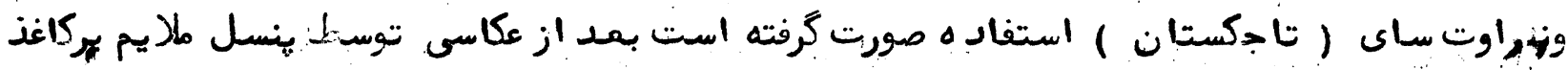

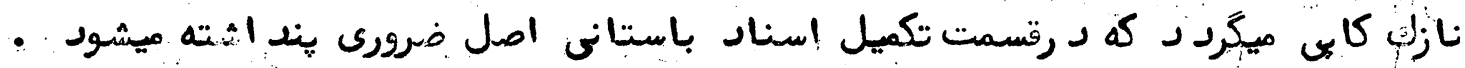

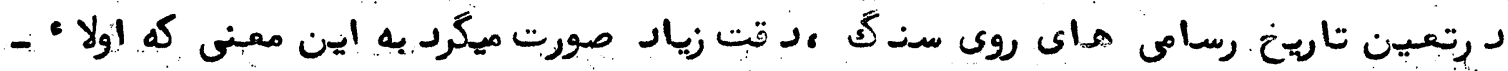

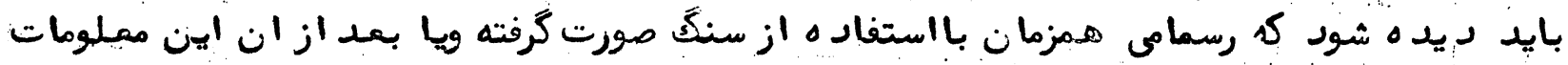

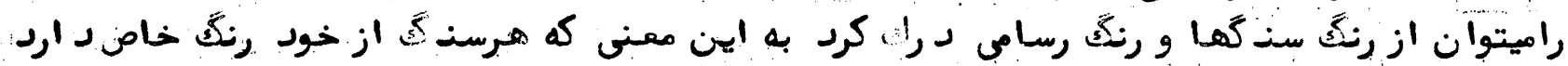

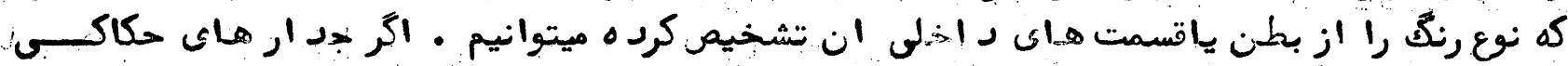

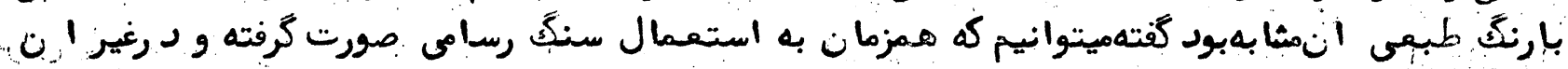

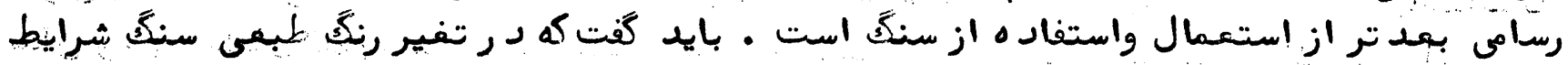

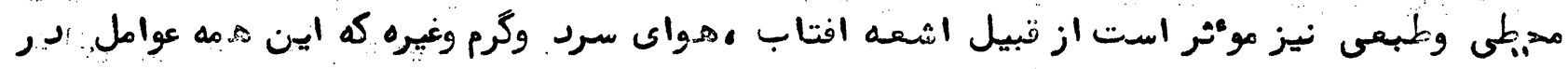

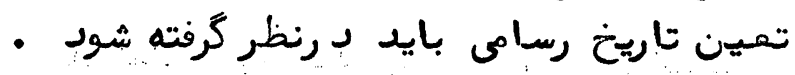




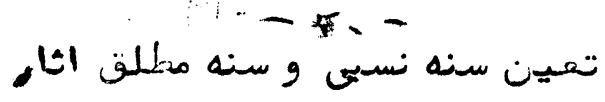

باستان

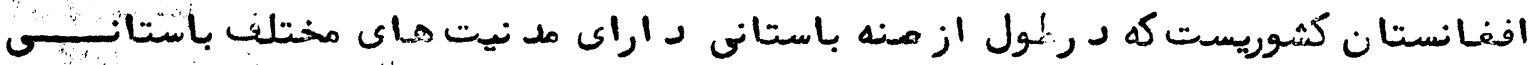

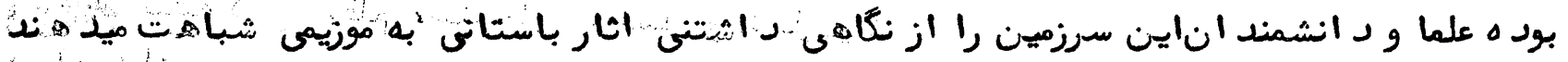

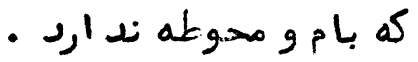

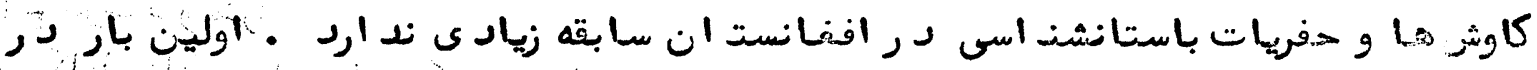

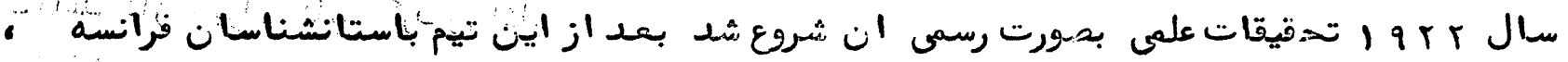

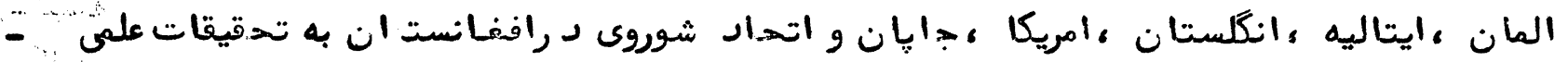

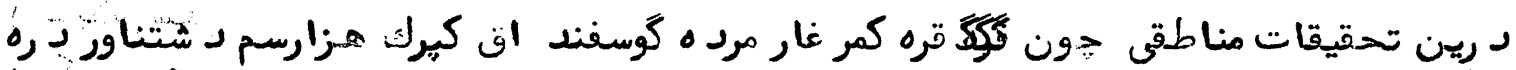

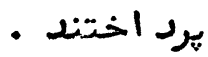

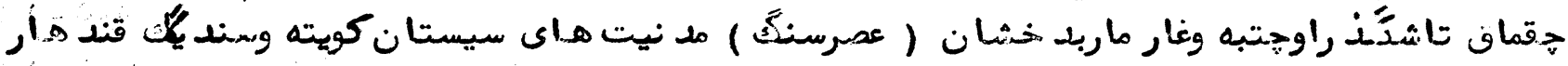

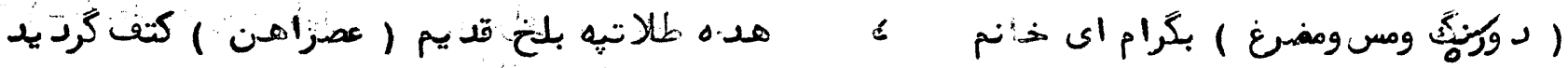

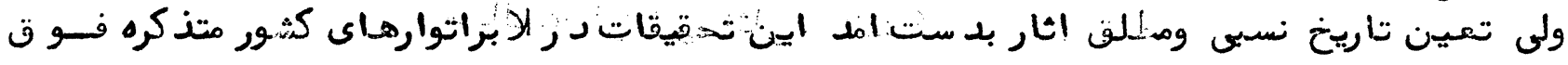

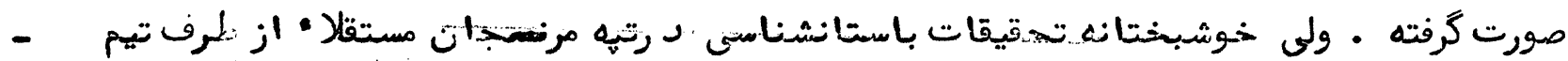

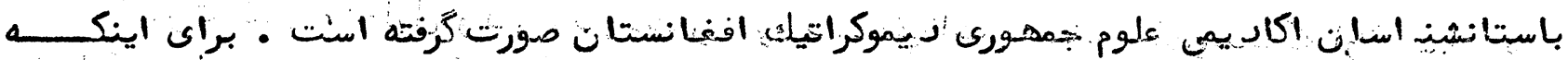

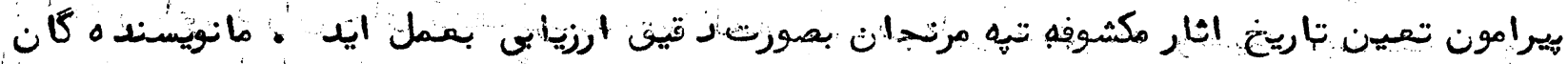

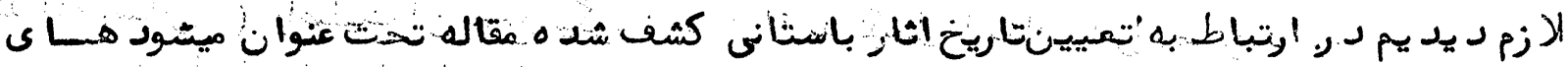

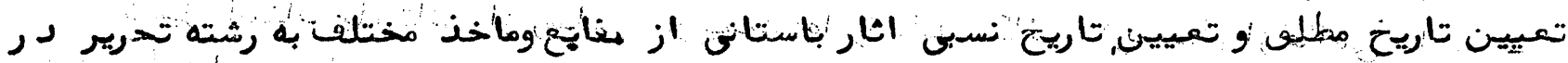

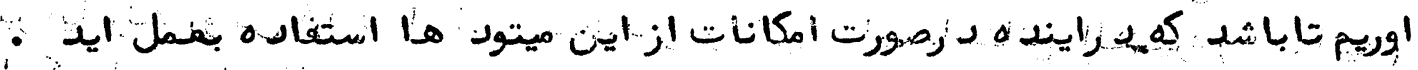

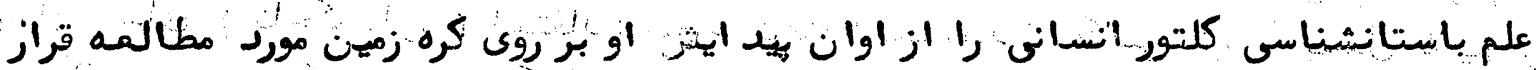

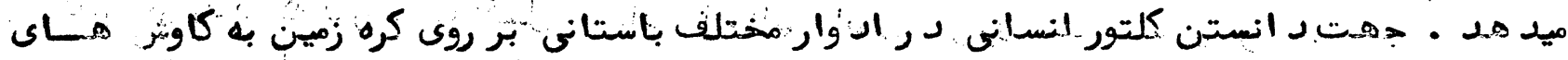

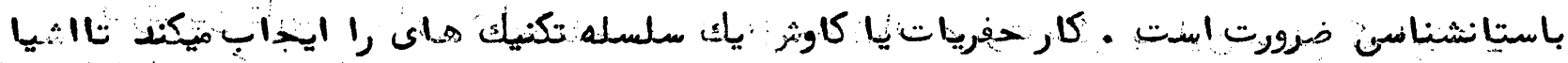

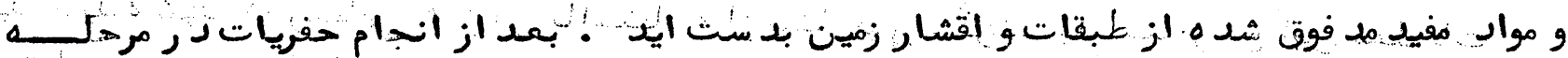

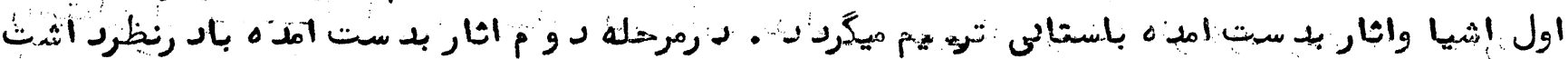

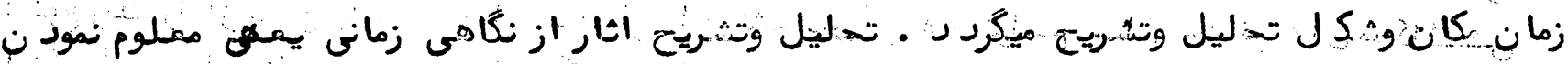

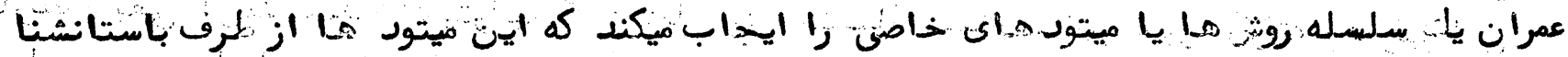

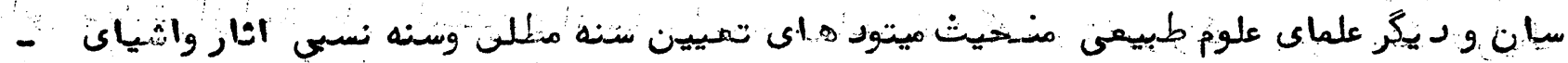

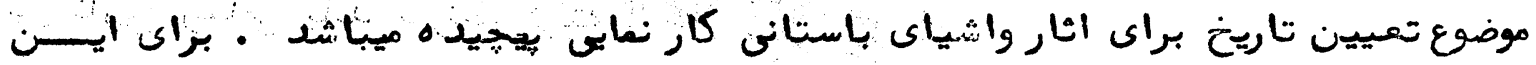

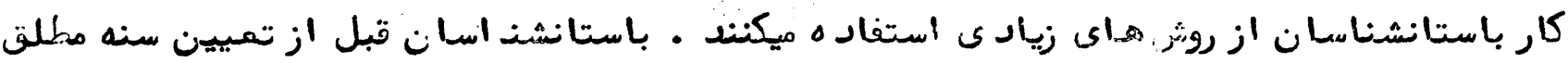

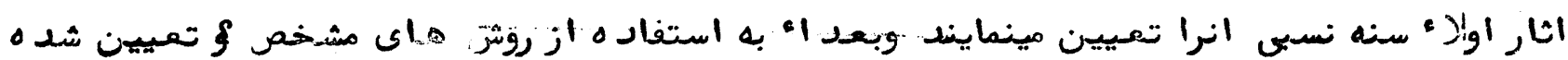

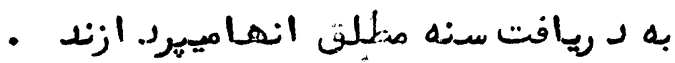

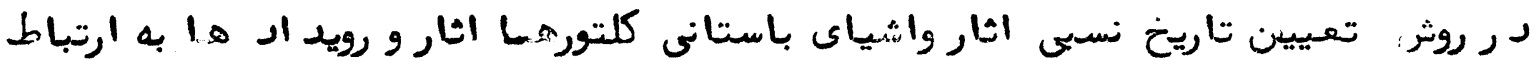

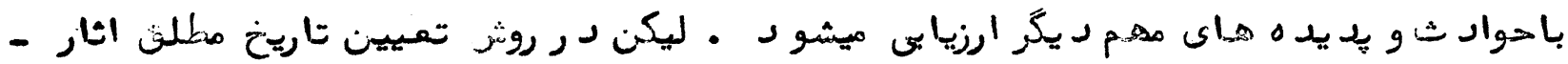

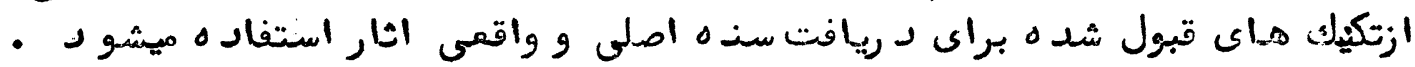


$-Y t-$

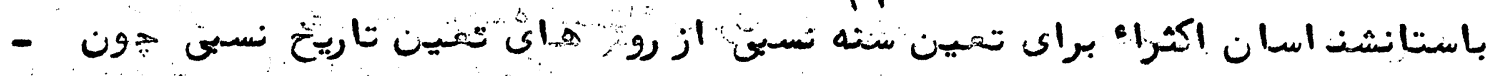

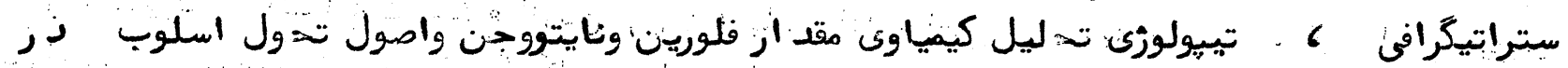

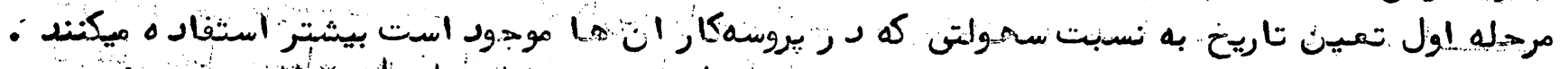

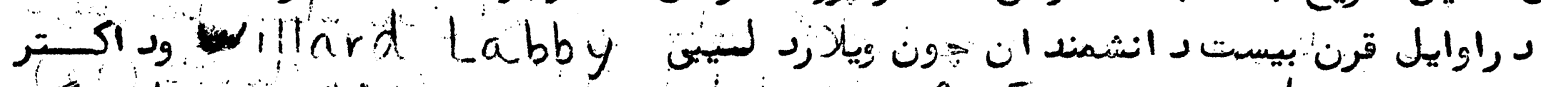

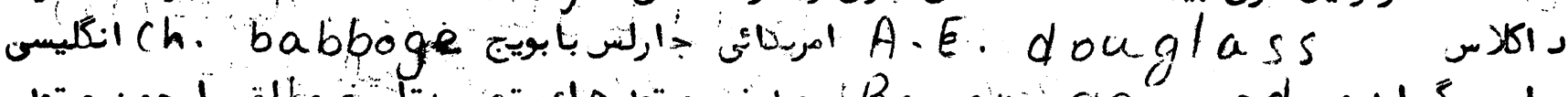
وبارون گيراردى Baron gerard

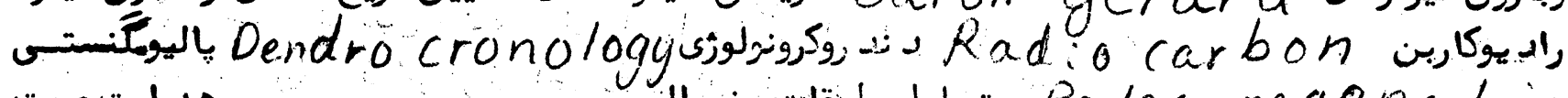
وفمد ايت صوت Paleo manatic

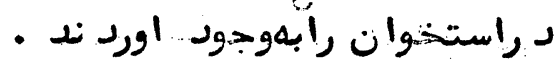

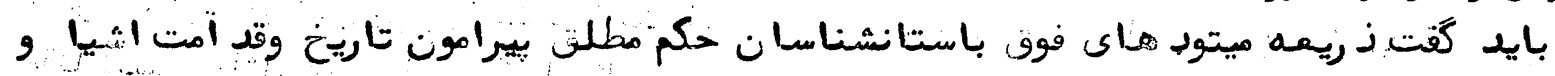

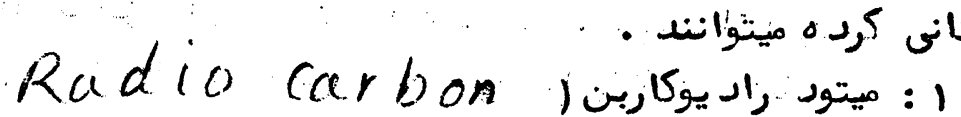

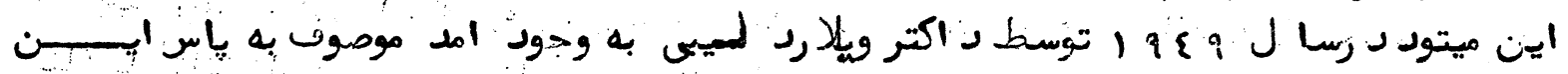

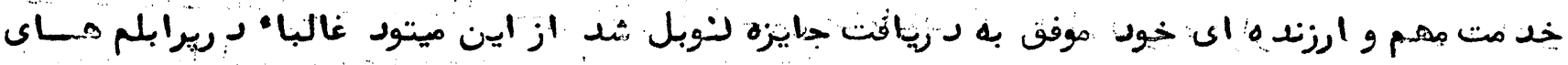

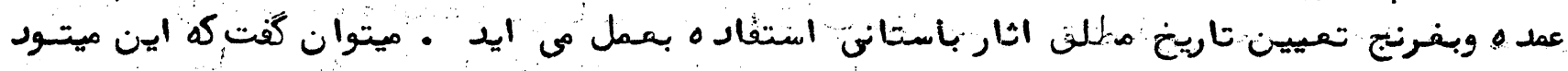

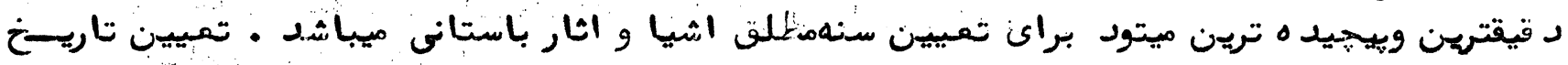

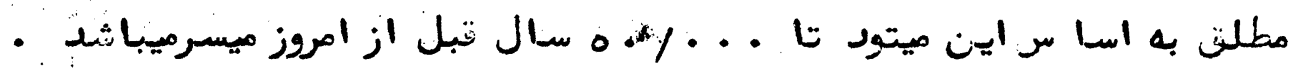

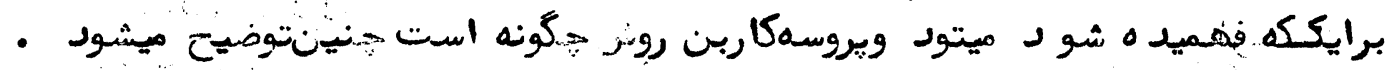

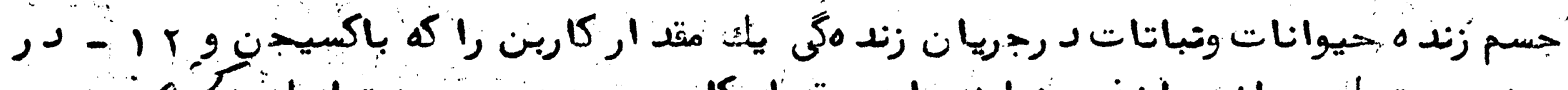

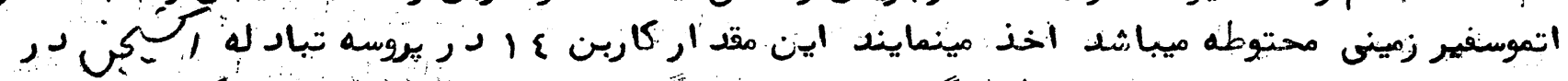

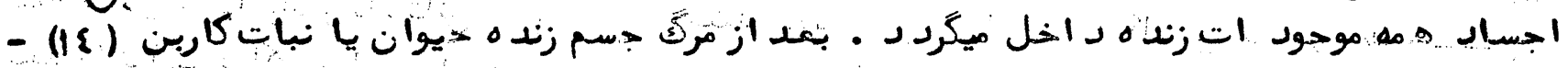

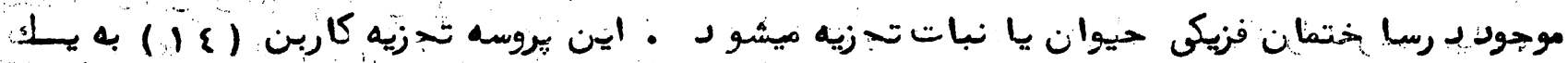

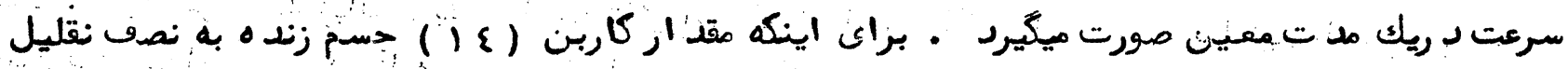

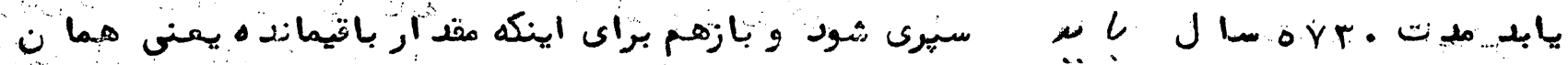

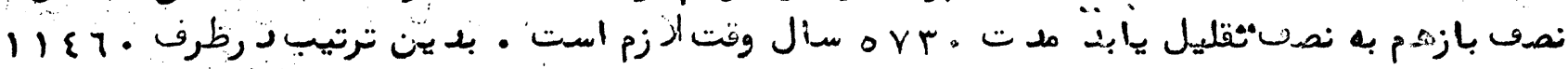

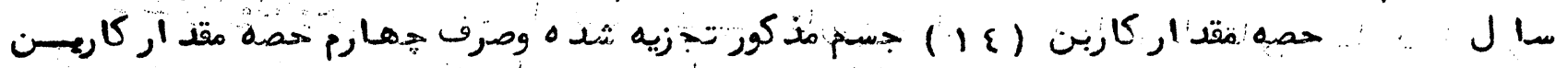

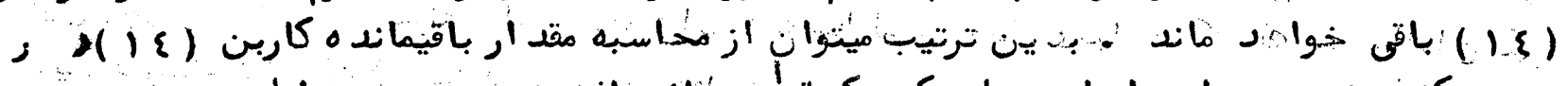

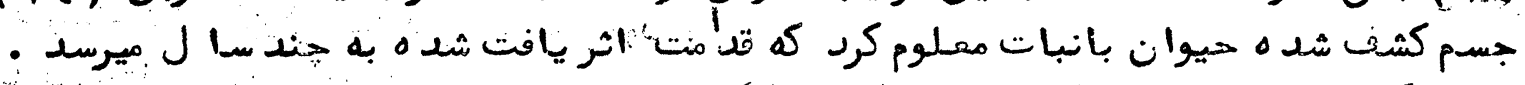

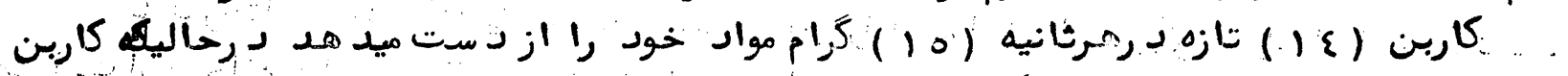

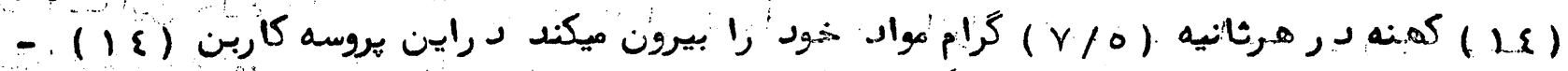

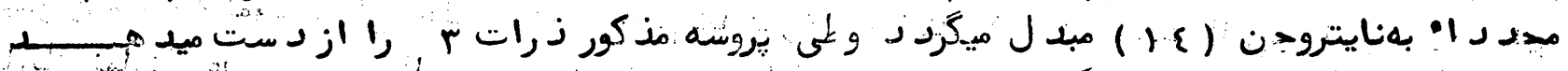

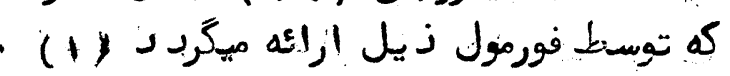
$-1\{-1\}$

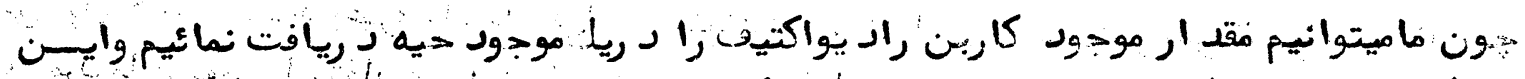

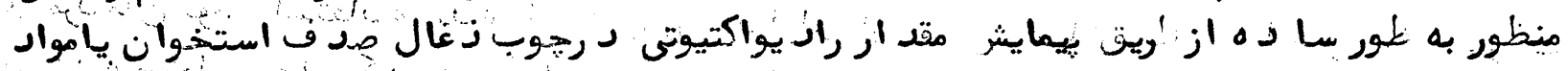

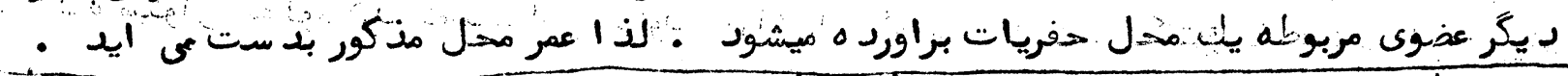

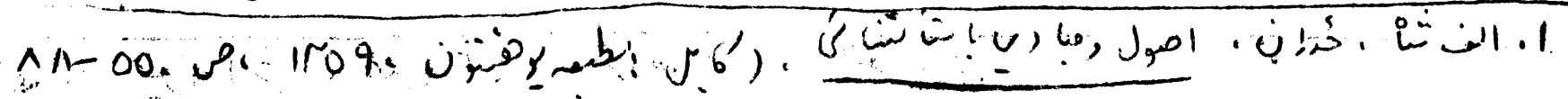




\section{$-r T-$}

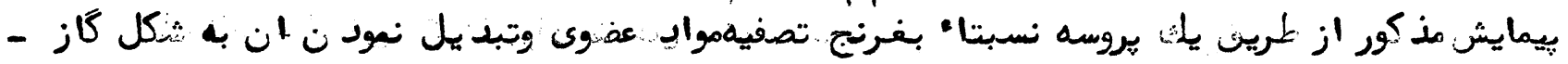

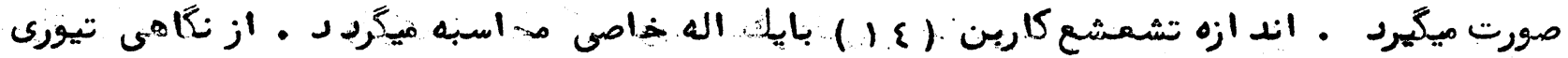

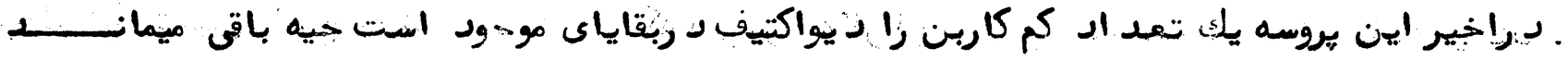

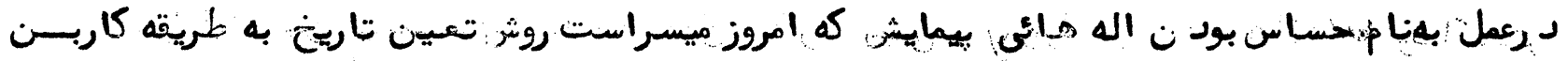

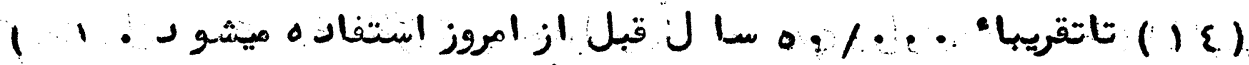

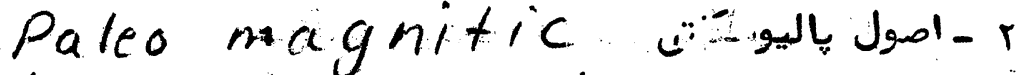

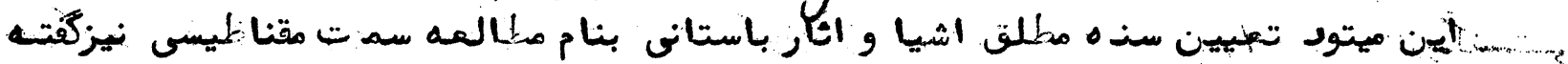

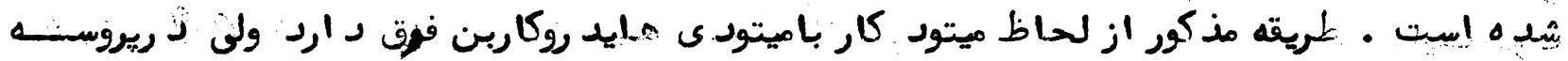

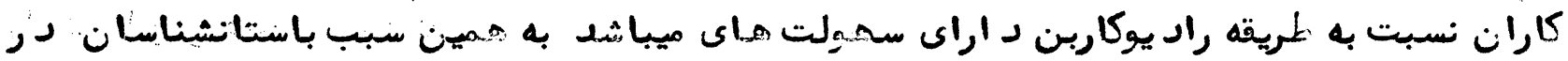

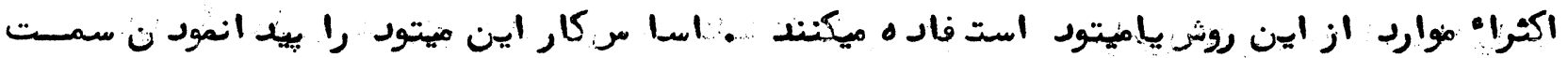

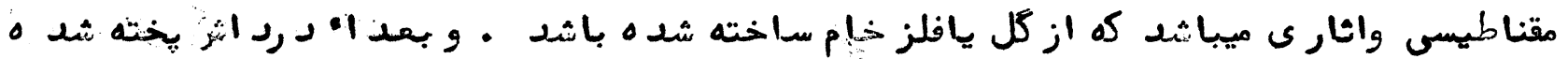

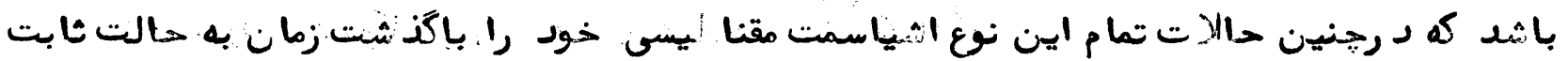

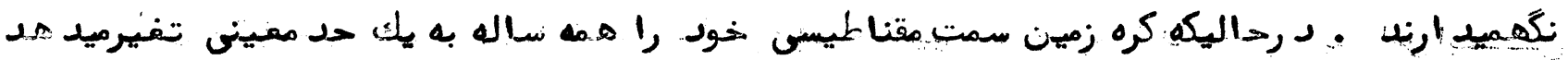

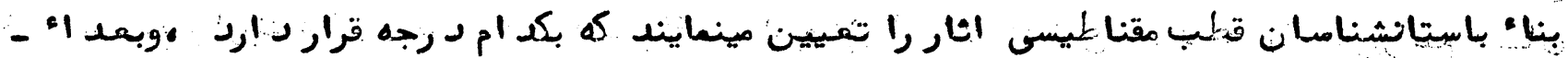

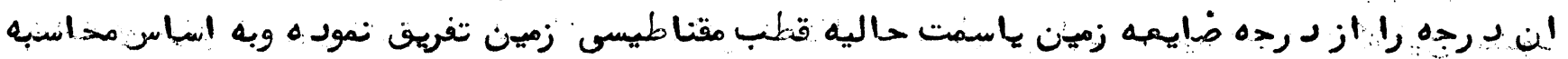

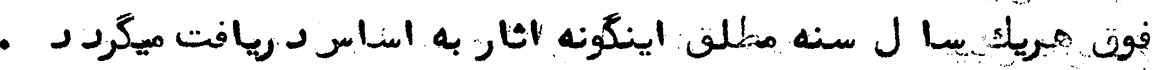

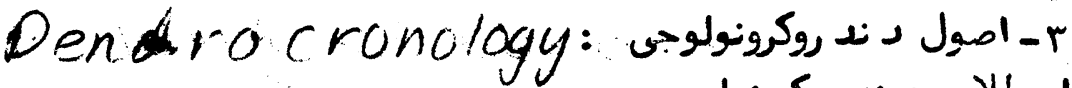

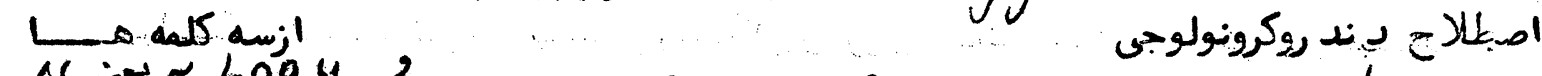

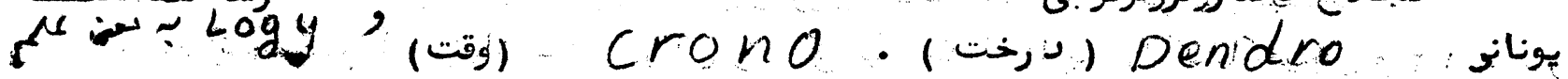

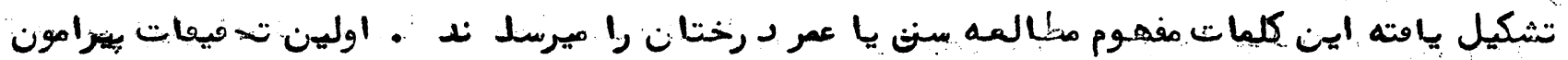

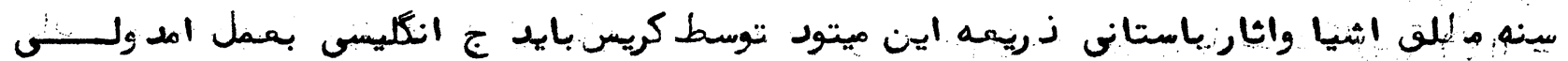

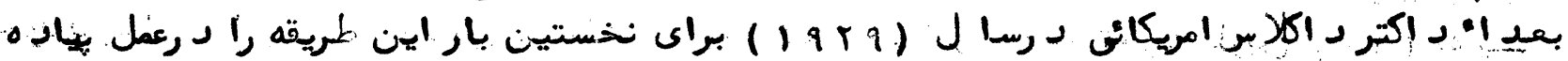

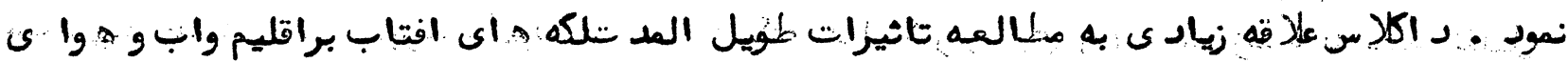

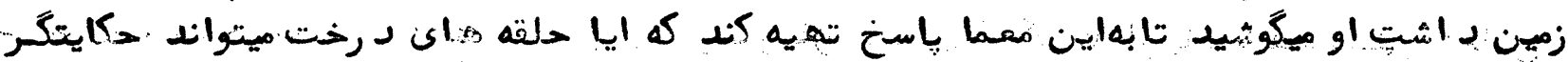

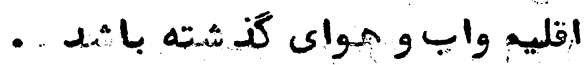

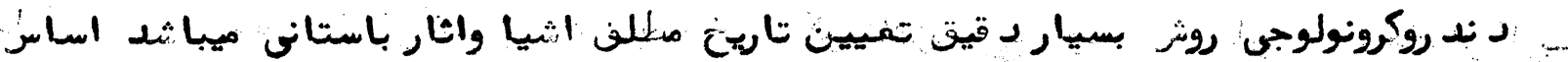

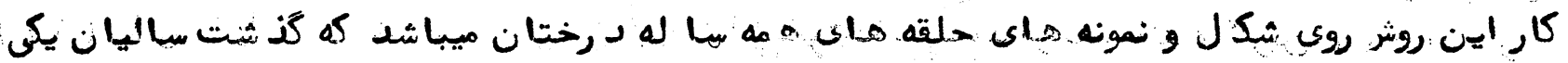

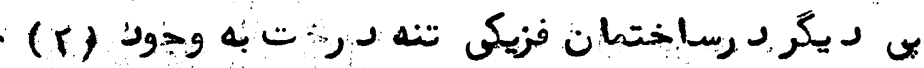

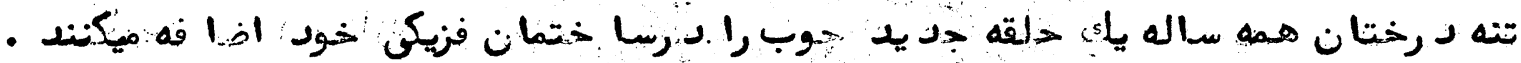

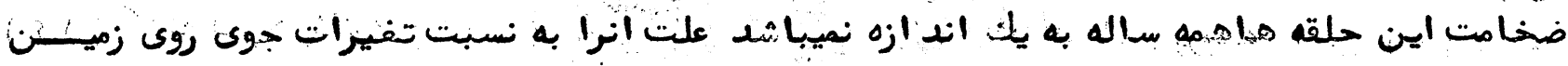

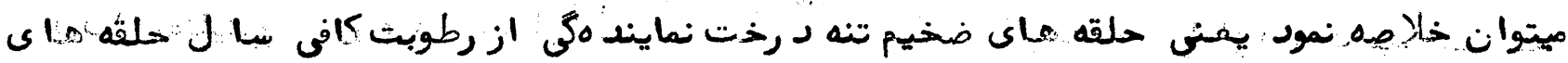

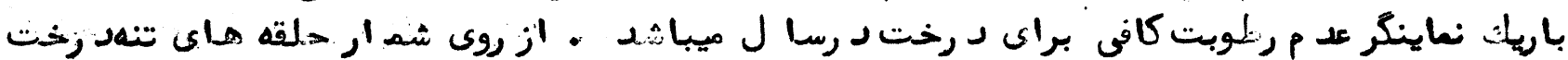

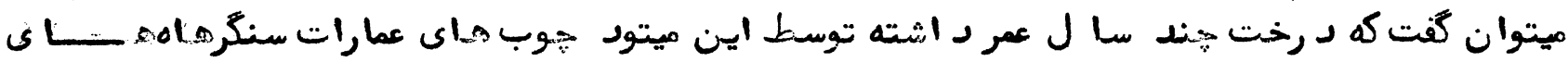

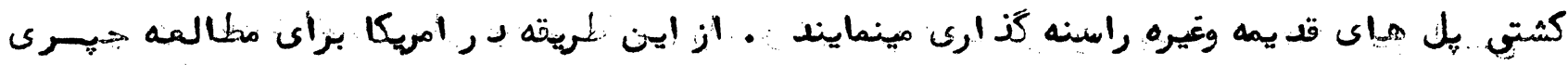

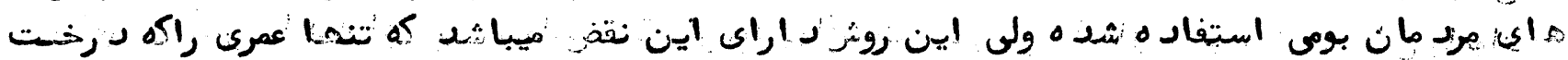

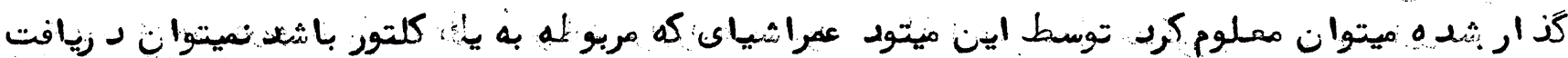

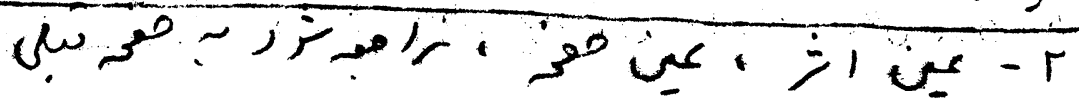




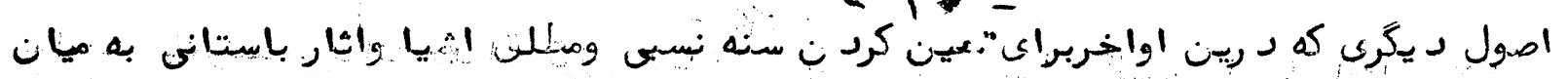

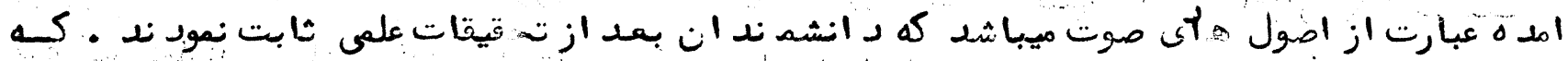

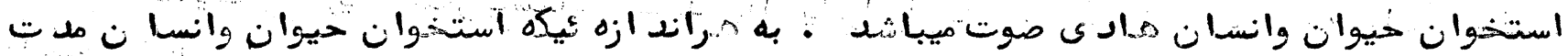

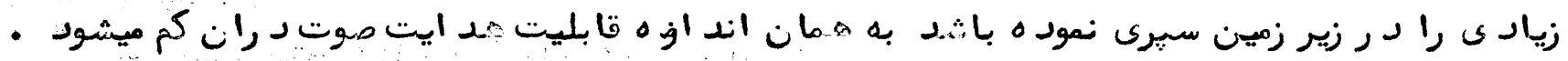

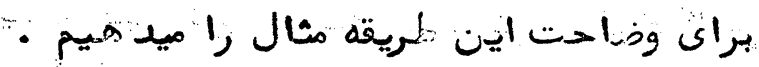

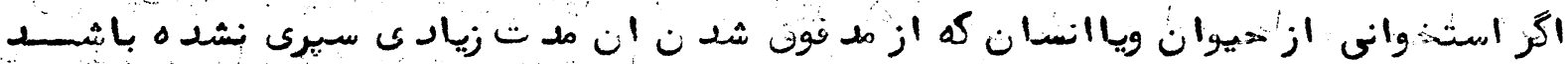

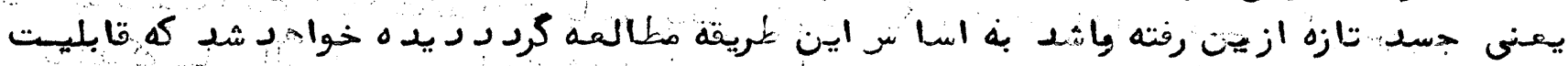

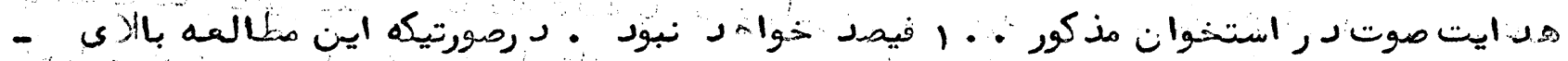

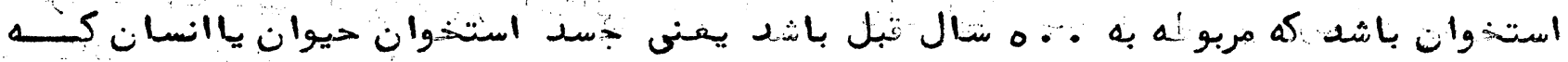

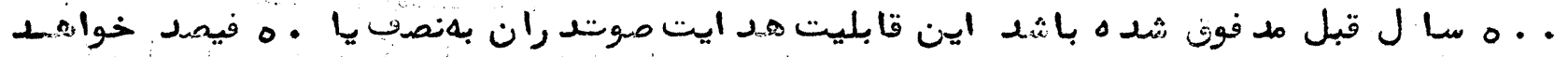

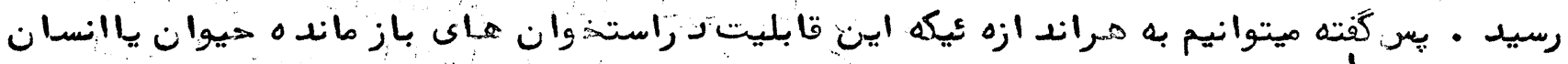

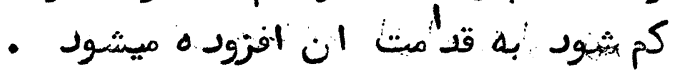

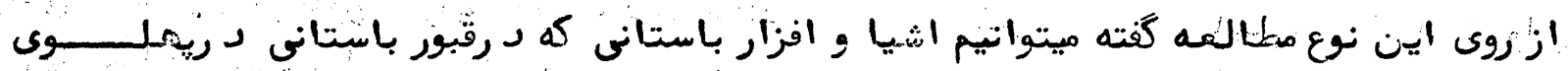

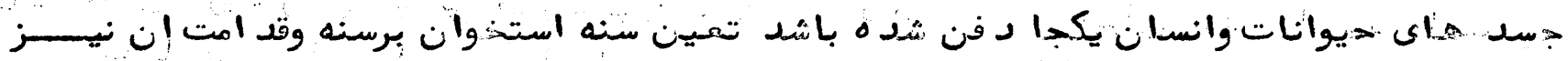

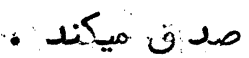

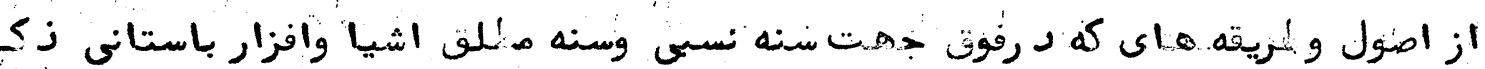

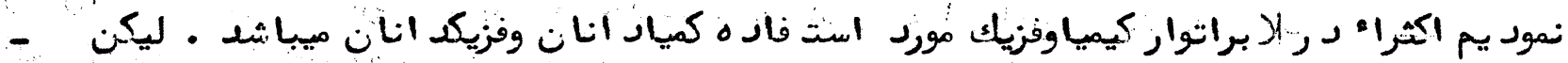

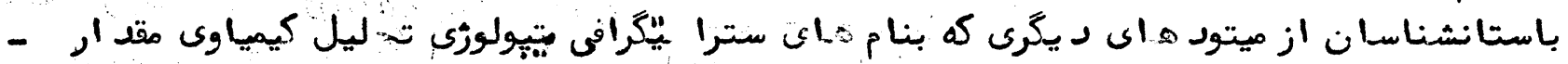

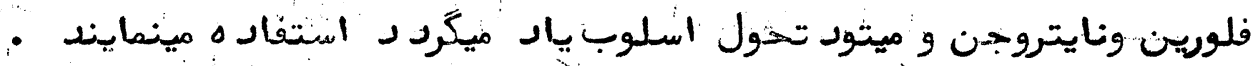

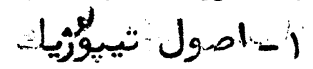

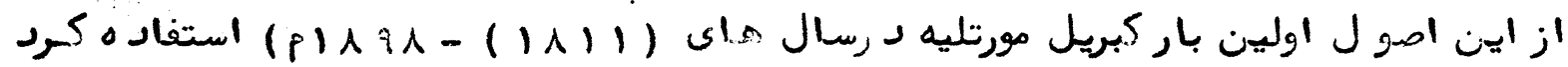

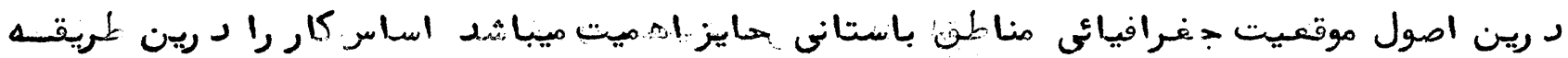

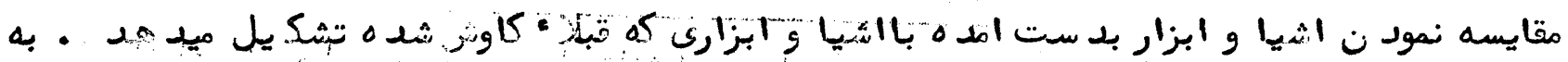

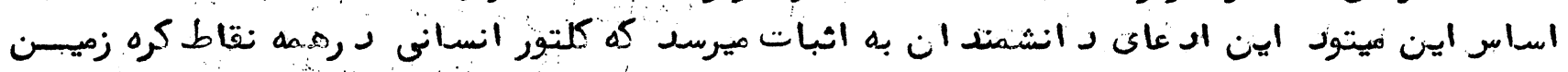

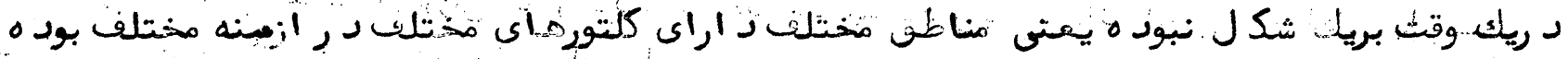

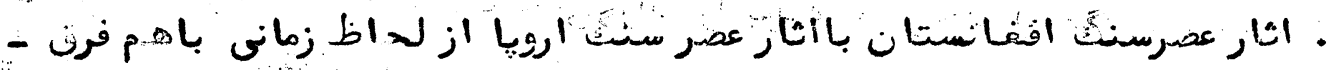

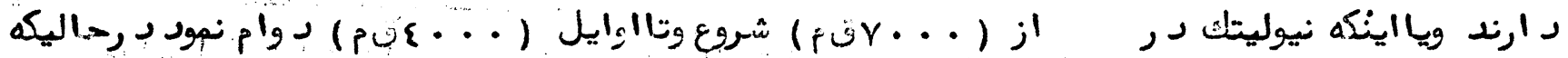

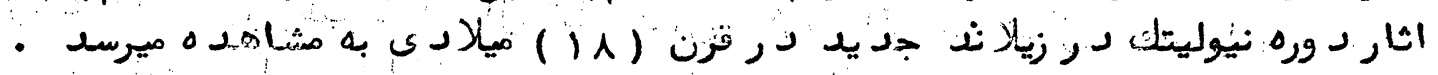

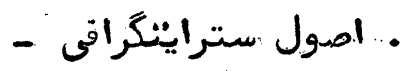

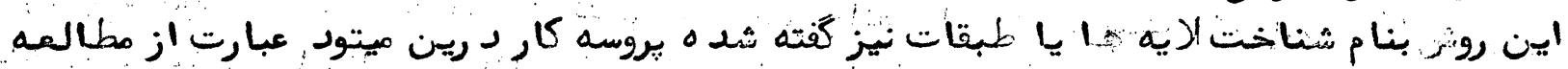

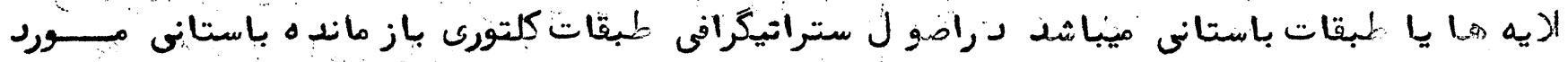

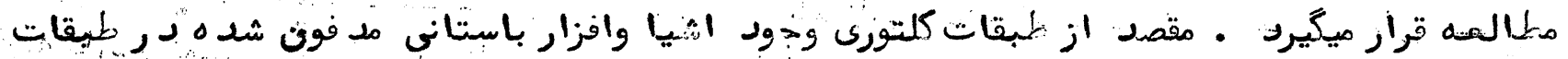

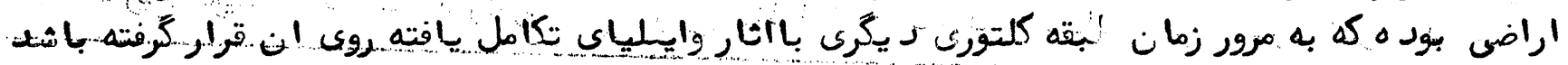

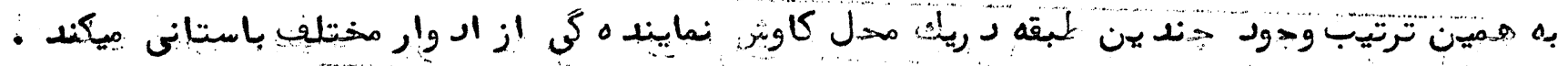

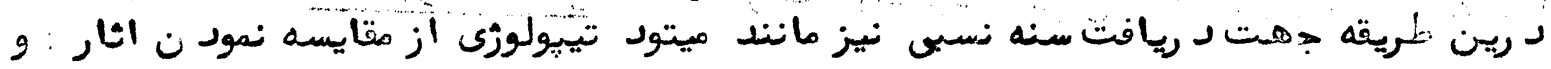

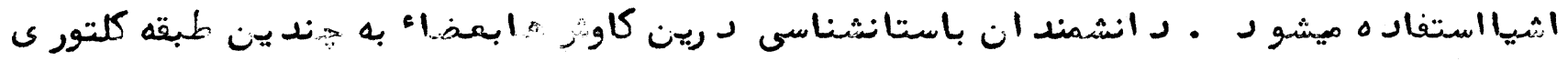

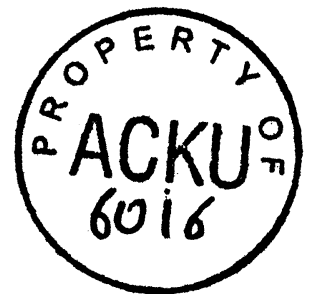




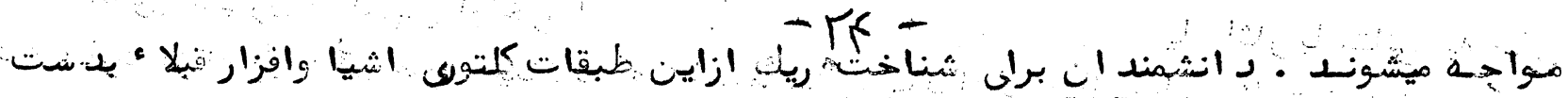

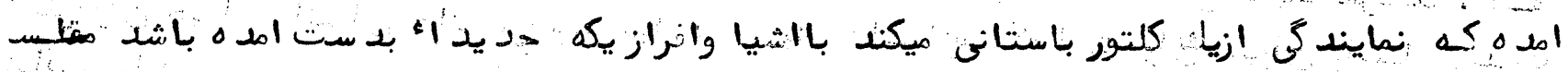

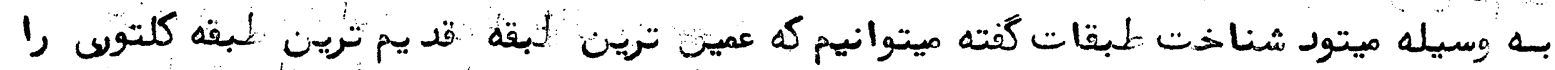

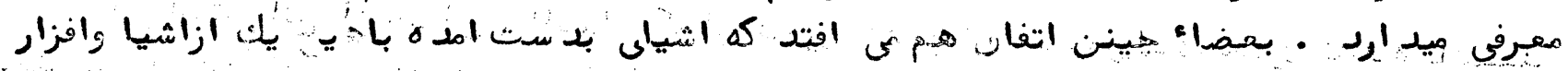

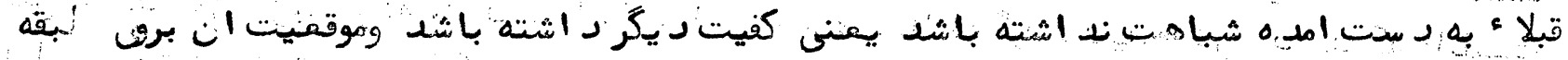

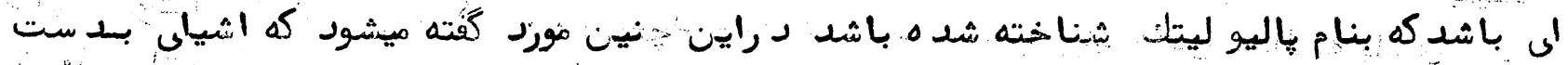

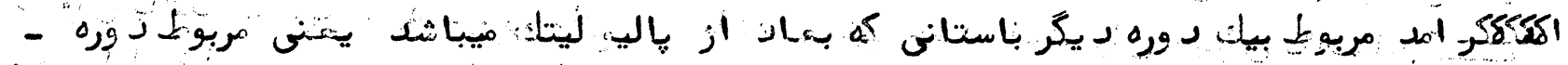

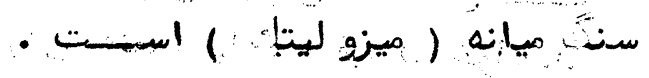

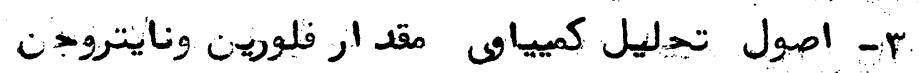

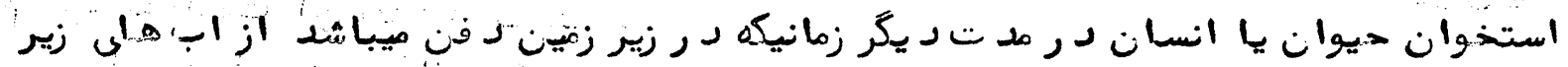

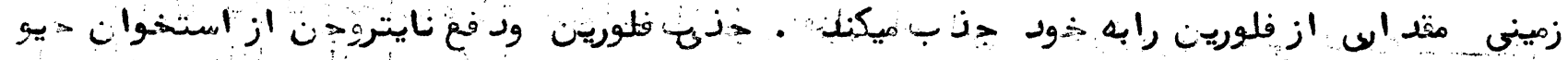

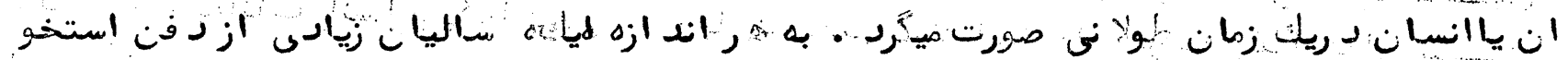

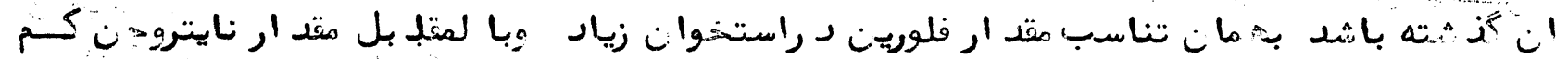

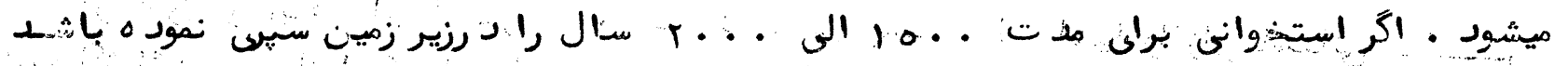

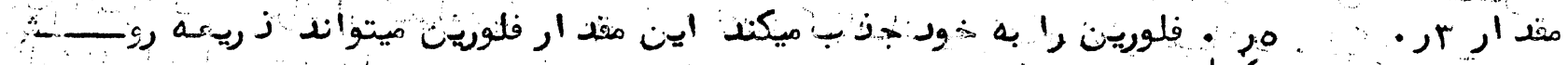

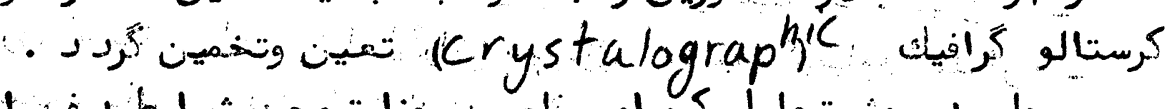

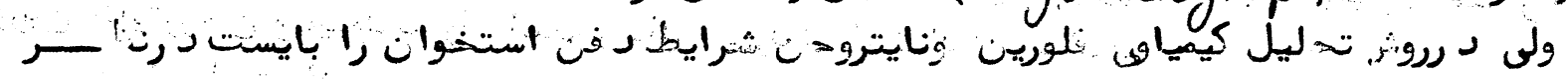

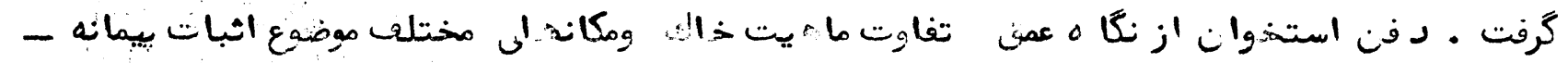

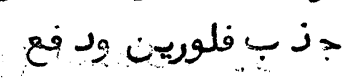

\section{مفنمو مد نيت د ر باستانشانى}

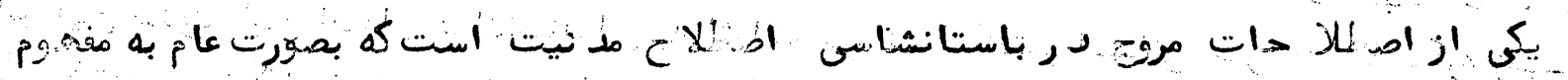

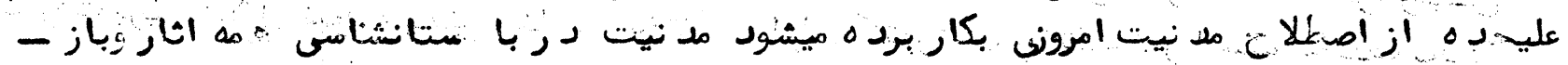

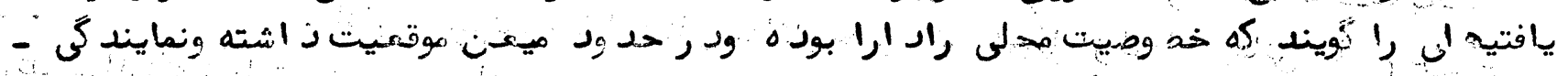

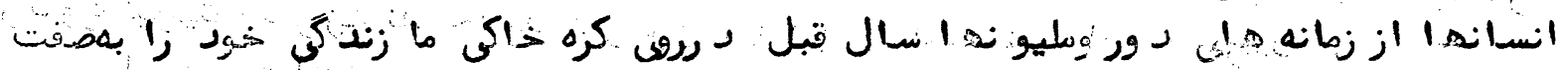

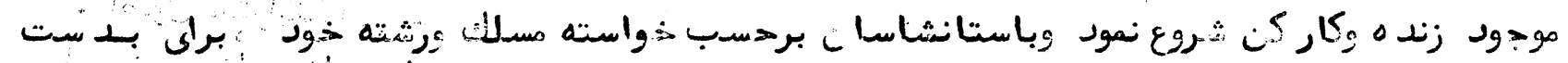

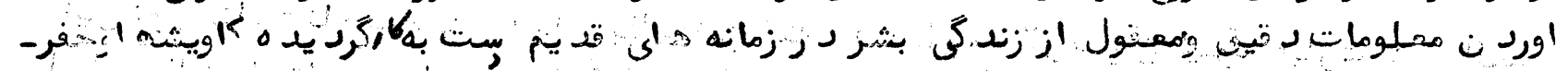

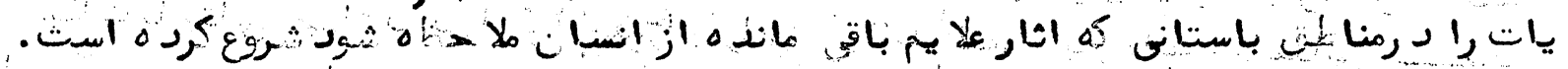

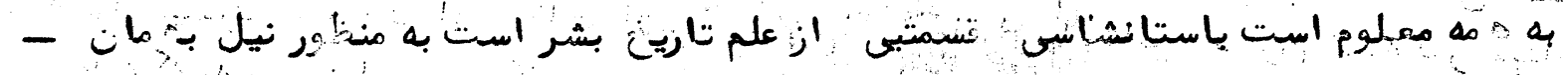

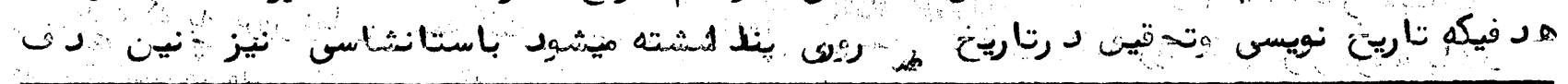

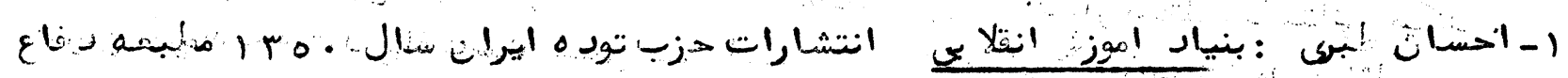
$99: 0$ : 90 


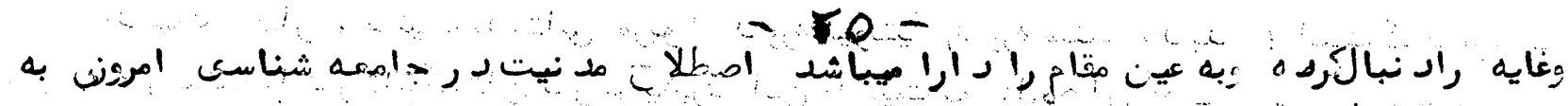

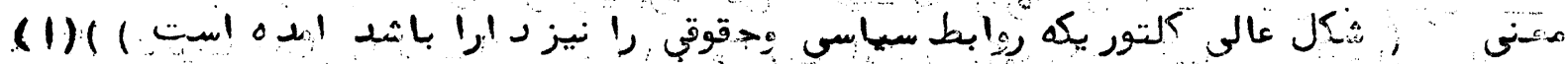

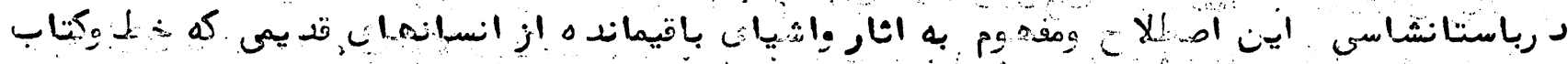

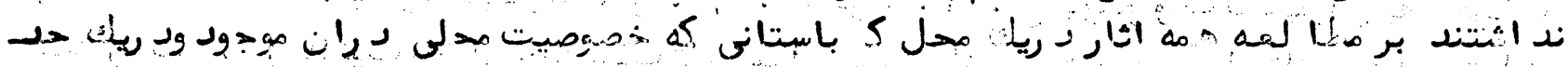

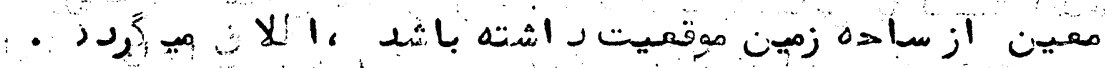

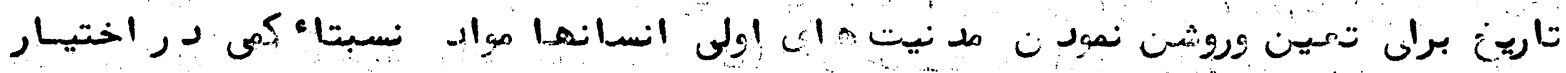

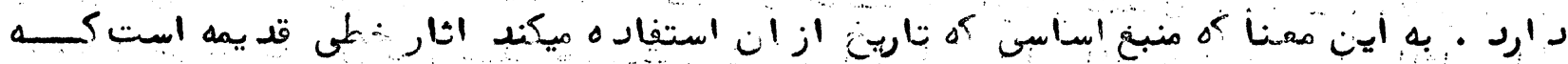

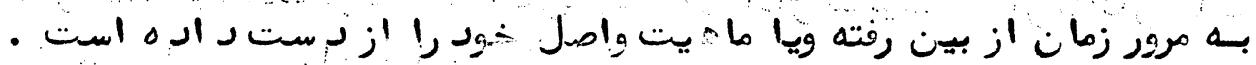

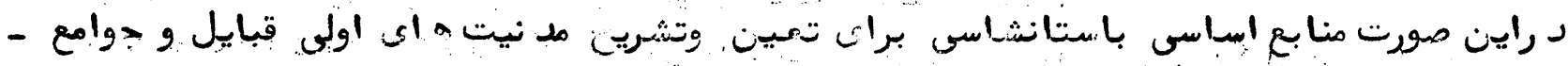

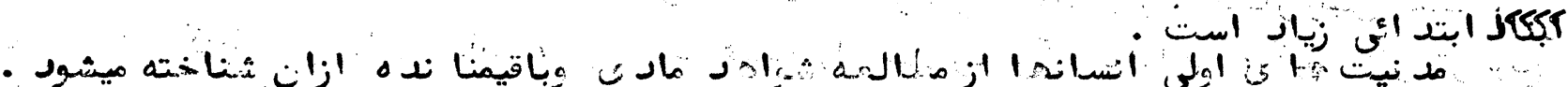

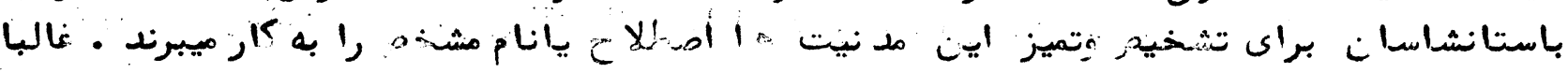

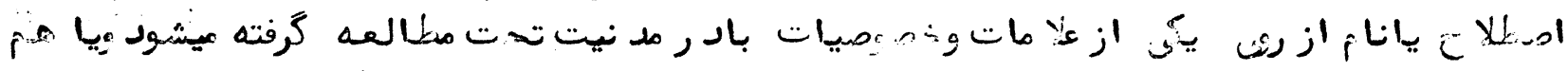

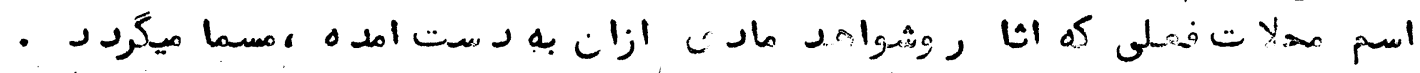

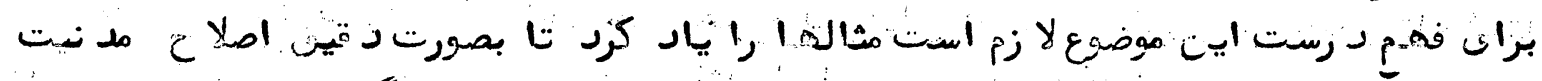

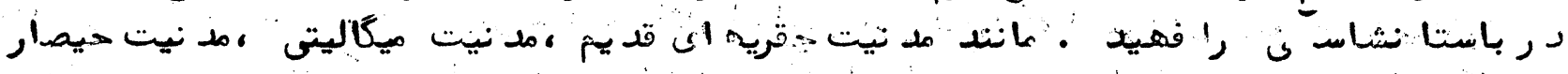
-

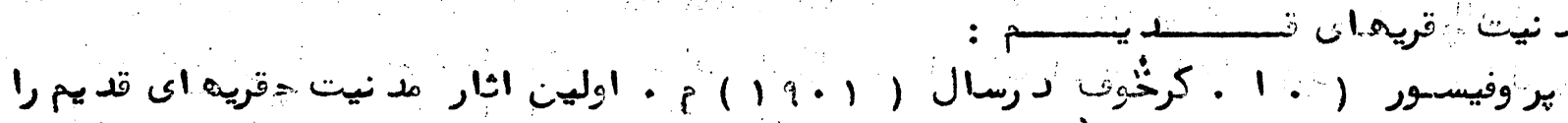

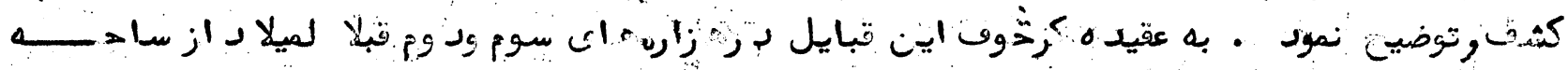

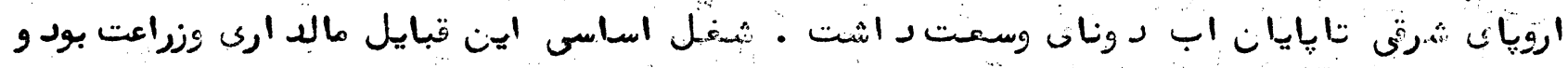

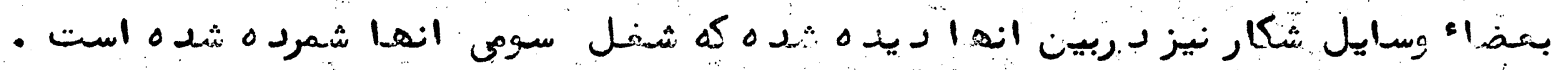

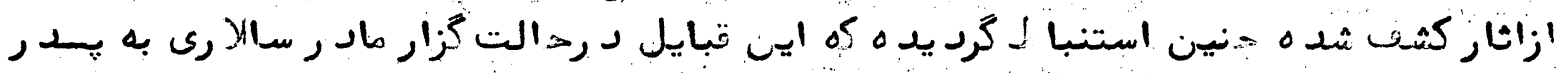

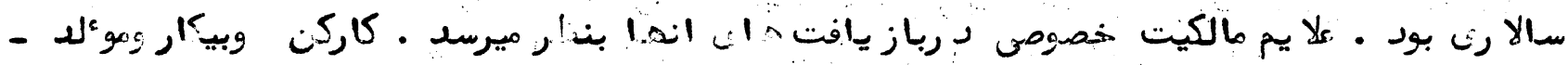

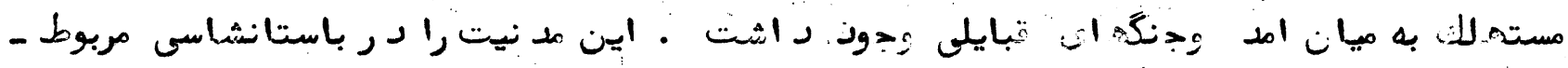

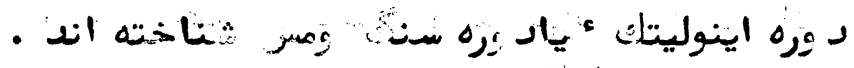

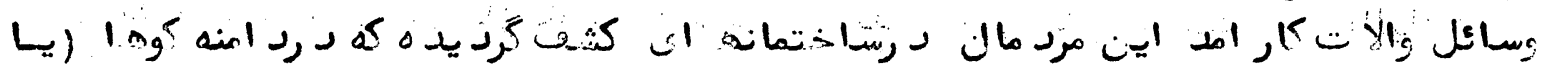

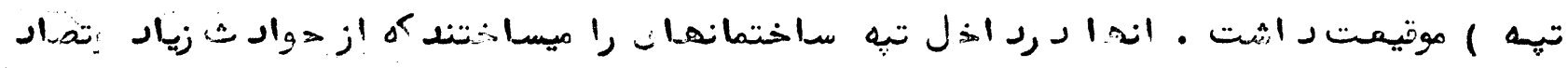

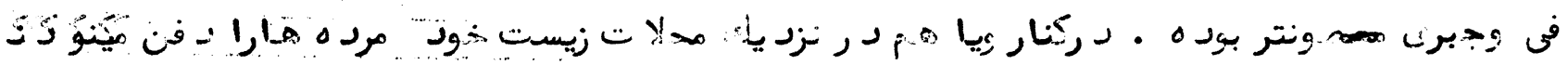

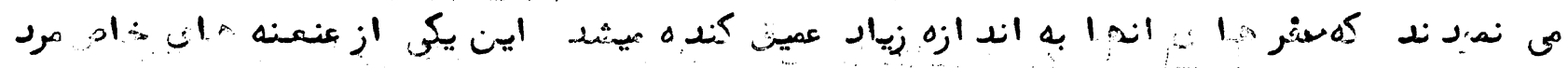

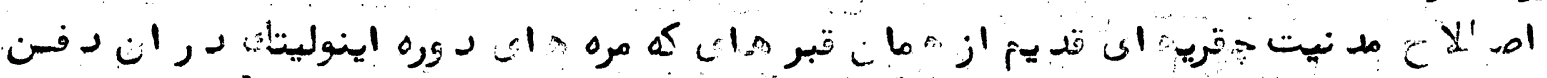

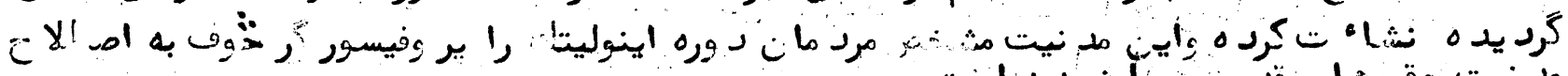

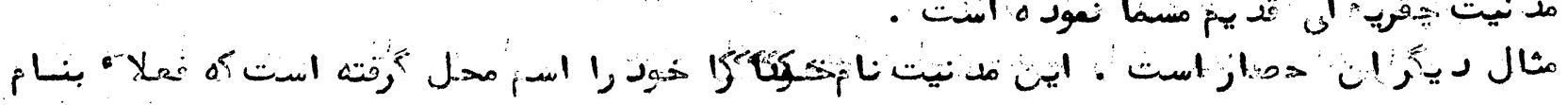

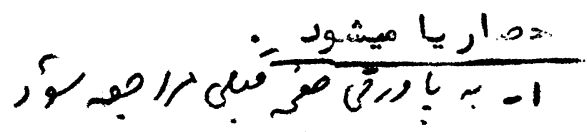




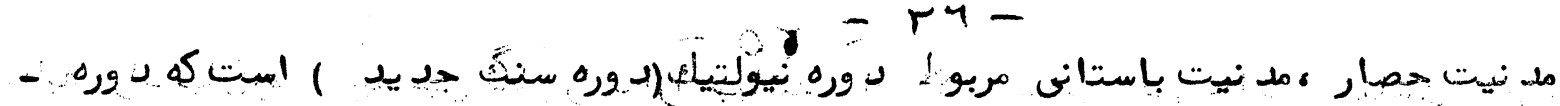

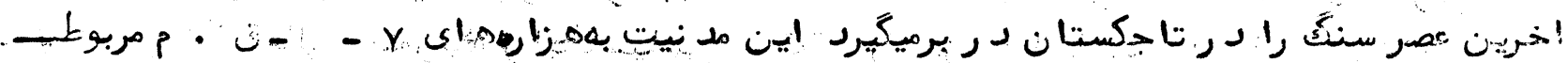

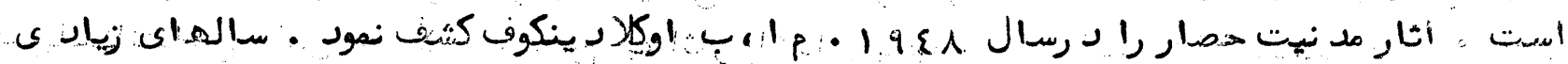

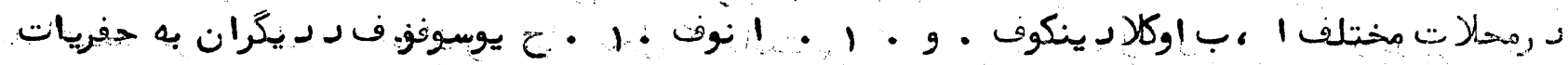

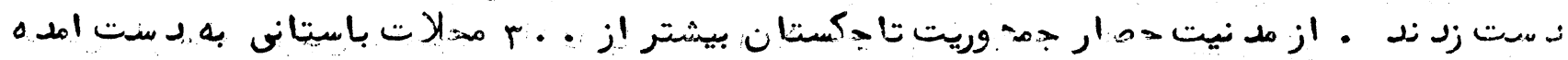

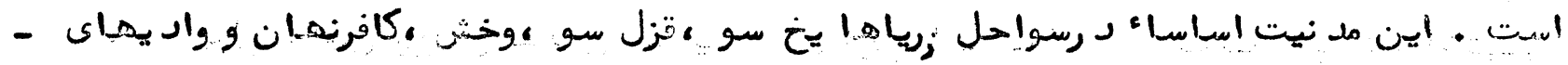

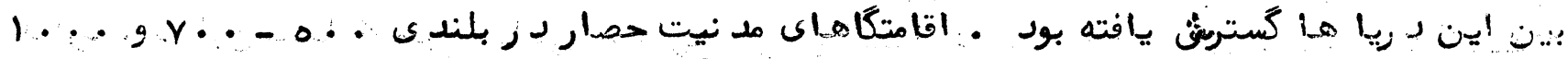

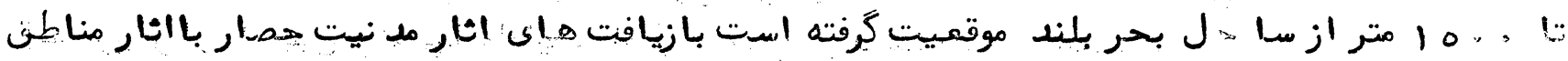

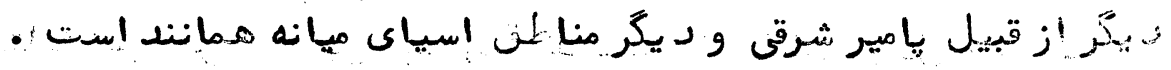

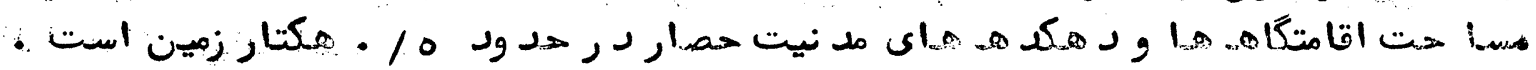

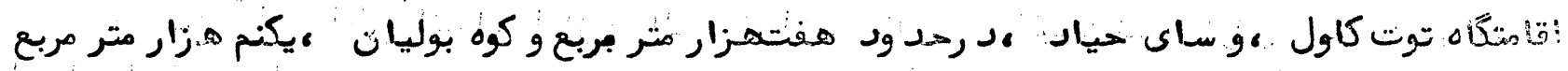

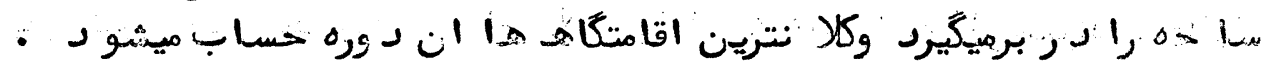

: مل نيتت وخشر:

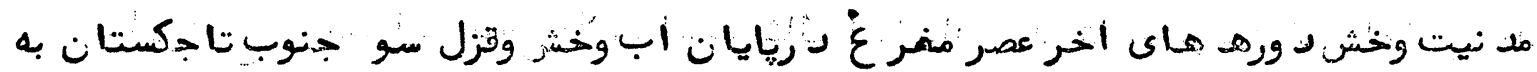

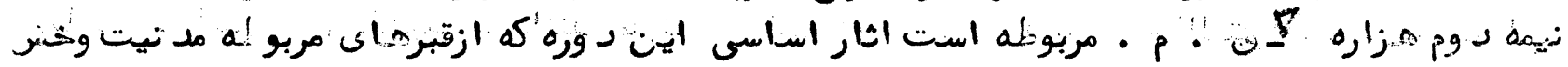

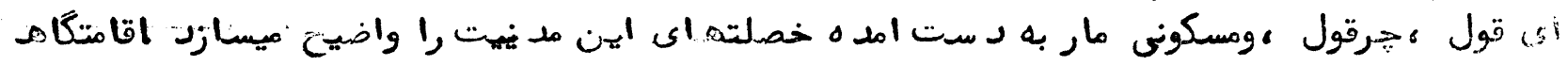

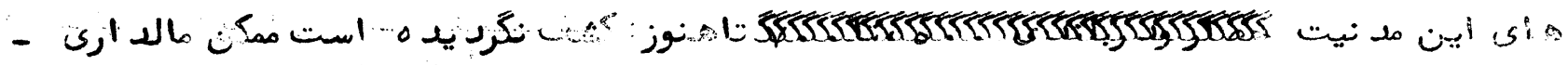

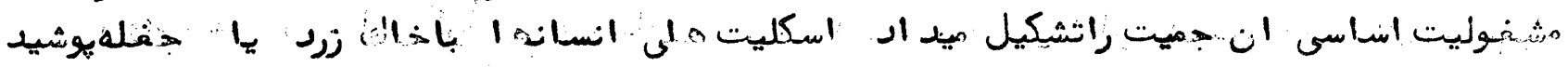

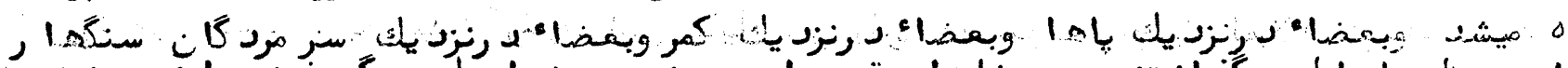

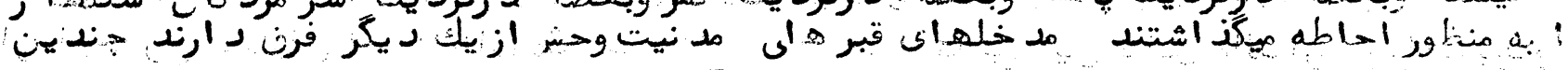

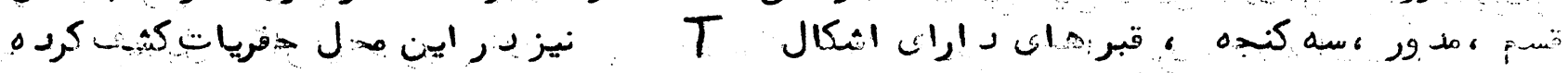

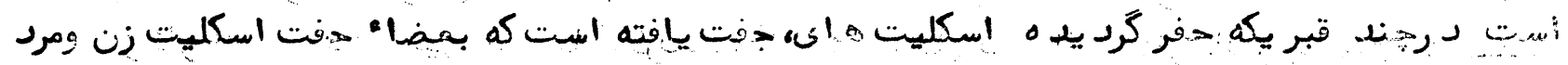

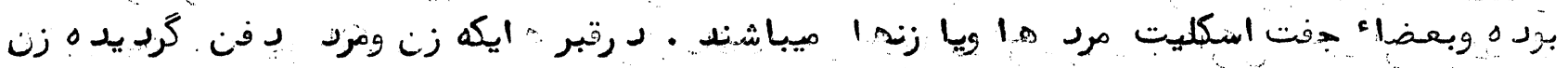

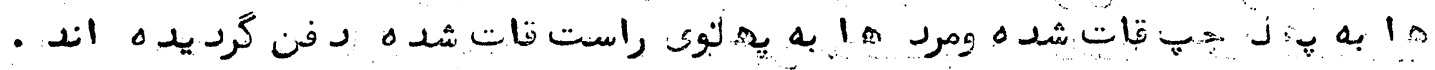

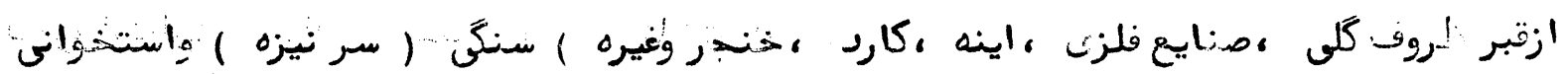

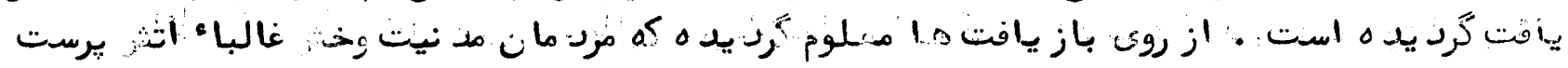

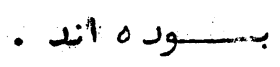

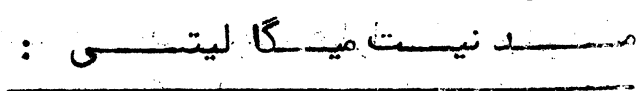

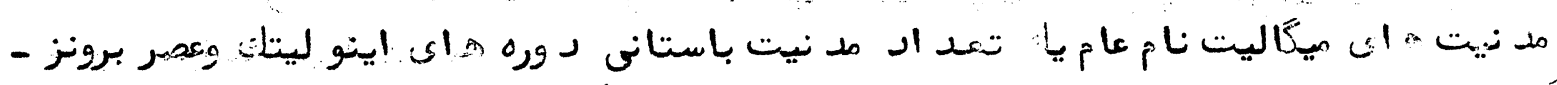

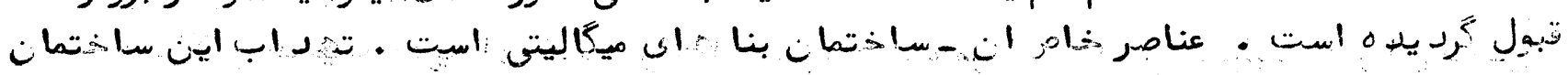

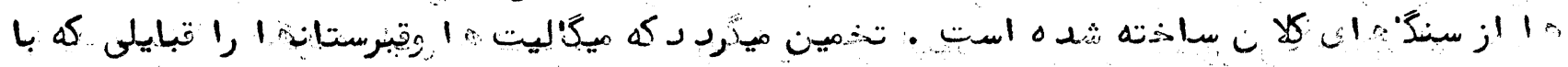

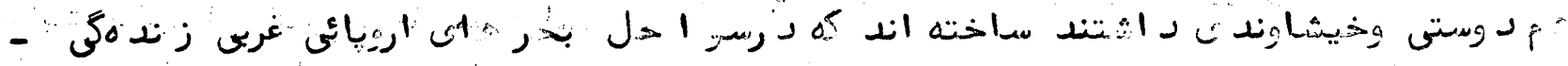

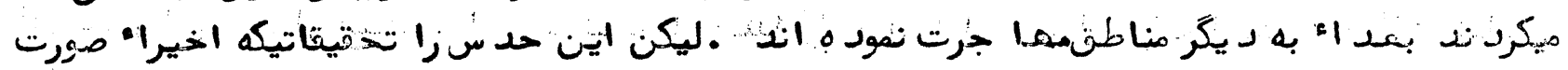
- 


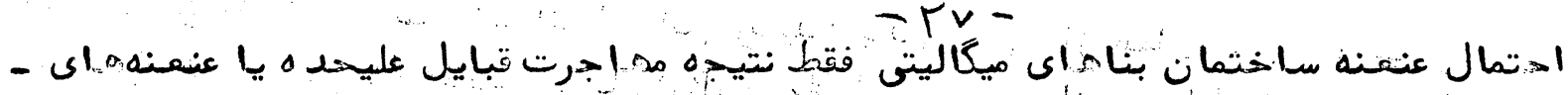

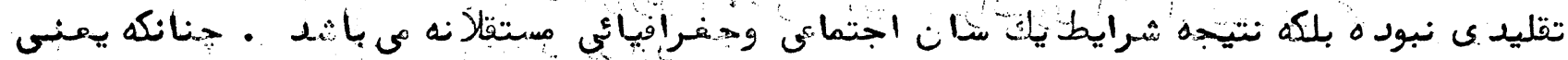

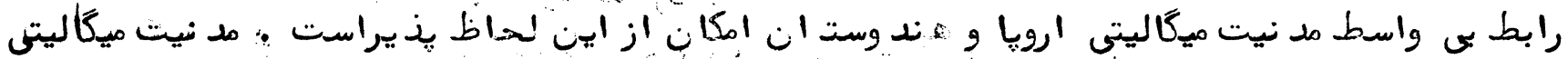

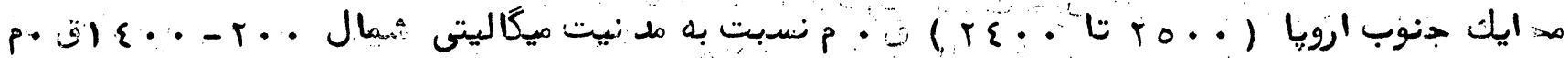

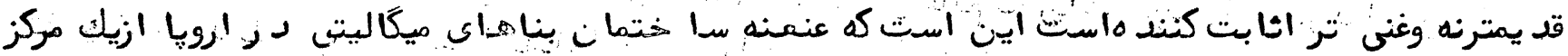

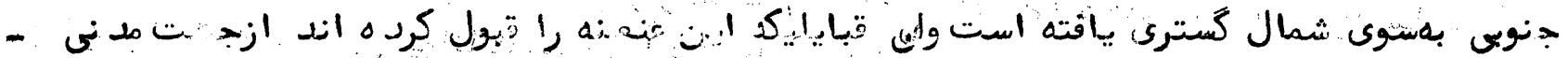

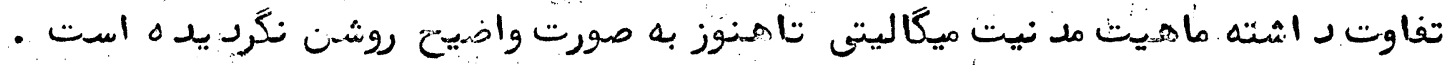

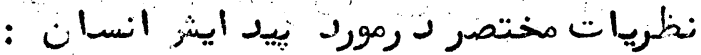

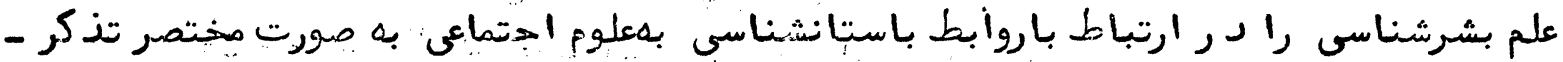

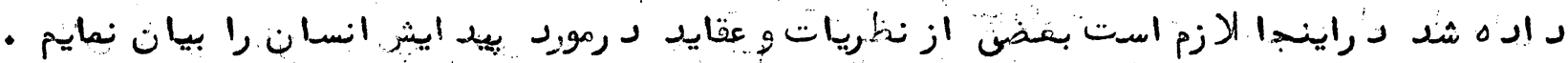

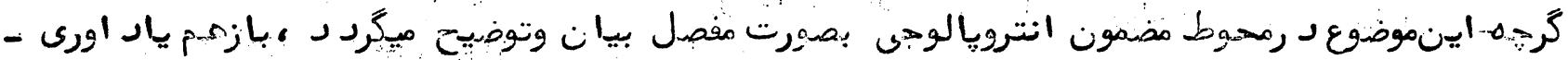

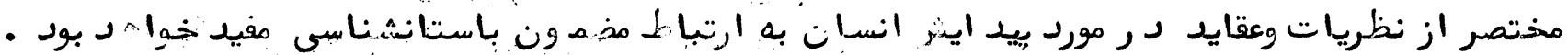

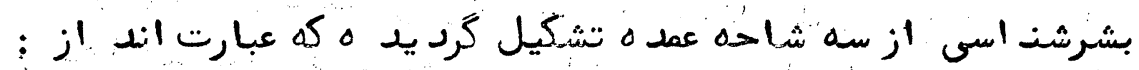

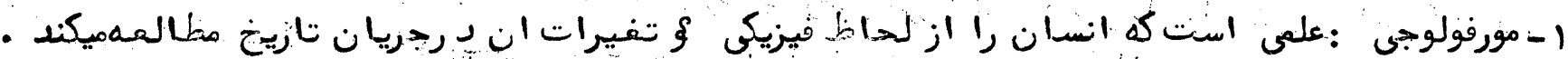

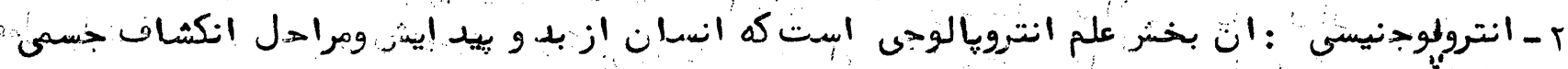

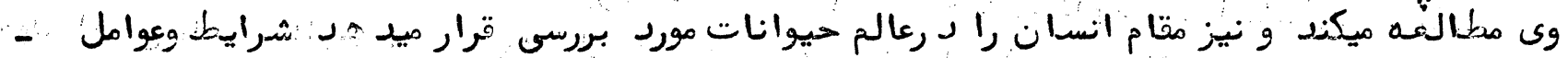

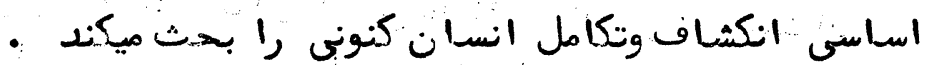

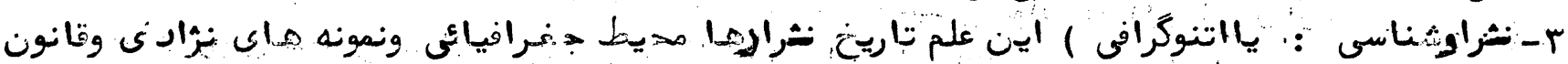

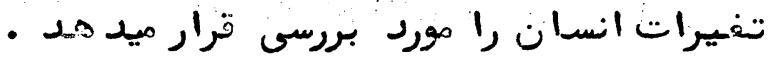

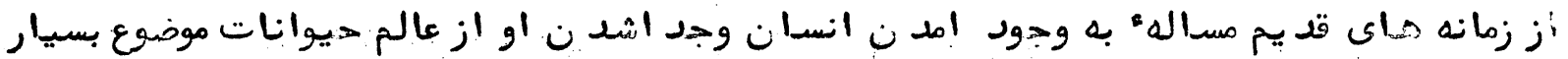

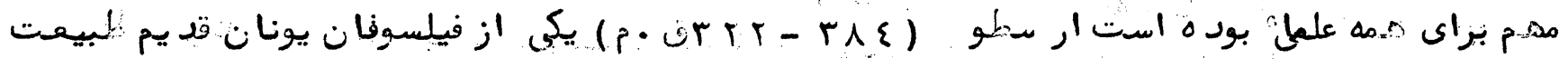

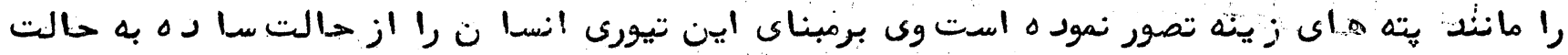

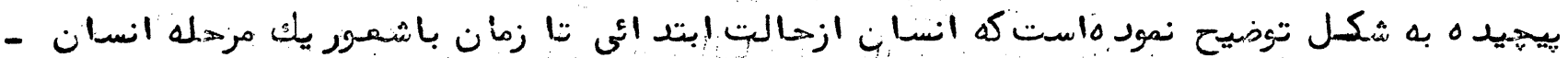

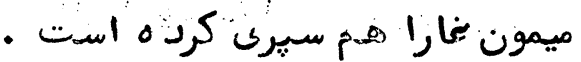

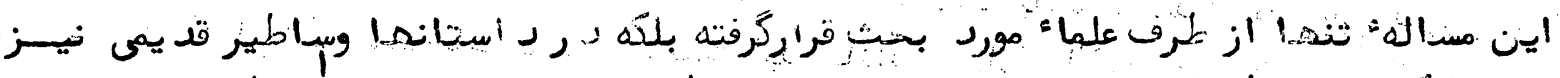

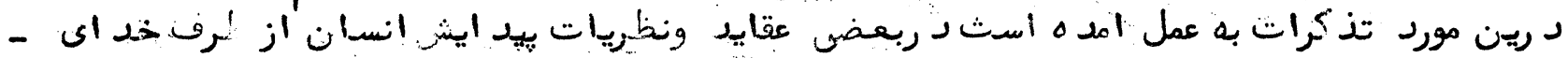

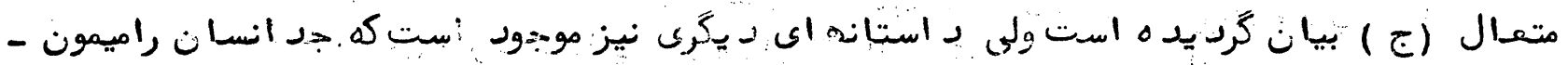

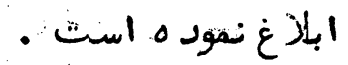

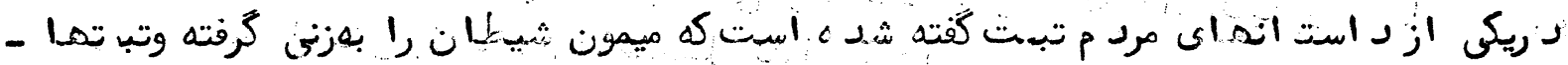

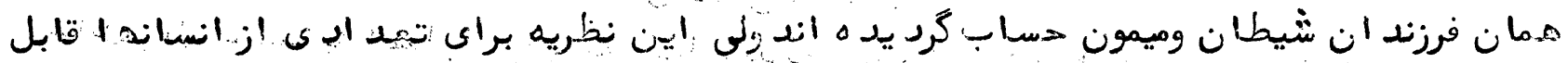

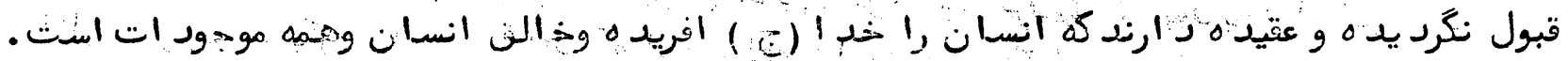

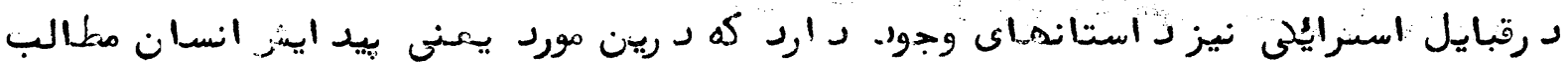

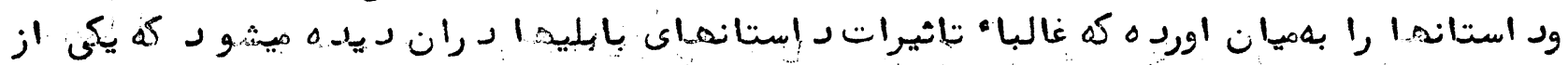

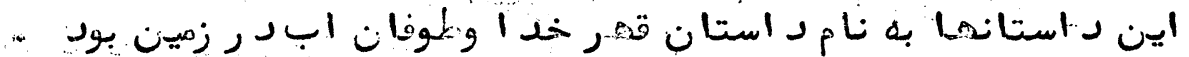

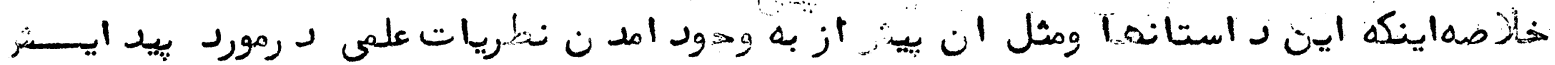




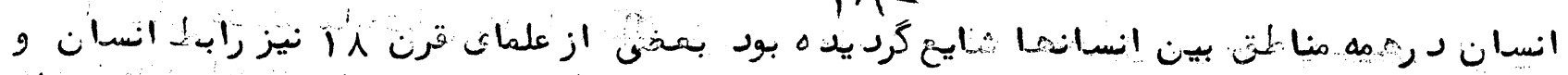

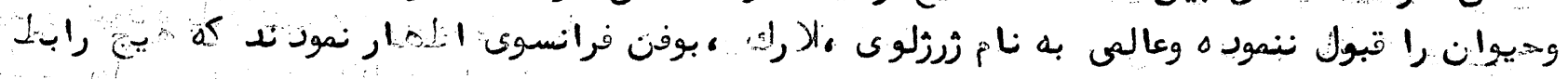

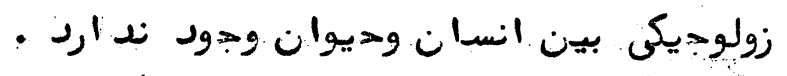

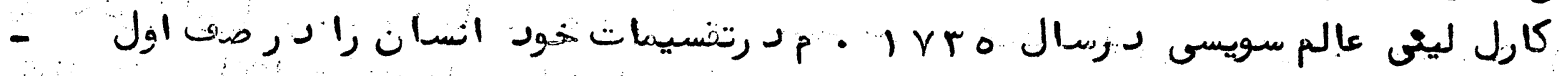

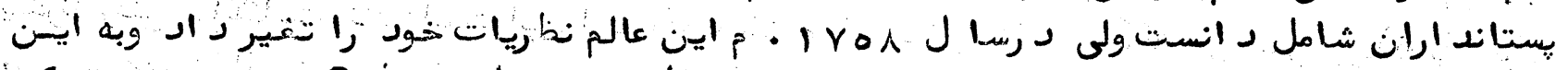

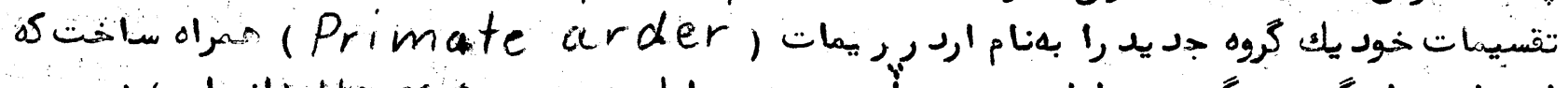

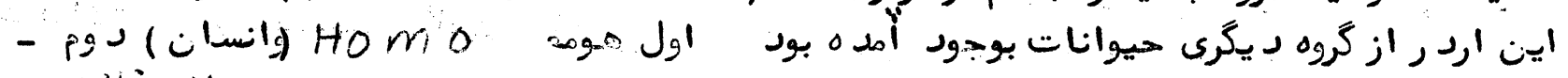

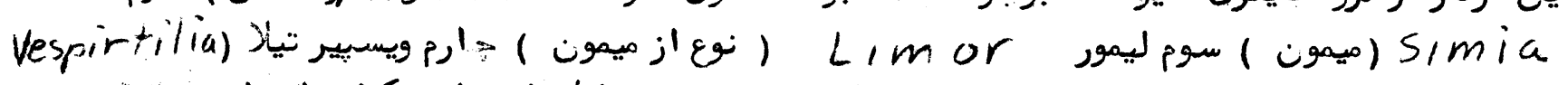

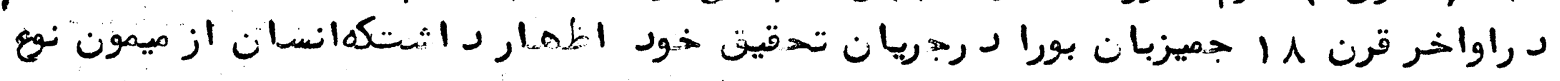

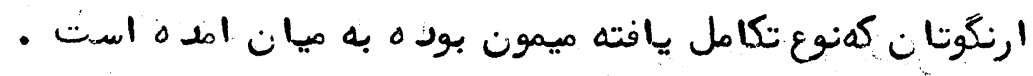

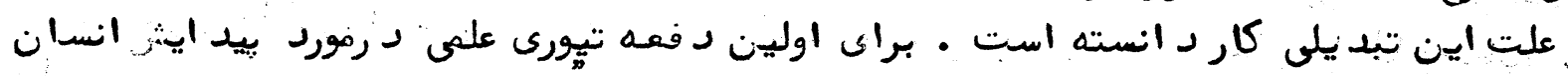

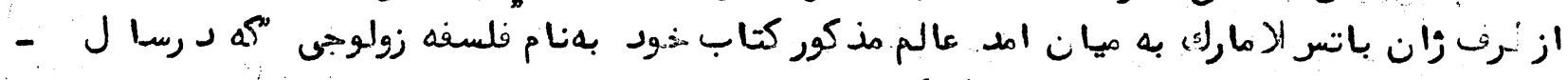

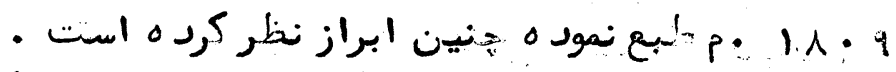

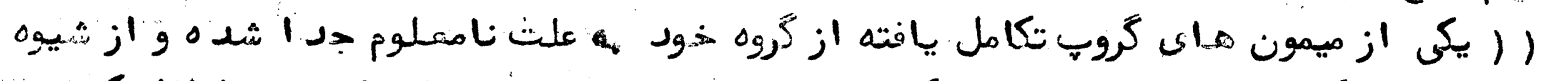

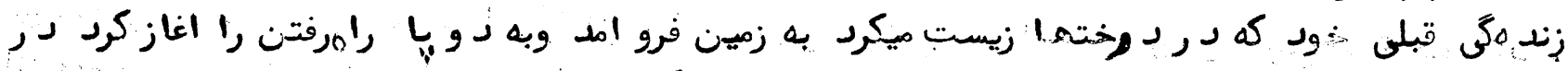

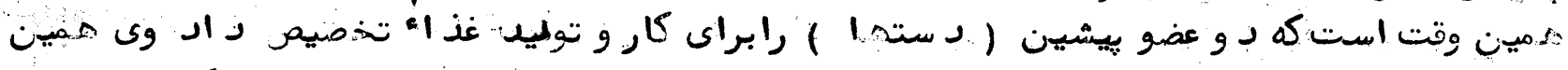

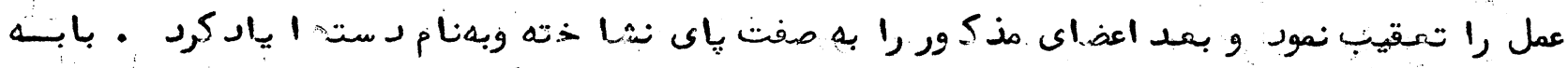

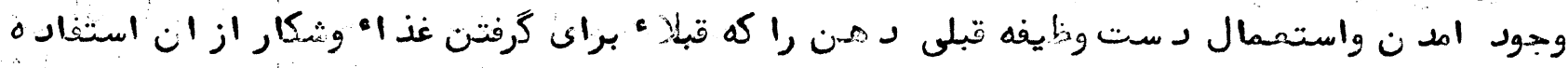

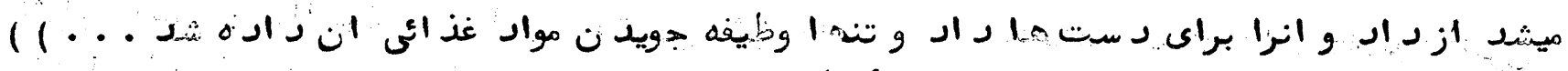

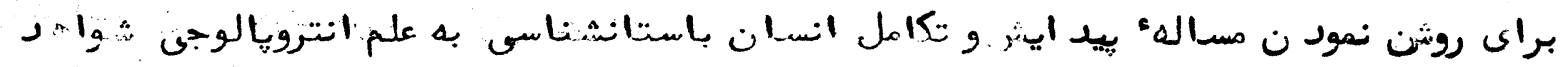

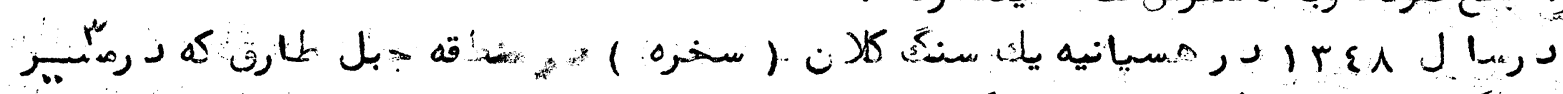

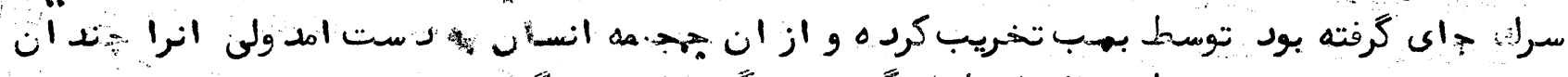

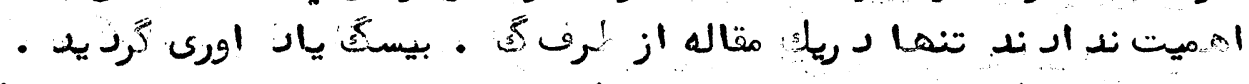

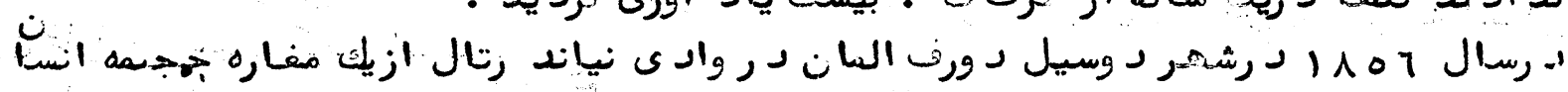

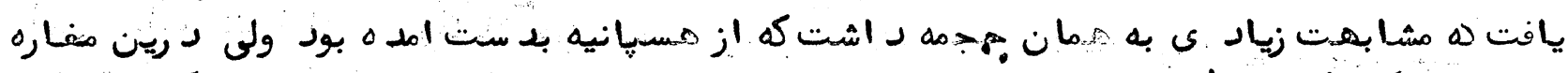

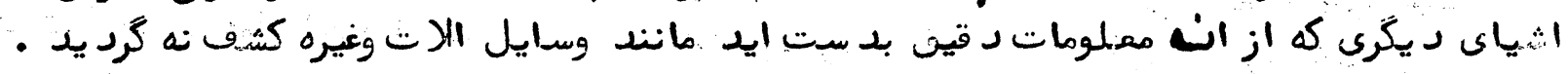

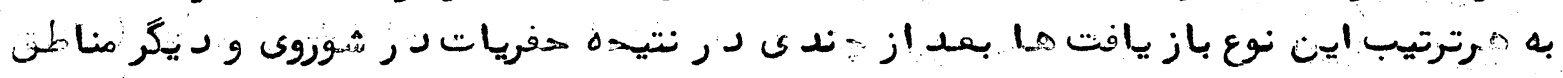

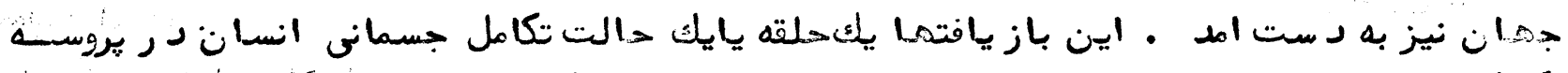

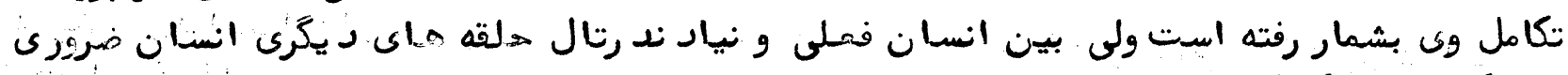

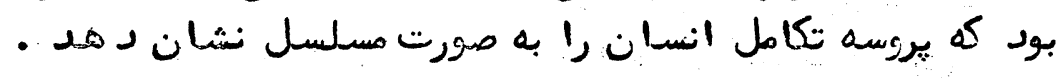

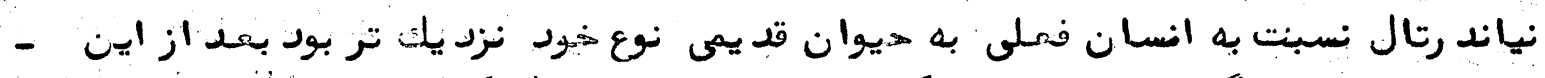

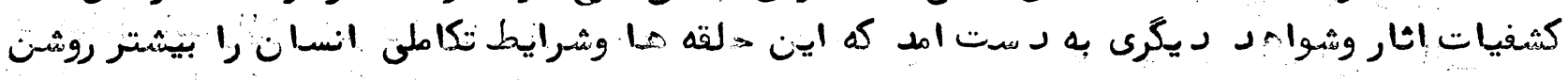

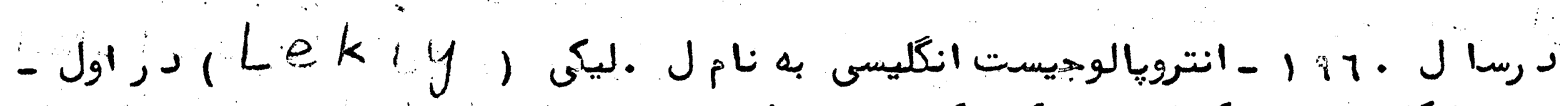

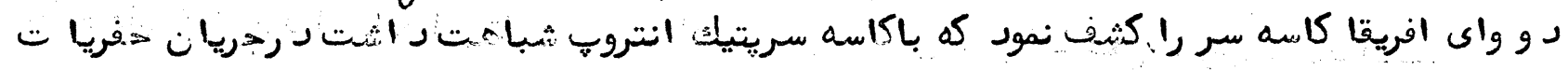




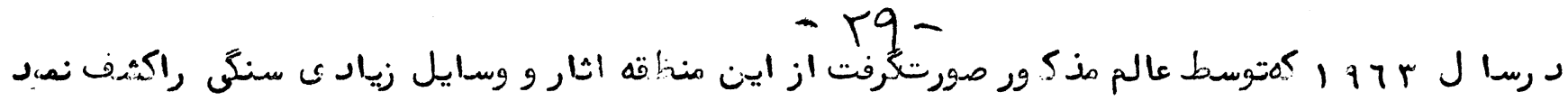

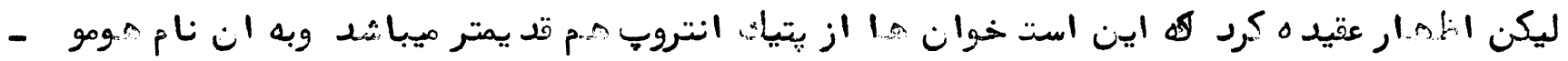

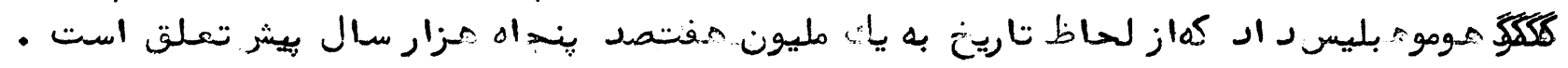

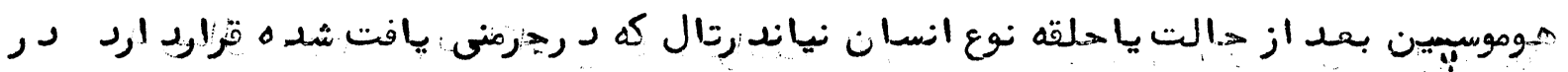

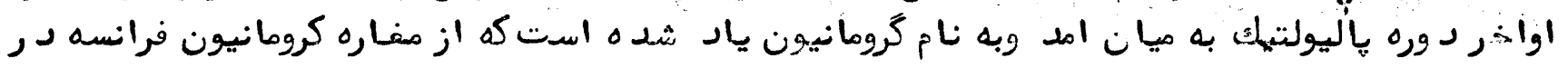

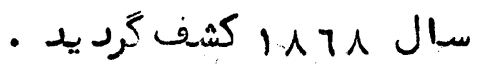

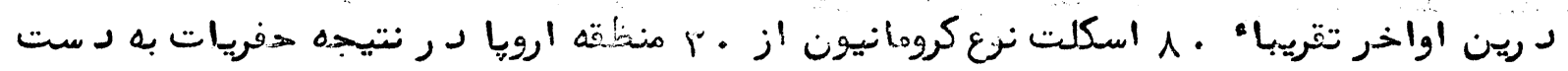

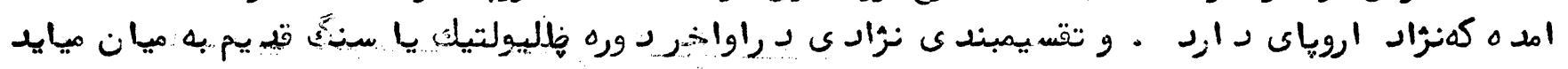

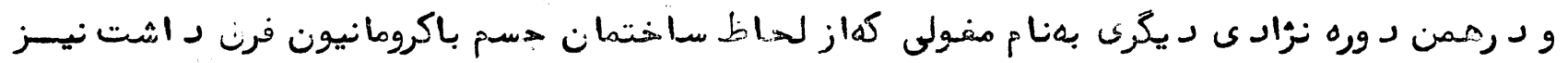

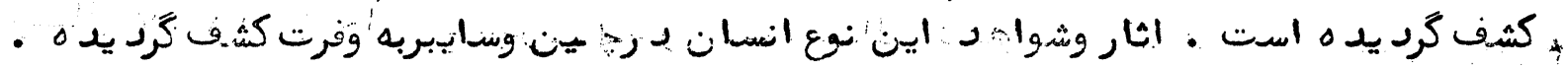

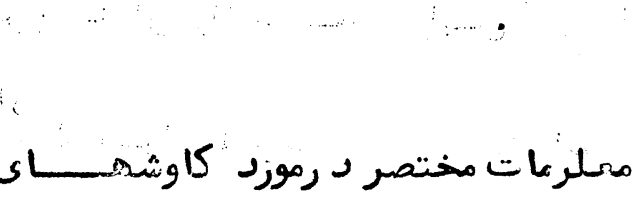

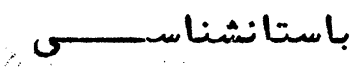

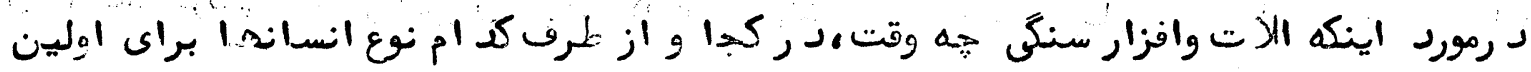

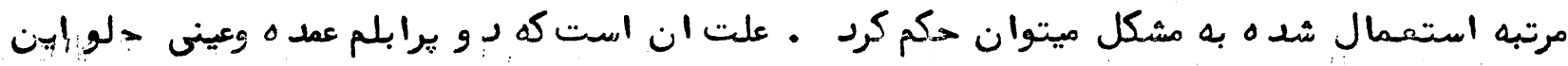

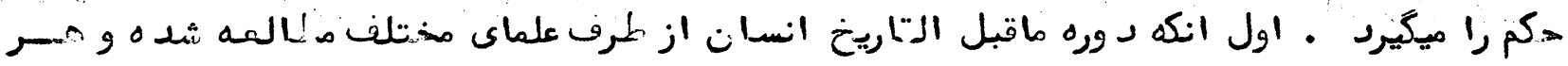

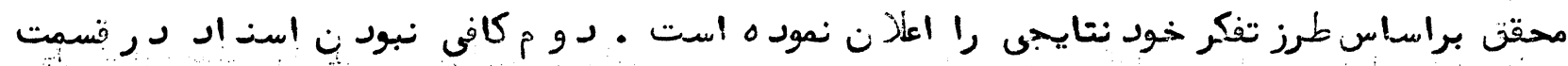

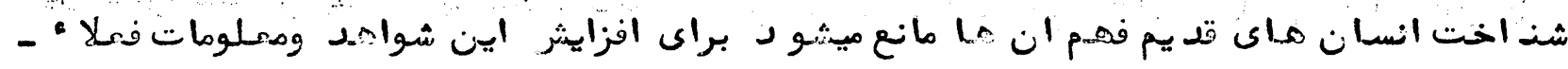

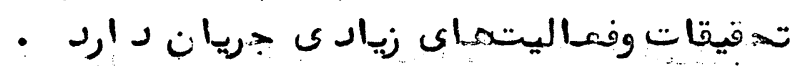

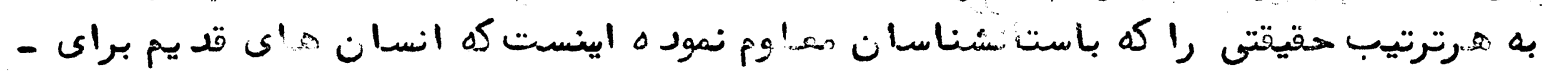

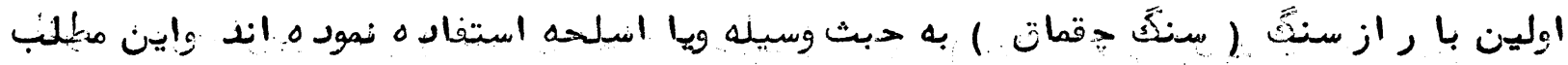

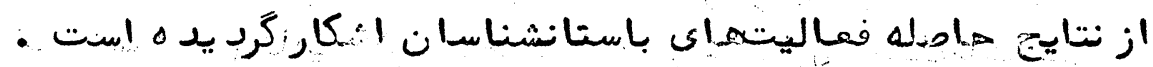

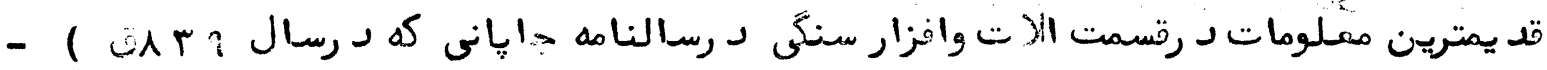

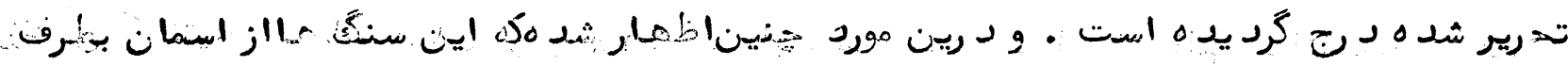

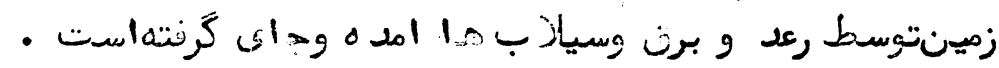

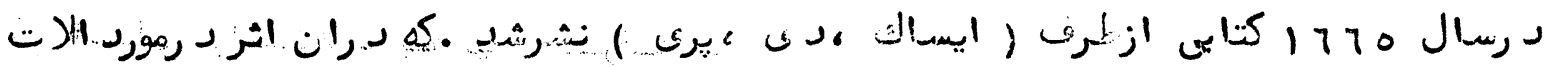

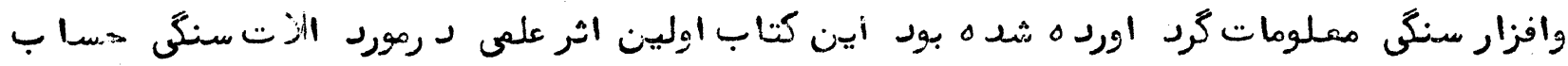

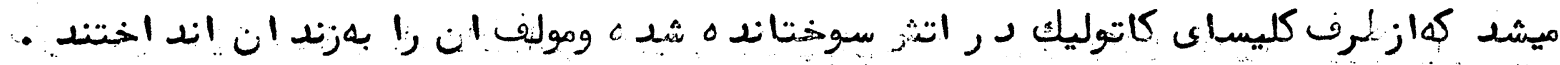

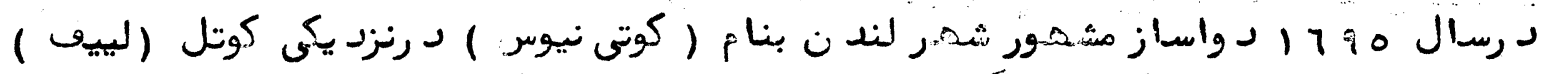

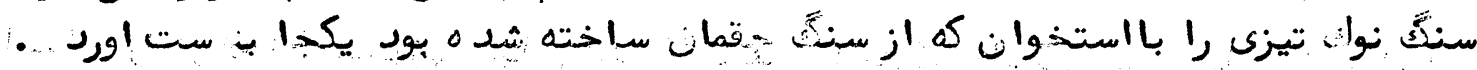




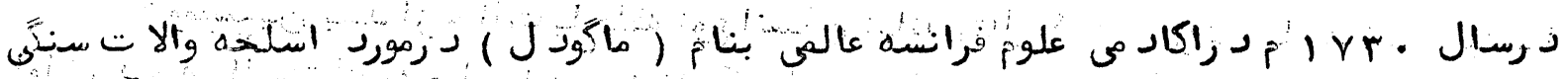

كنفرانسى راترتيب كرده بود كه از لمرف اعضاى اين اكاد مى شينده شد ولى تويه كننده كنفرانسر را

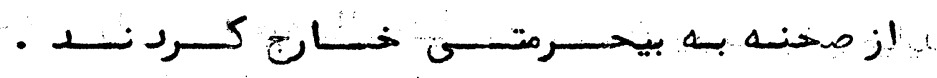

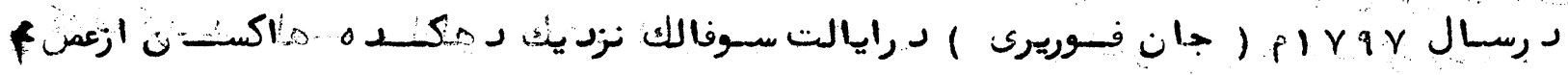

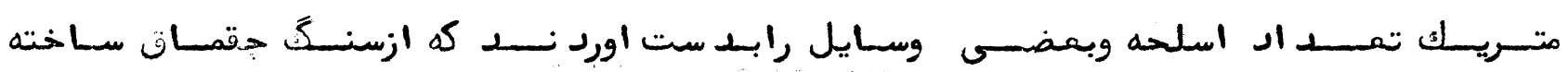

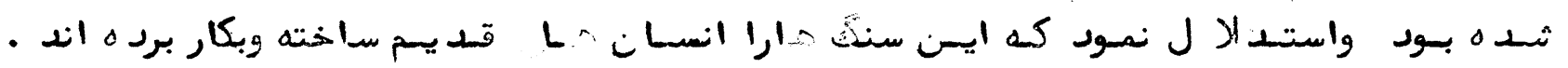

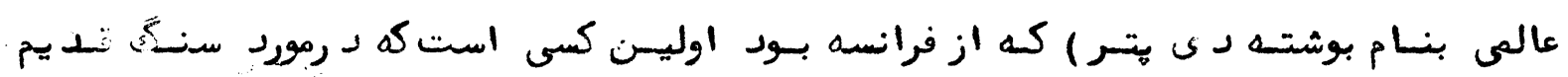
Palealithic

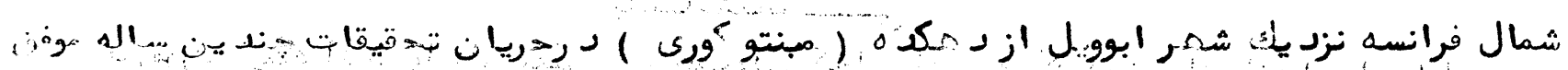

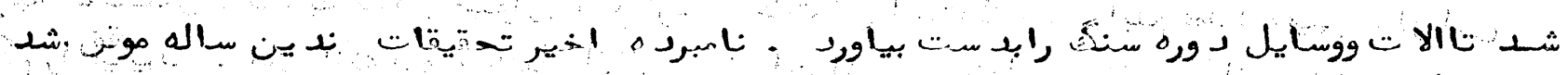

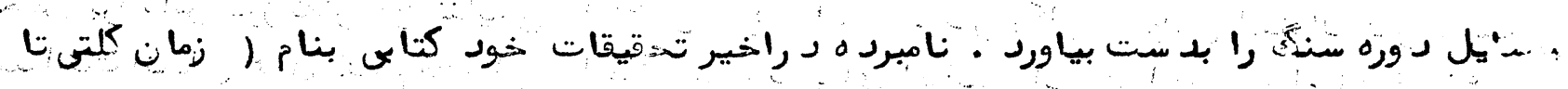

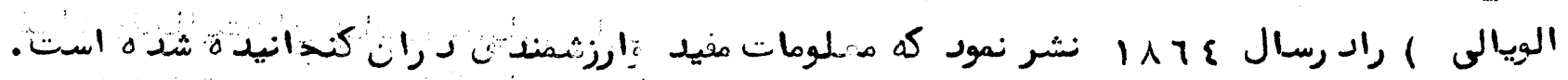

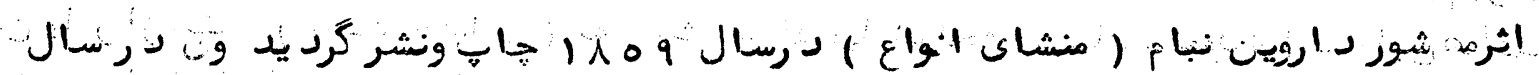

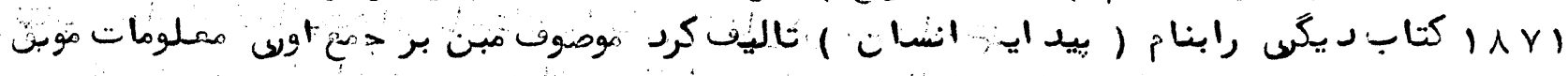

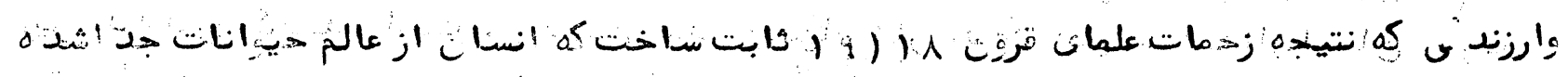

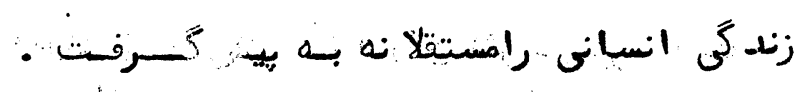

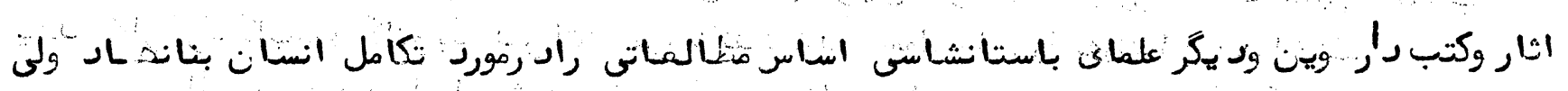

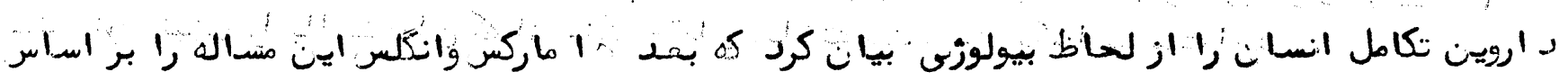
تيورن ماركسيت تحليل نمود ند ورءشن ساختن م د رتبديلى ميهون به انسان برؤه كار نقنر عده ه 


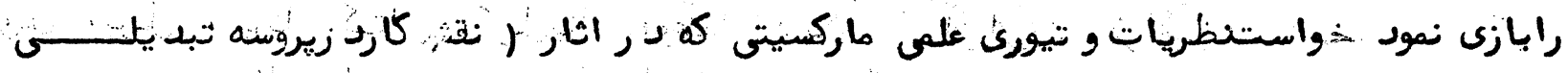

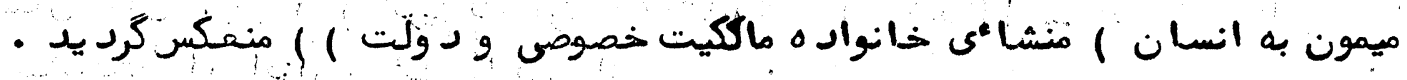

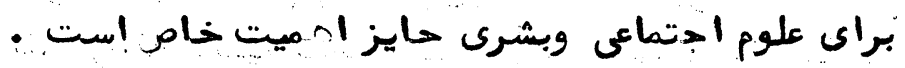

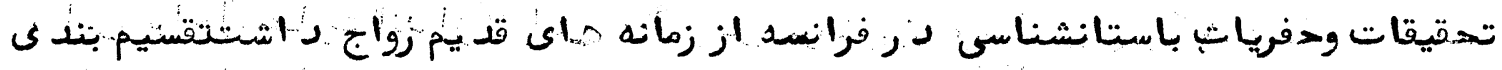

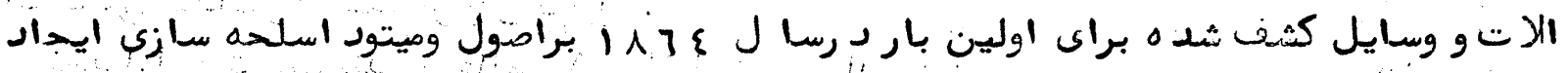
كرد يُ

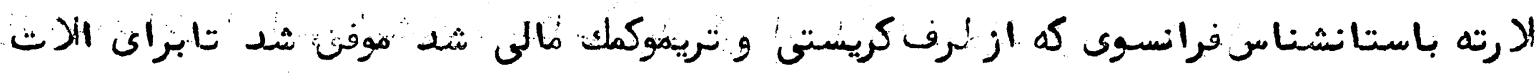

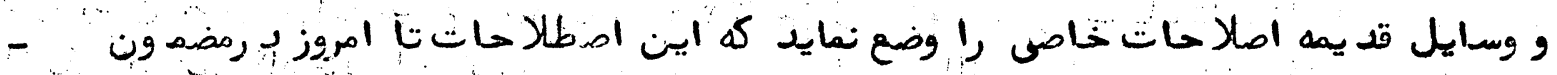

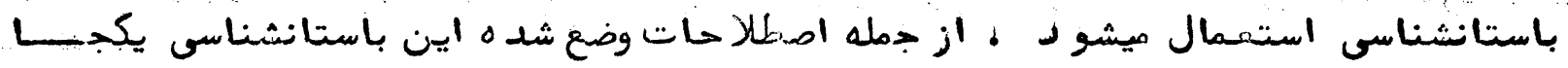

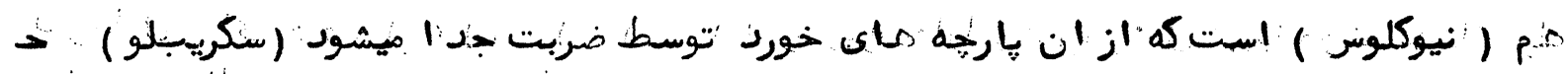

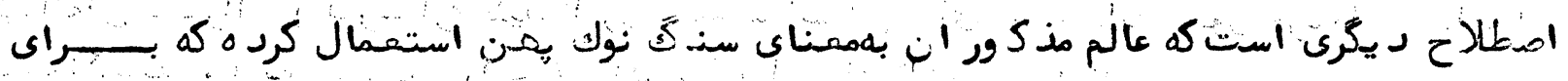

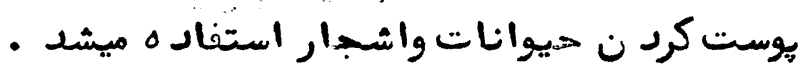

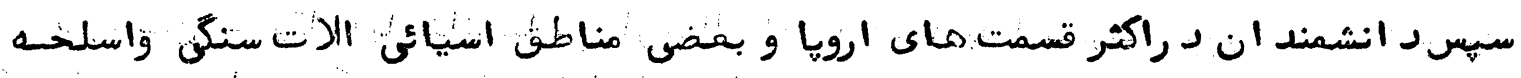

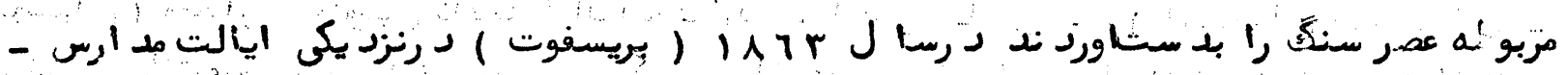

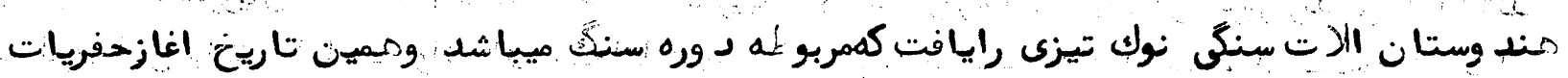

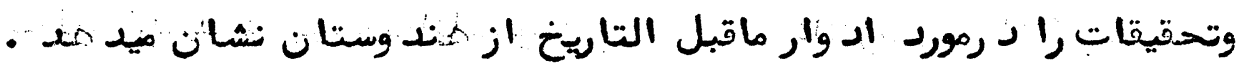

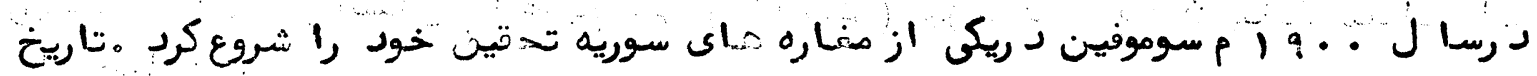

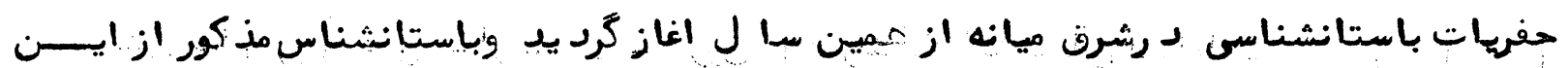

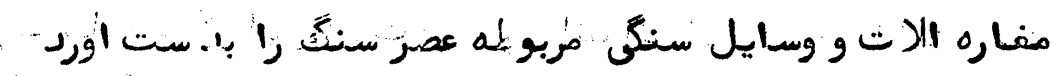

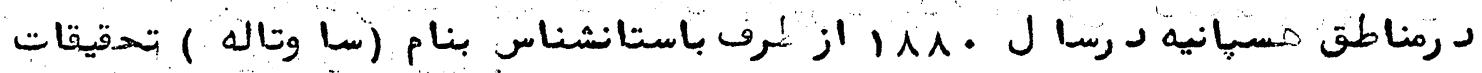

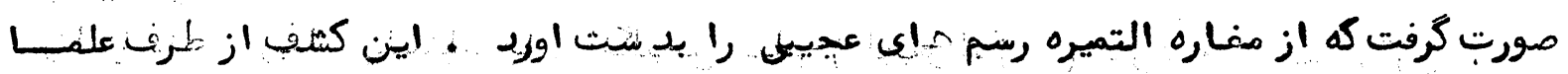

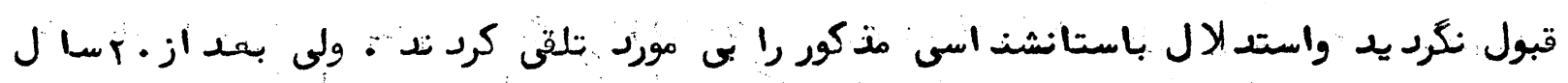

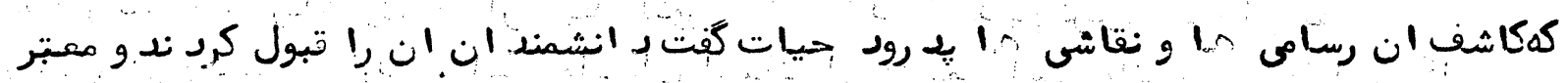
رانستر

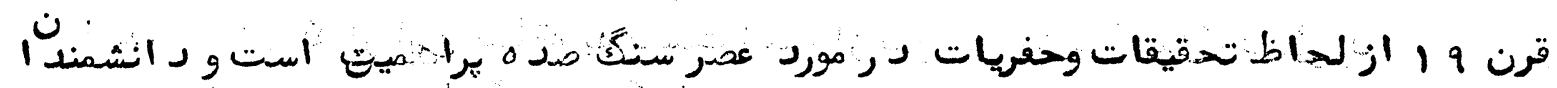

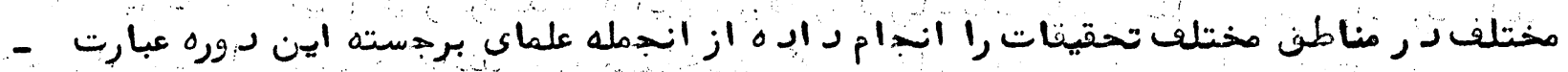




\section{Fr}

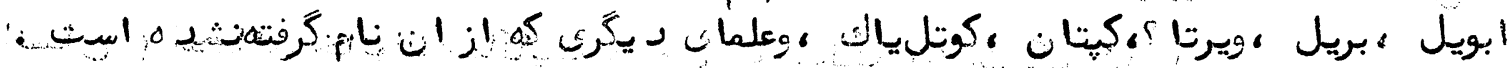

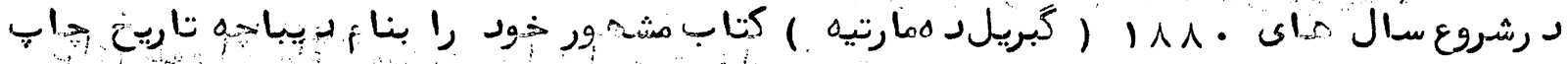

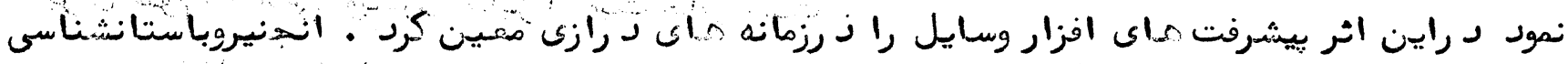

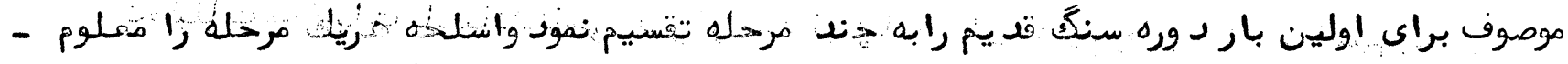

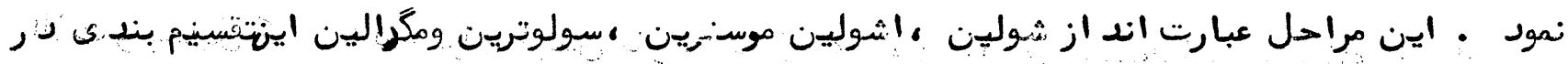

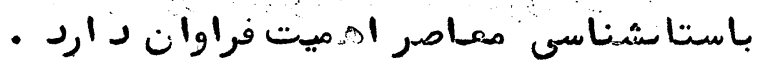

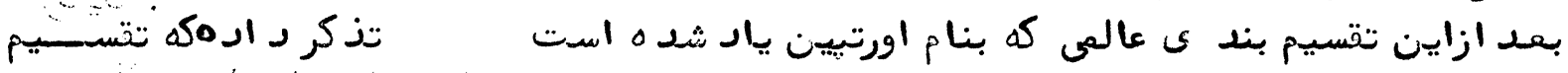

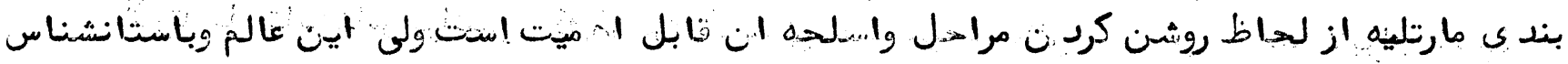

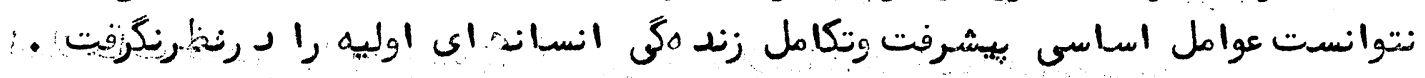

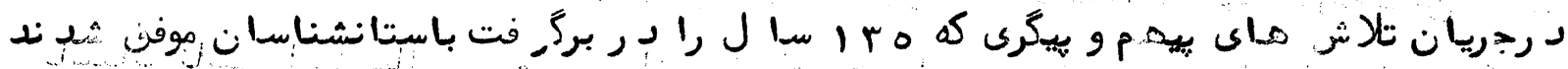

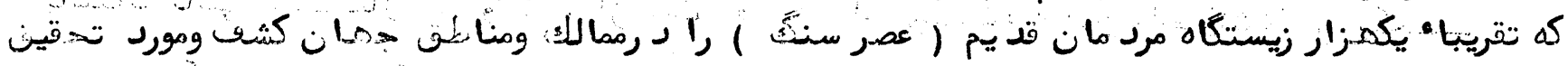

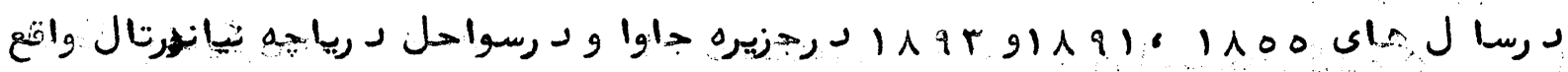

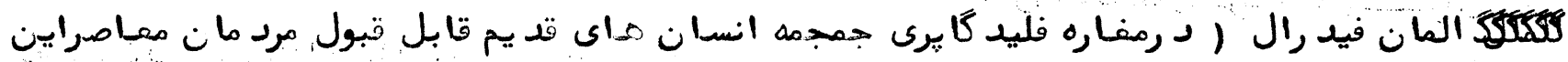

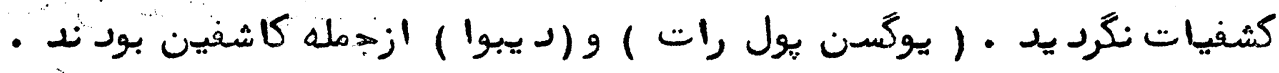

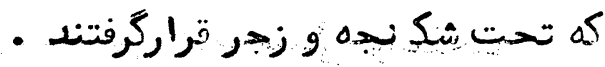

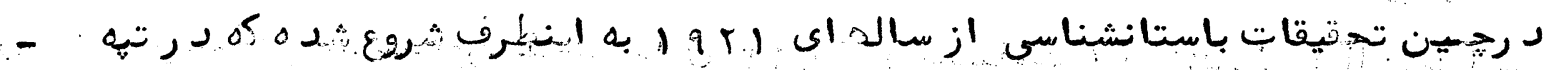

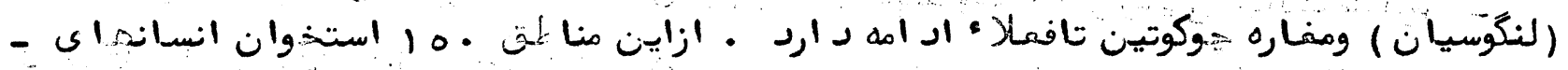

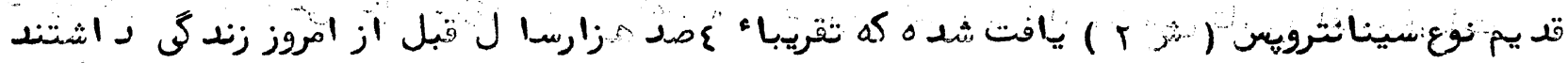

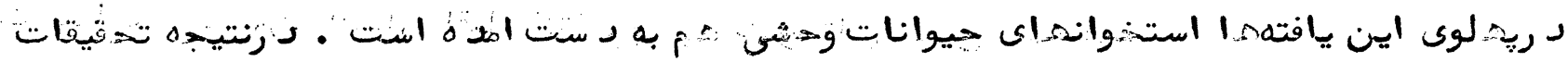

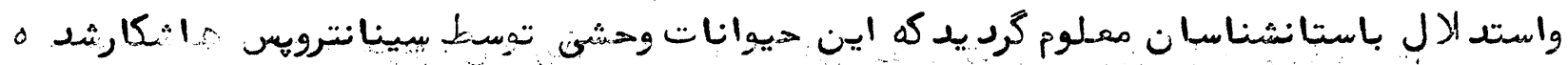

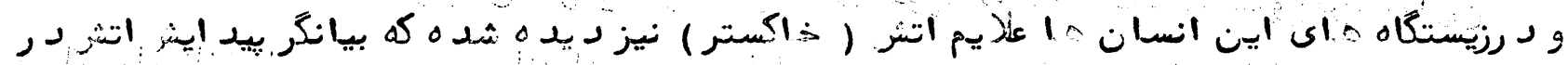

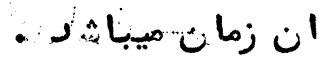

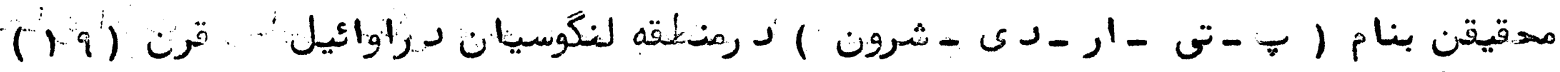

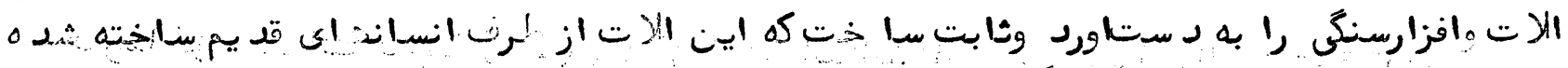

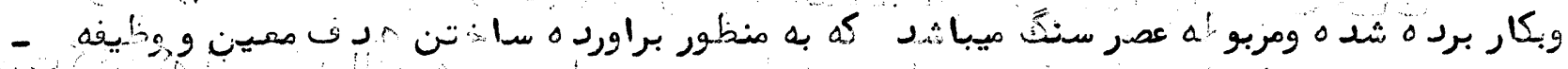

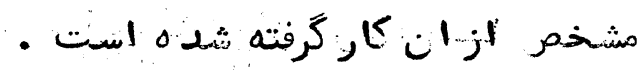

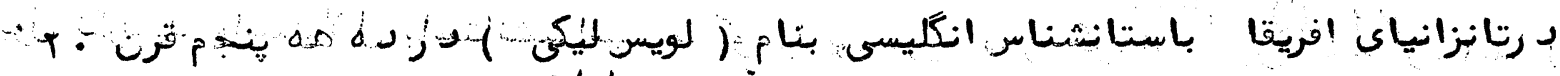

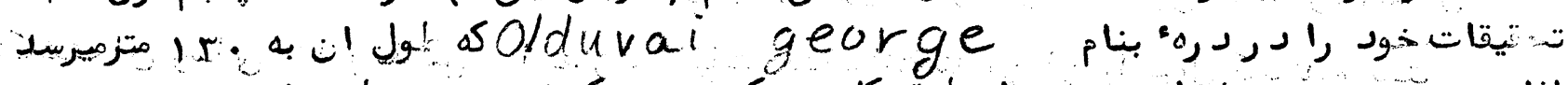

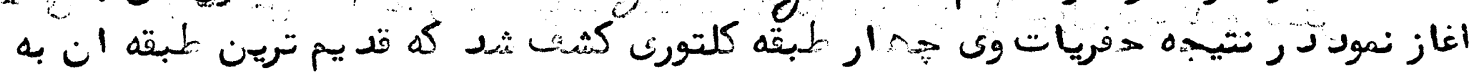

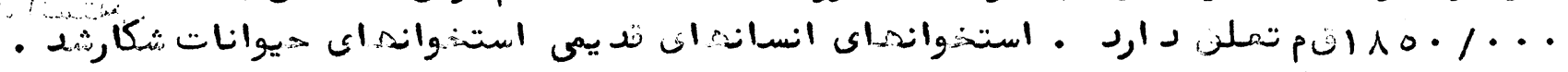

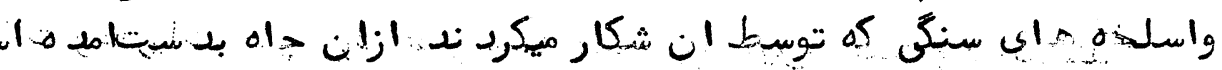

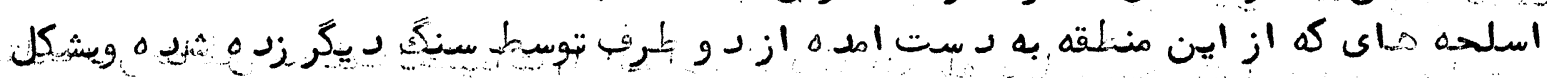

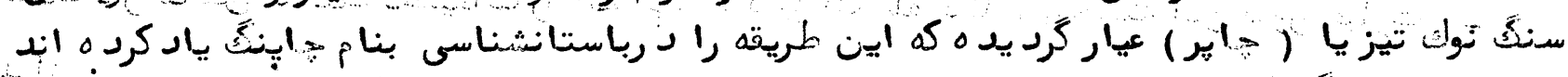

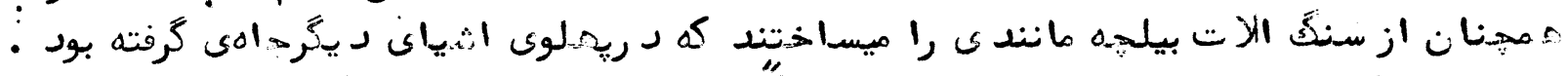

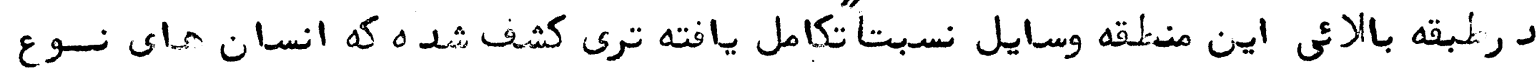

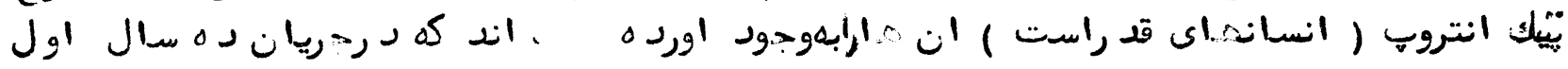




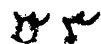

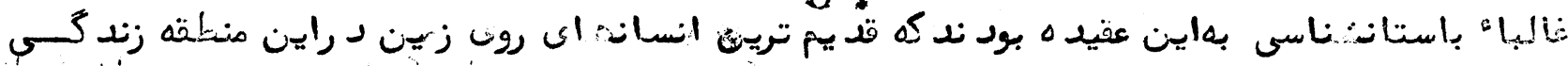

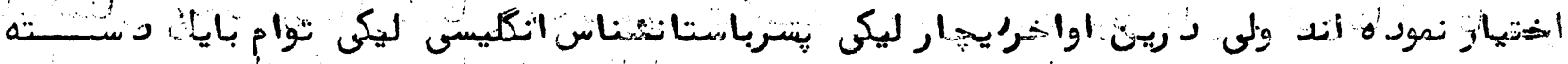

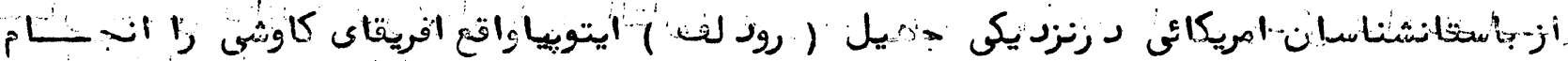

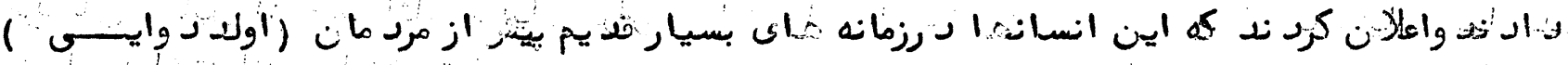

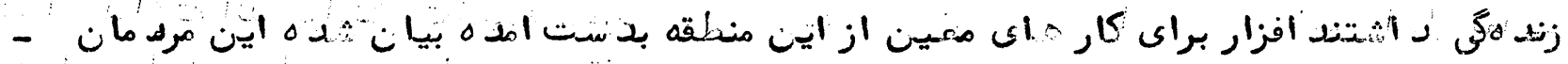

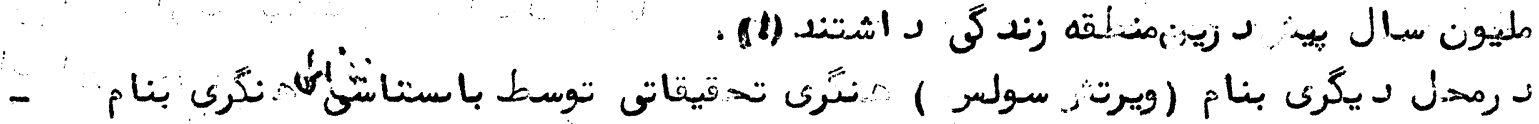

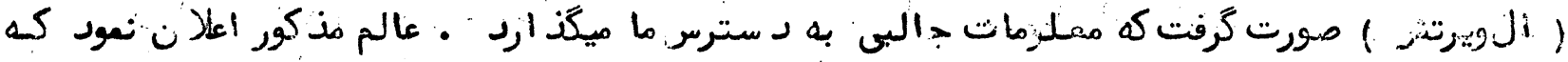

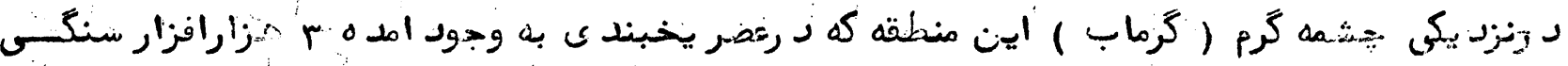

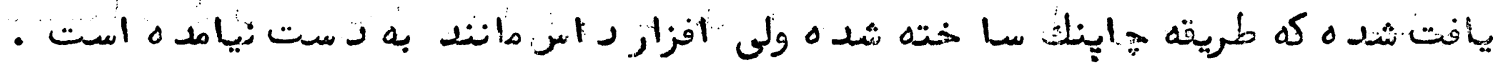

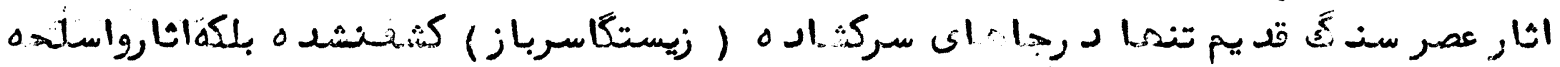

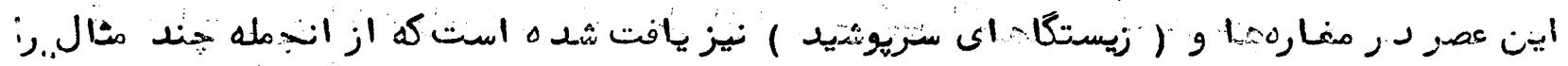
نكر مينسئ

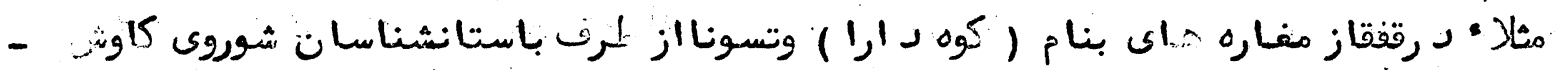

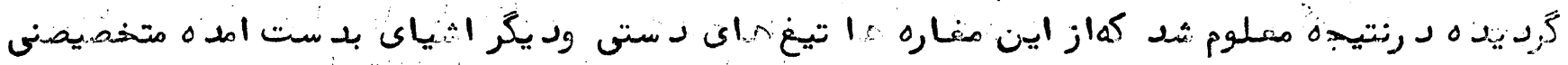

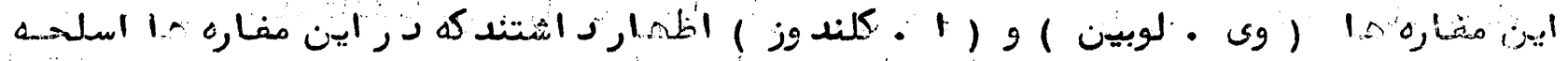

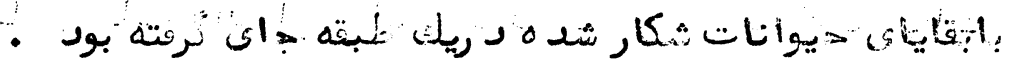

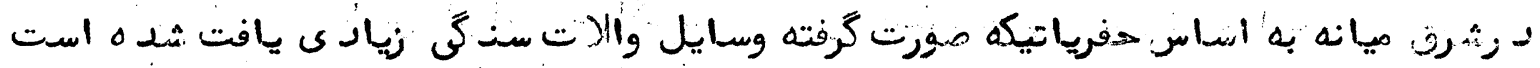

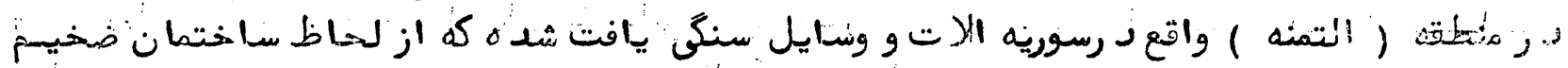

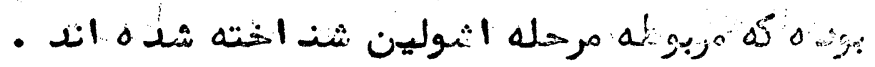

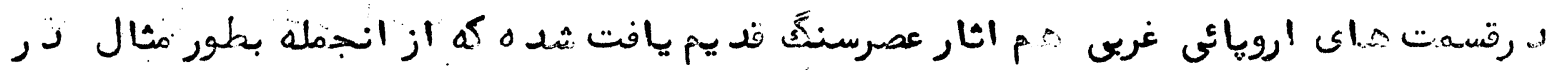

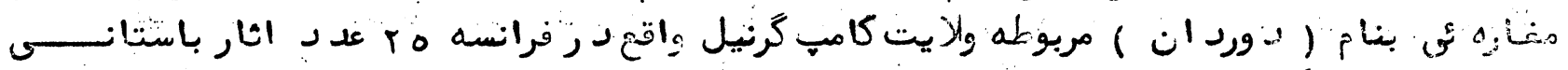

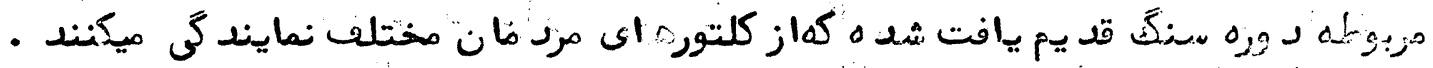

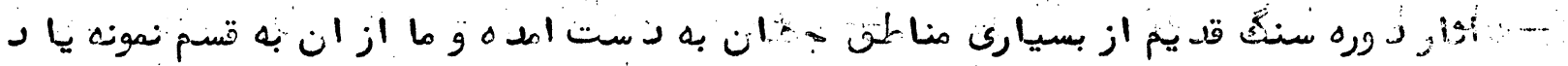

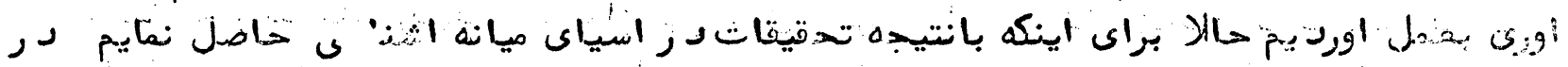

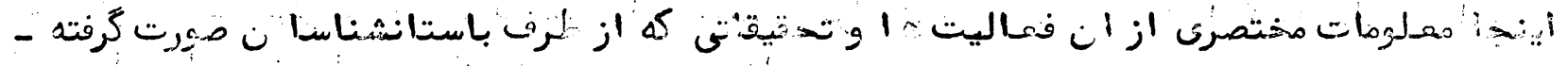

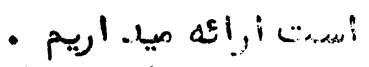

\section{تاريخته ه

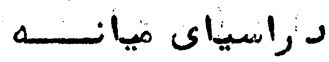

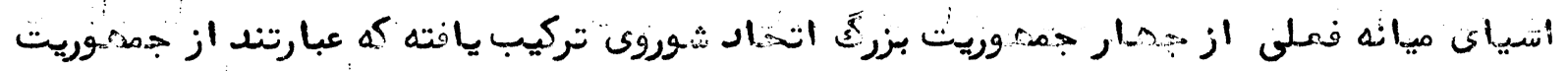

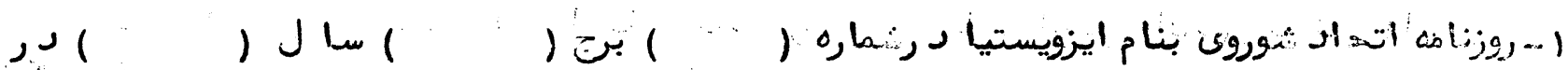

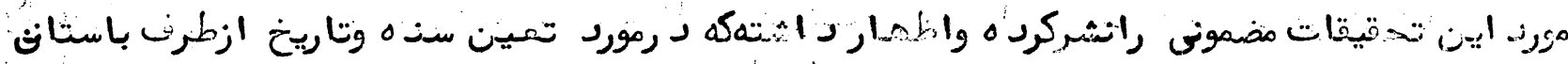

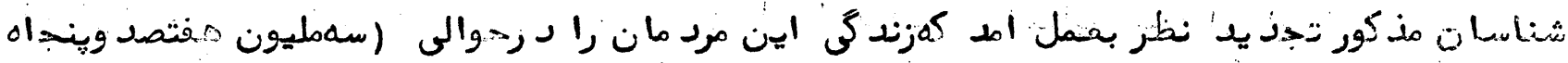

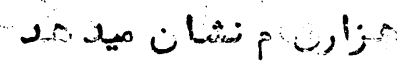




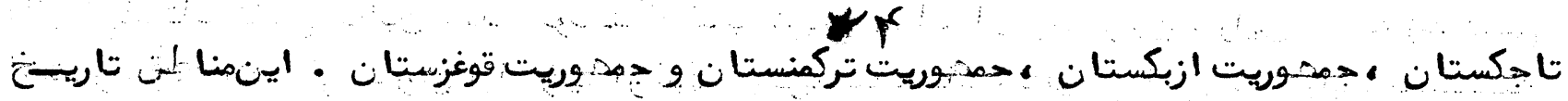

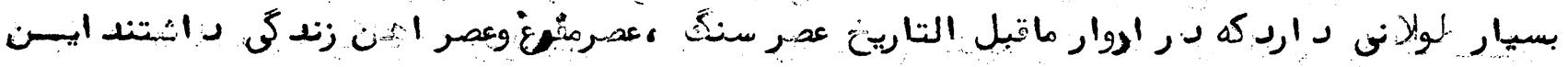

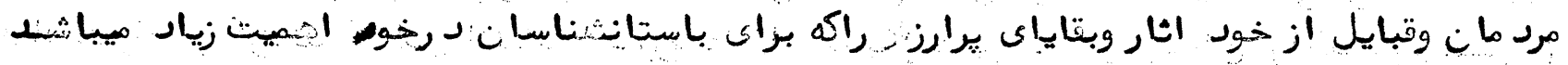

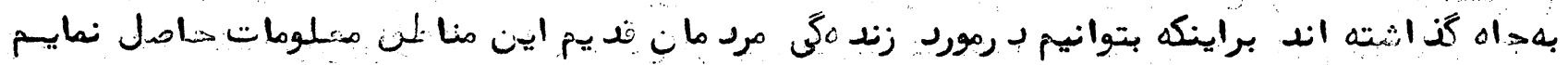

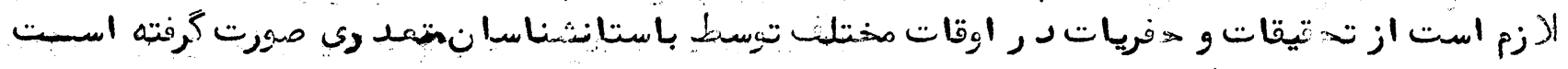

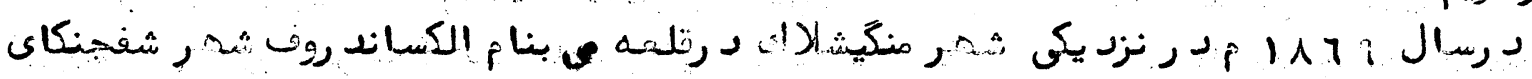

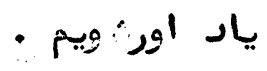

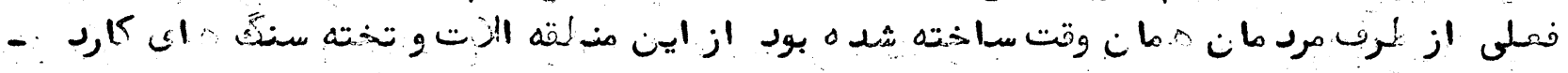

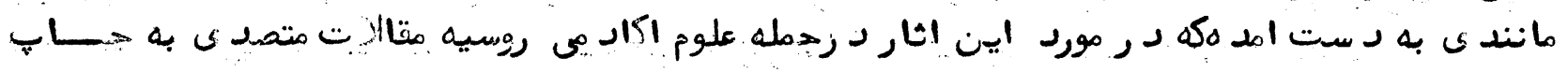
ربسيد ه استيل

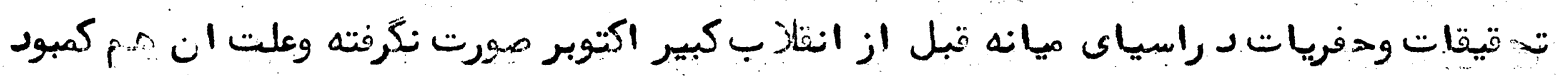

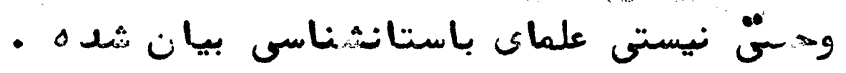

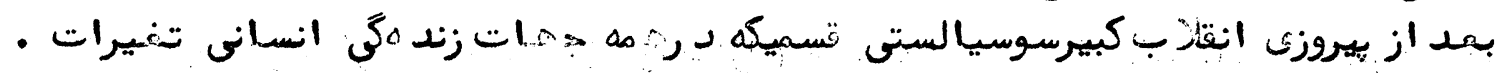

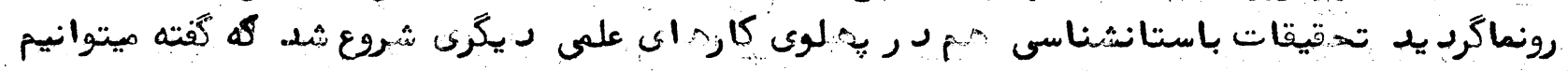

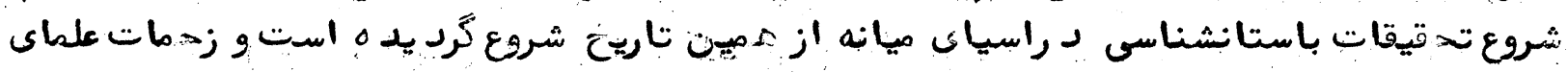

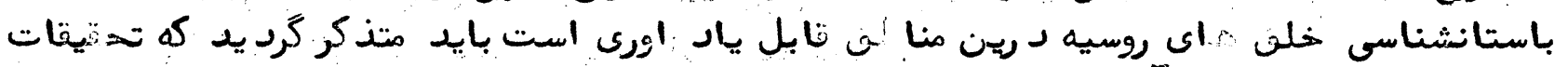

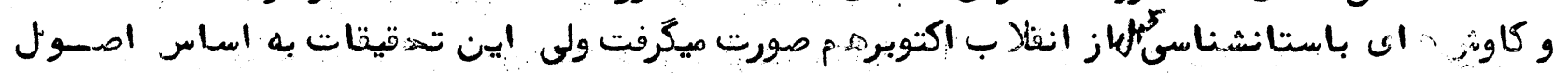

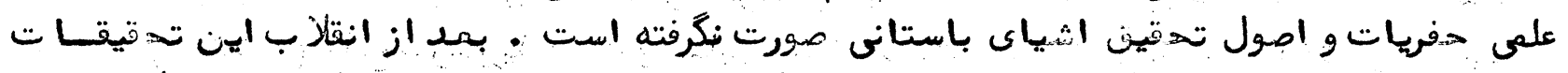

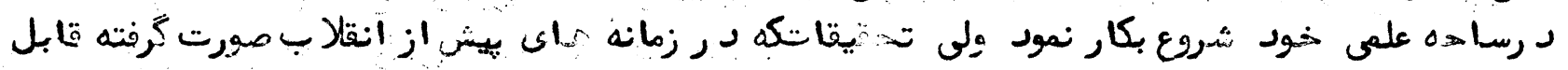

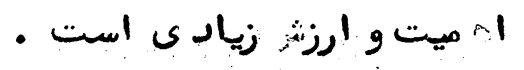

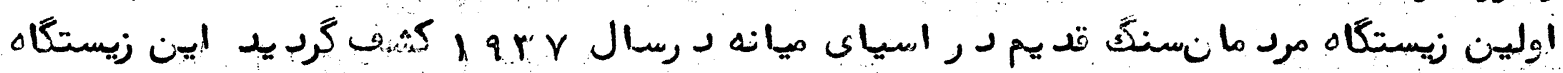

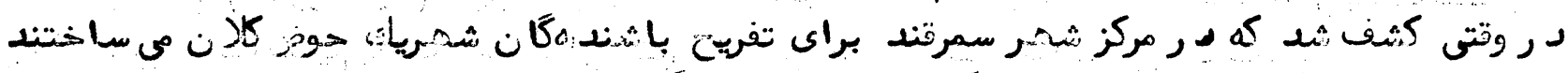

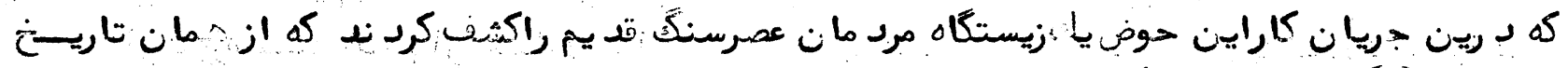

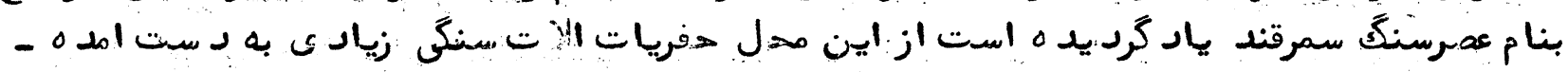

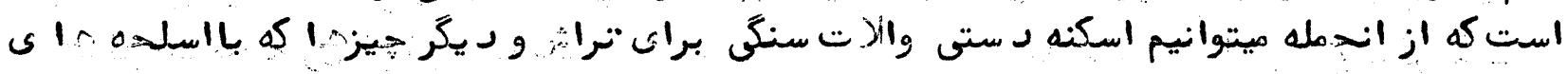

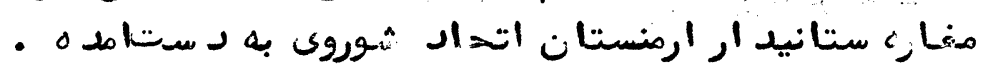

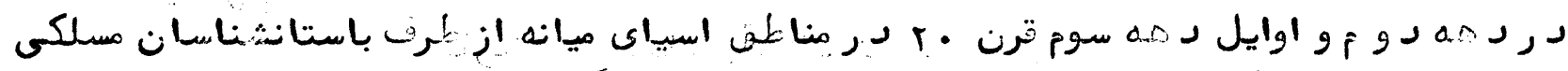

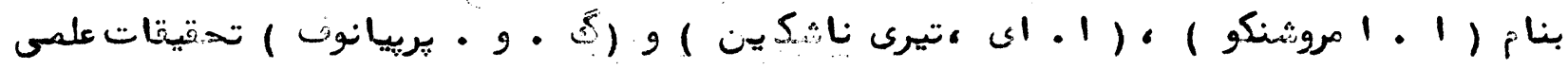

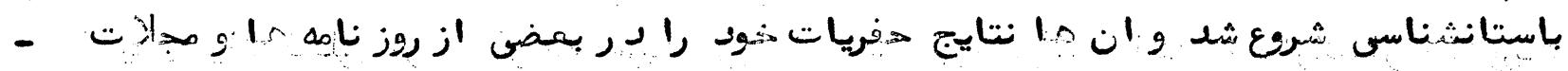

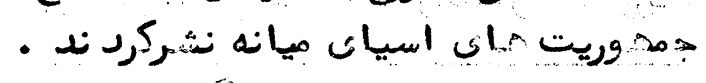

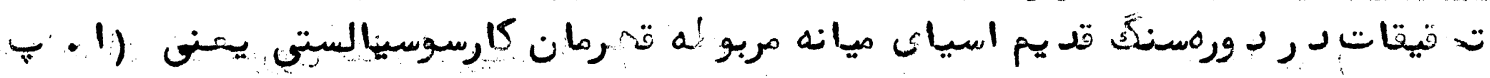

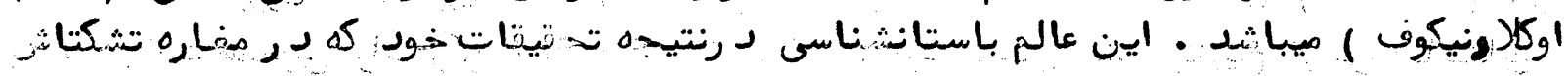

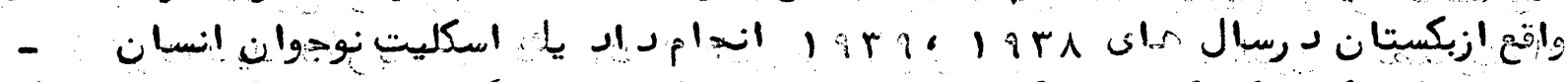

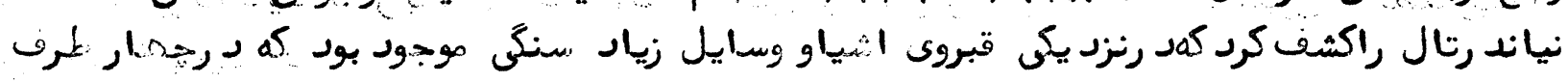

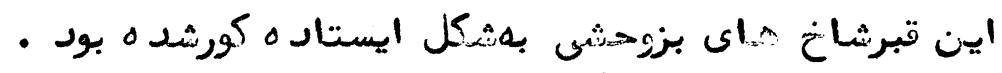

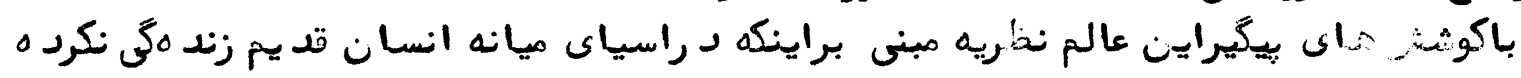




\section{ro}

الستك رد خرد يد كشف جمجمه نياند رتال ثابت ساخت كهانسان سنك قد يم د راينمناطنى زندكى -

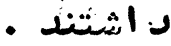

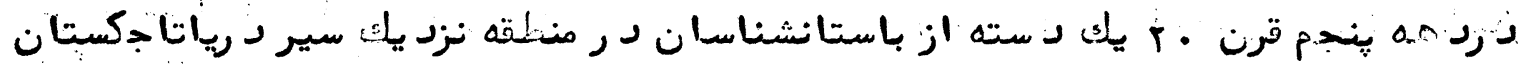

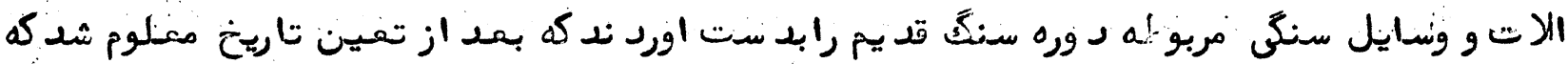

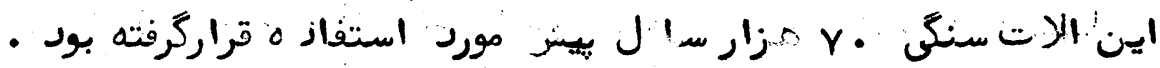

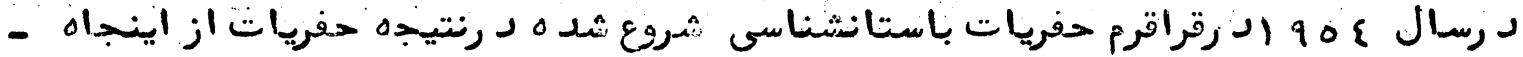

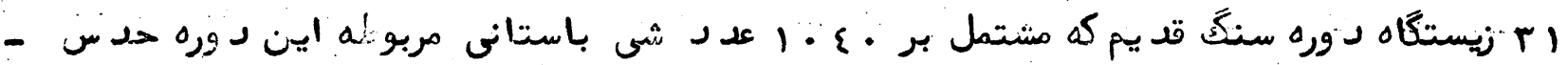

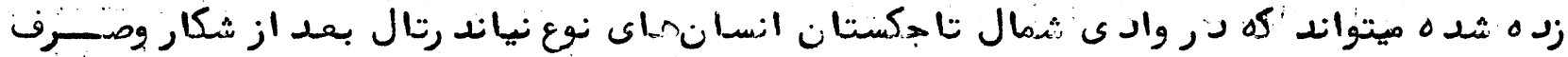

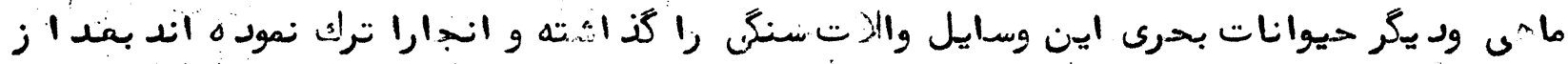

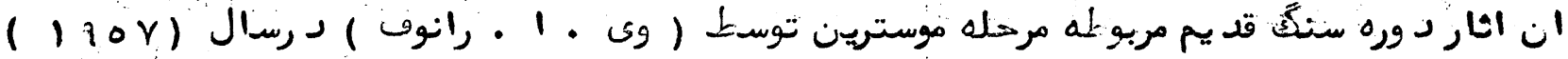

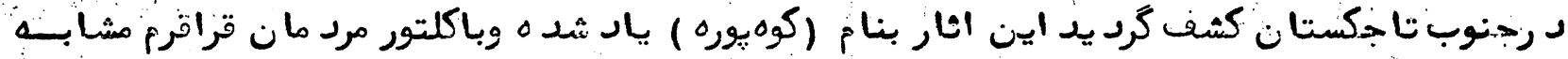

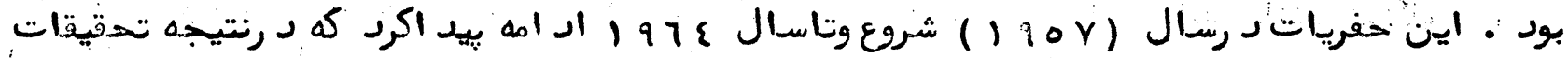

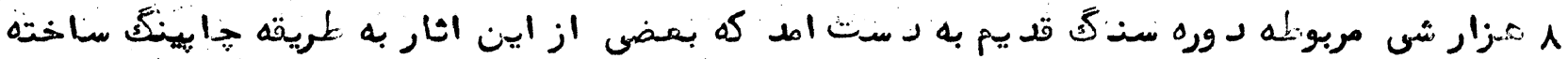

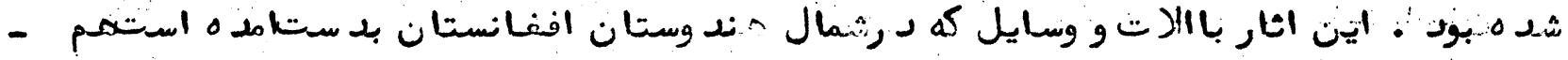

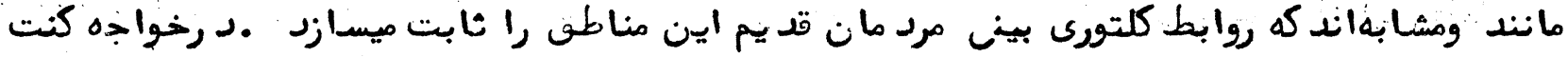

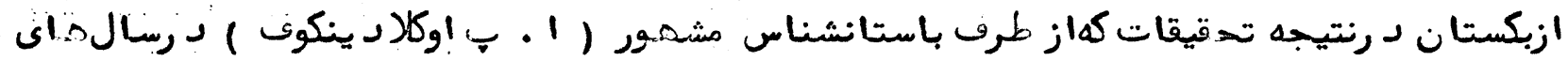

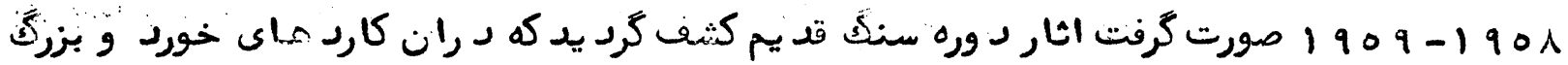

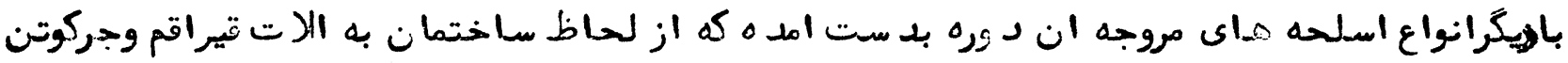

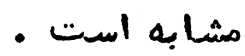

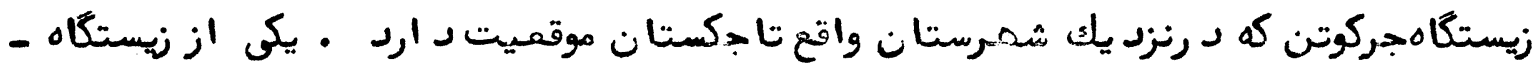

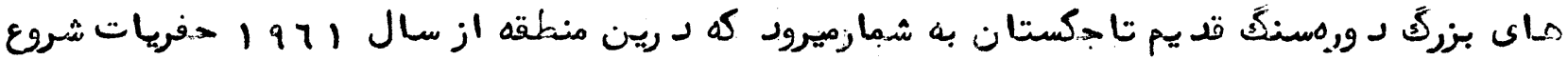

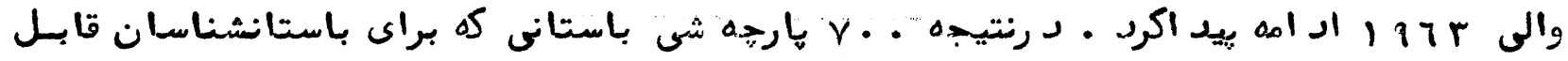

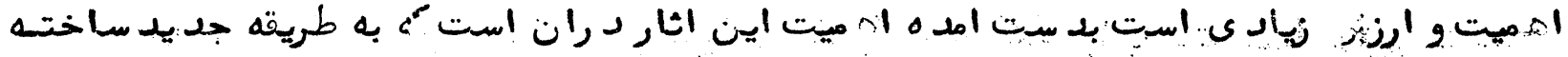

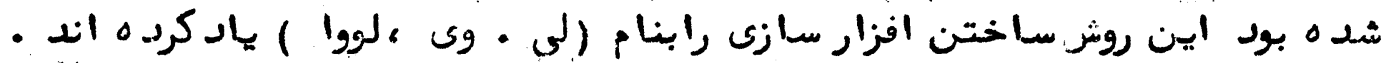

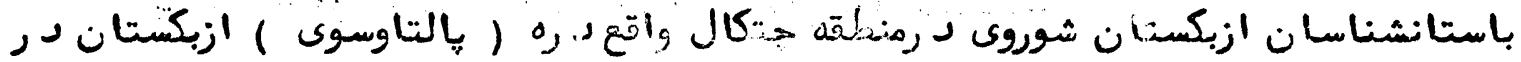

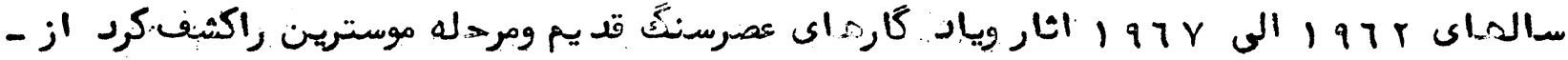

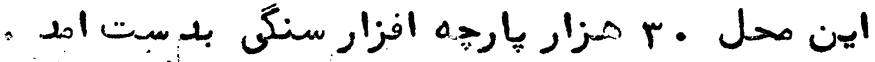

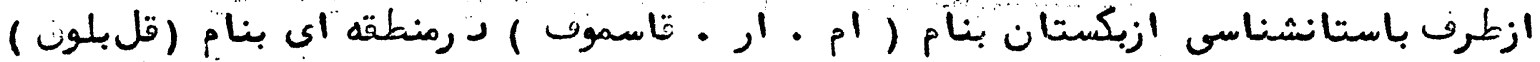

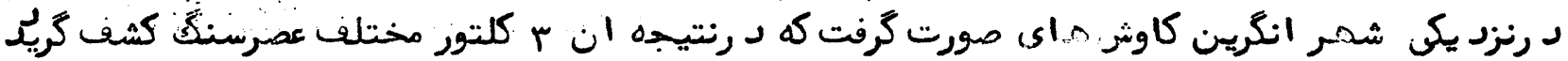

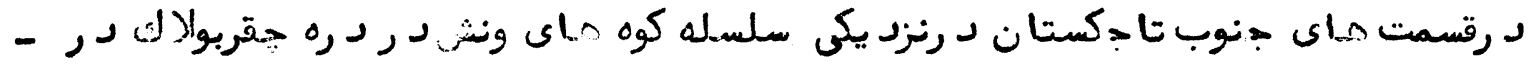

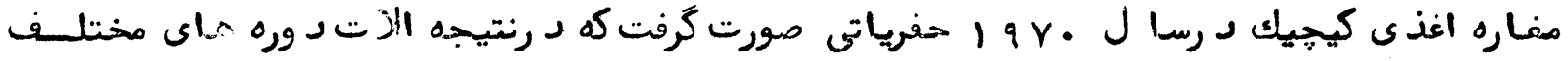

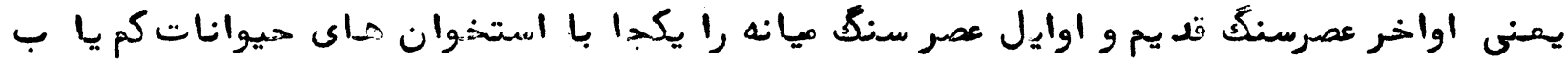

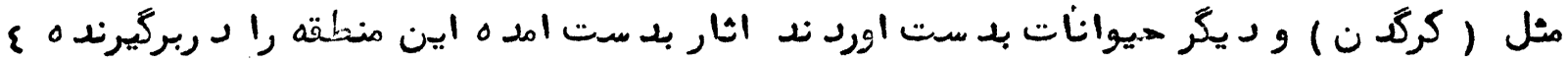

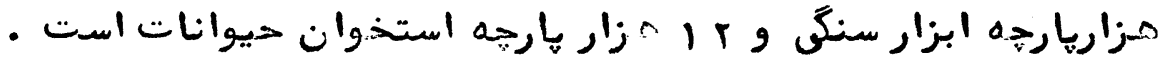

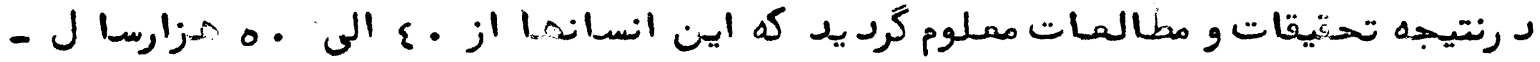

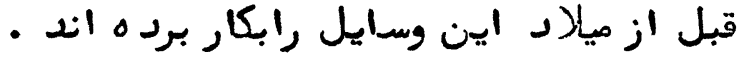


ry

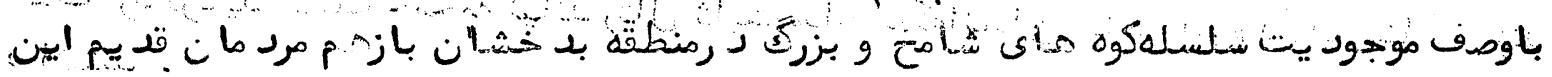

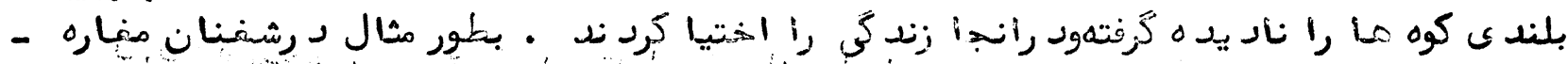

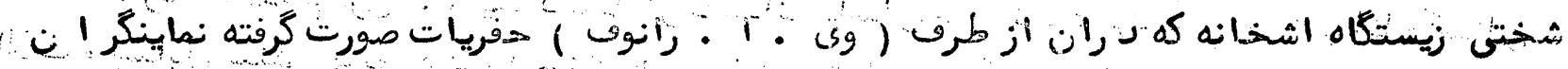

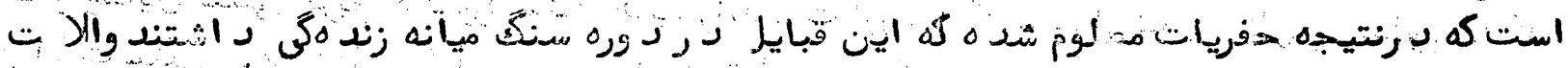

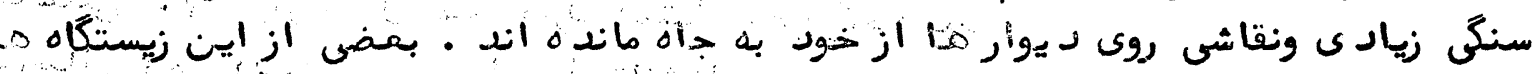

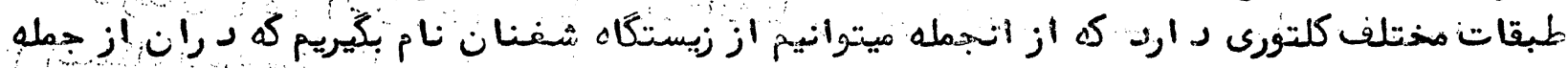

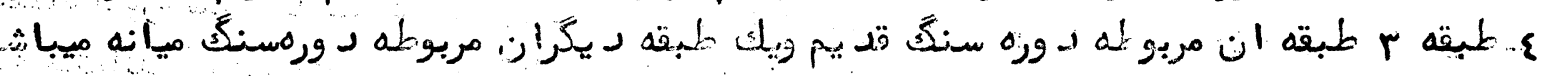

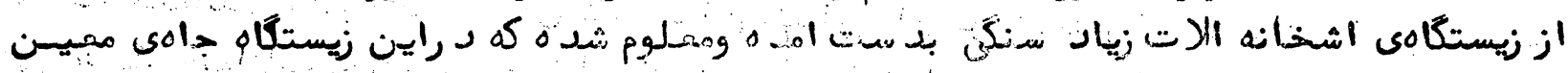

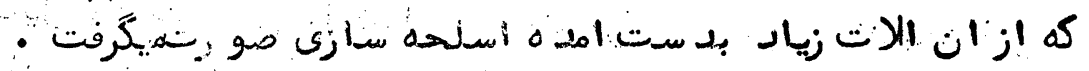

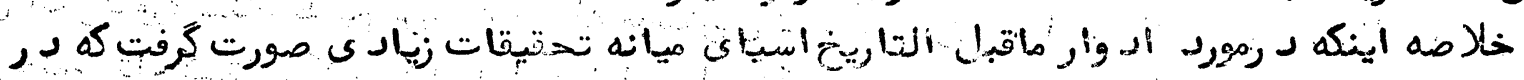

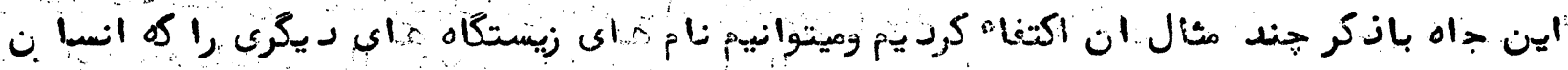

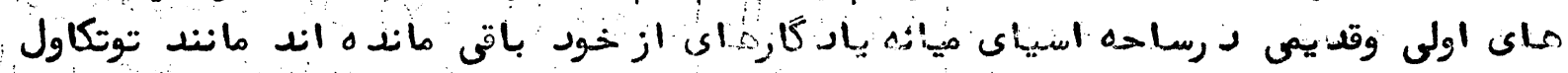

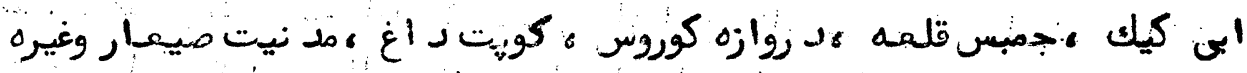

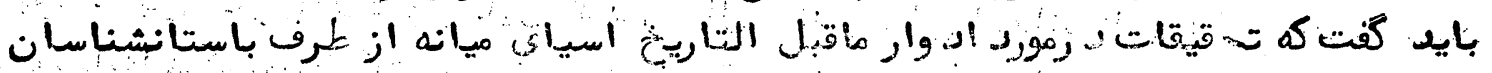

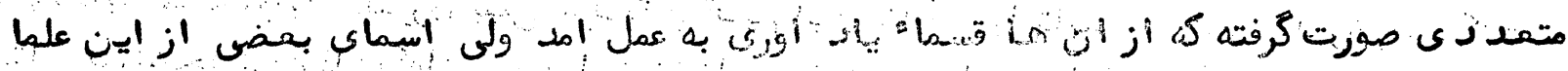

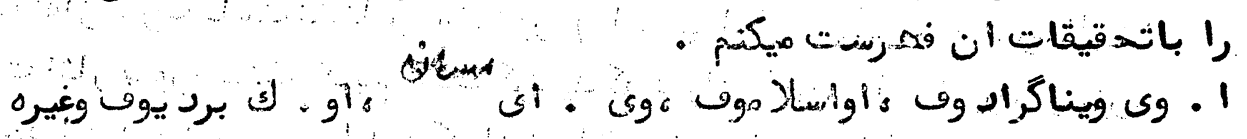

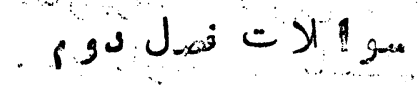

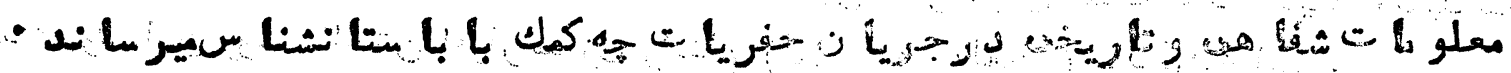

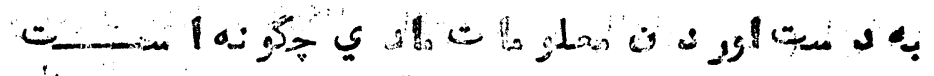

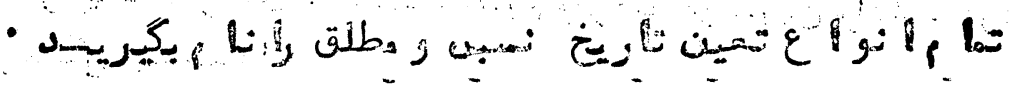

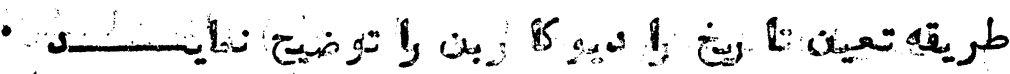
سترا :

1

r

$r$

\{

。 


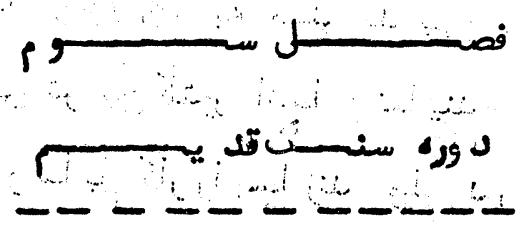

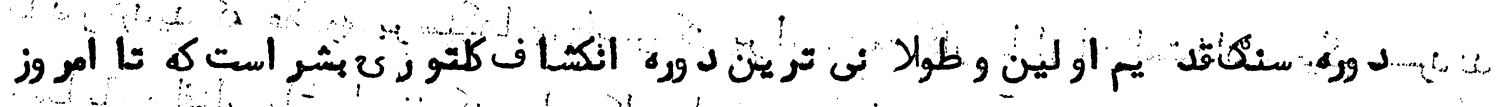

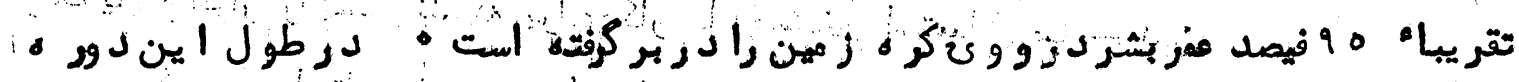

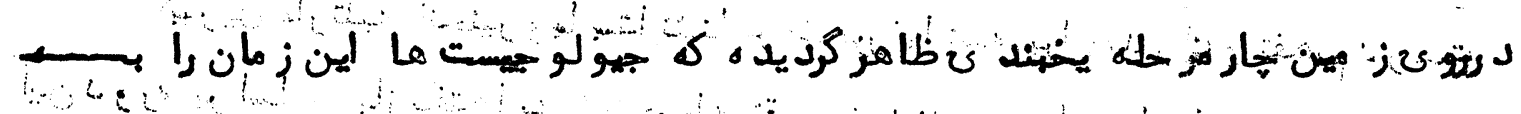

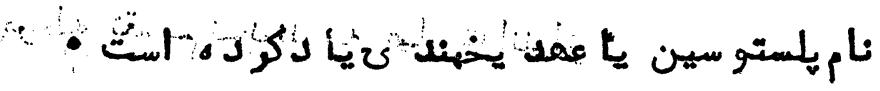

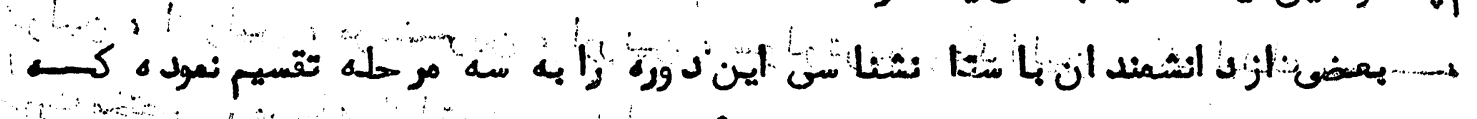

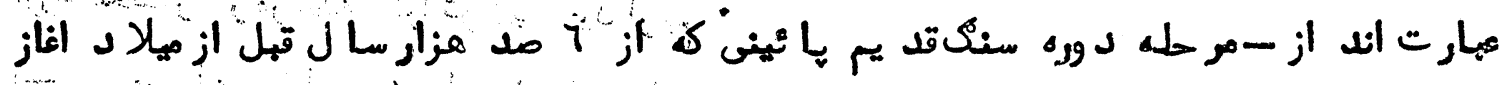

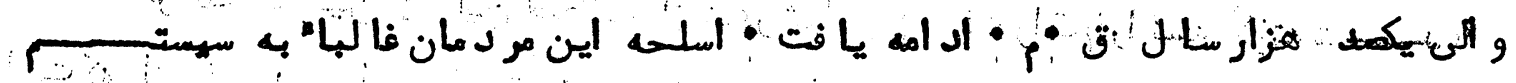

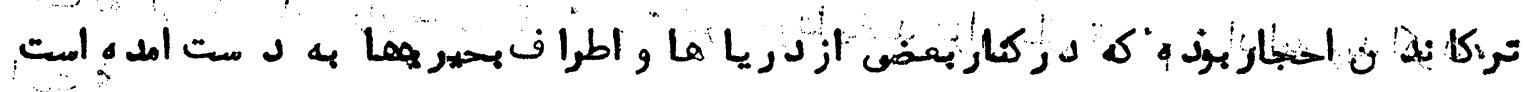

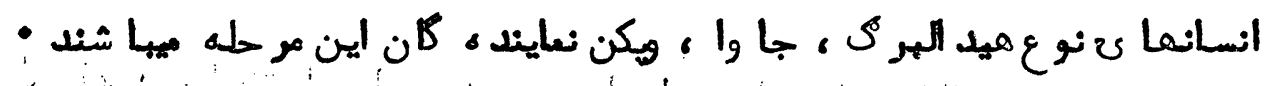

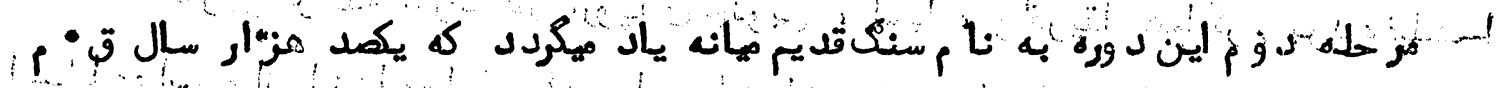

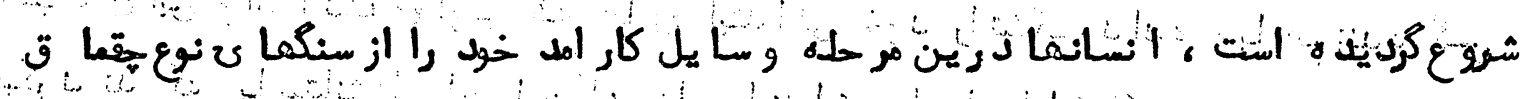

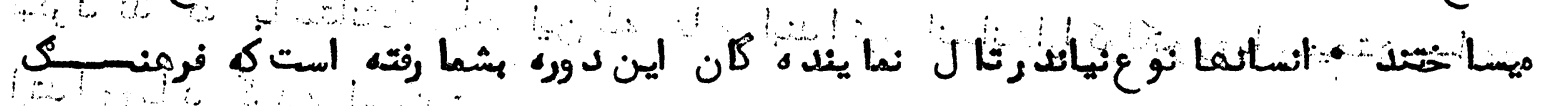

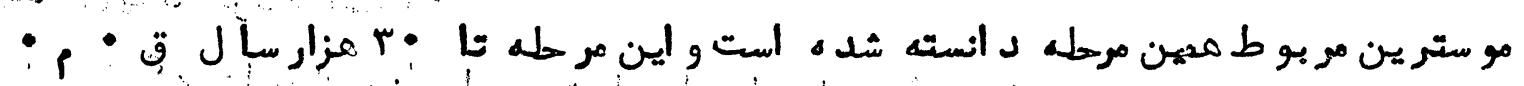

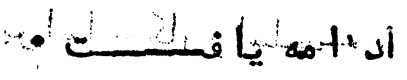

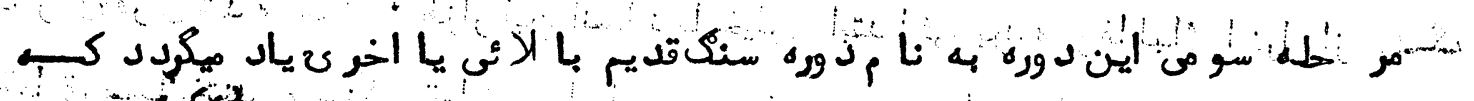

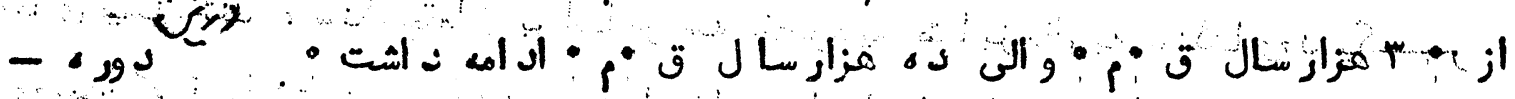
9

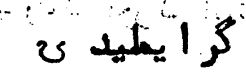

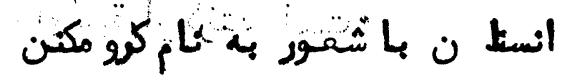

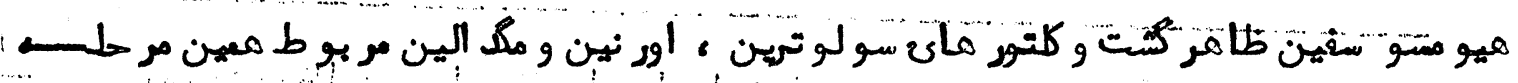

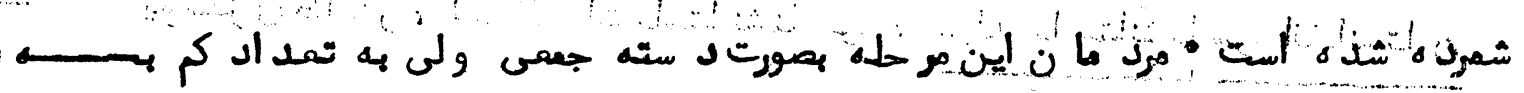

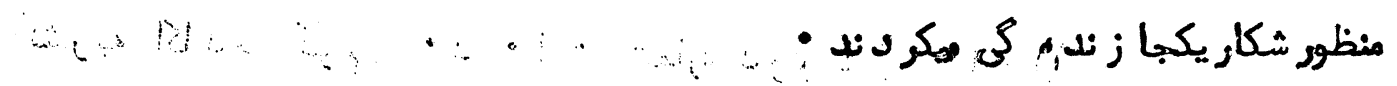

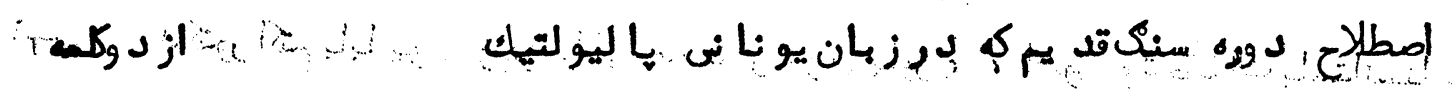




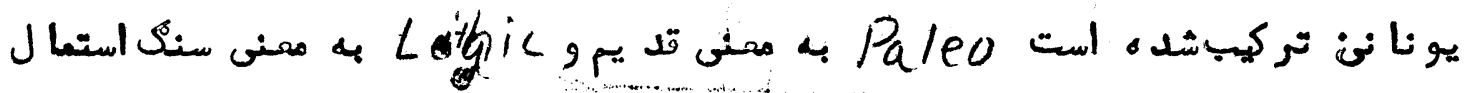

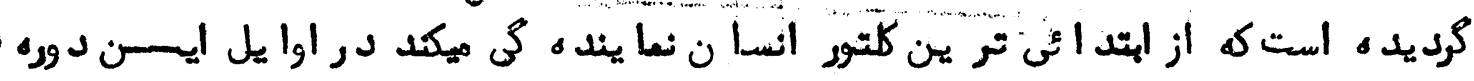

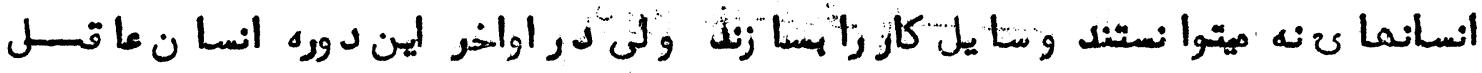

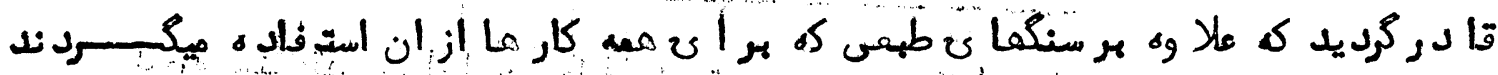

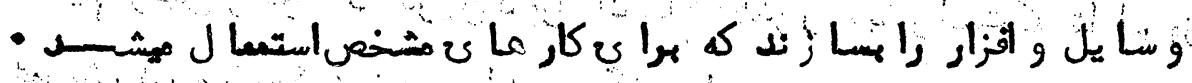

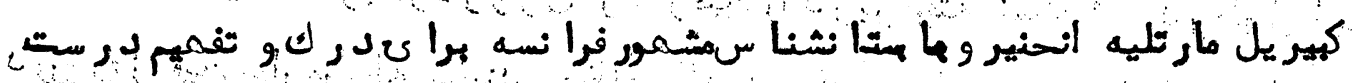

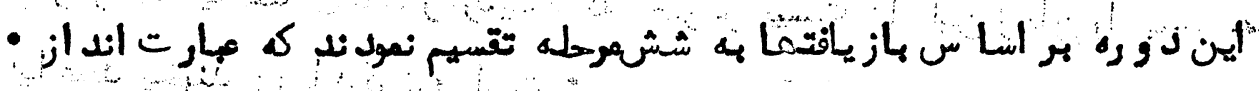

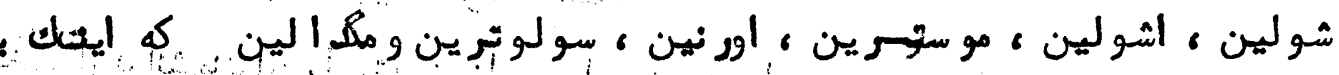

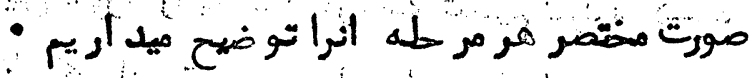

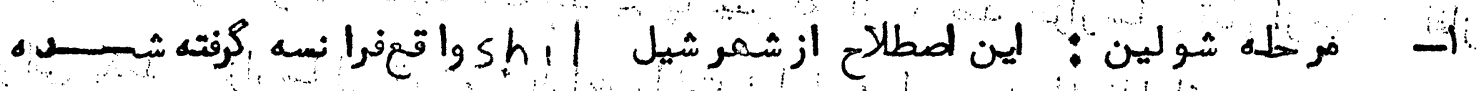

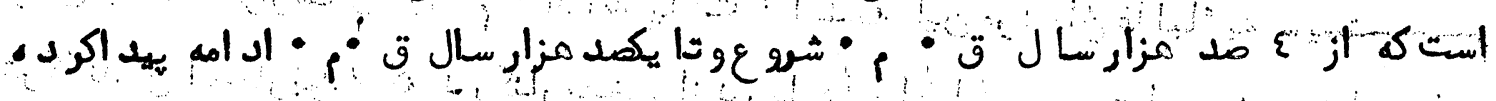
(c)

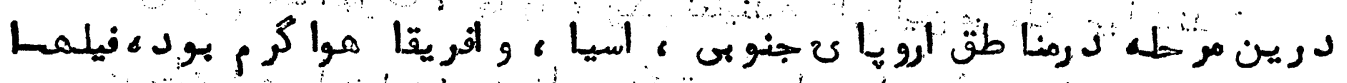

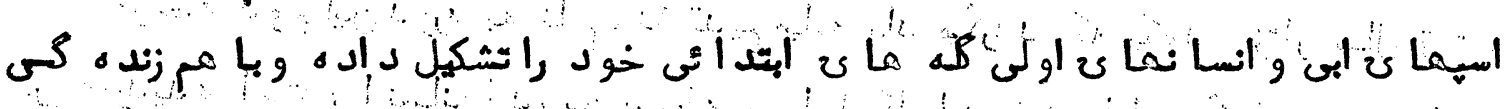

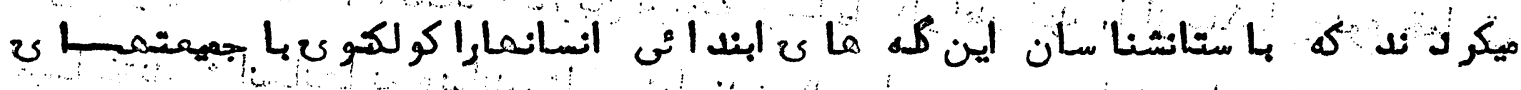

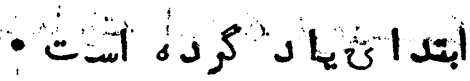

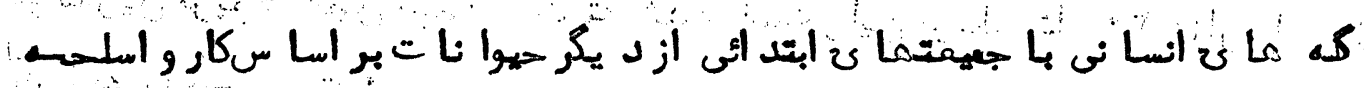

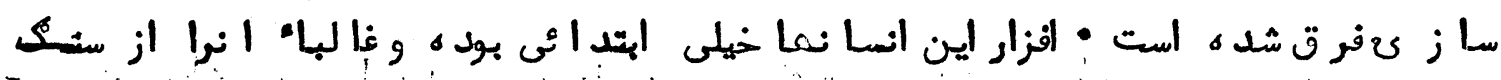

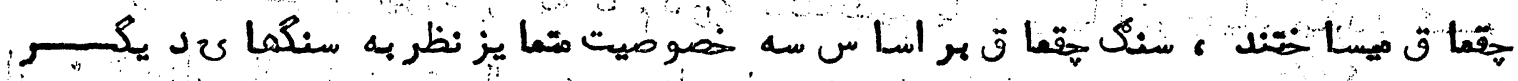

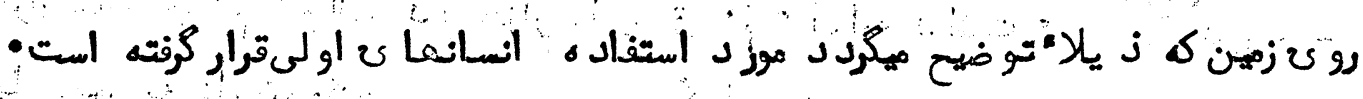

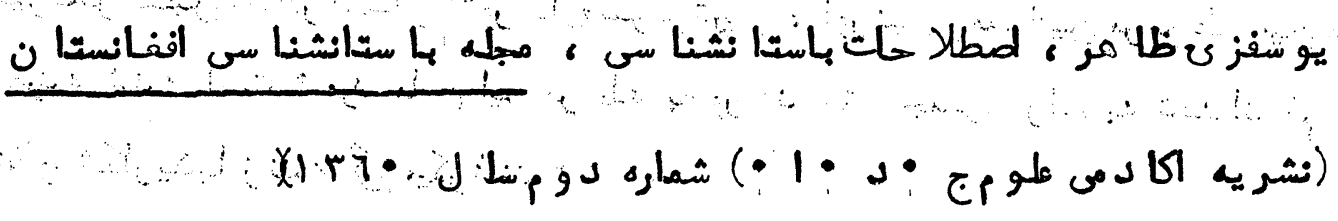

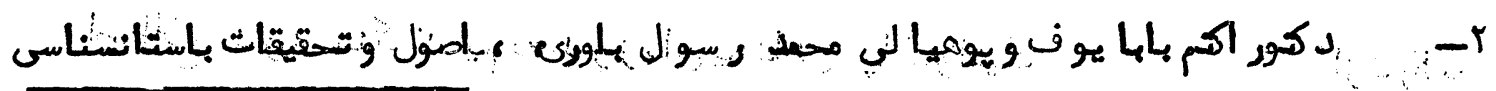

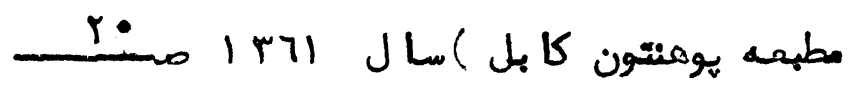




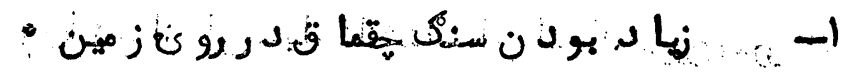

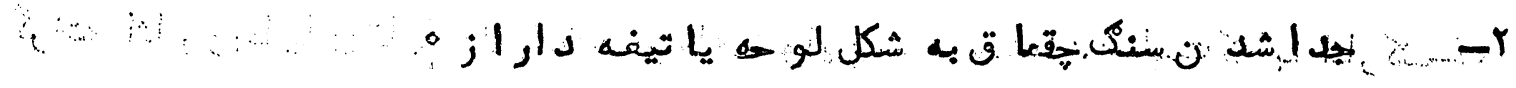

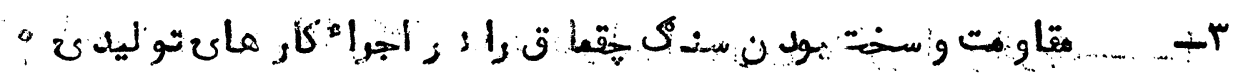

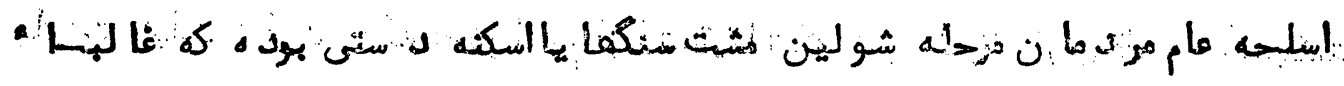

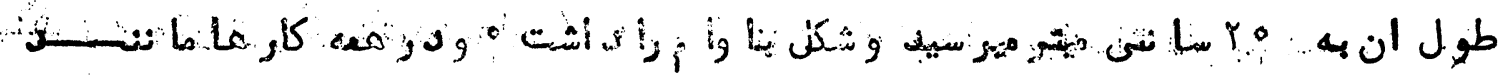

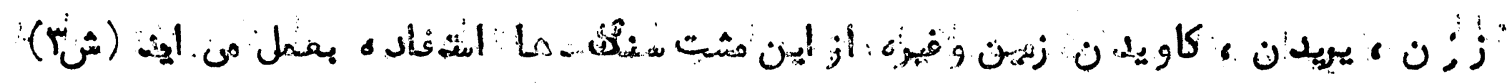

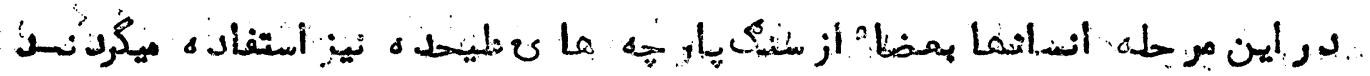

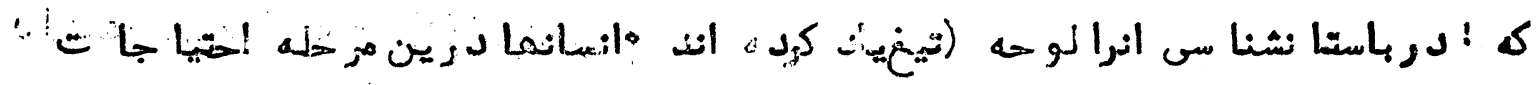

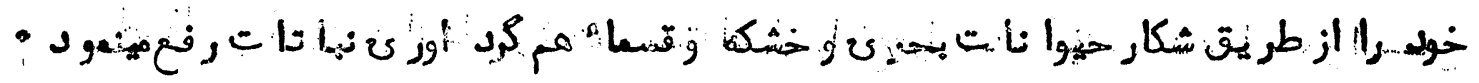

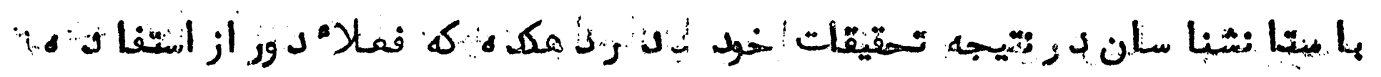

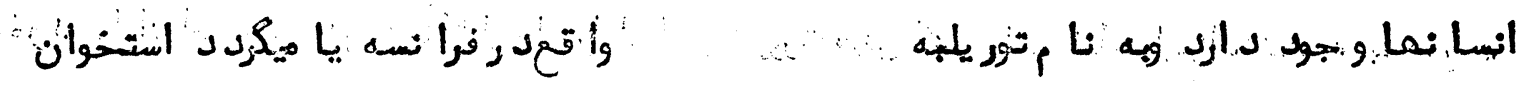

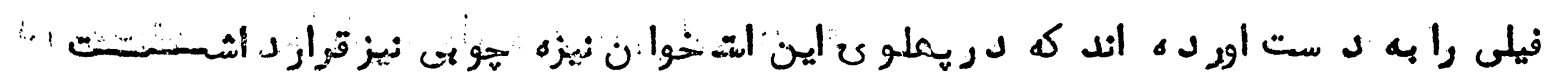

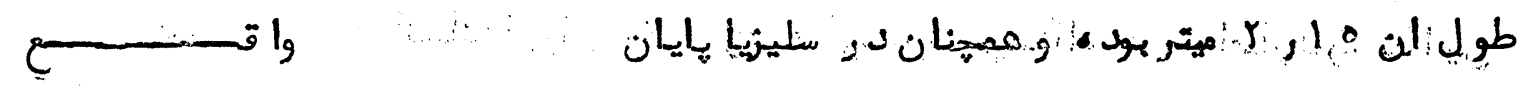

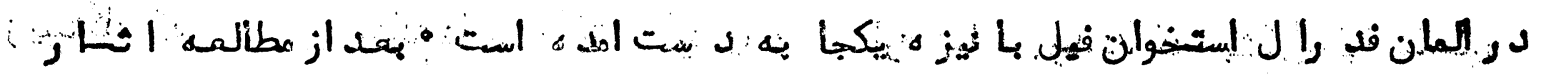

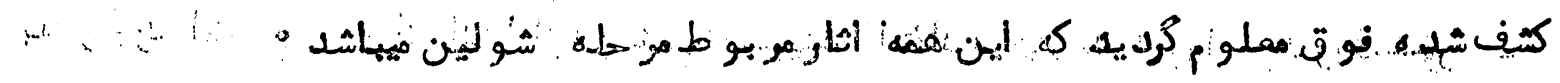

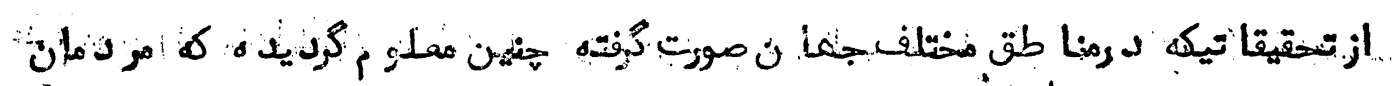

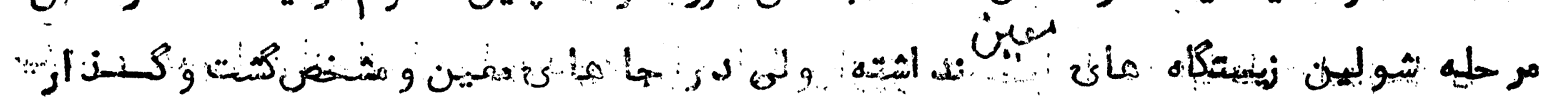

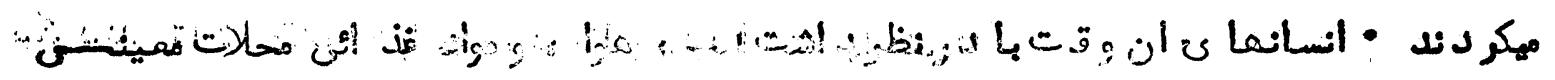

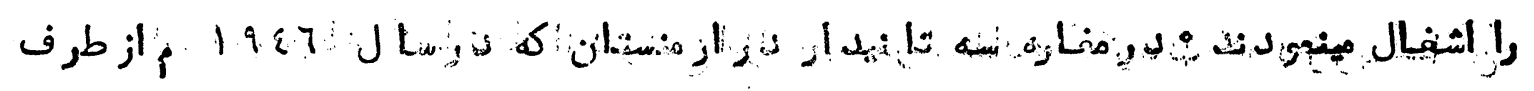

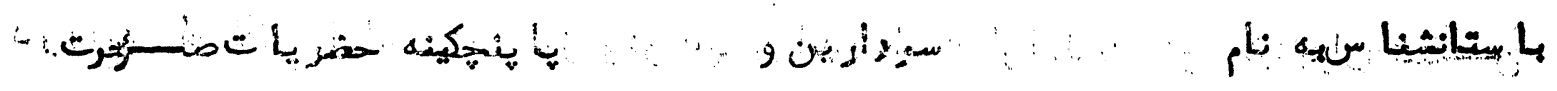

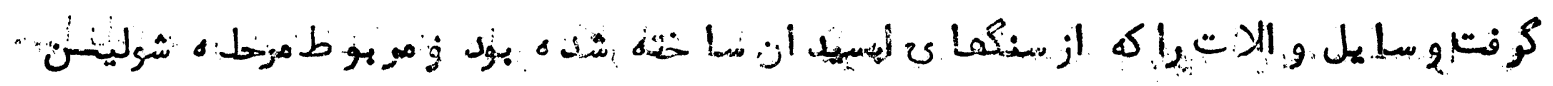

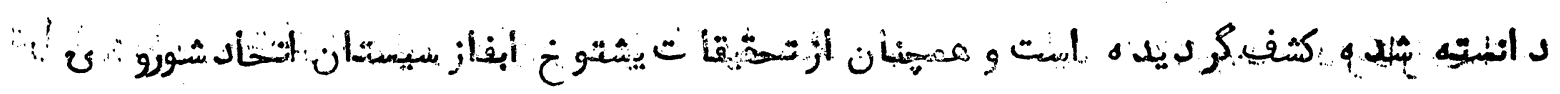

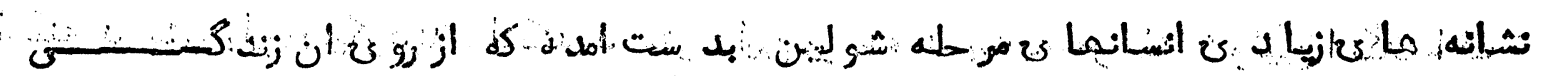
10

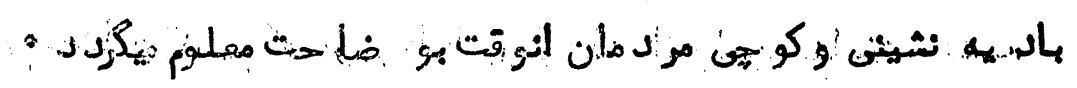




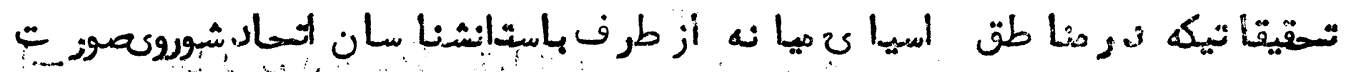

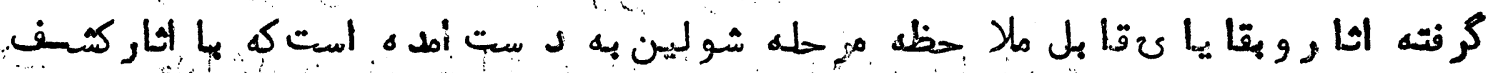

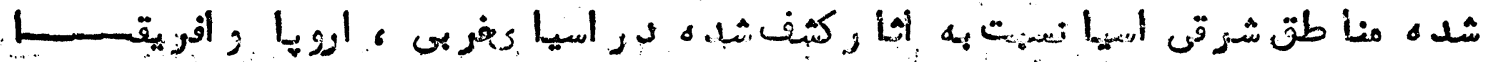

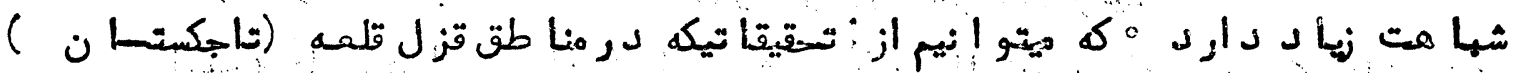

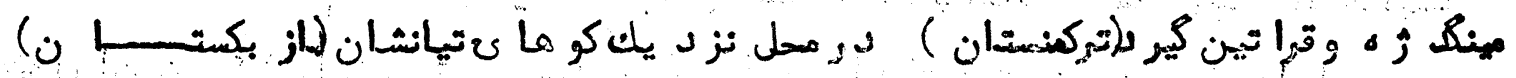

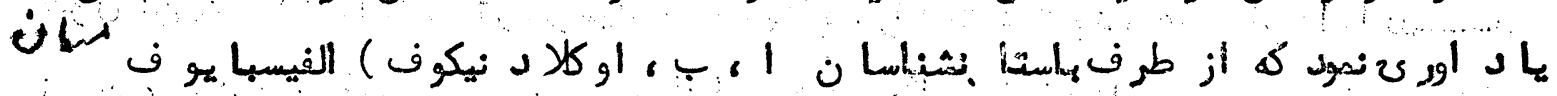

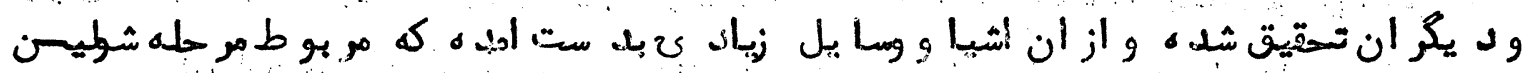

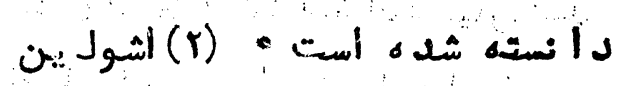

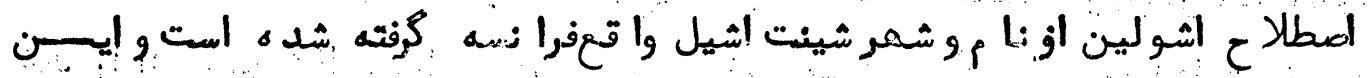

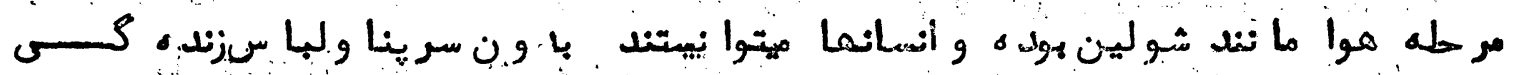

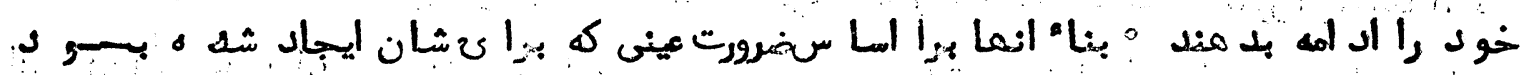

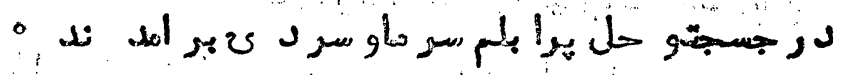

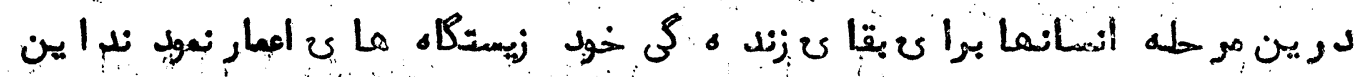

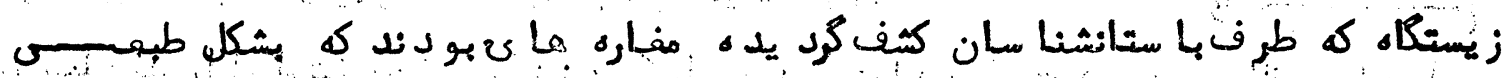

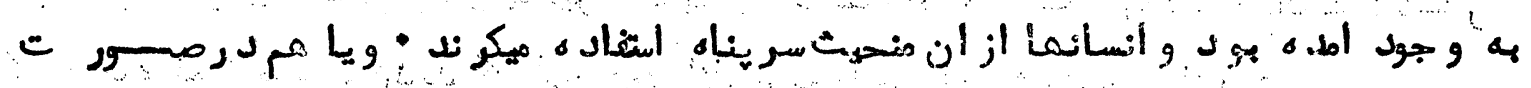

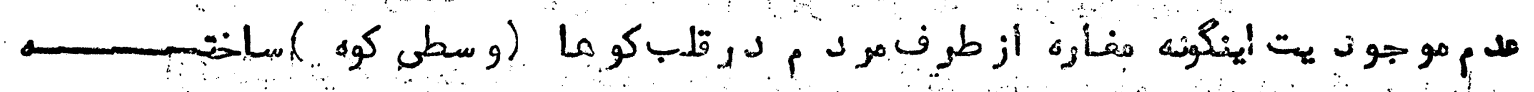

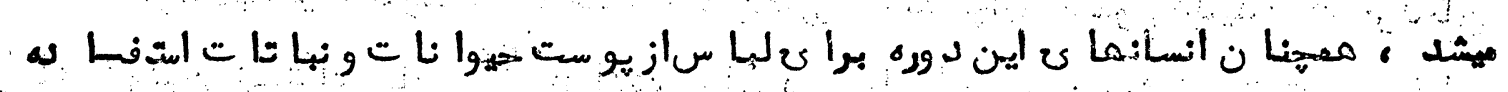

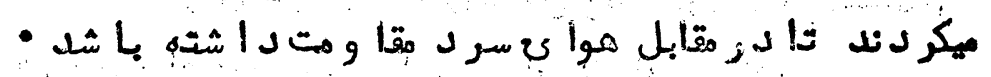

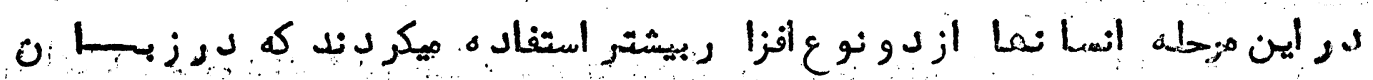

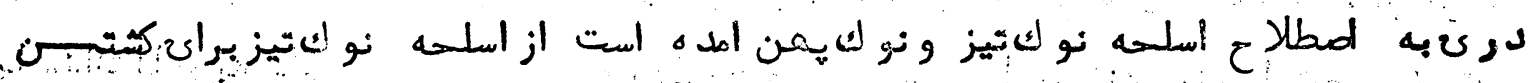

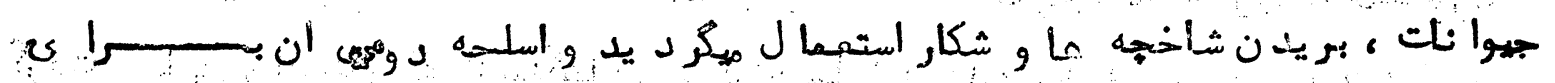

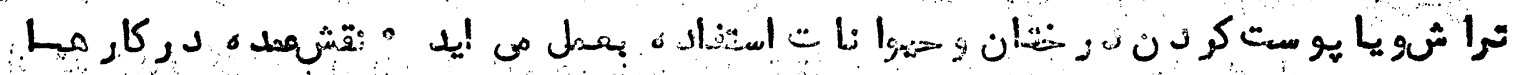

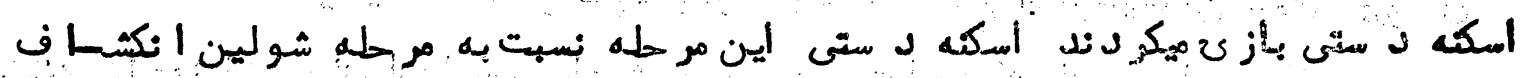

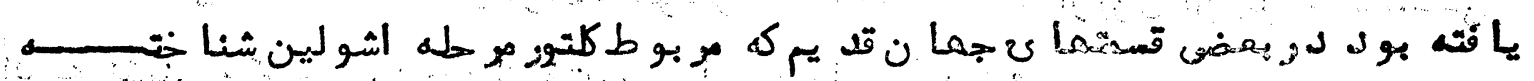




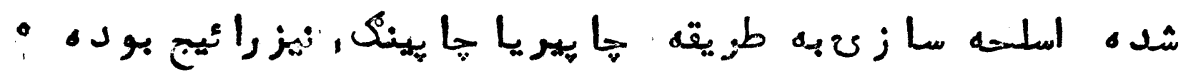

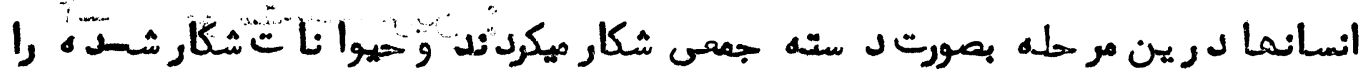

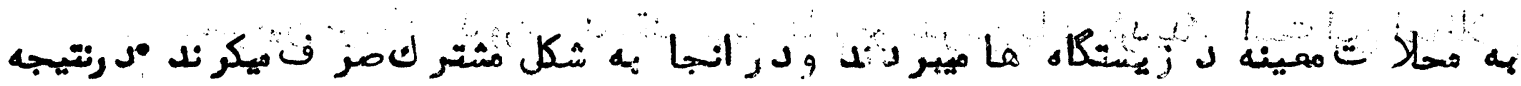

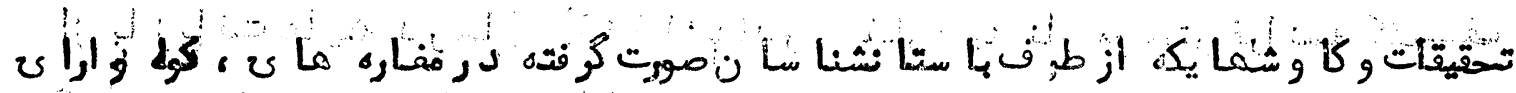

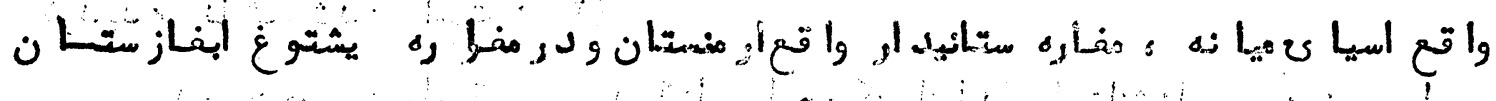

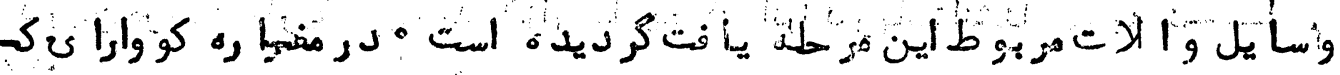

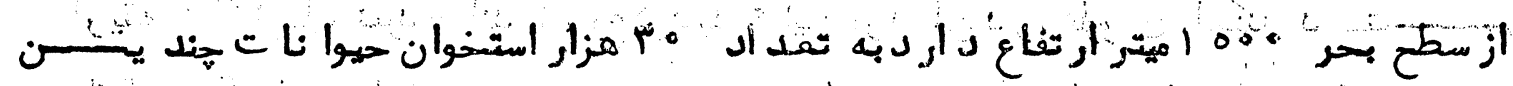

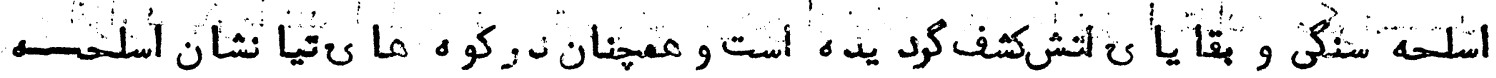

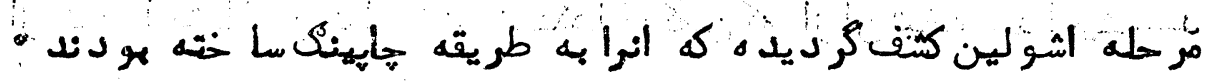

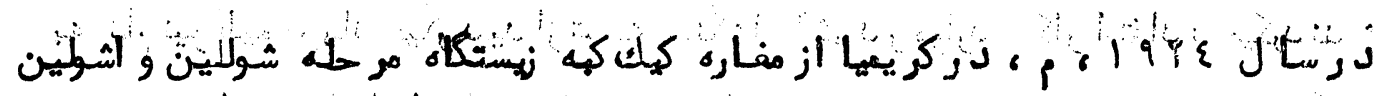

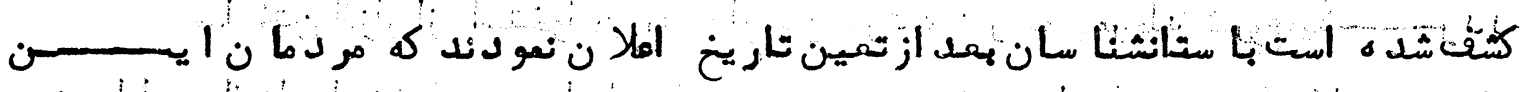

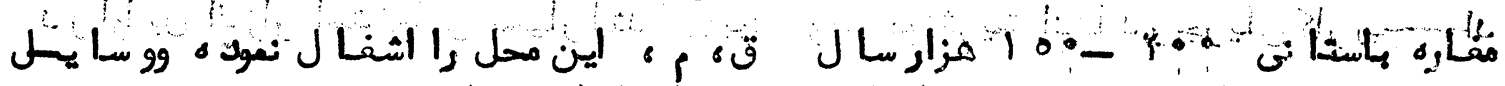

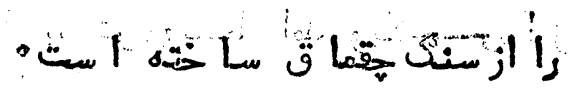

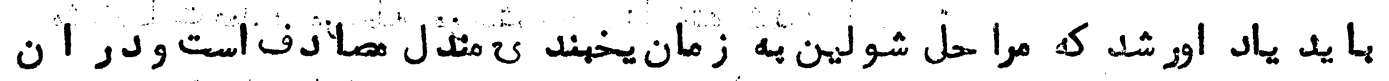

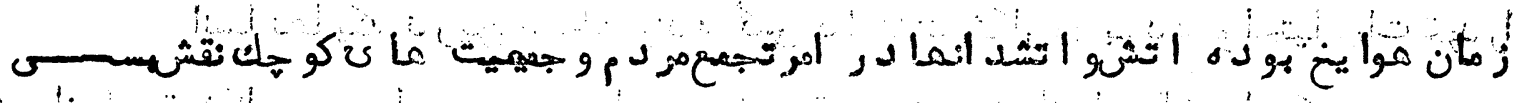

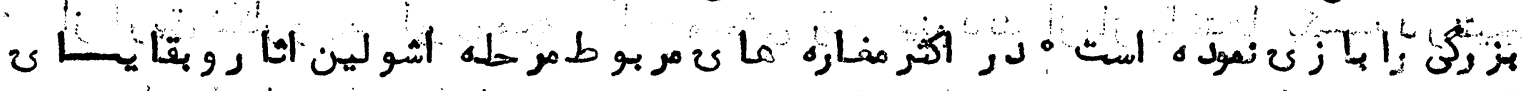

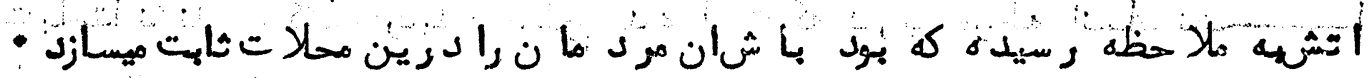

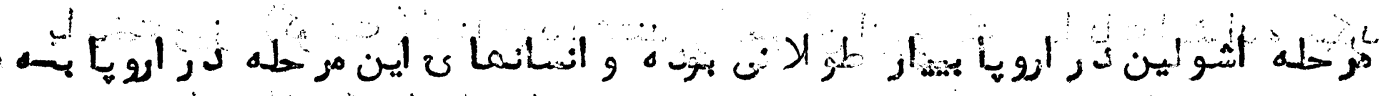

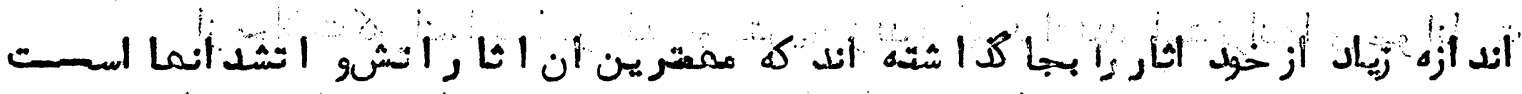

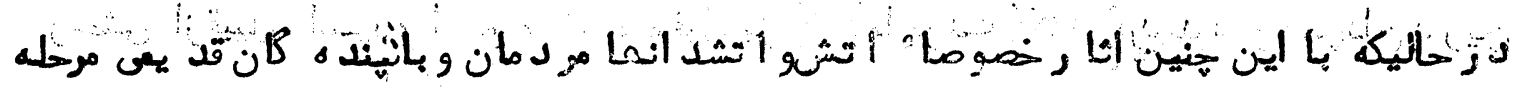

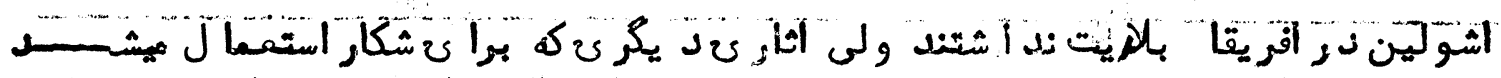

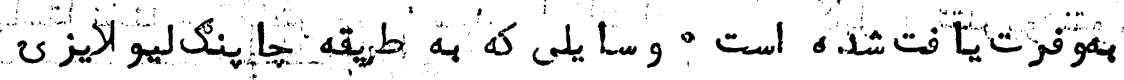

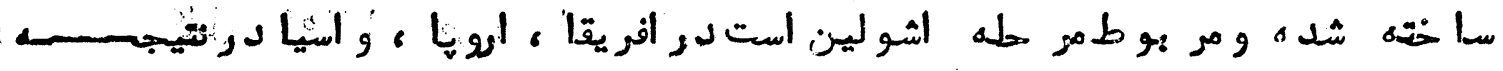

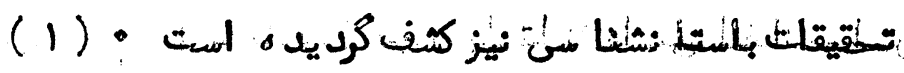


:

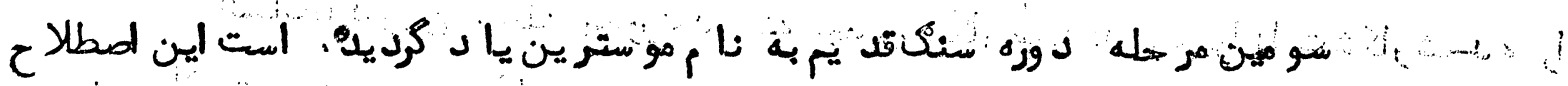

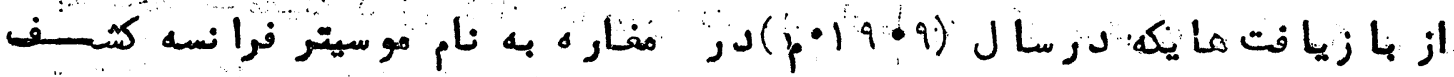

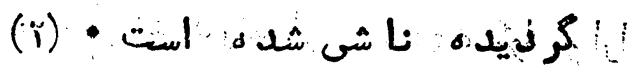

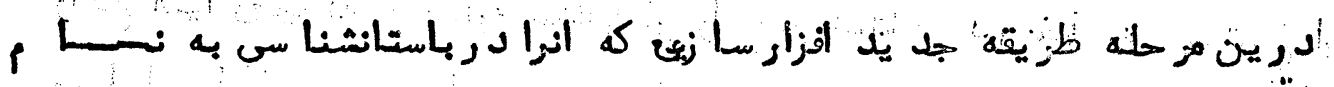

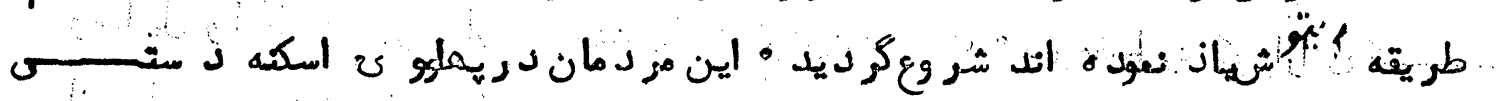

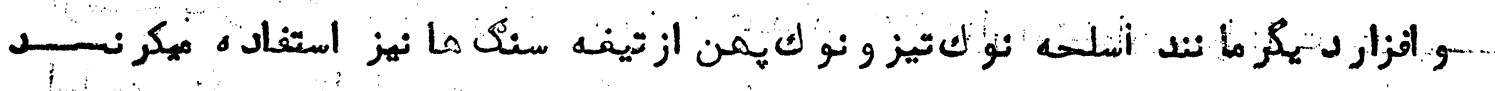

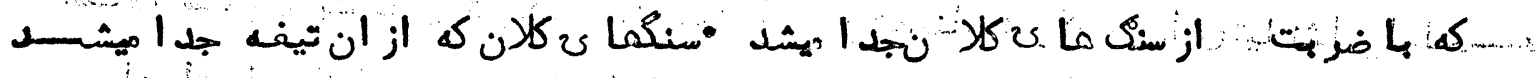

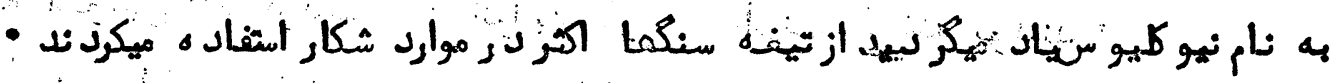

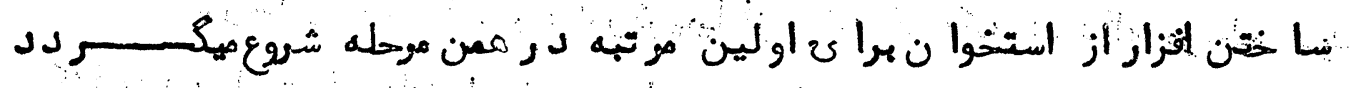

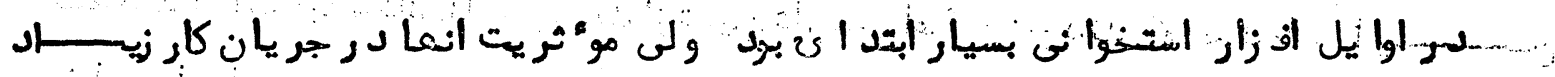

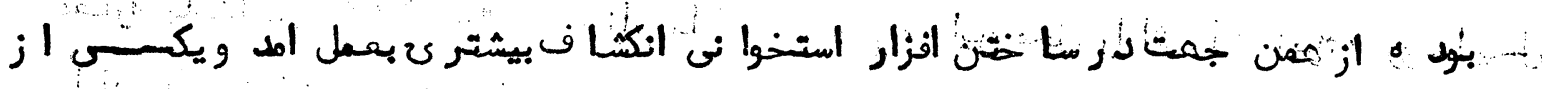

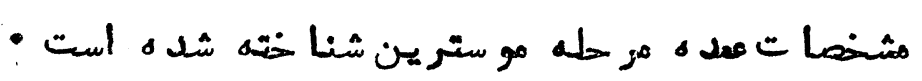

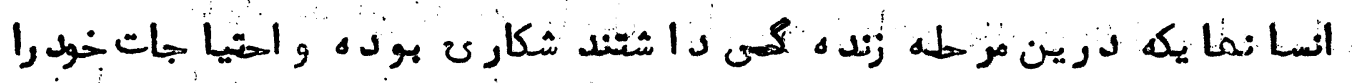

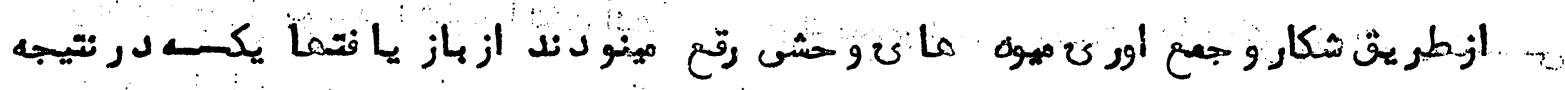

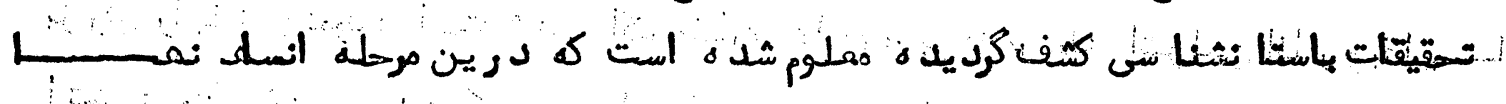

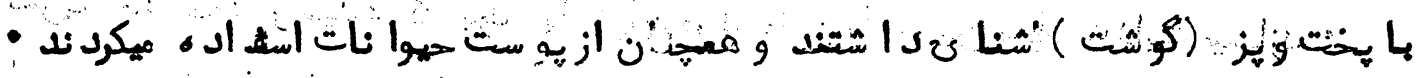

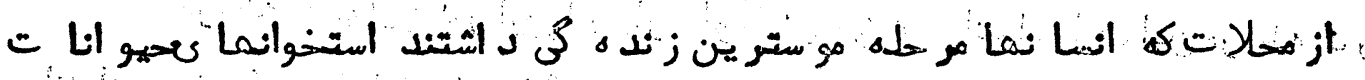

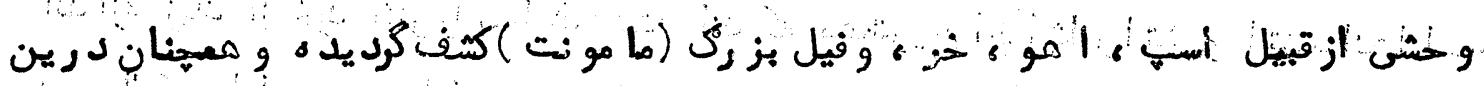

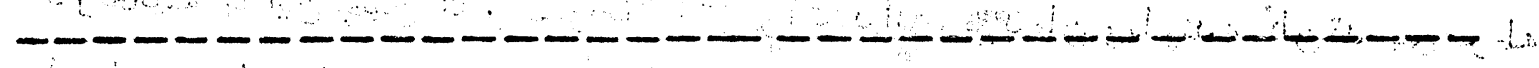

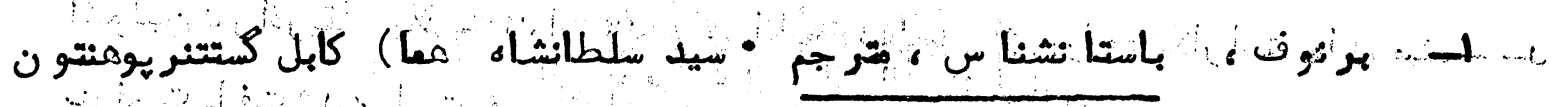

1 كابل 1 rog

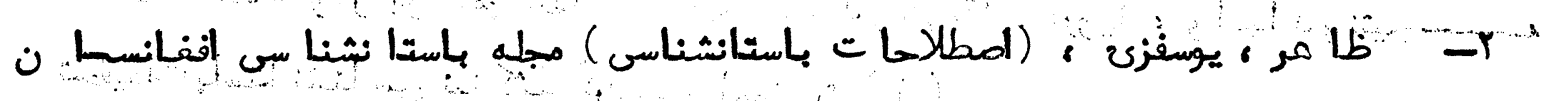

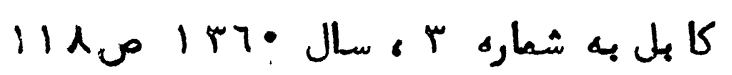




$$
\text { f }
$$

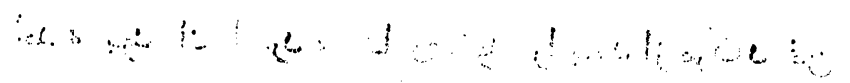

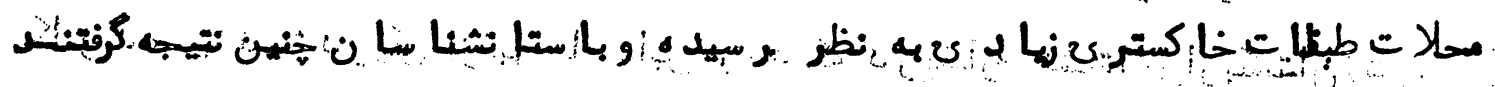

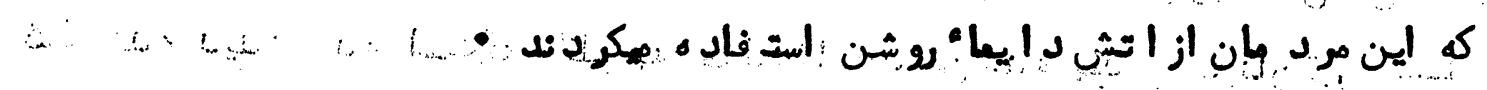

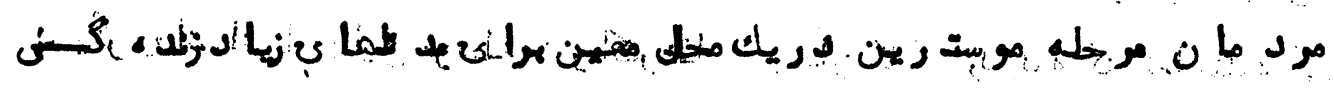

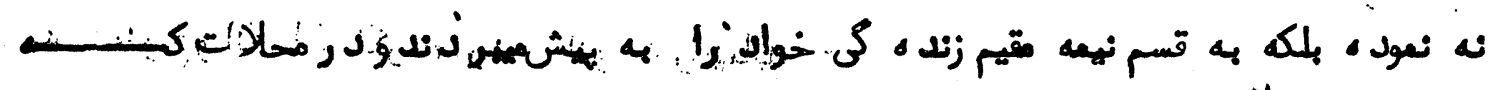

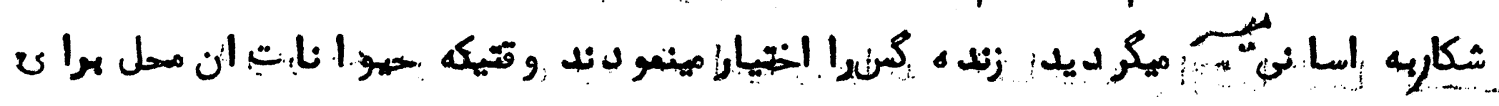
:

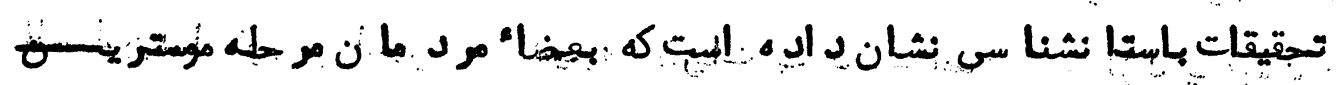

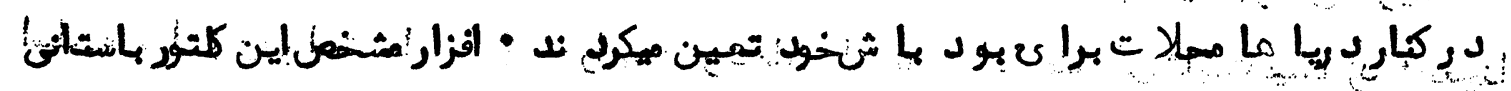

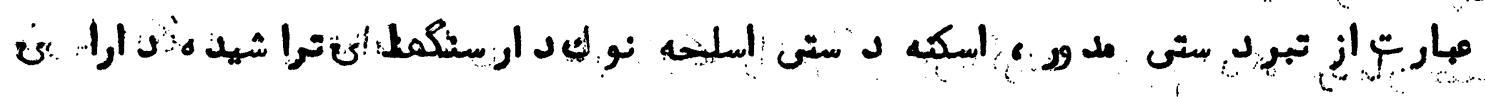

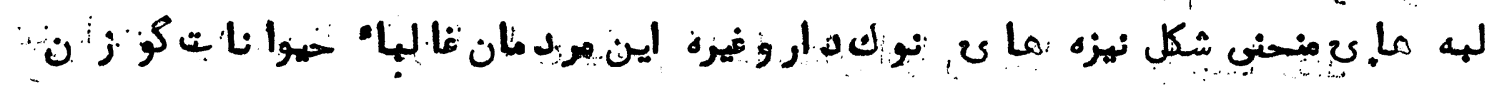

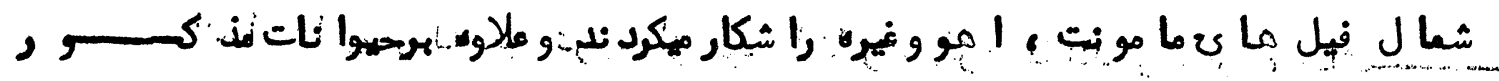

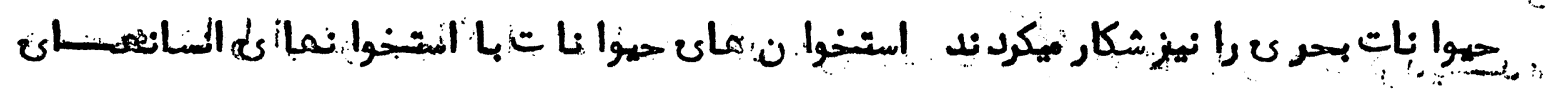

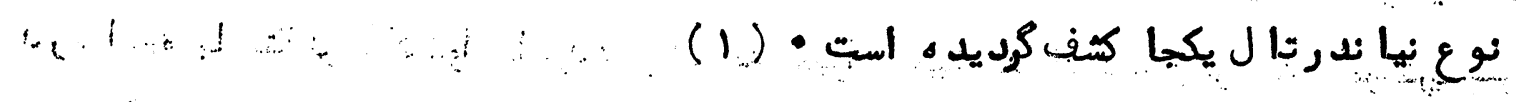

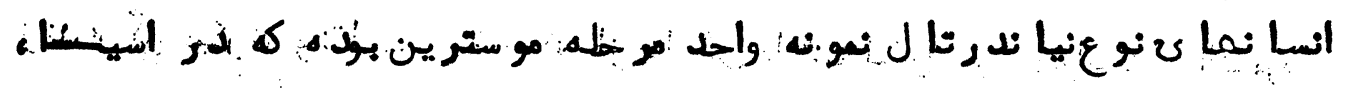

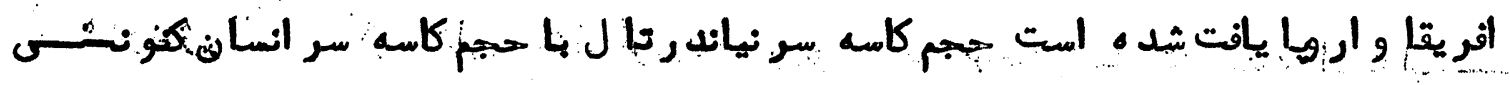

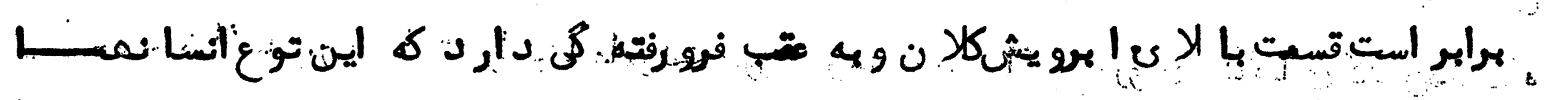

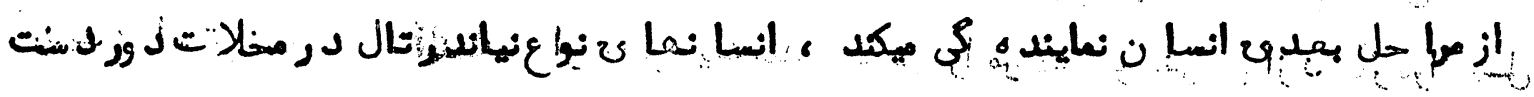

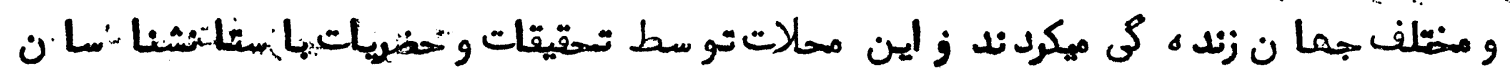

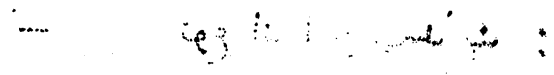

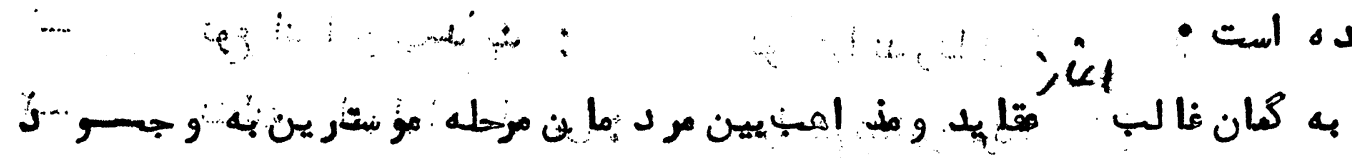

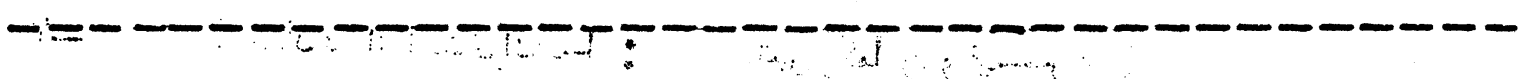

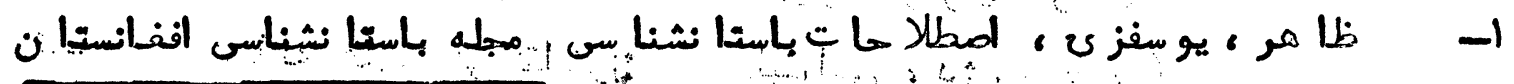

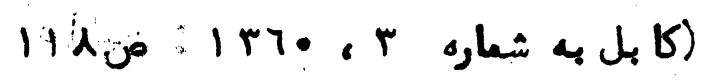




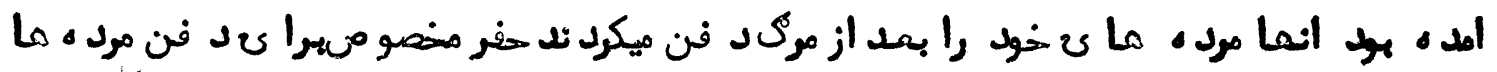

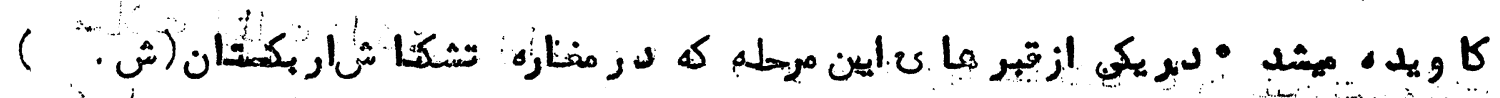

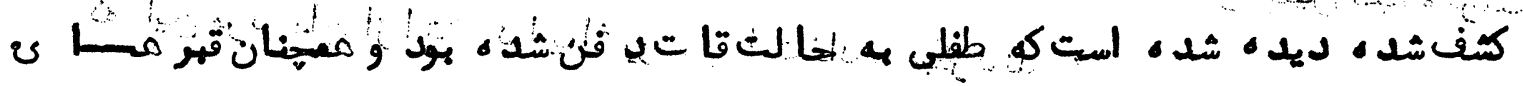

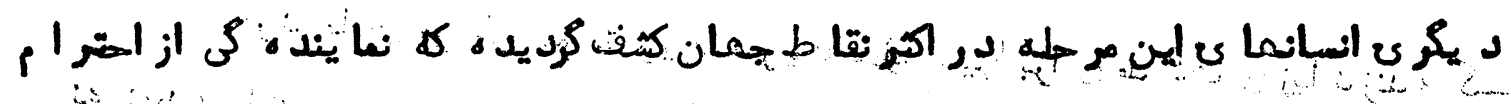

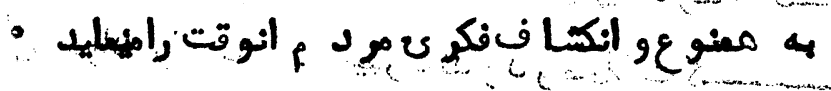

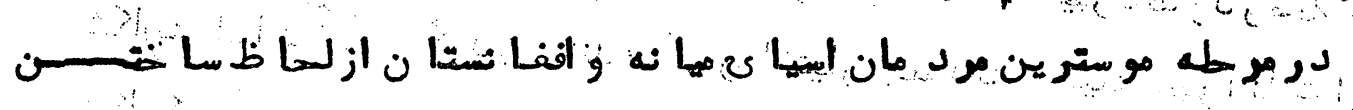

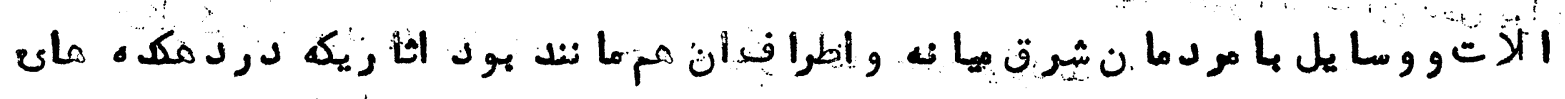

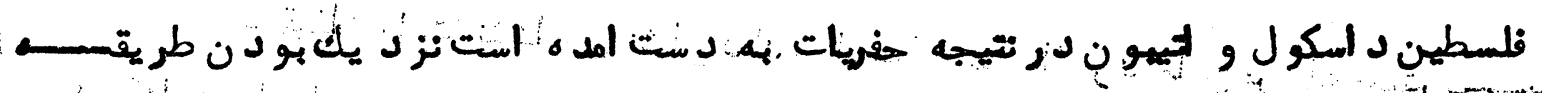

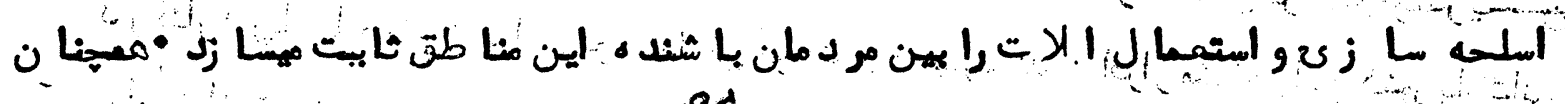

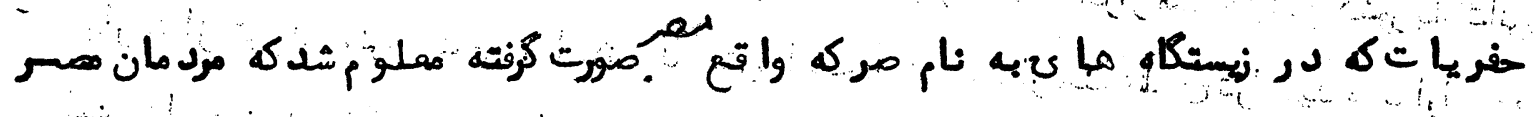

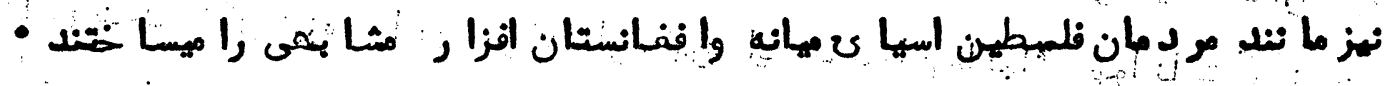

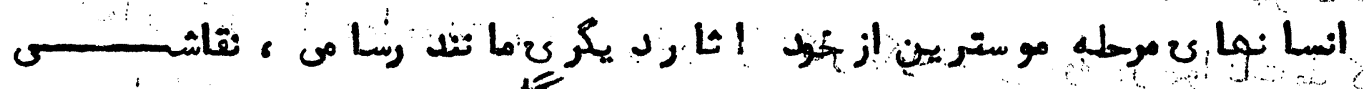

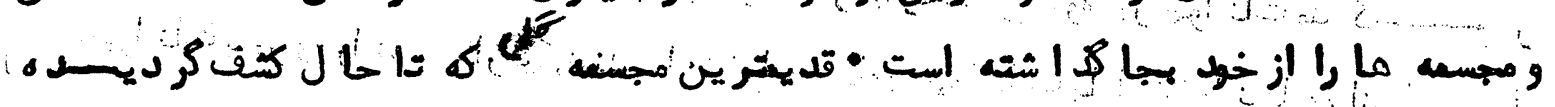

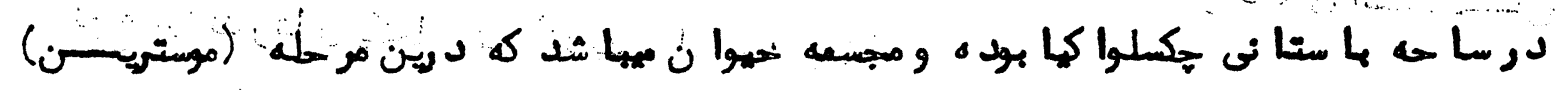

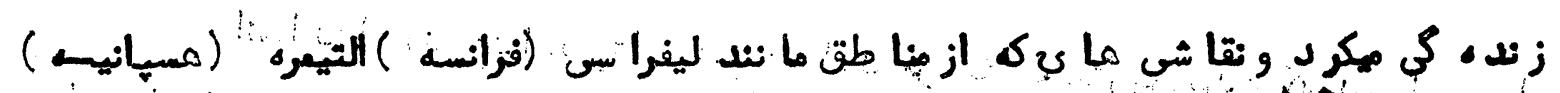

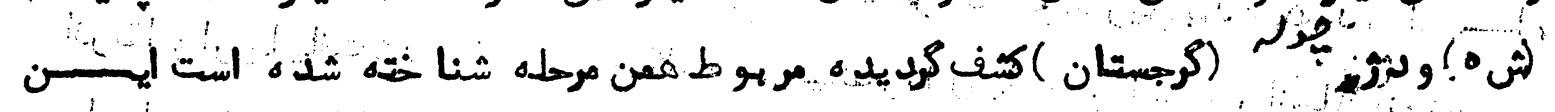

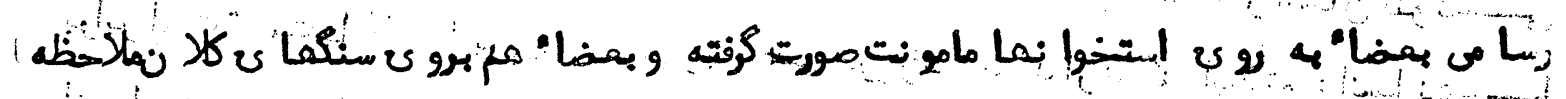

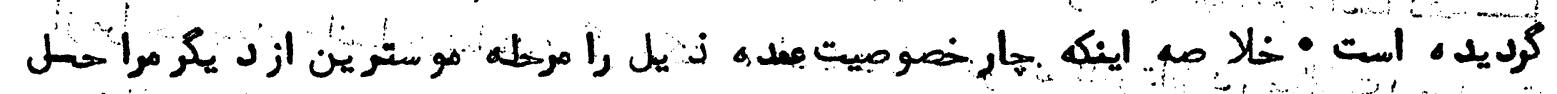

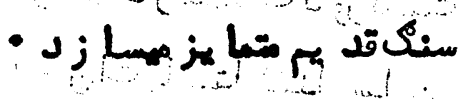

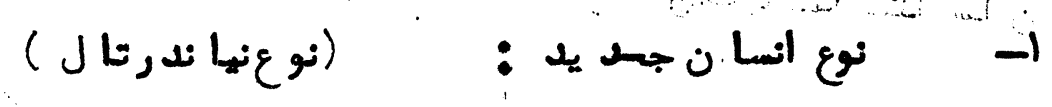

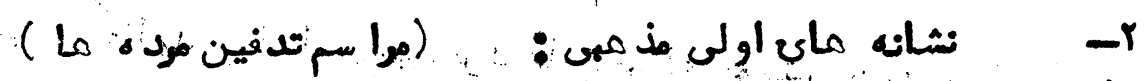

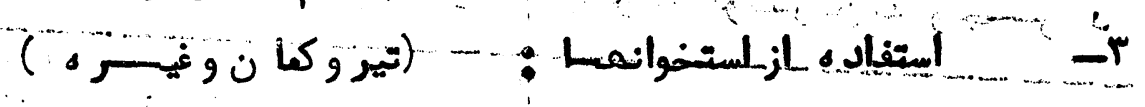

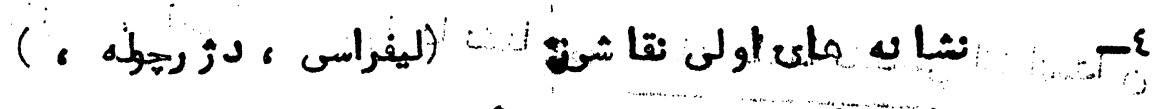

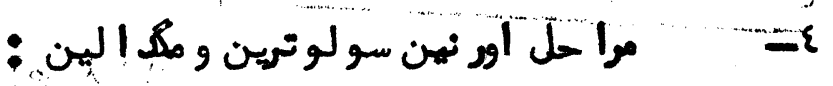




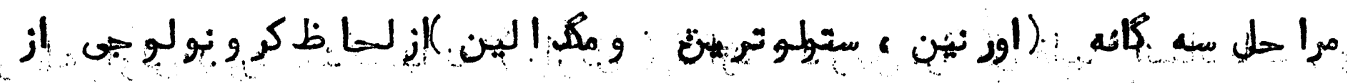

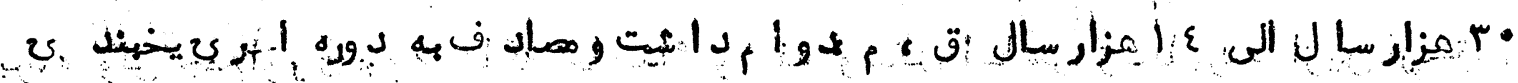

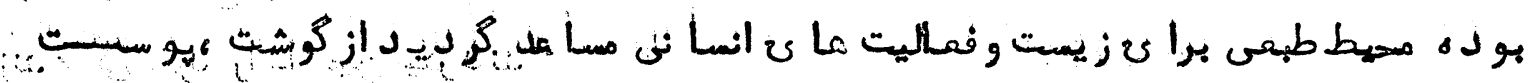

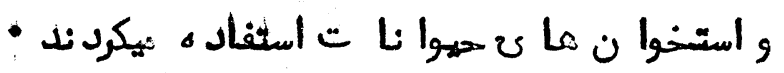

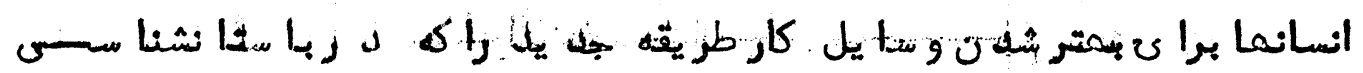

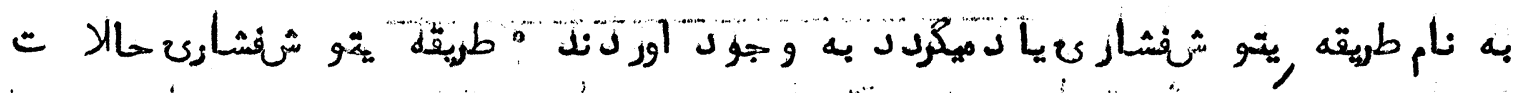

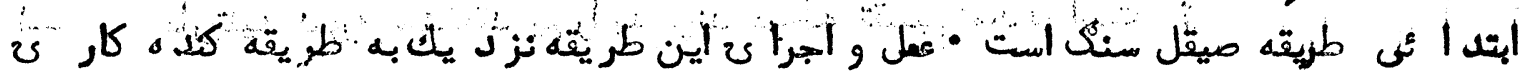

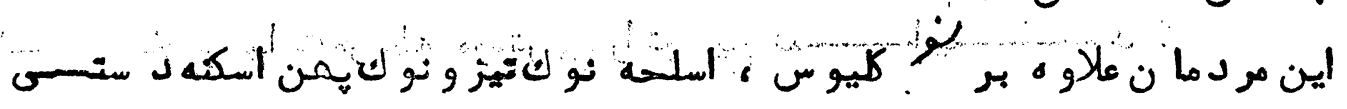

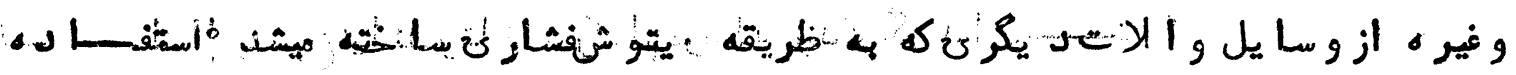

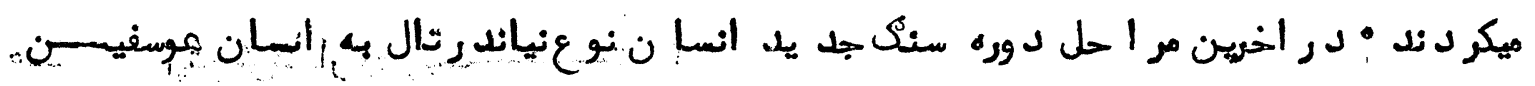

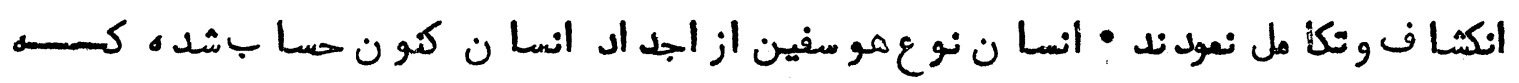

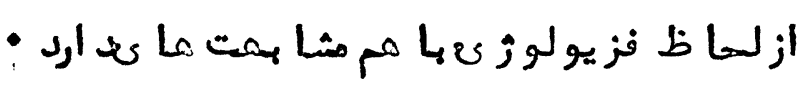

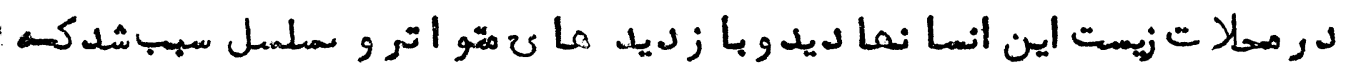

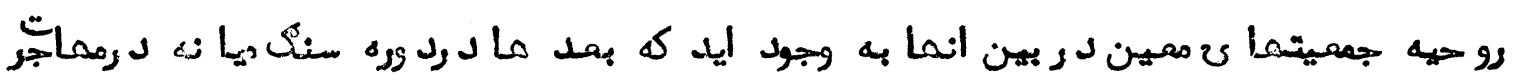

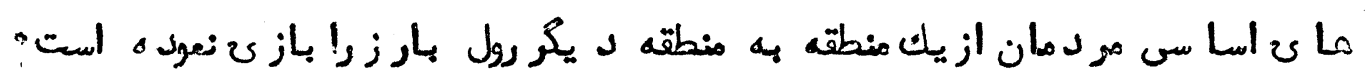

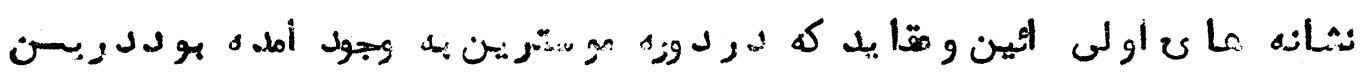

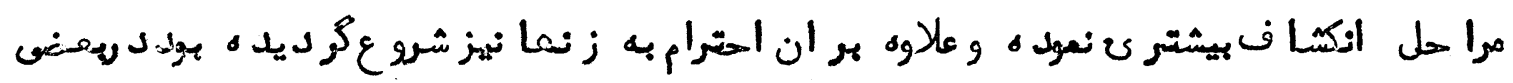

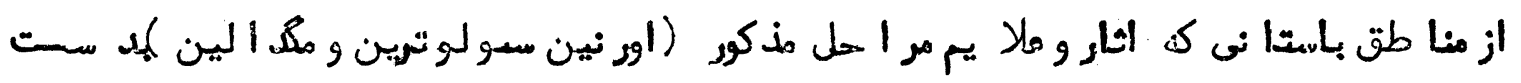

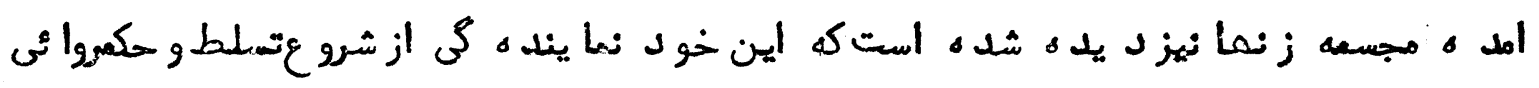

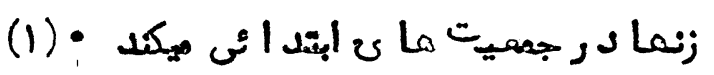

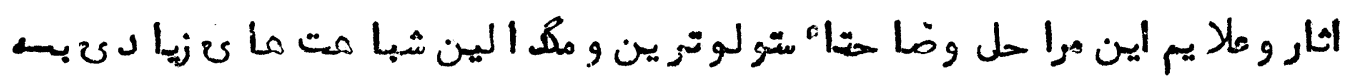

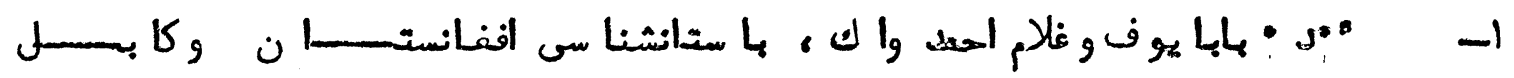

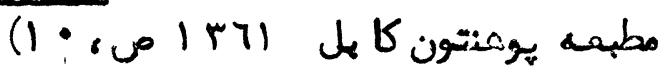




$$
<4
$$

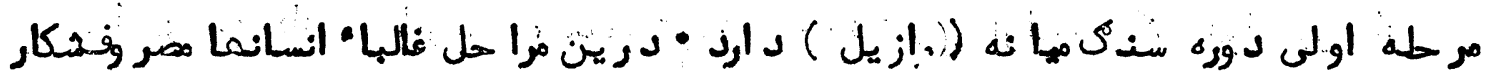

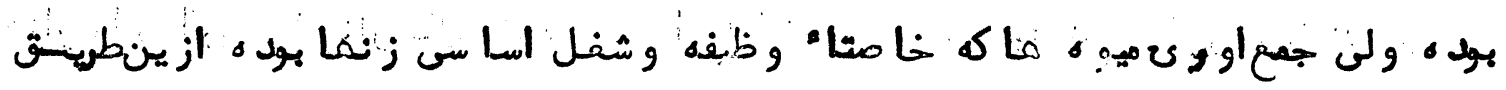

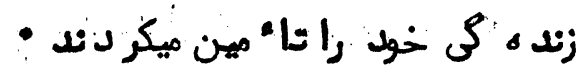

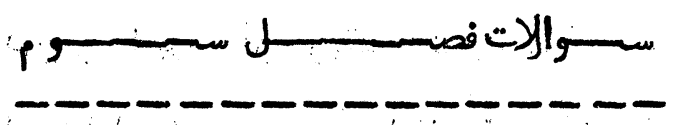

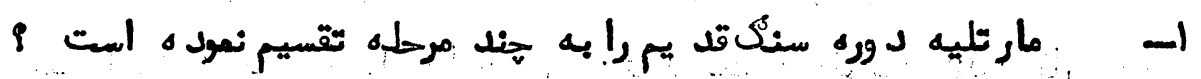

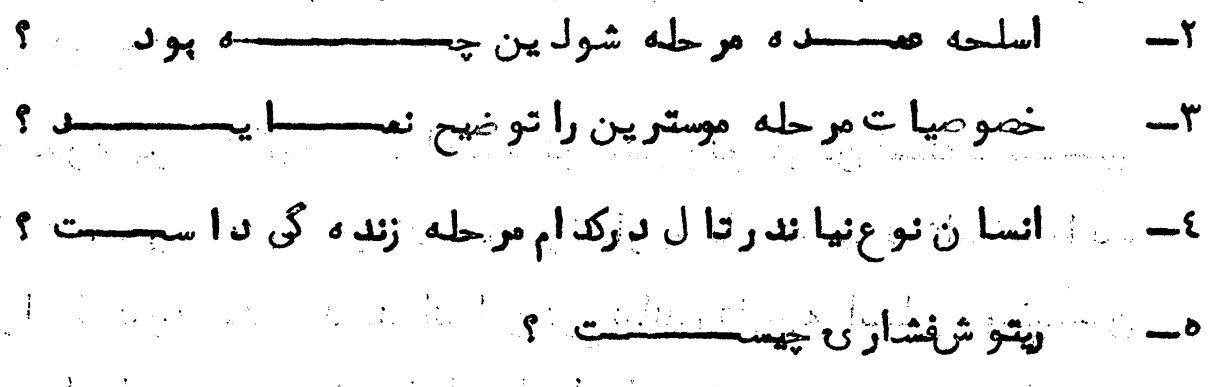




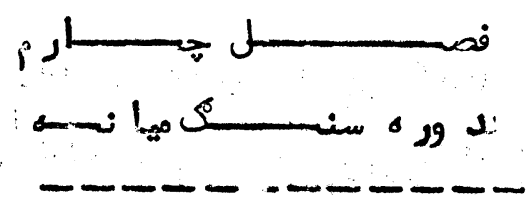

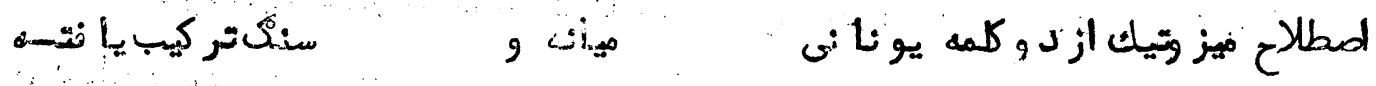

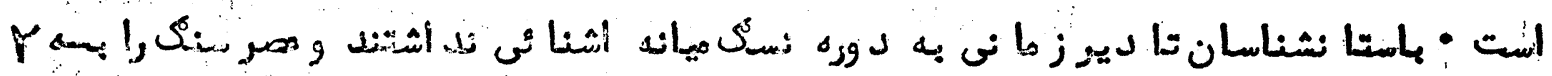

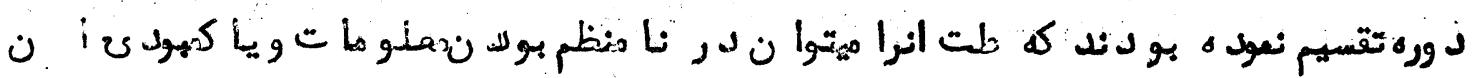

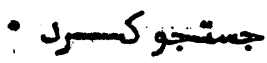

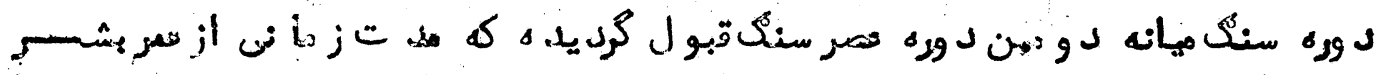

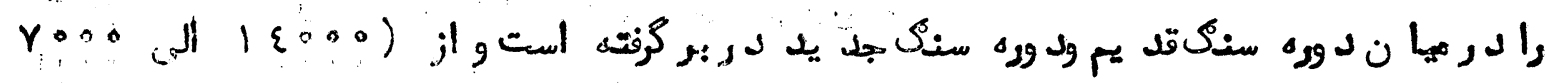

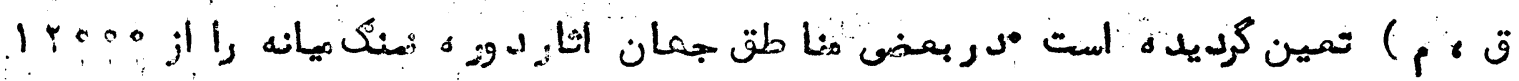

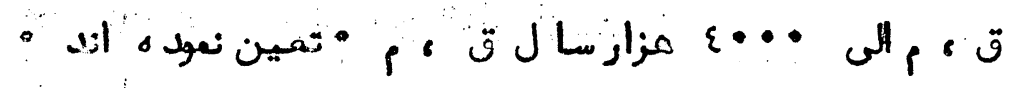

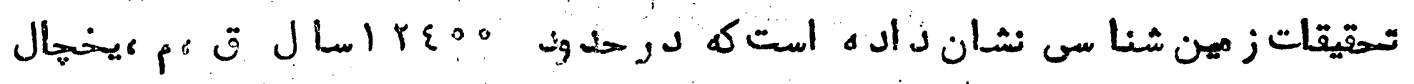

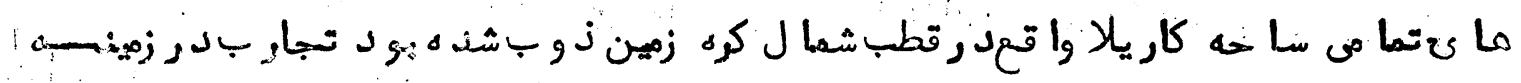

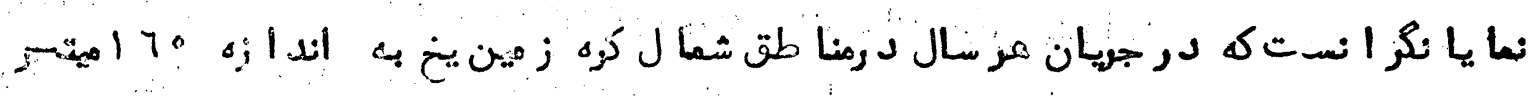

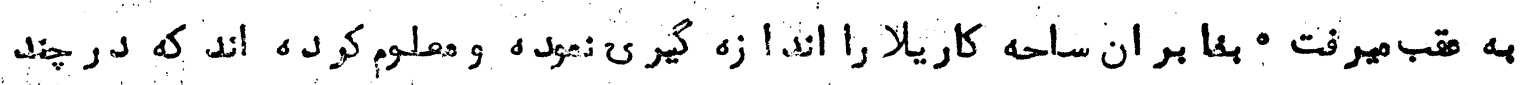

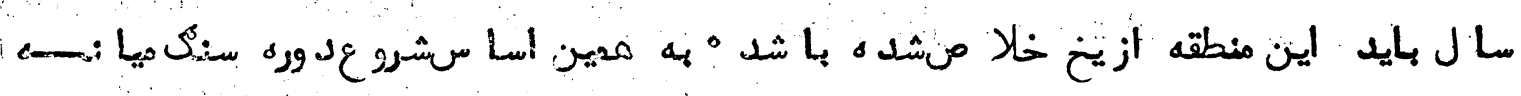

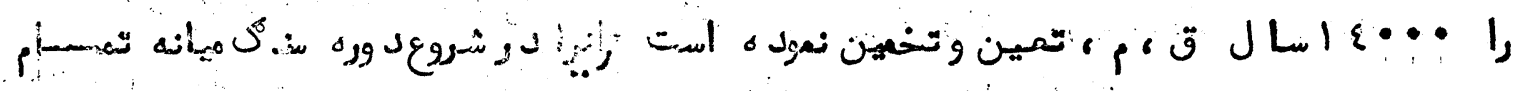

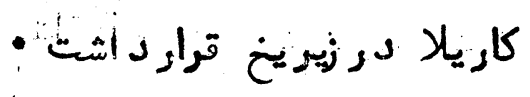

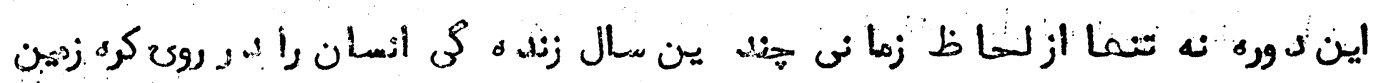

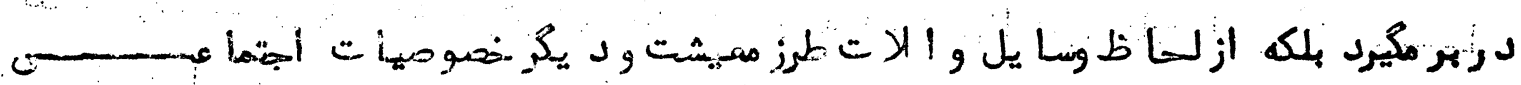

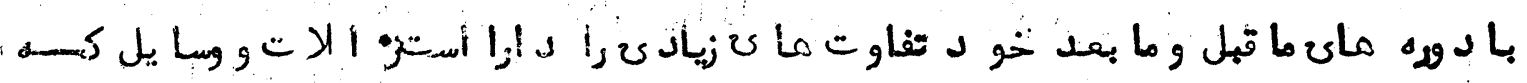

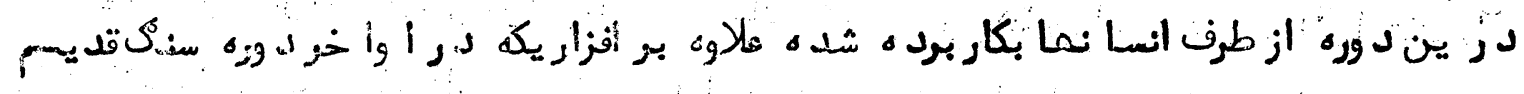

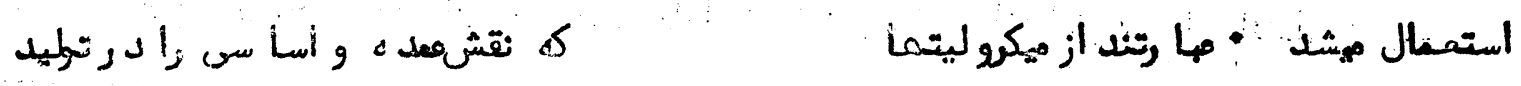

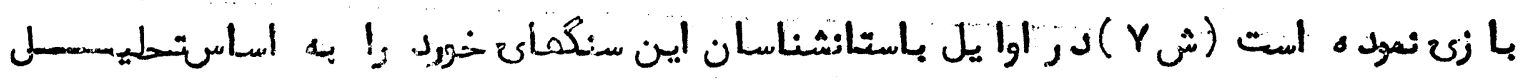




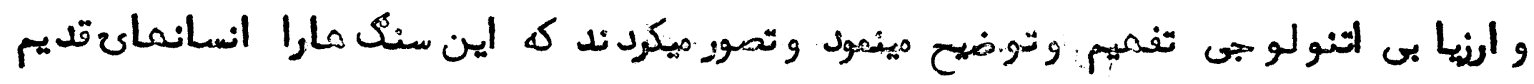

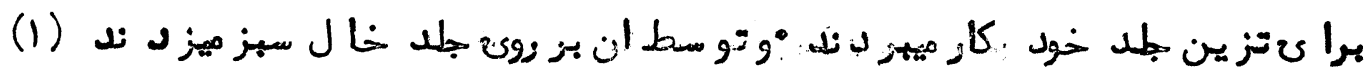

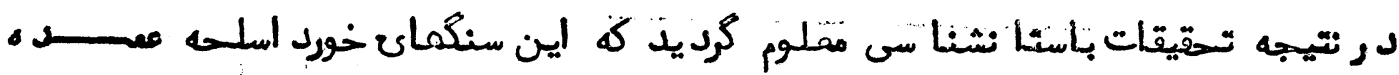

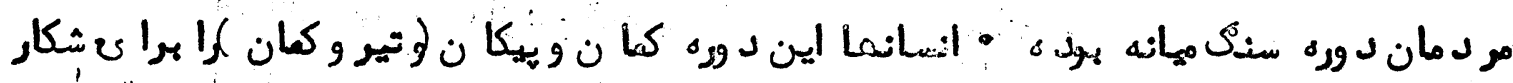

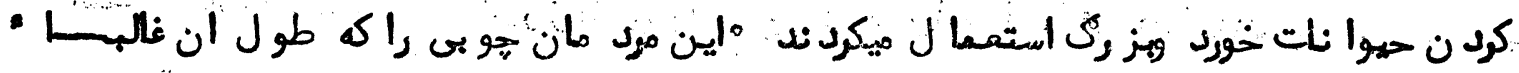

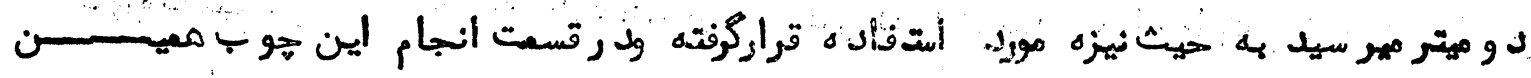

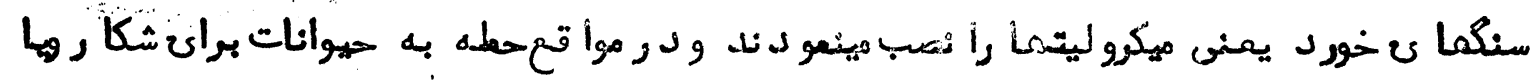

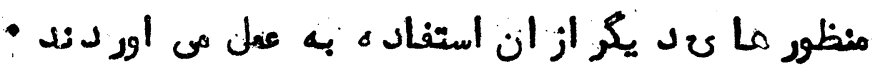

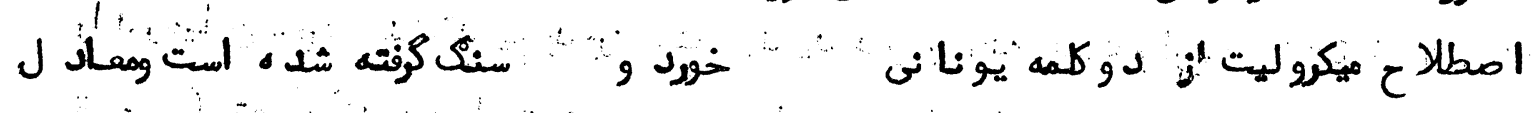

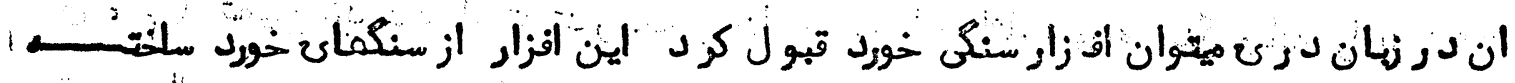

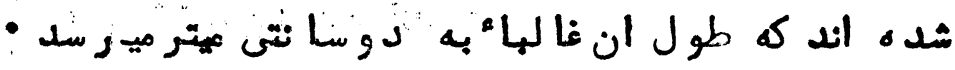

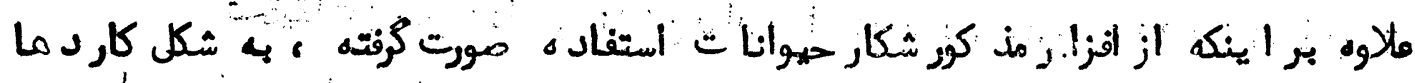

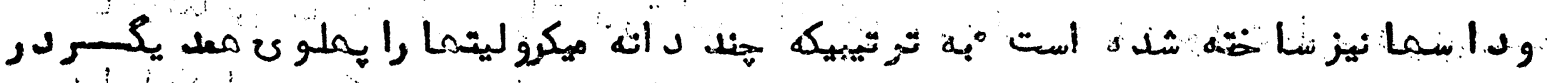

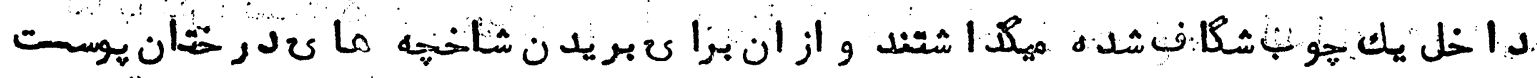

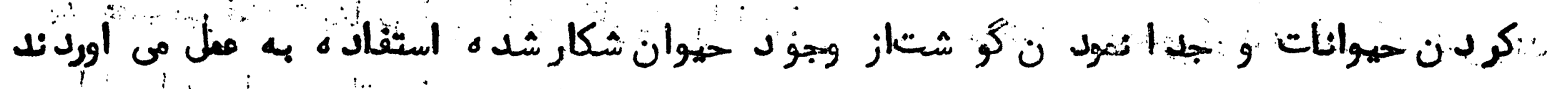

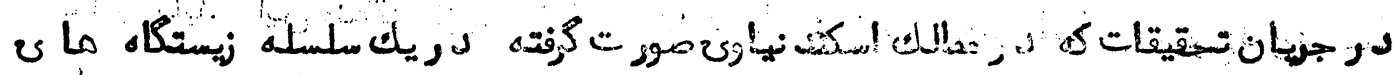

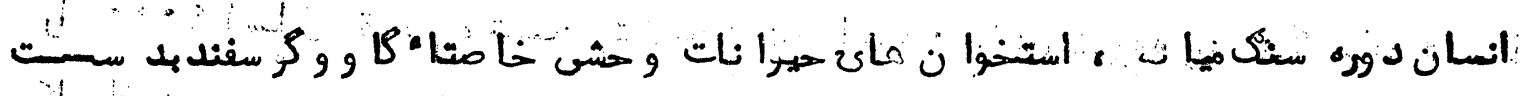

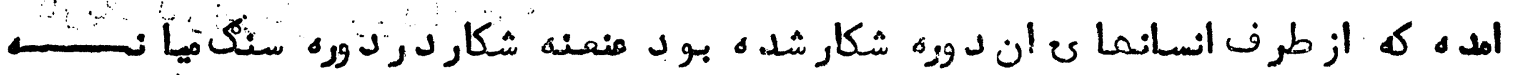

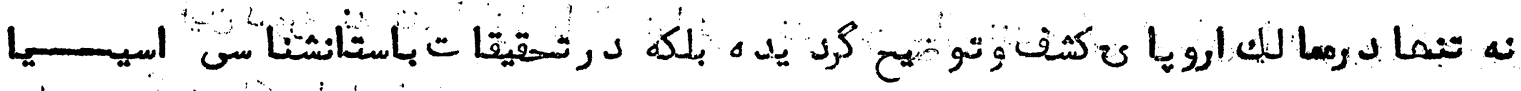

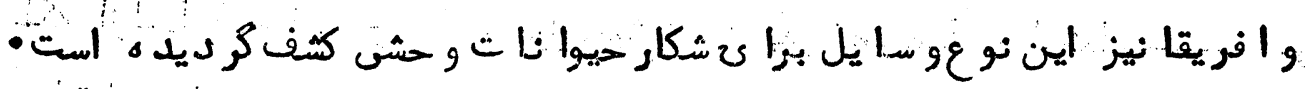

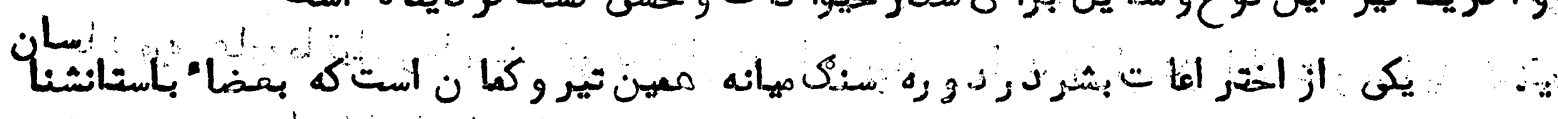

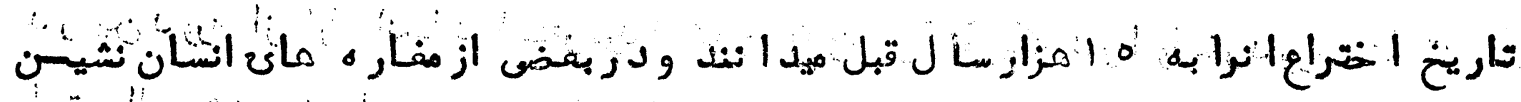
-

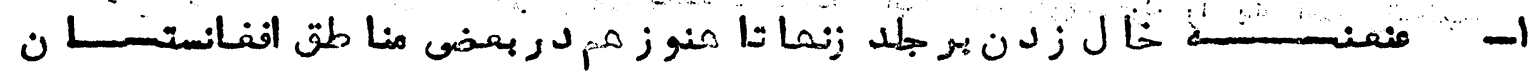
رانس 
$: 9$

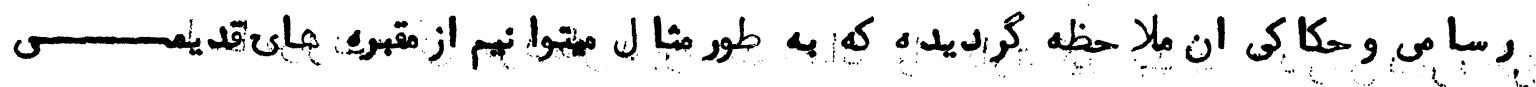

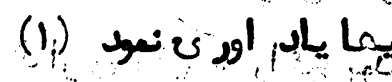

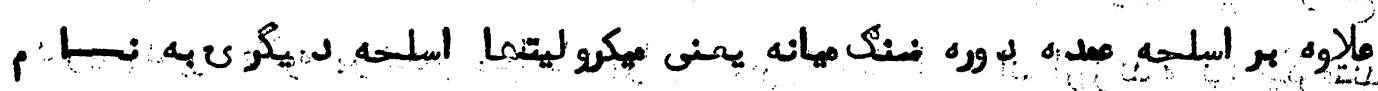

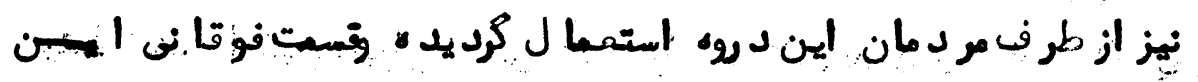

بو بين

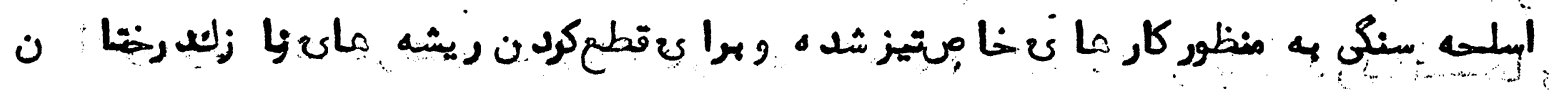

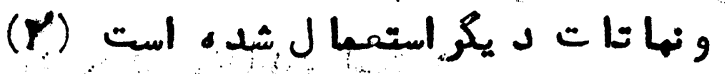

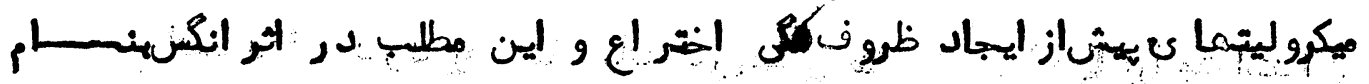

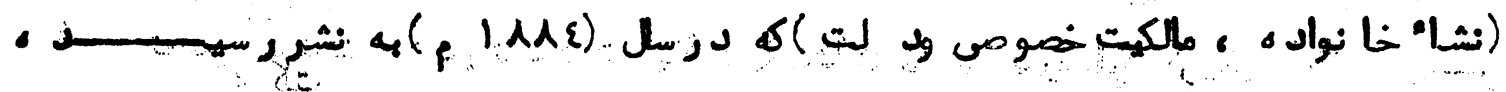

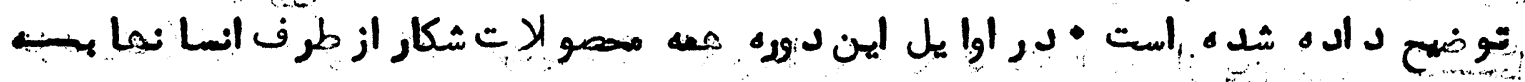

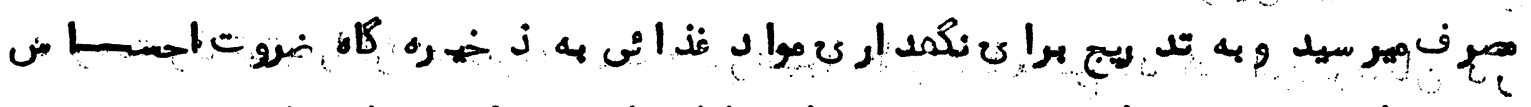

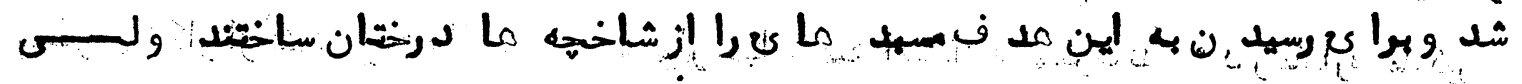

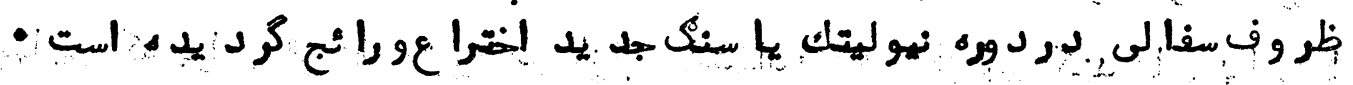

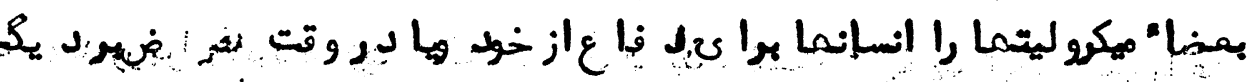

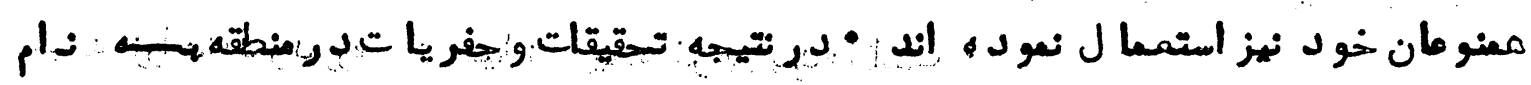

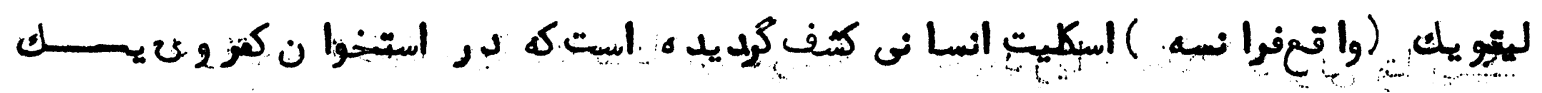

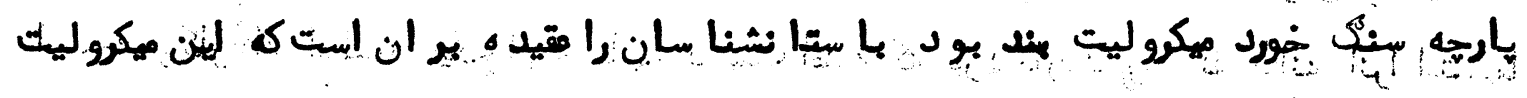

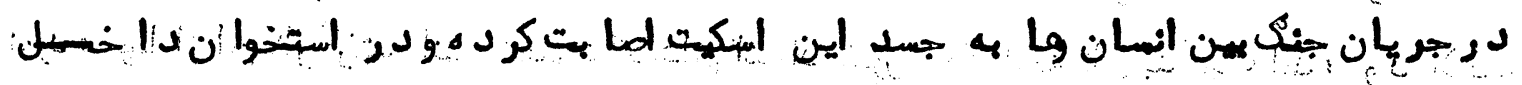

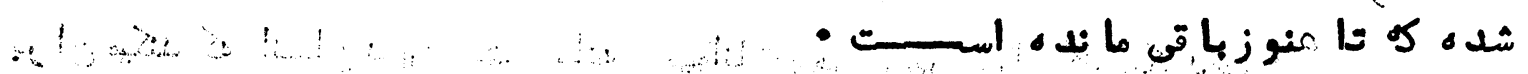

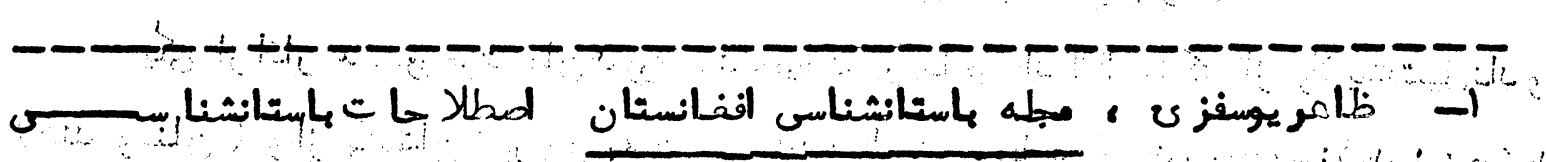

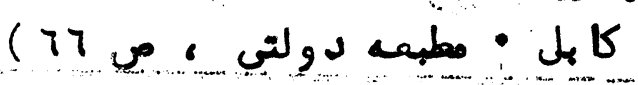

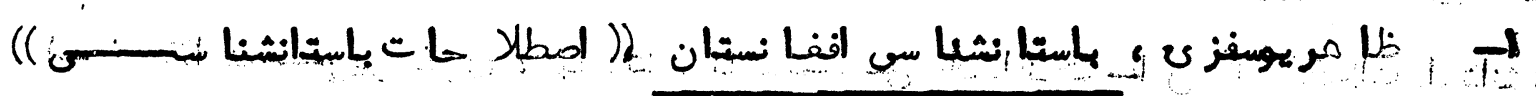

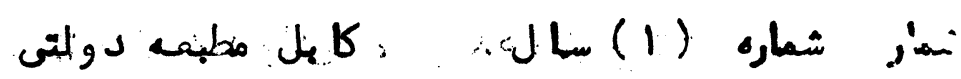




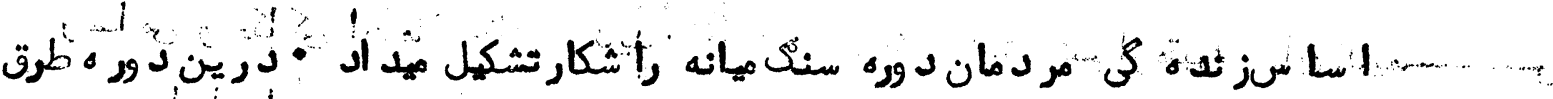

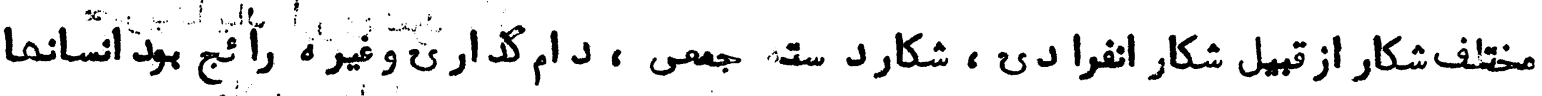

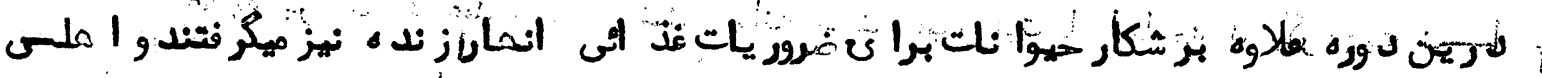

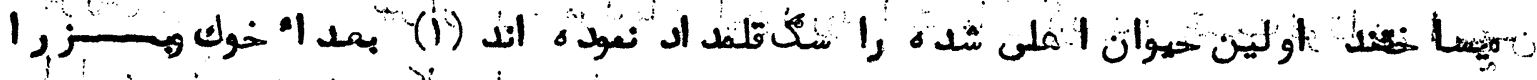

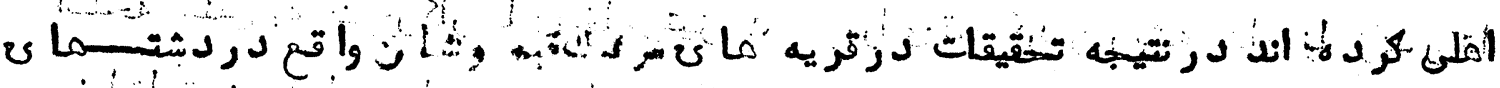

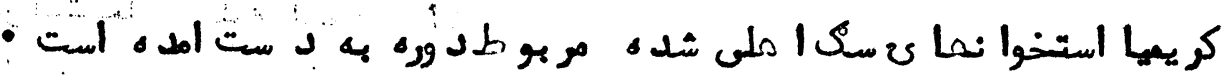

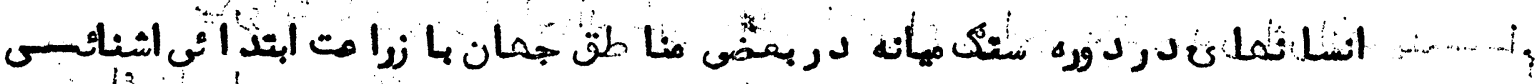

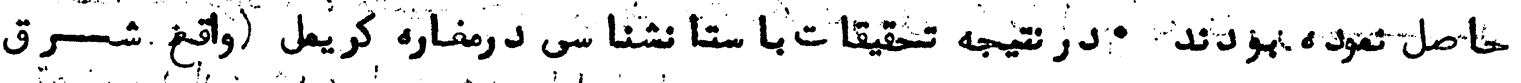

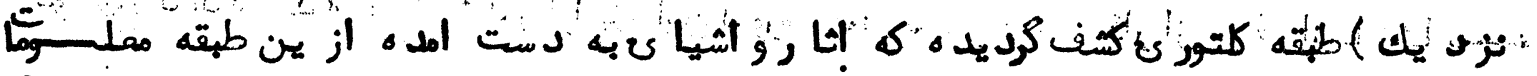

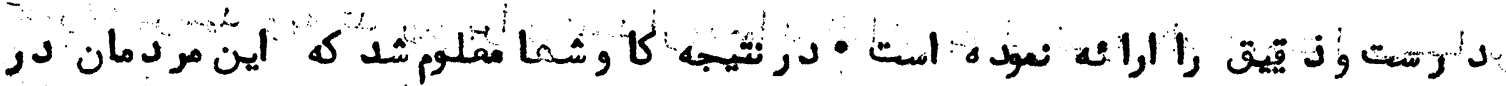

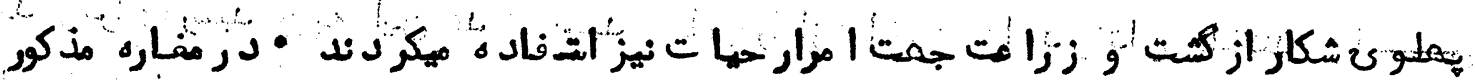

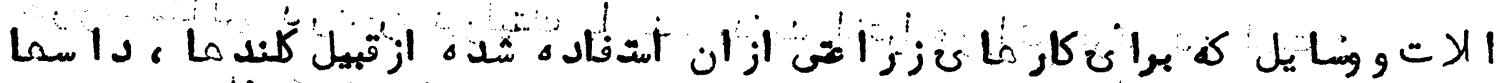

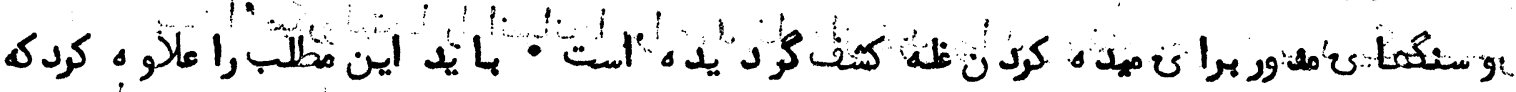

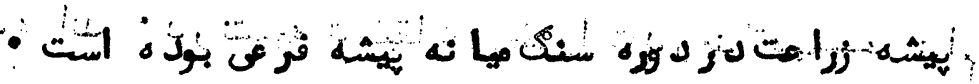

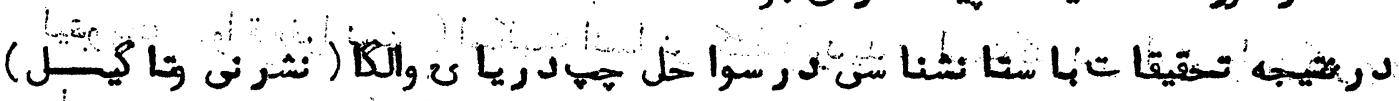

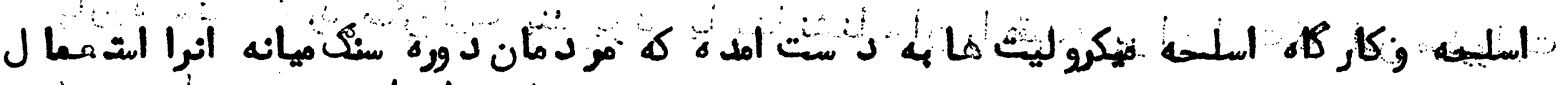

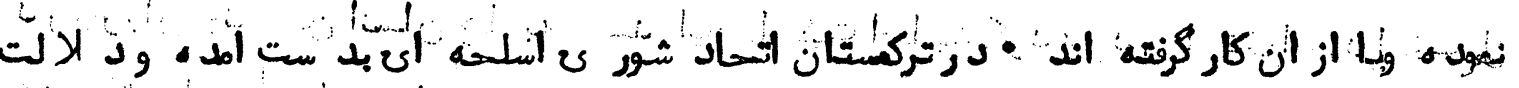

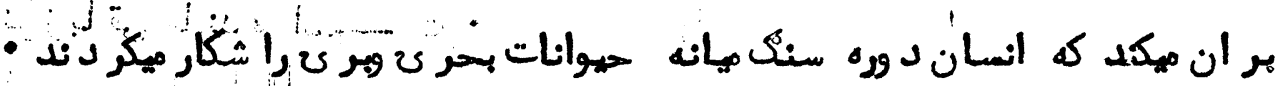

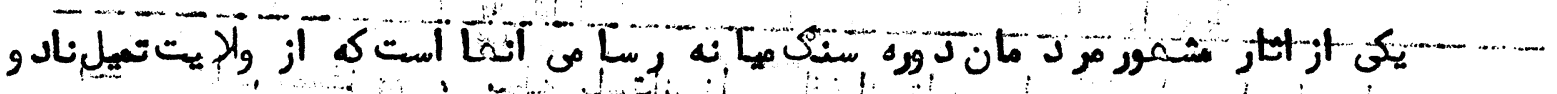

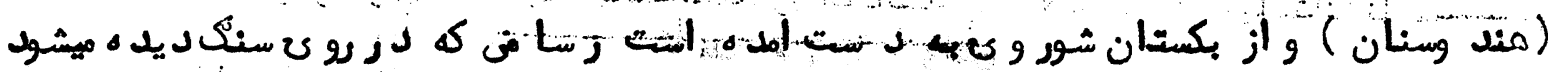

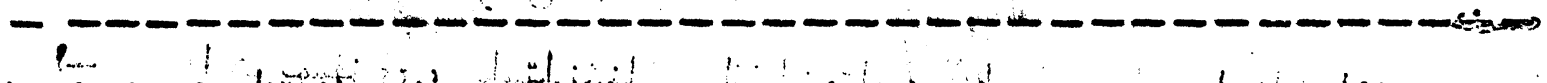

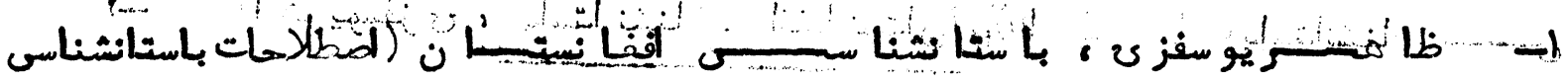

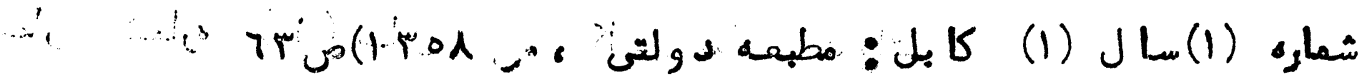




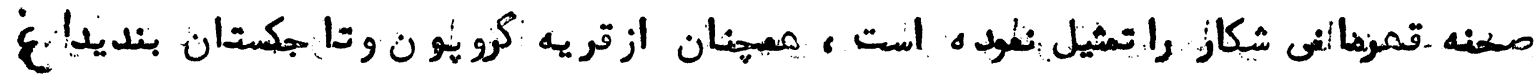

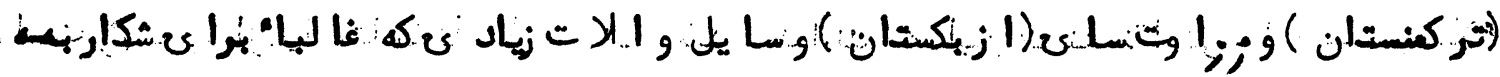

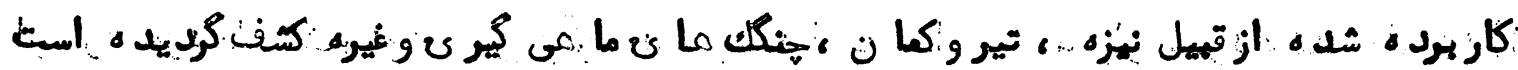

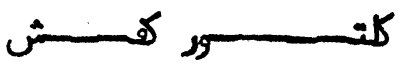

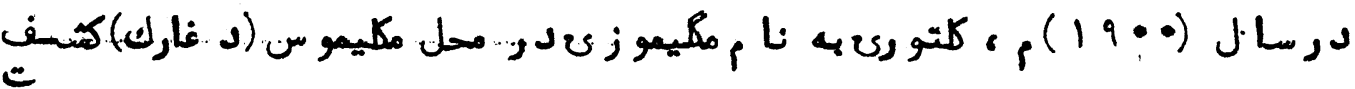

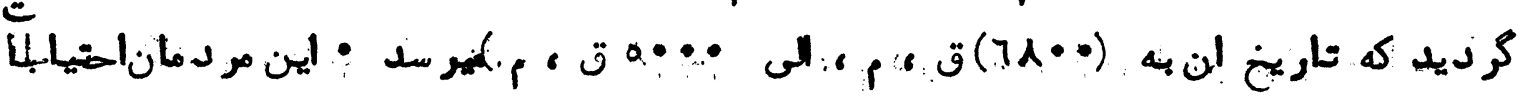

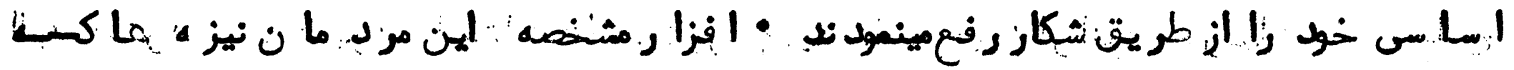

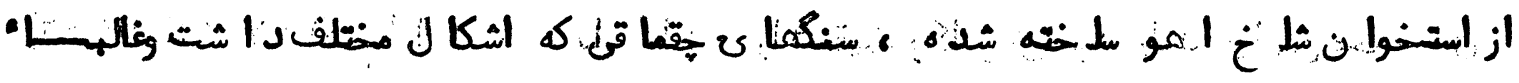

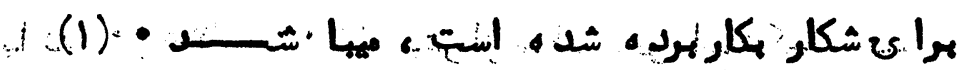
كت

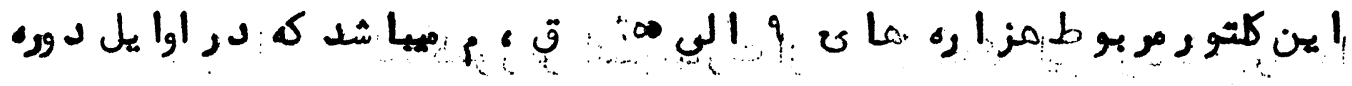

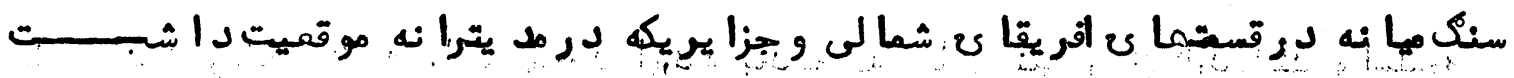

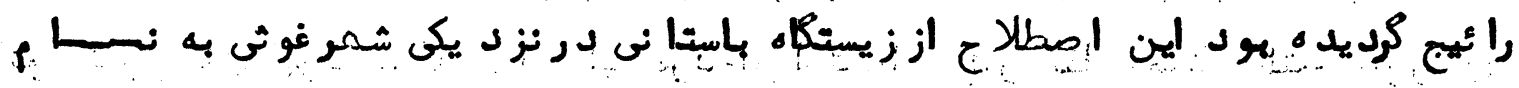

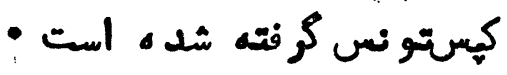

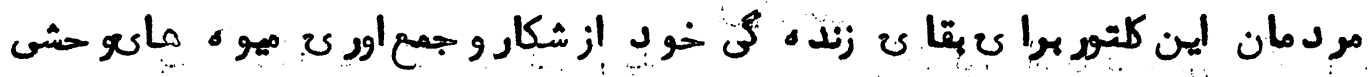

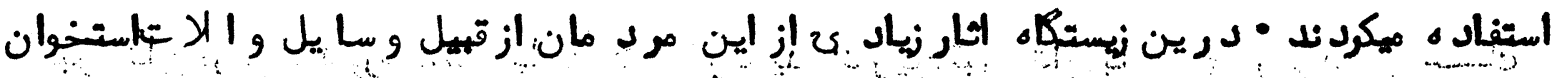

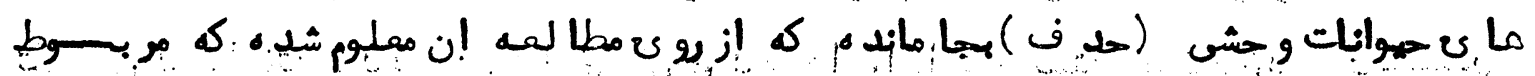

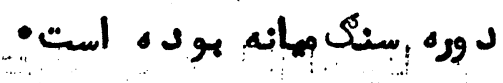

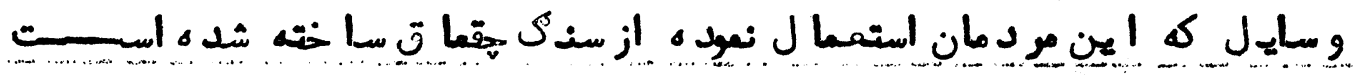

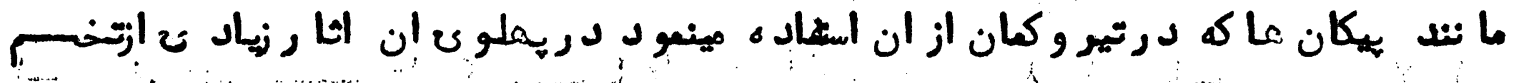

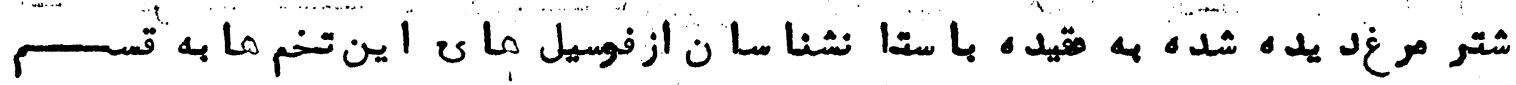

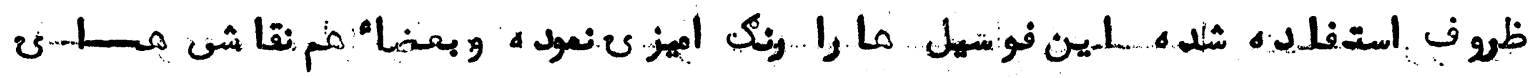

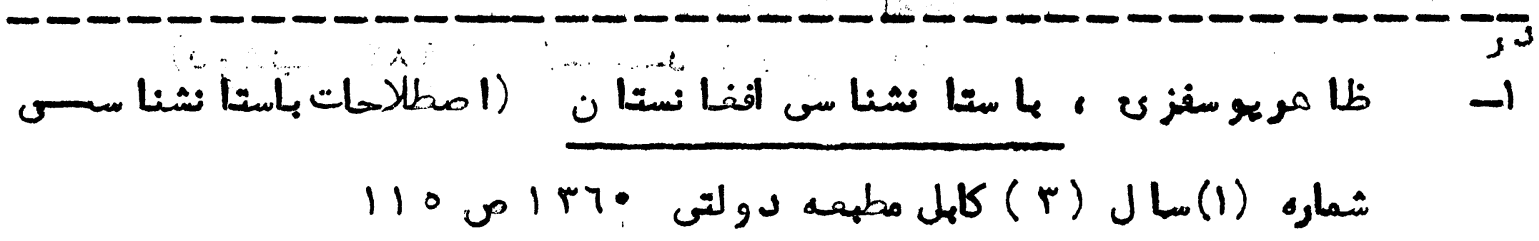




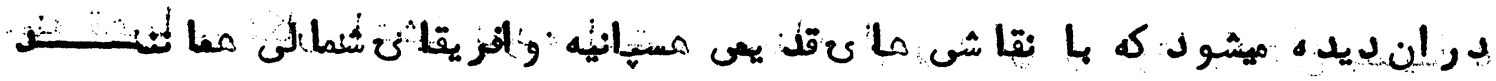

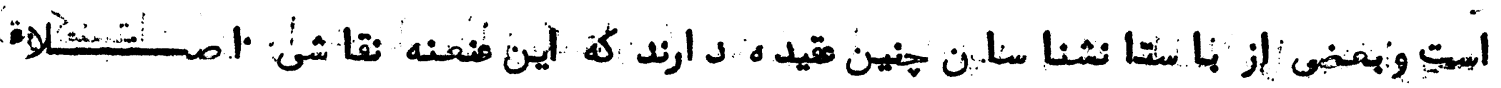

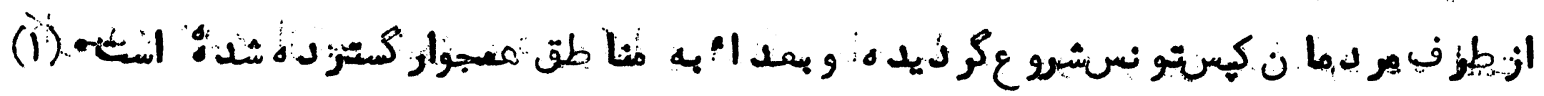

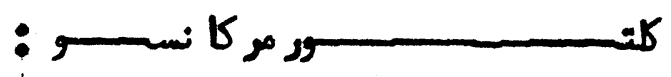

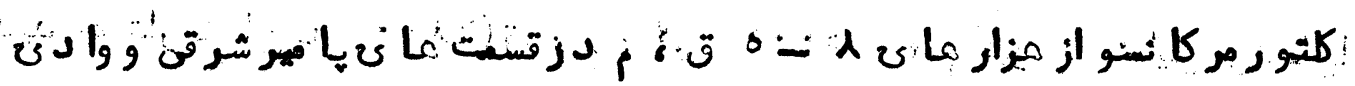

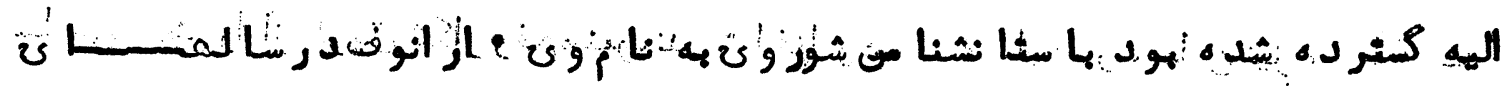

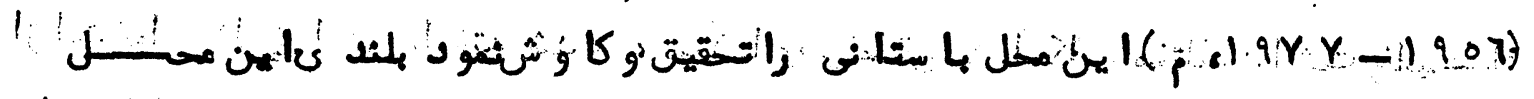

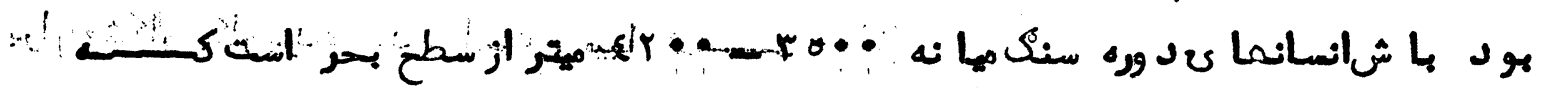

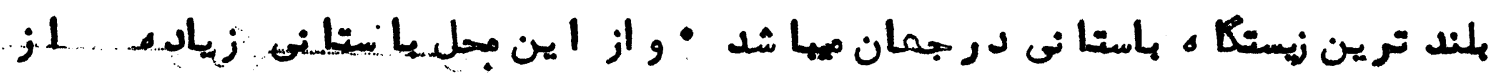

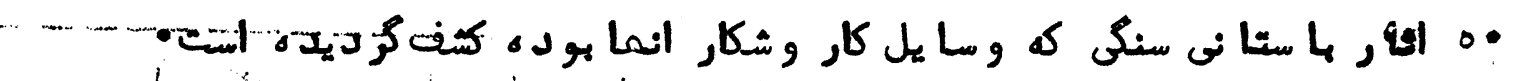

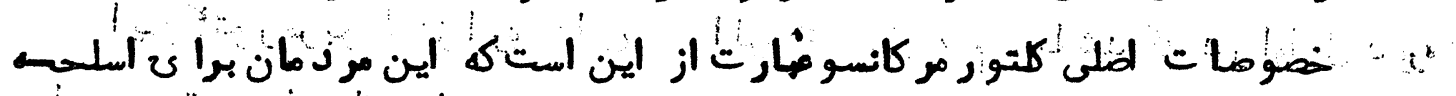

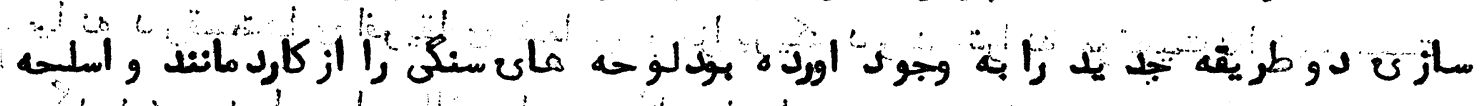

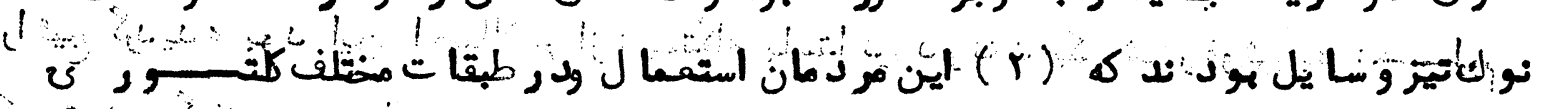

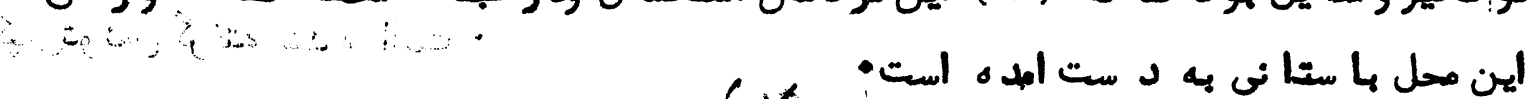

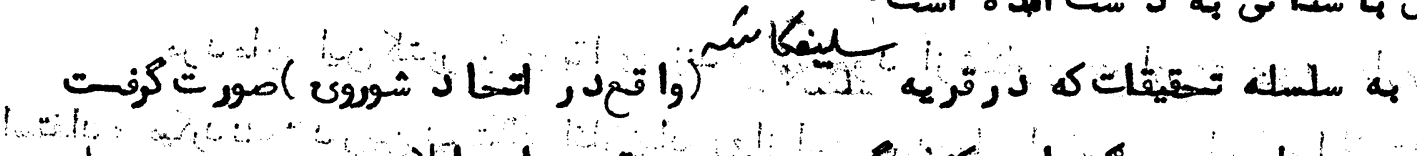

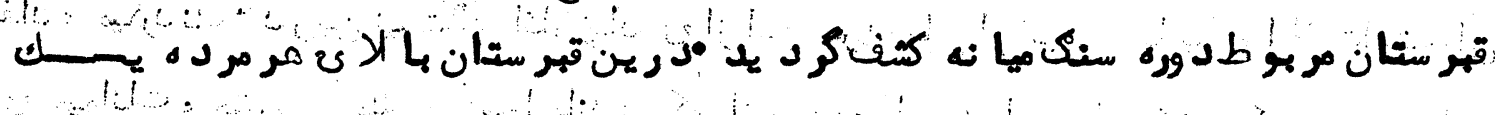

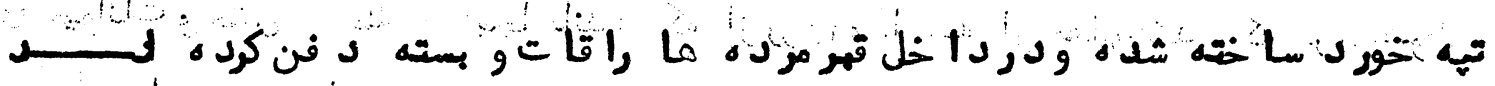

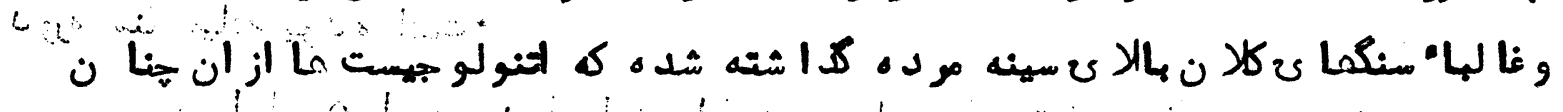

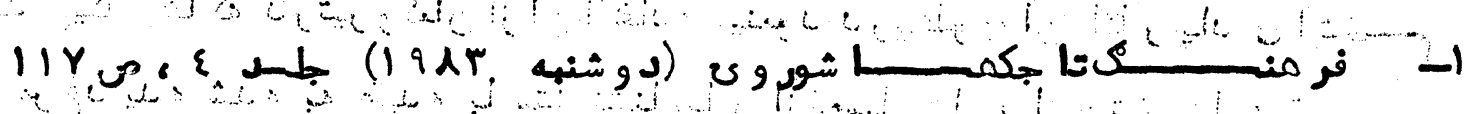

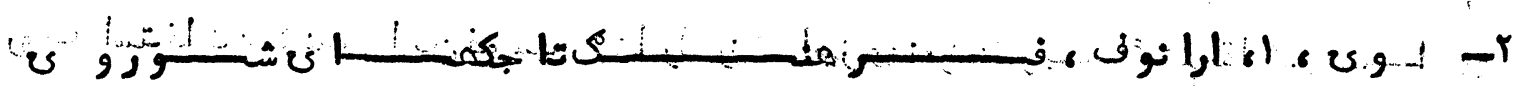

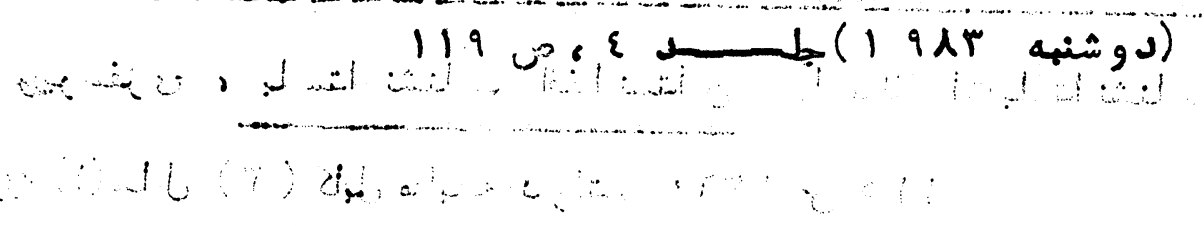




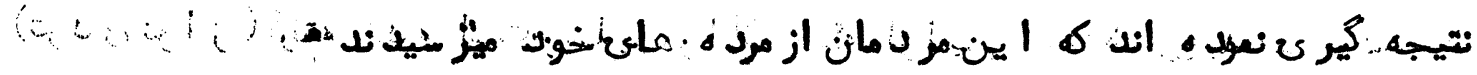

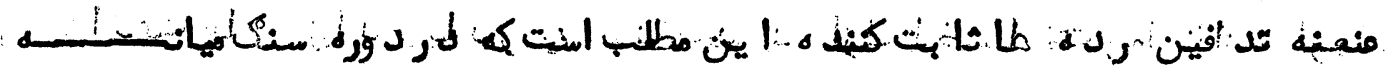

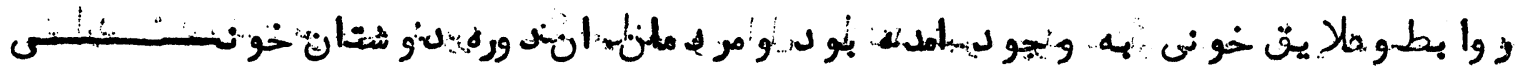

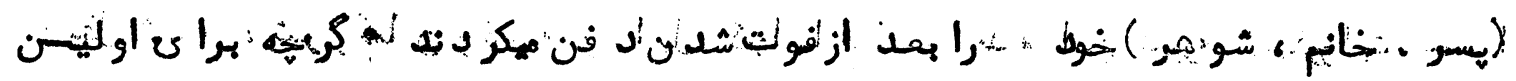

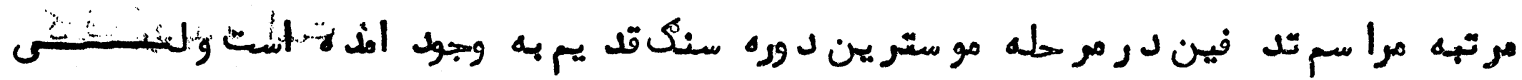

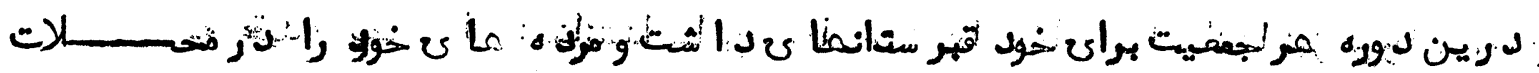

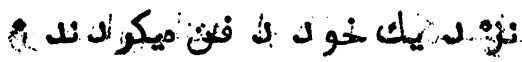

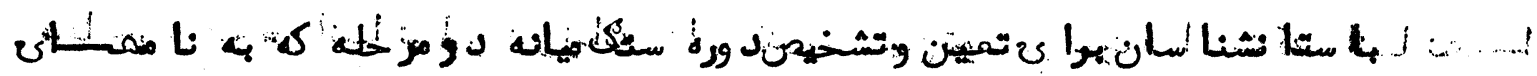

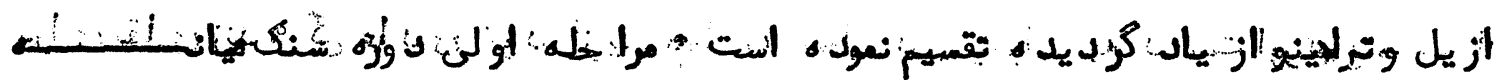

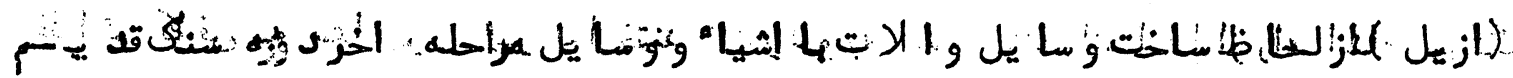

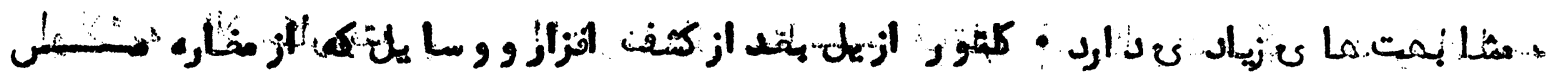
و أزيل

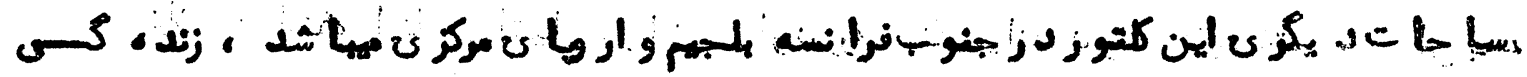

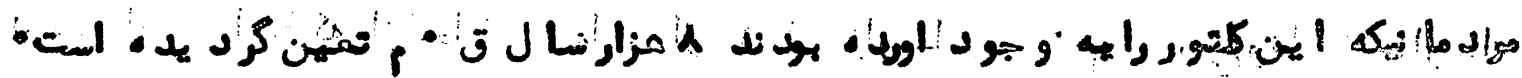

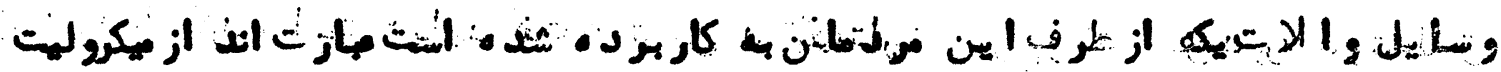

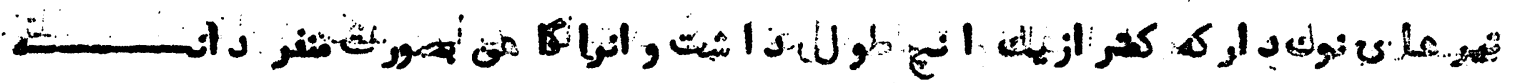

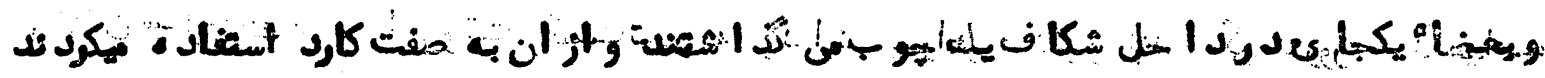

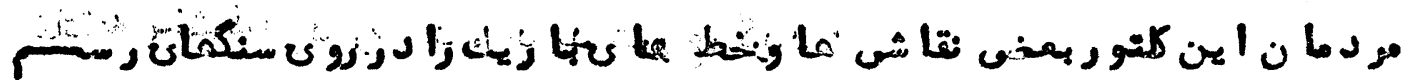

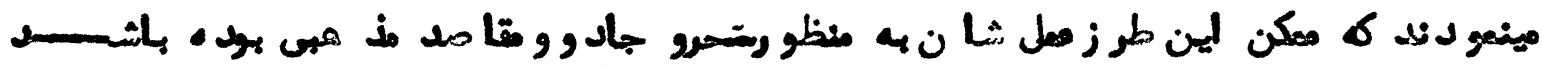

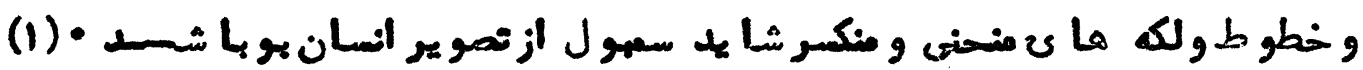

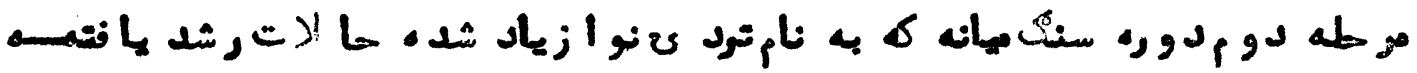

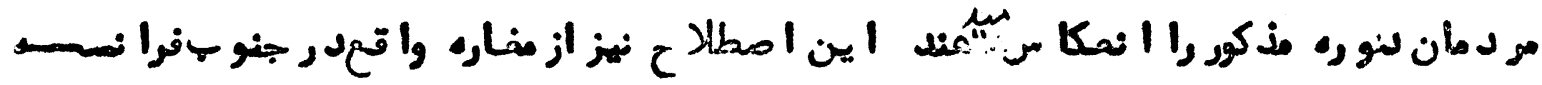
o

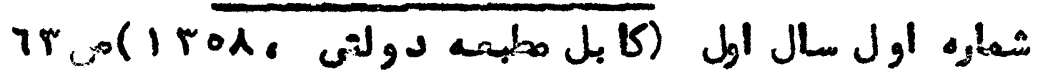


$0+5$

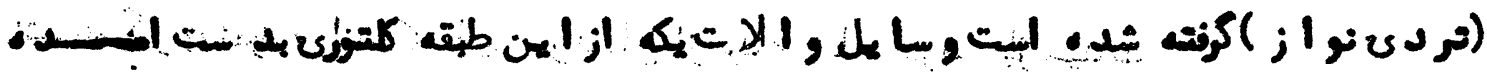

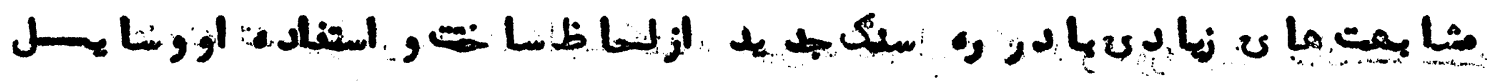

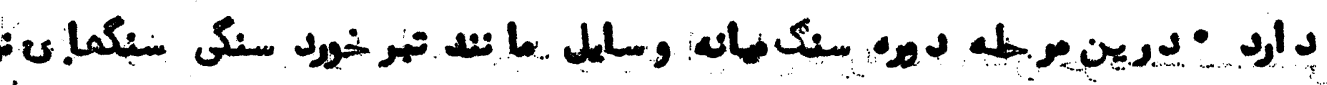

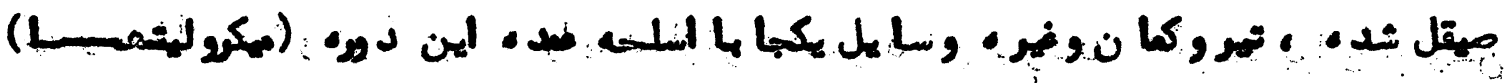

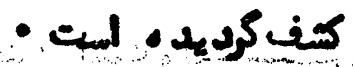

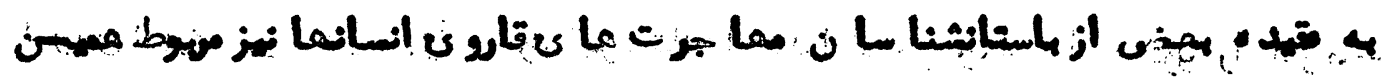

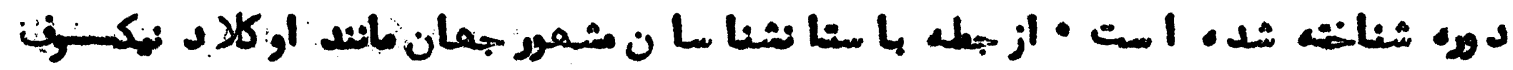

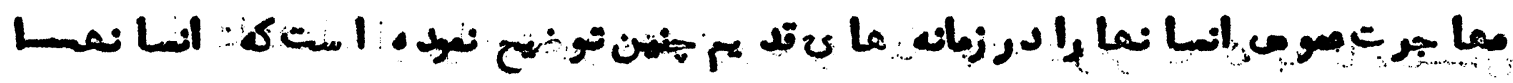

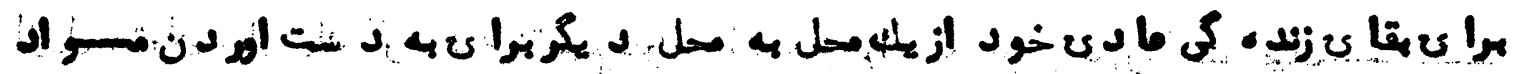

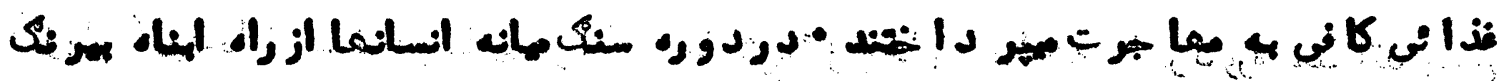

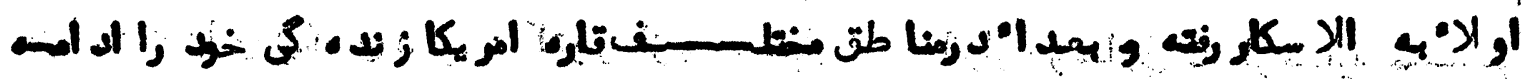

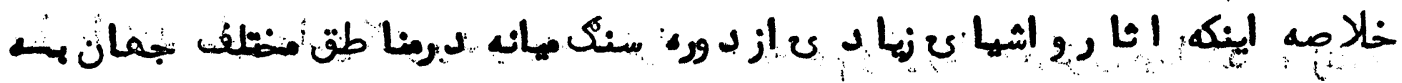

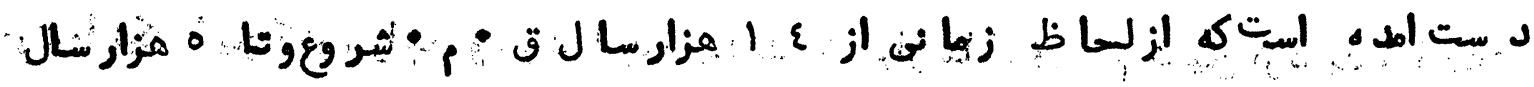

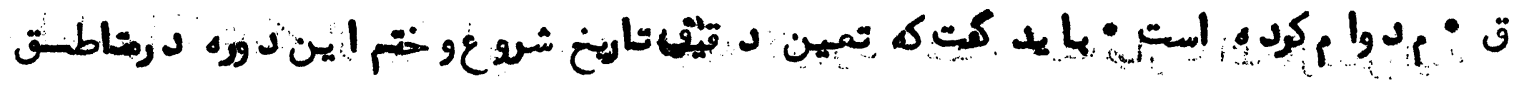

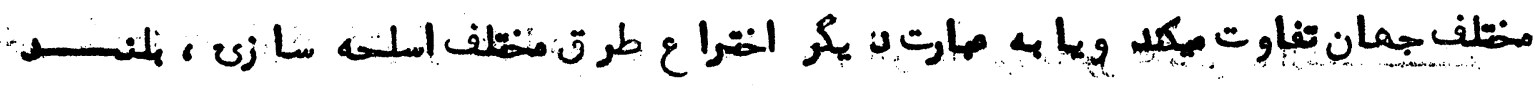

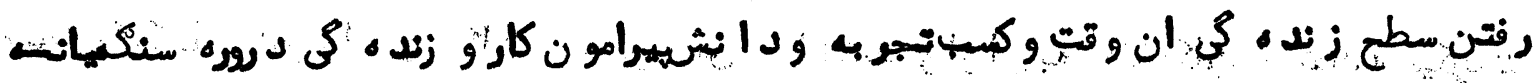

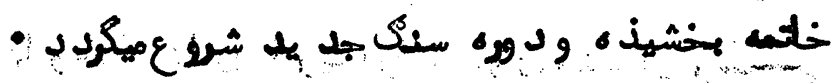


00

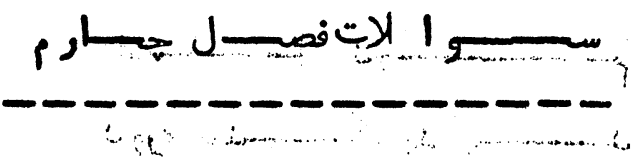

6.

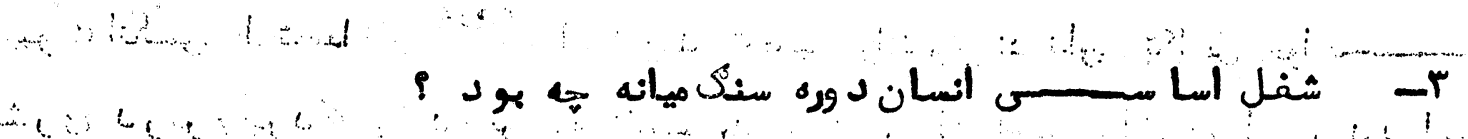

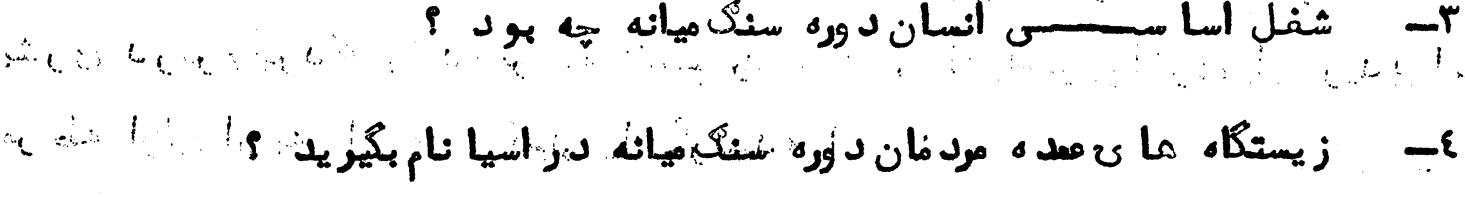

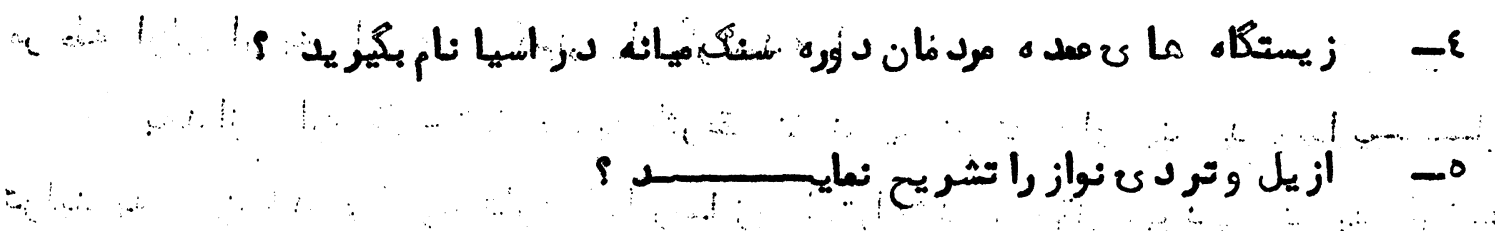

․:

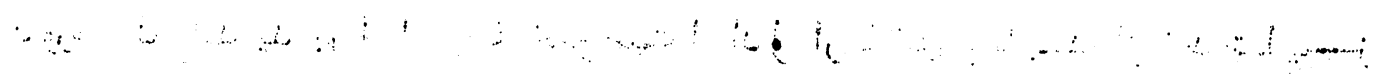

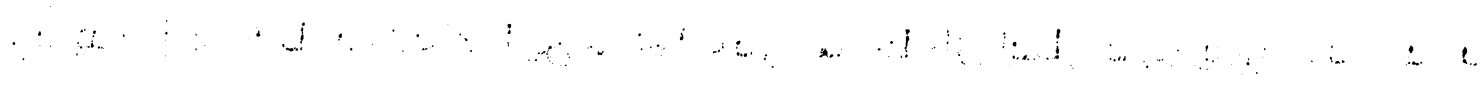

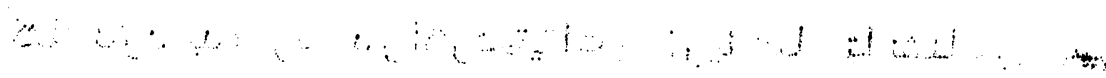

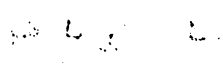

$a$

i- $\quad \therefore \quad \therefore \quad \therefore \quad \therefore$

(6) 101

acalt: lat:

$\because \quad$

6.6

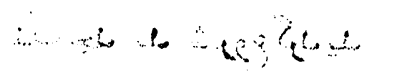

(3)

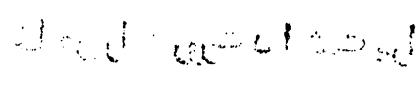

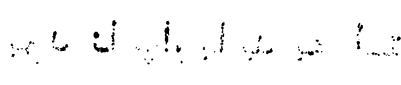

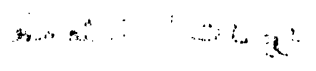

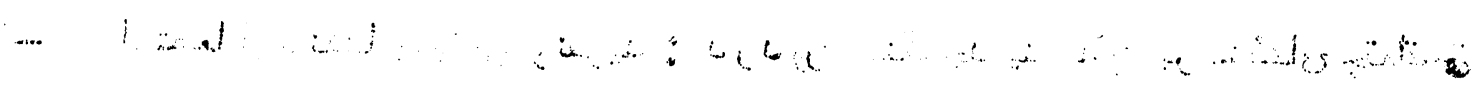

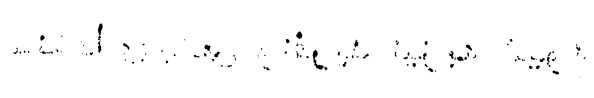



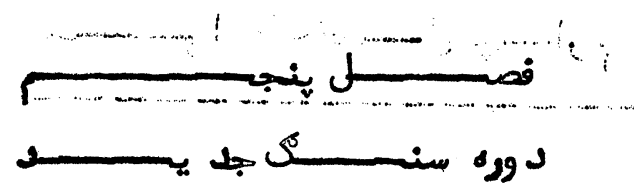

-TT:- $-7---5-$

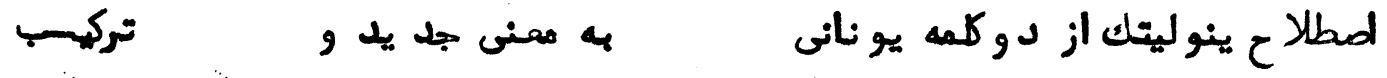

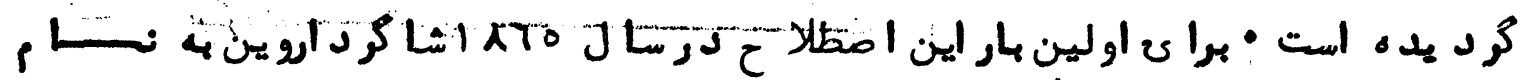

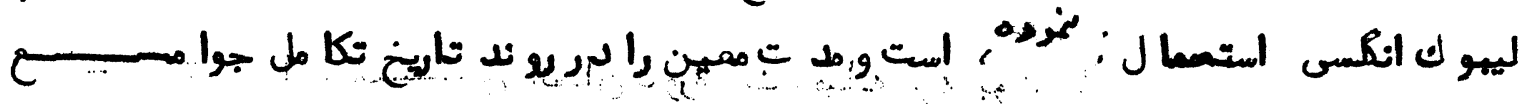

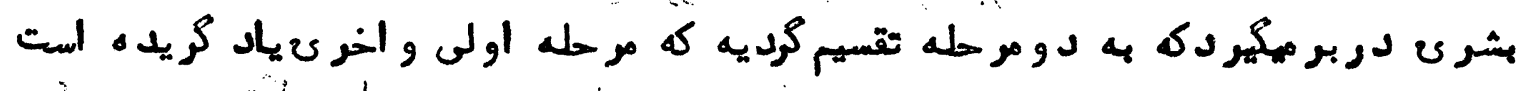

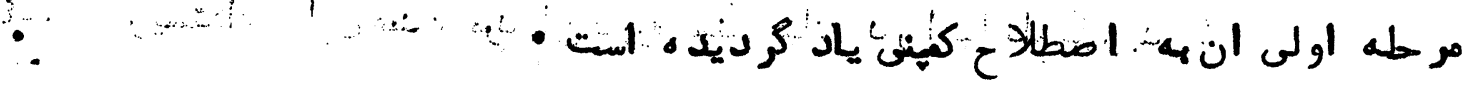

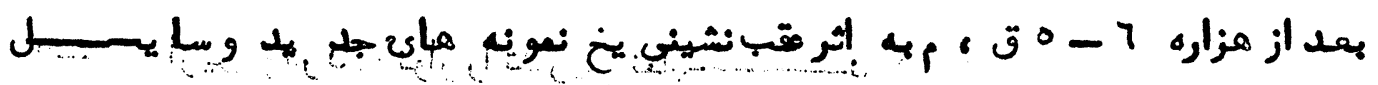

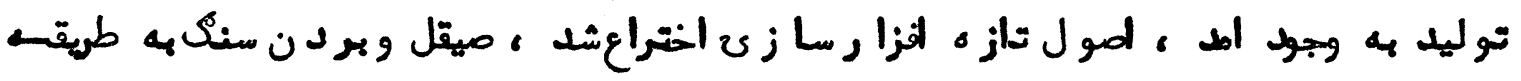

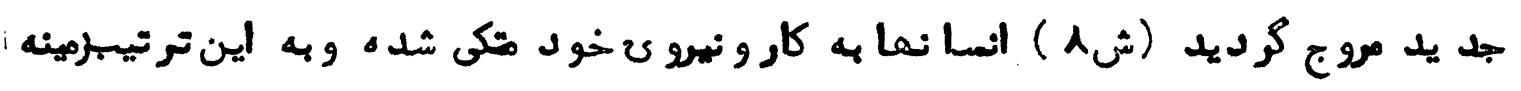

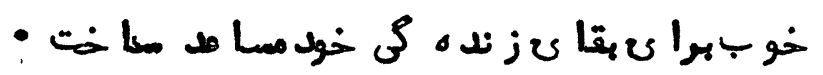

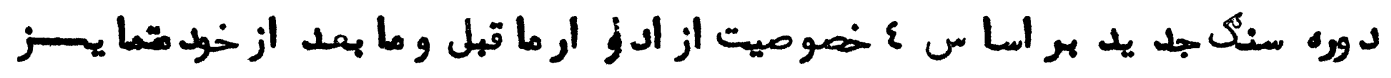

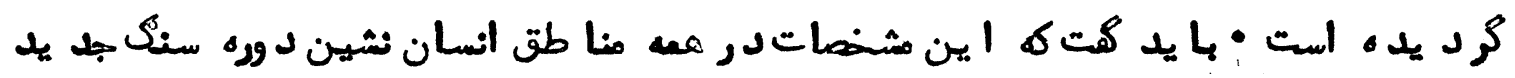

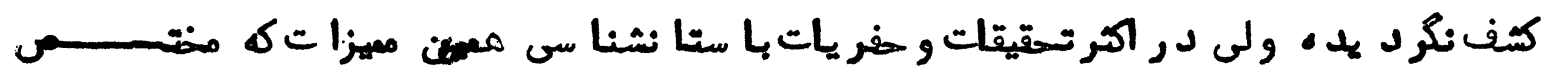

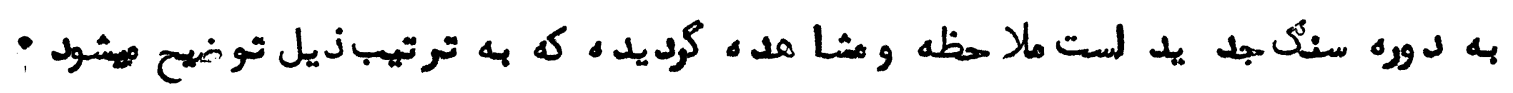

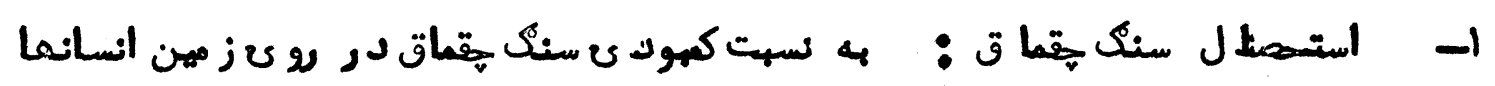

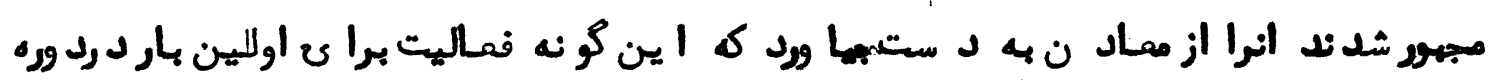

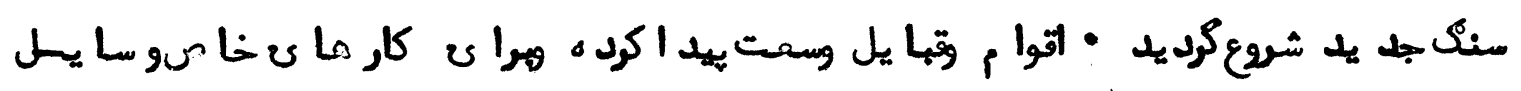

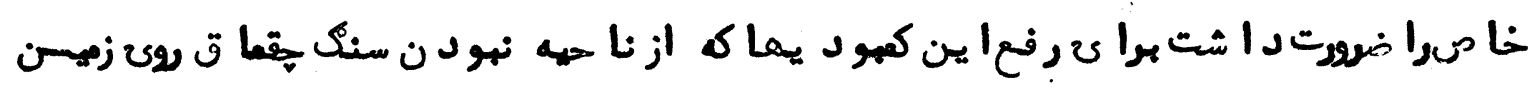

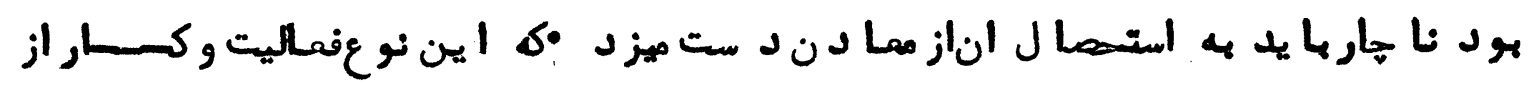

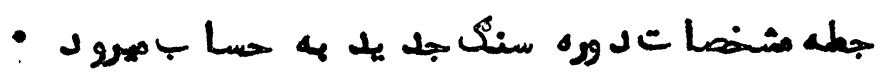

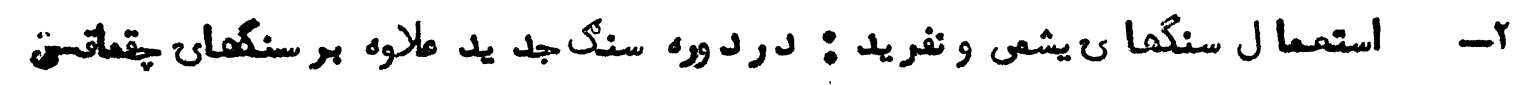

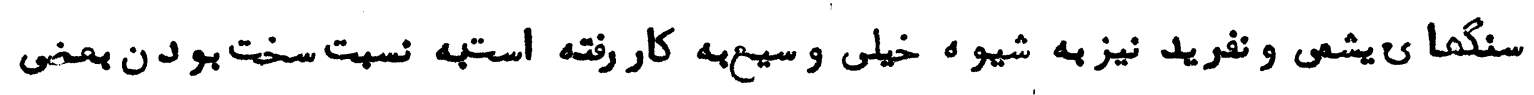




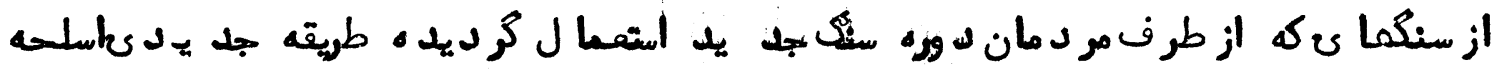

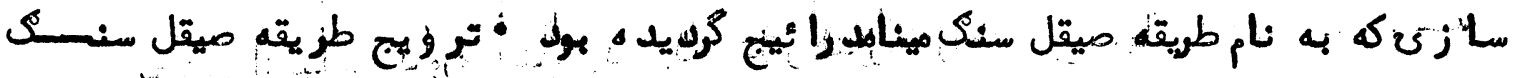

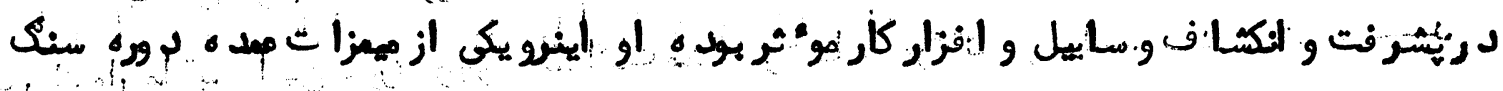

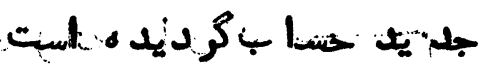

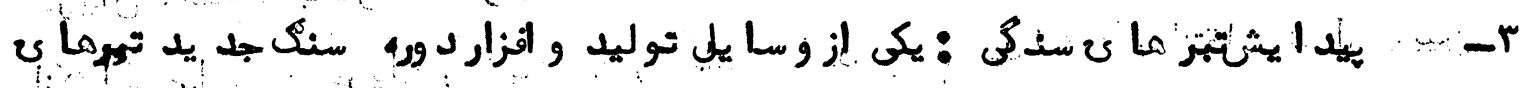

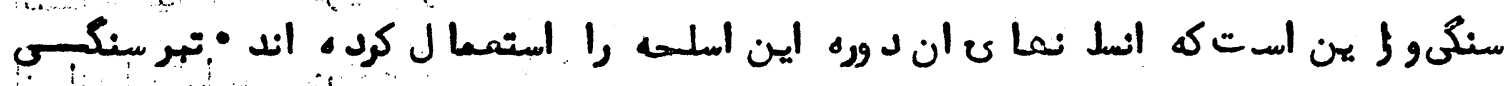

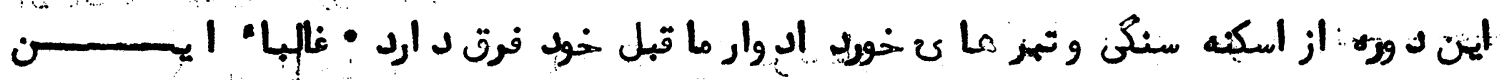

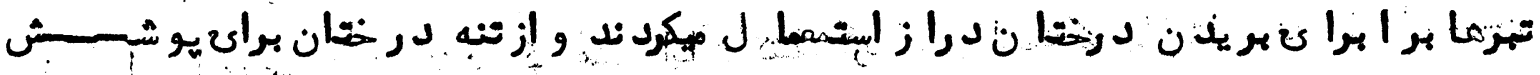

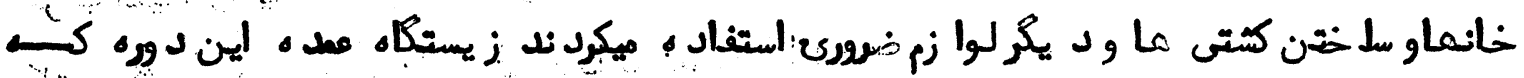

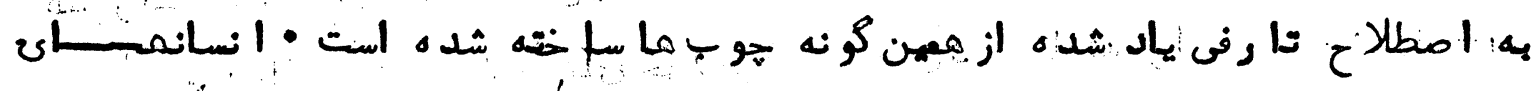

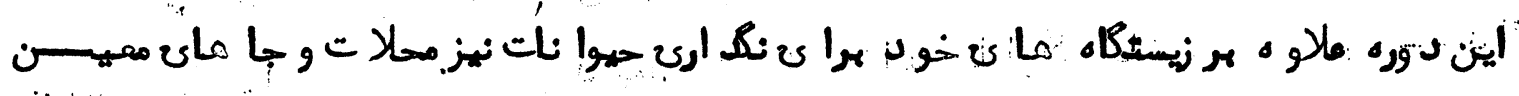

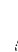

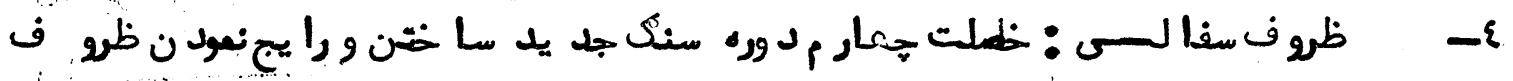

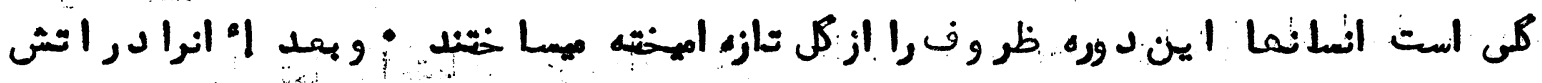

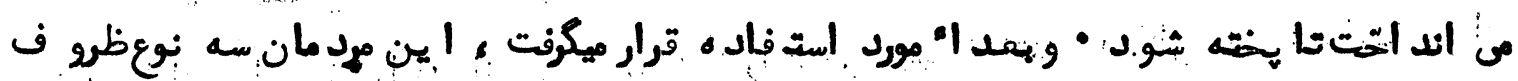

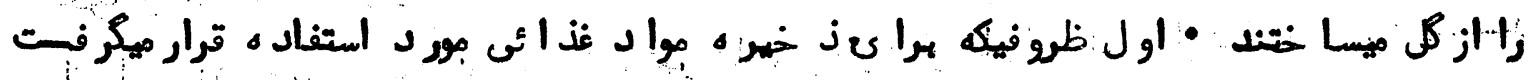

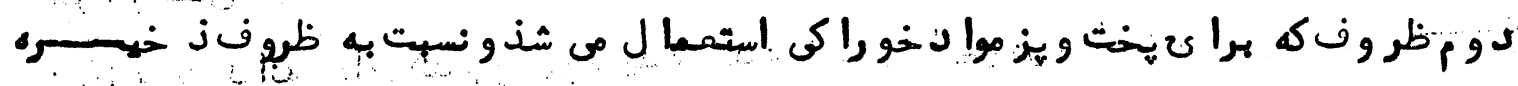

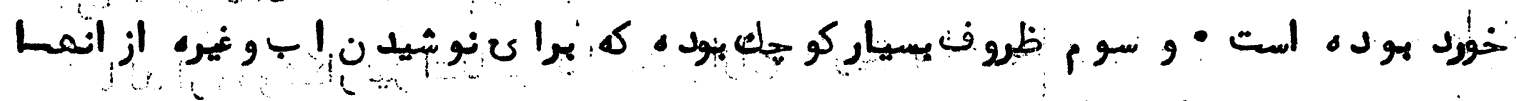

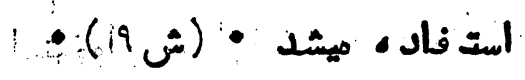

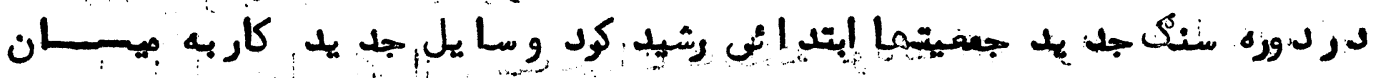

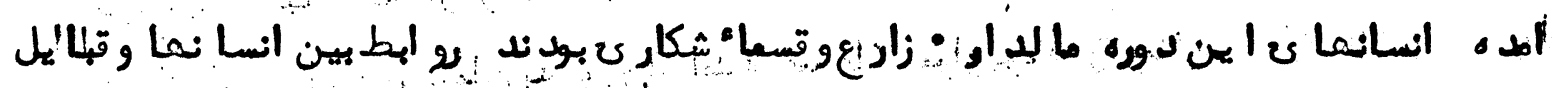

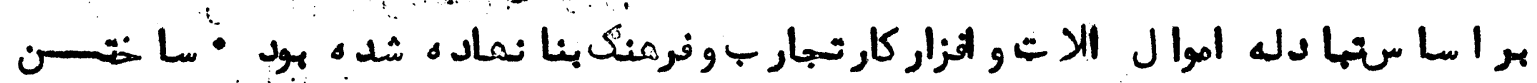

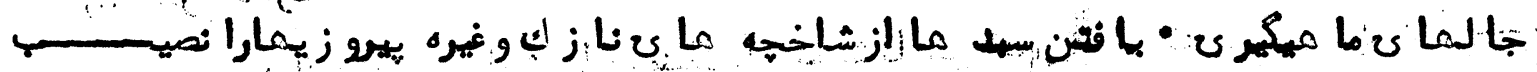

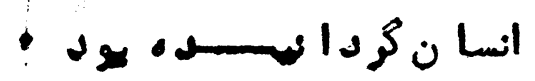


$1+\cdots, y+a$

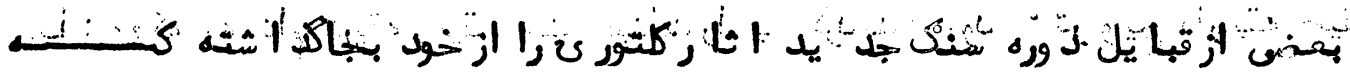

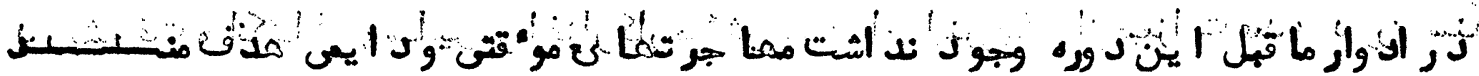

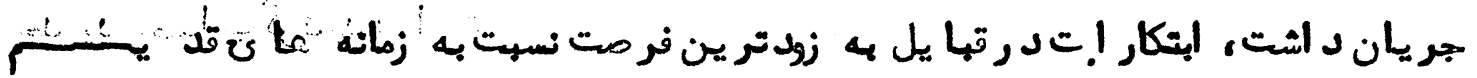

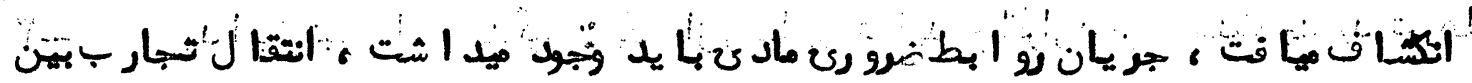

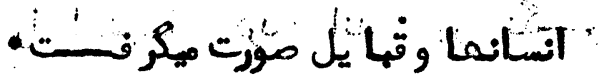

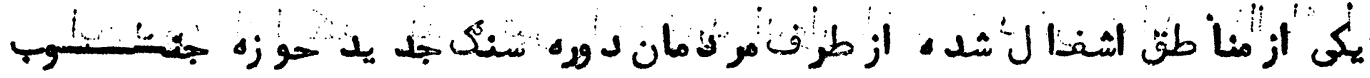

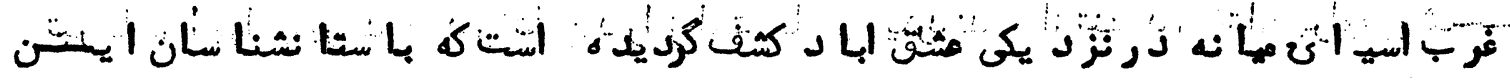
l. 1

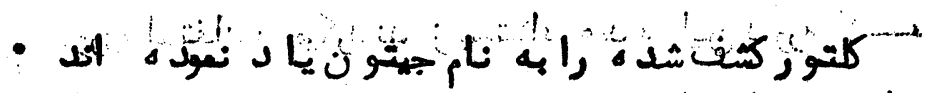

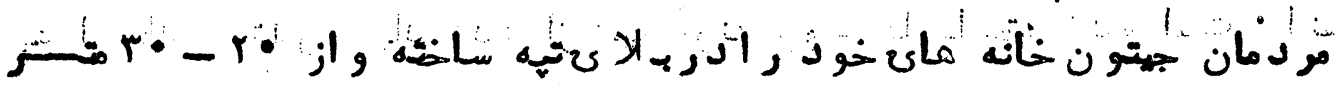

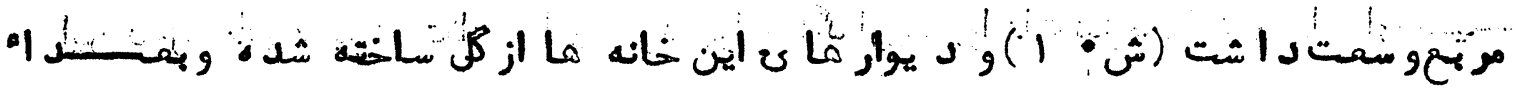

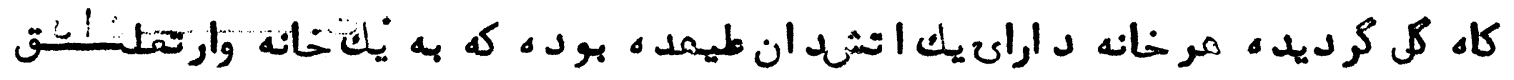

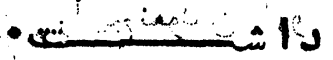

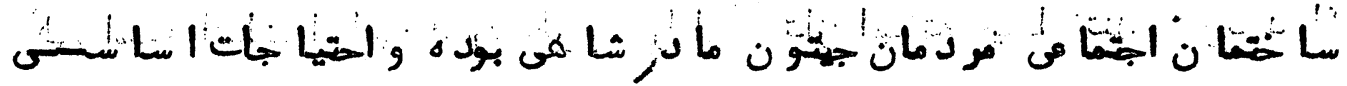

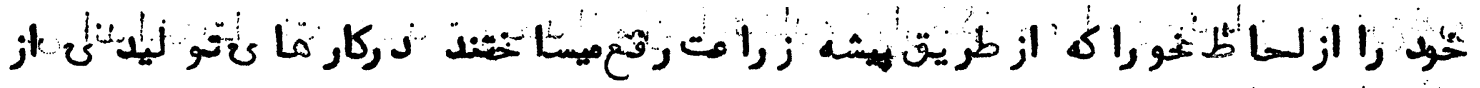

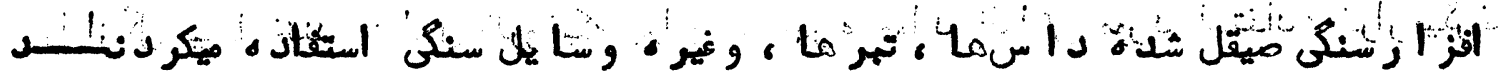

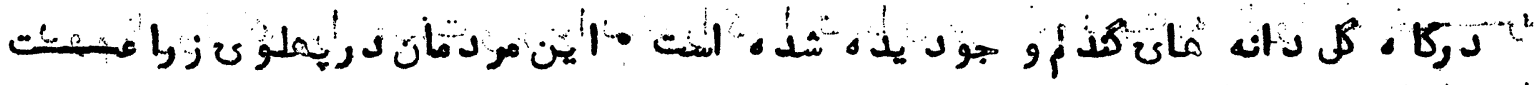

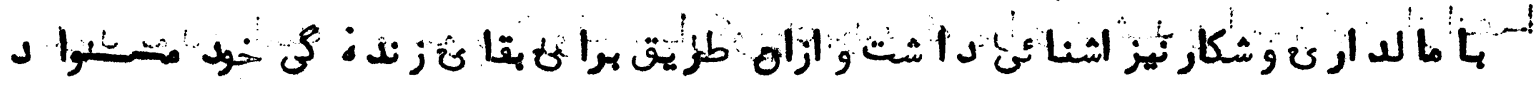

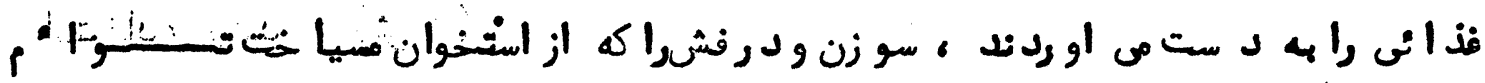

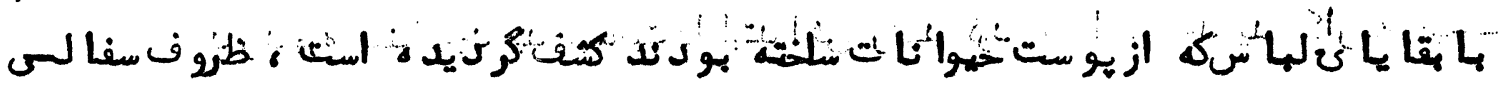

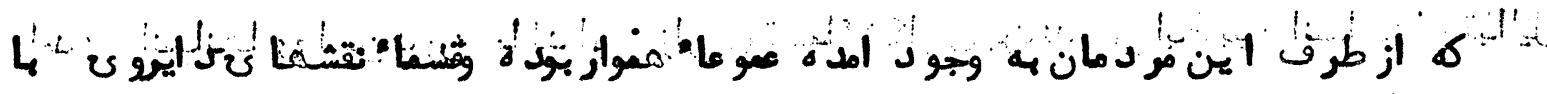

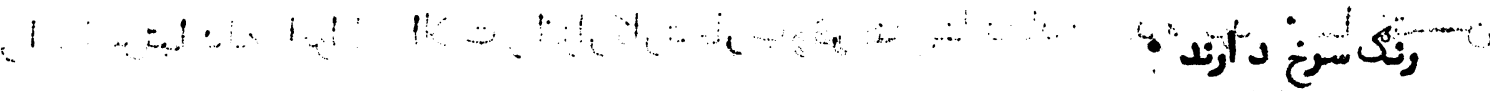

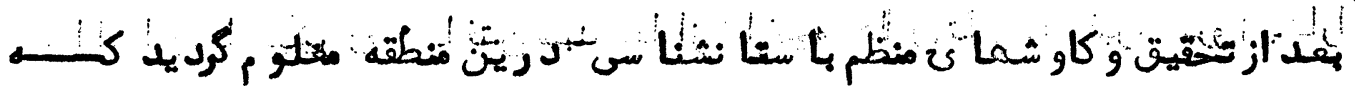

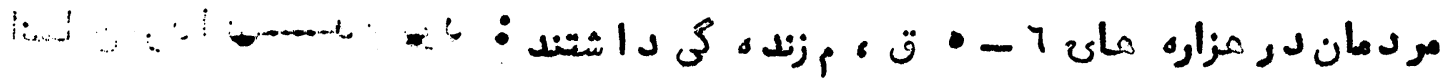

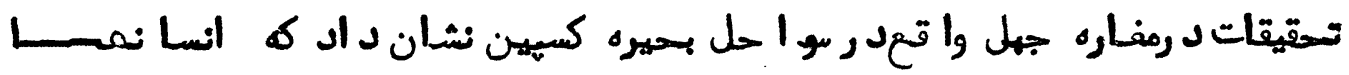


09

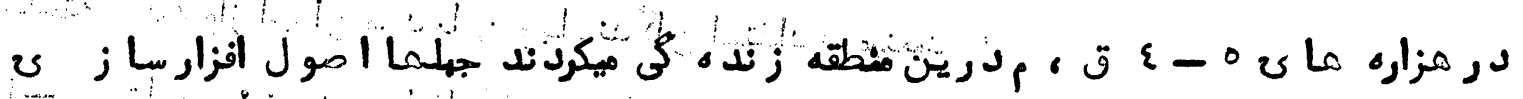

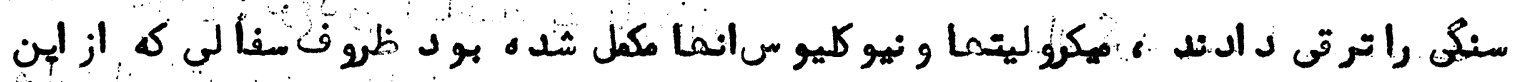

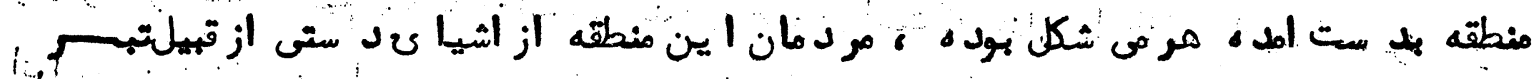

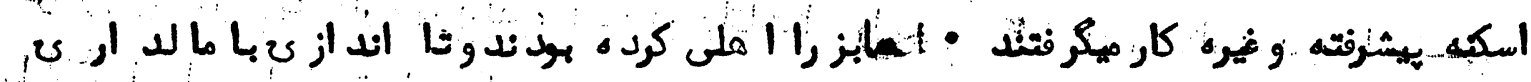
$\because \ldots$.

قهر ستان كتن كوذيده كه مر نو طمر دمان

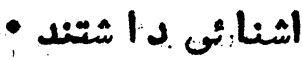

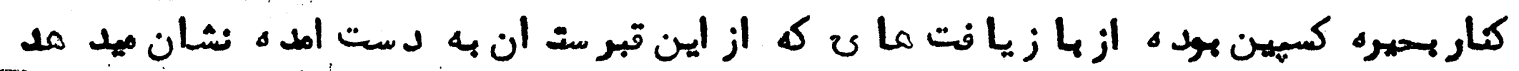

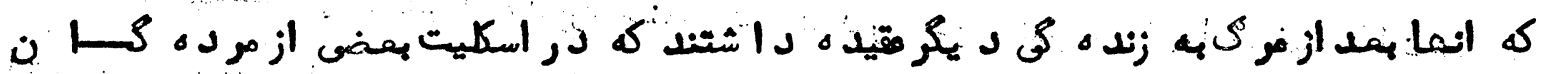

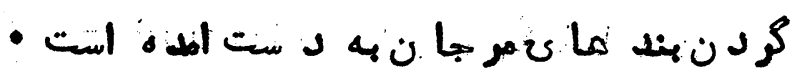

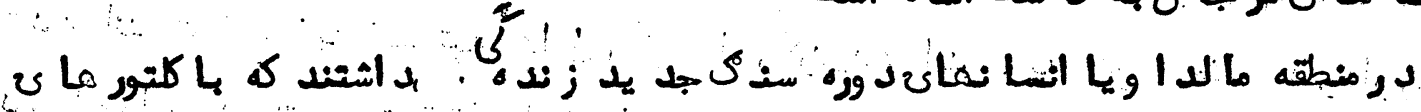

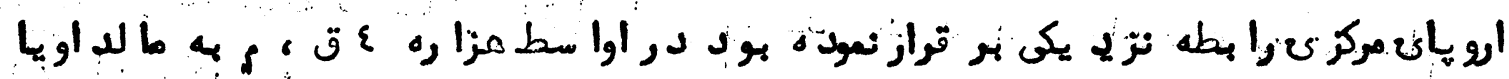

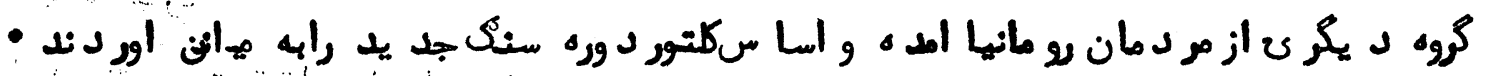

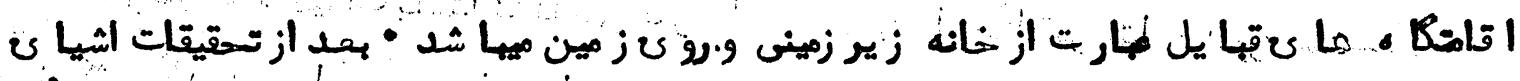

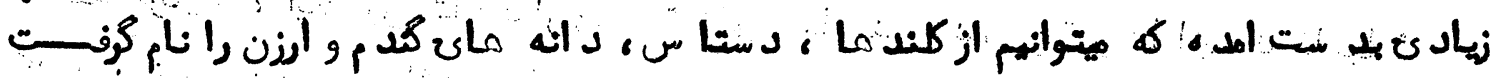

(i)

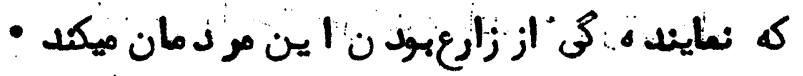

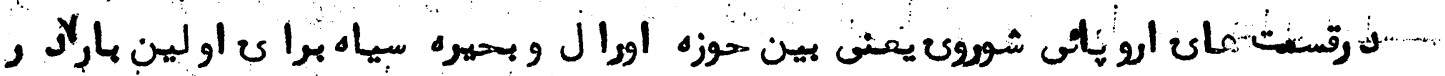

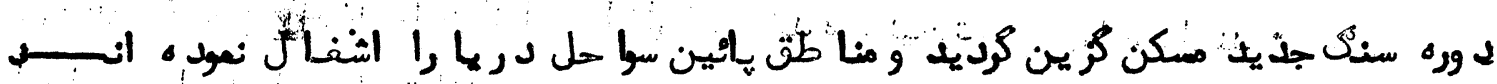

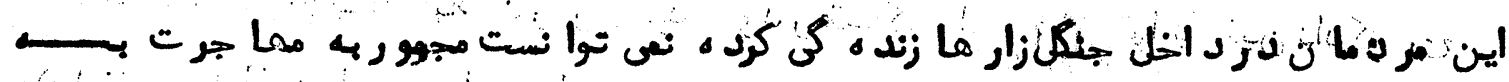

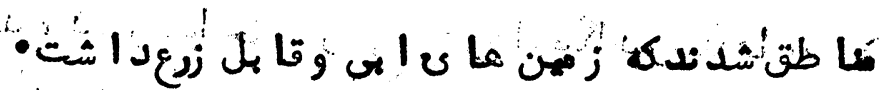

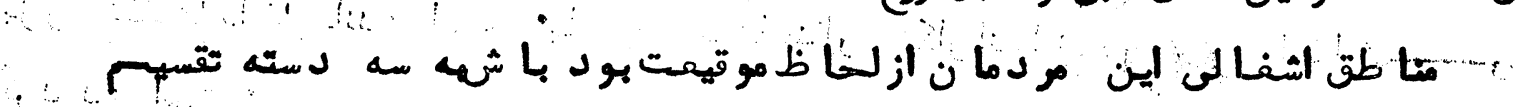

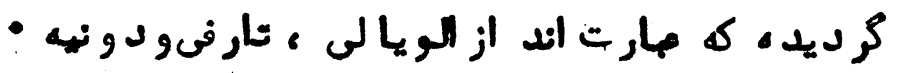

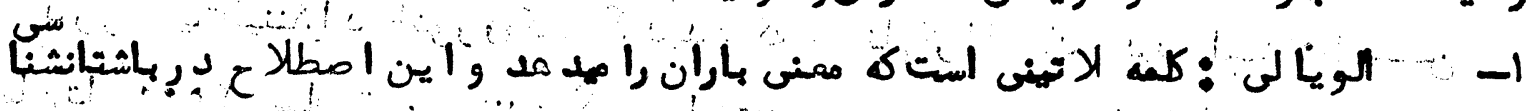

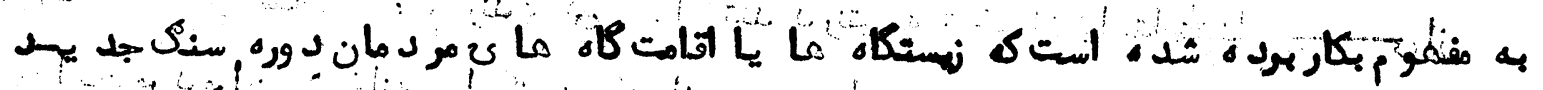

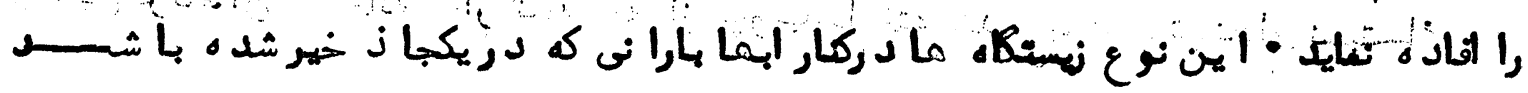




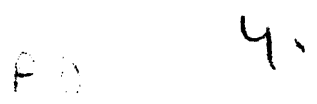

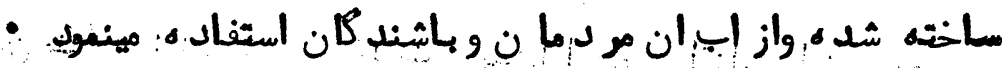

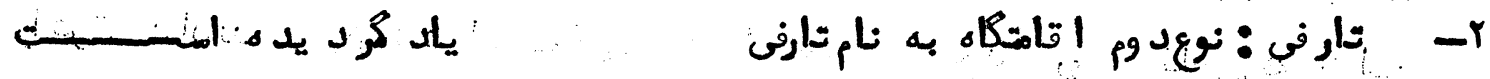

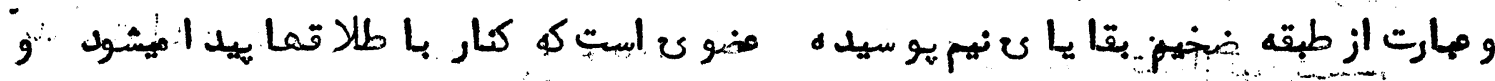

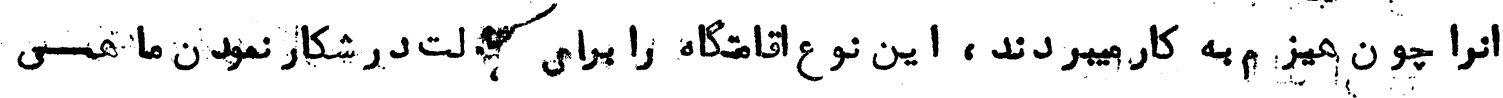

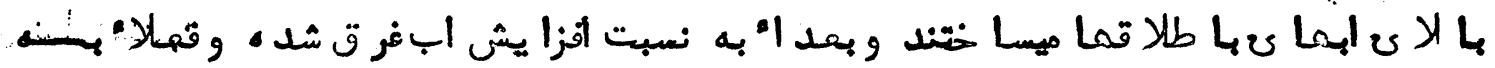

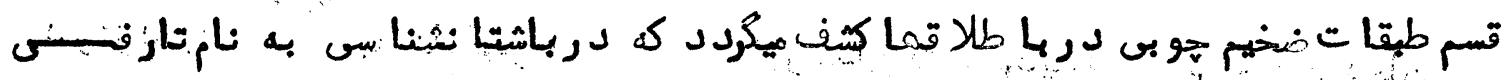
$\forall$

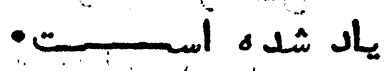

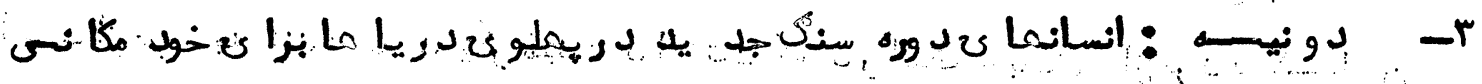

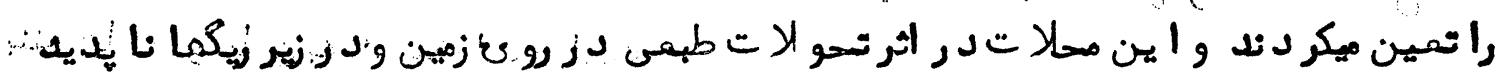

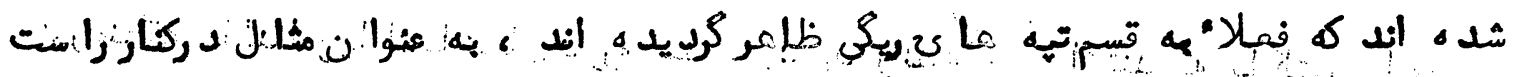

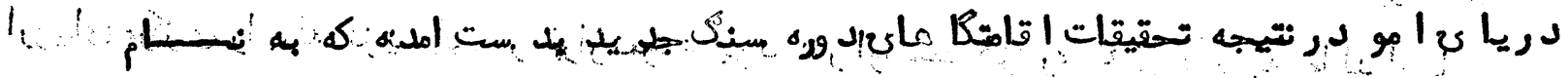

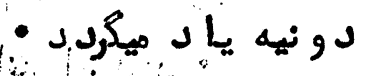

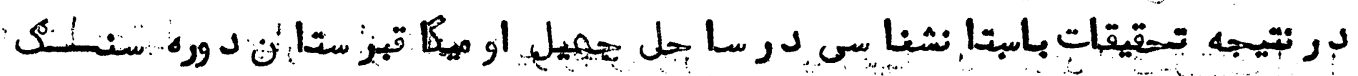

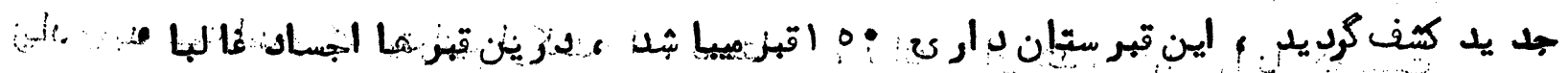

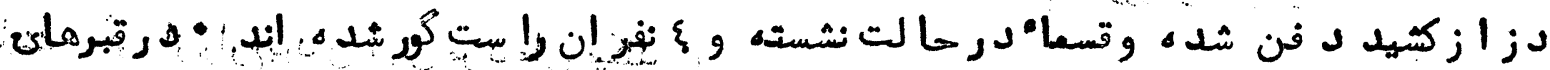

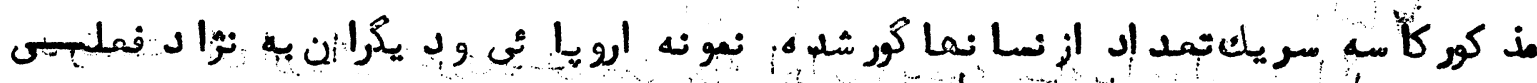

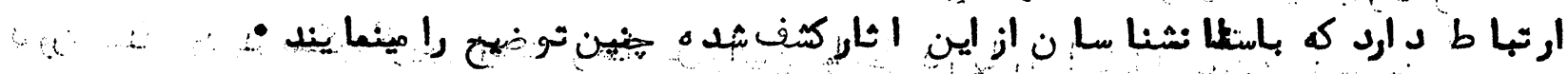

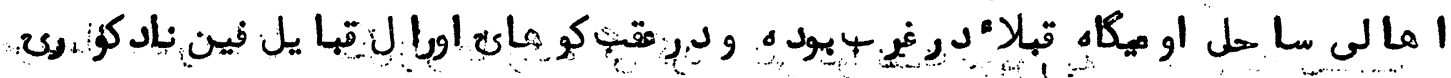

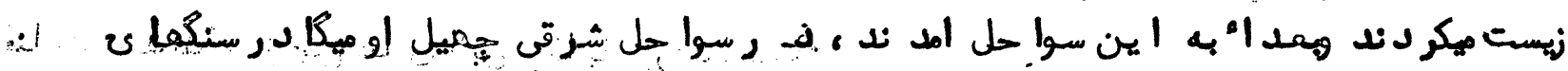

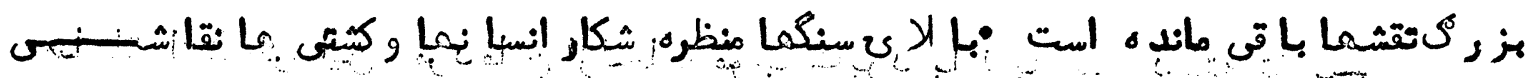

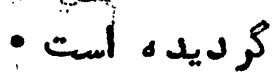

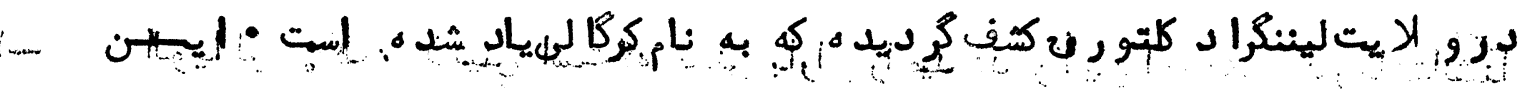

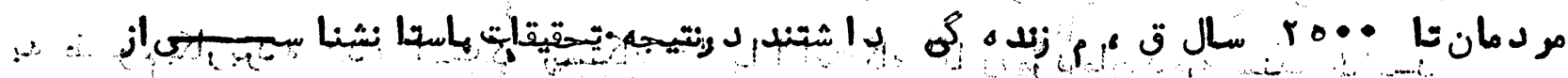

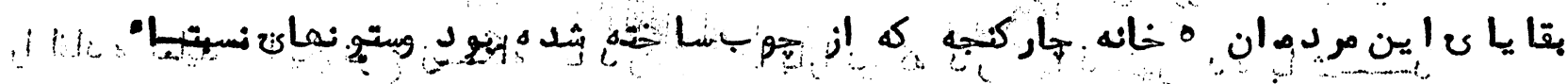




\section{. 41}

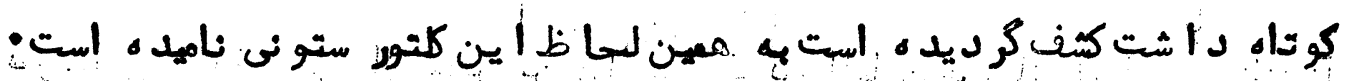

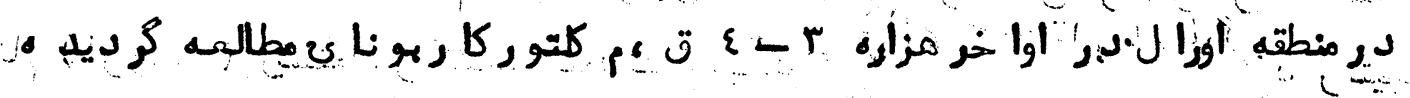

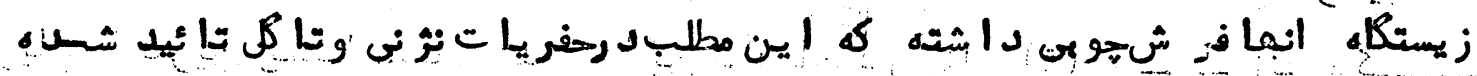

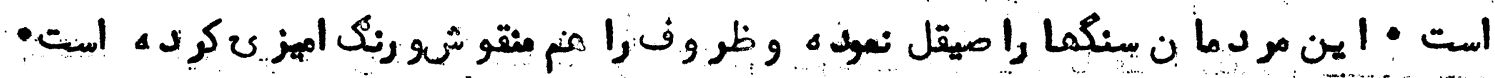

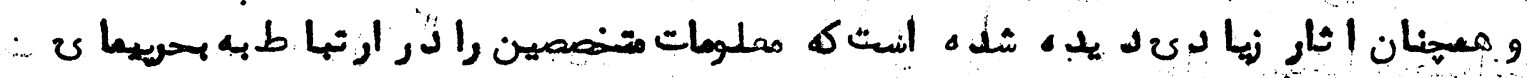

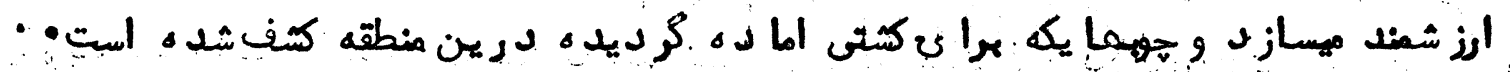

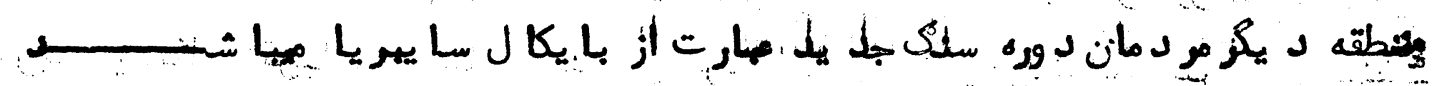

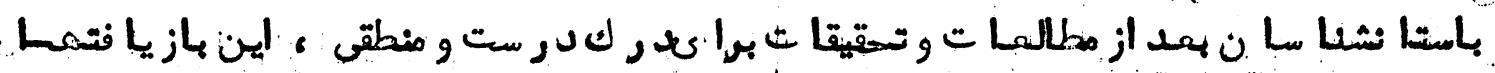

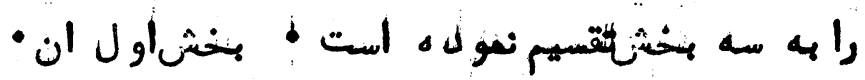

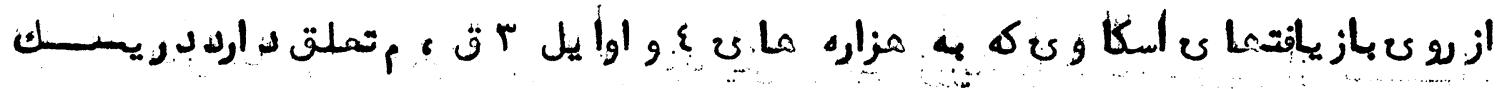

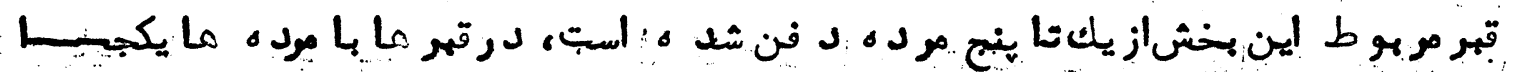

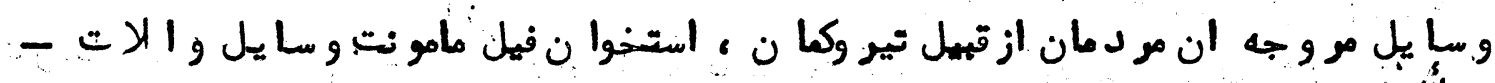

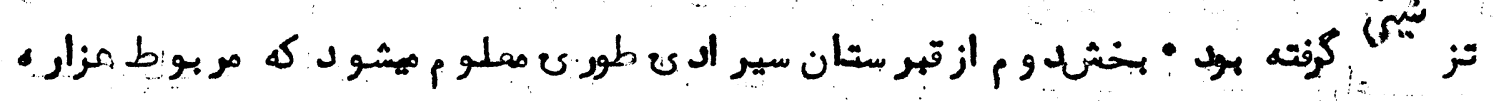

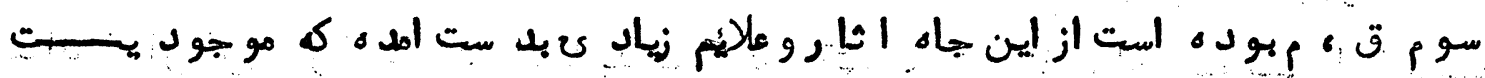

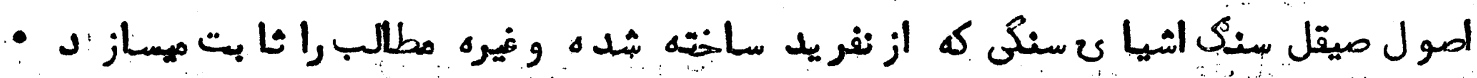

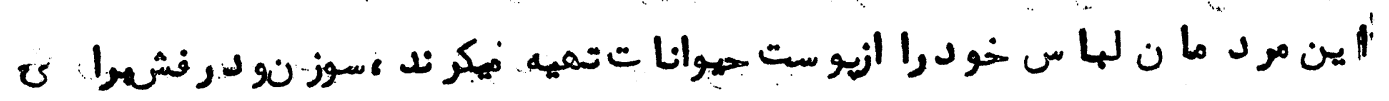

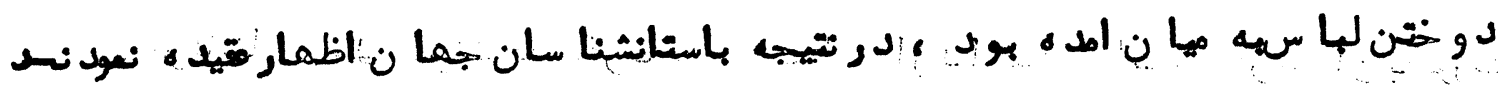

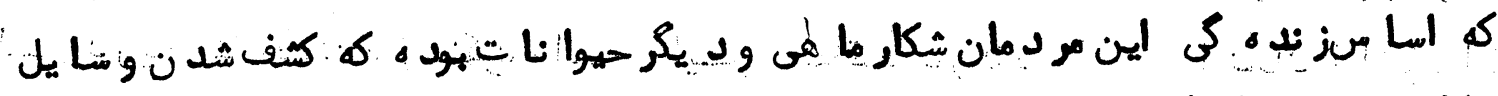

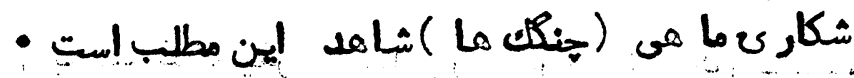

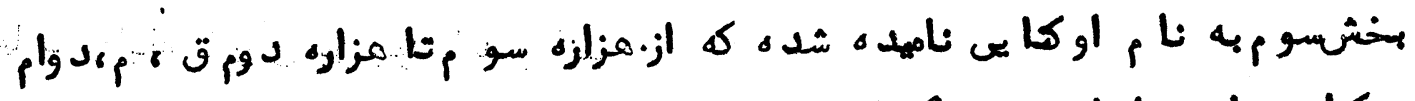

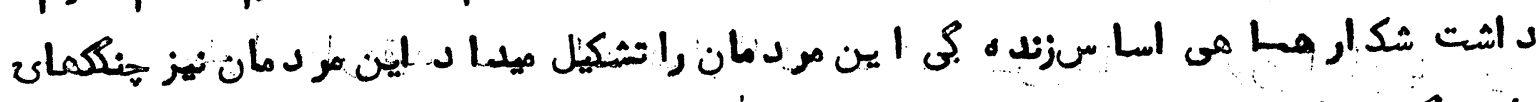

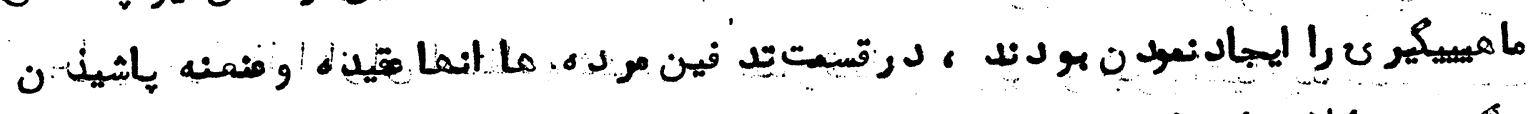

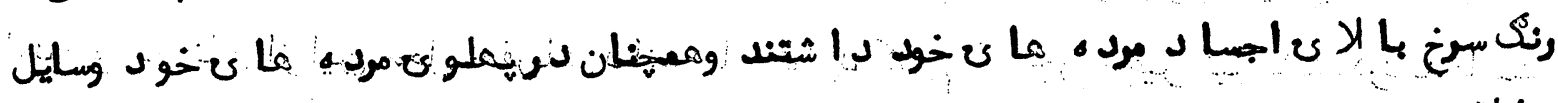

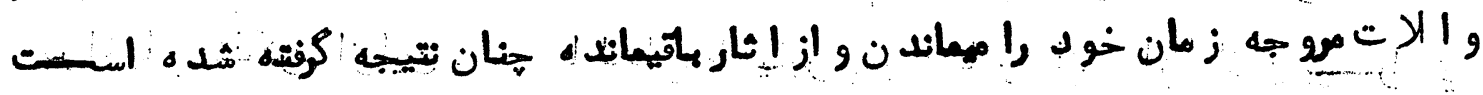

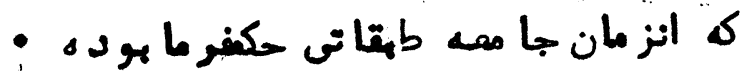


!

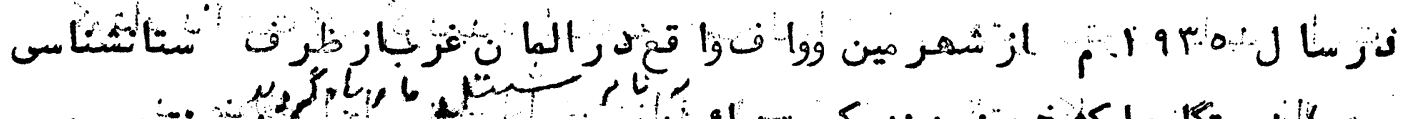

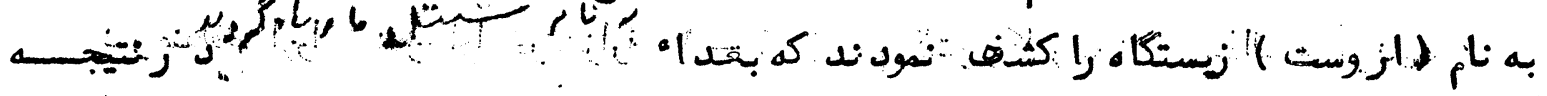

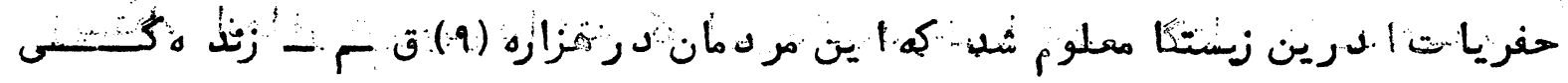

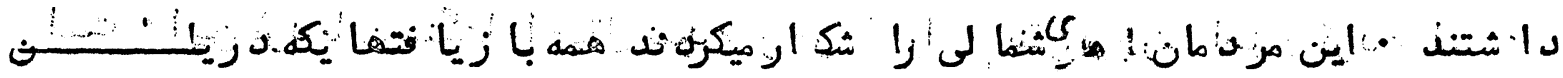

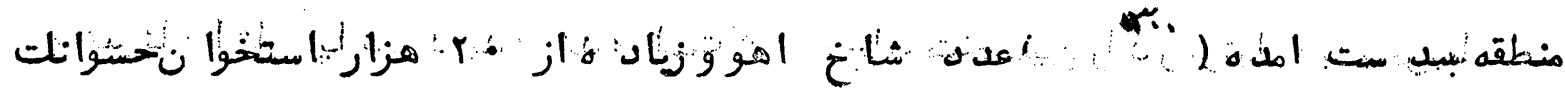

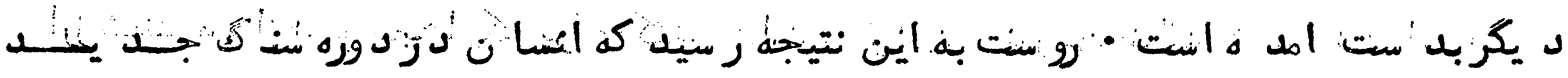

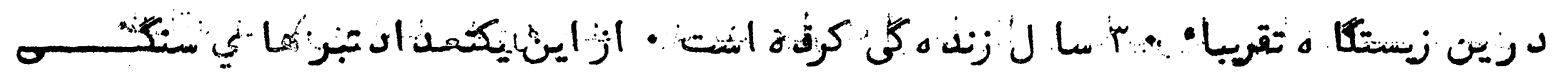

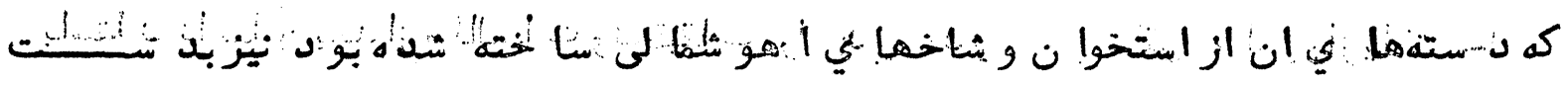

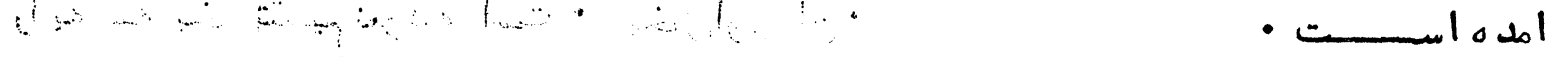

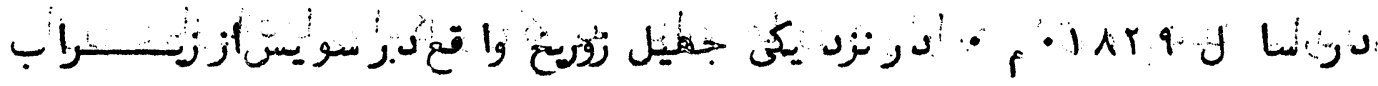

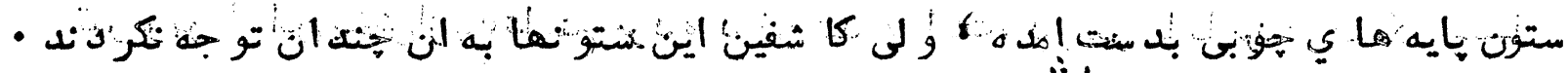

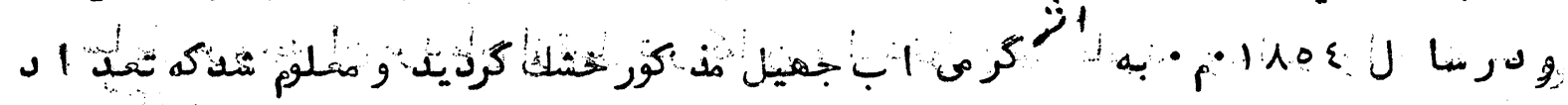

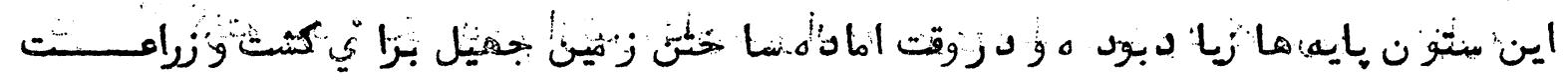

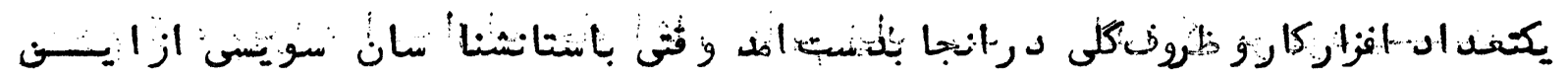

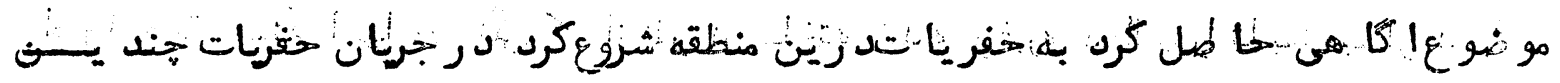

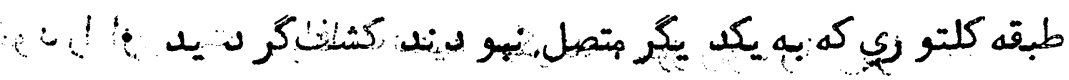

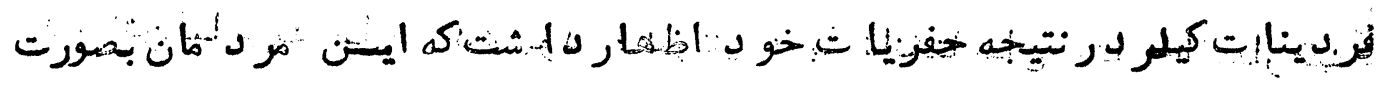

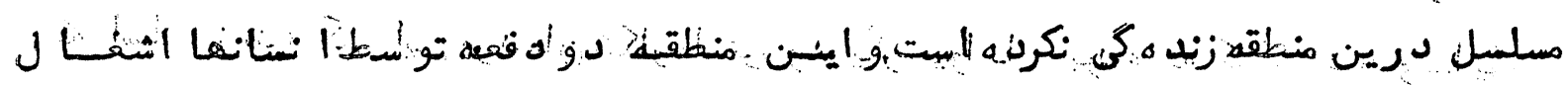

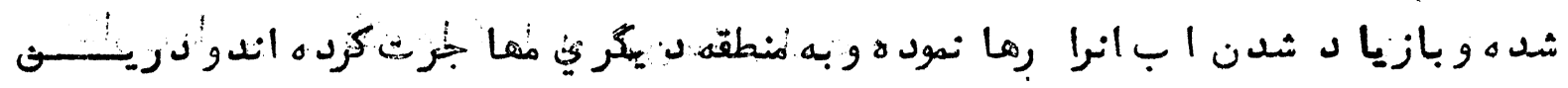

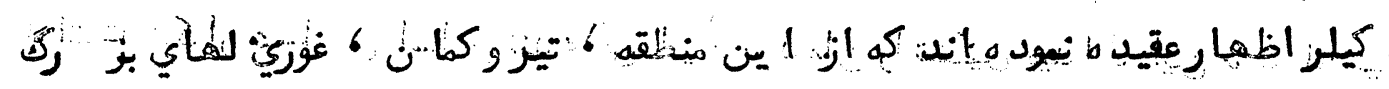

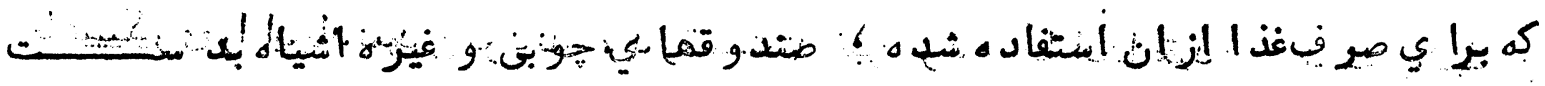

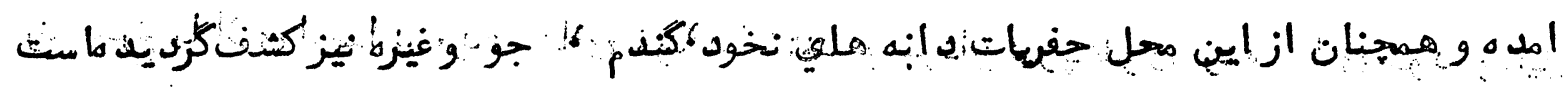

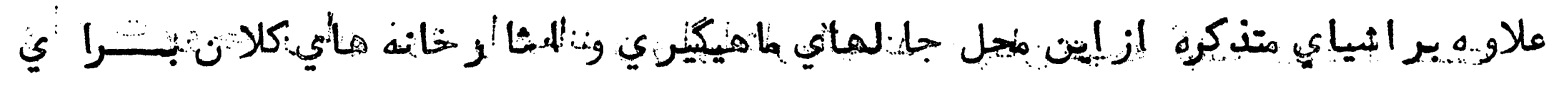


بود با شمشا هد مكرديد :

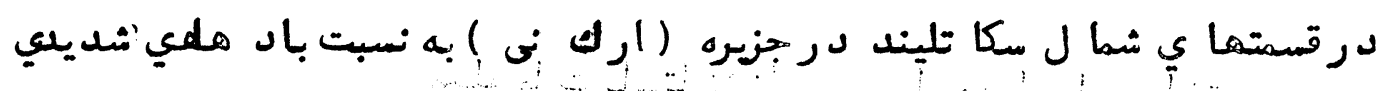

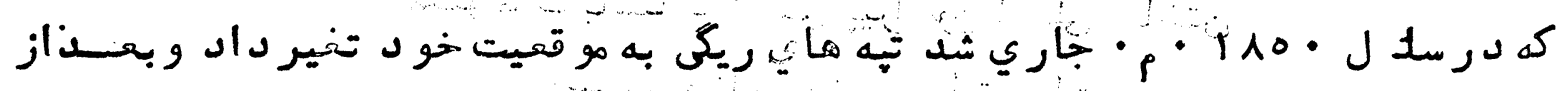

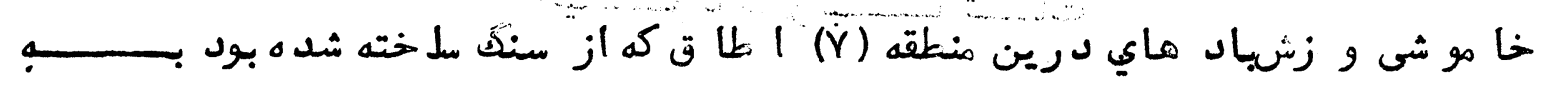

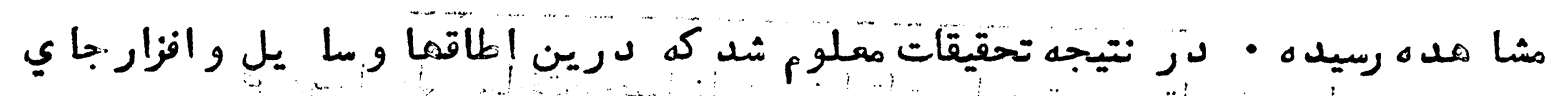

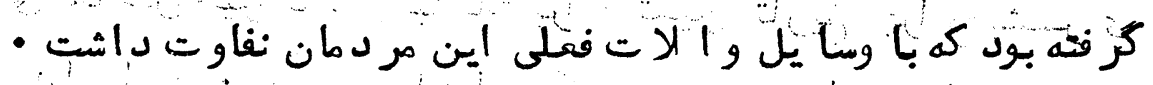

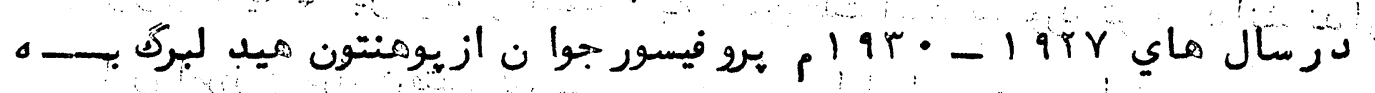

نام كوردن جا يلق (

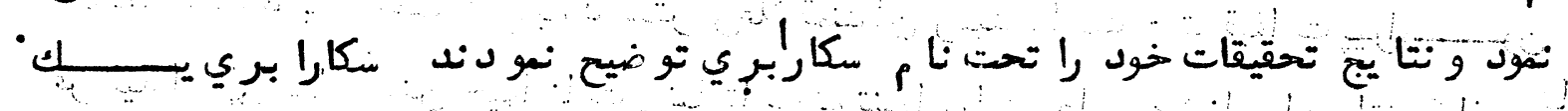

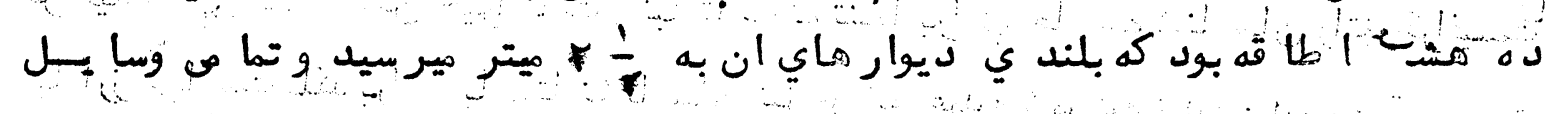

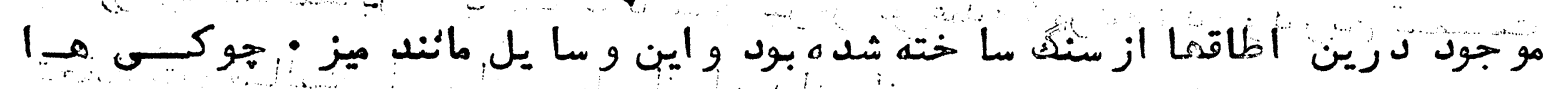

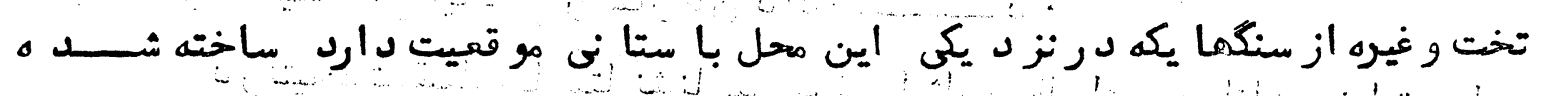

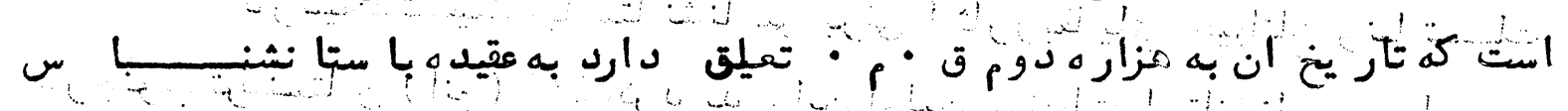

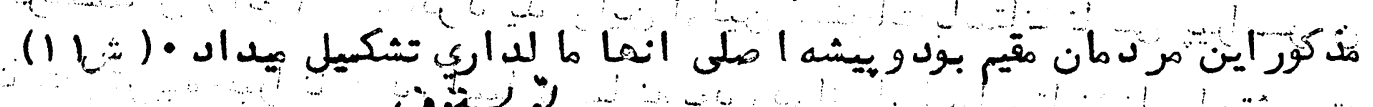

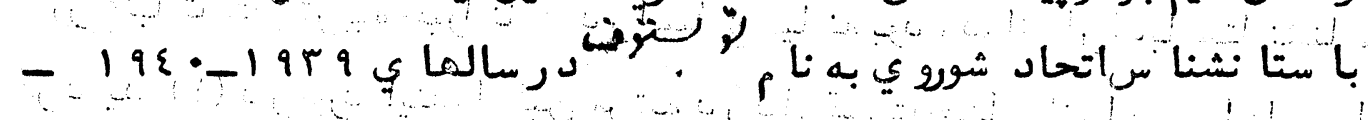

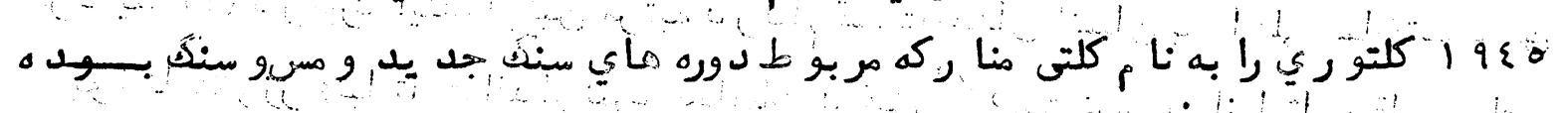

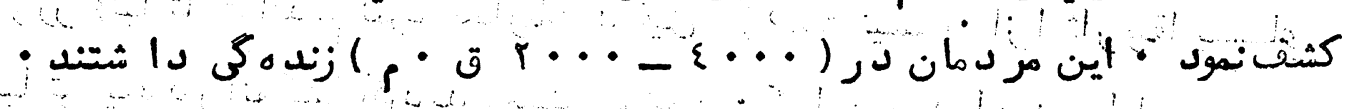

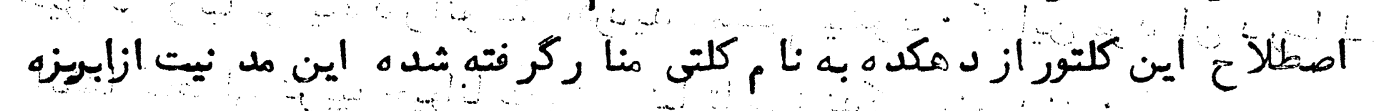

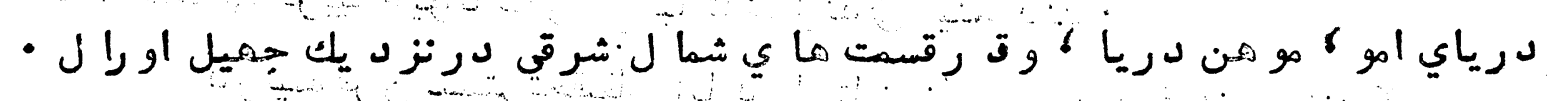

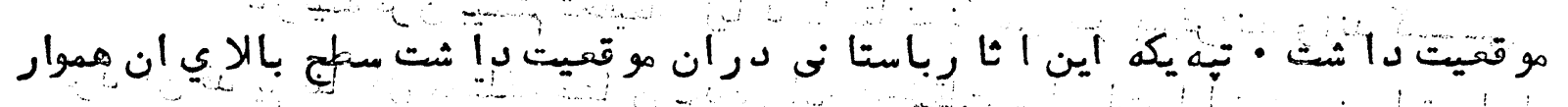

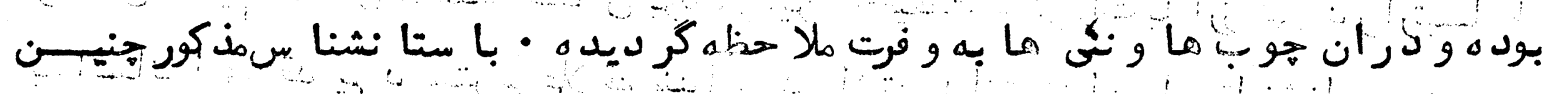

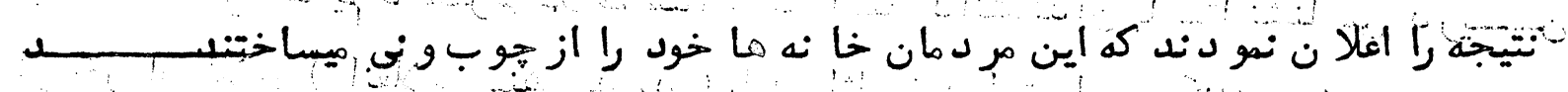

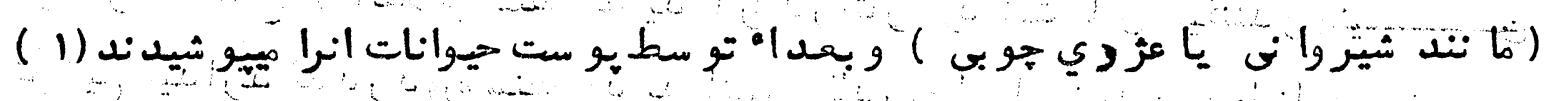
(1)-- -

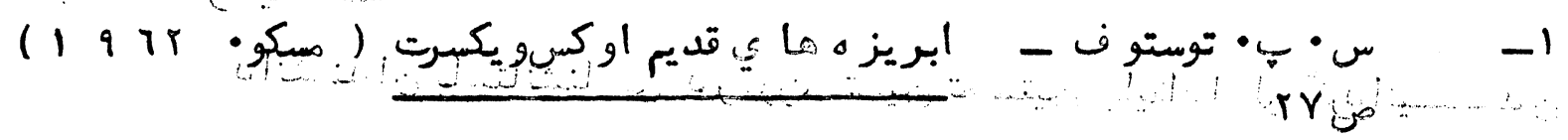




\section{هـلو ما ت باستا نتنا سى بيرا مون الملى ساختن

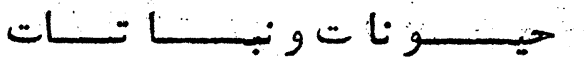

فرويهه الملى ساختن حيوا نا ت و نبا تات برا ي تعين تاريخ جوا مع بشـري

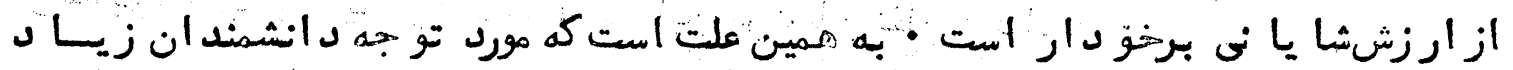

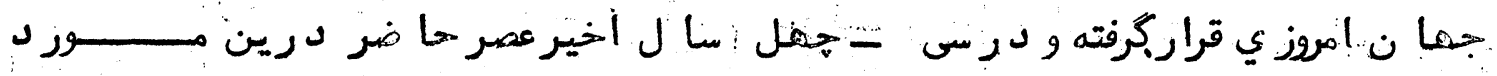

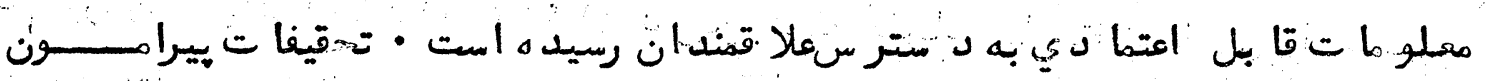

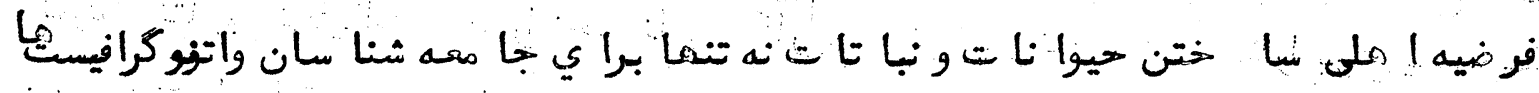

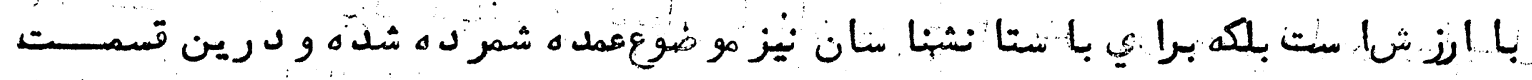

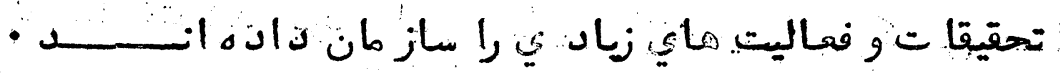

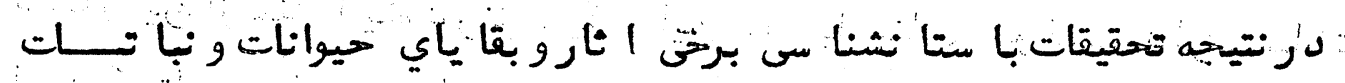

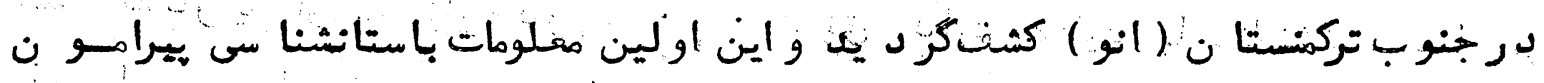

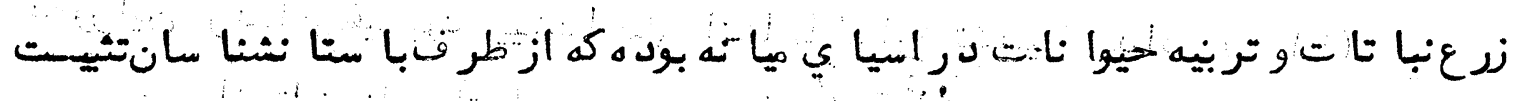

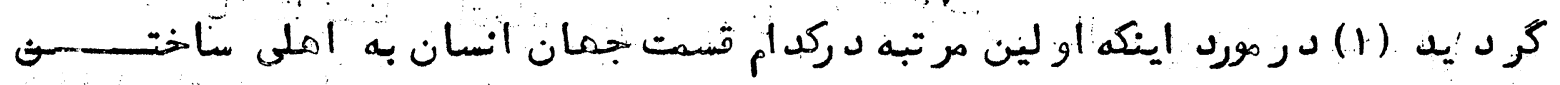

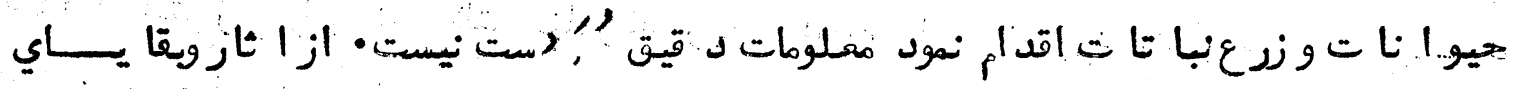

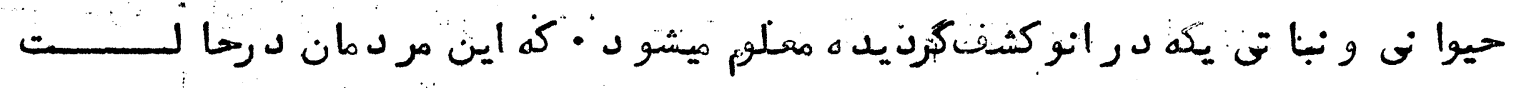

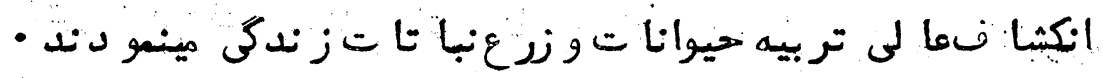

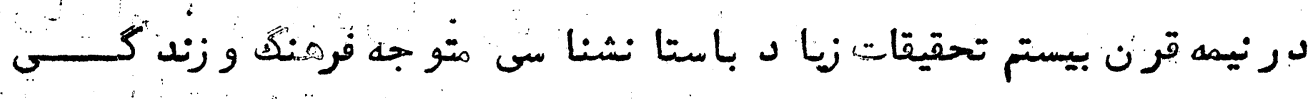

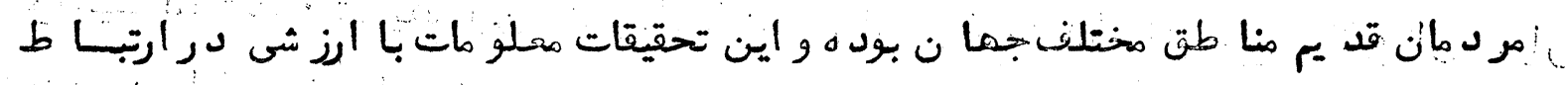

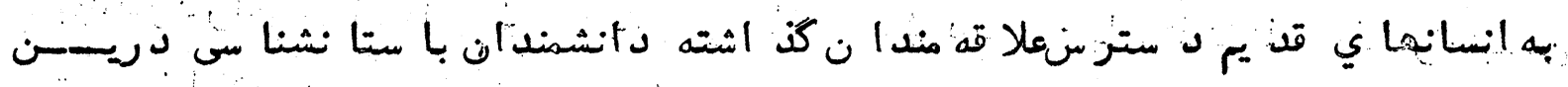

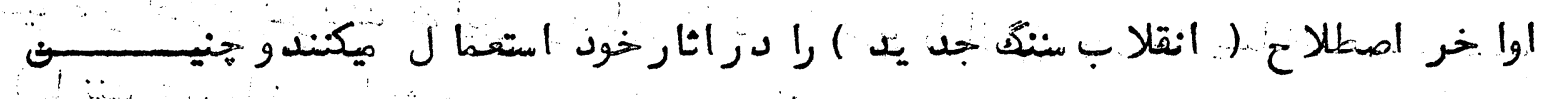

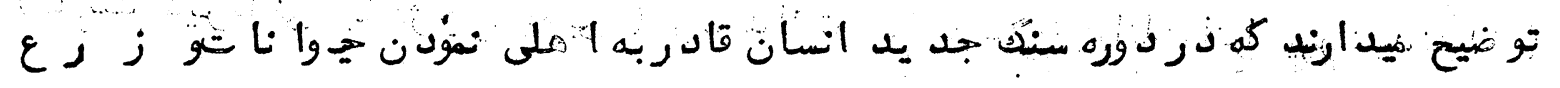

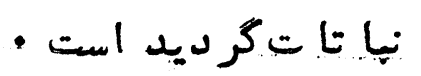

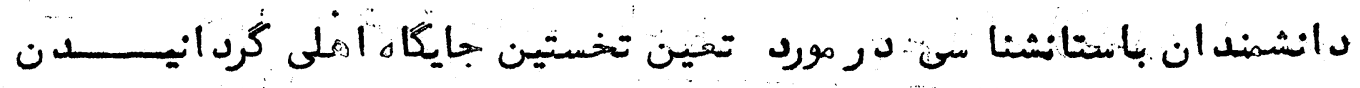




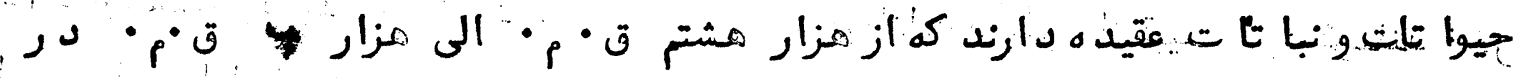

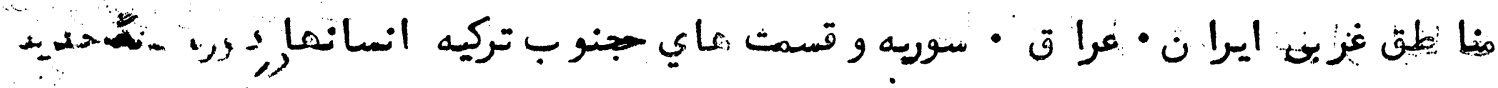

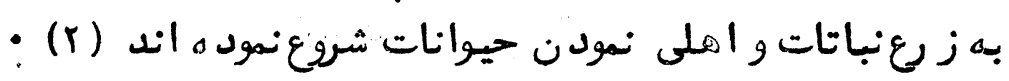

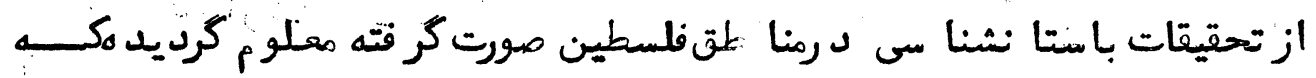

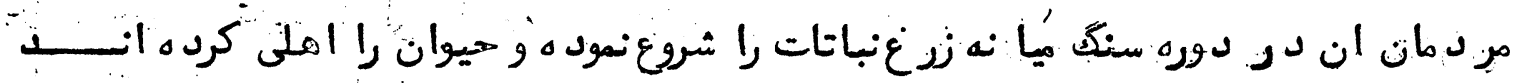

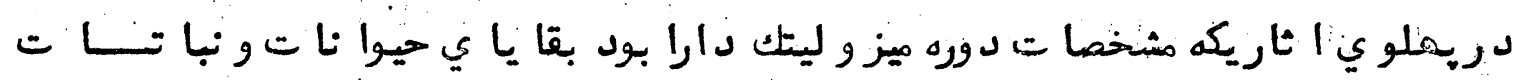

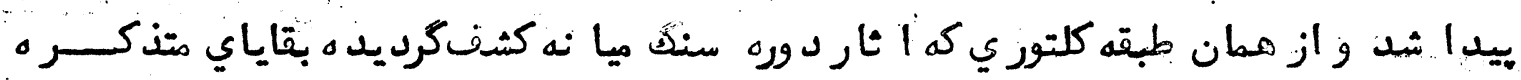

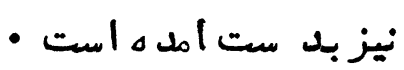
رانشمنب ان با ستا نشنا سى اين كلتور رابه نام نطو في "Natufi ياد نموده - (r)

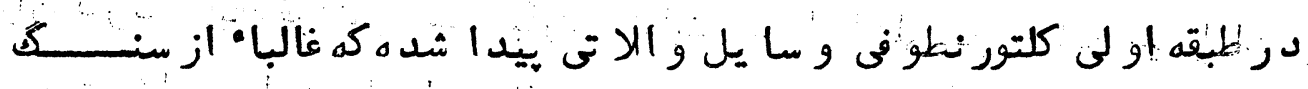

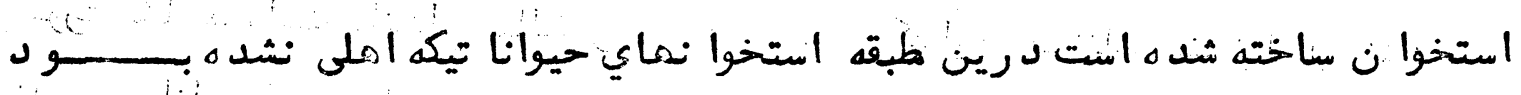

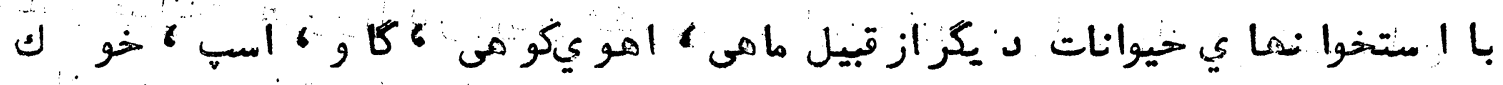

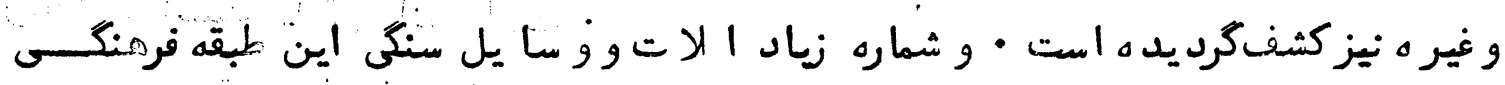

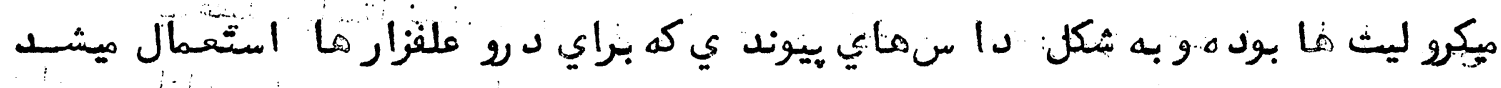
باستا نشنا سان بعد ازكثفا ثار مذكور اعلام نمود ند كه و سا يل وراتأرمذكور

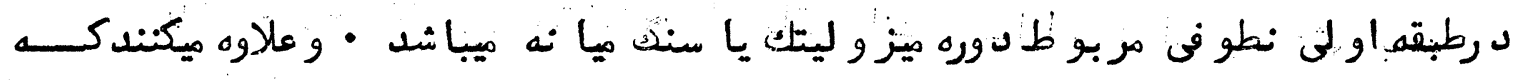

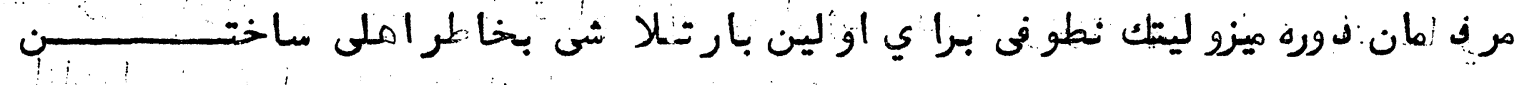

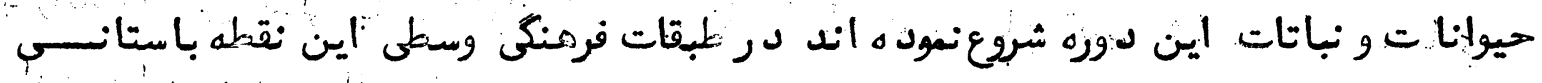

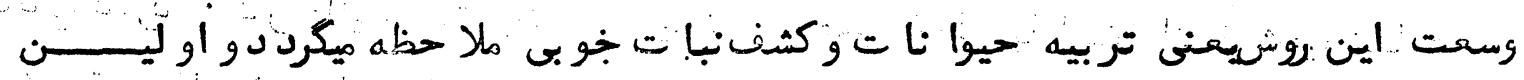

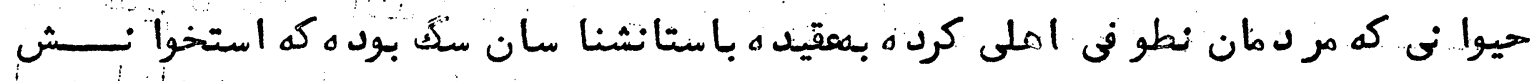

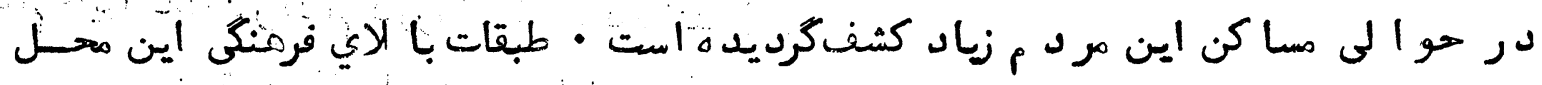

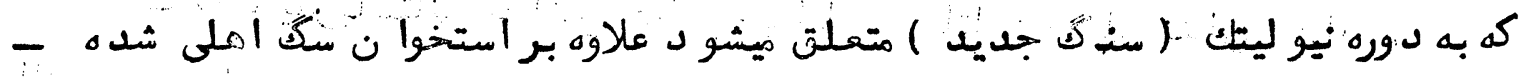

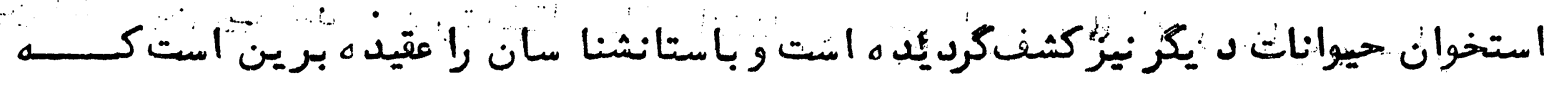




\section{4}

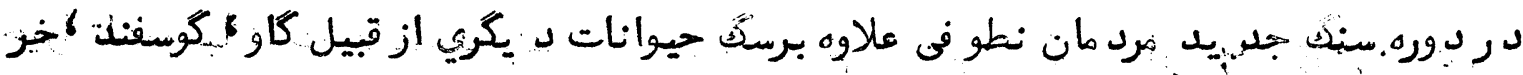

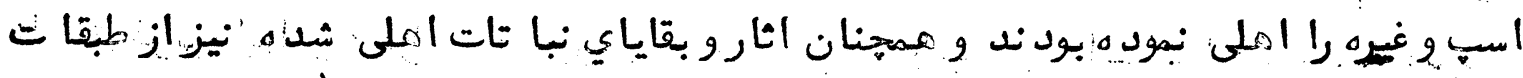

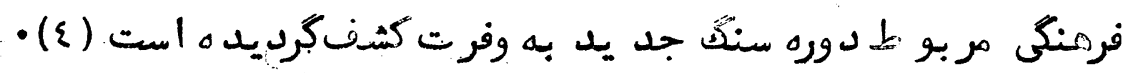

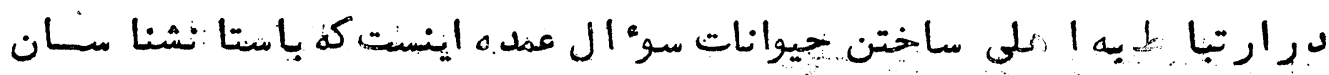

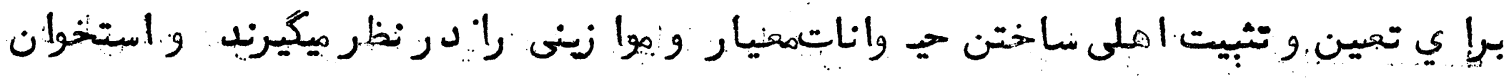

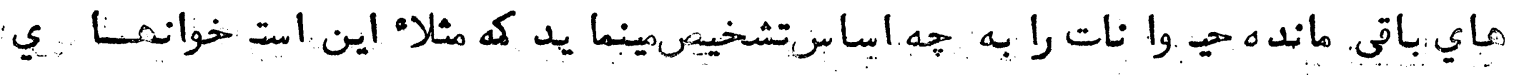

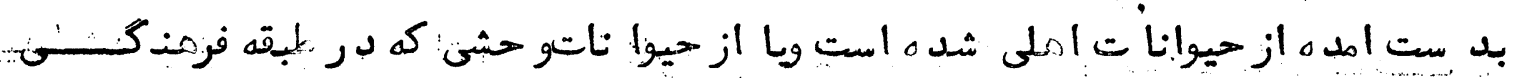
$\div$

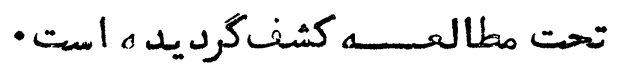

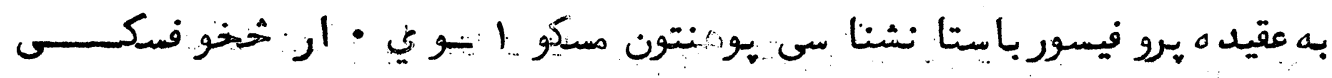

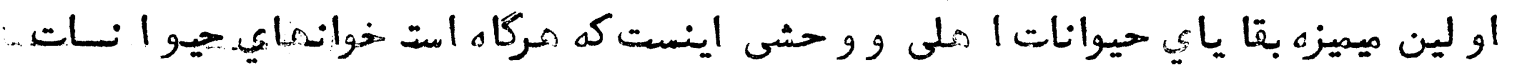

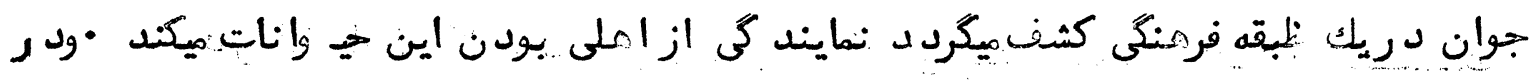

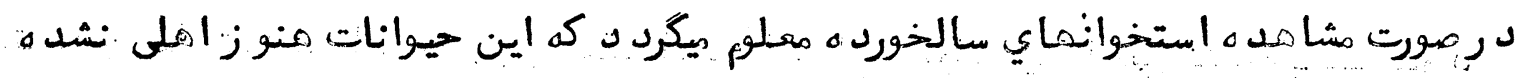

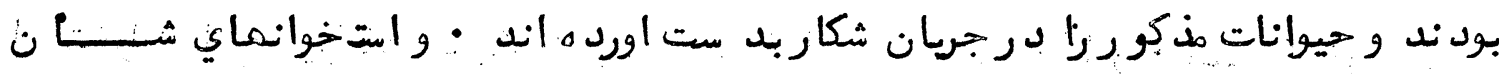

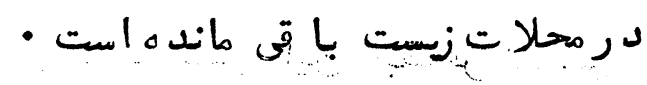

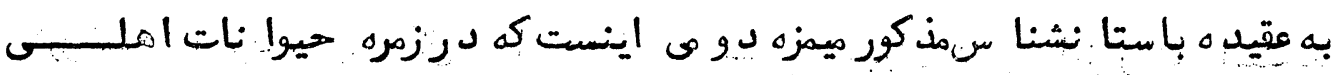

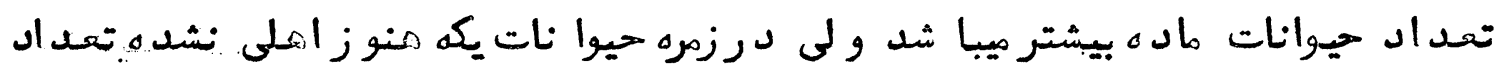

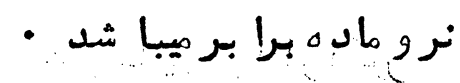

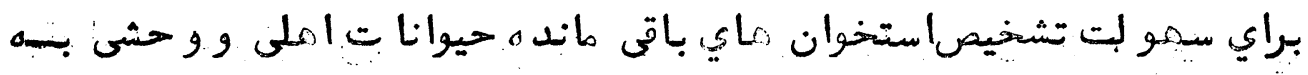

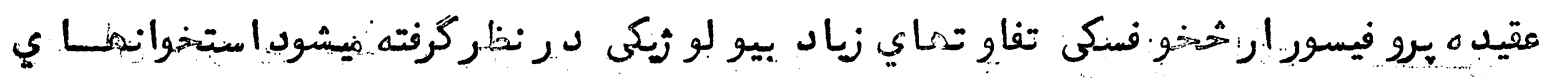

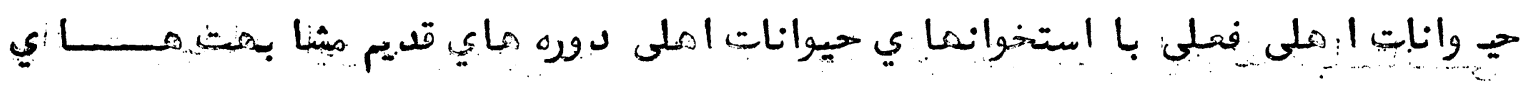

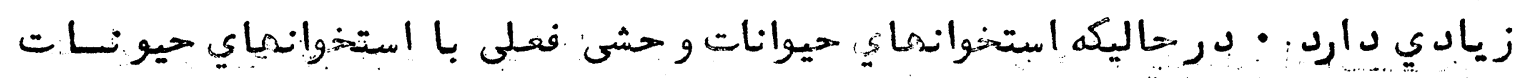

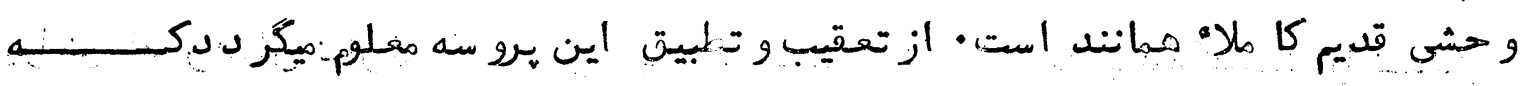

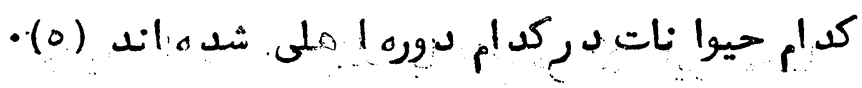

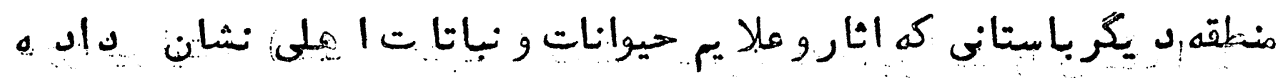

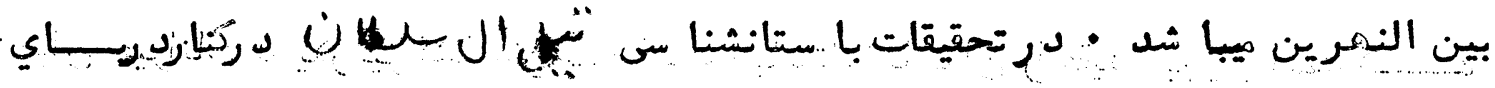




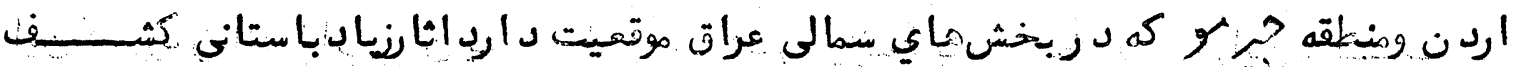

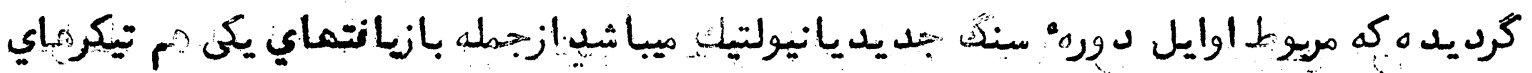

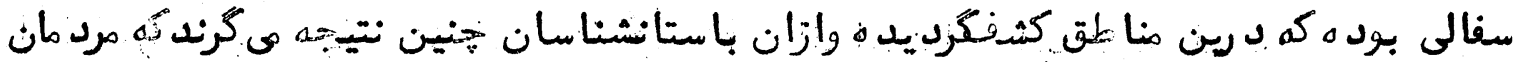

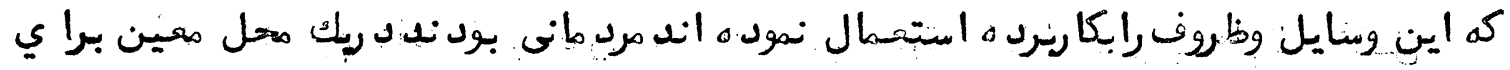

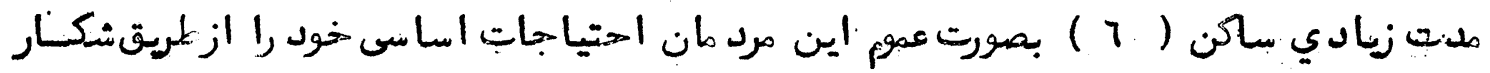

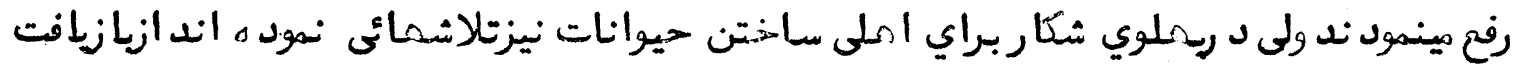

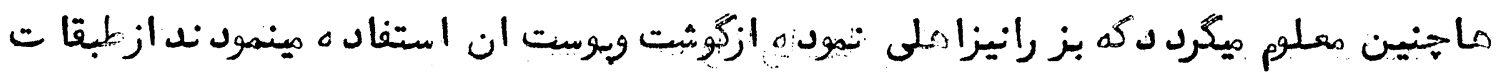

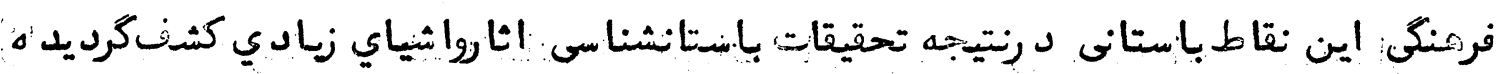

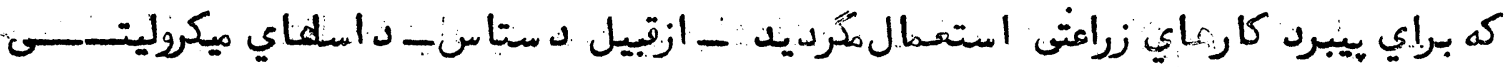

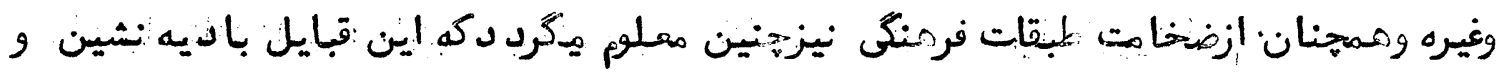

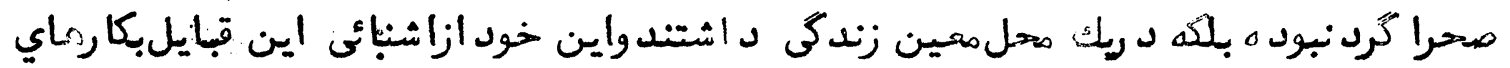

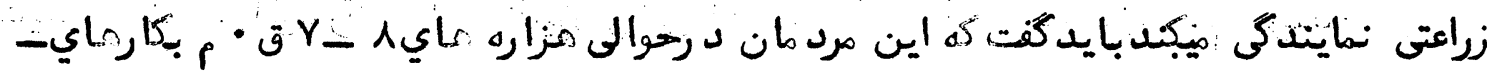

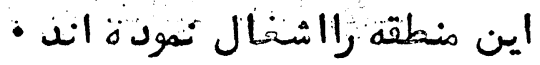
بازيافتهاي مذ بور تنكادرين هنطقة نبوده بلكه ازنقاط دورونزديك ان نيزيد ست

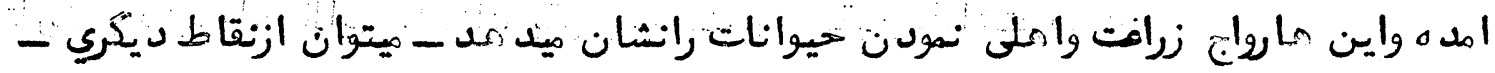

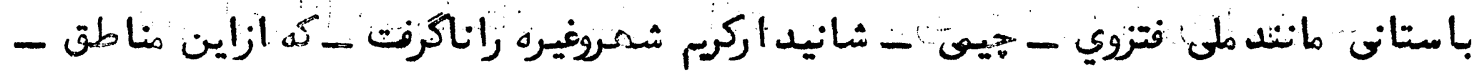

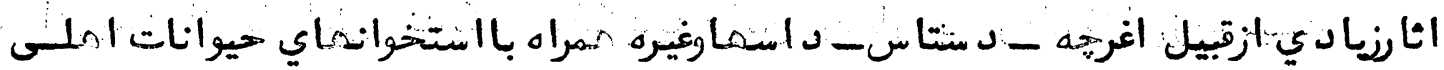

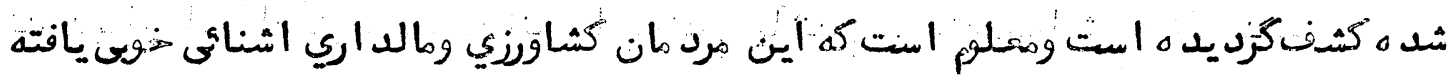

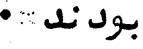

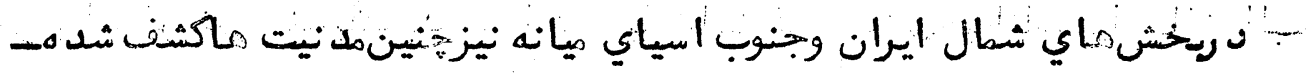

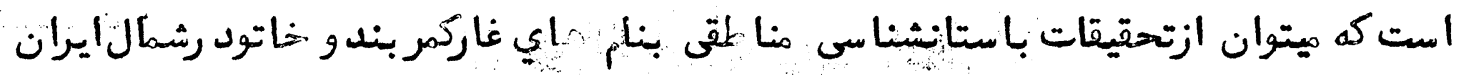

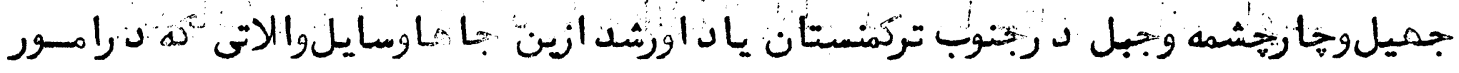
كشاوزي ومالد أري استفاده من شدكثفكرديده است (V)

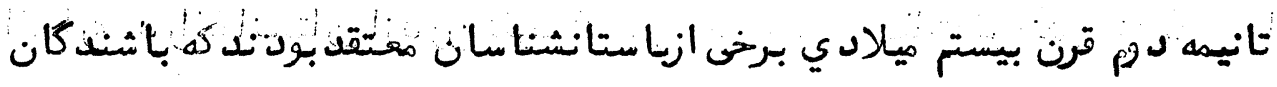

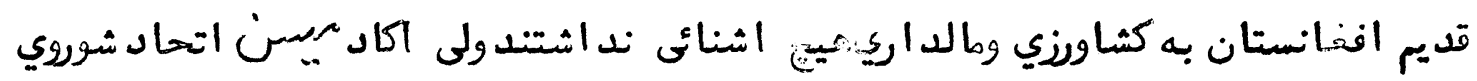




\section{$4 \wedge$}

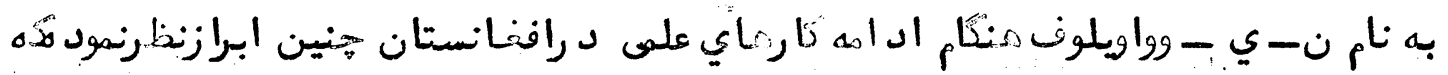

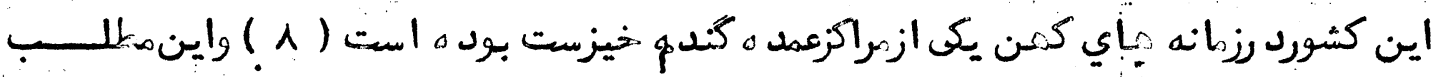

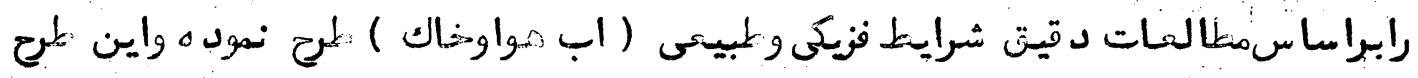

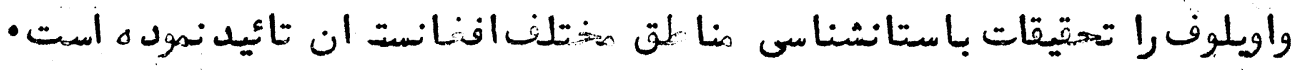

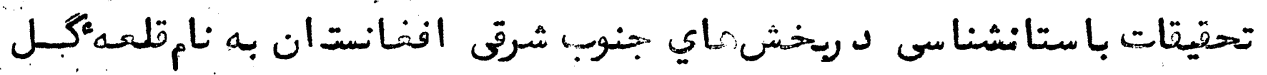

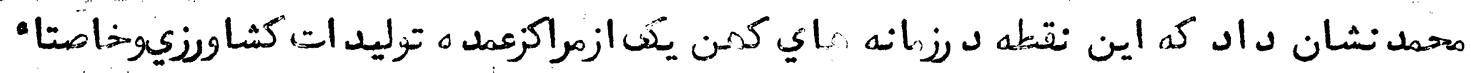

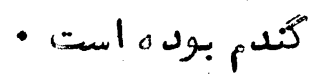

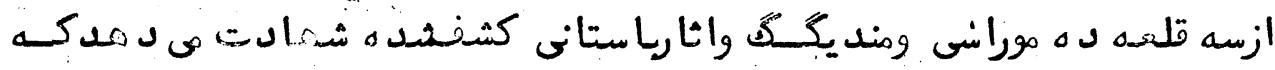

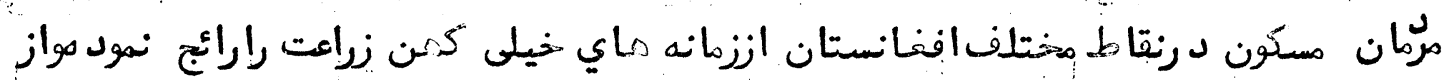

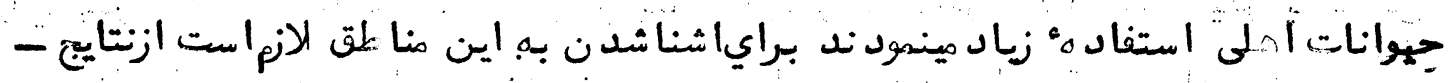
تحقيقات باستانشناسى د رارتبا لـ بموضوعاين مقاله بصو رت ميتصرياد اورينطائيم.

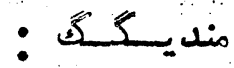

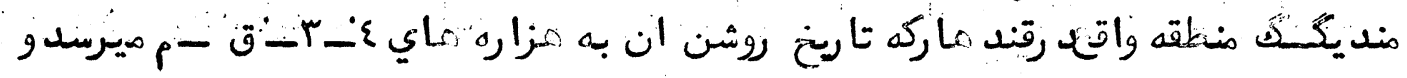

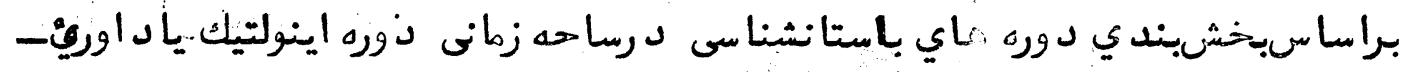

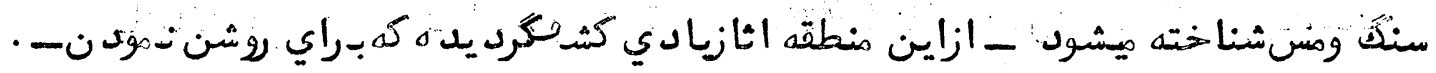
1

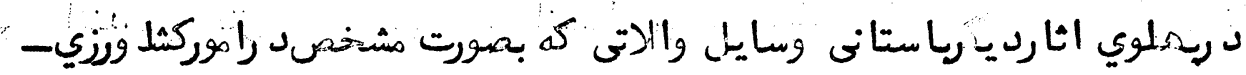

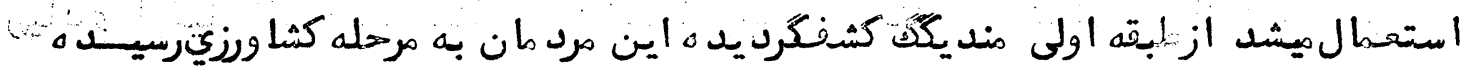

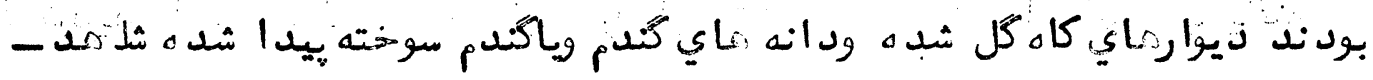

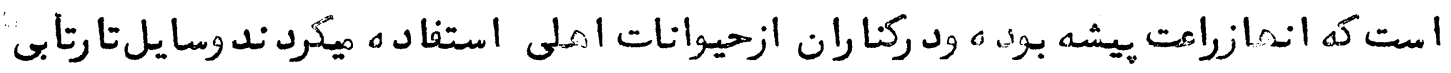

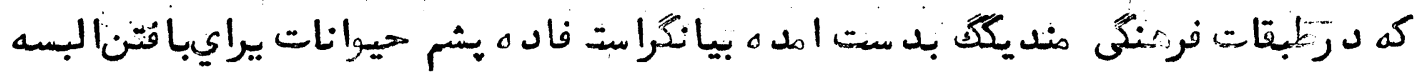
بايدياناورشدكه املى كردن حيوانات ونباتات د رافنانستان اززمانه مايمشين شروعرديده بود وبعنى ازياستانشناسان به اين عقيده اندكه شنسل كثلا ورزي

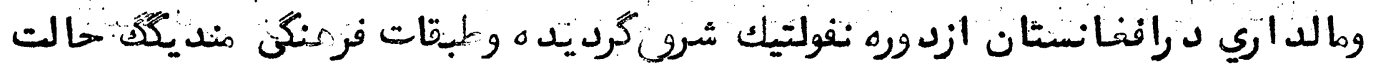




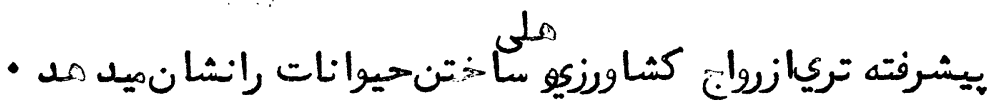

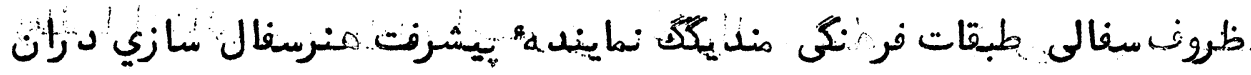

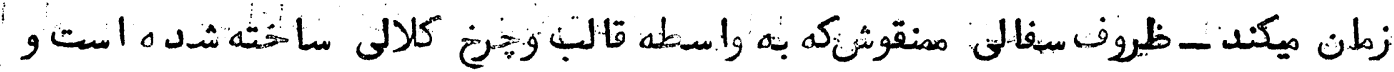

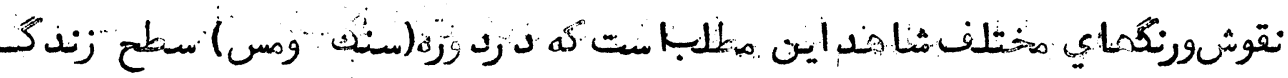

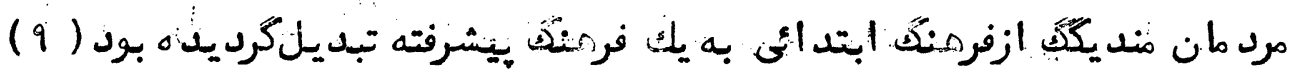

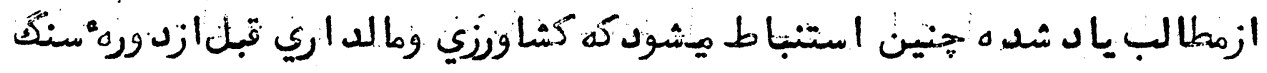

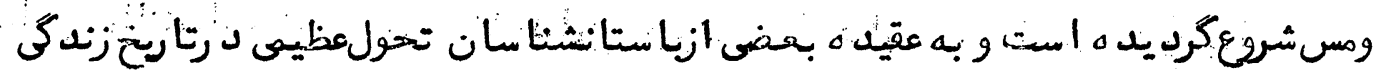

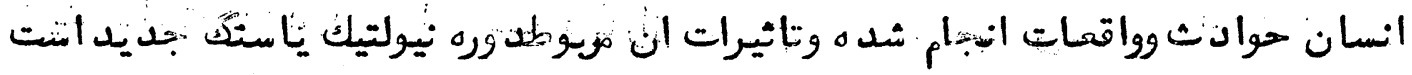

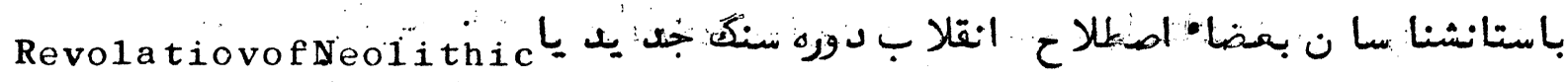

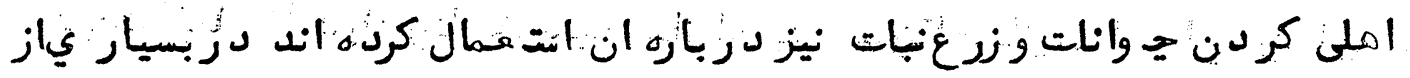

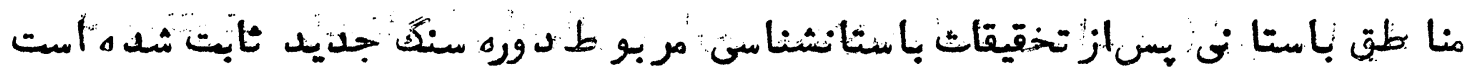

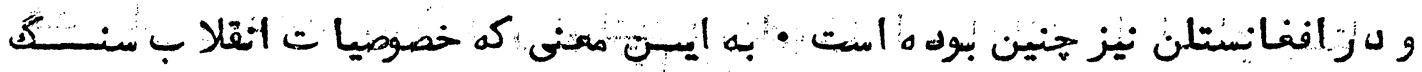

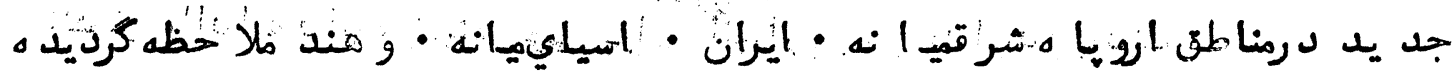

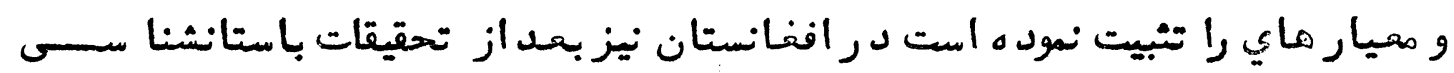

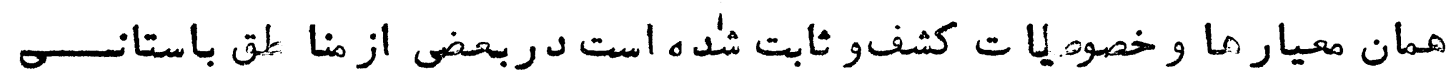

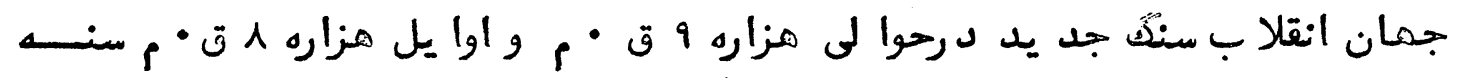

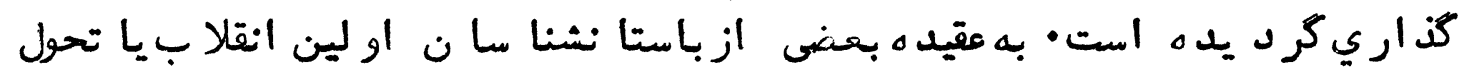

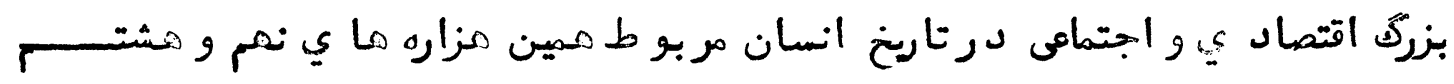

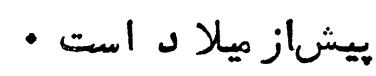

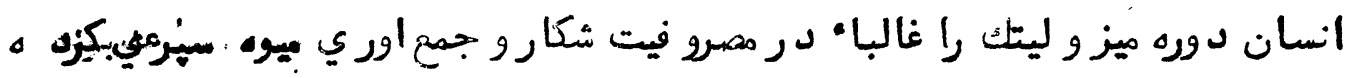

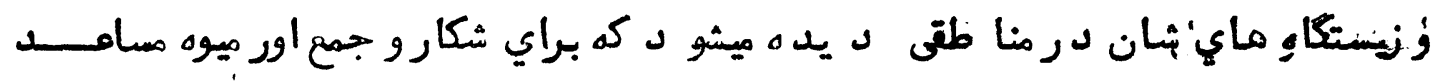

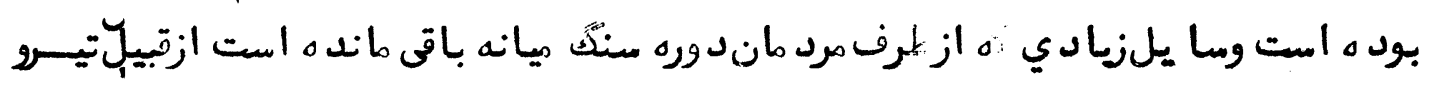

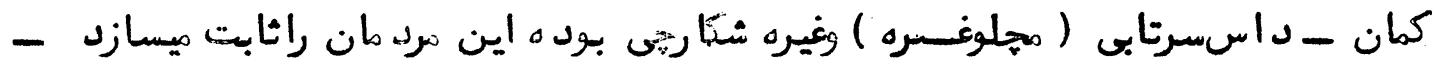

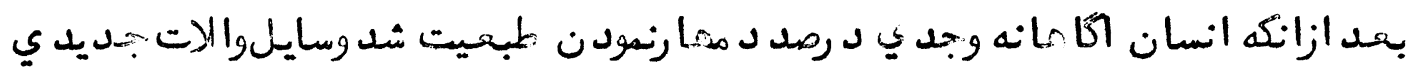

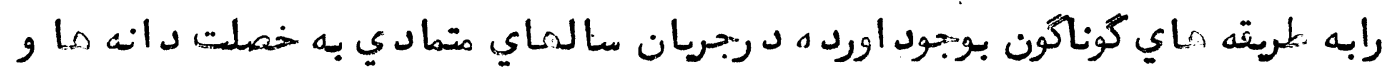




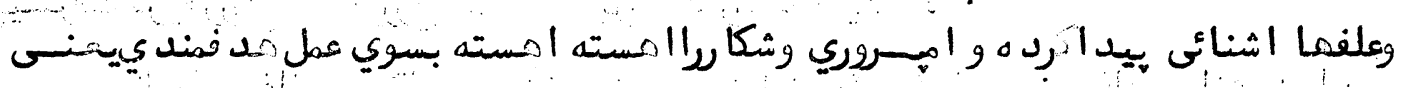

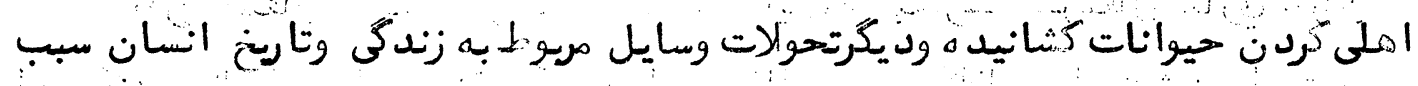

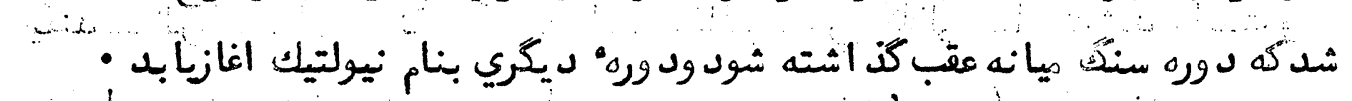

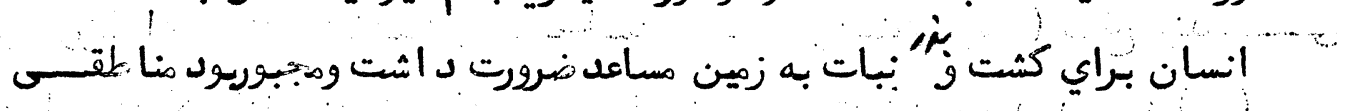
رالشغال نمايندكه براي رشدنبات سناعد باشد - دريملوي ان براي نكا مد اريجي وانات

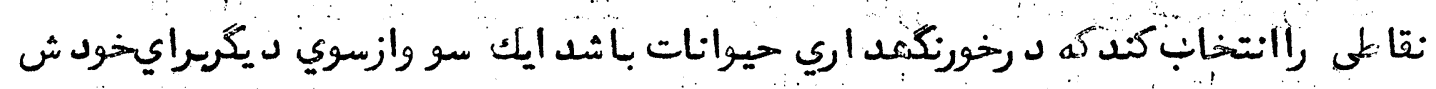

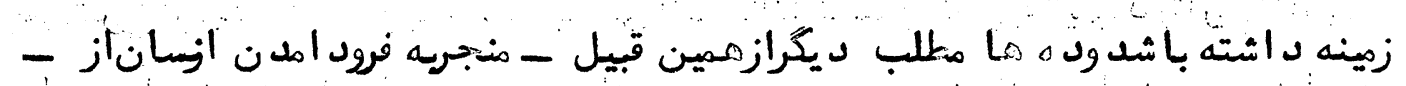

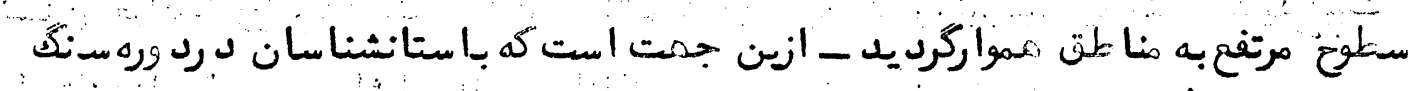

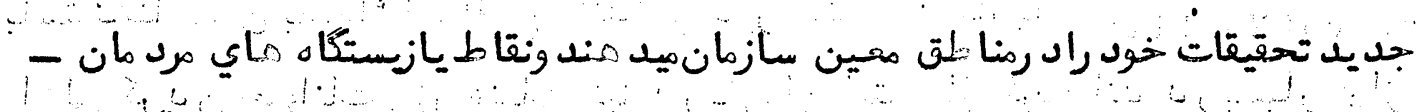

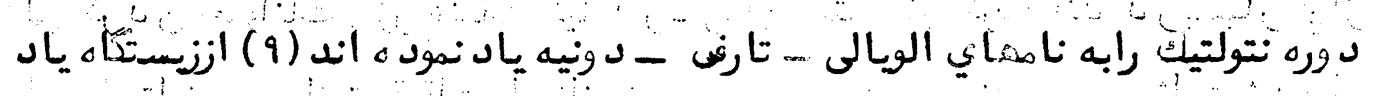

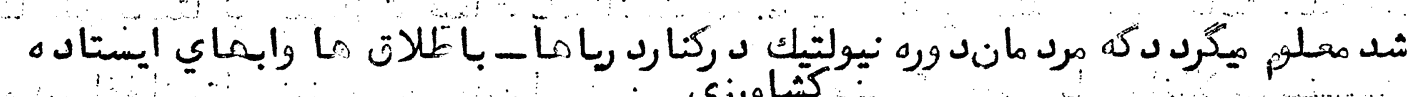

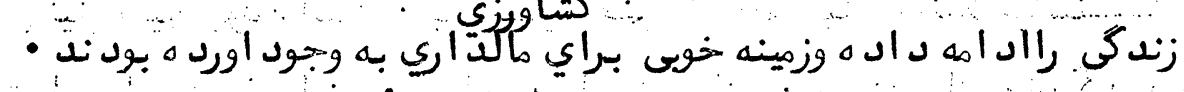

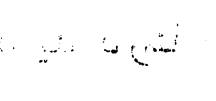


VI

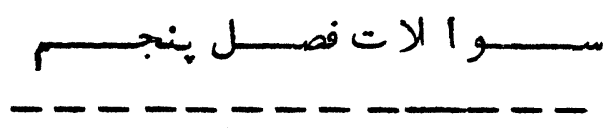

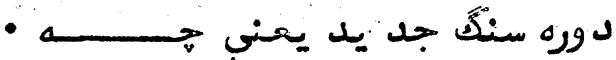

$-1$

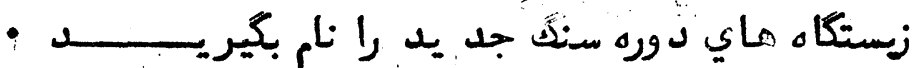

$-r$

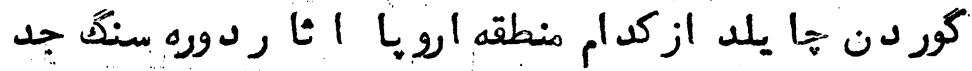

$-r$

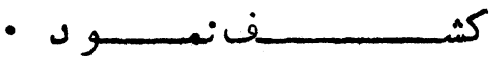

فردينا ند كيلر از جميل زوريخ كدام الثار را كثقنمودند

$-\varepsilon$

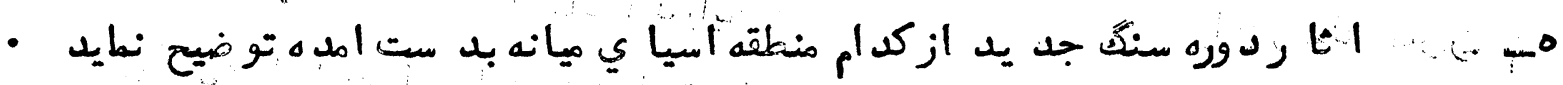




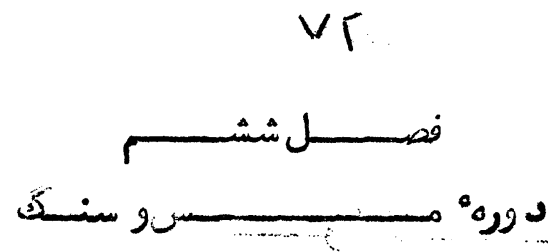

د رين اواخرباستانشناسان دروه ديكري راد رتقسيمات بيشترخود

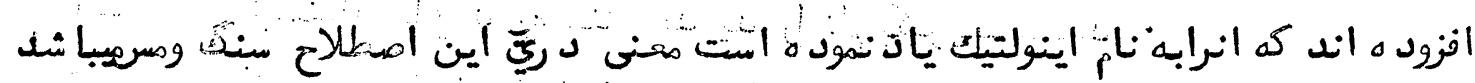

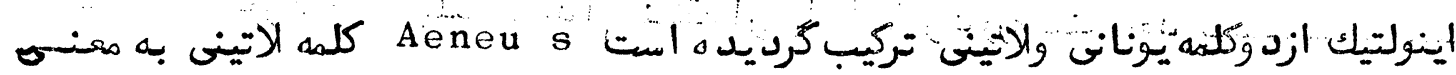

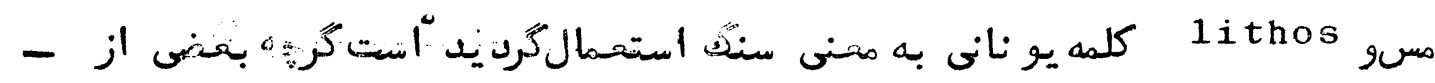

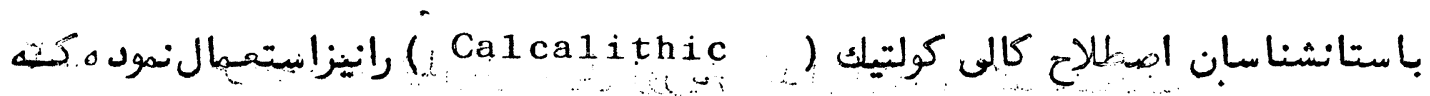

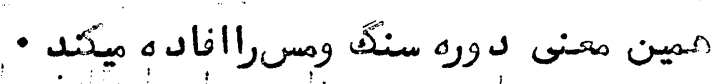

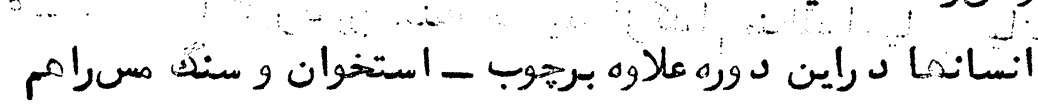
به حيث اسلحه ياوسيله، توليد استحسال مينمول ند ـ اين د وره ازلحاظ. زمانى وكلتـوري

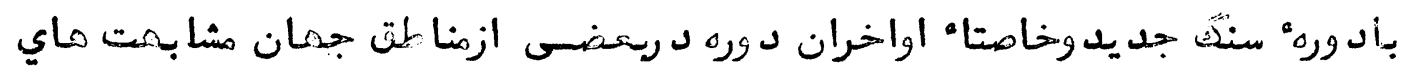

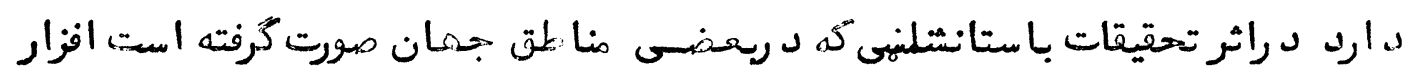

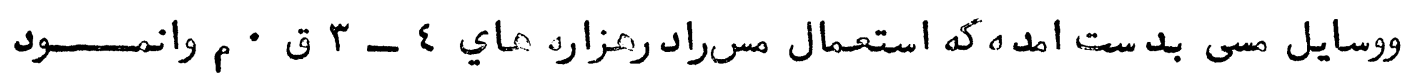

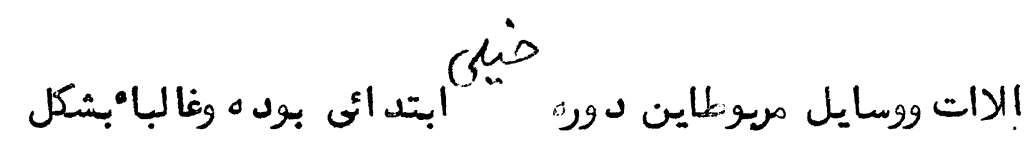

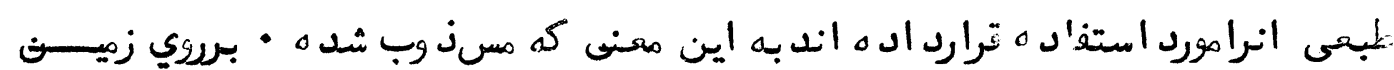

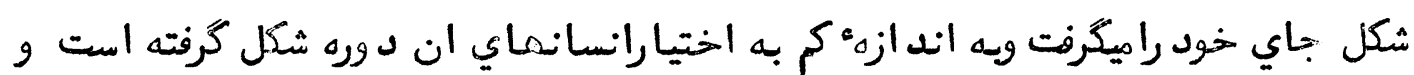

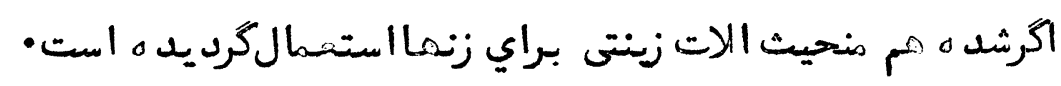

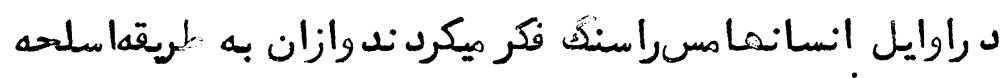

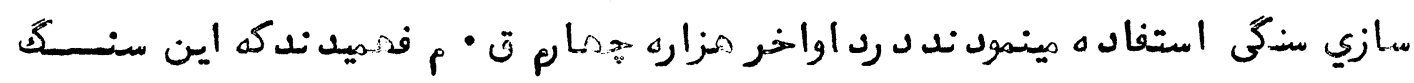

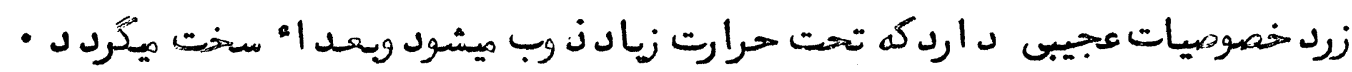

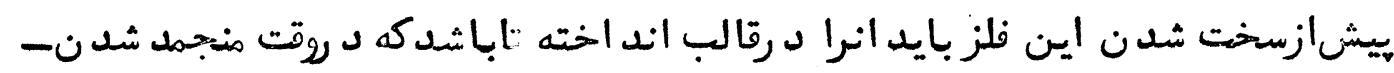

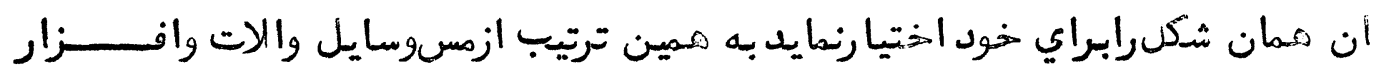

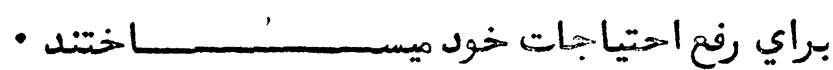


$v r$

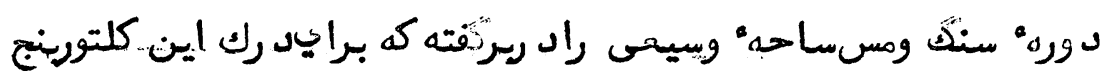

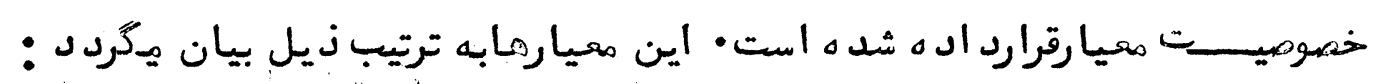

ا- تسلط زراعت كلندي نذلربه ديكرنمونه ماوسايلتوليدي -

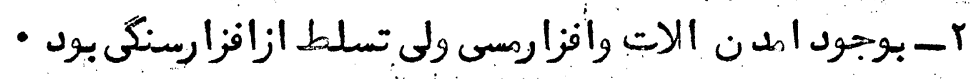

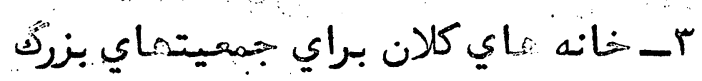

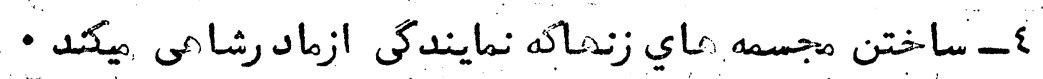

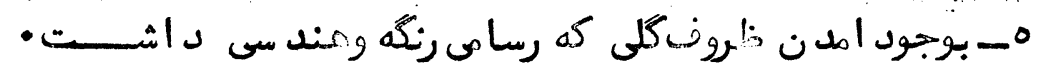

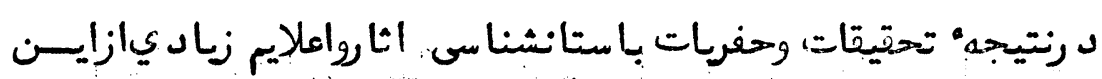

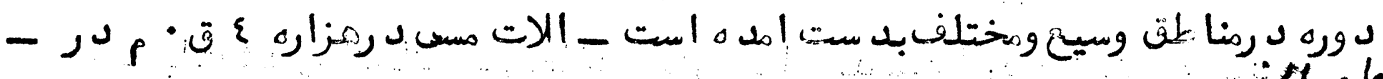

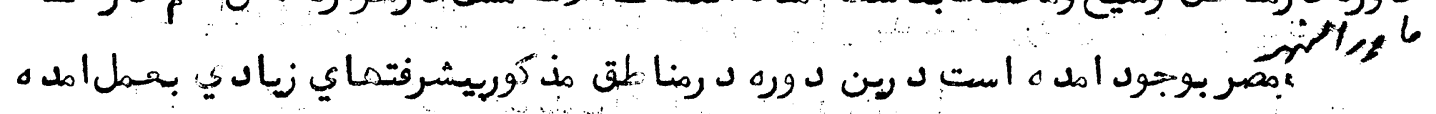

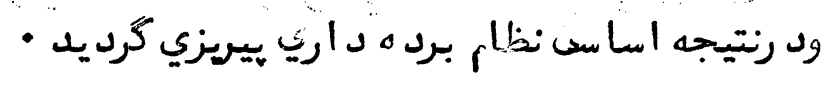

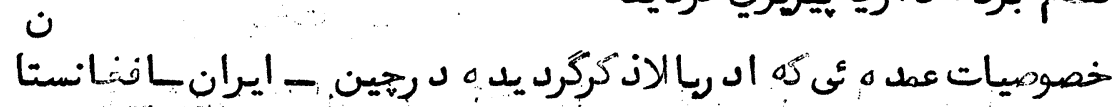

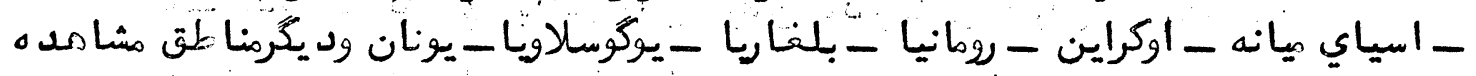

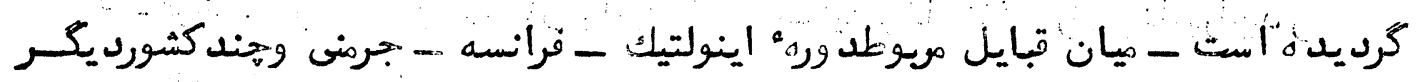

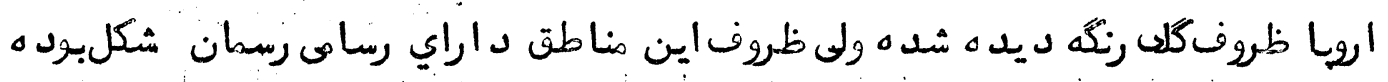

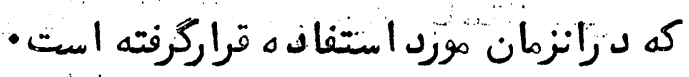

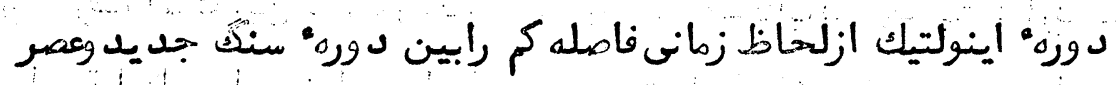

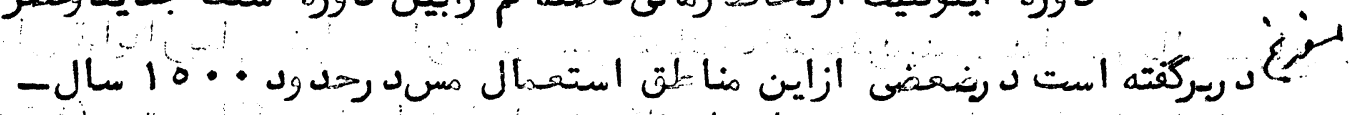

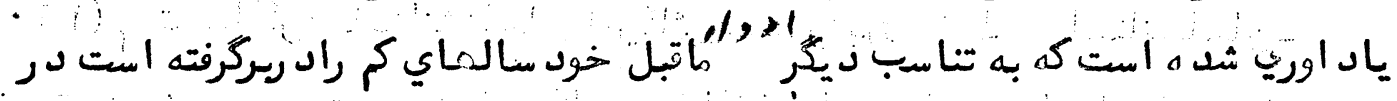

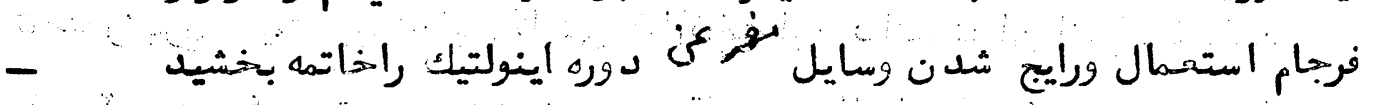

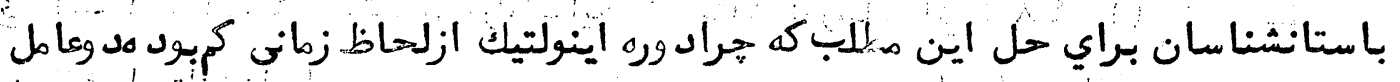

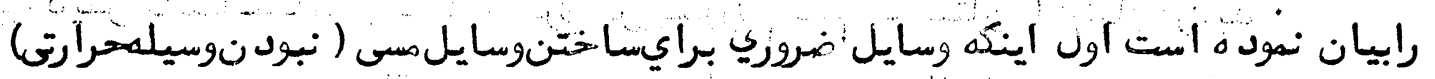

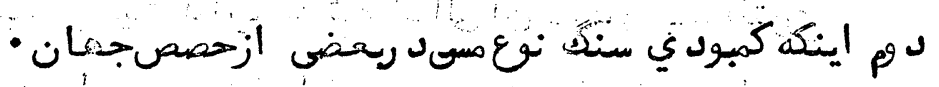


ياسينكُ جد يد اسياي ميانه كلتورتكا مليافتهاي

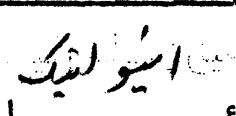

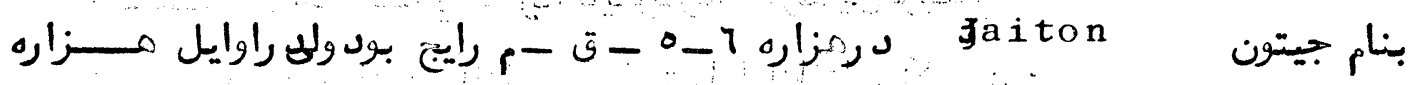

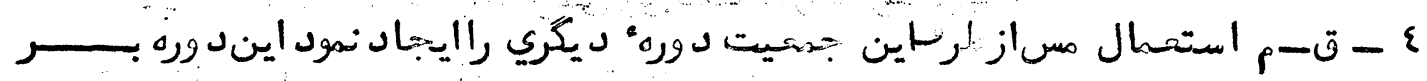

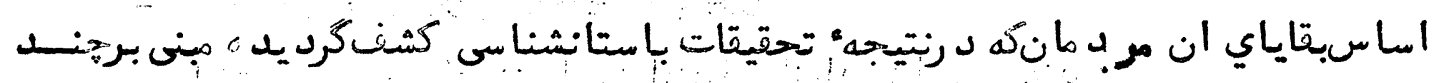

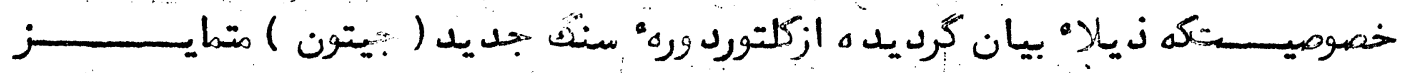

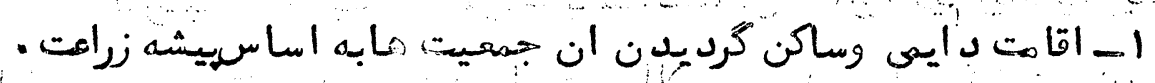

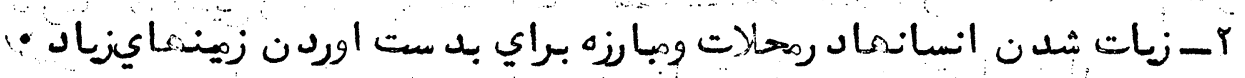

r- راين شدن وسايل جد يد براب استفاد ه د ركارماي خانه - تارتابي ساخت

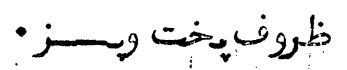

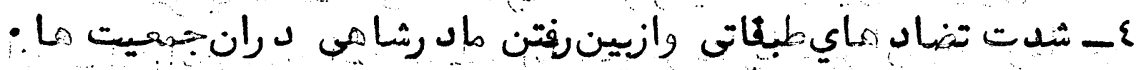

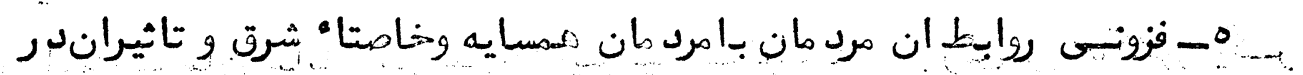

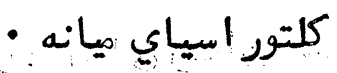

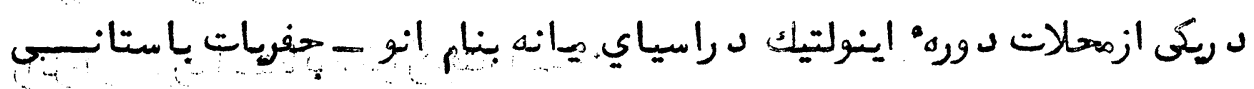

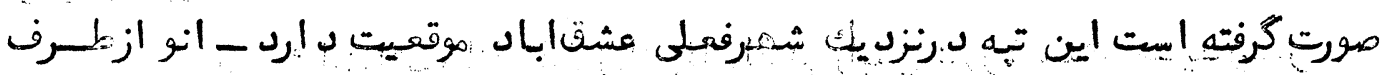

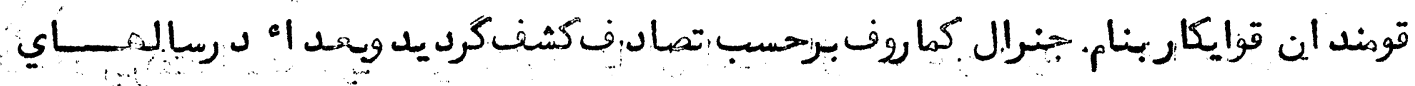

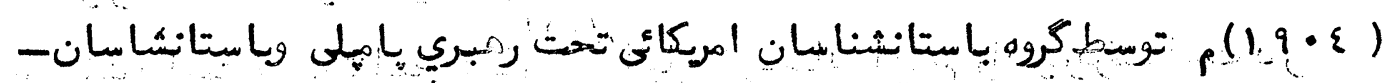

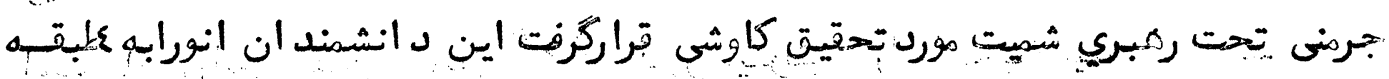

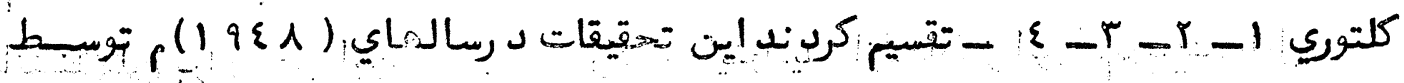

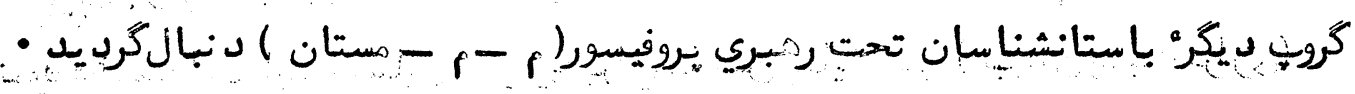

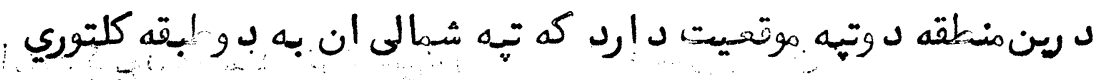

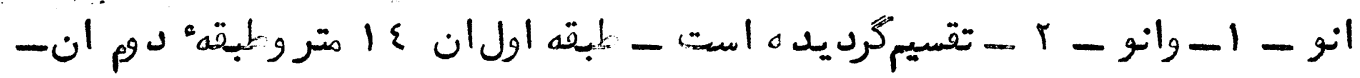

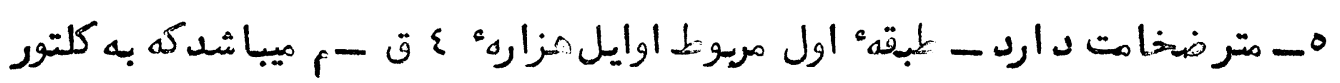




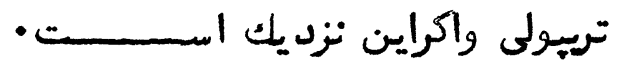

درنتيجهء تحقيقات باستانى ازاين ليقة وسايلنولالات زياد سنكى بذست امده كه

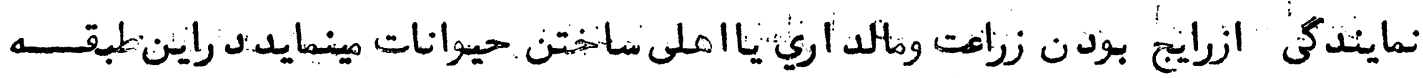

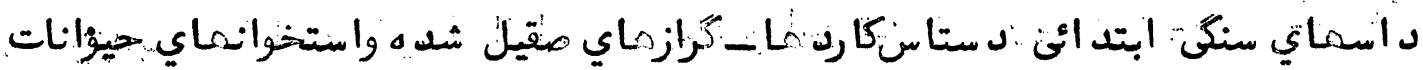

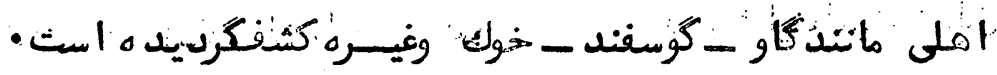

ظموفكليى كه ازين ليبقه بد ست اهده است د اراي رسمماي سه كنجه و هيا ركنجه

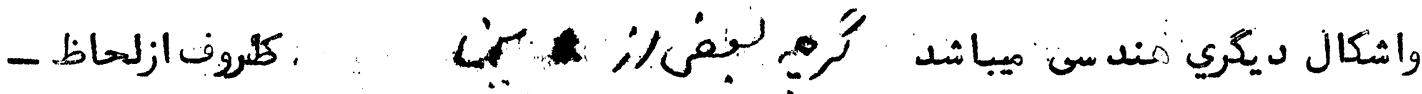

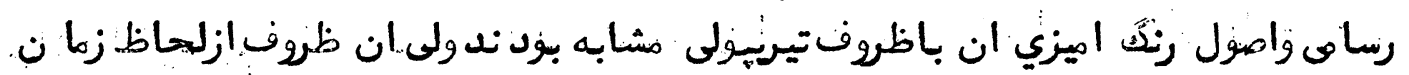

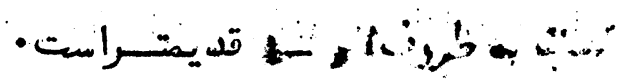

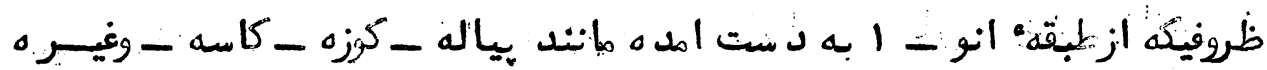

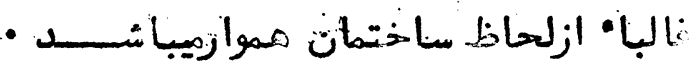

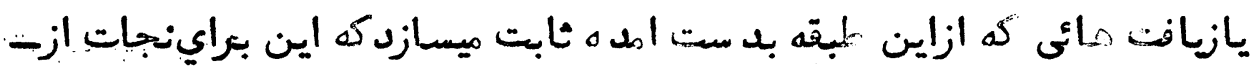

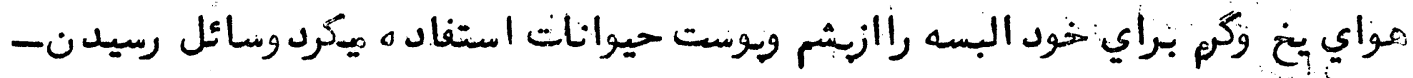

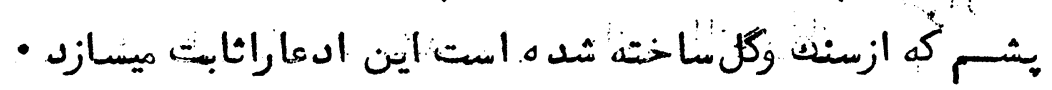

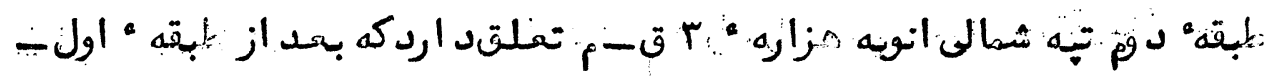

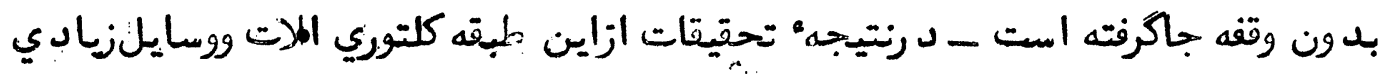
مسن وسنكى كثنكرديده الست اين انفزأرووساين نمايانكرانست كه برابياولين مرتبه اين

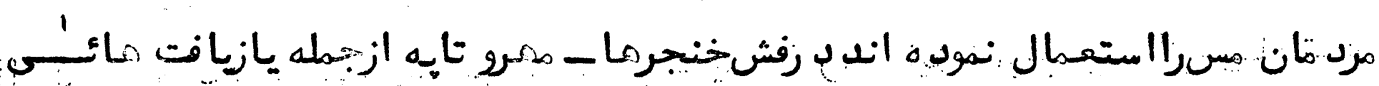

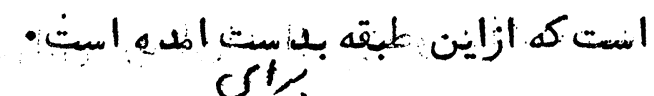

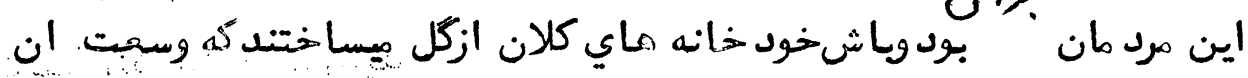

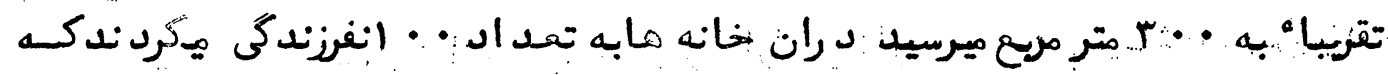

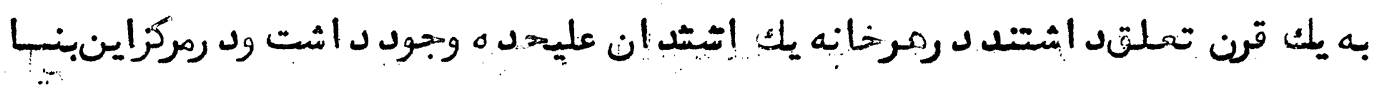

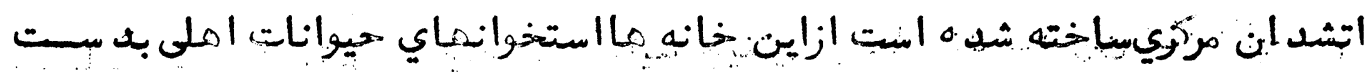

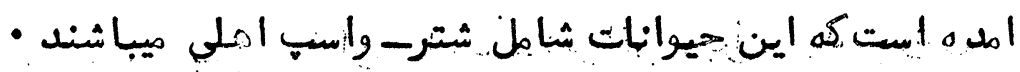

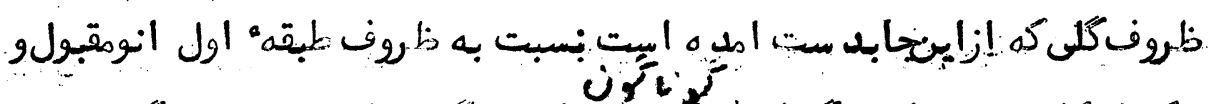

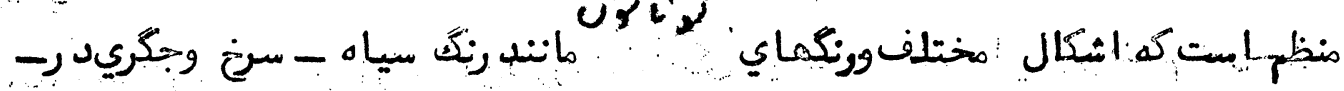




\section{V4

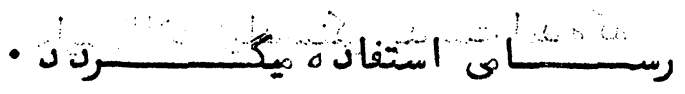

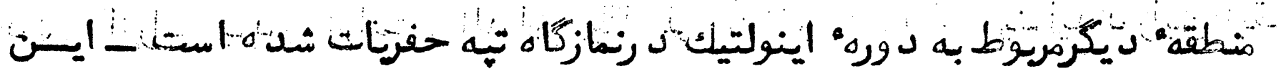

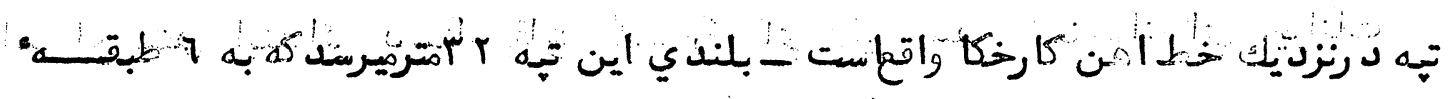

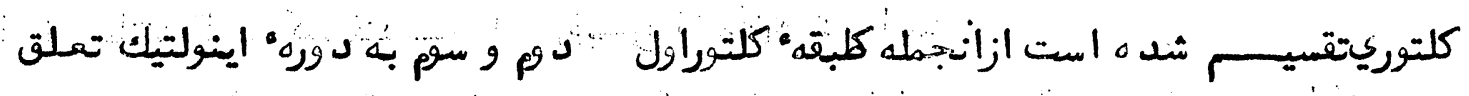
•

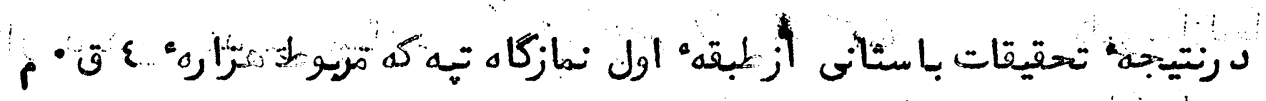

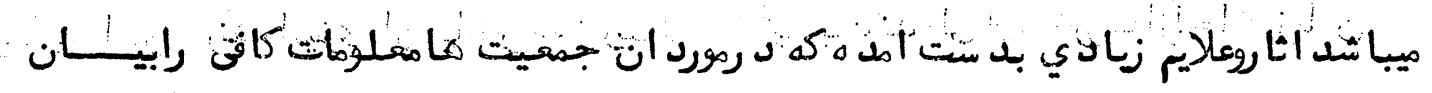

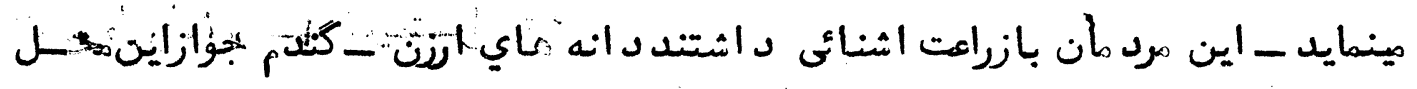

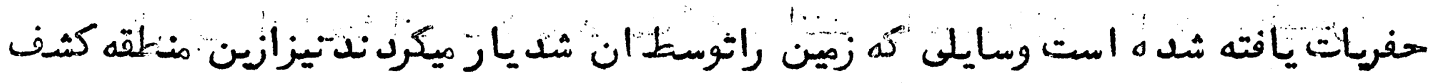

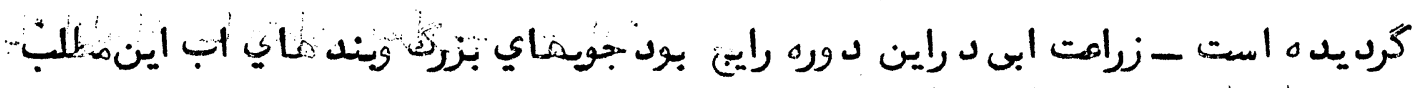

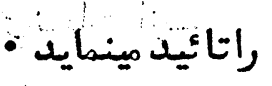

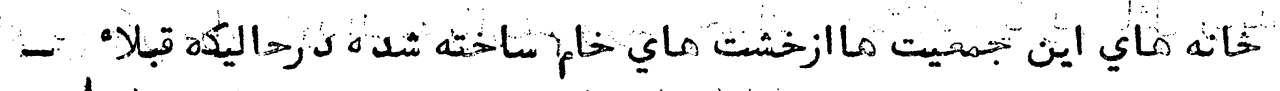

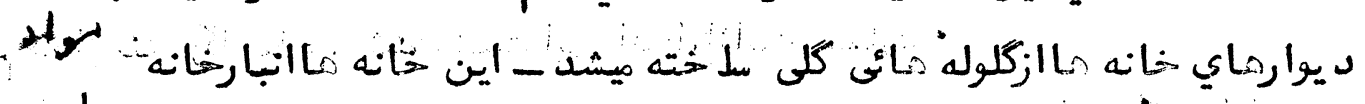

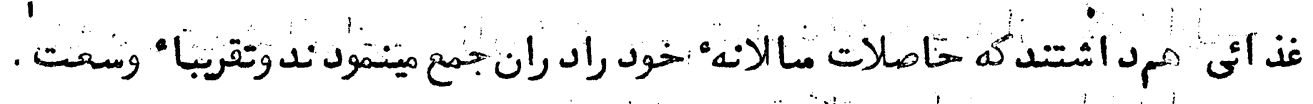

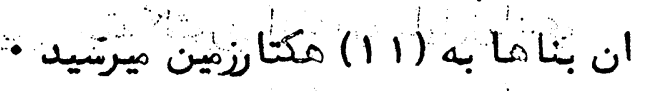

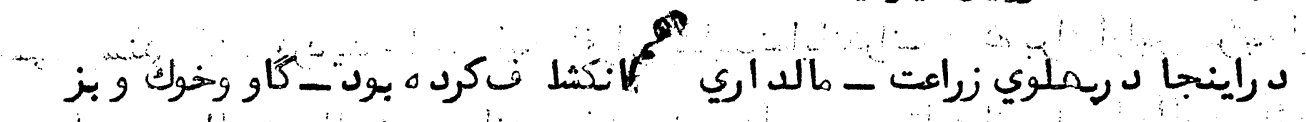

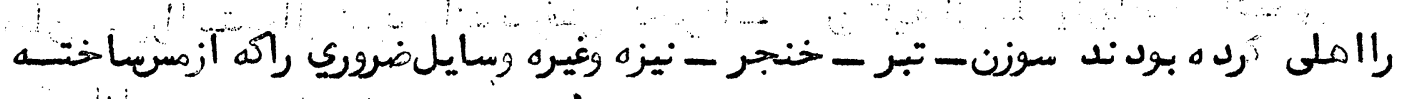

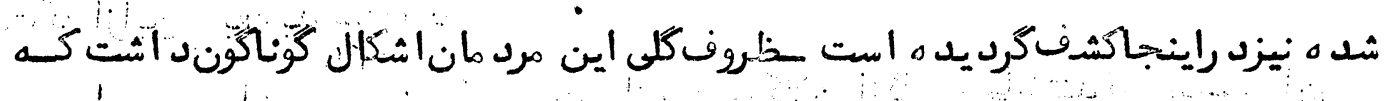

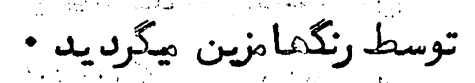

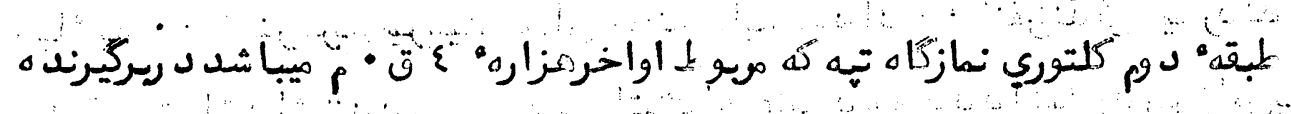

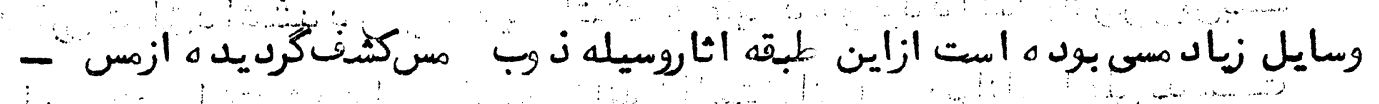

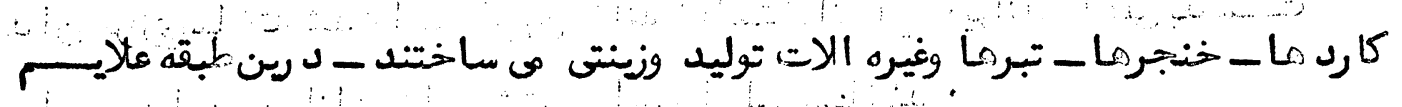

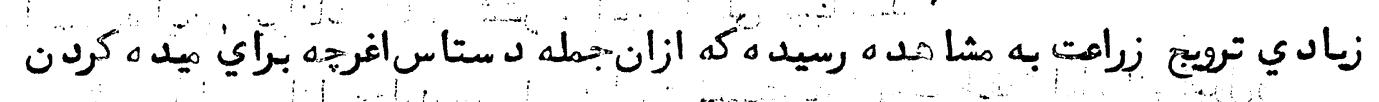

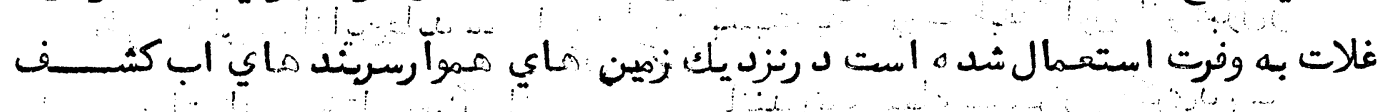

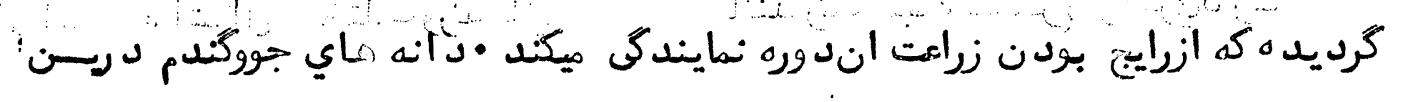




$$
\begin{aligned}
& v v
\end{aligned}
$$

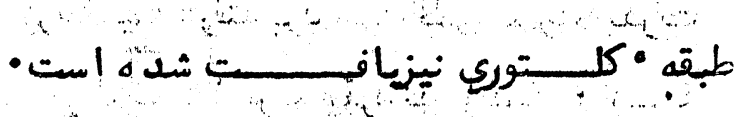

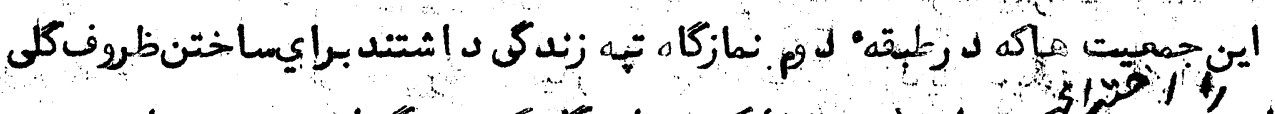

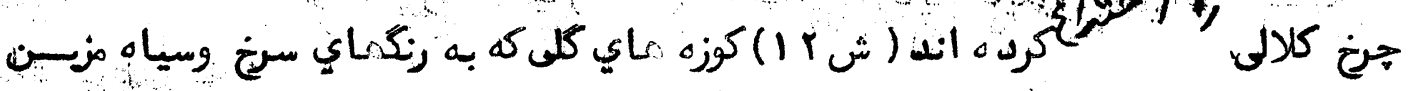

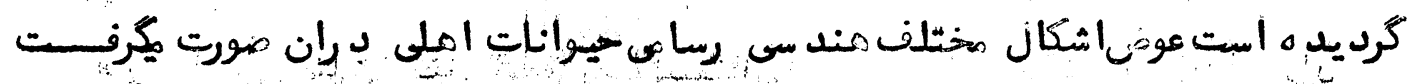

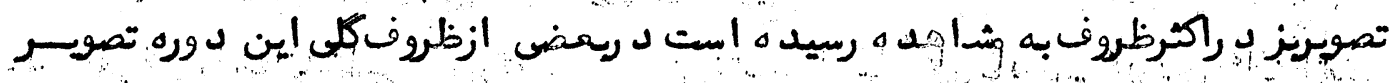

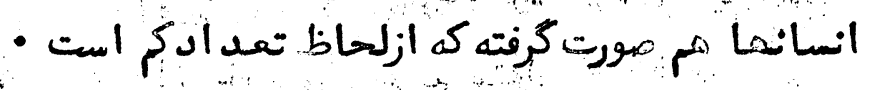

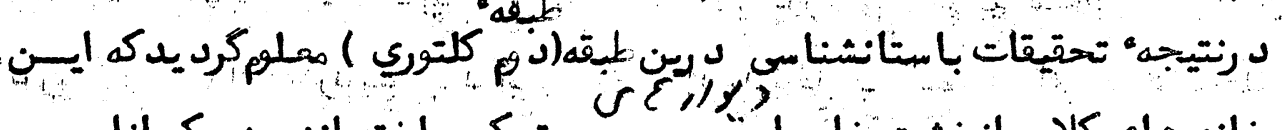

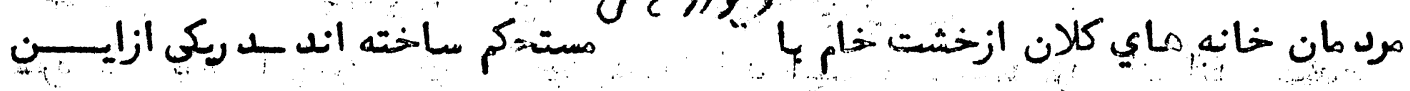

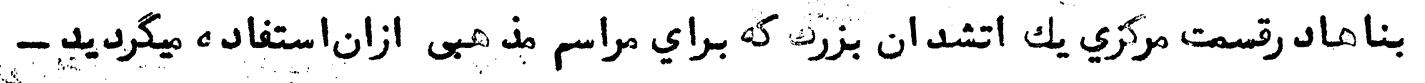

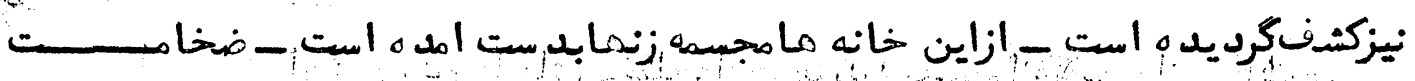

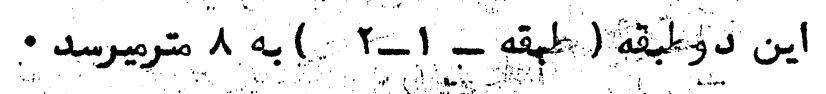

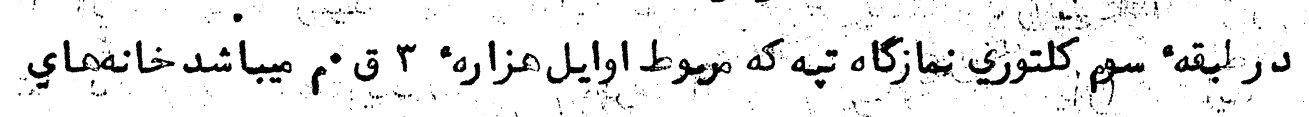

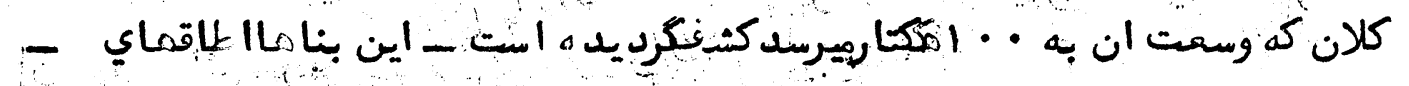

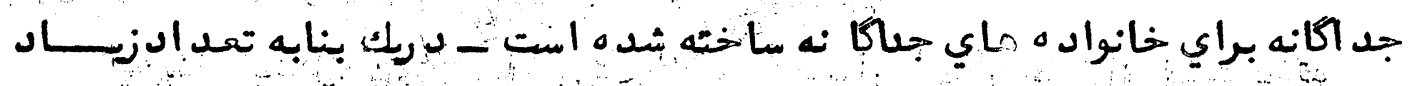

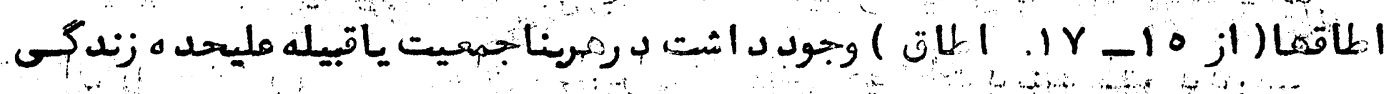

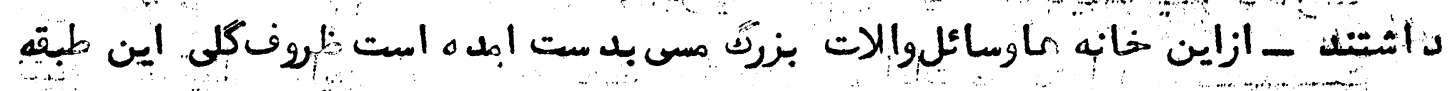

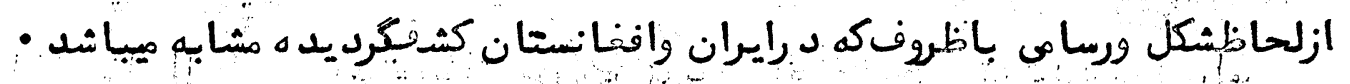
كلثورتريسهولـ

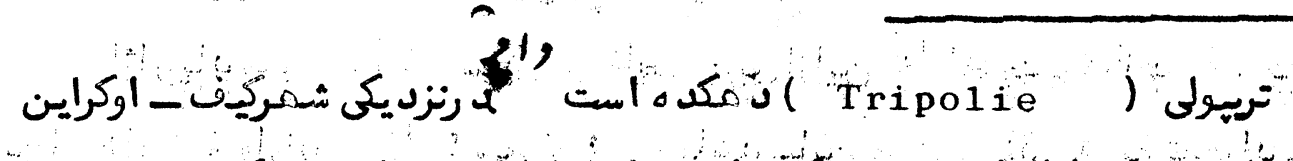

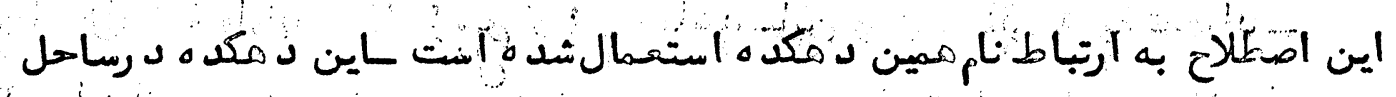

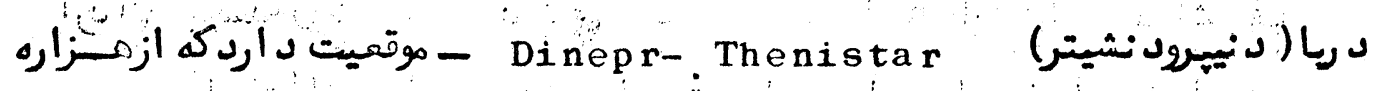

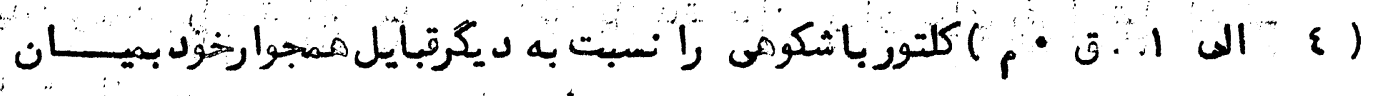

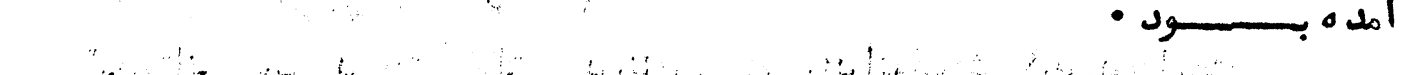

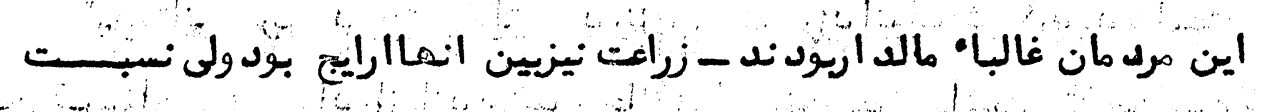


كمى اب د ريعنى منامقت ان كه ازاب د ربا با الاترموقعيت كرفته بودكت للهى صورت ميكرفت

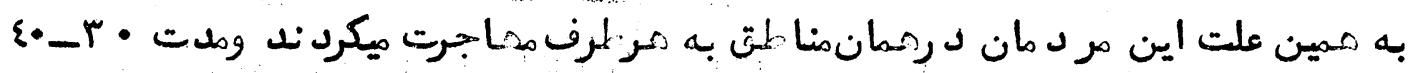

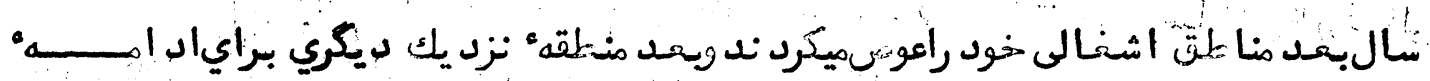

ميات ميرفتنــ

لد رينى ازاين منائق بنام (لوكارويب ليستكايا) . Lokarop 1eskaya

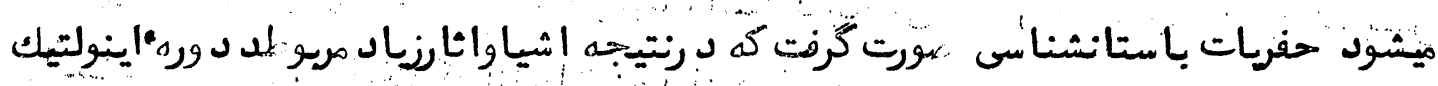

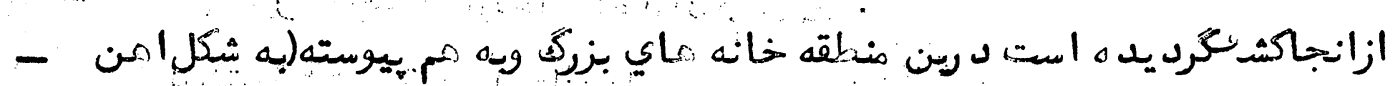

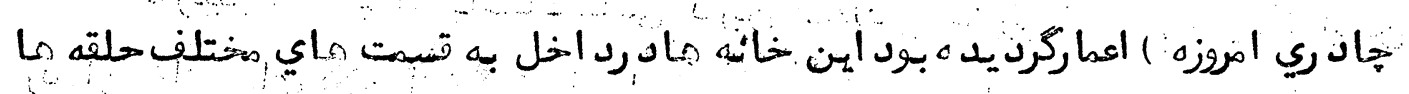

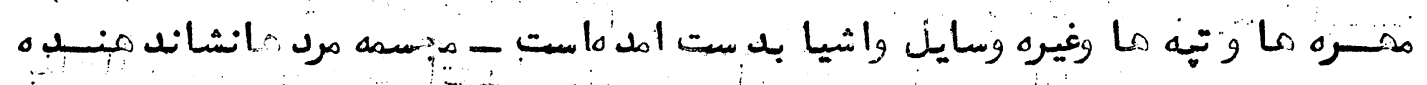

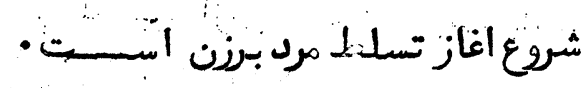

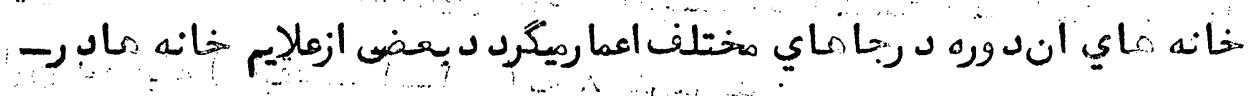

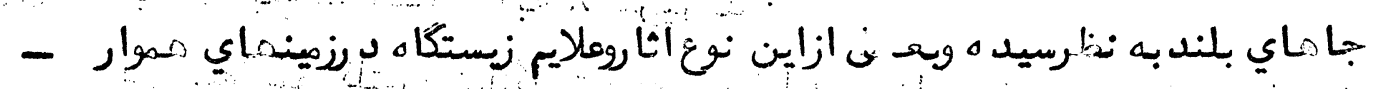

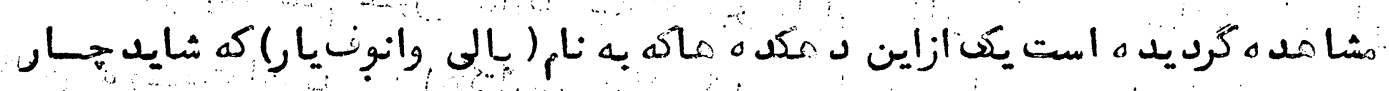

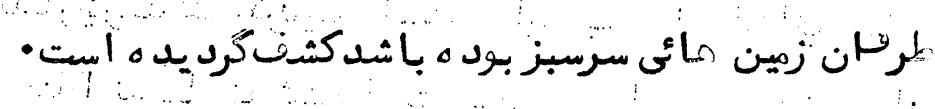

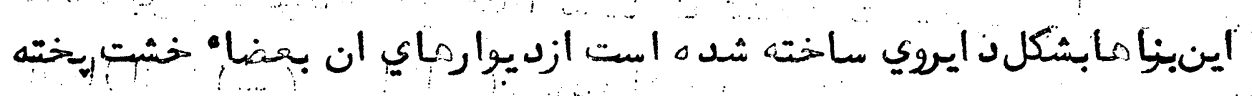

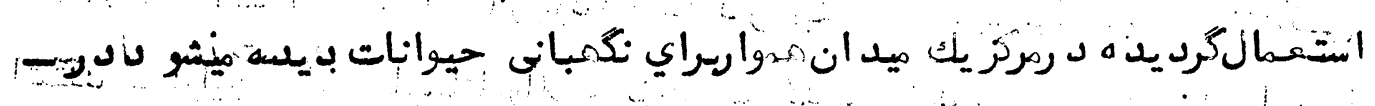

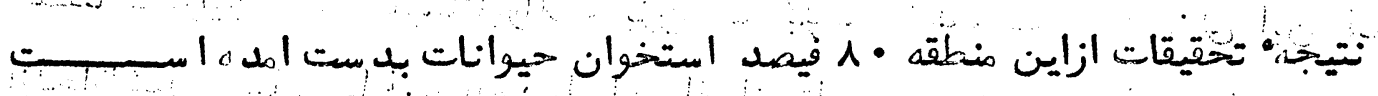

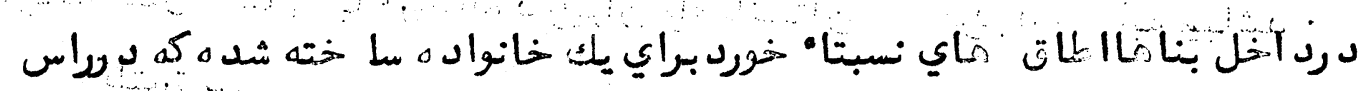

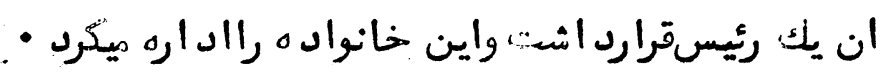

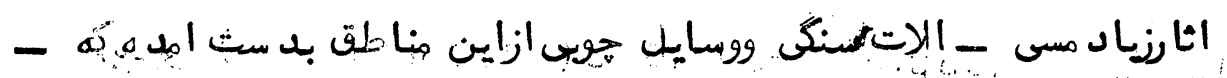

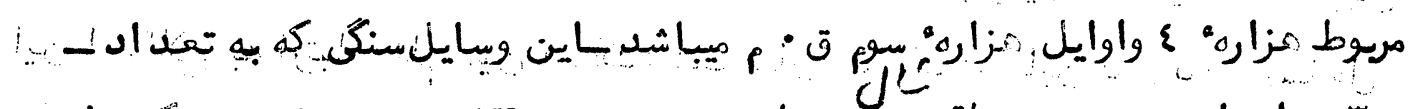

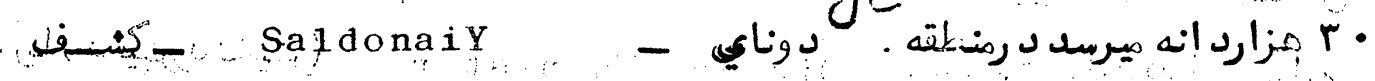

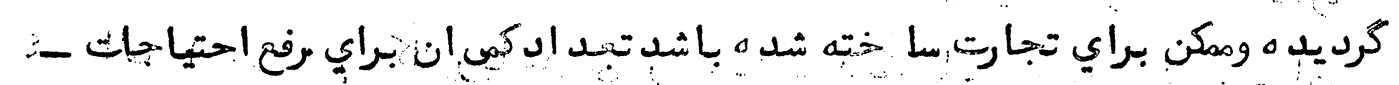

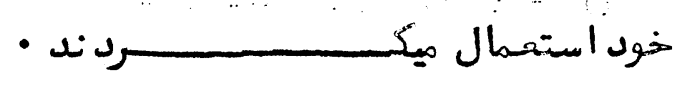

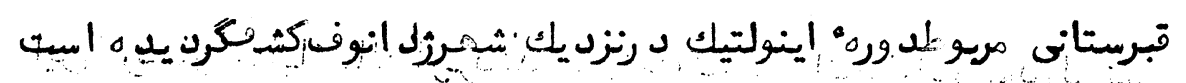

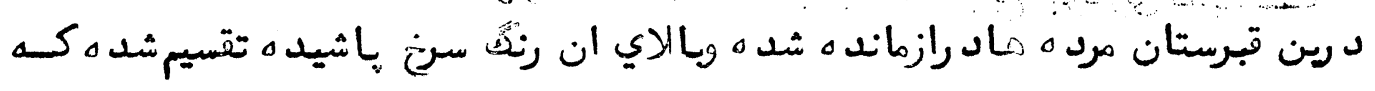




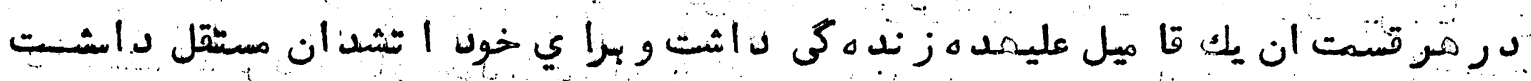

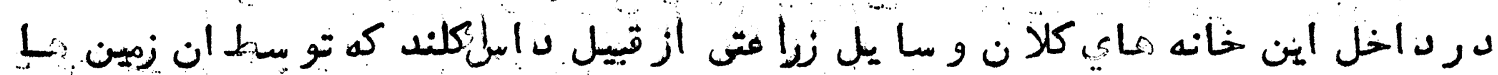

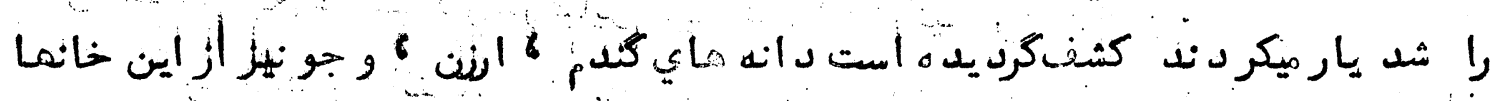

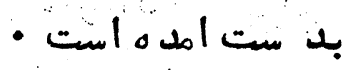

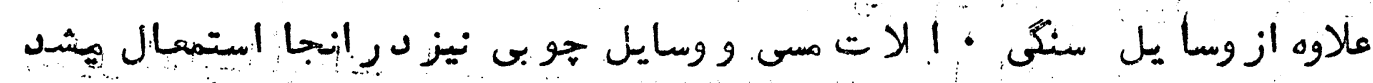

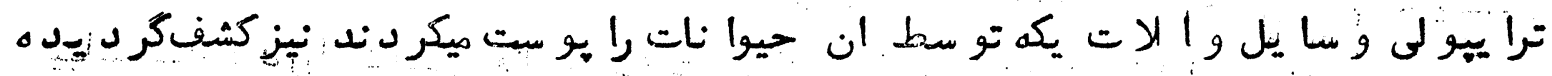

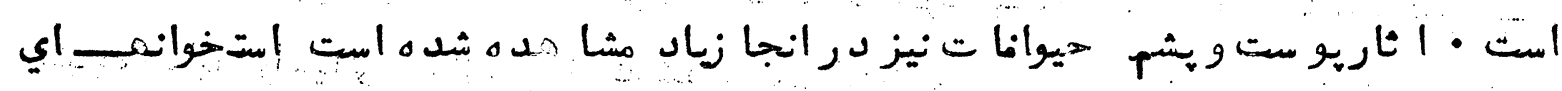

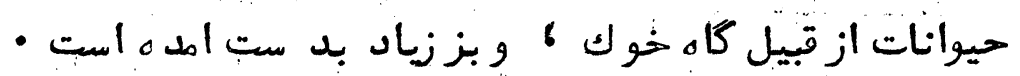

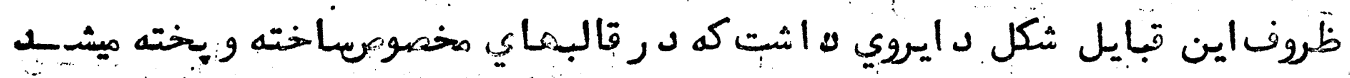

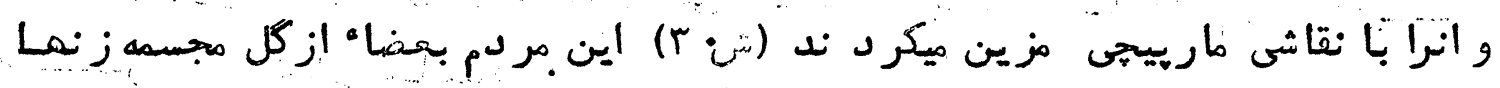

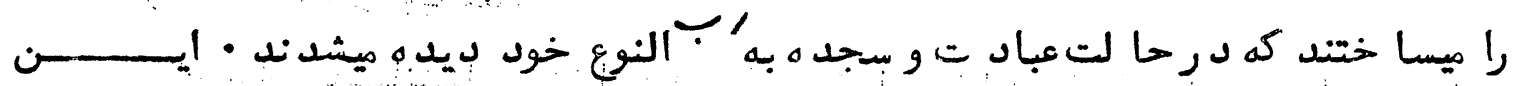

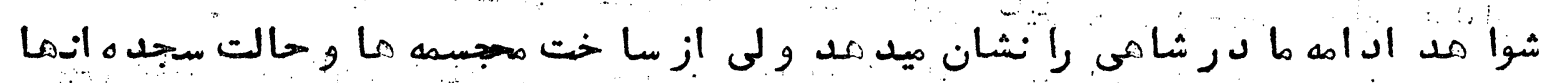

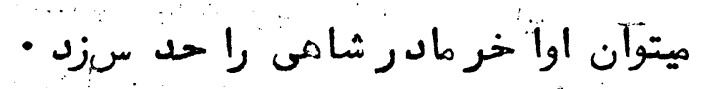

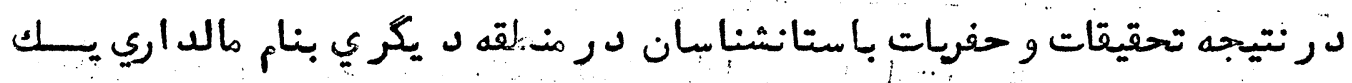

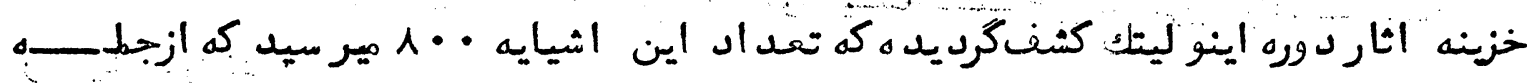

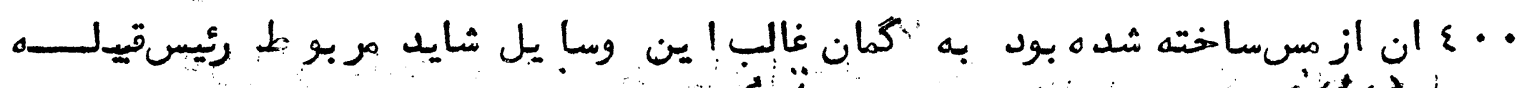

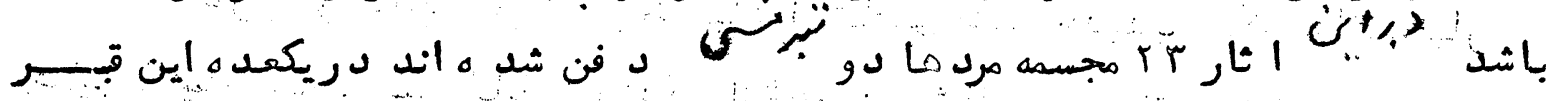

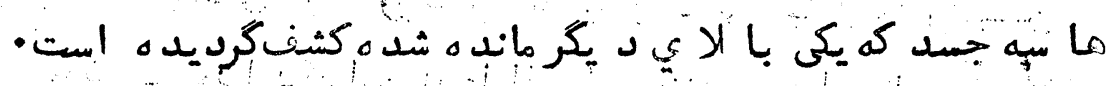
: كلت

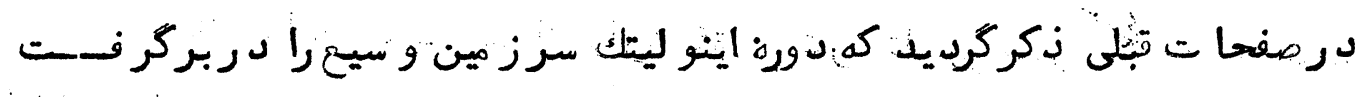

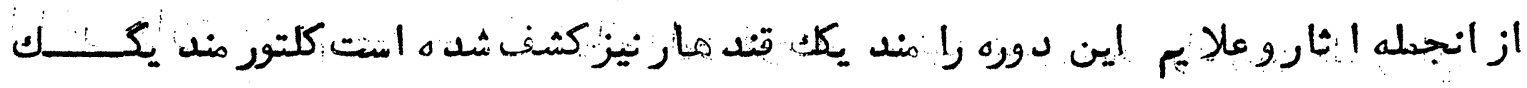

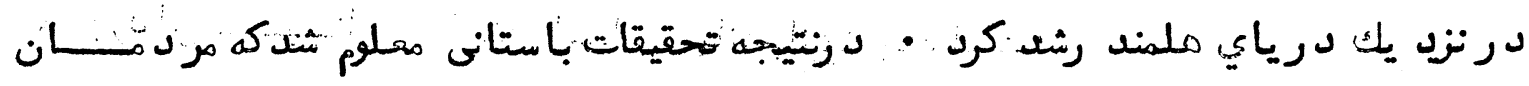

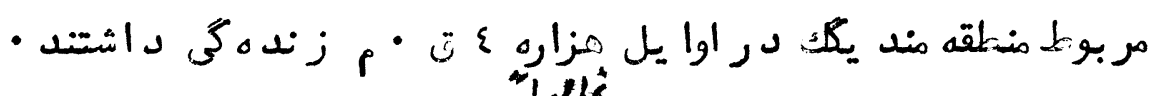

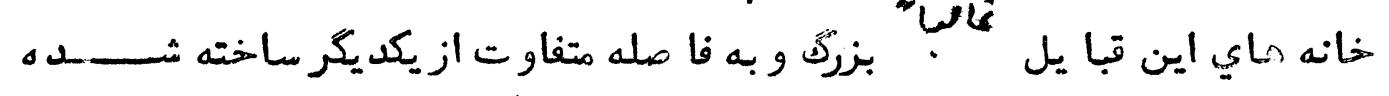


$\wedge$

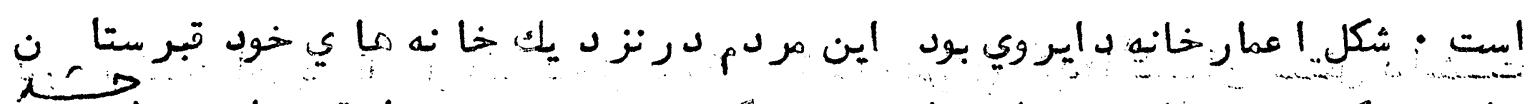

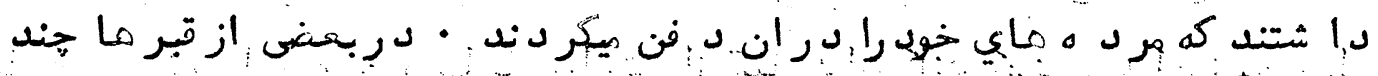

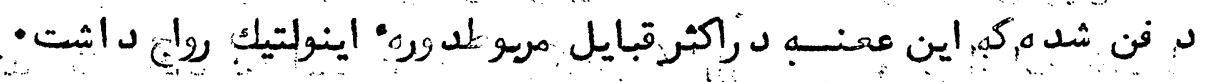

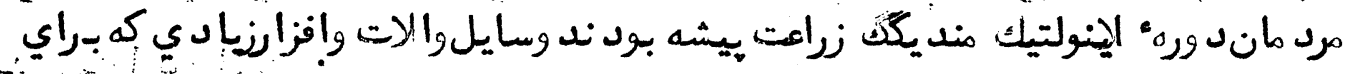

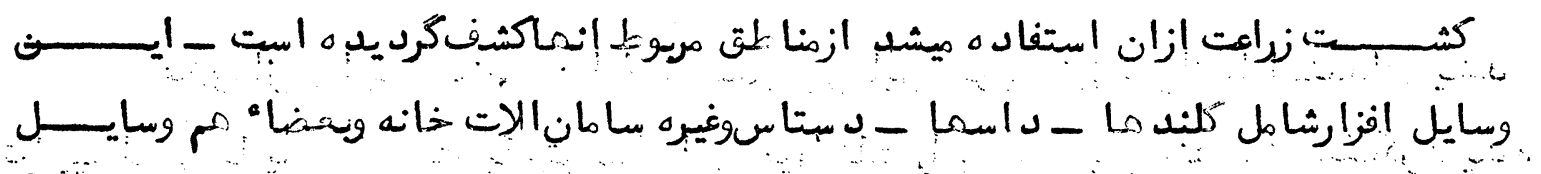

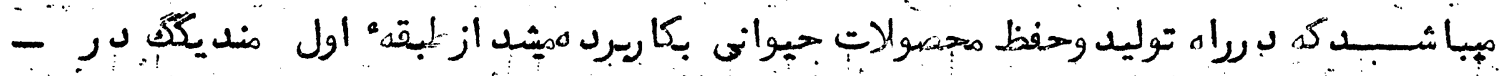

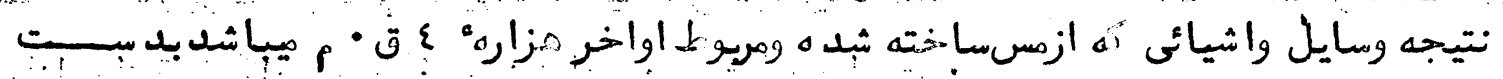

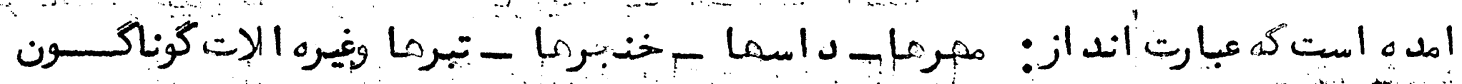

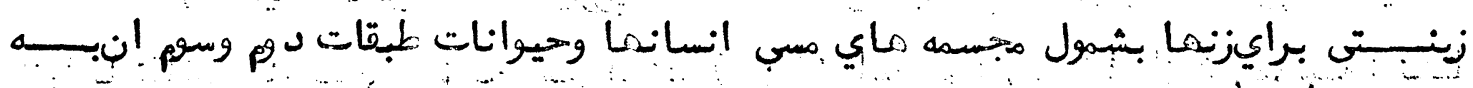

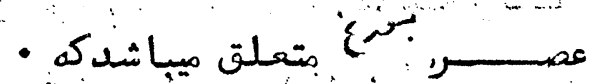
تحقيقات باستانشناسى نشانب اده است كه اين قبايل باديكرقبايل همسايه خوداز

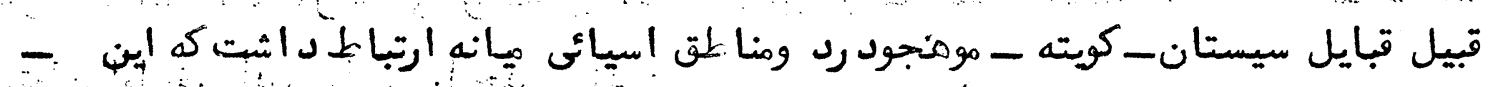

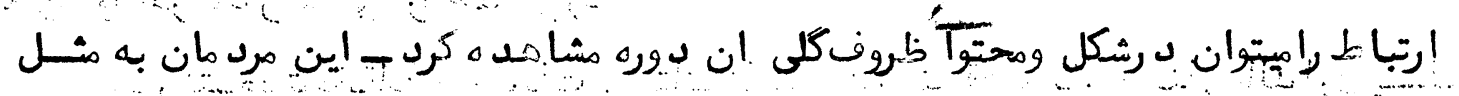

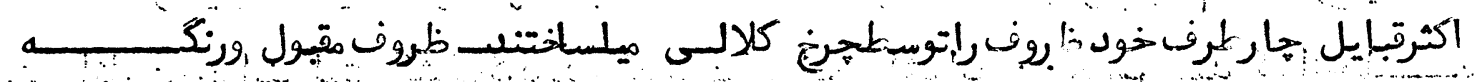
راتوليب ميكرد ند

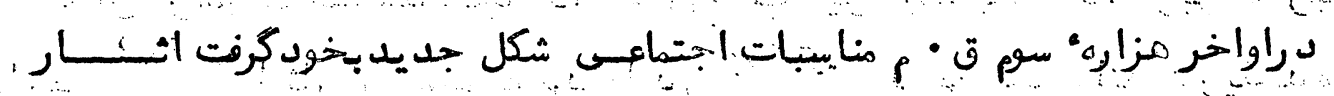

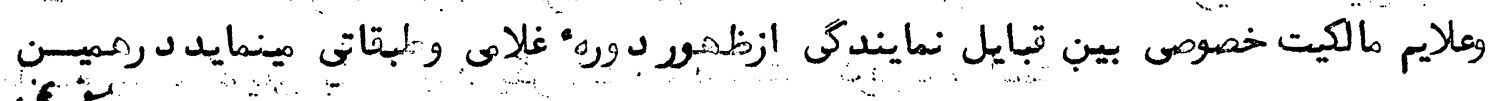

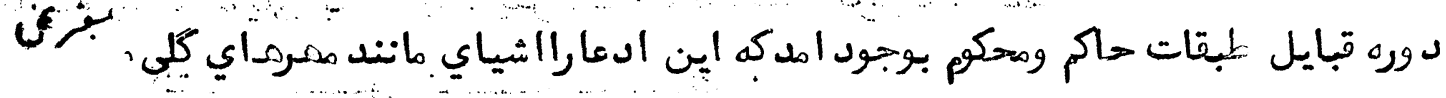

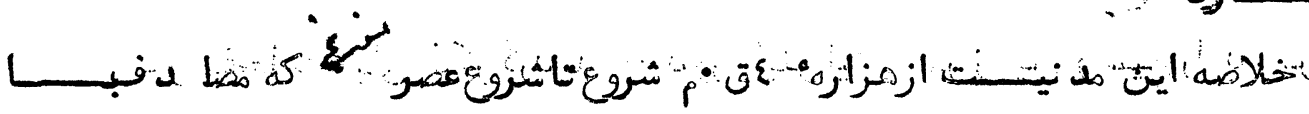

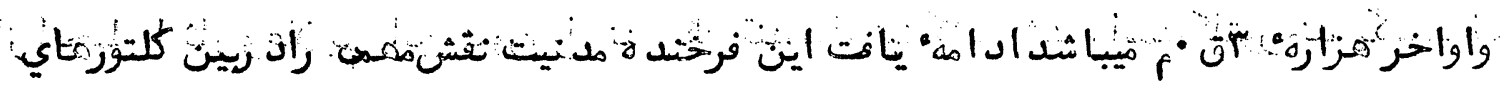

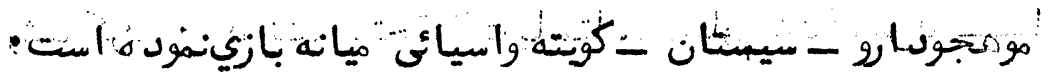


AI

يورالات فصل ششـ

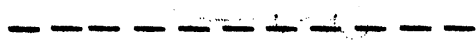

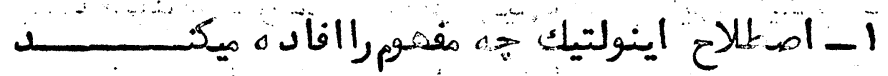

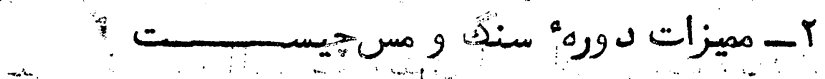

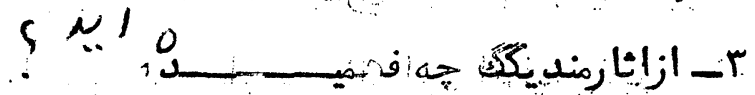

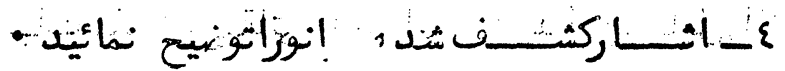

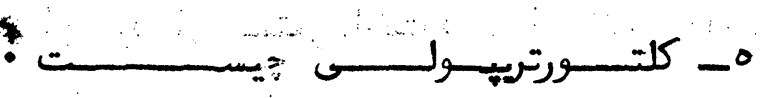


$\Lambda r$

مفت

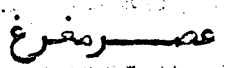

استبعهال وسايل مثرغنى باعث خاتمه د ادن لدوره سنك ومسوياسنك جديدكرديد وسايل

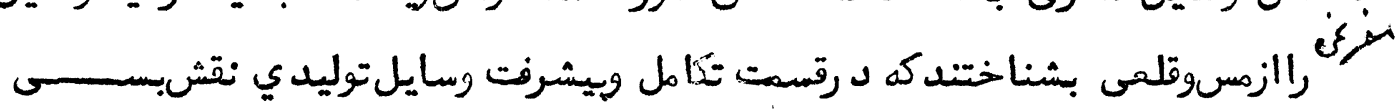

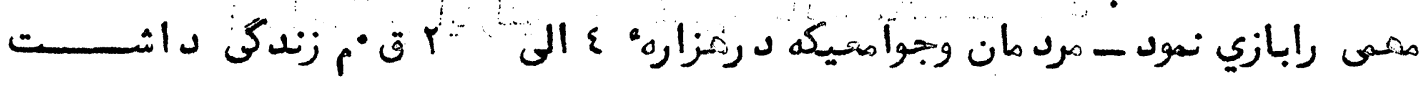

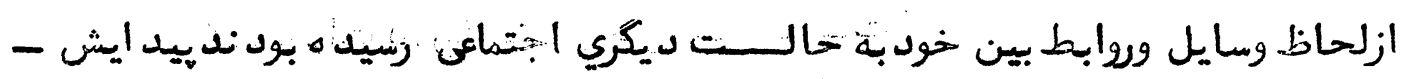

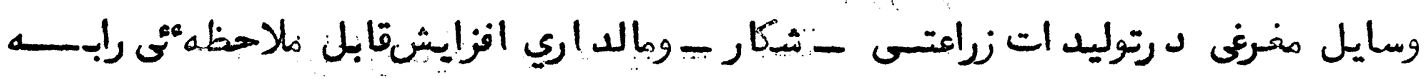

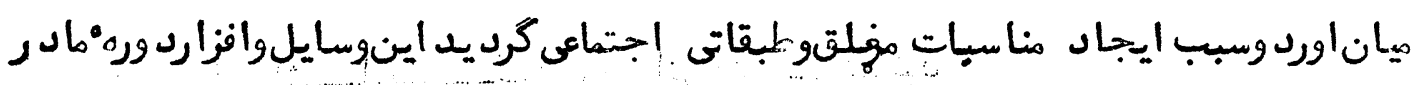

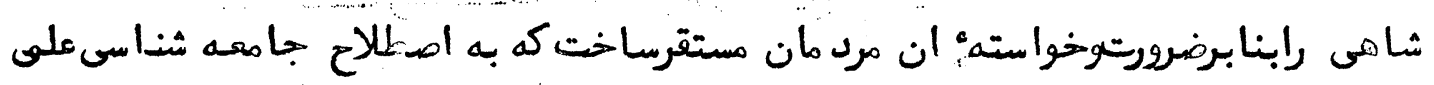

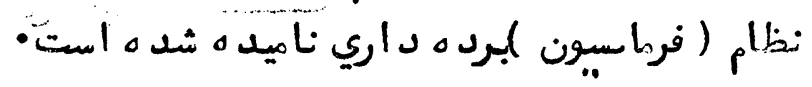

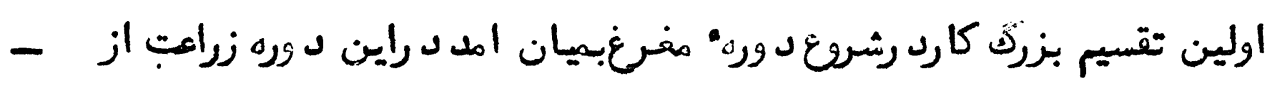

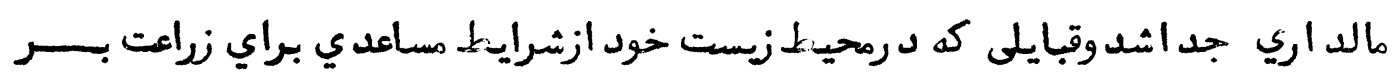

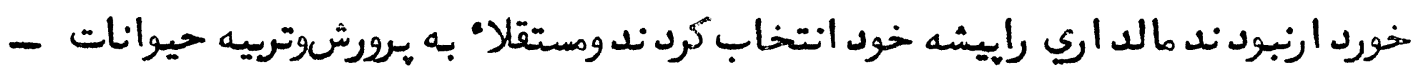

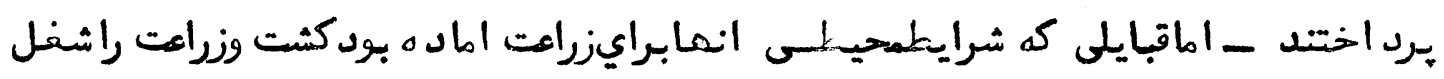

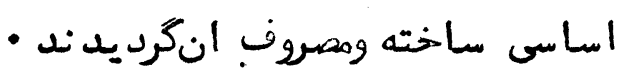

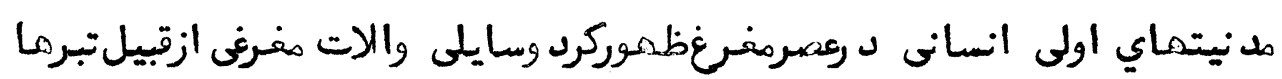

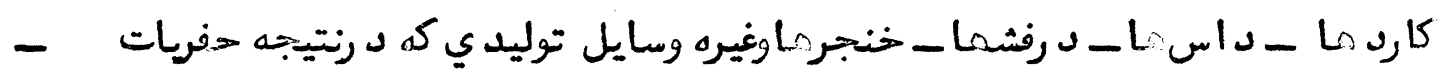

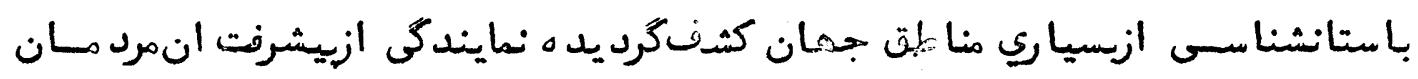

ميكنـــــــ

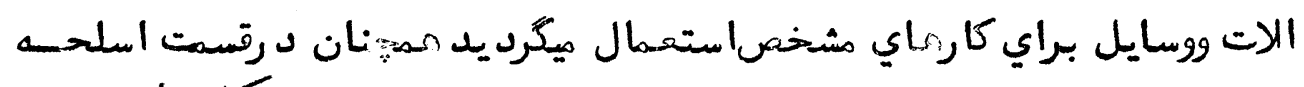

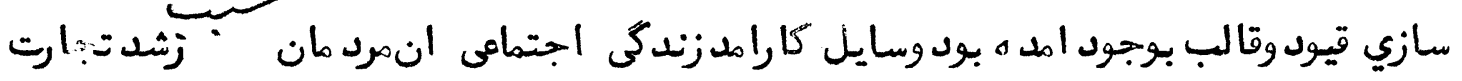

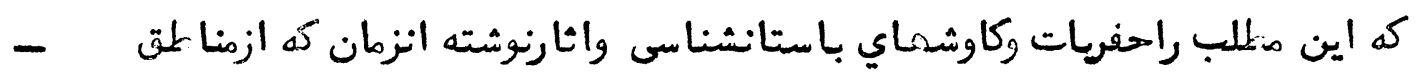

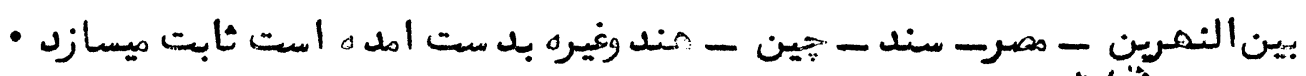

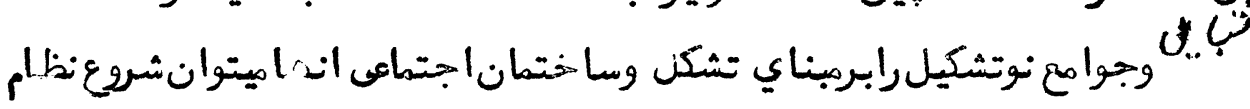

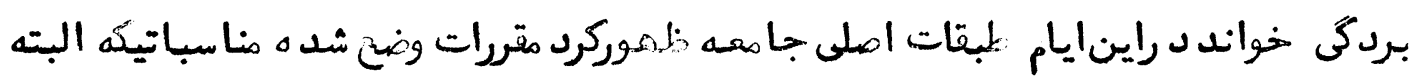




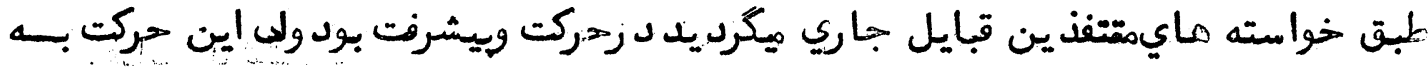

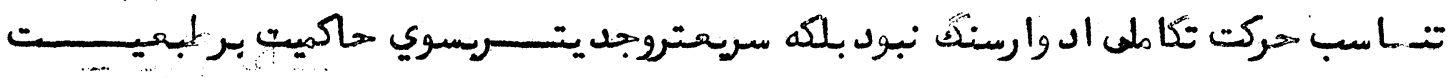

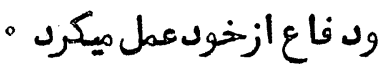

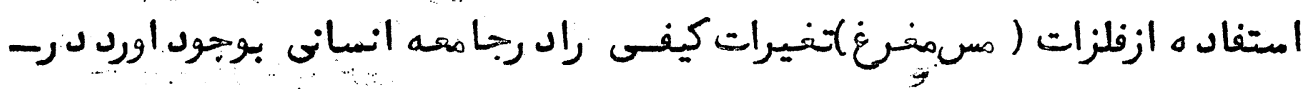

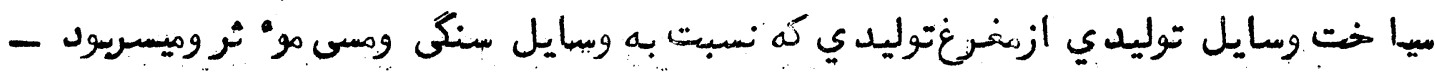

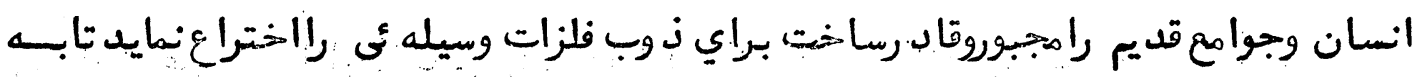

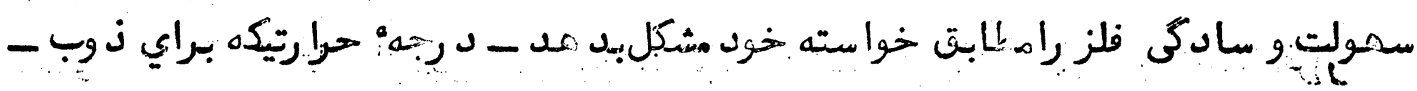

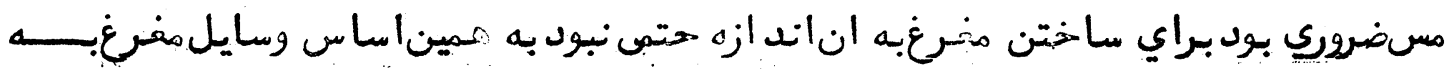

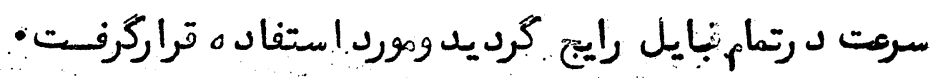

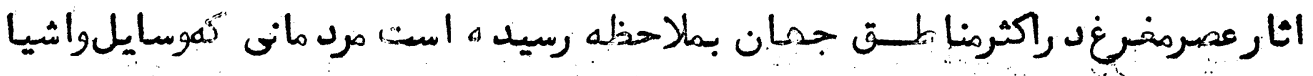

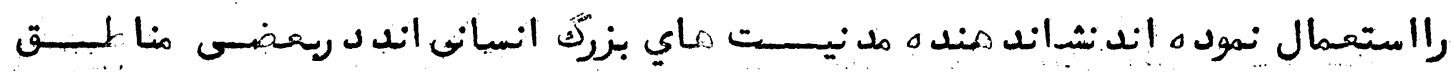

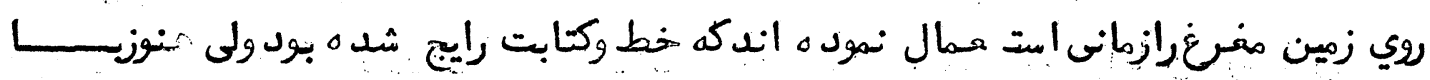

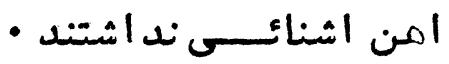

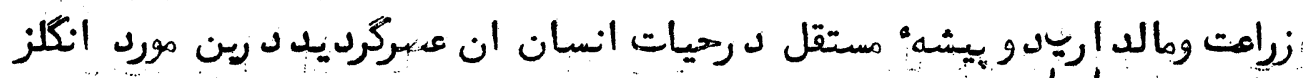

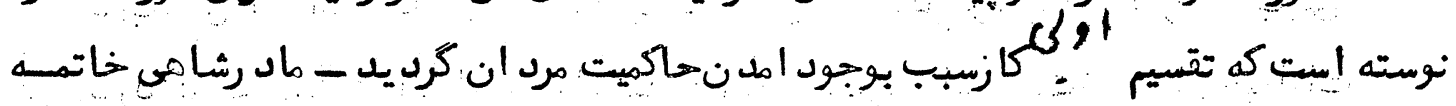

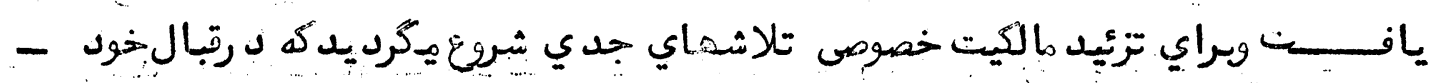

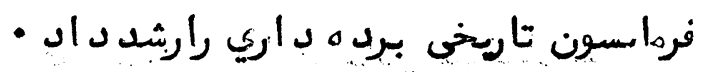

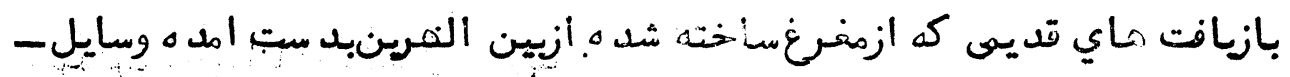

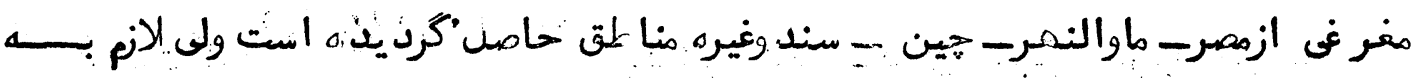

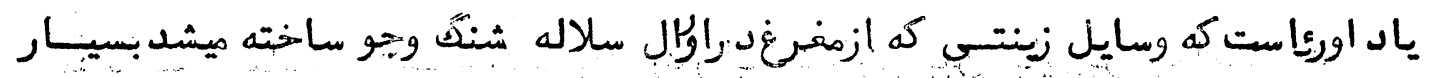

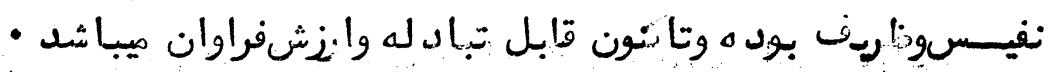

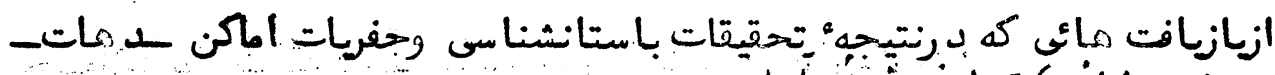

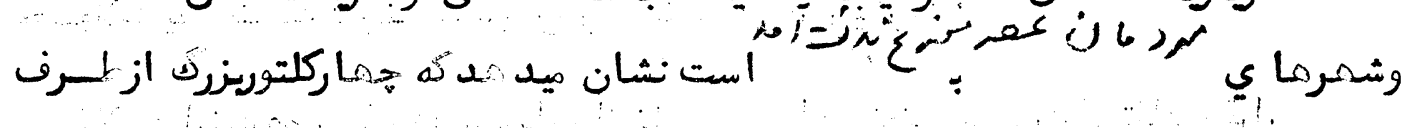

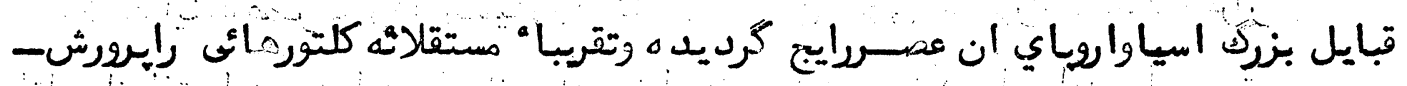
داد ه استكه مبارتند ازي 


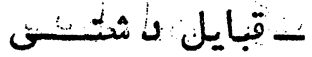

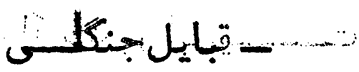

$$
\begin{aligned}
& \text { - قبايل اروياشطال شرقى }
\end{aligned}
$$

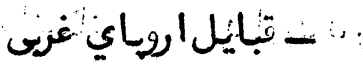

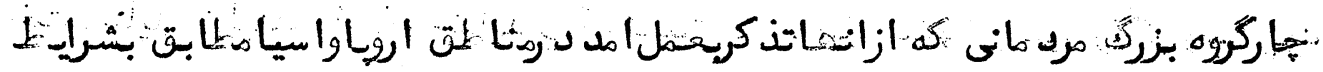

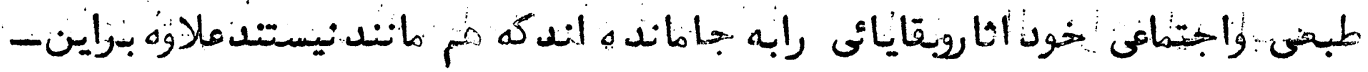

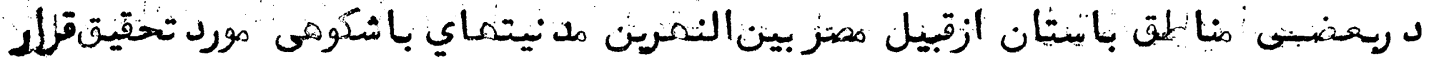

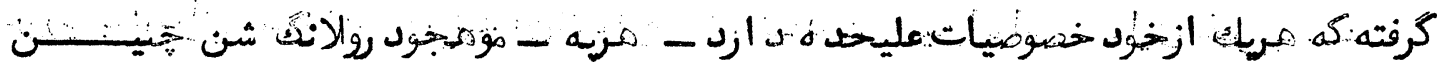

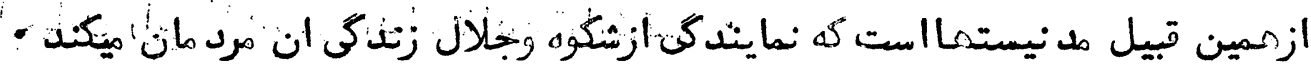

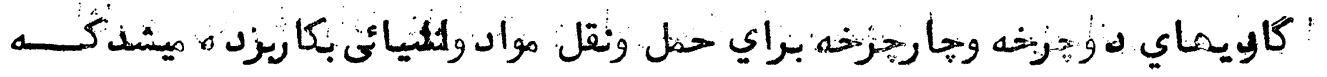

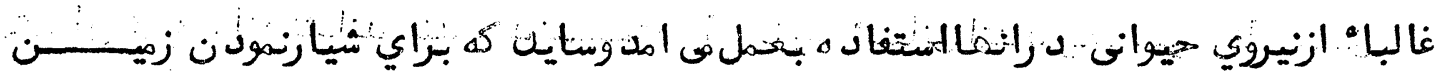

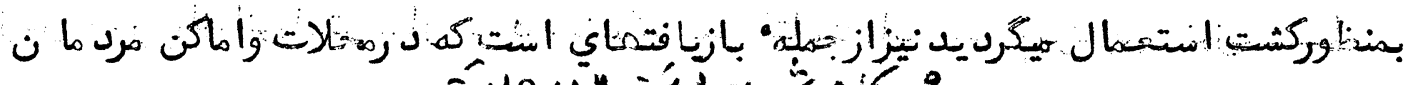

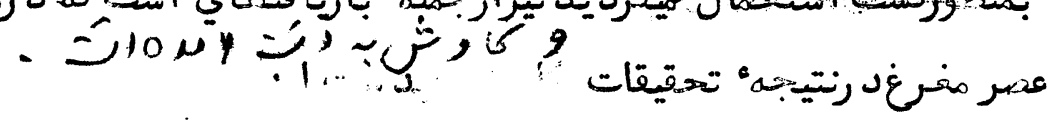

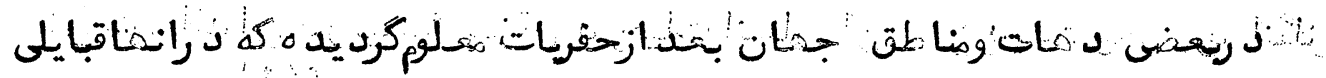

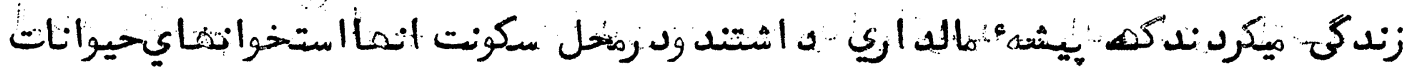

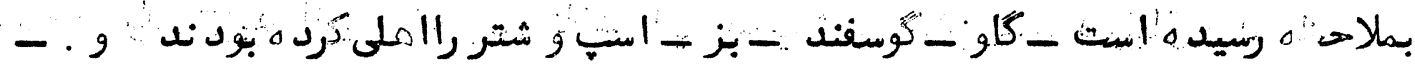

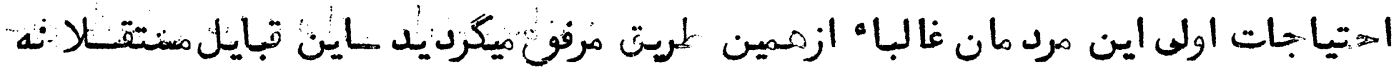

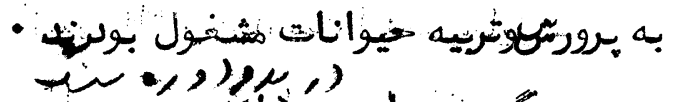

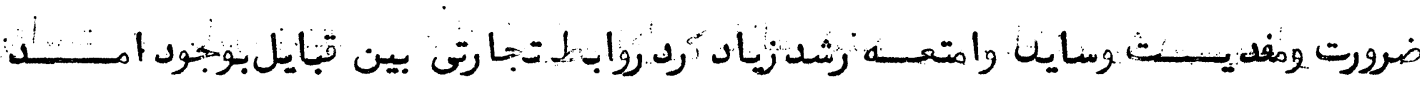

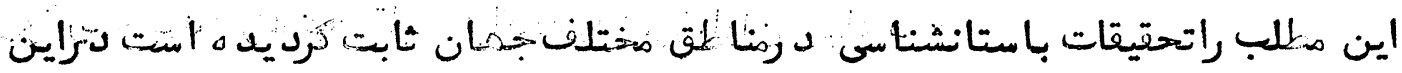

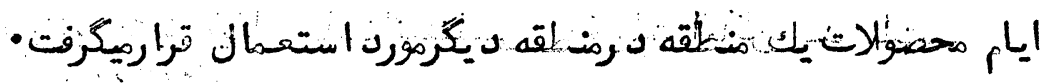

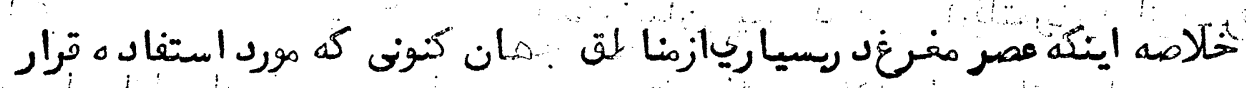

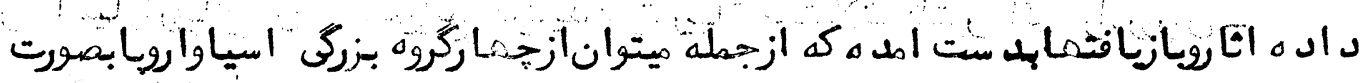

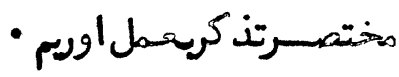


AO

:

يكى ازكروه ماي بزرك مرد مان عمرمغرغكه د رمنا لمن اسياي ميانه - ايران

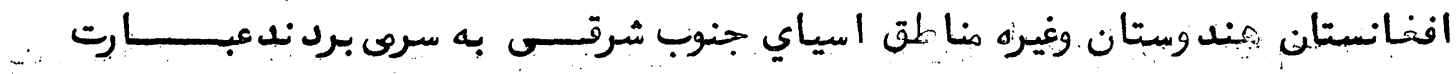

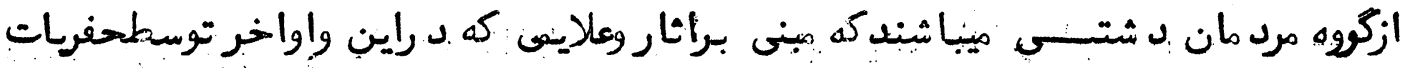

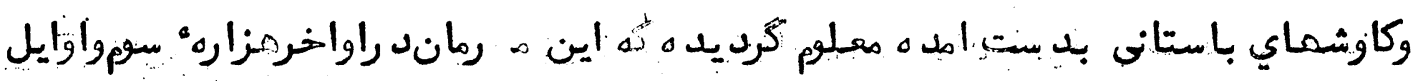

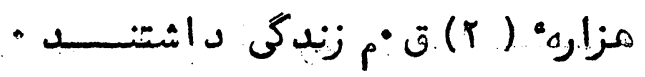

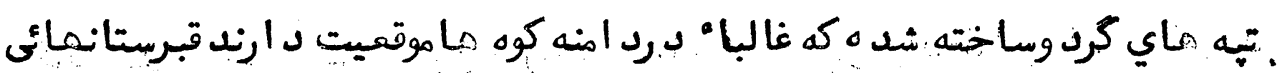

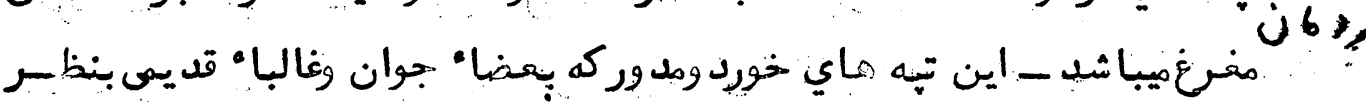

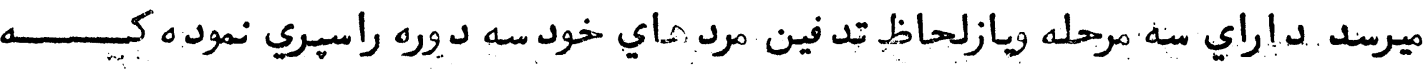

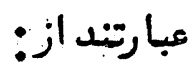

Katakambi

1-قبرنيائي قديم (عيبـــق )

ب- إكته كامبي

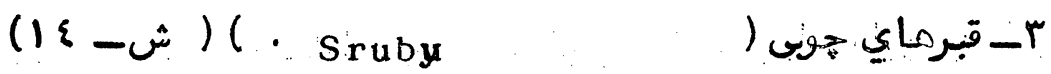

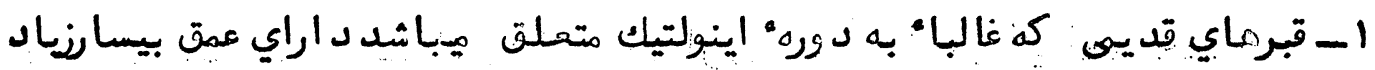

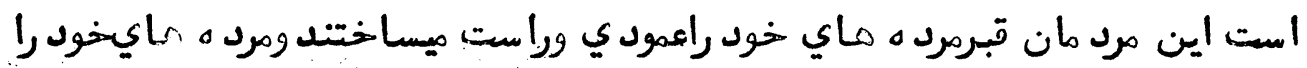

دران يد في نيكرد نيد :

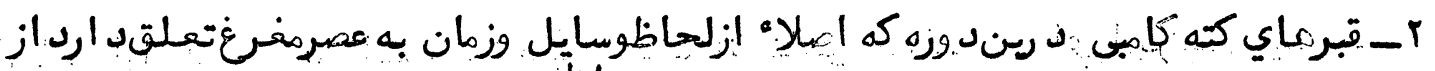

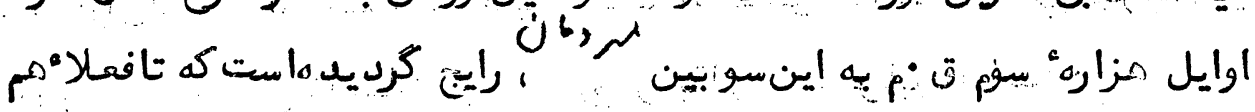

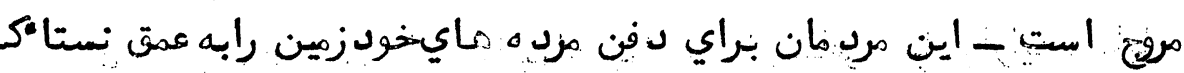

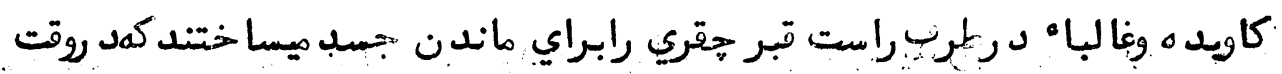

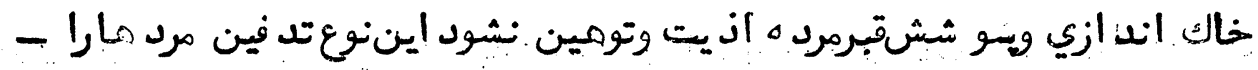

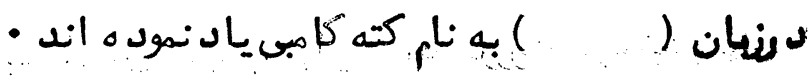

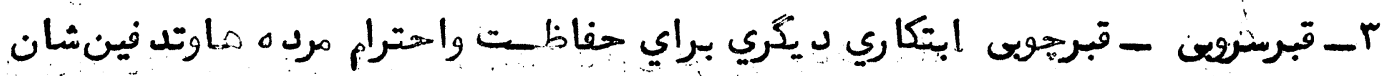

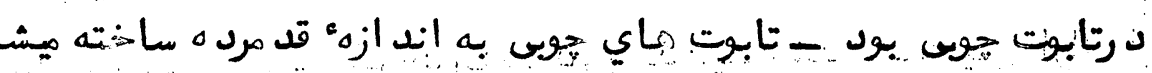

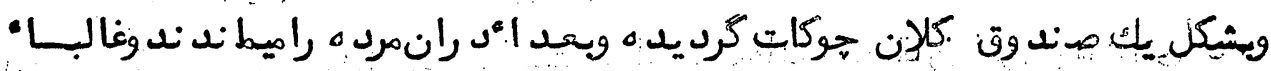




\section{$\Delta 4$}

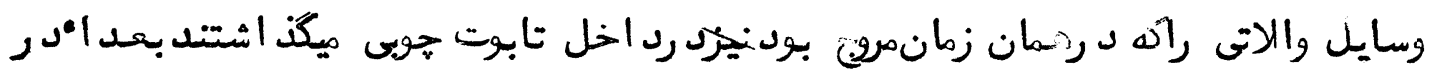

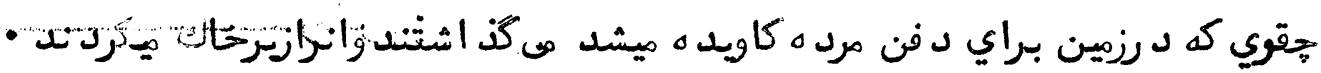

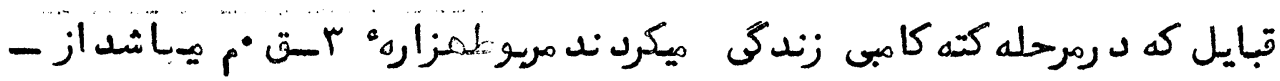

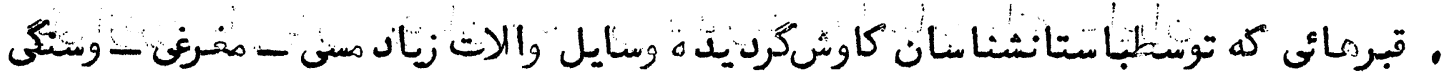

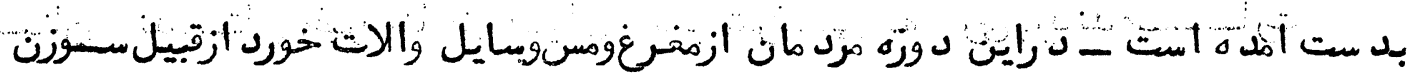

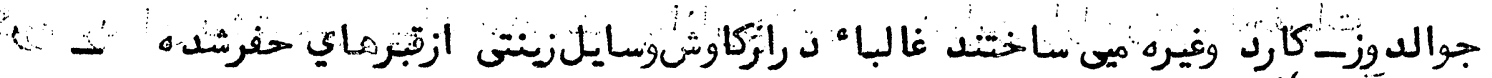

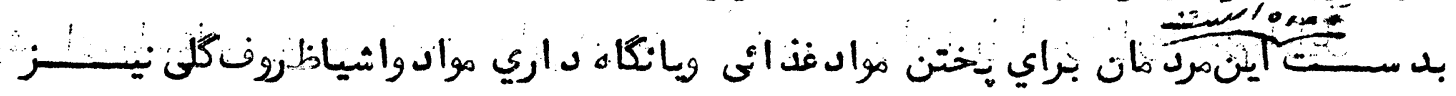

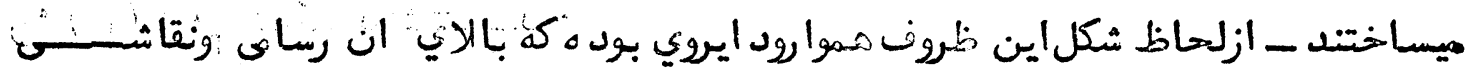

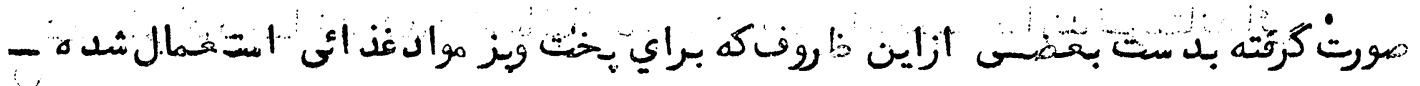

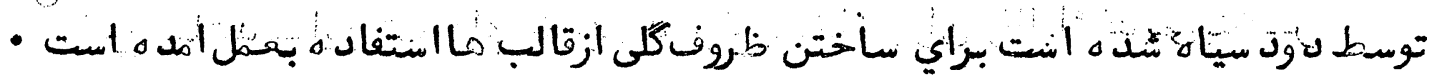

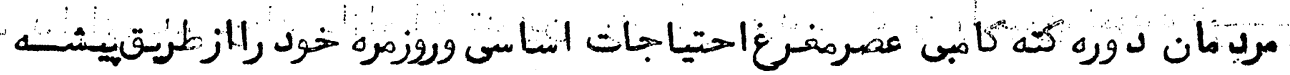

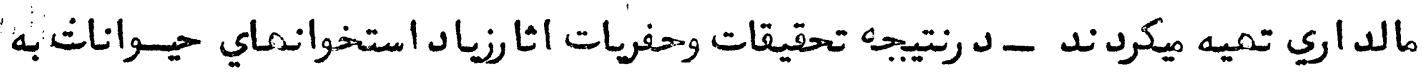

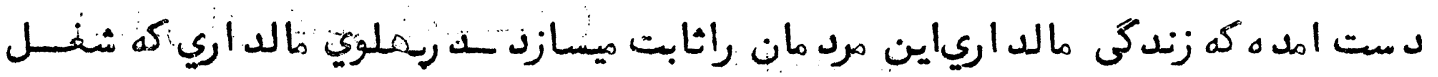

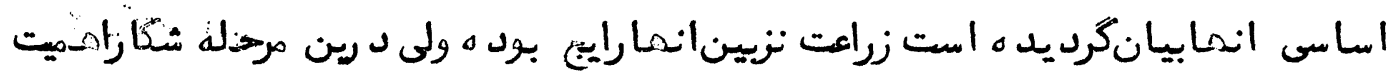

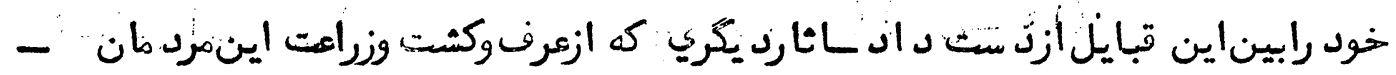

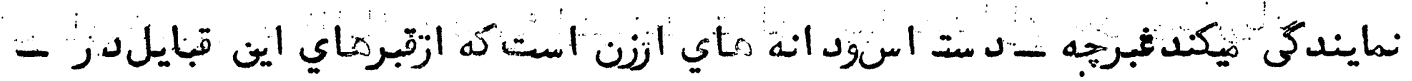

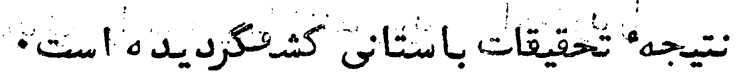

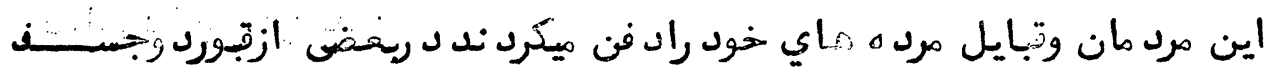

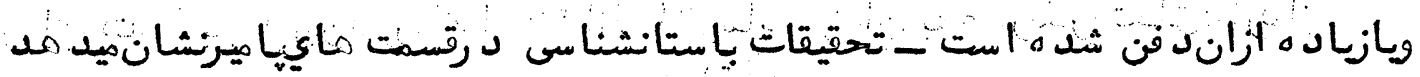

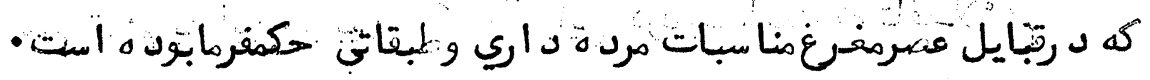

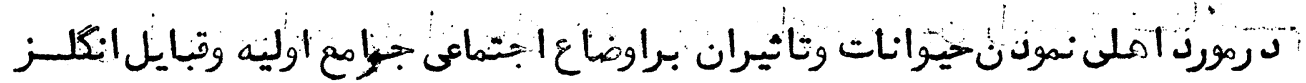

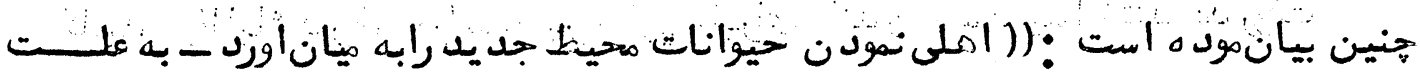

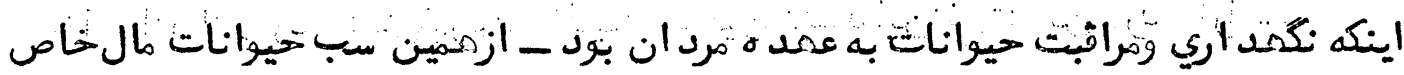

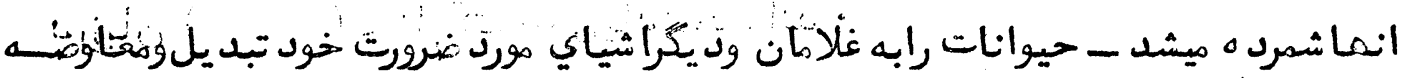

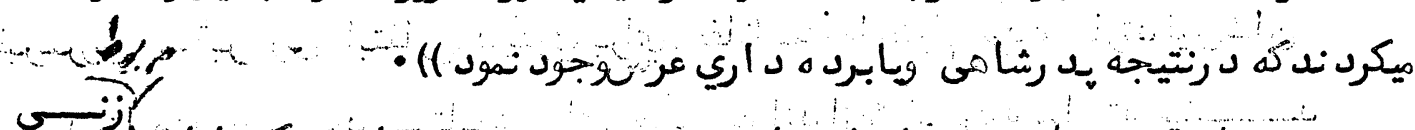

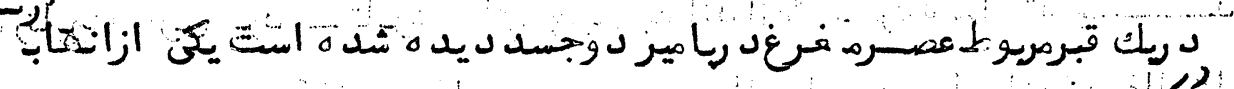

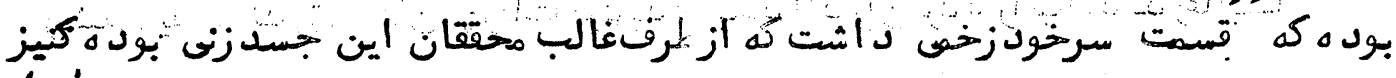
, l)

جسد د يكري كه مرد بود - د انسته شده است وتموركرد ه اند كه اين كنيزد روقت فوت 


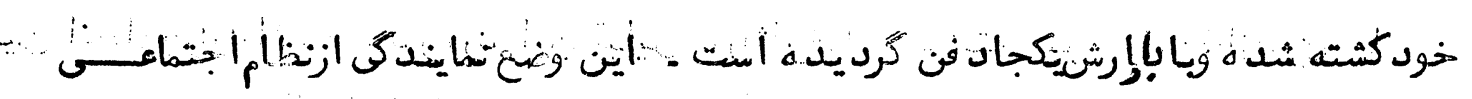

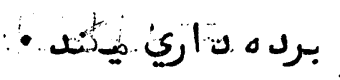

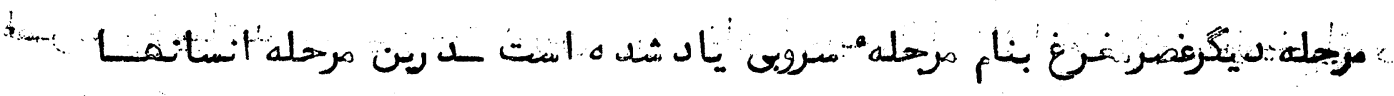

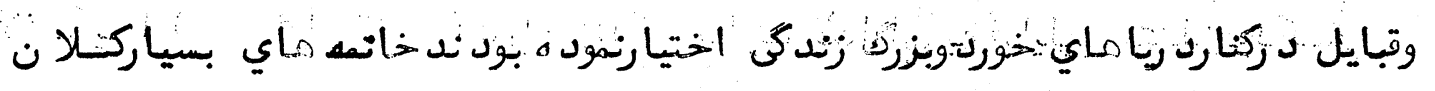

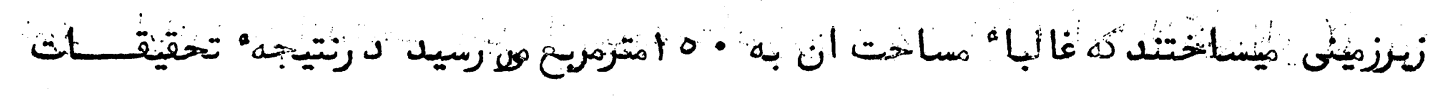

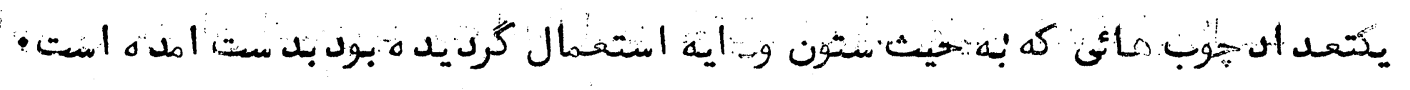

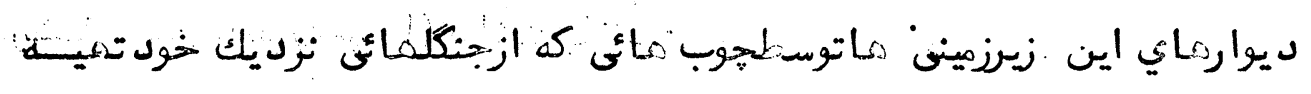

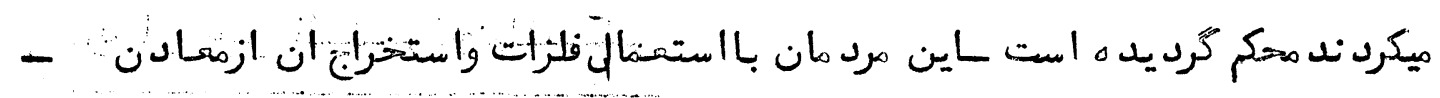

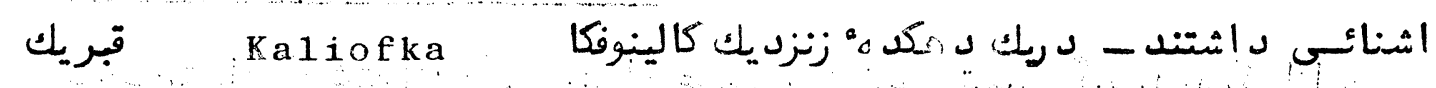

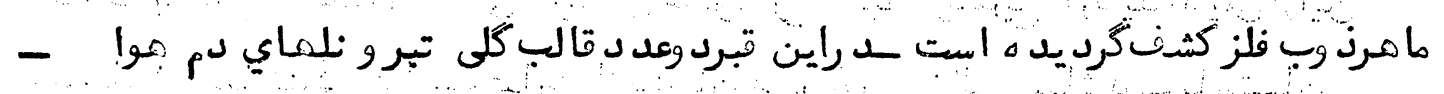

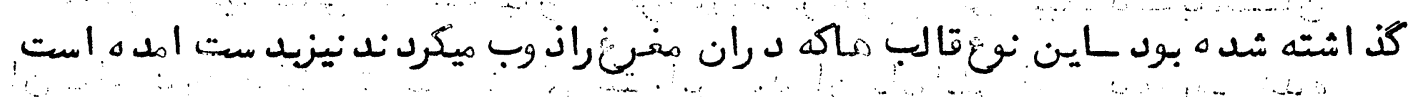

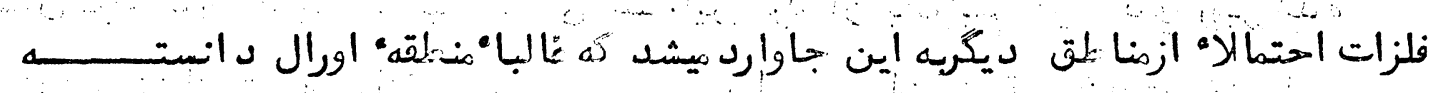

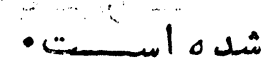

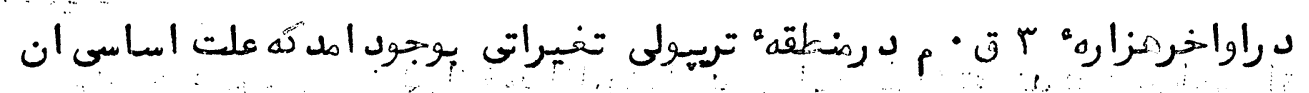

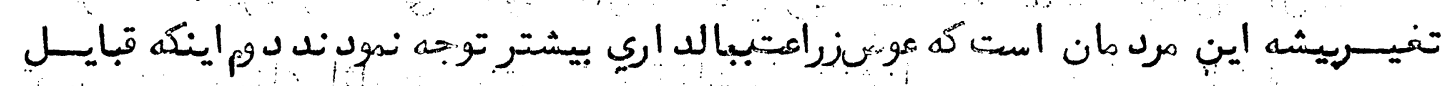

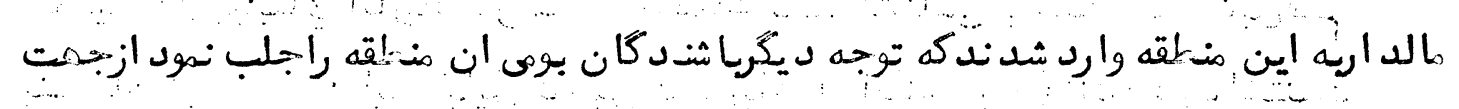

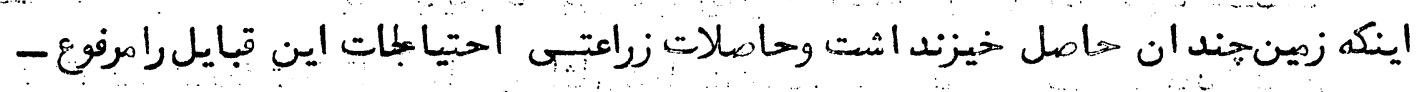

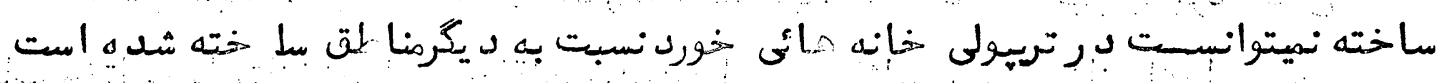

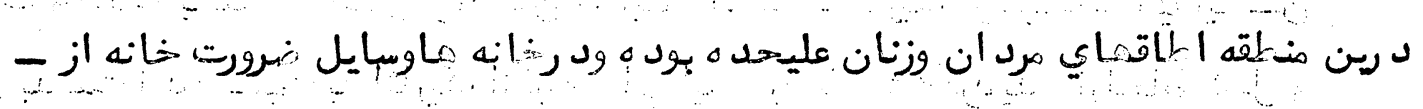

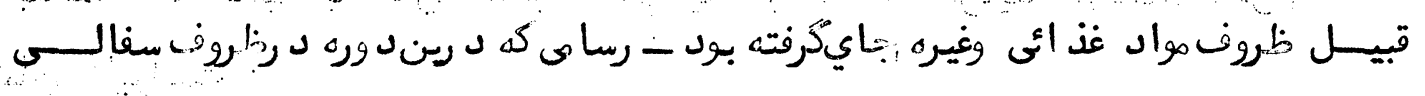

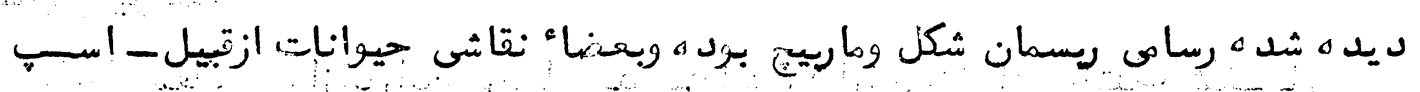

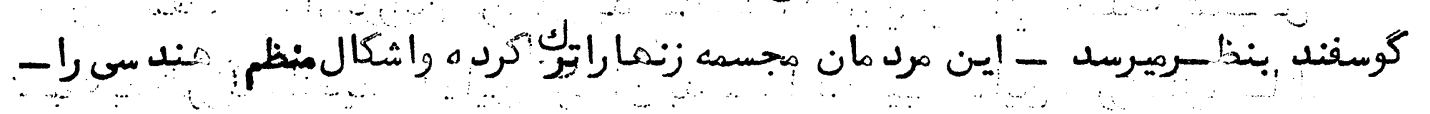

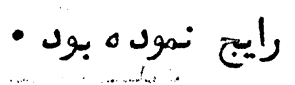

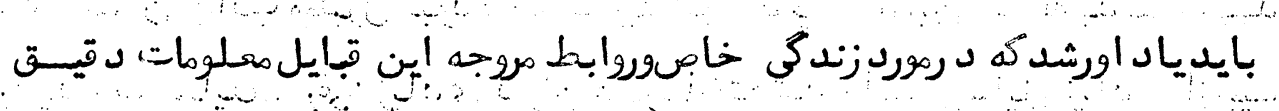

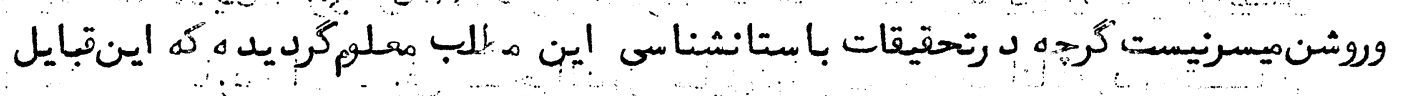

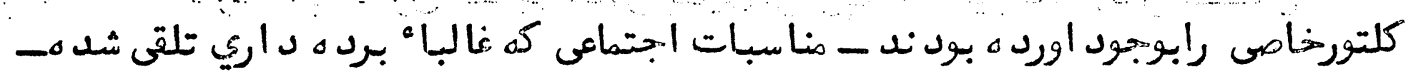


$\wedge \wedge$

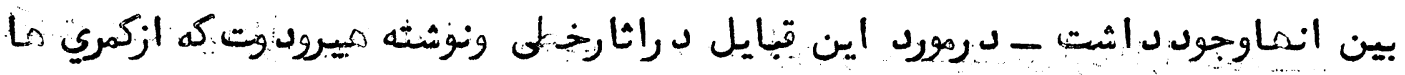

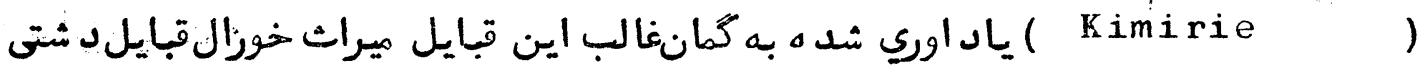

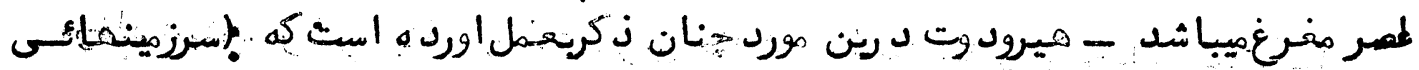

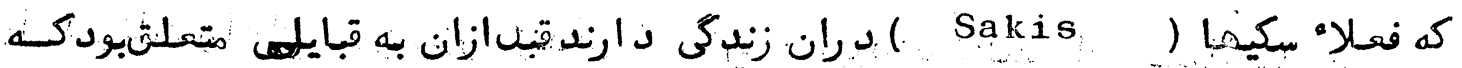

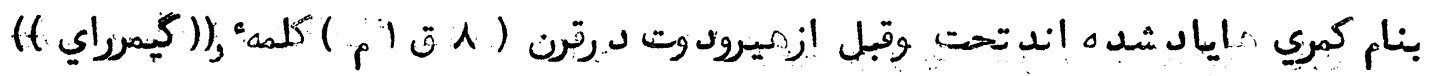

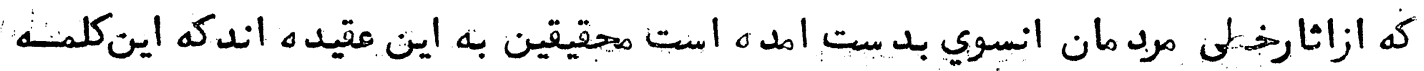

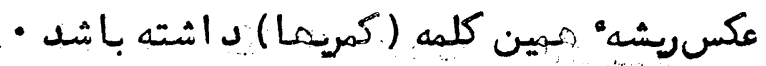

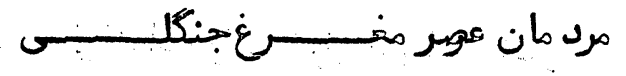

درحبتحاي كذ شته زنده كى مرد مان عصرمغرغتوغيح وتشريح كرد يدكه يكى ازاين.

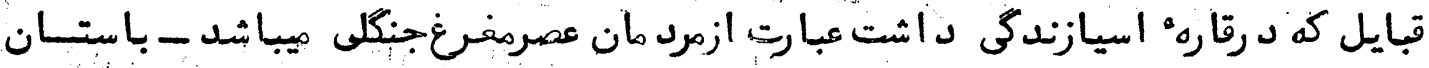

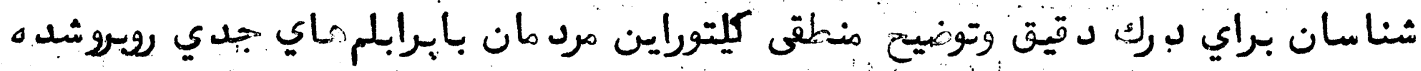

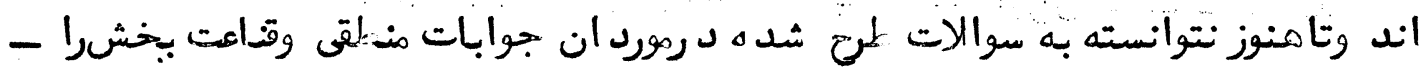

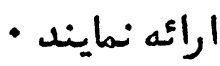

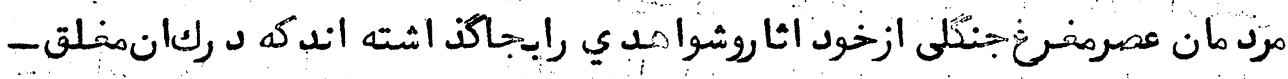

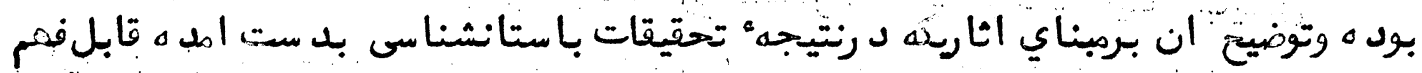

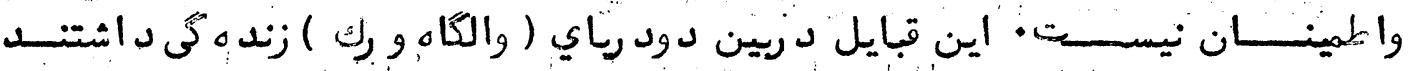

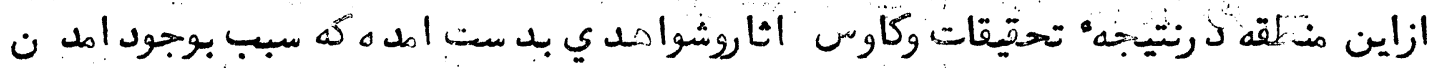

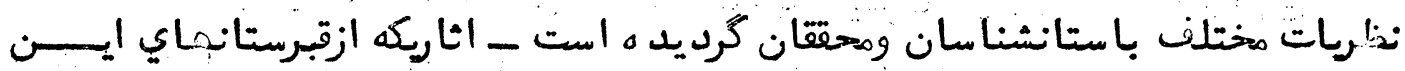

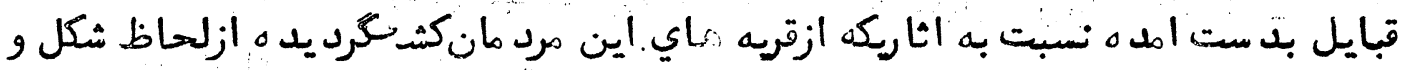

ساختمان متايزاست

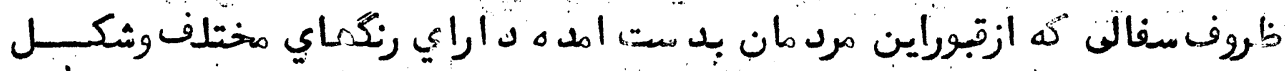

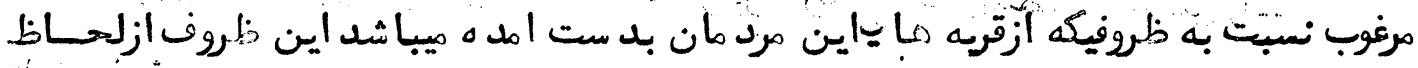

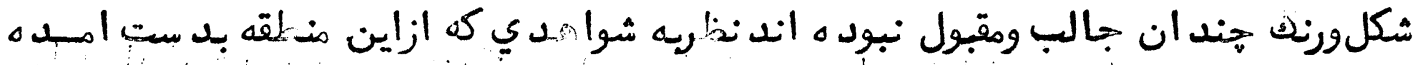

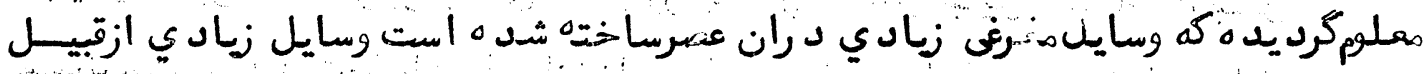

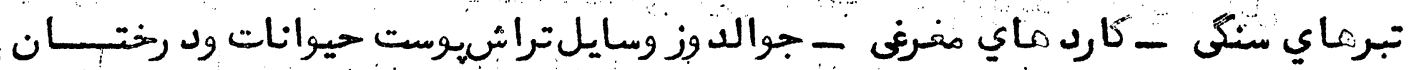




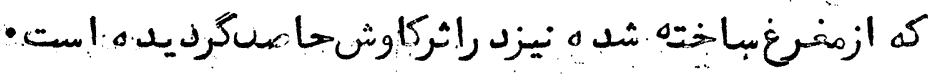

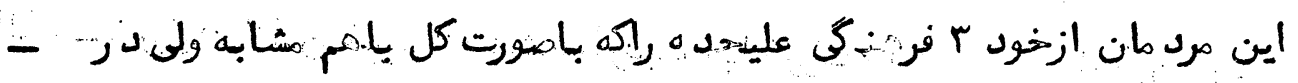

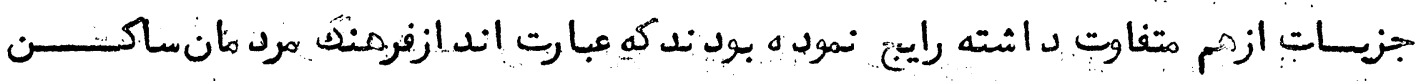

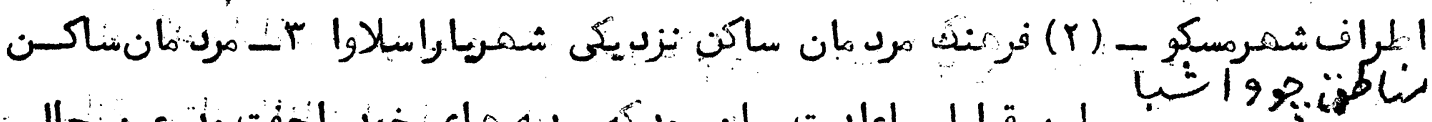

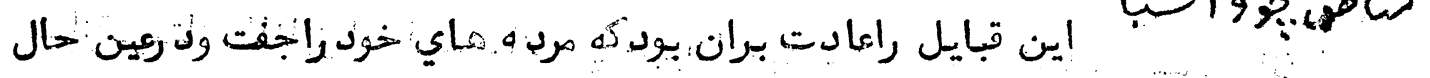

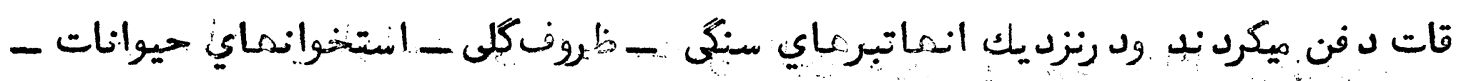

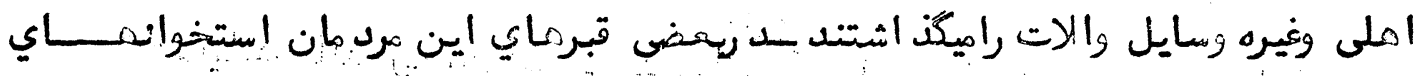

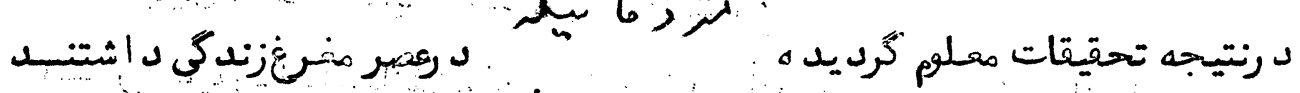
حيوانات وحشى نيزديده شده هـ است

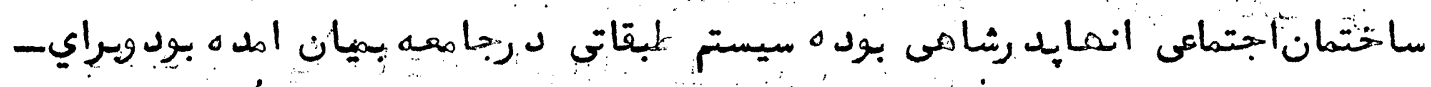

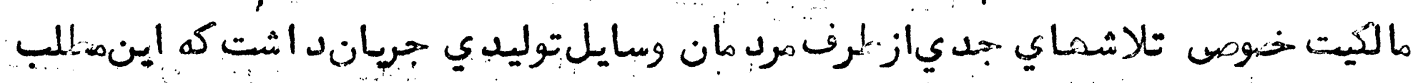

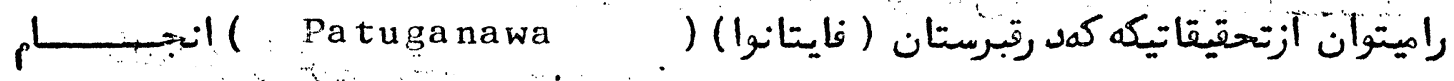

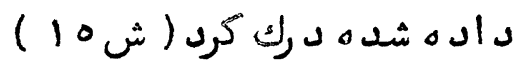

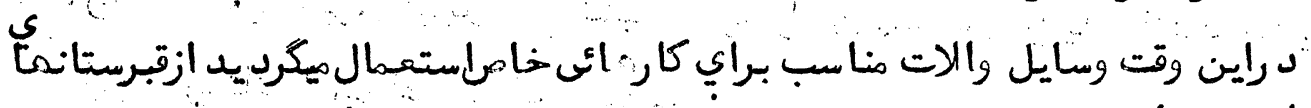

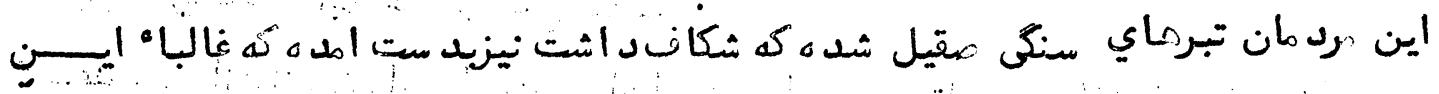
اسلحه درجنك بين قبايل استعمال ميكرديد - تبرهاي سنكي وتبرمائى مضرغى كه ازاين

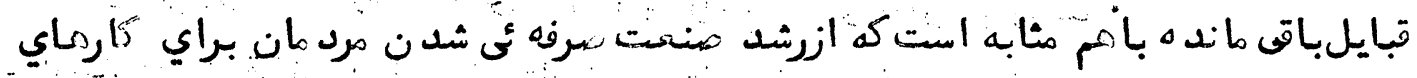

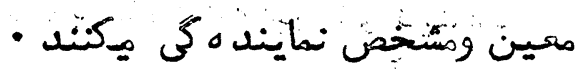

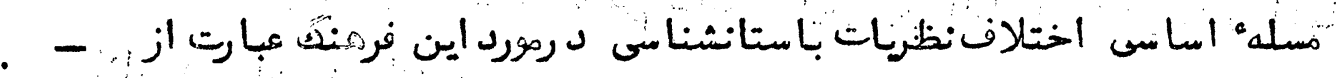

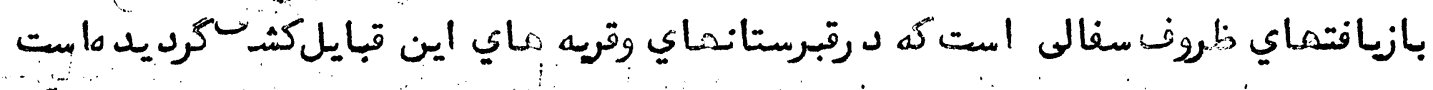

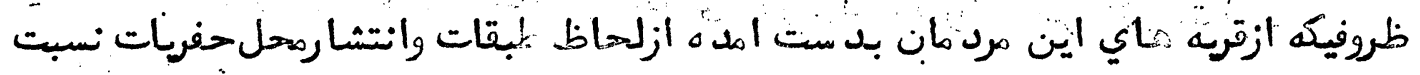

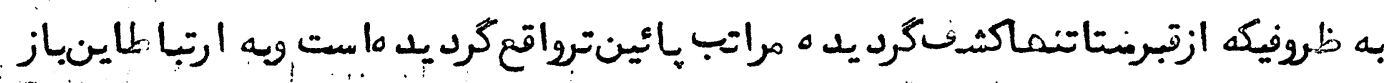

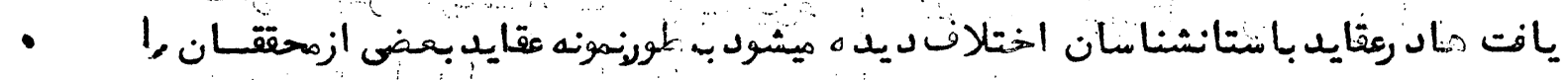

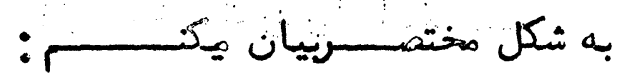


ا - مدكن اين قبرستان ازبانب المالى دمعه اين قريه هـاكه د رعين وقت زنده كى ميكرد ند

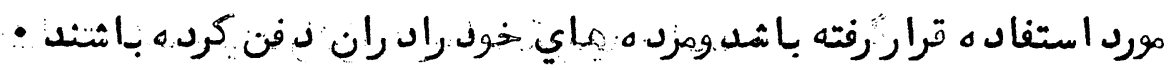

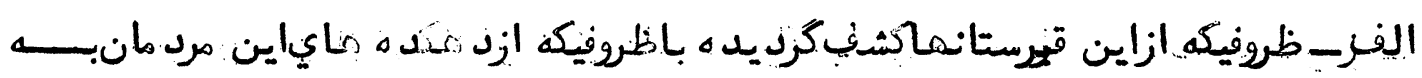

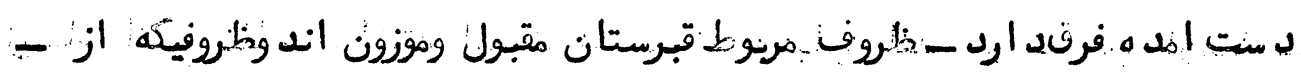

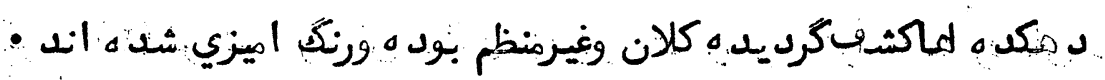

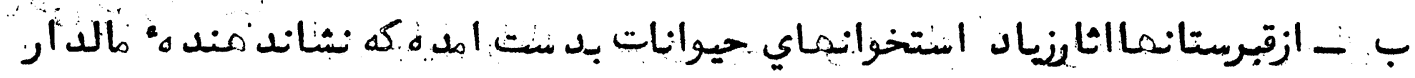

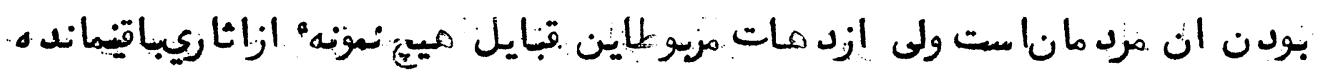

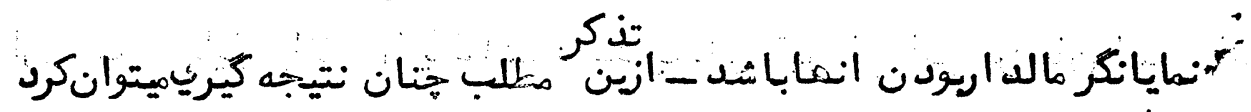

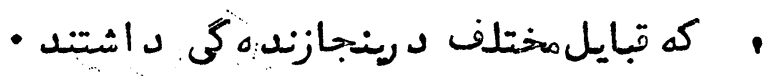

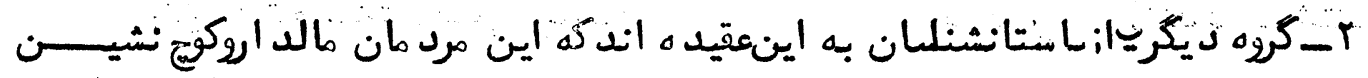

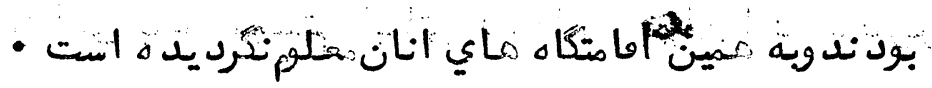

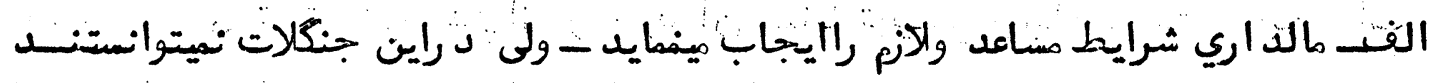

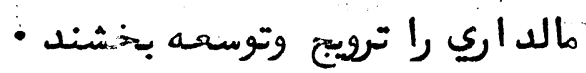

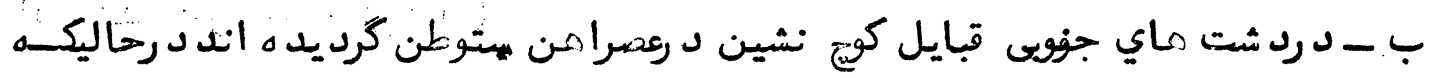

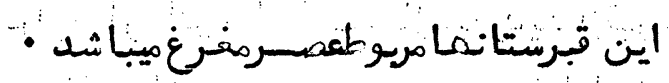

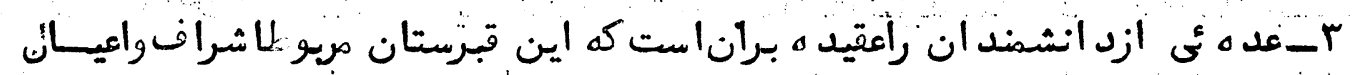

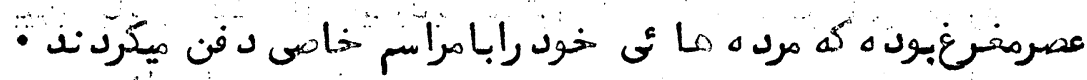

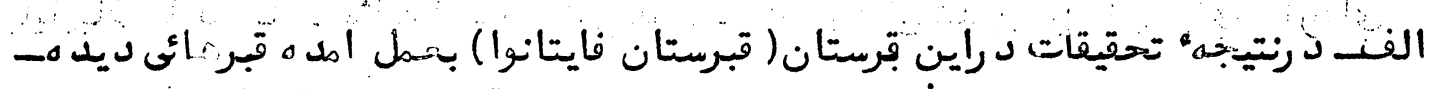

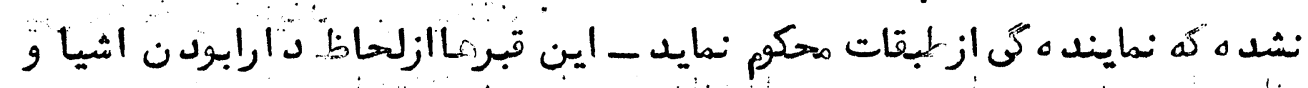

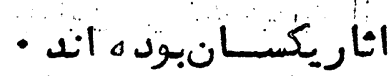

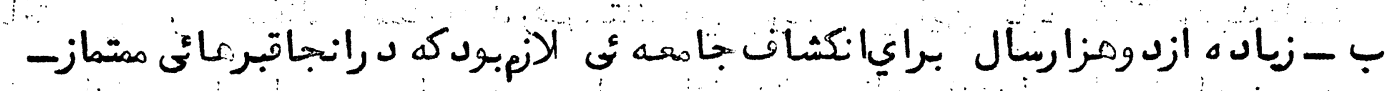
- بيد اشودود ع_كروه ديكري ازيستانشناسان به اينعفيده هاندكة اين قبرستان مريويل مرد ما ن

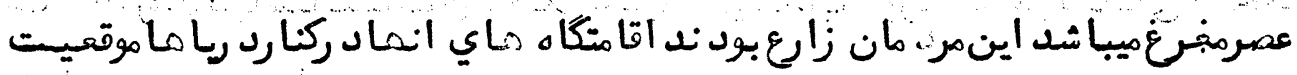

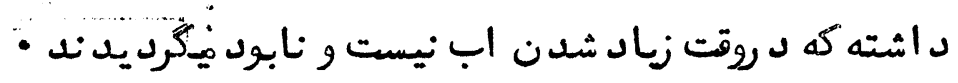




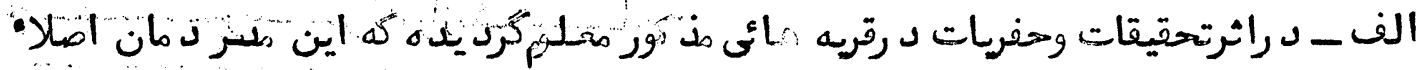

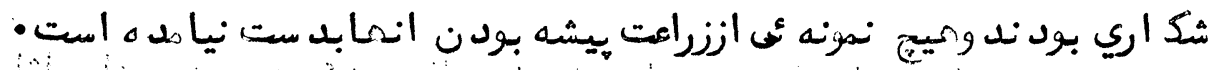

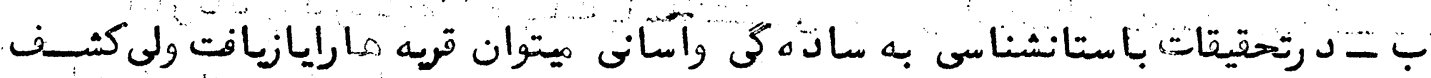

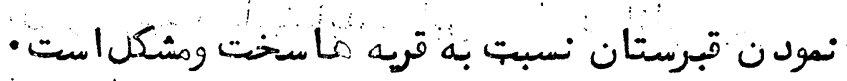

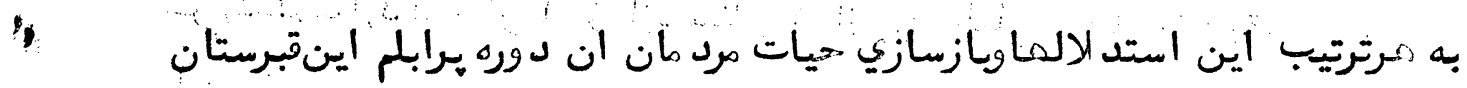

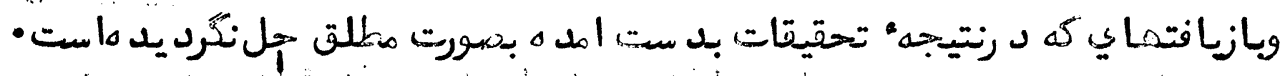
بعضى باستانشناسان راعقيده بران الست كه قبرستان فاتيانوا) مريـوط

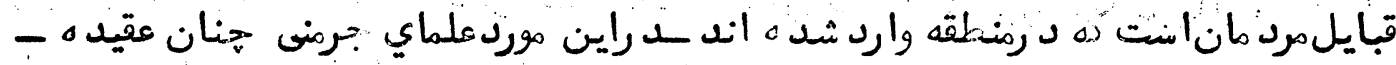

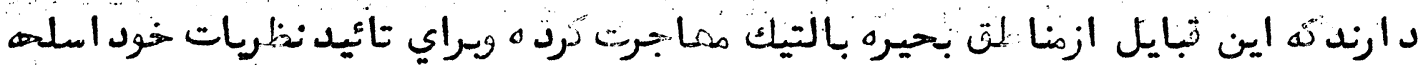

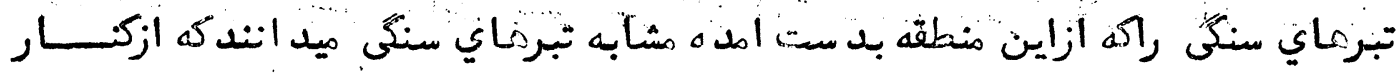
بحيره بالتيك كث سكرديده است اين راعلاوه مينمايدكه اين قبايل ازسويد نوكناره ماي

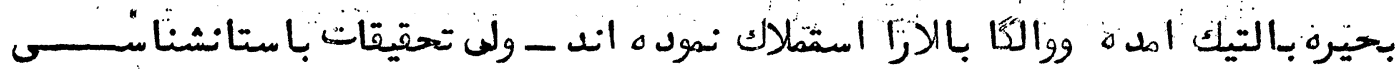

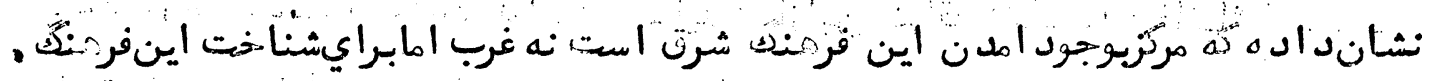

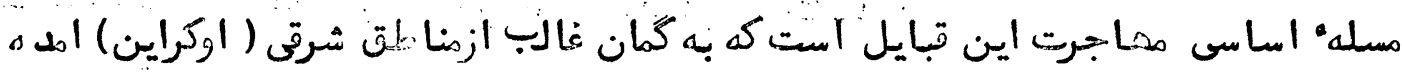

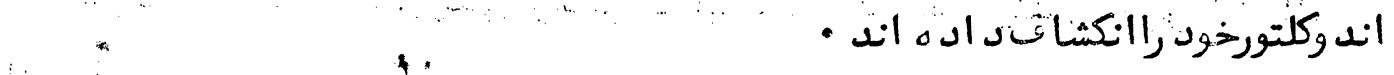

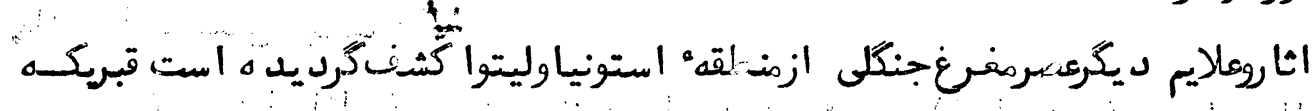

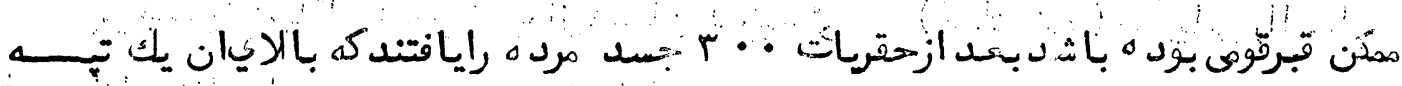

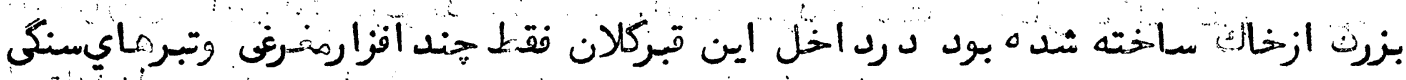

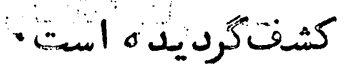

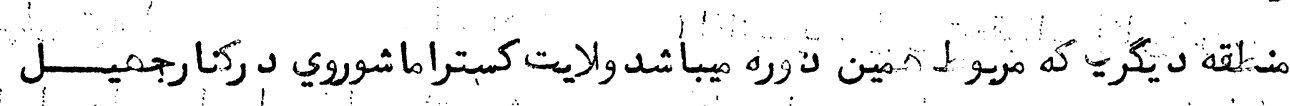

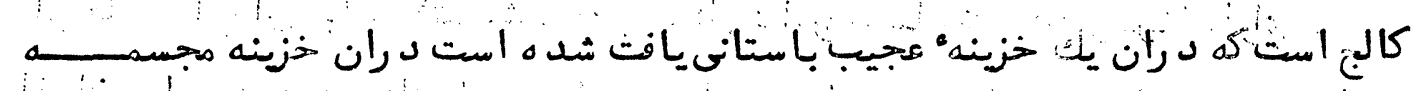

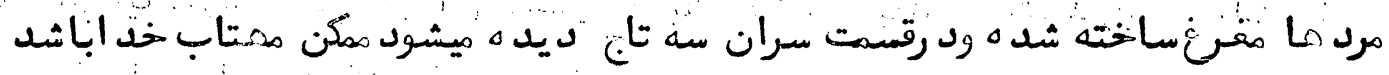

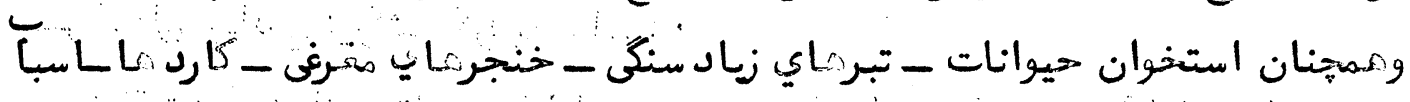

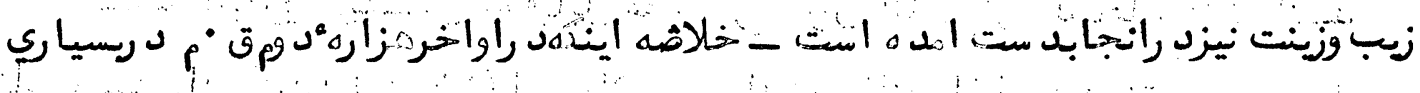

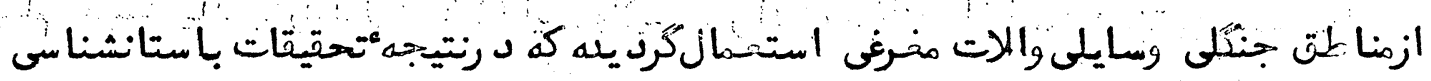

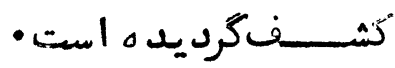




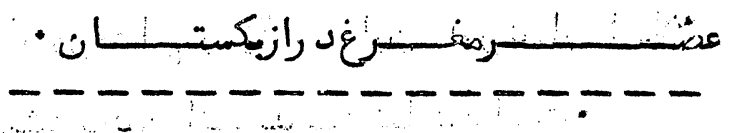

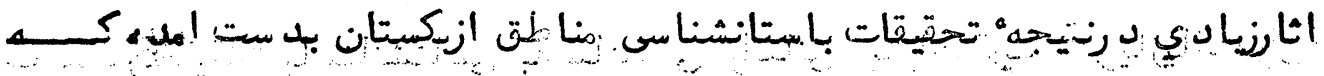

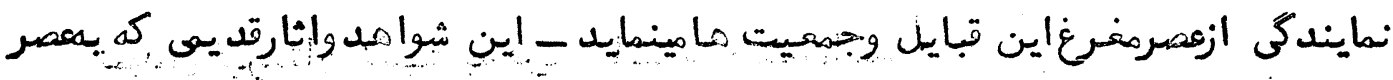

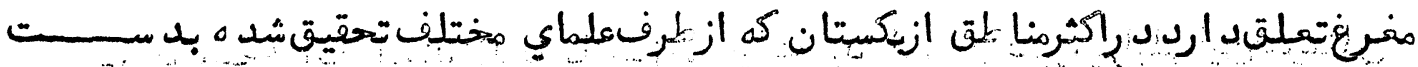

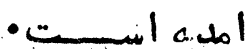

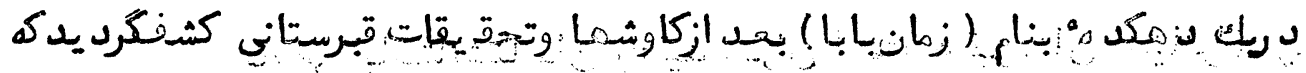

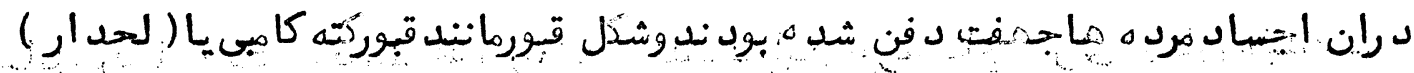

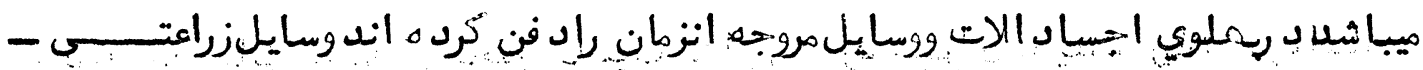

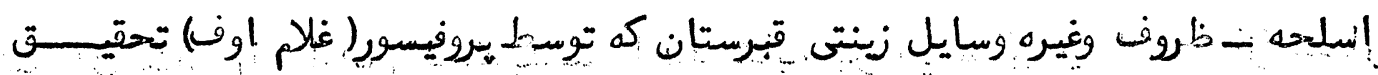

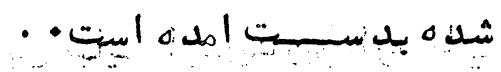

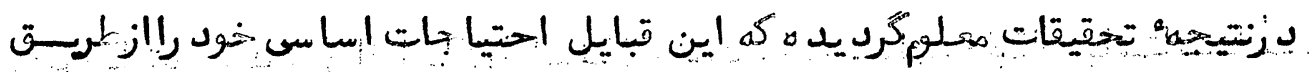

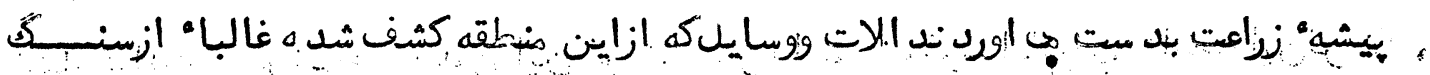

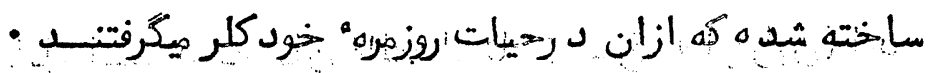

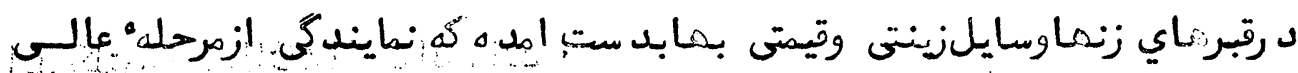

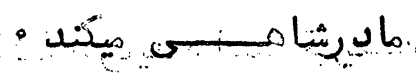

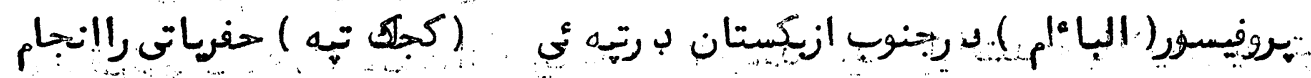

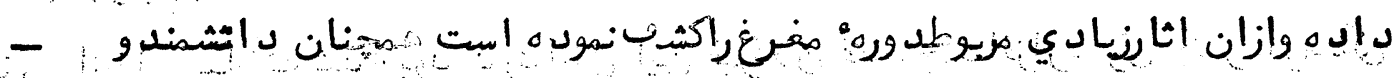

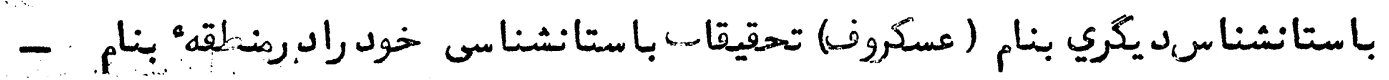

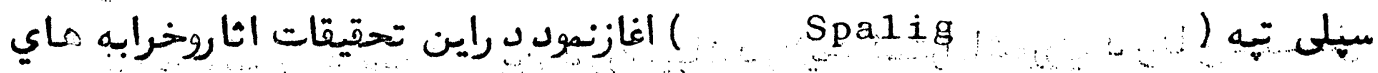
بنامياو خائه هاي ان قبايل كثف شد كه به شكل به ايروي ساخته شده ومهربناد اراي-

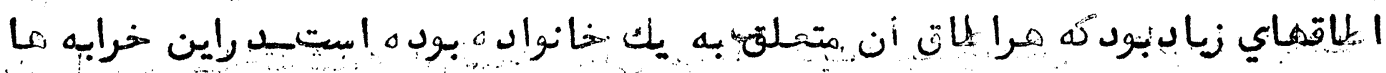

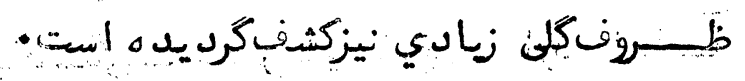

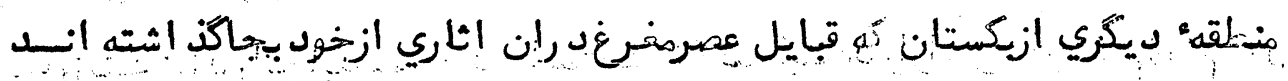

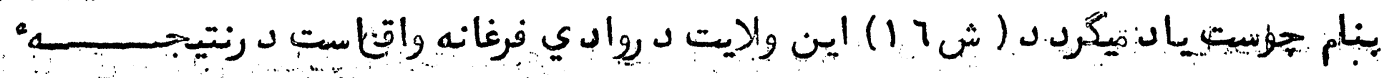


$9 r$

تحقيقات محلبم كرديد هكه اين تبايل زراعت هيشه د زاواخر هزازه" دوم و.اوائل مبزارهيكم

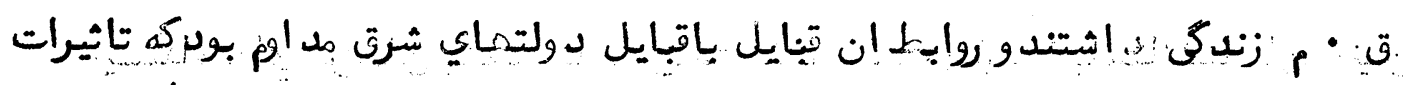

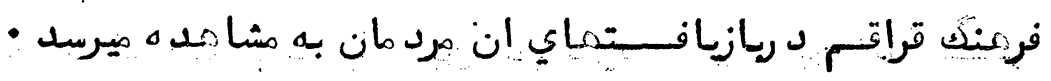

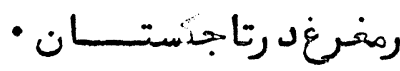

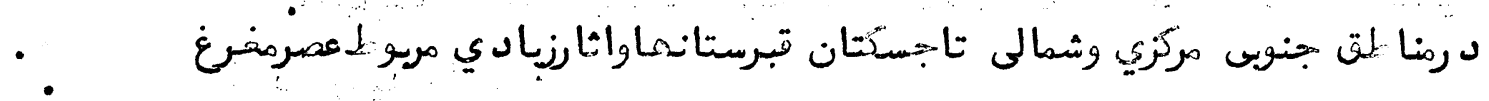

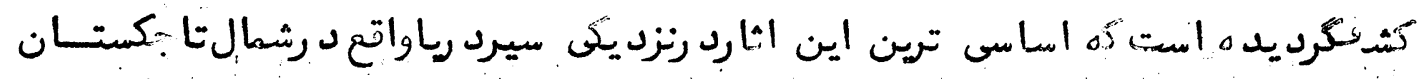

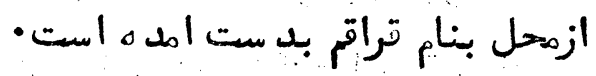

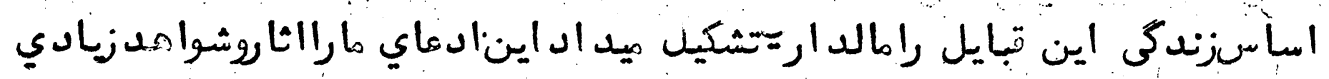

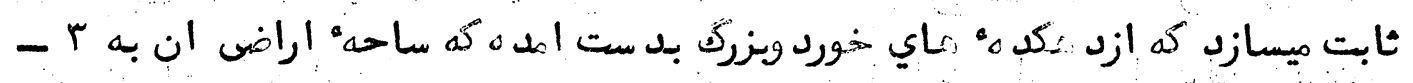

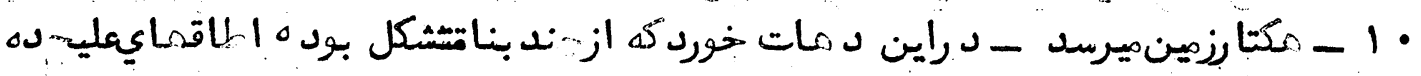

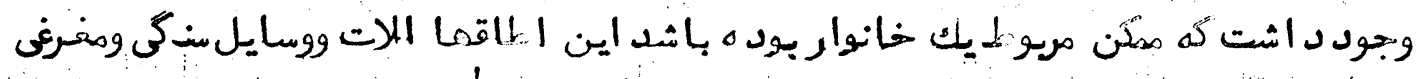

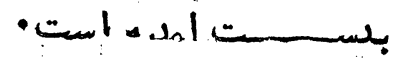

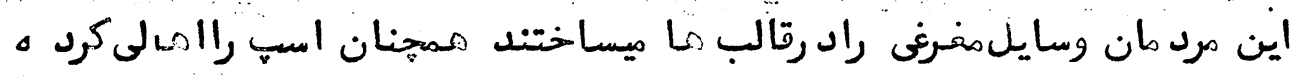

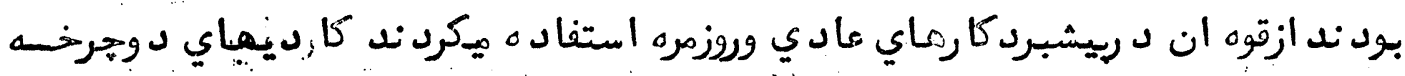

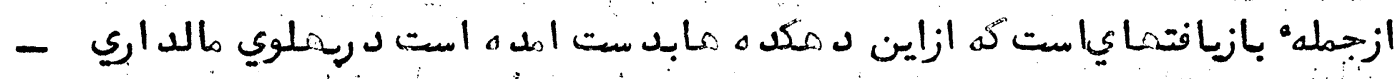

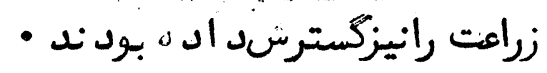

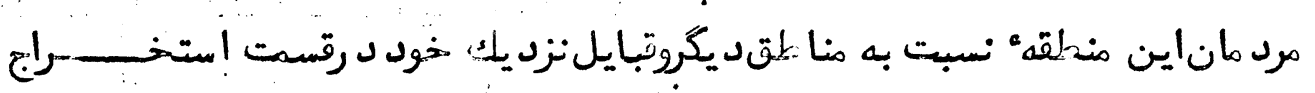

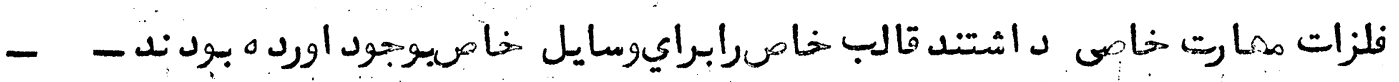

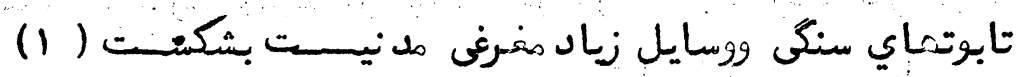

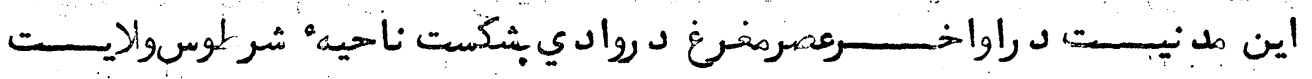

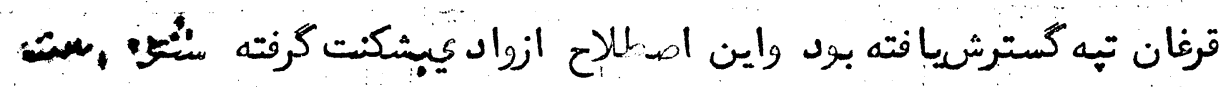

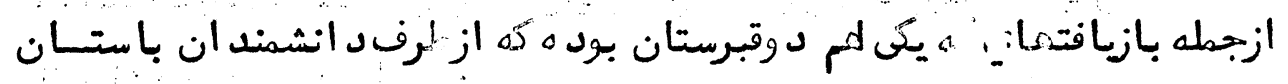

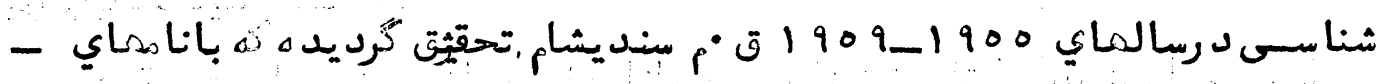

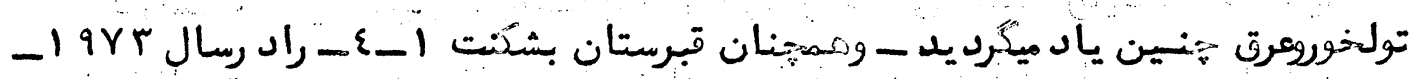




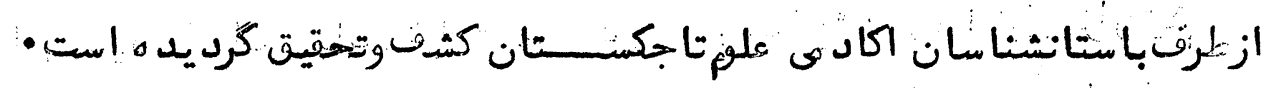

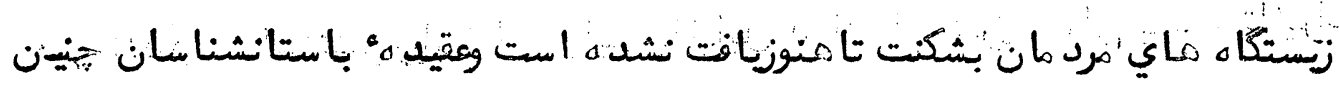

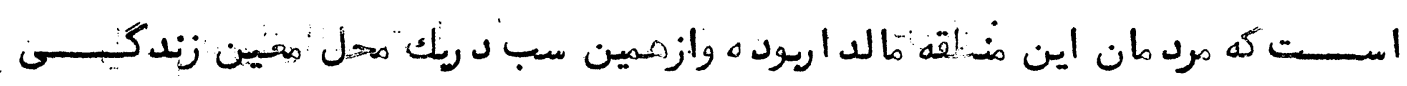

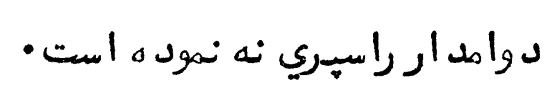

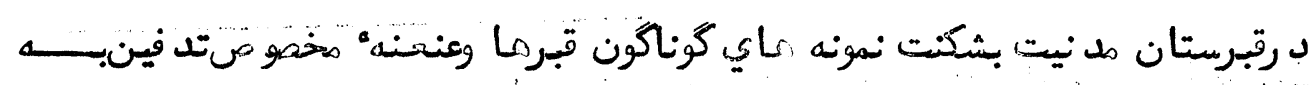

$$
\text { مثامبده رسيد ه استيكان }
$$

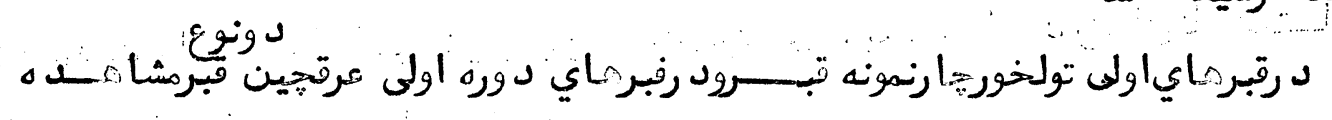

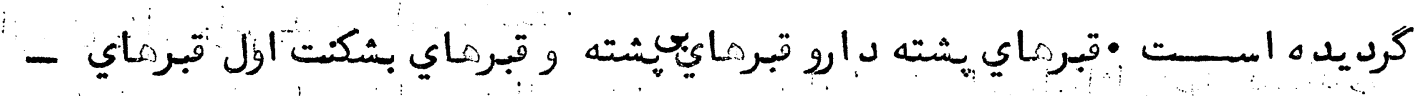

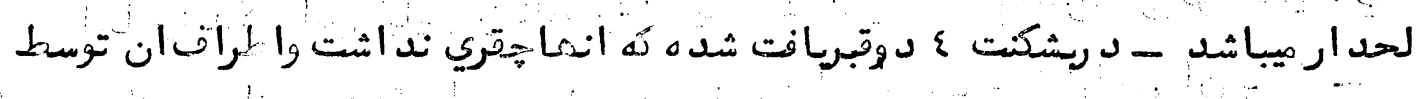

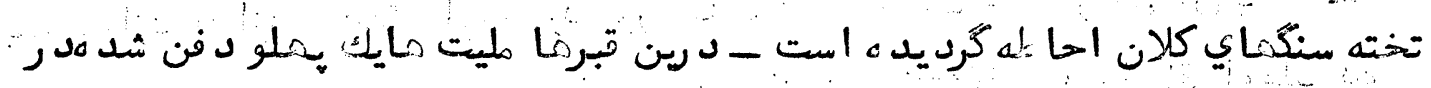

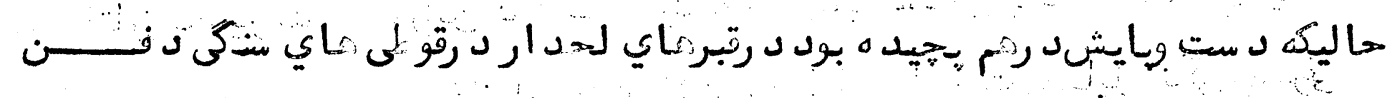

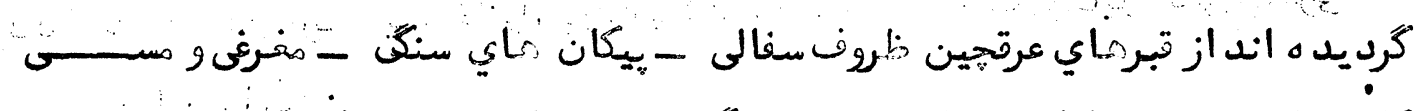

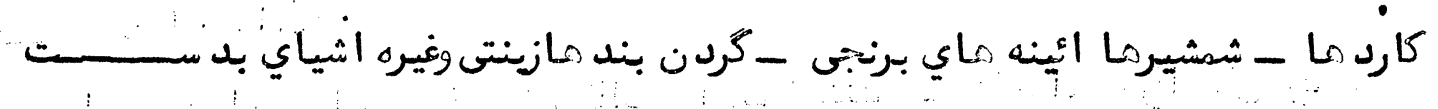

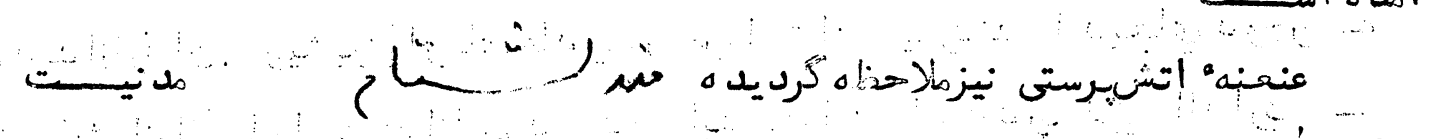

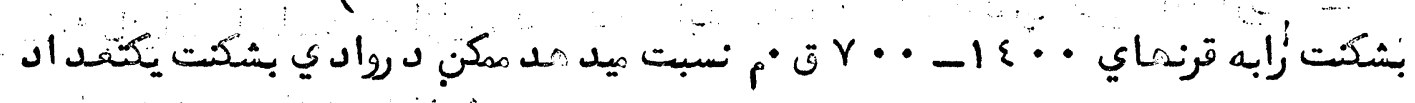

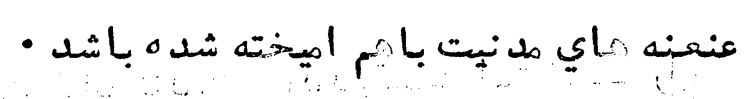

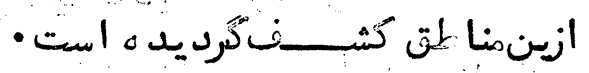

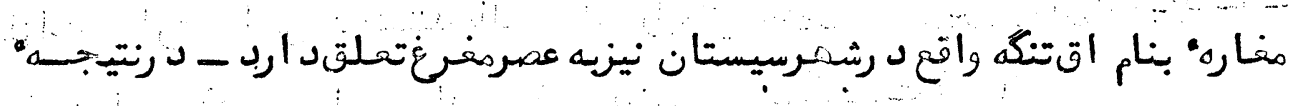

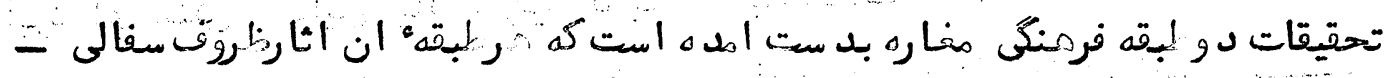

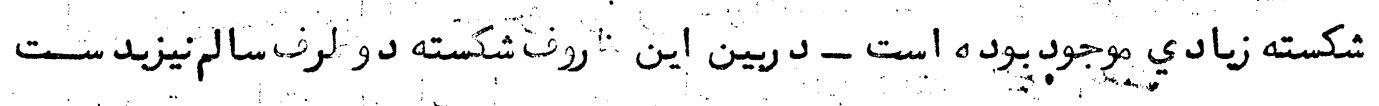

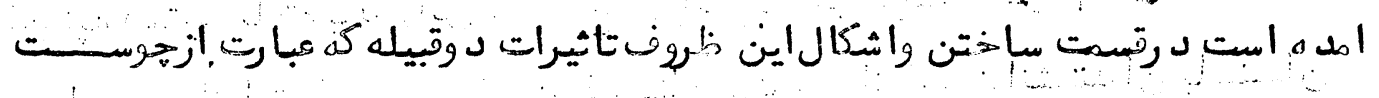
وقيراقم باشد ديده شده ه است

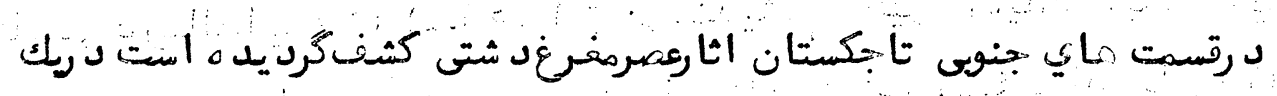

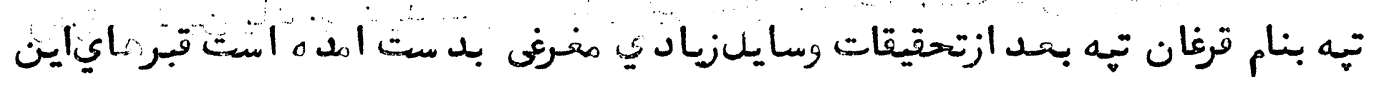


مرد مان عييق وبشكل لحدا إرساخته شده است مربه مارا غالباه انفرادي يابحضاهجوره ئى

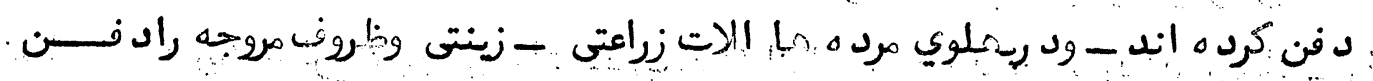

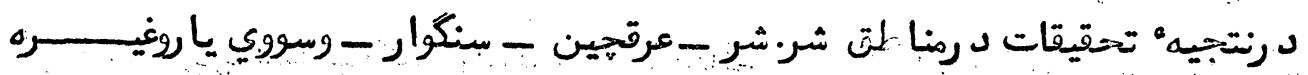

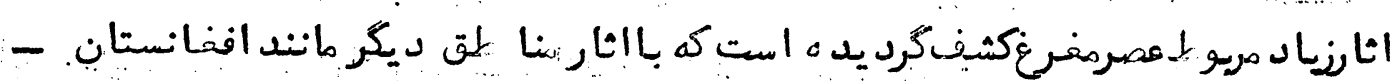

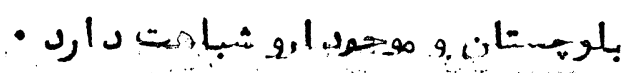

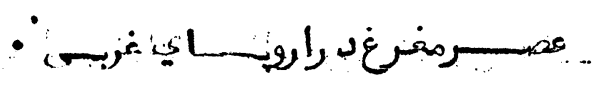

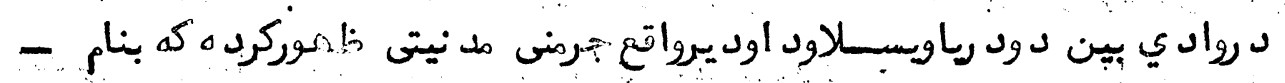

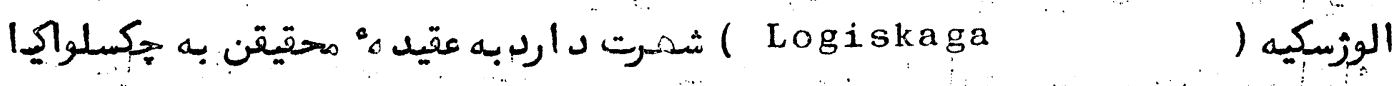

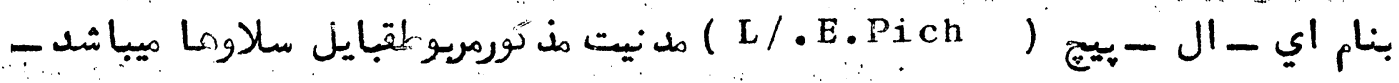

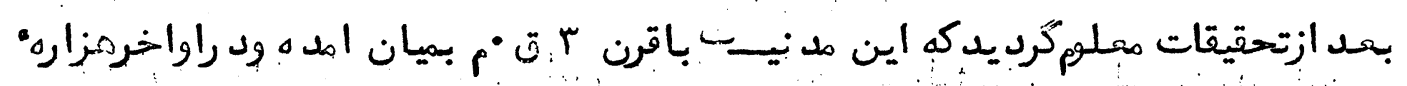

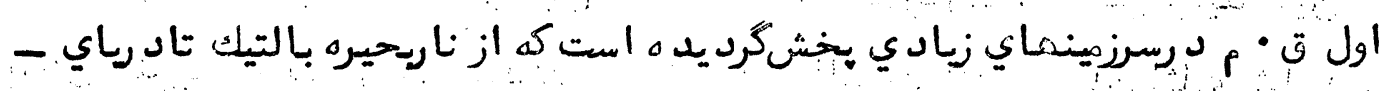

دوناي وازكتأرباي د دراي ايلبه تافريييات ساحه وسيع راد ربركرفته بود (

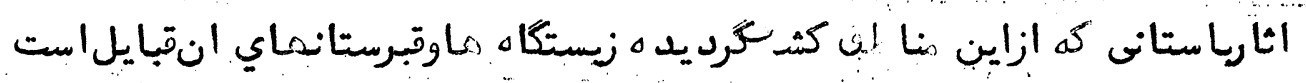

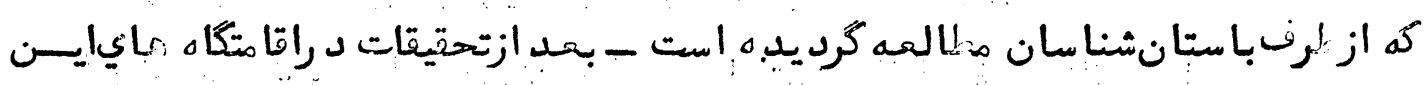

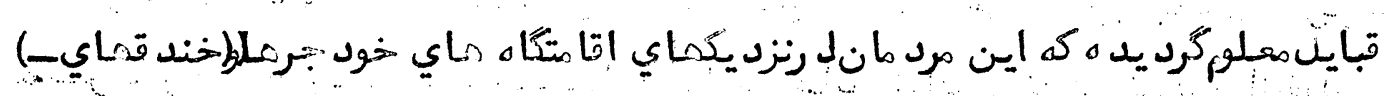

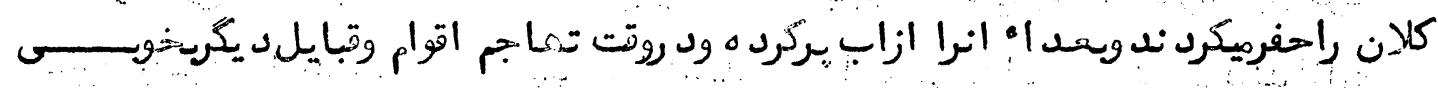

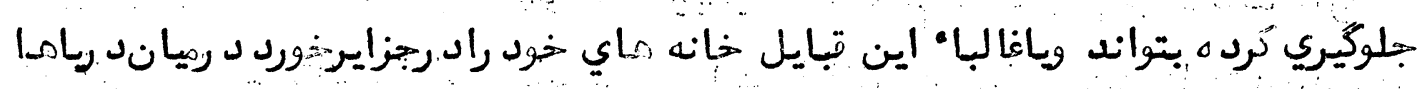

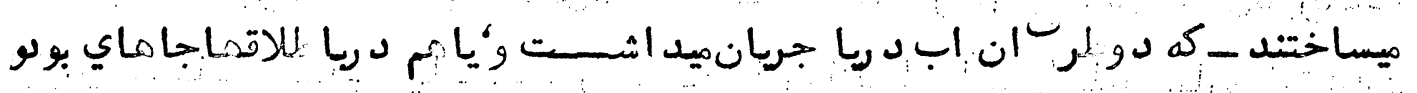

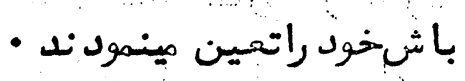

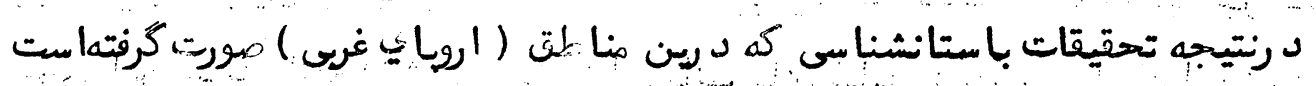

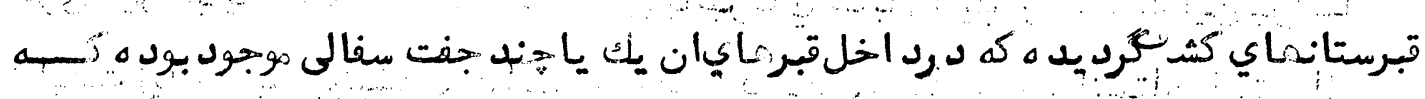

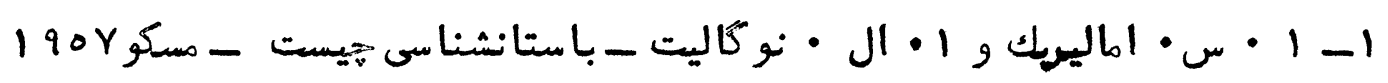

ص- آז (بزيان روسى ) 


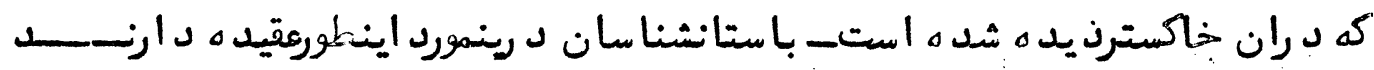

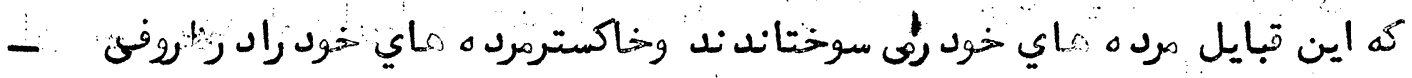

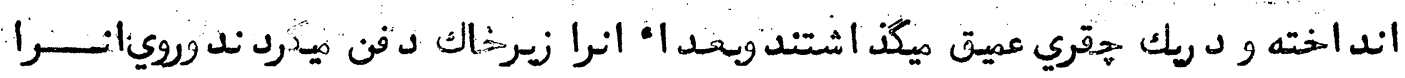

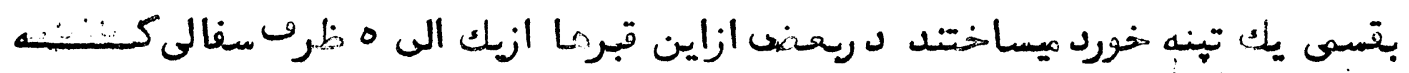

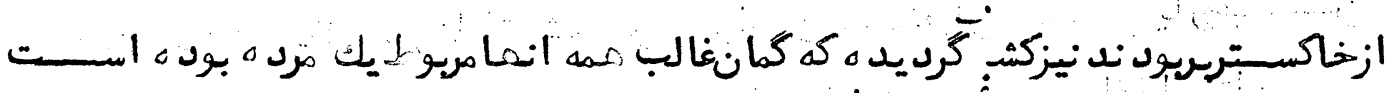

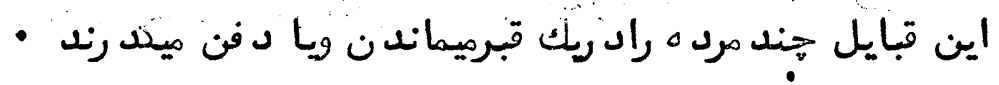

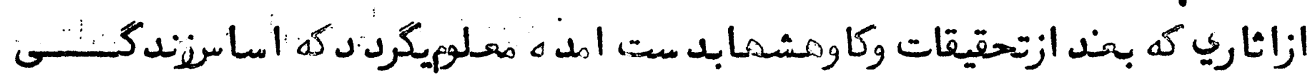

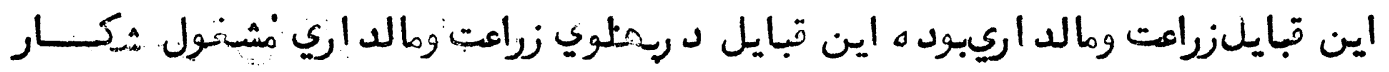

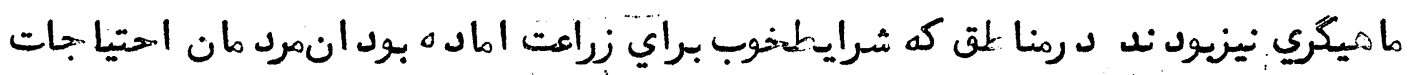

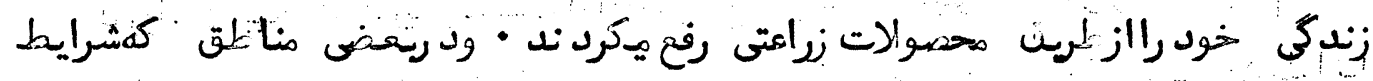

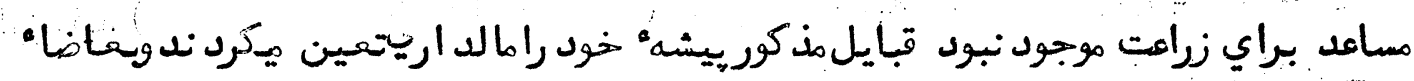

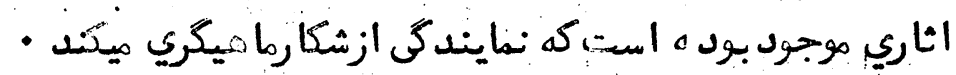

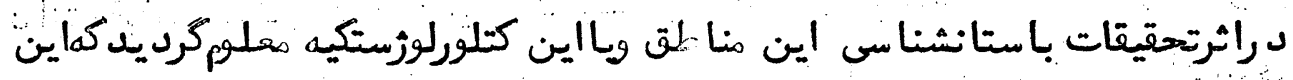

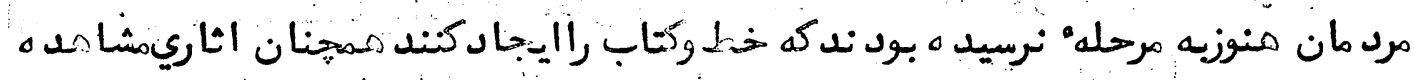

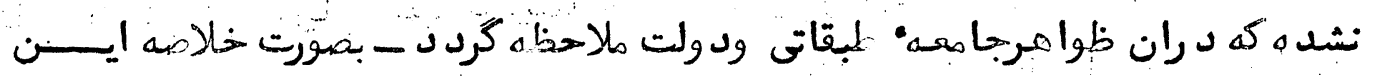

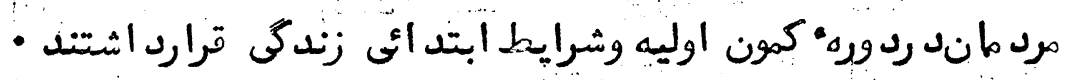

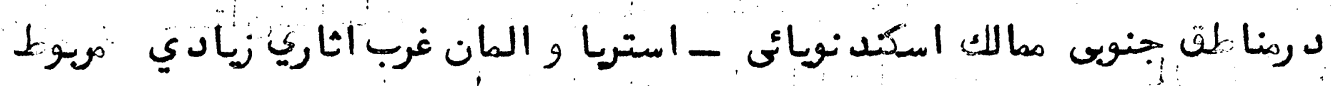

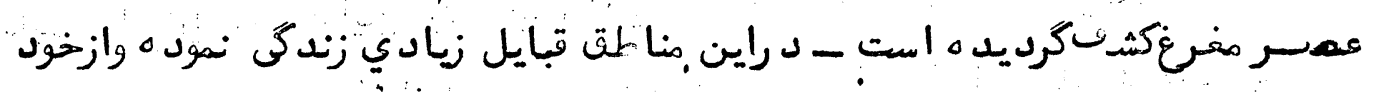

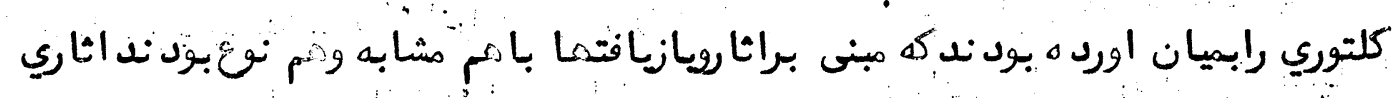

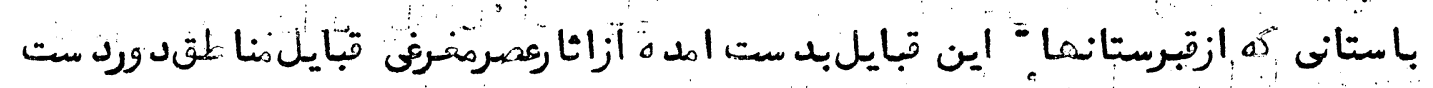

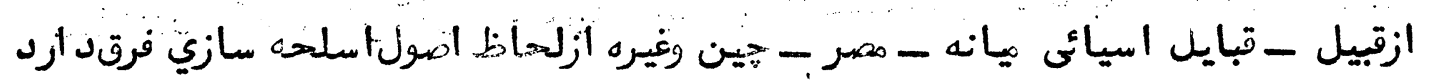

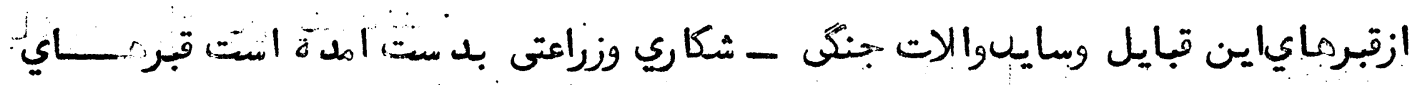

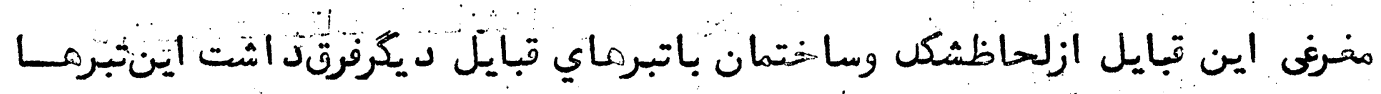

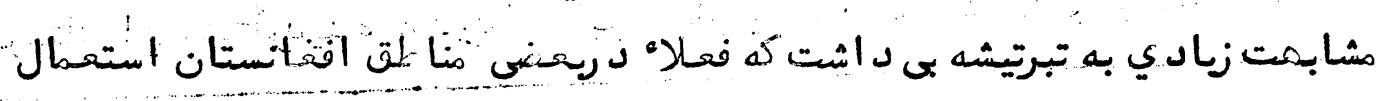




\section{$9 v$}

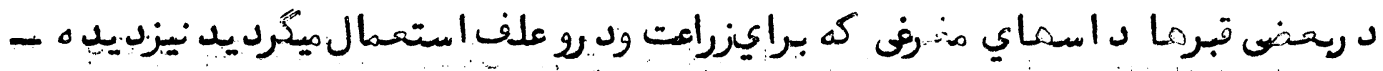

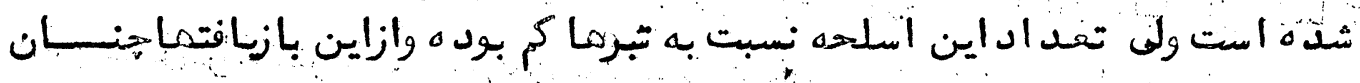

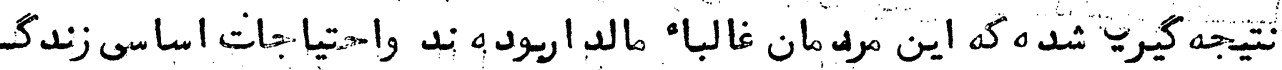
•

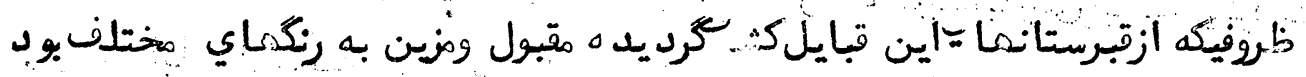

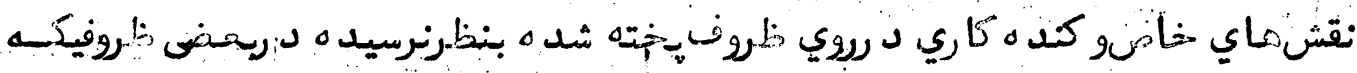

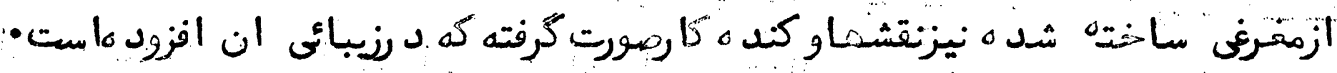
ازتبرستانهاي اين تبايل وسايل زياد جنكى بد بت إده ه است كه شامل نيزه ماي

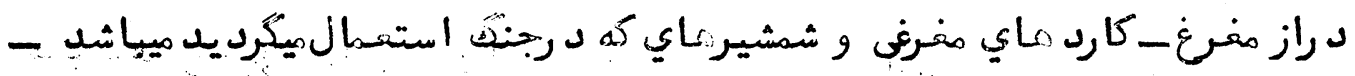

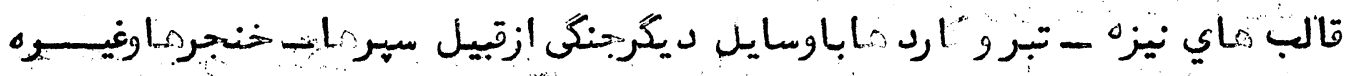

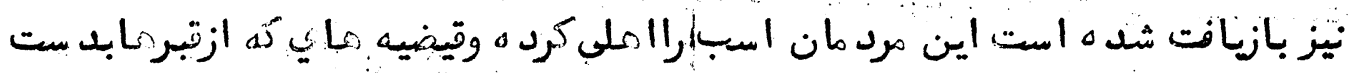

$$
\text { - }
$$

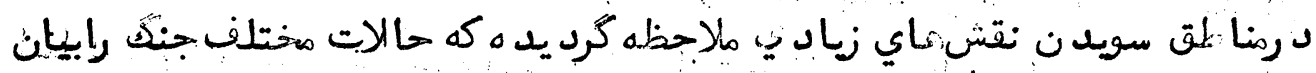

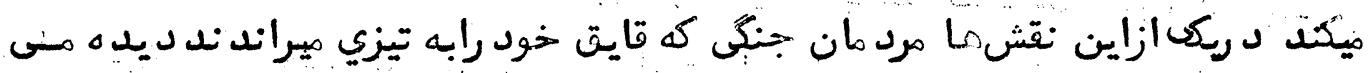

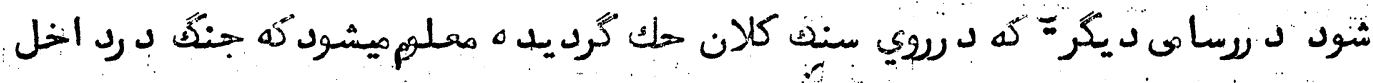

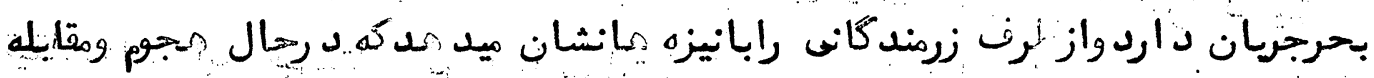

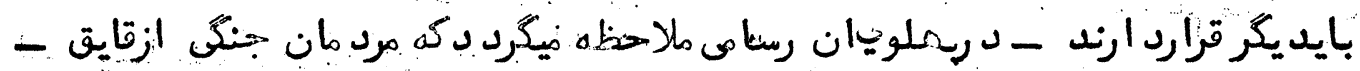

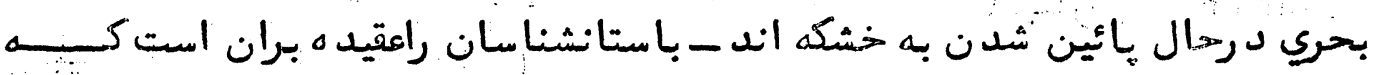

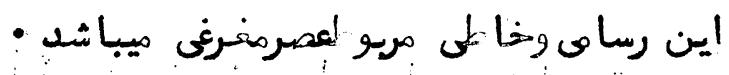

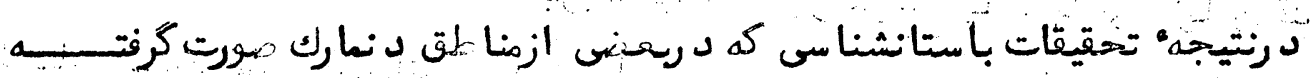

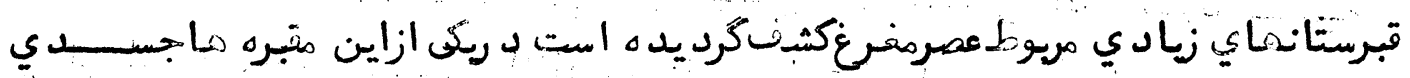

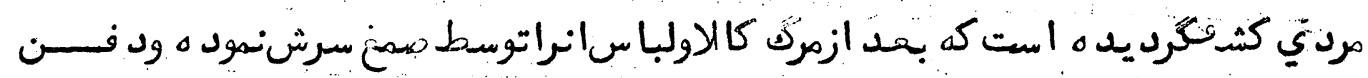

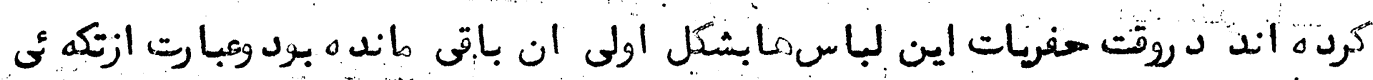

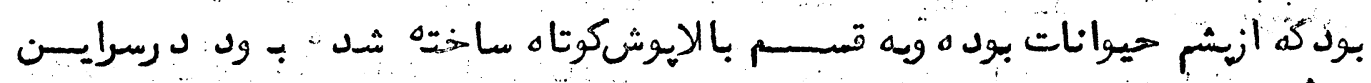

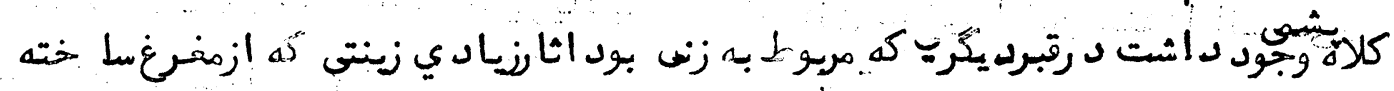




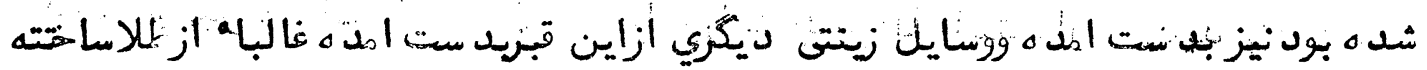

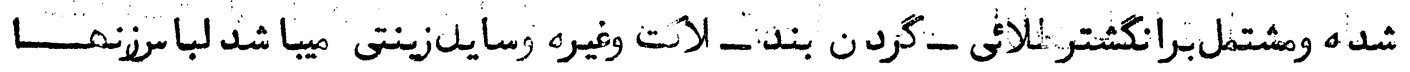

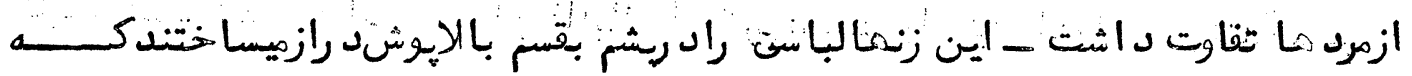

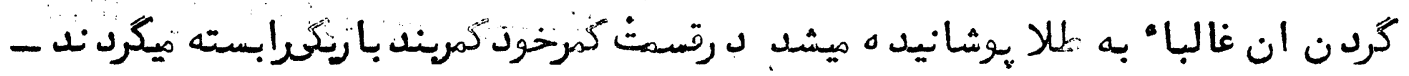

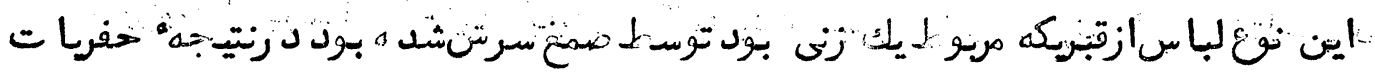

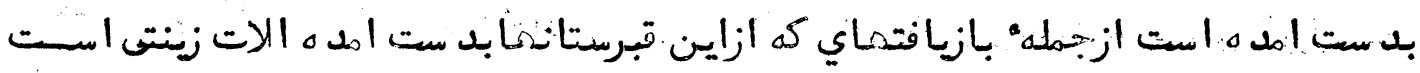

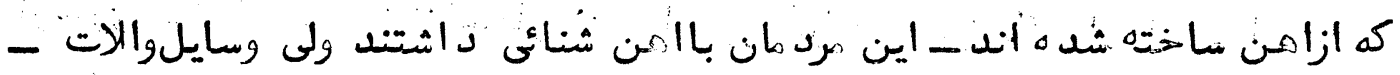

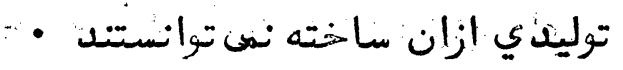

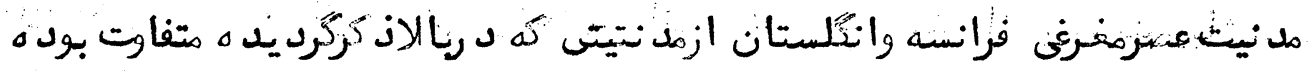

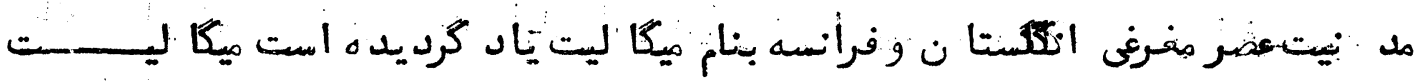

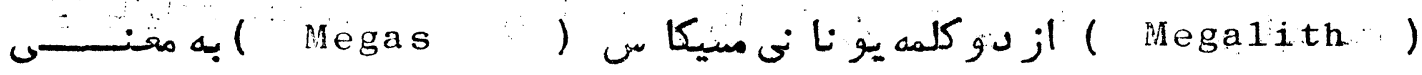

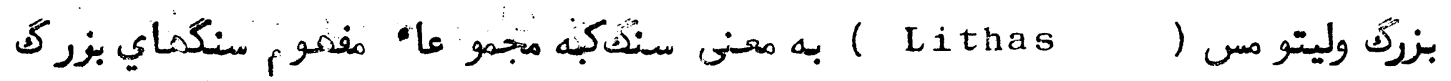

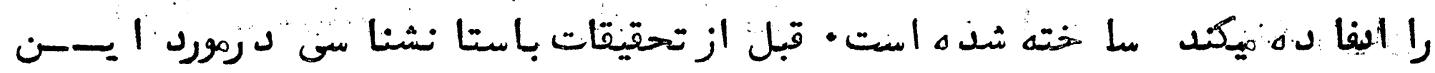

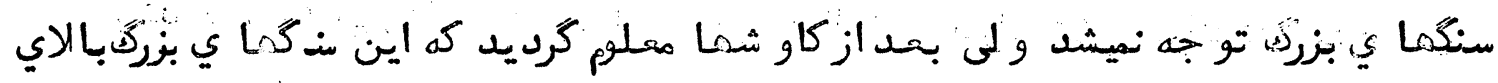

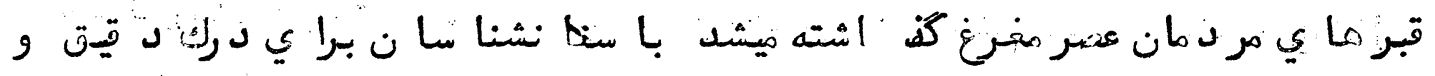

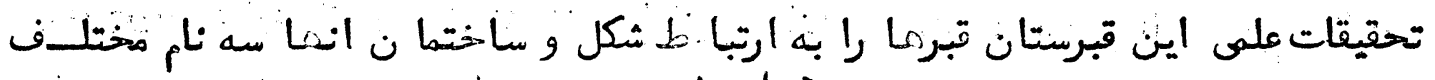

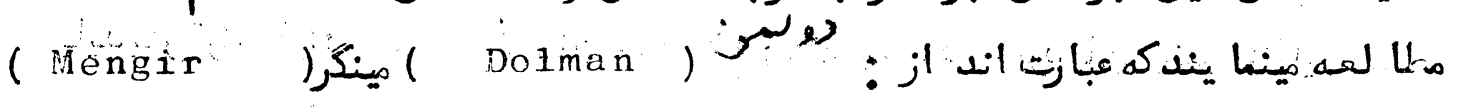

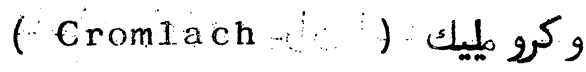

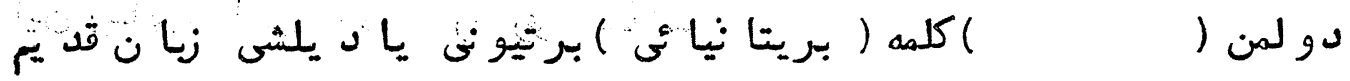

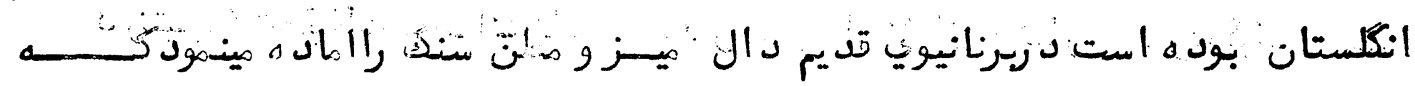

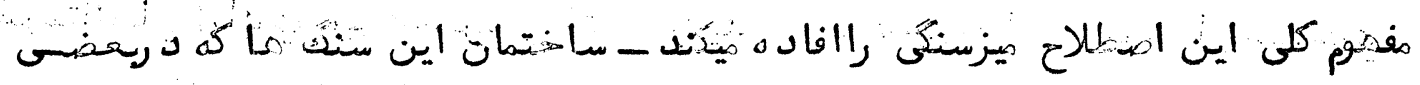

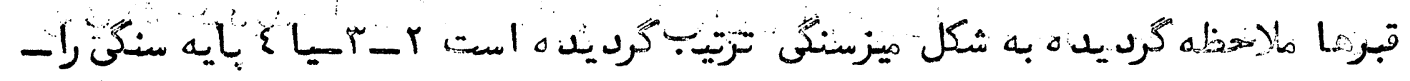

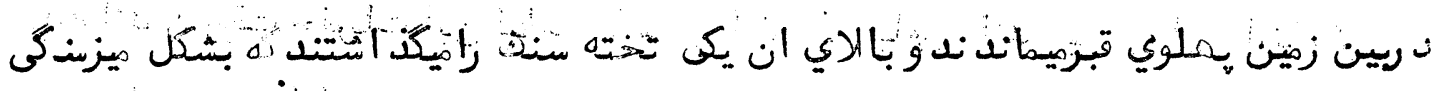

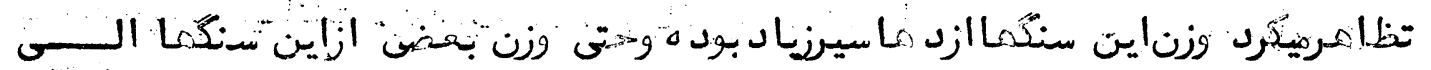

$$
\text { (1) } 1 \frac{1}{r}
$$




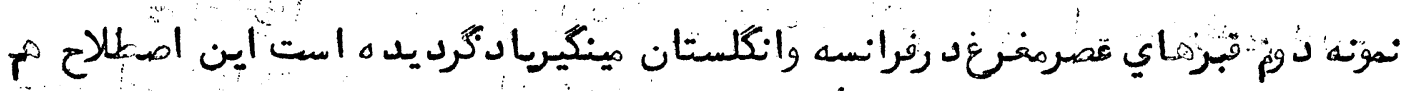

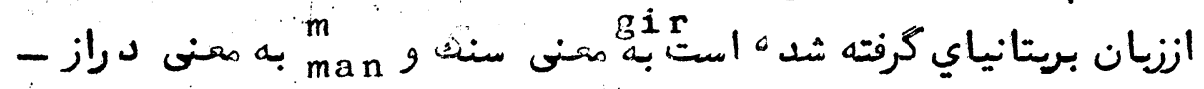

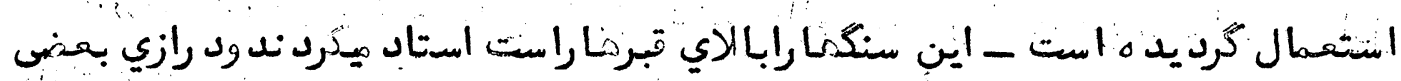

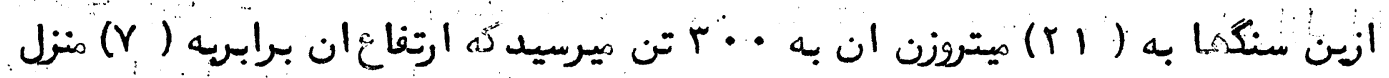
- امتزوي ميباشد

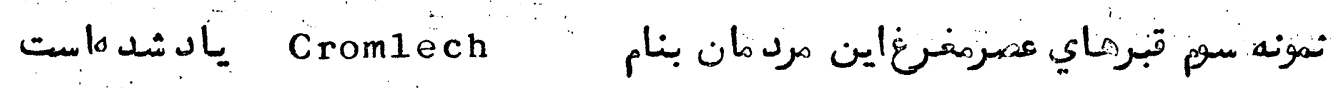

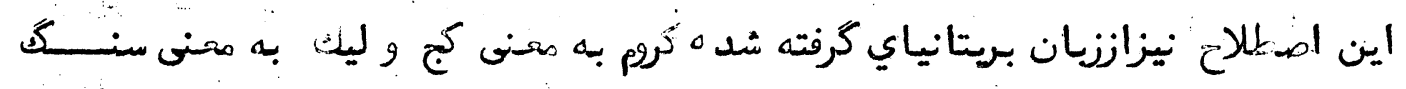

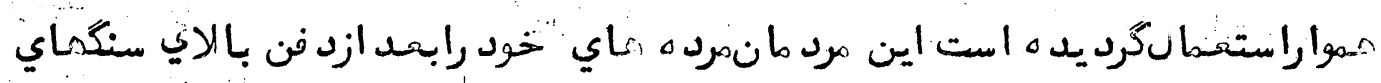

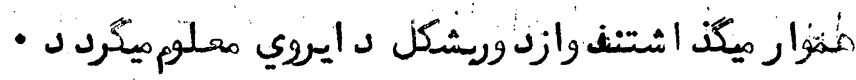

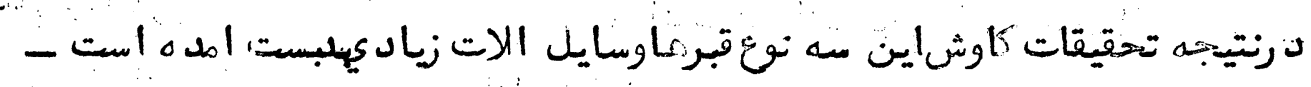

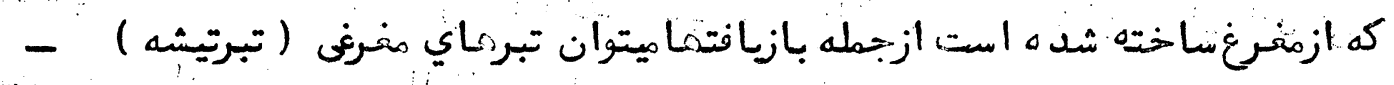

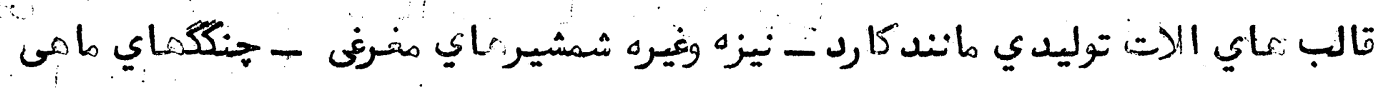

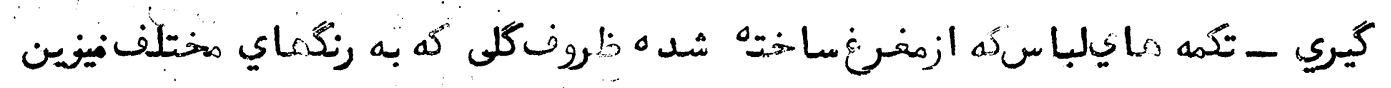

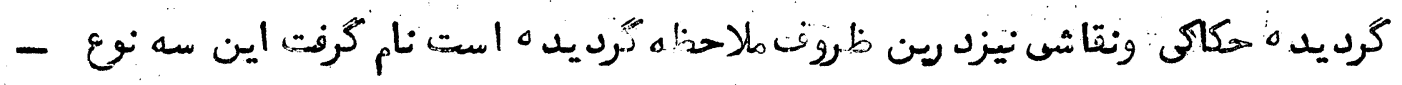

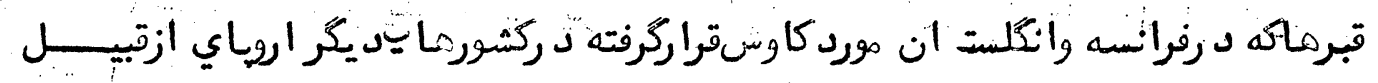

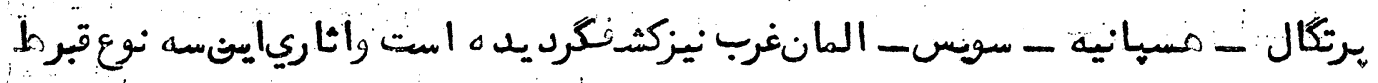

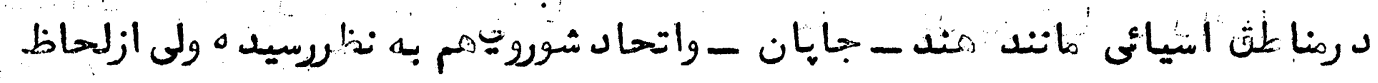

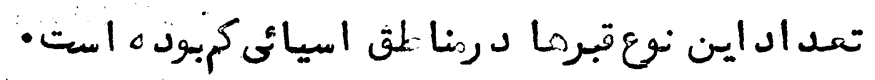

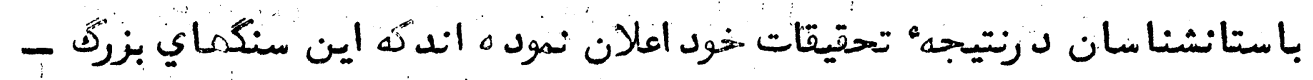

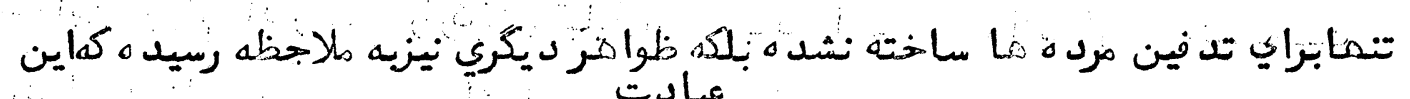

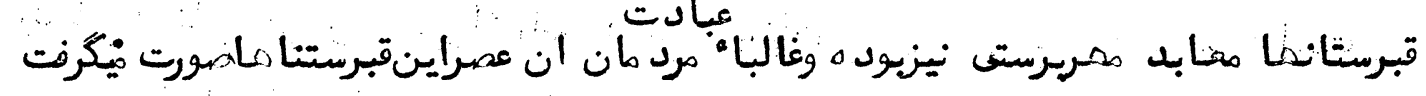

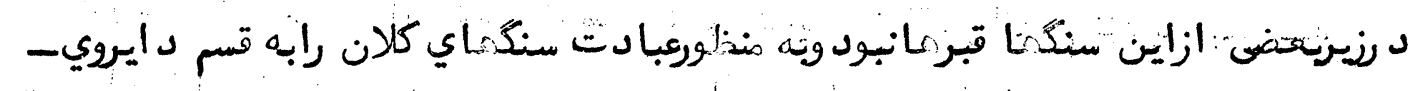

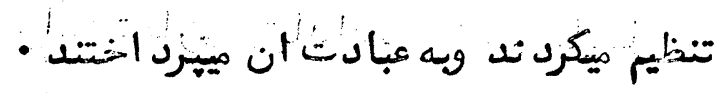

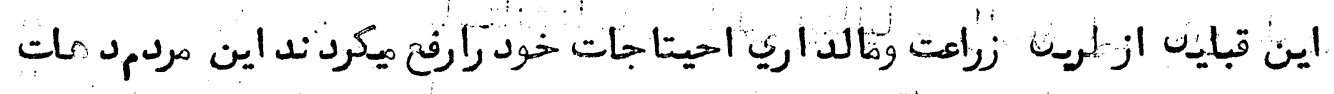

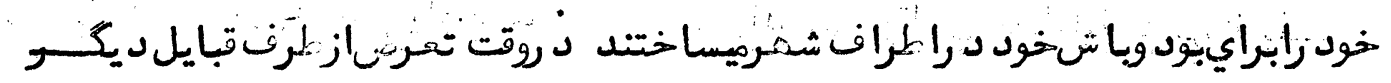




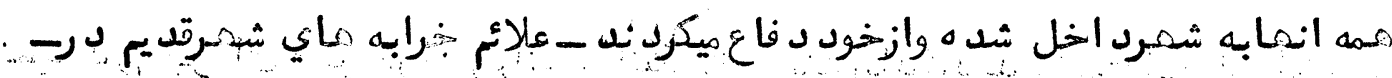

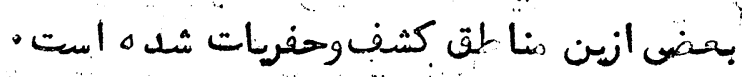

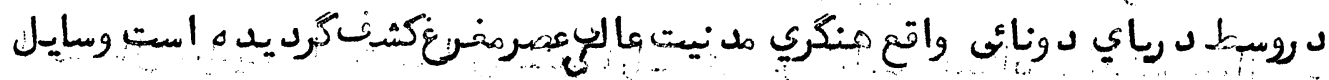

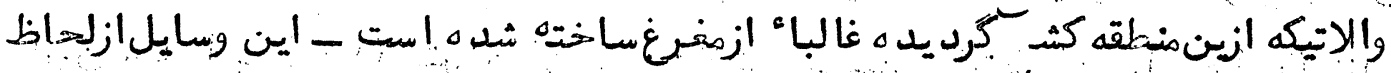

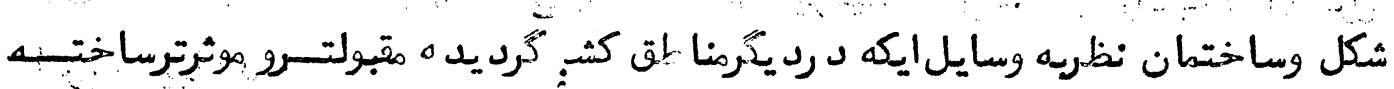

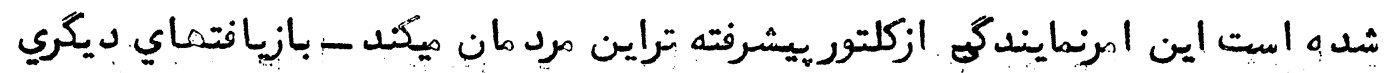

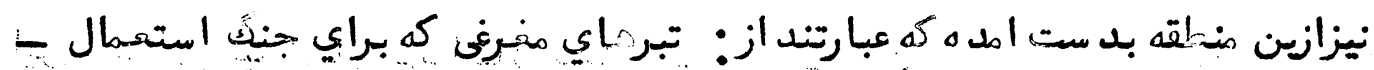

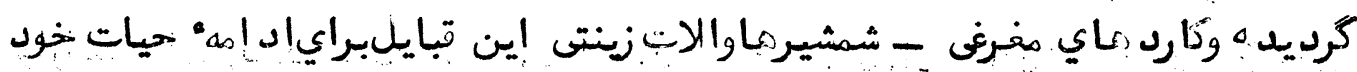

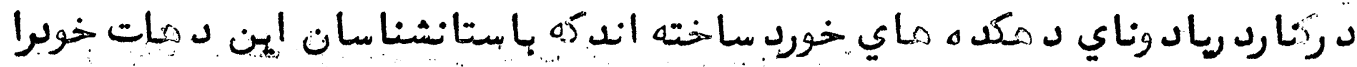

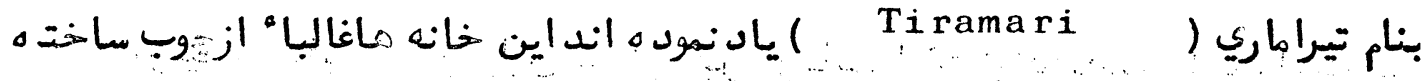
شده باخانه مائي كه د رشمريانا كثبفكرديده ازلحاظ شكلوسا ختمان مثابه اندولى

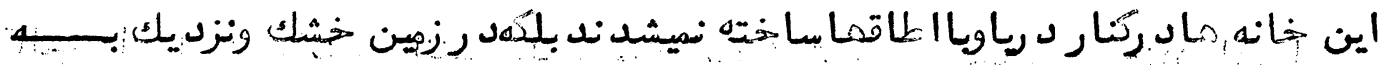

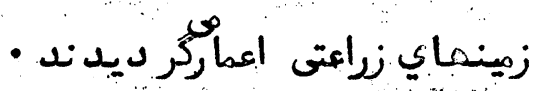

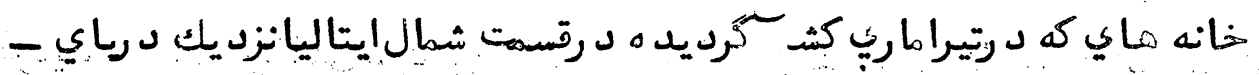

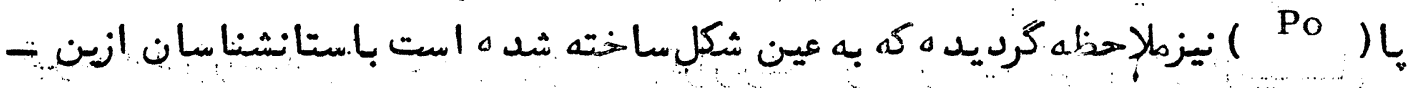

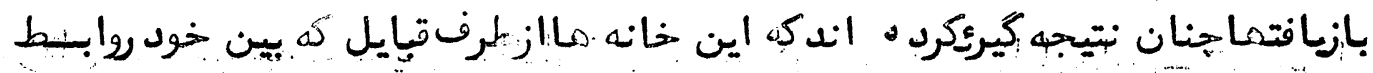

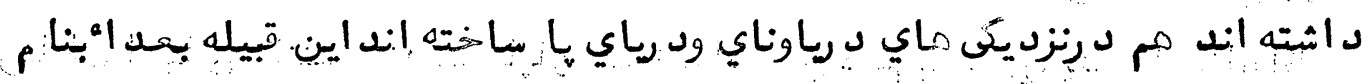

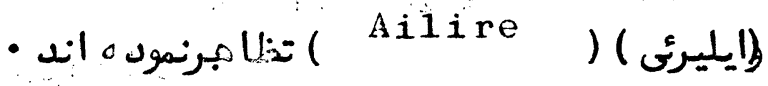

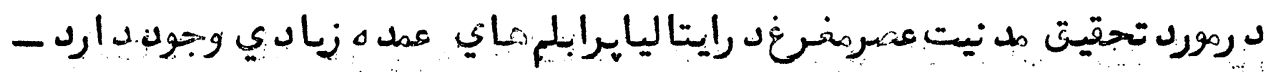

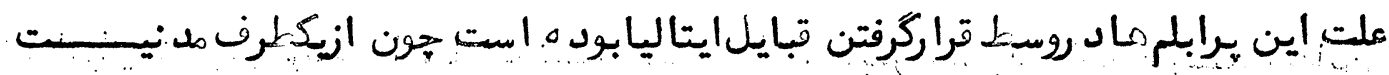

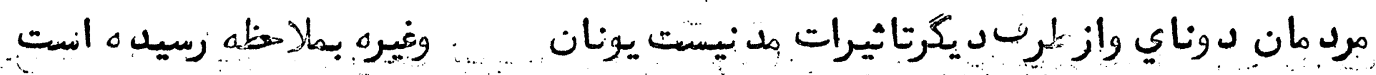

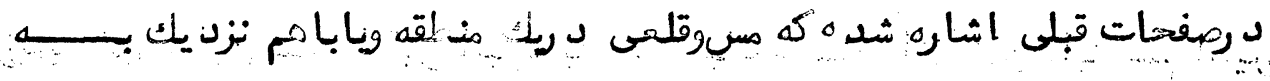

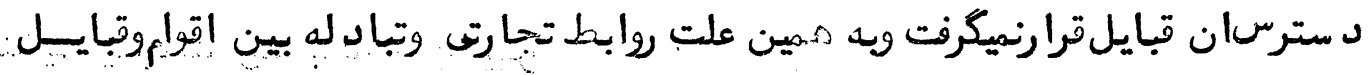

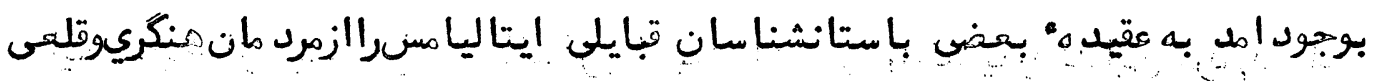

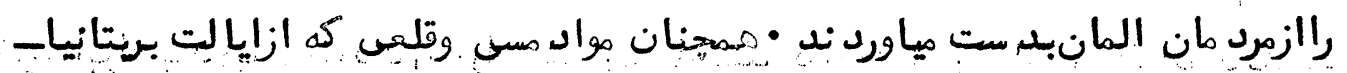


1.1

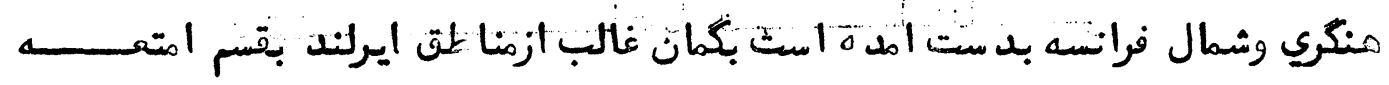

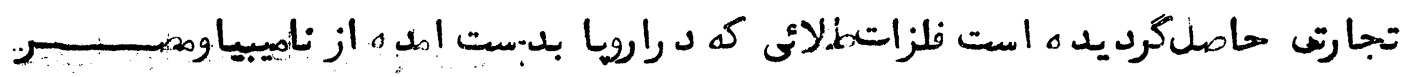

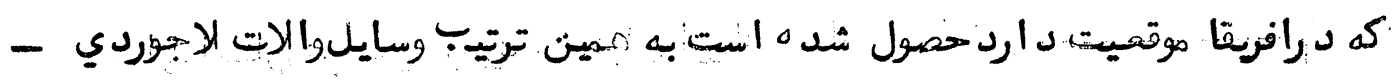

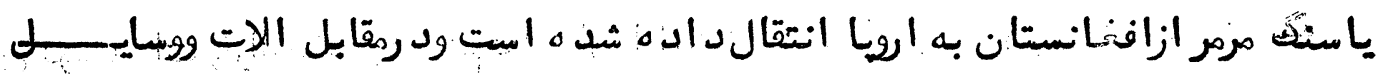

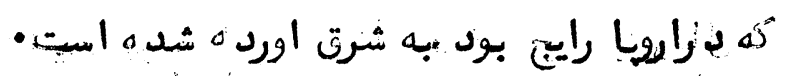

2. 2:

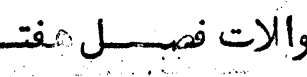

|

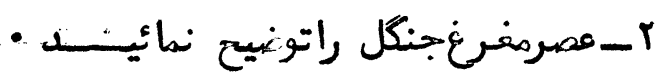

- م-ازاثارعصر مـرغ رارواي غرى نام بكيريد

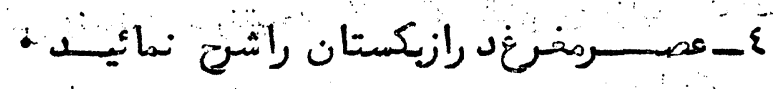

0- مدموبيات وتاثيرات رايج شدن الات مغرغى راتوضيح نمائيد - 


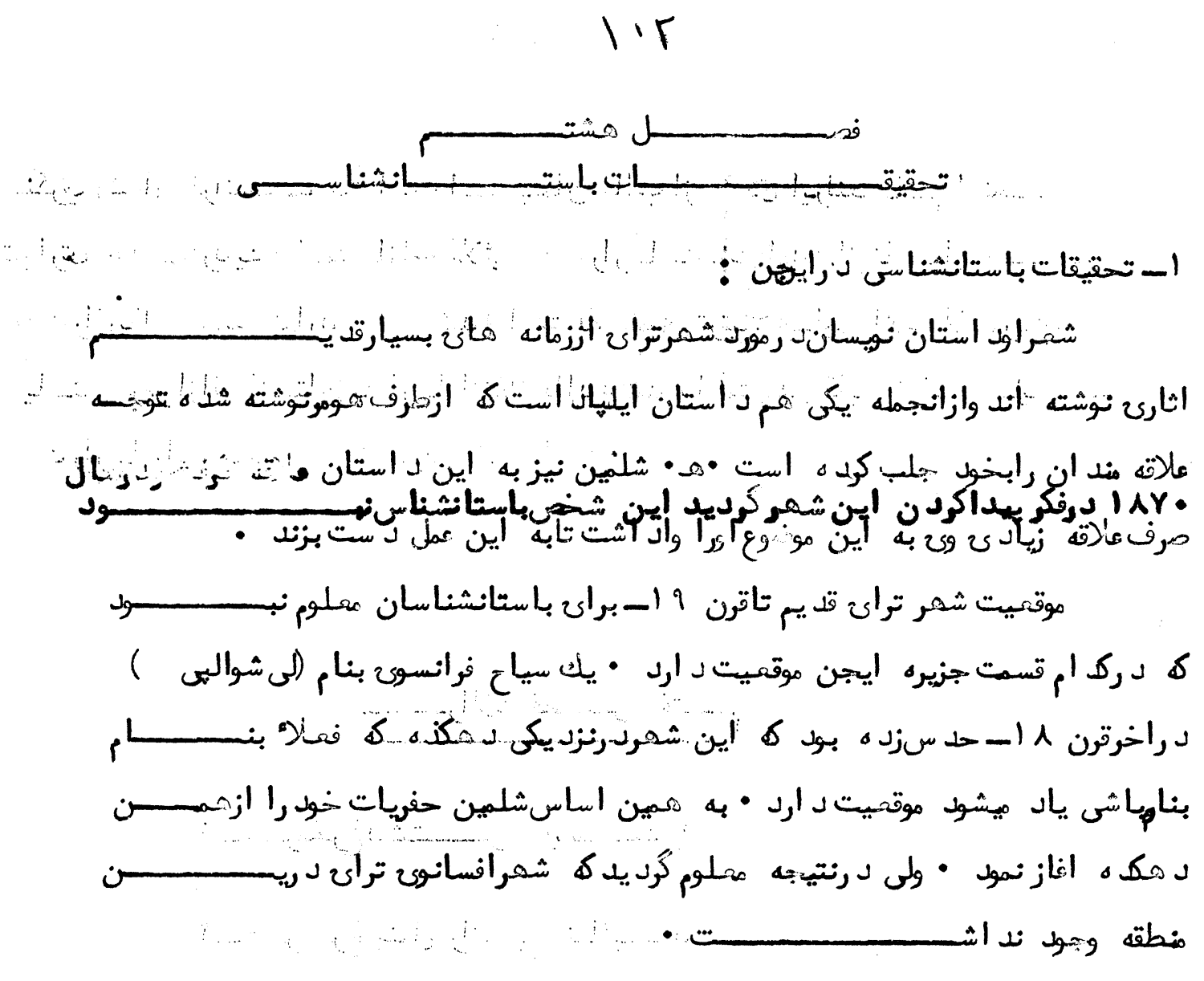

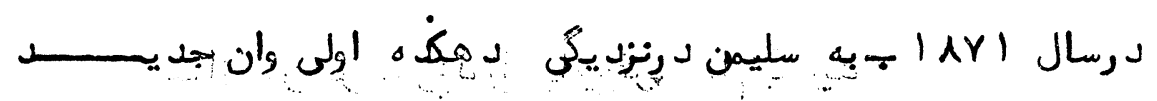

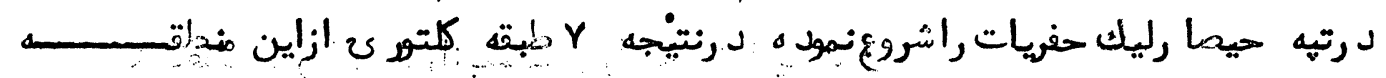

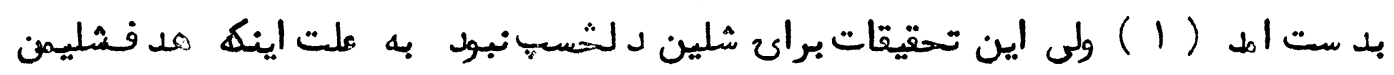

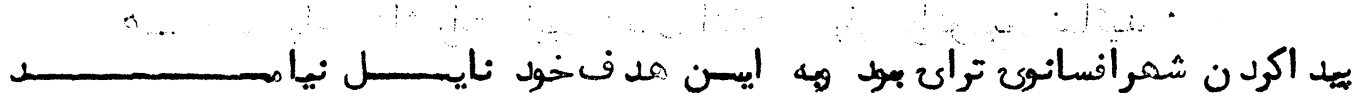

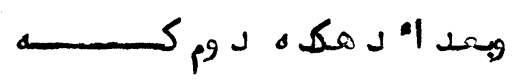

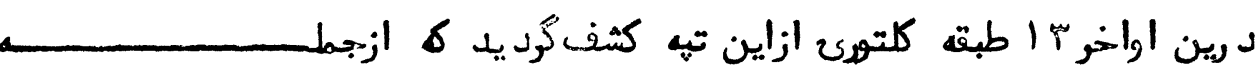

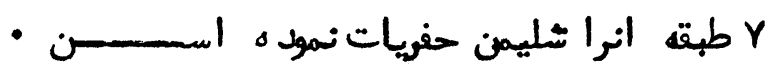




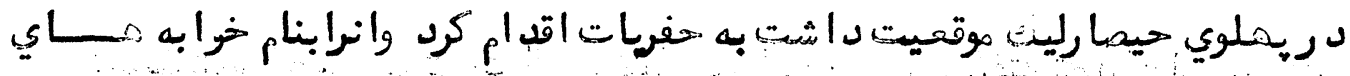

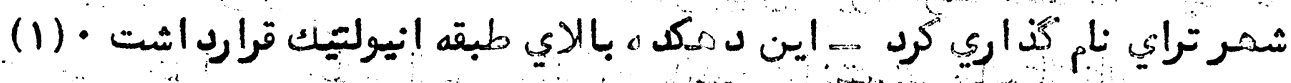

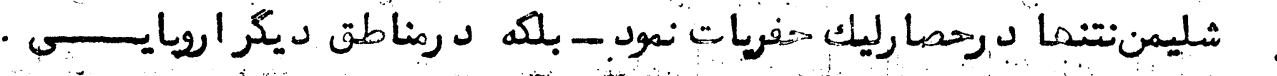

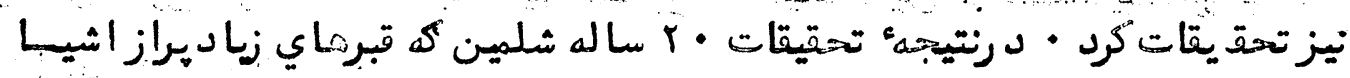

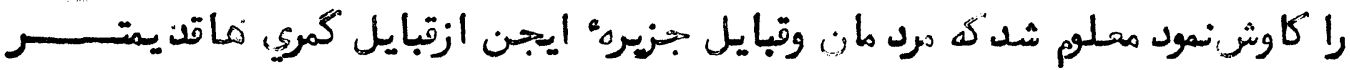

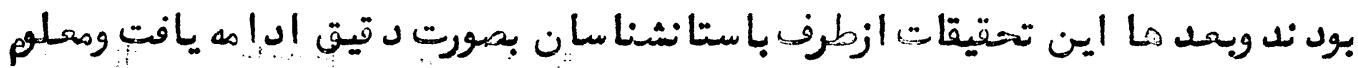

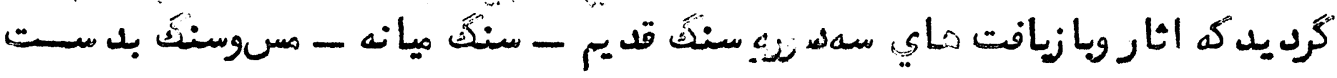

l

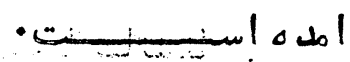

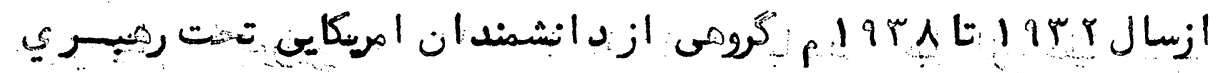

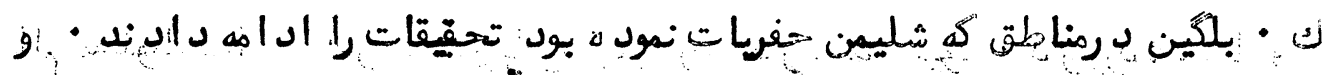

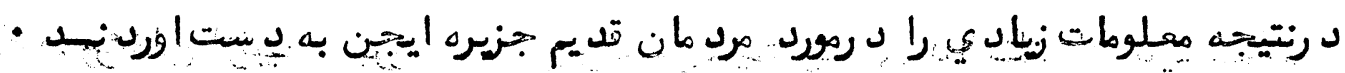

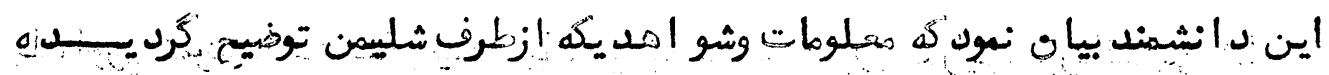

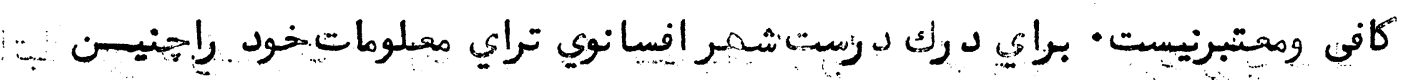
ارائه كرد

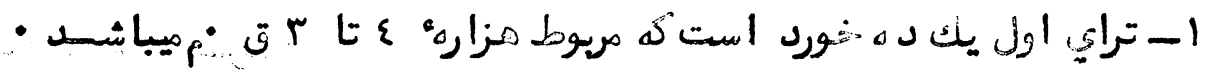

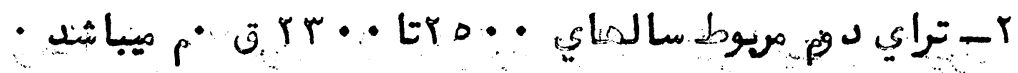

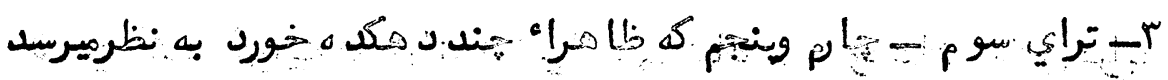

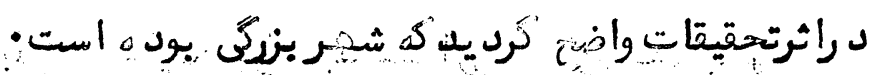

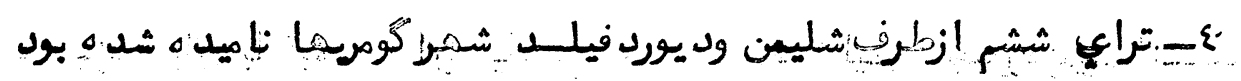

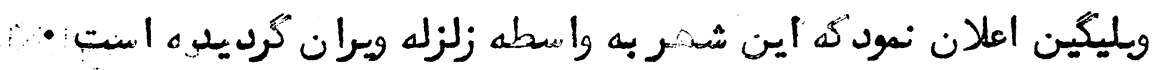

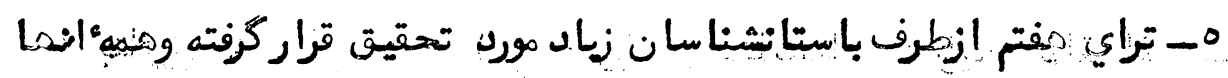

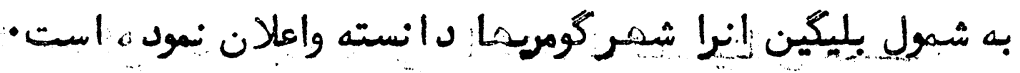

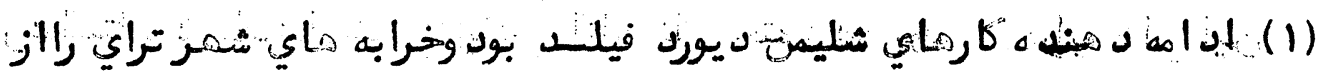

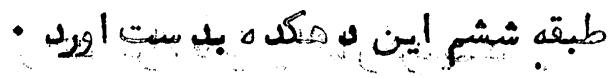




\section{$\cdot r^{2}$}

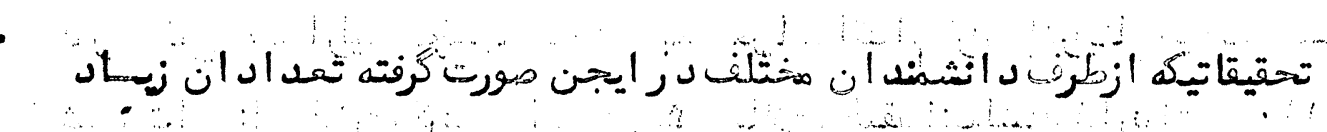

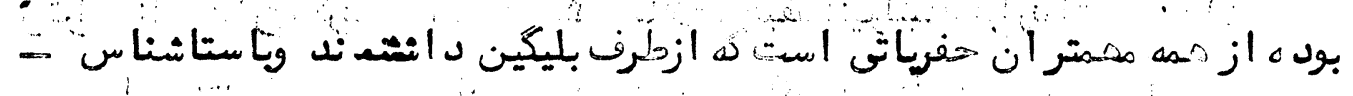

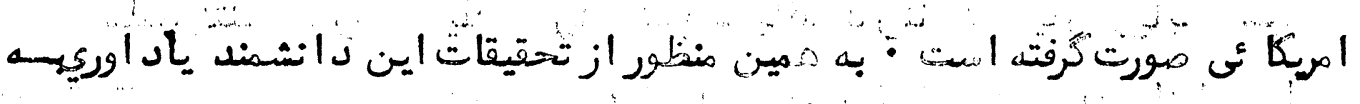

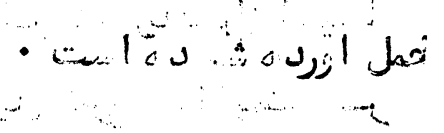
: r

مهلومات د روورد كلتور مرد مان قديم كريت سريوط به تحقيقات باستانتسنا سبق

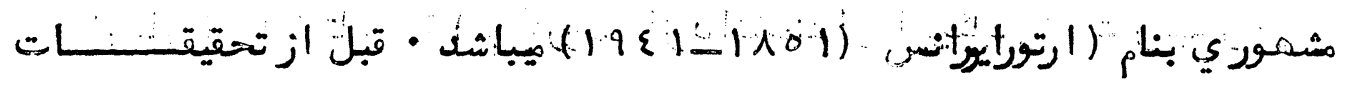

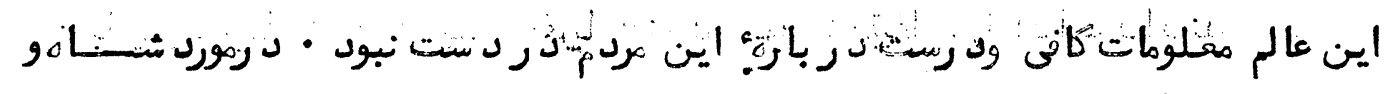

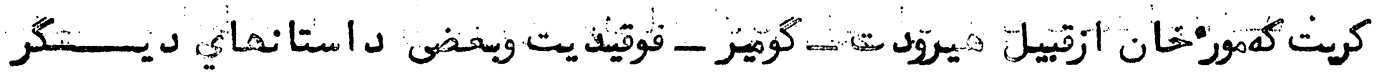

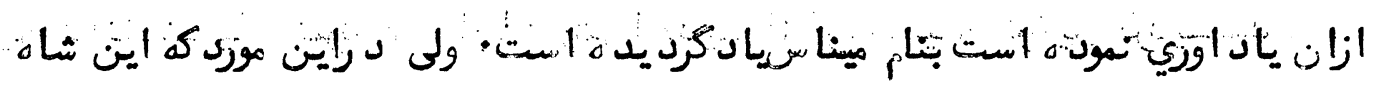

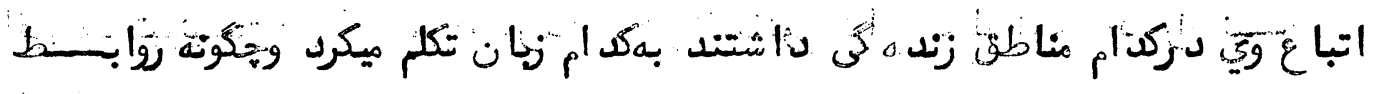

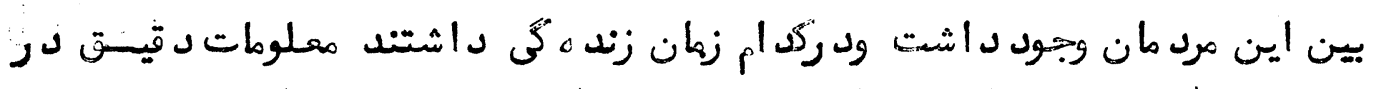

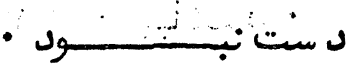

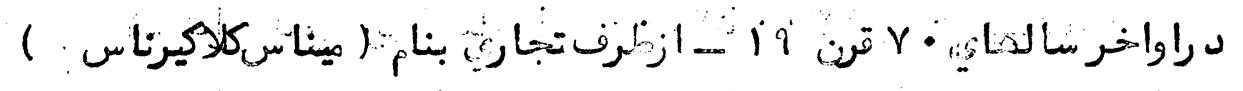

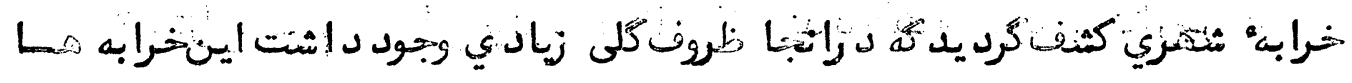

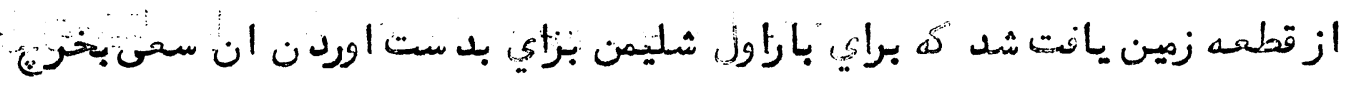

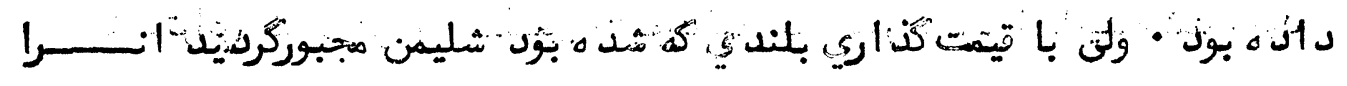

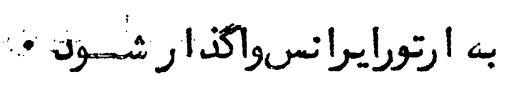

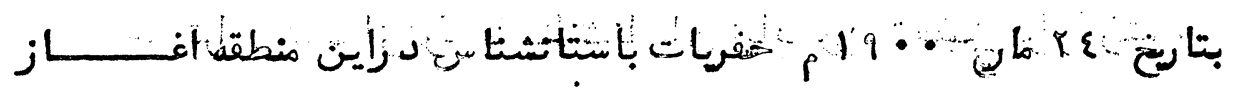

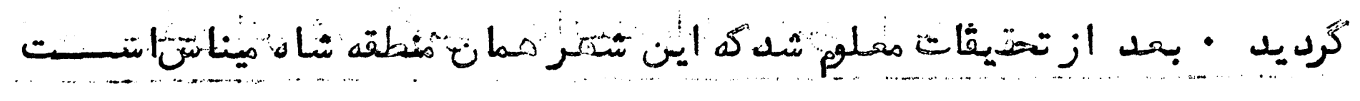

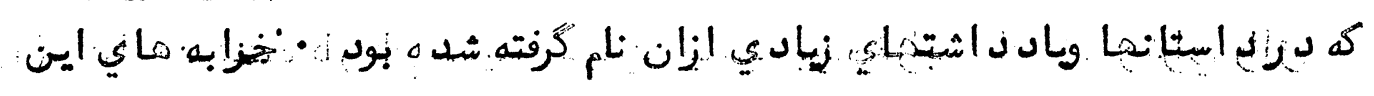

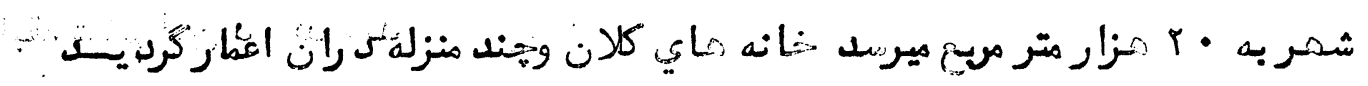




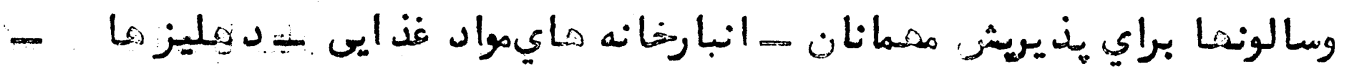
تشنا بها براي نظافت وغيره د ران به نغالر رسيد ه است.

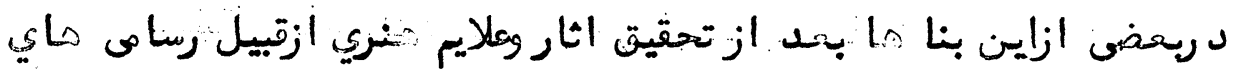

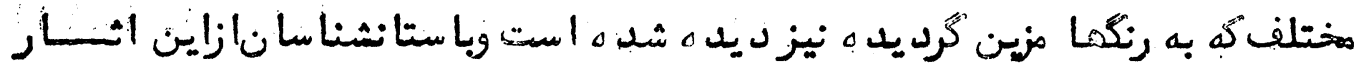

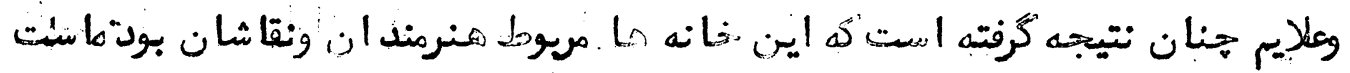

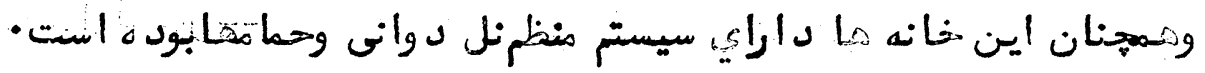

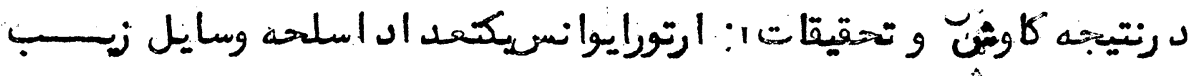

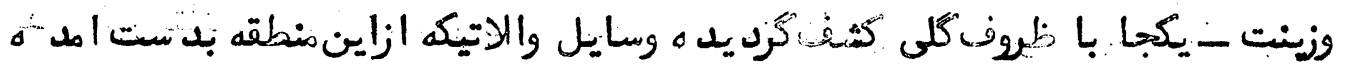

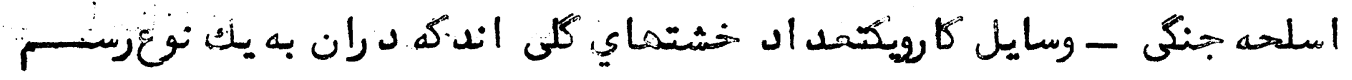

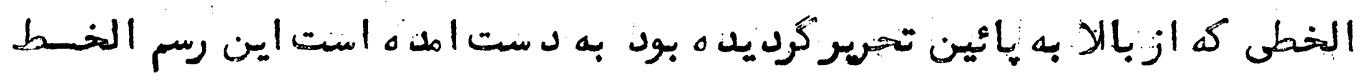

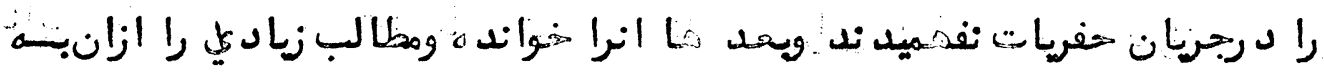

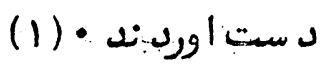

لد انشمند مذكور مد نيت اين مرد مان را زاد ه؛ زخطات وسعى ان مرد مانوإنعود

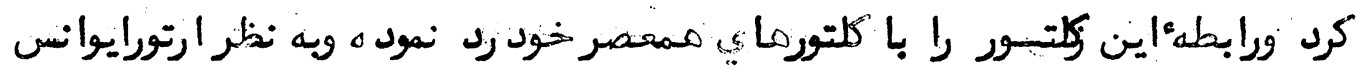

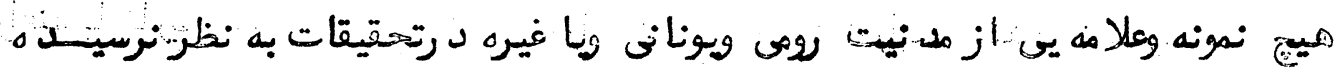

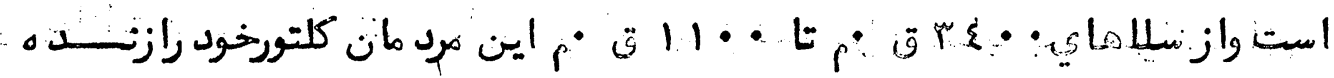

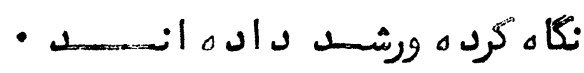

لد ريملوي تحقيقات باستانثبناسى ارتورايوا نستحقيقات و حفريات لد رمناطقة

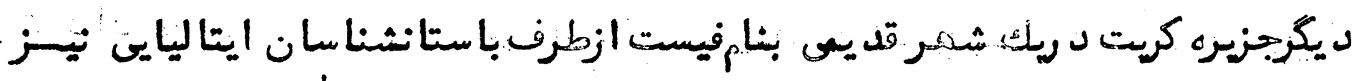

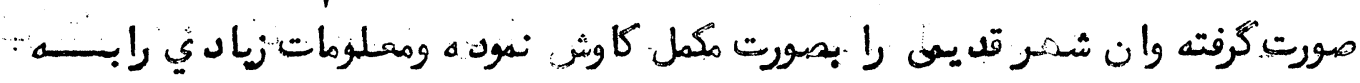

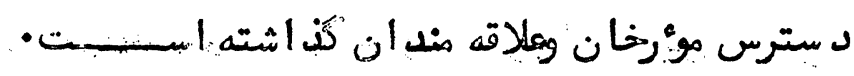

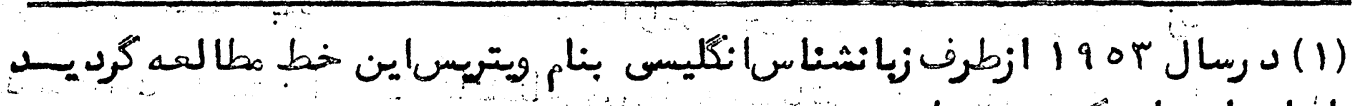

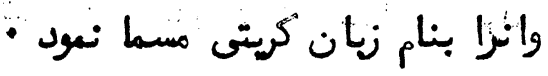




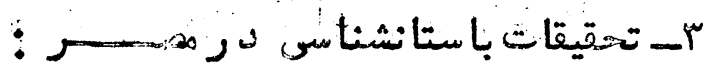

ثحقيقات باستانشناسي لبوهوروابسته بنام باستانشبنا مبفرانسوي (ماري يت)

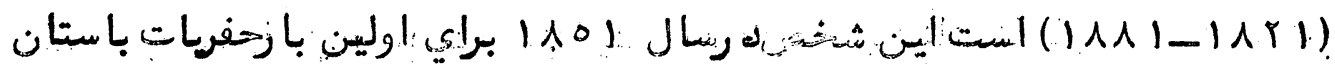

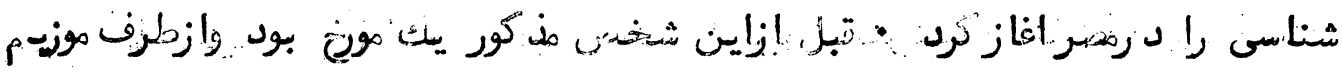

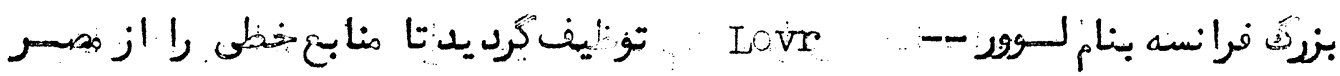

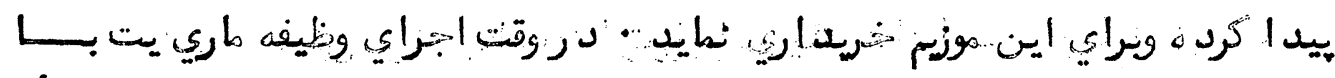

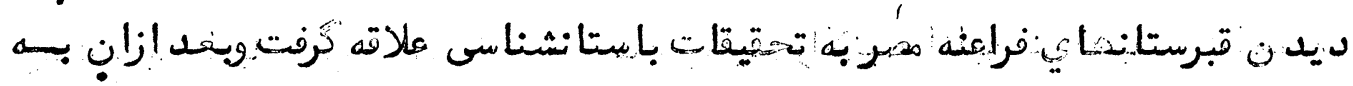

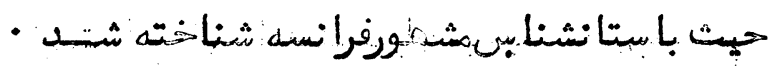

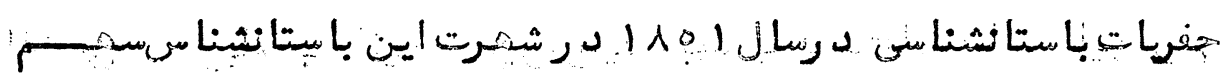

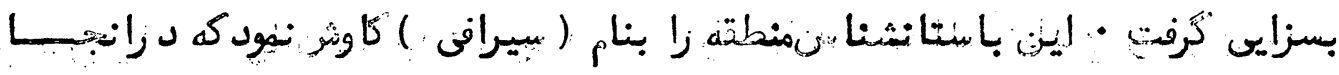

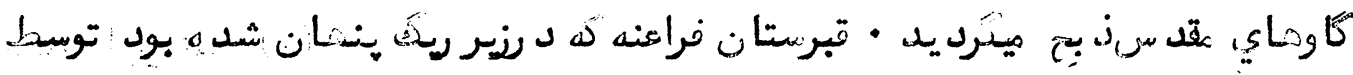

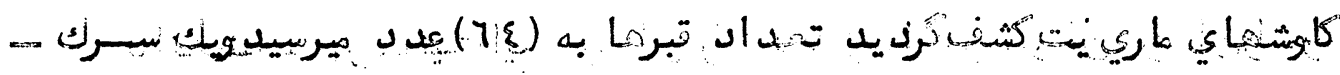

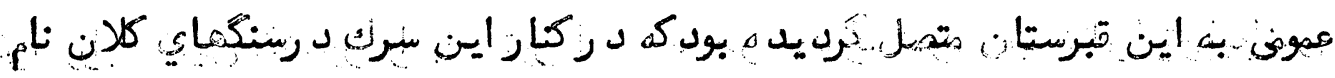

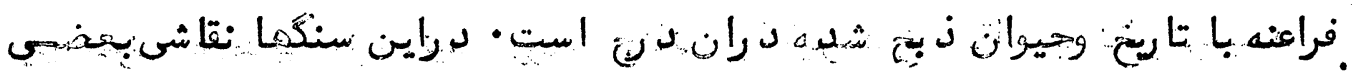

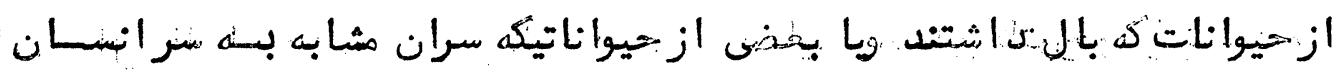

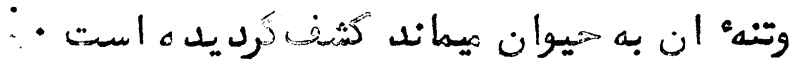

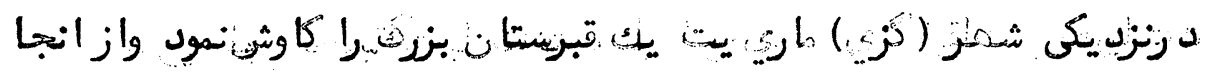

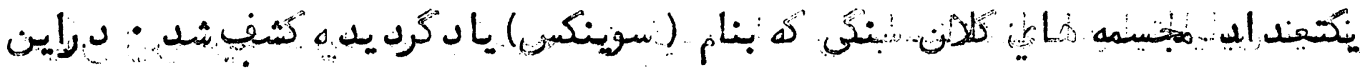

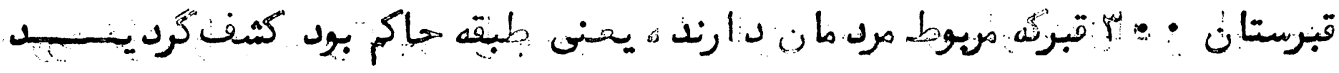

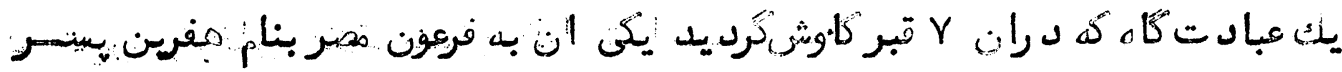

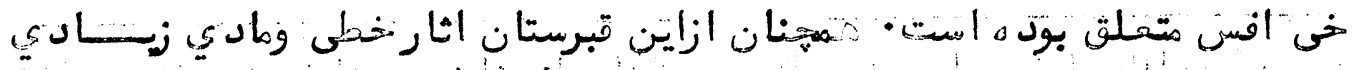

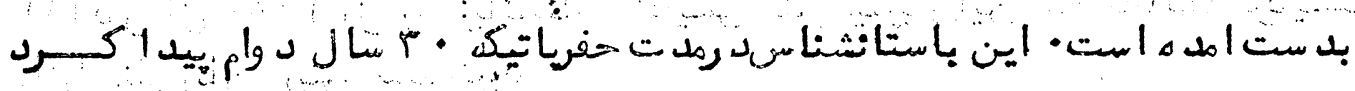




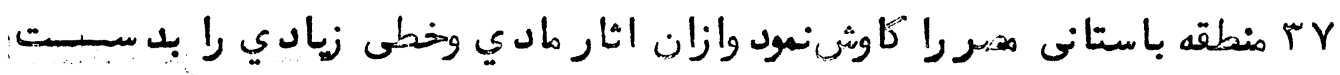

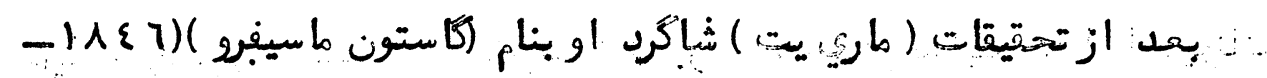

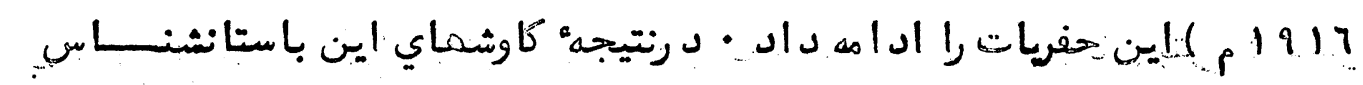

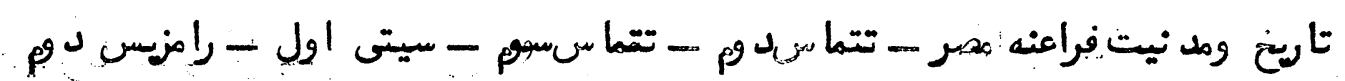

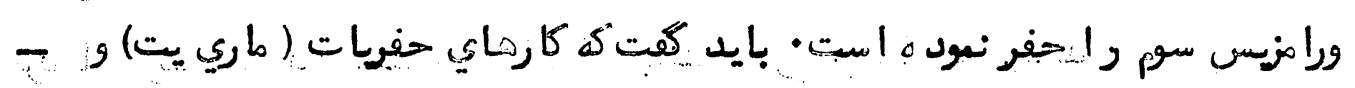

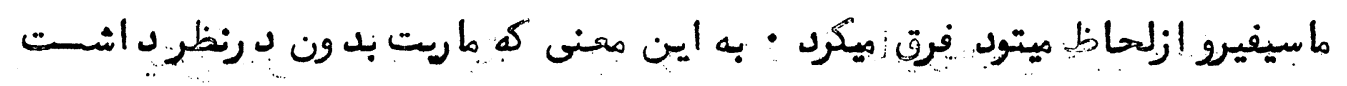

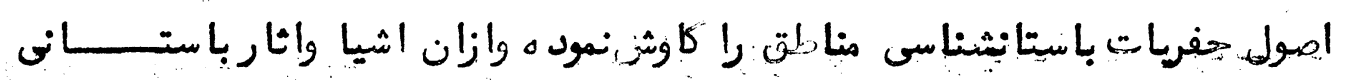

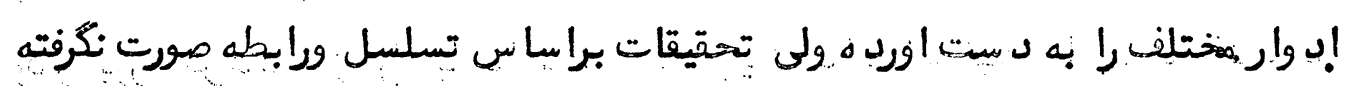

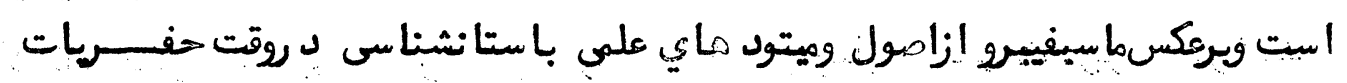

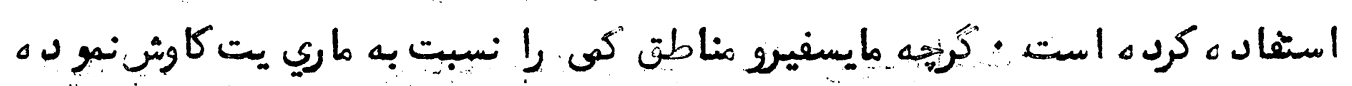

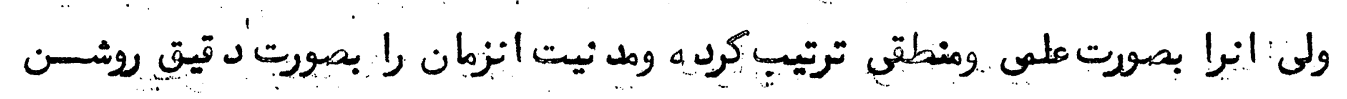
نمودِ ه إن

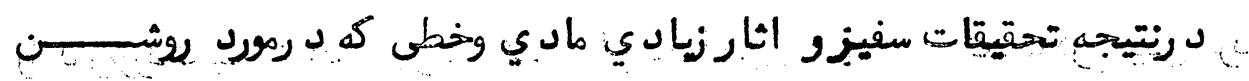

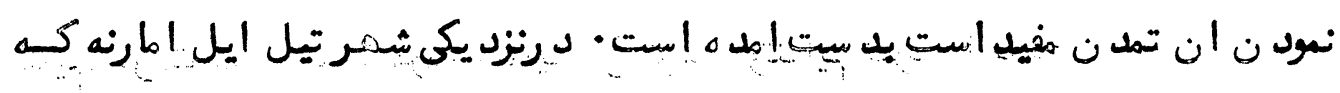

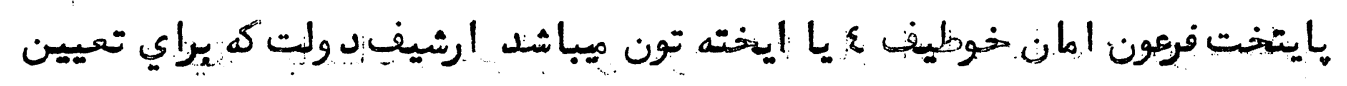

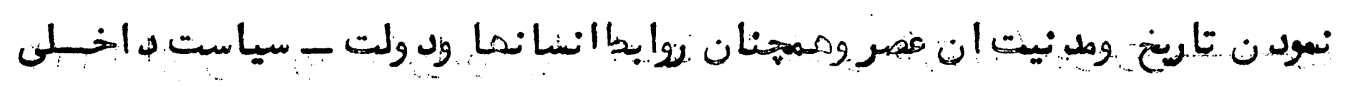

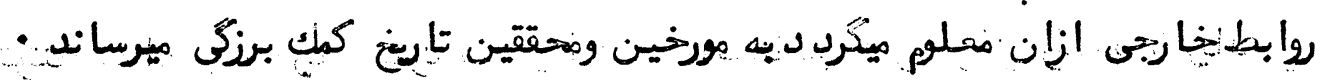

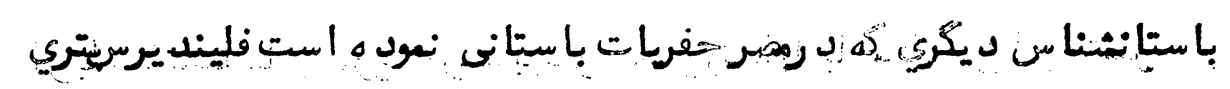

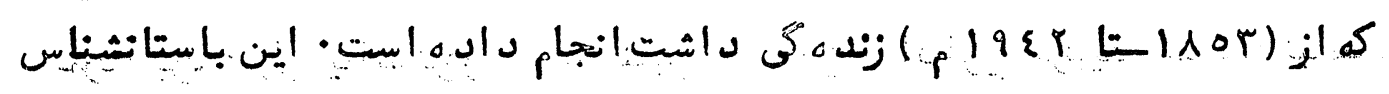

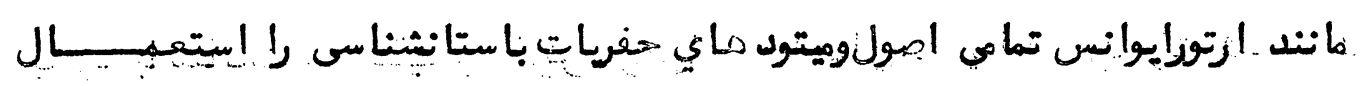

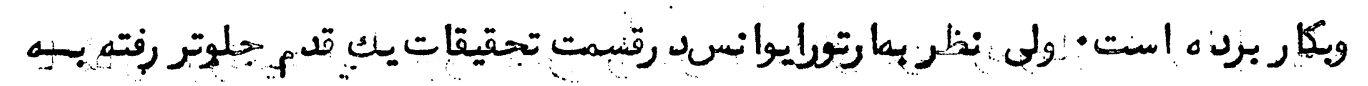

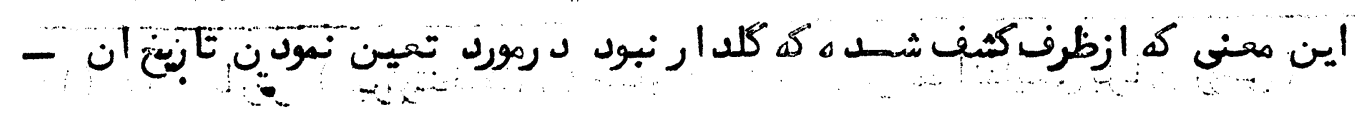


| استفاد ه نموب ه:است)

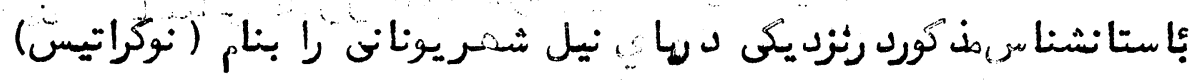

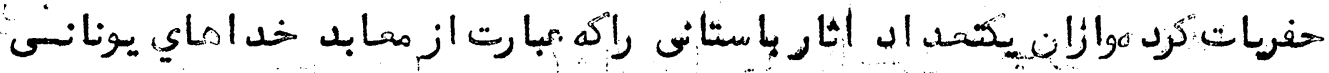

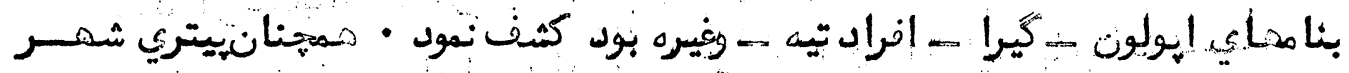

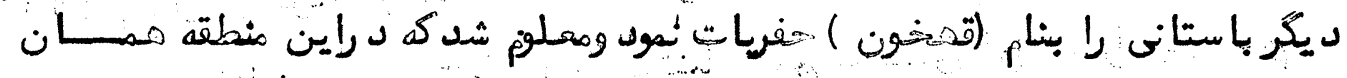

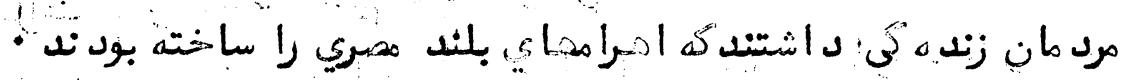

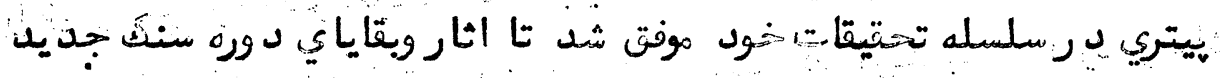

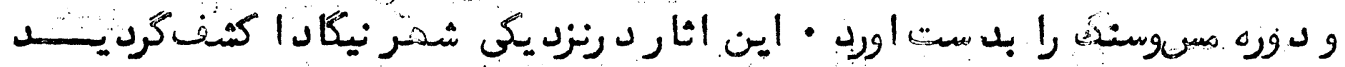

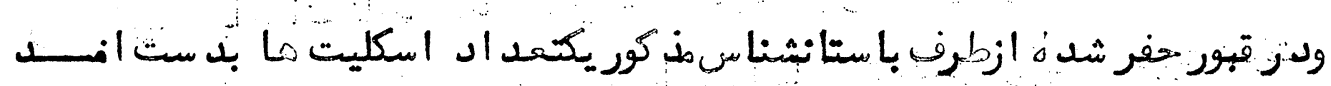

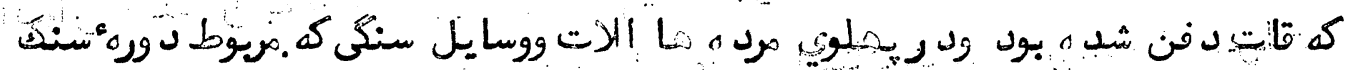

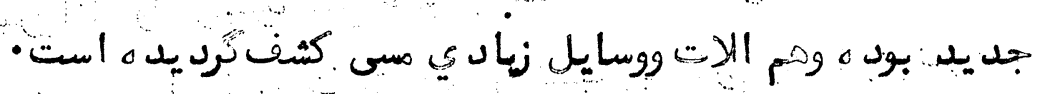

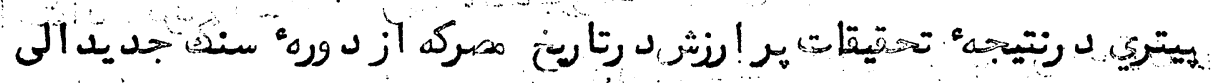

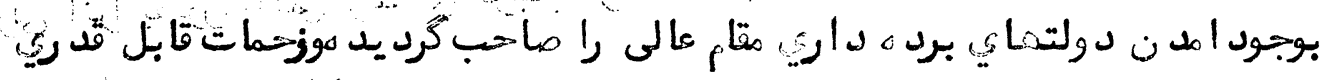

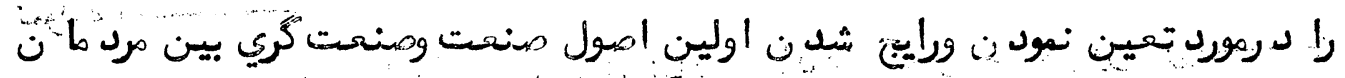

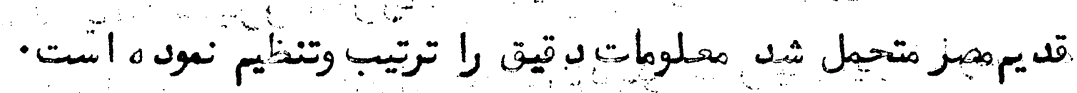

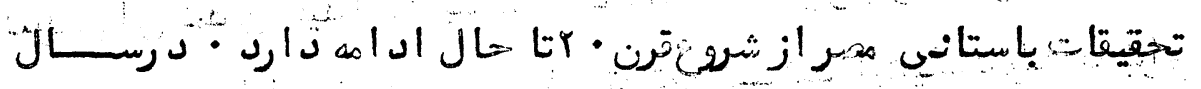

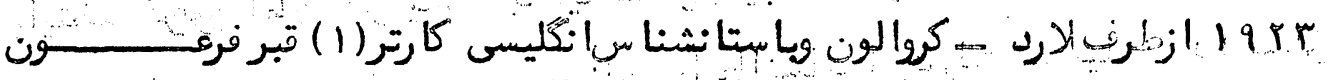

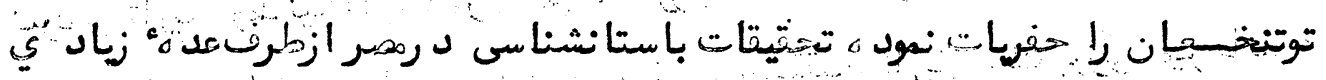

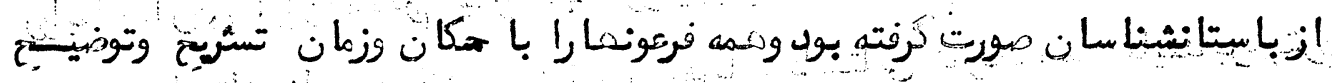

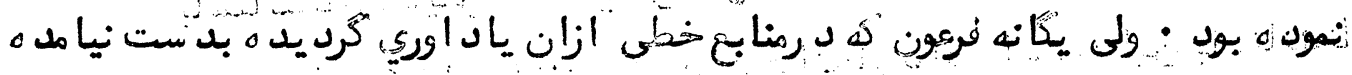

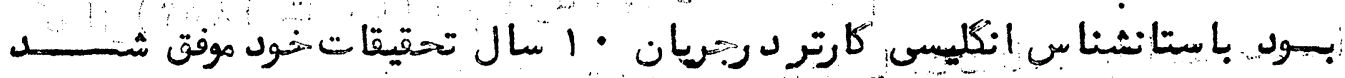

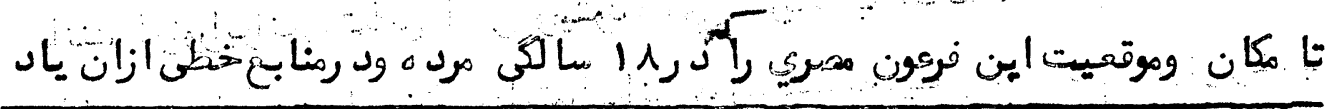

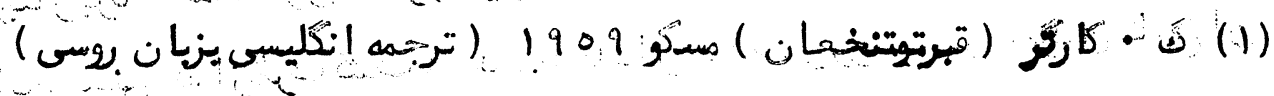


ثنده بود كثيف نمايسـيد

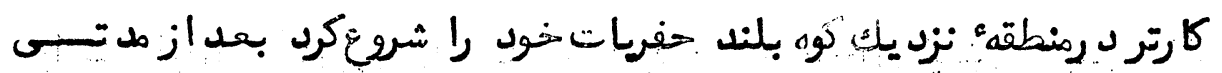

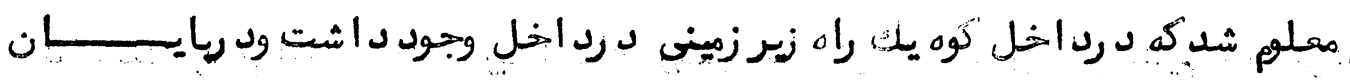

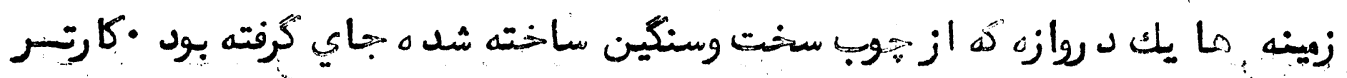

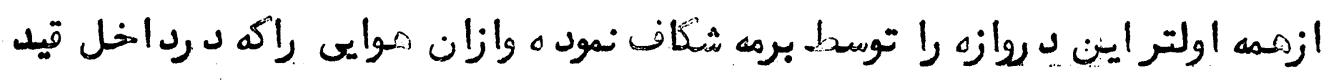

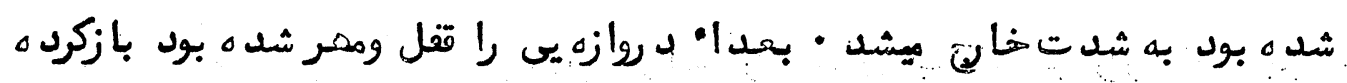

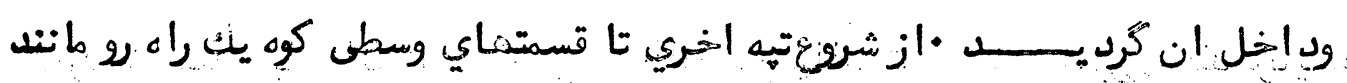

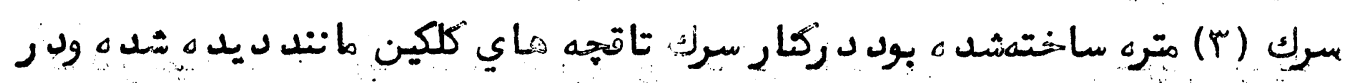

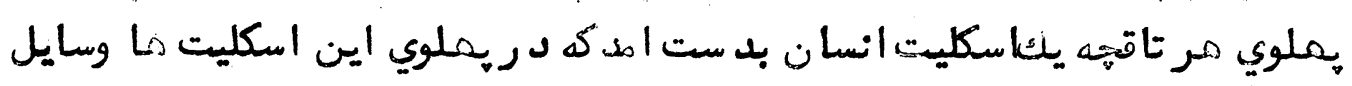

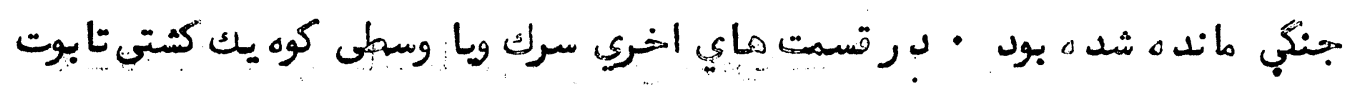

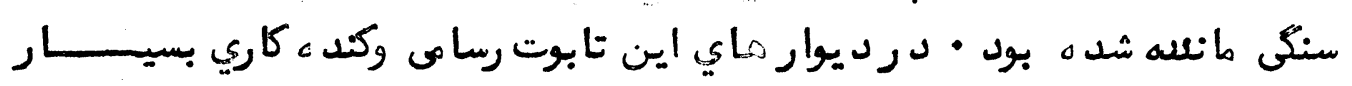

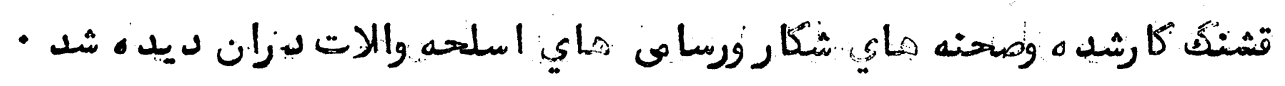

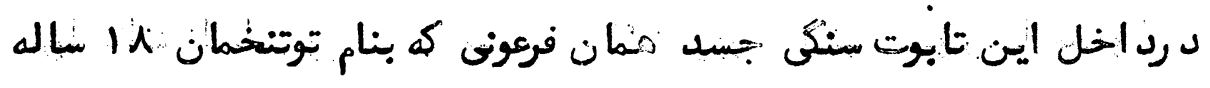

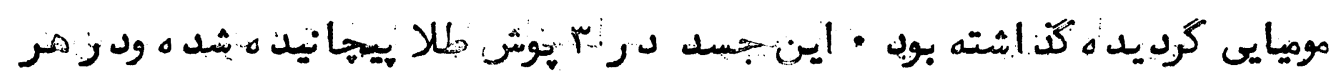

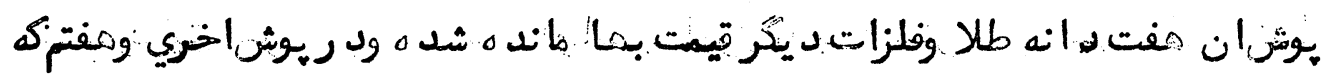

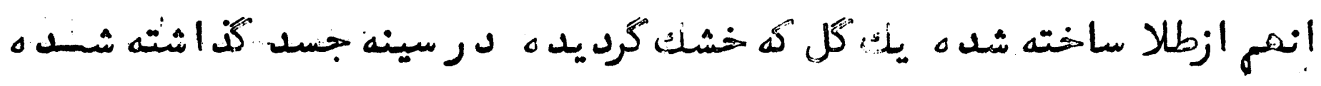

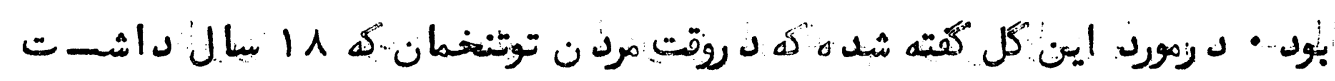

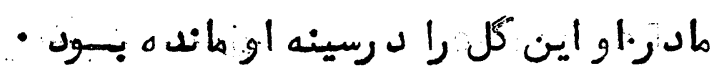
ئ

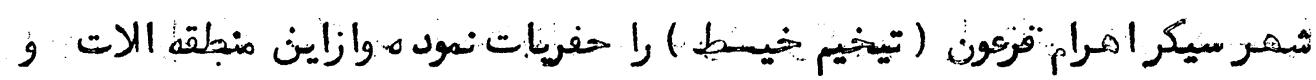

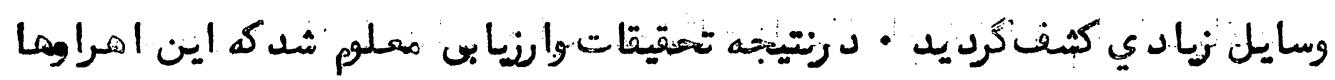

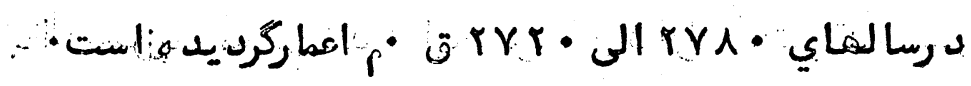

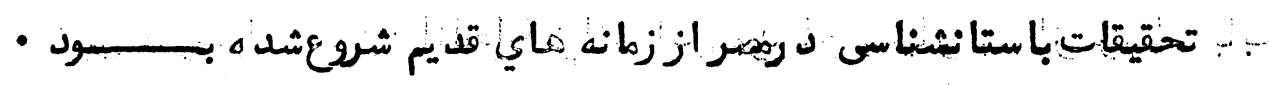

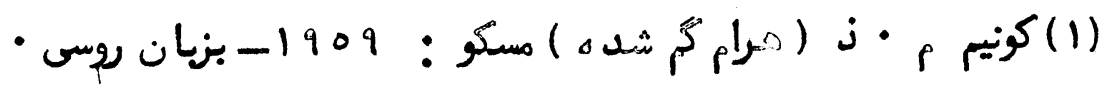


11.

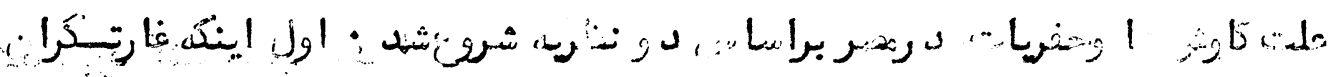

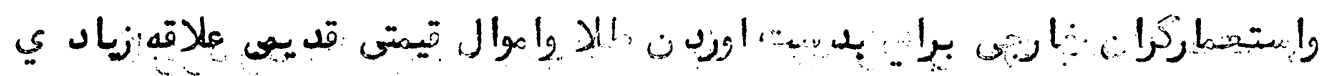

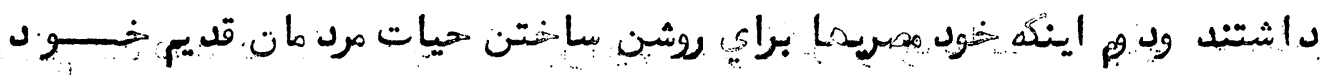

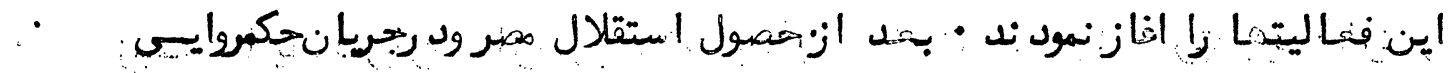

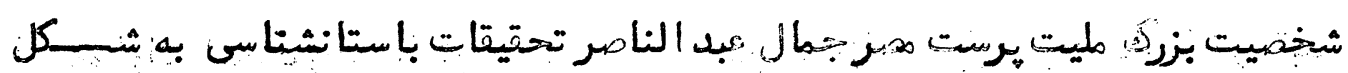

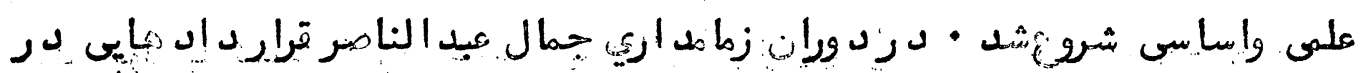

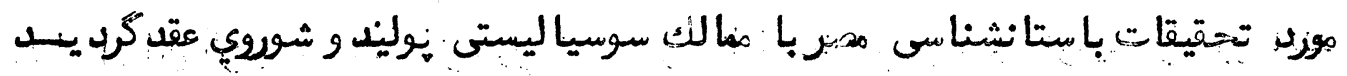

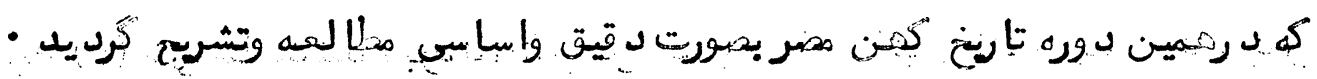

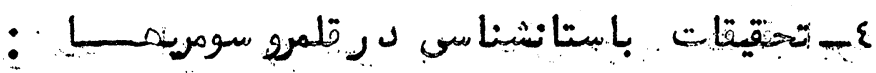

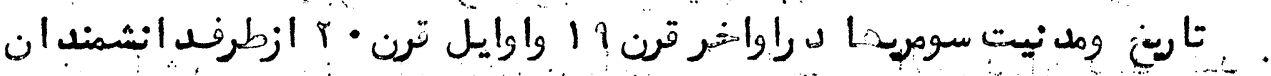

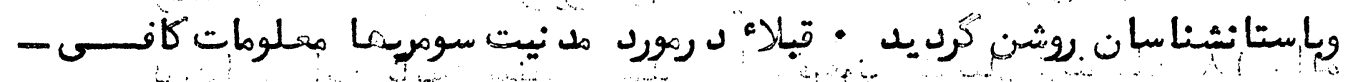

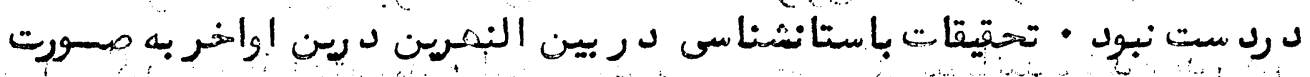

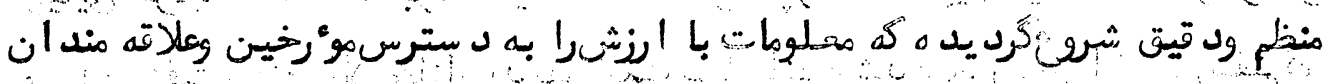
كذا بثنه

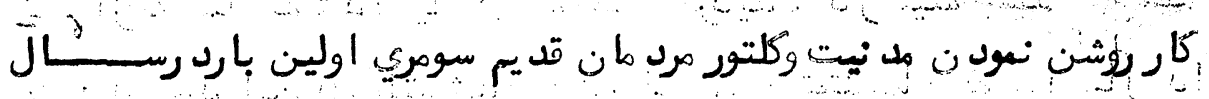

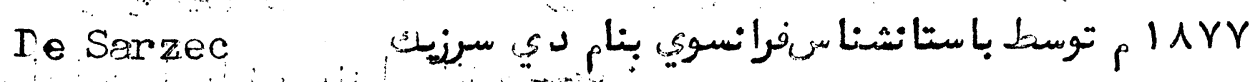

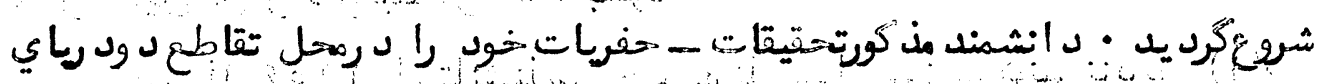

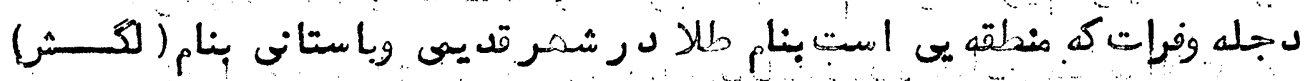

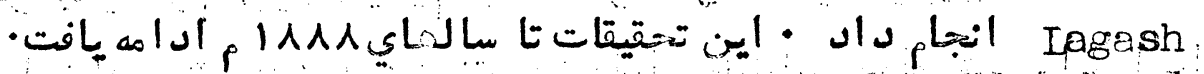

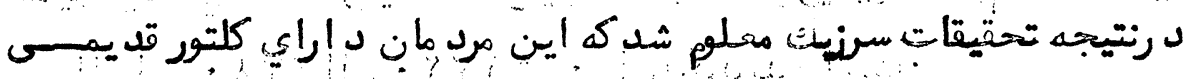

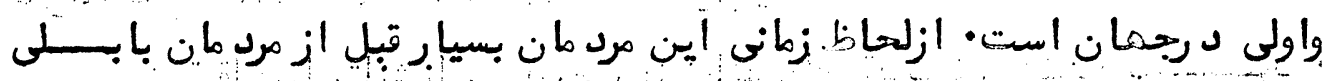


sant

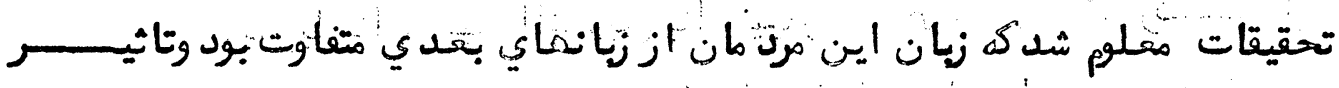

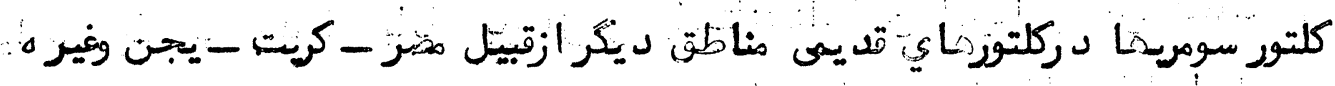

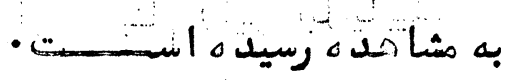

Lagash

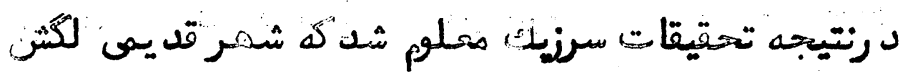

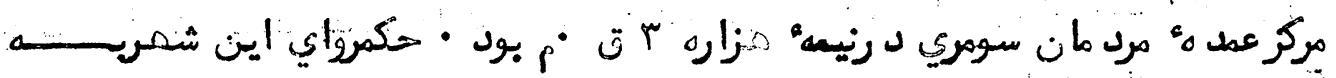

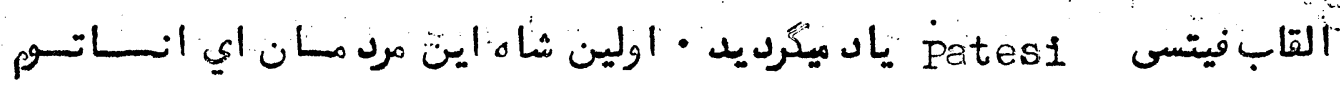
Eanatwom

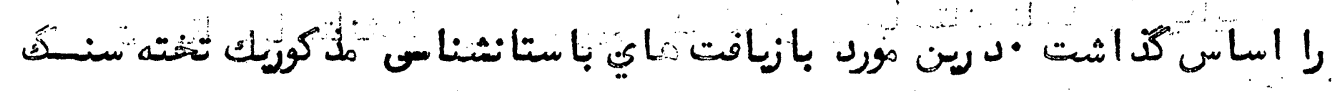

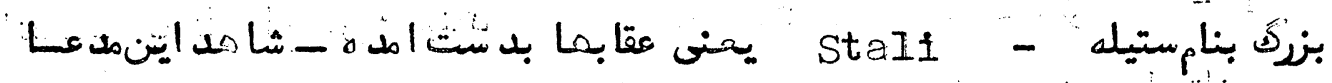

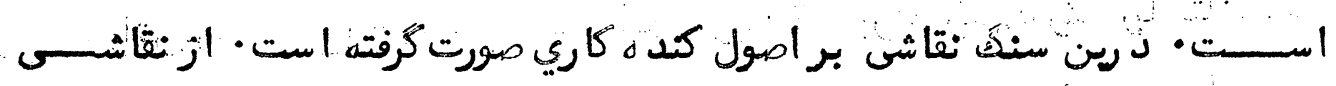

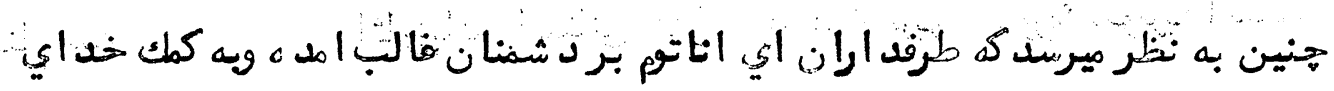

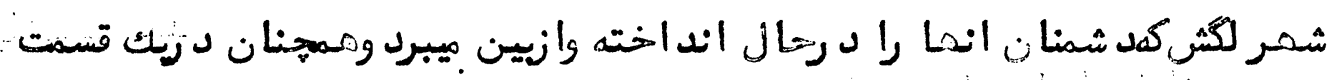

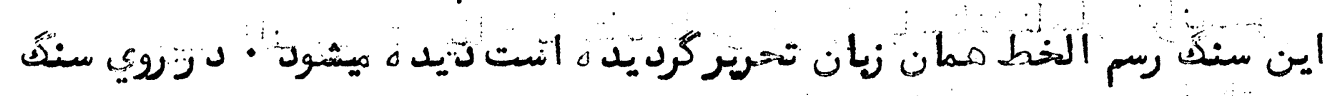

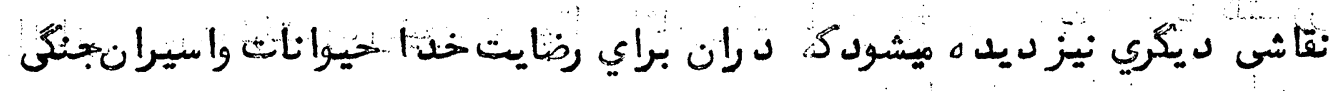

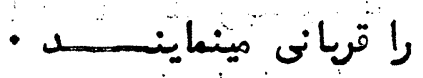

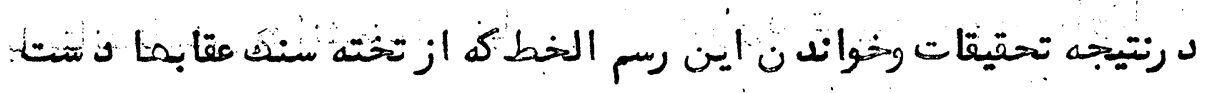

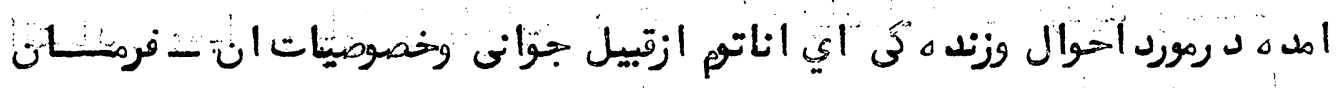

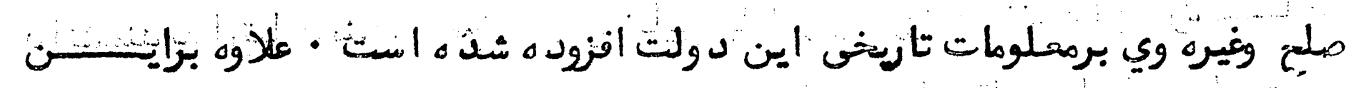

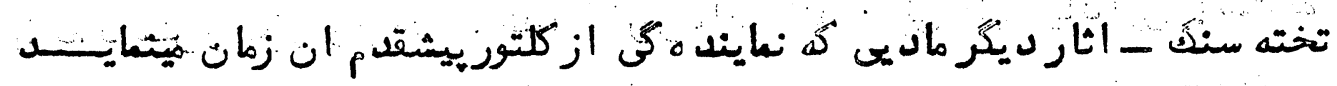

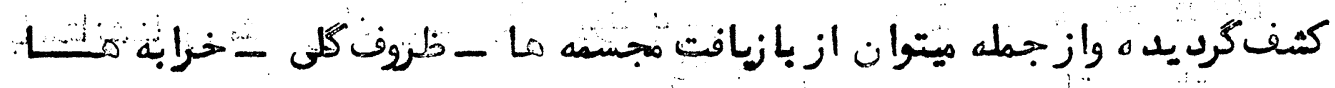

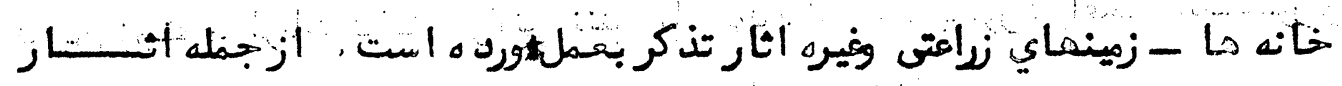

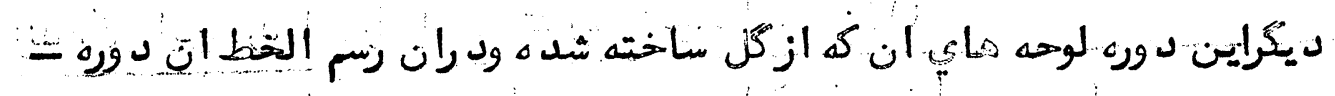




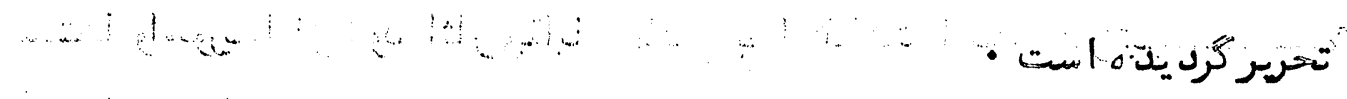

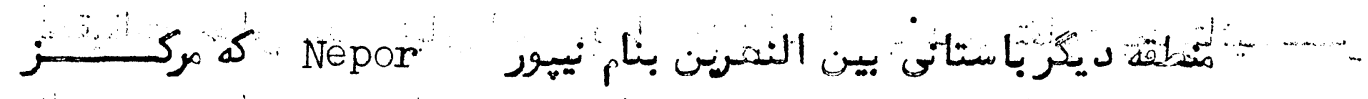

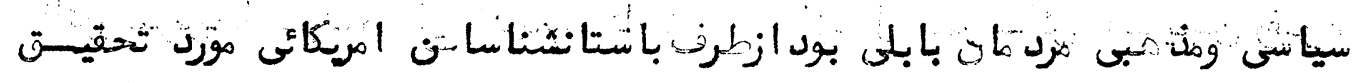

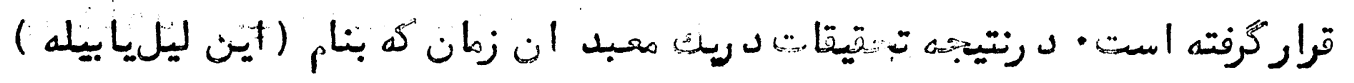

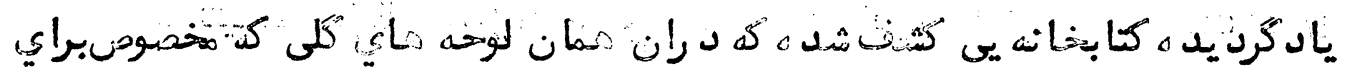

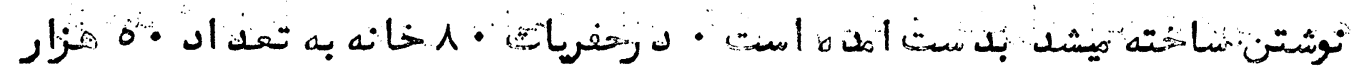

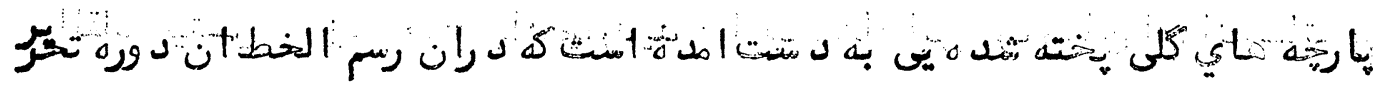
كزئسن

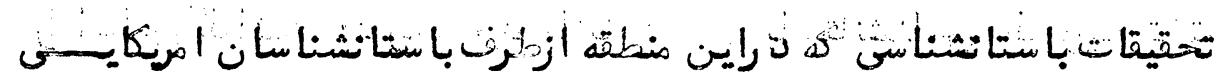

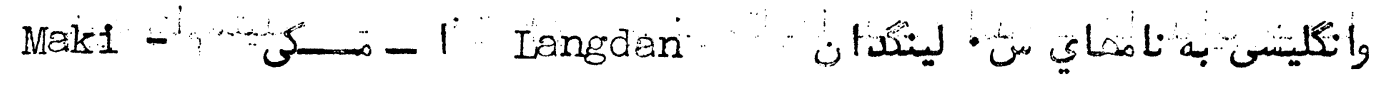

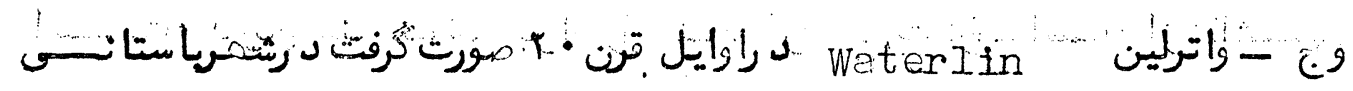

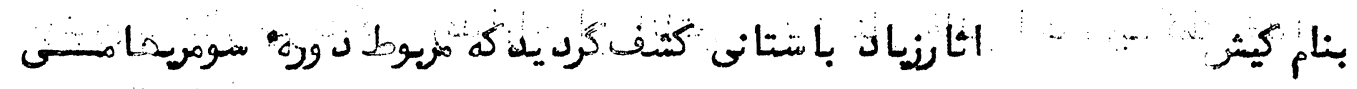

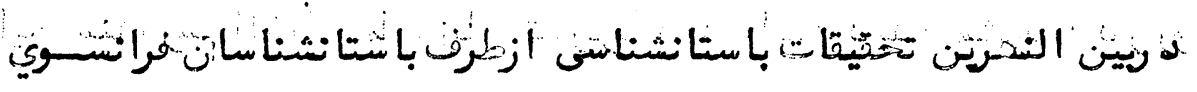

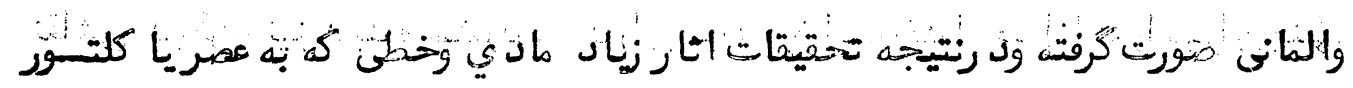

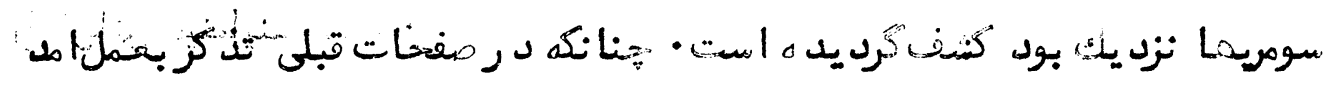

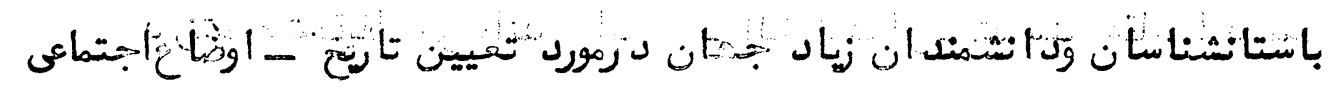

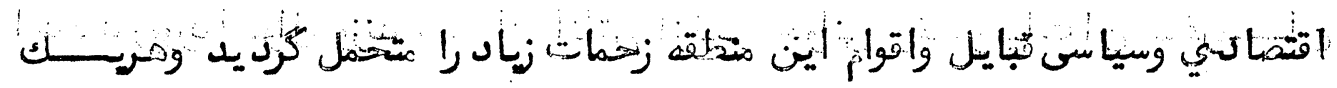

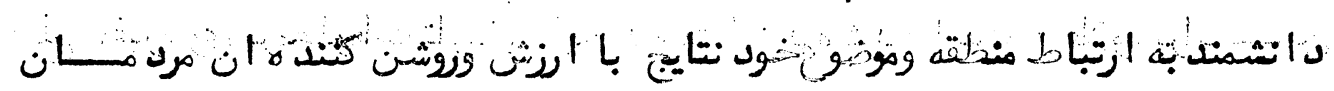

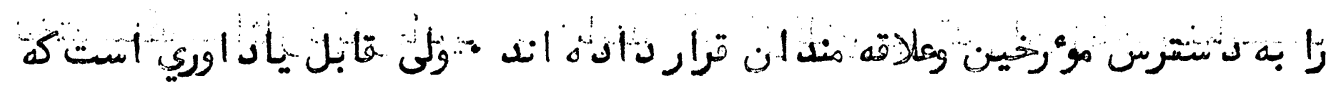

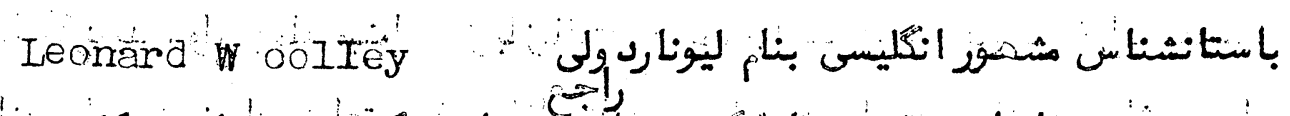

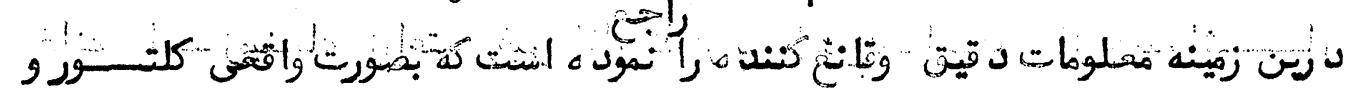

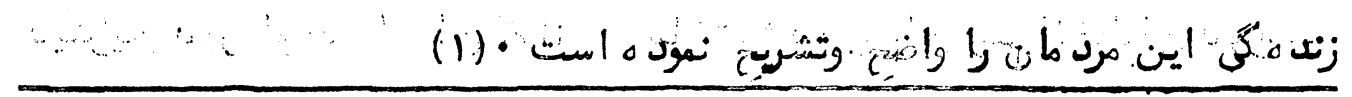

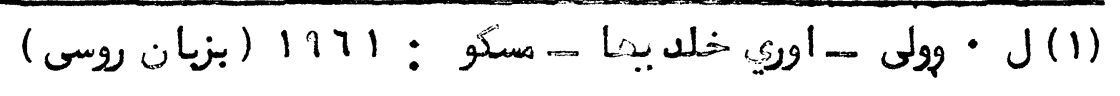




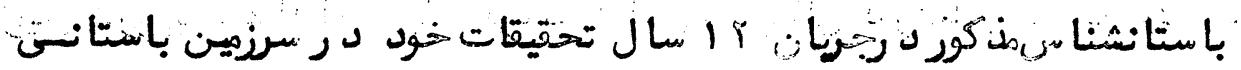

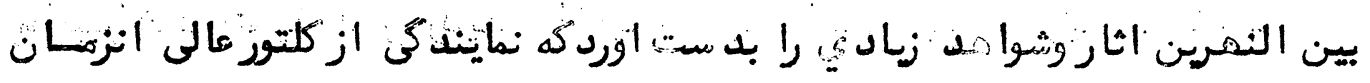

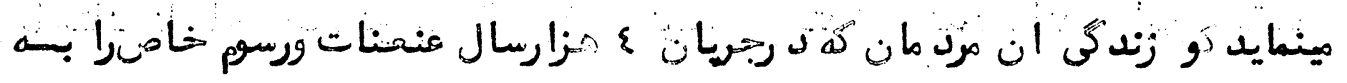

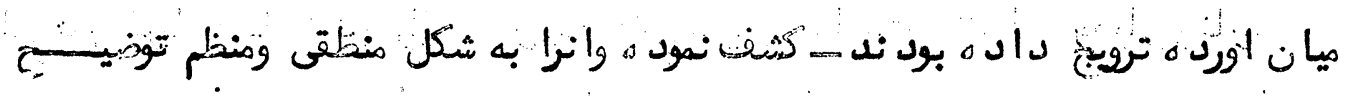

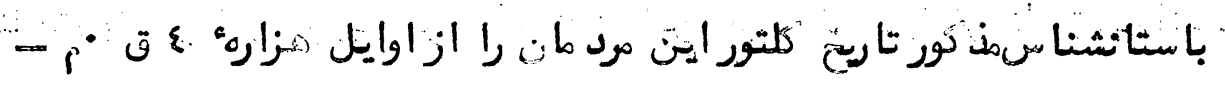

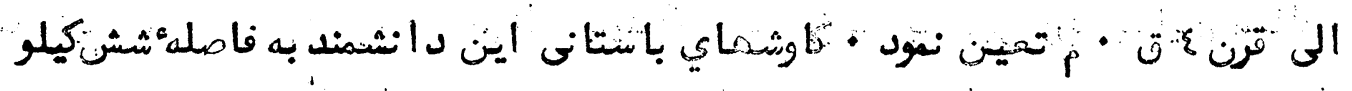

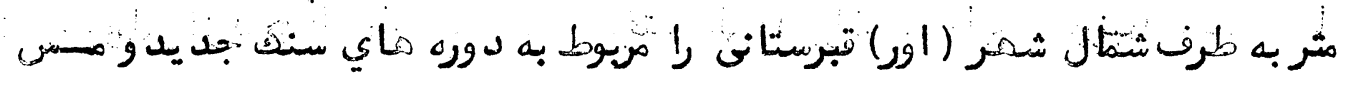

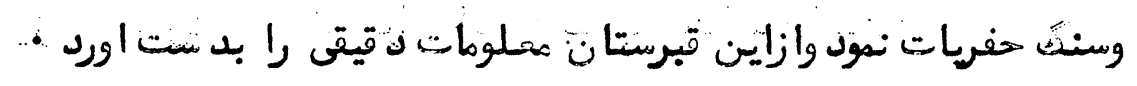

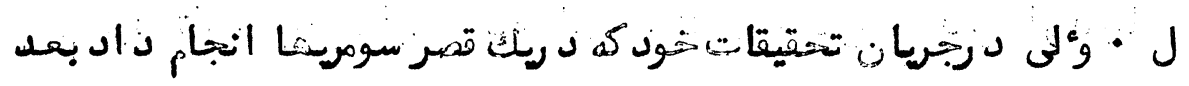

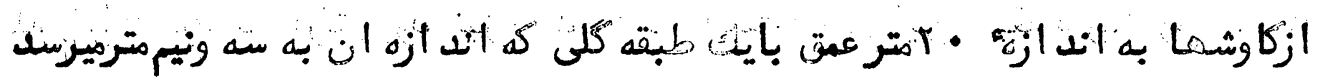

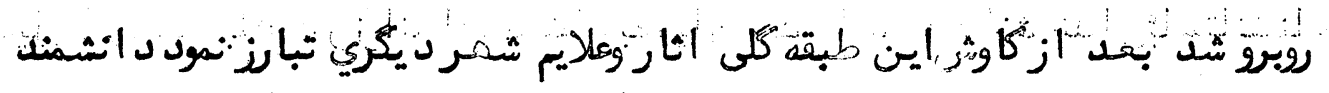

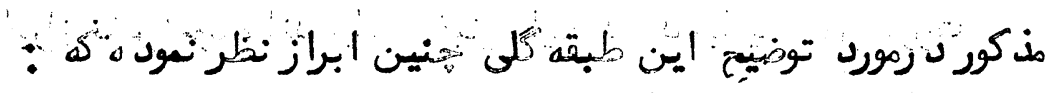

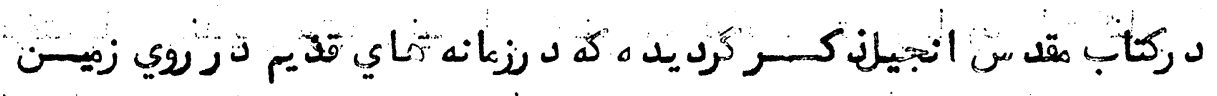

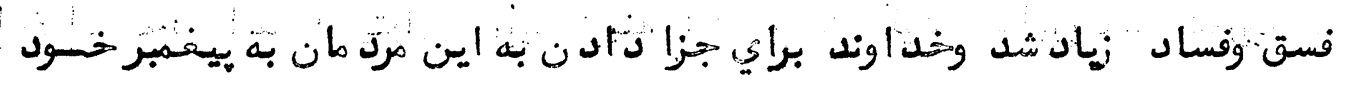

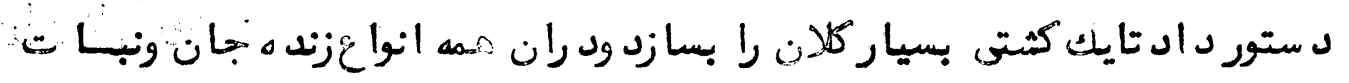

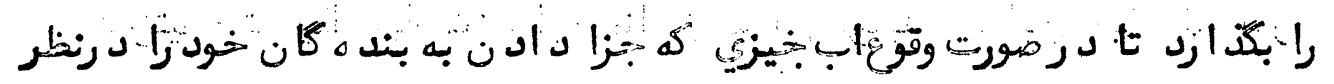

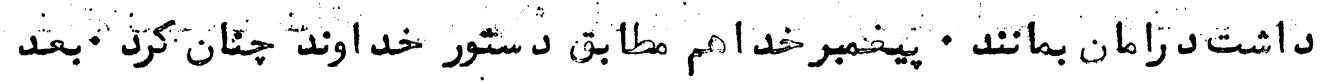

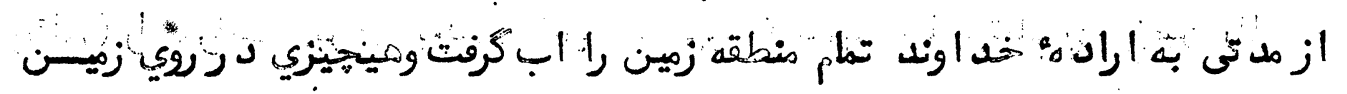

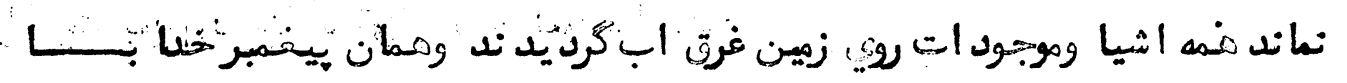

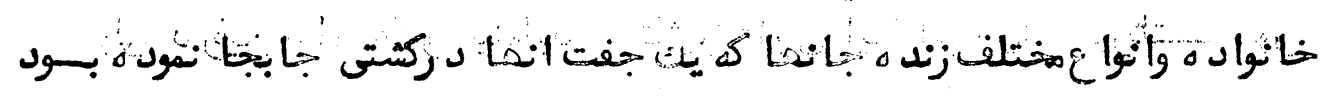

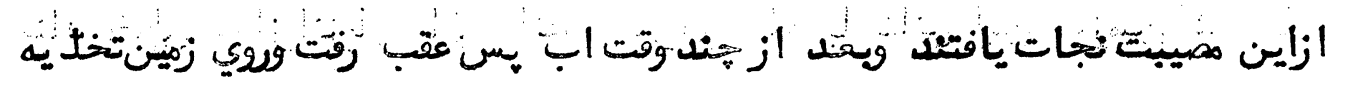

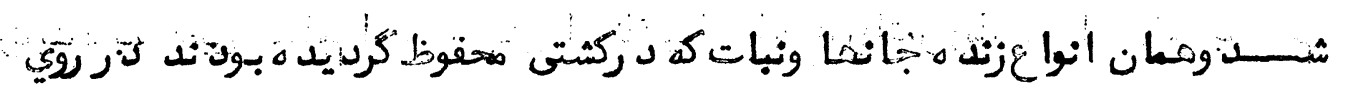




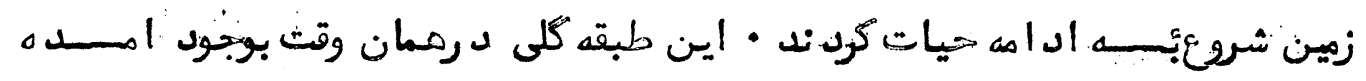

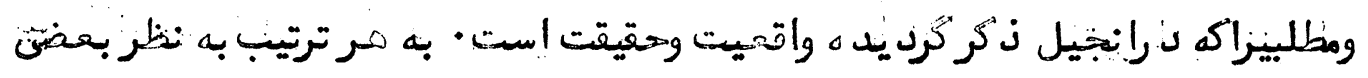

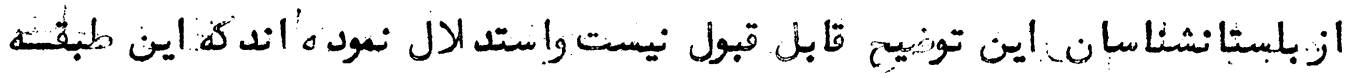

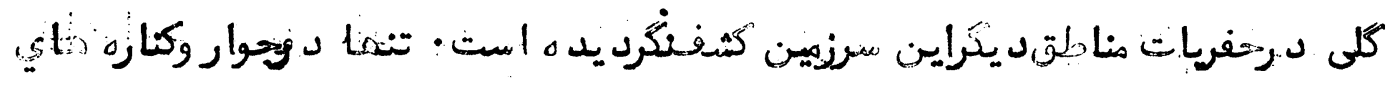

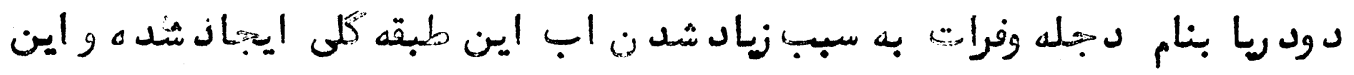

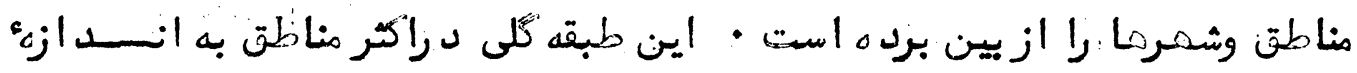

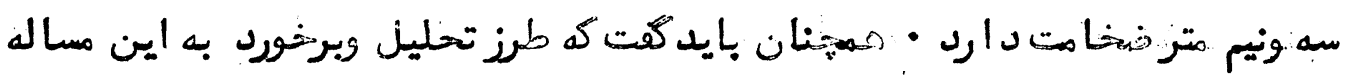

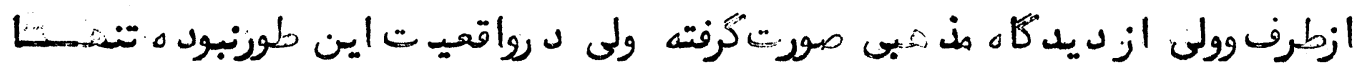

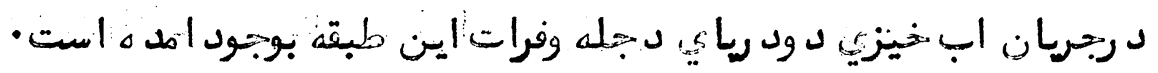

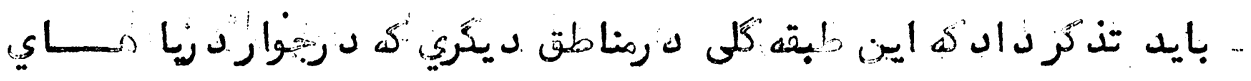

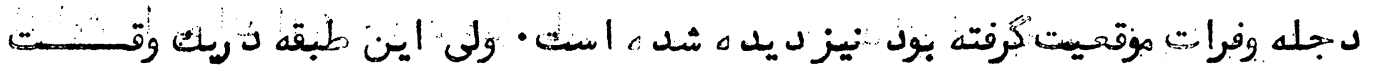

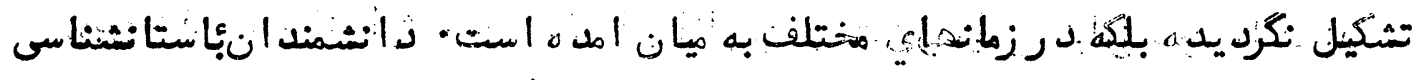

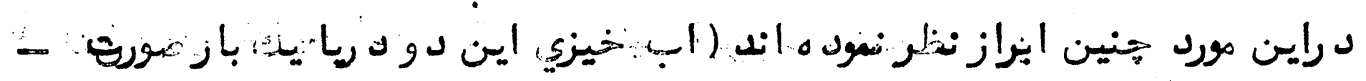

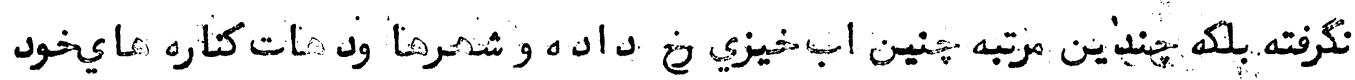

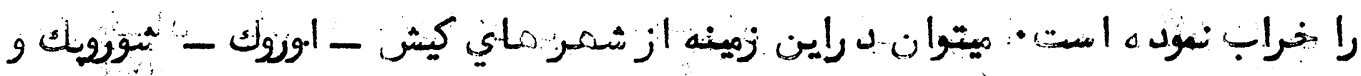

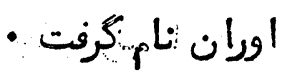

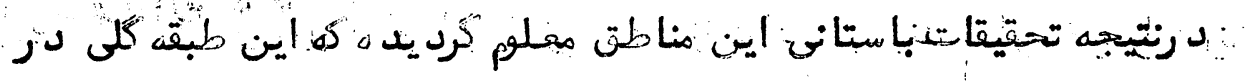

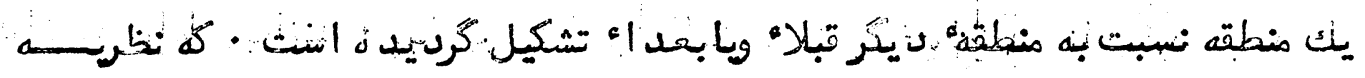

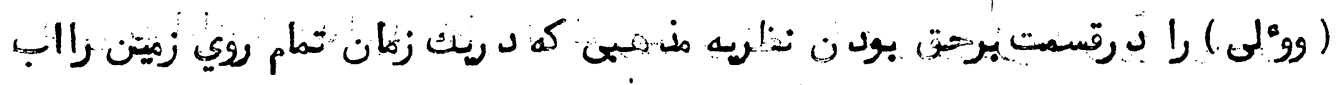

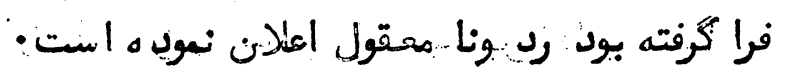

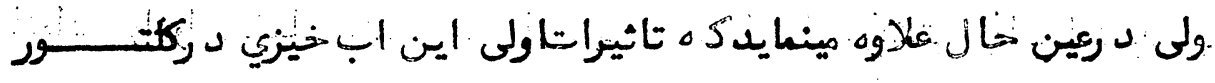

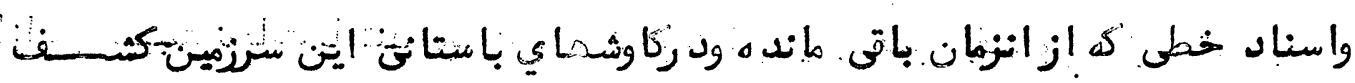

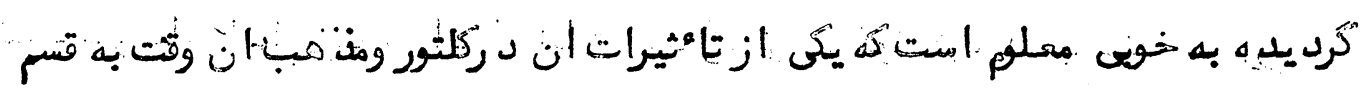




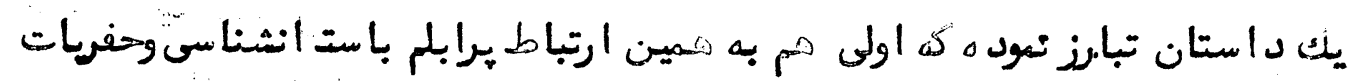

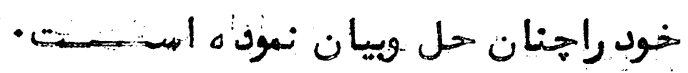

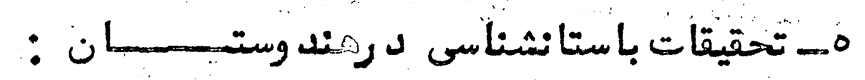

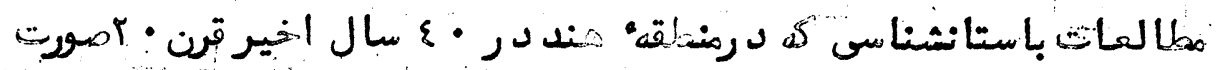

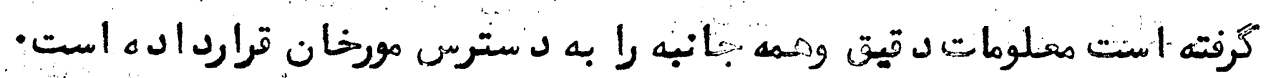

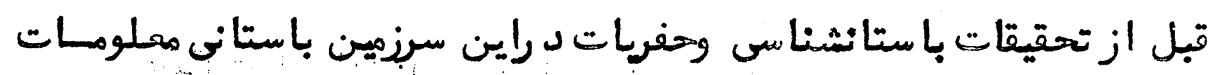

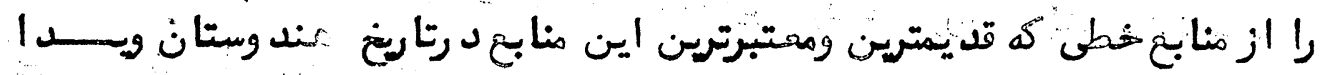

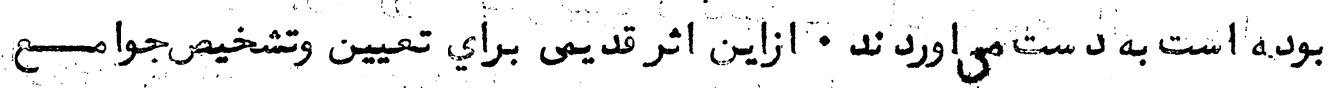

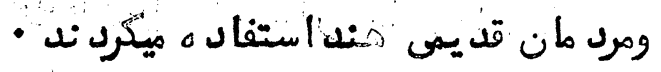

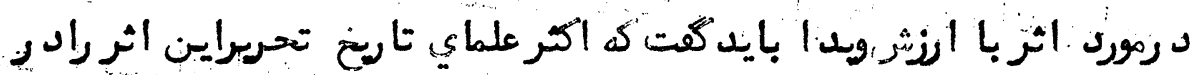

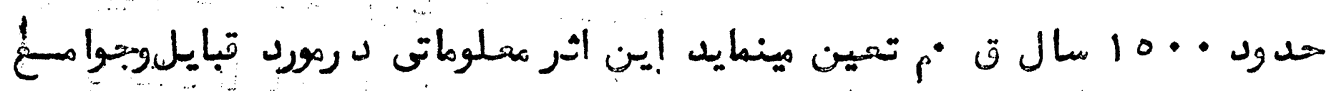

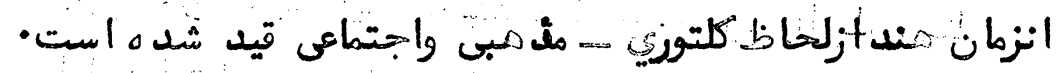

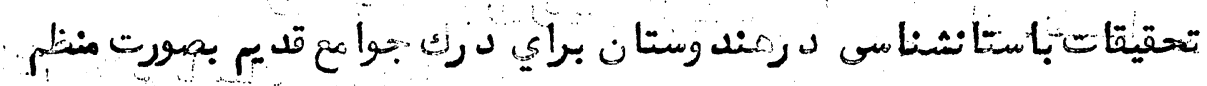

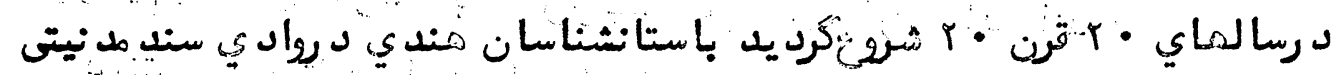
را كثف نهود ند كه مريوط هزازه ميباشد اين مل نيت بنام مبد نيت مريه

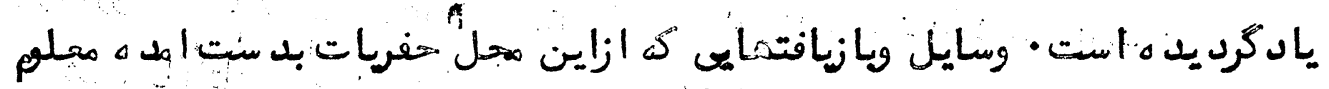

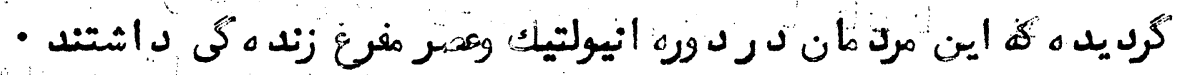

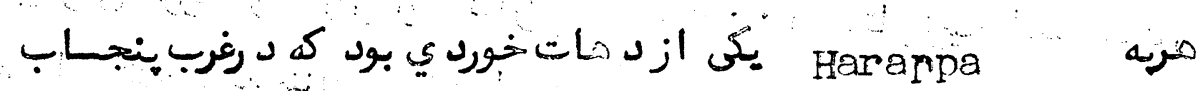

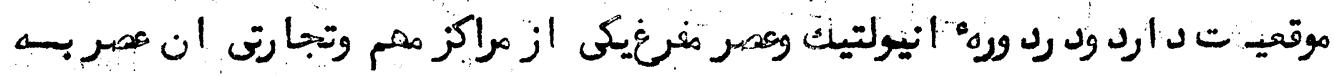

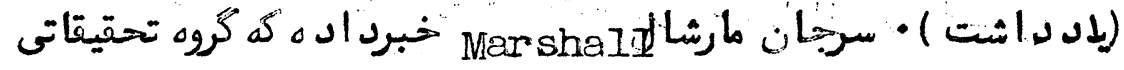




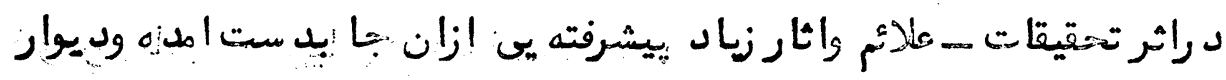

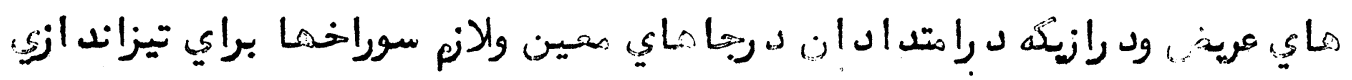

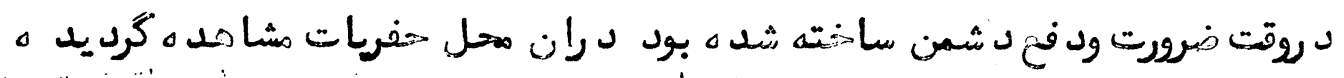

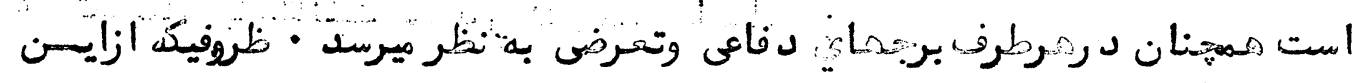

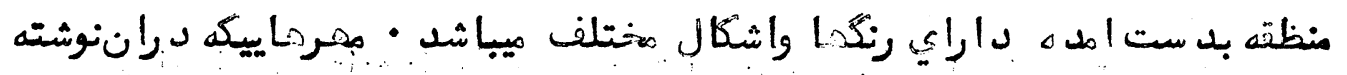

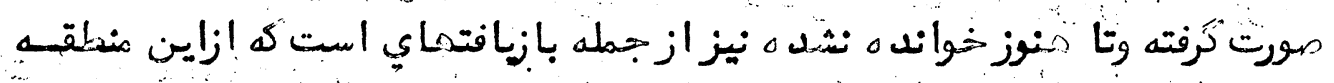

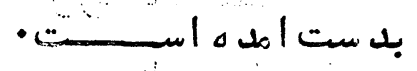

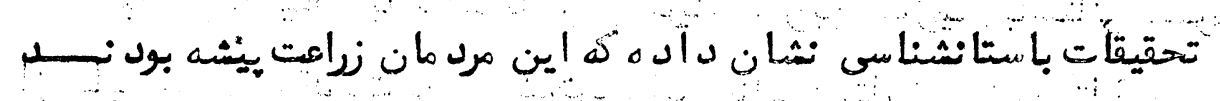

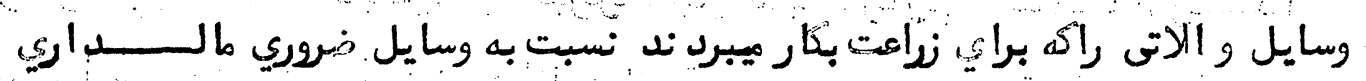

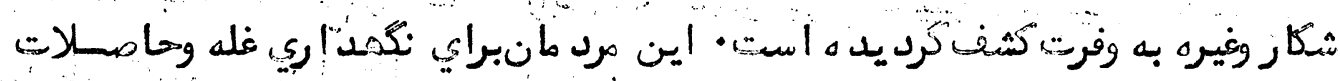

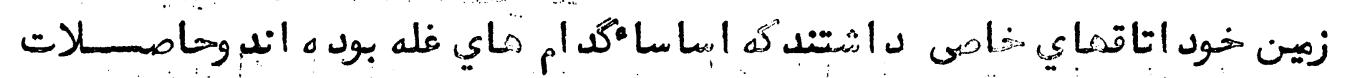

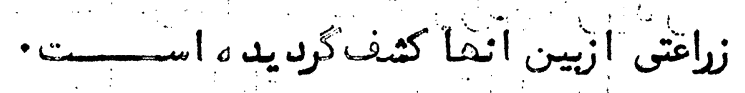

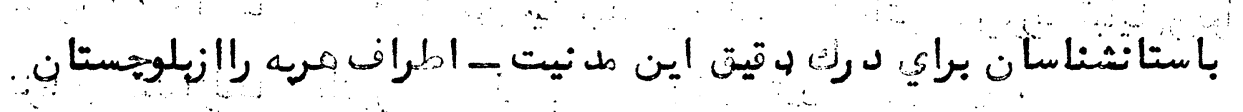

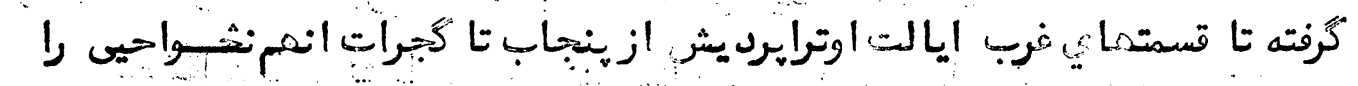

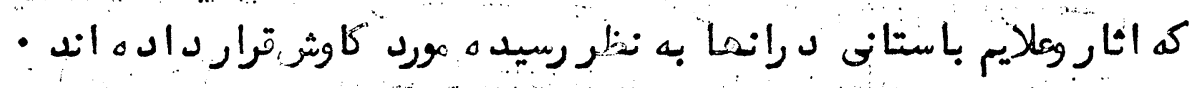

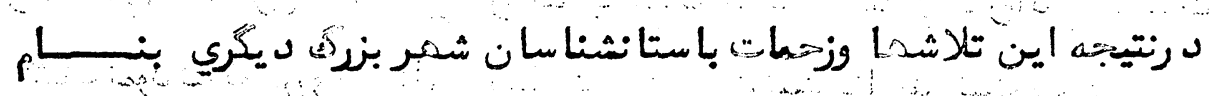

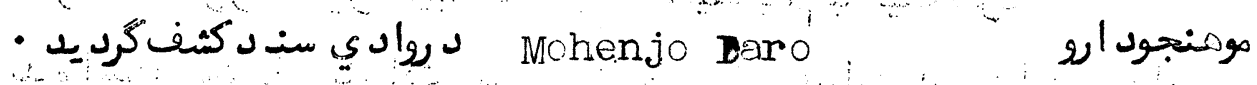

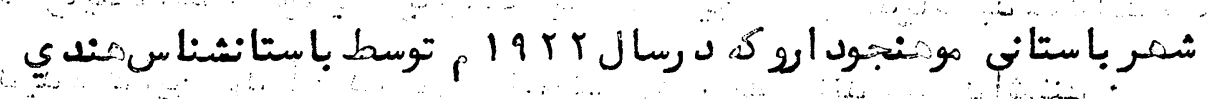

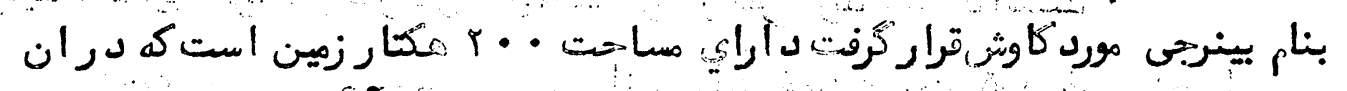

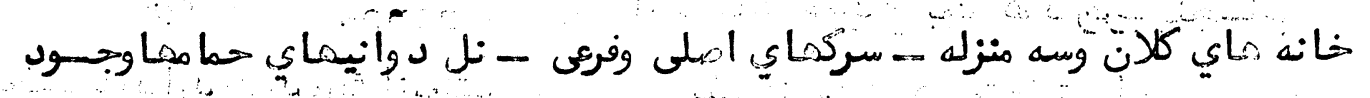

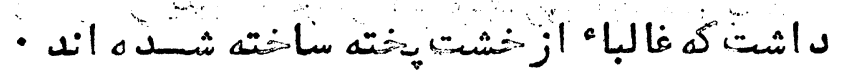

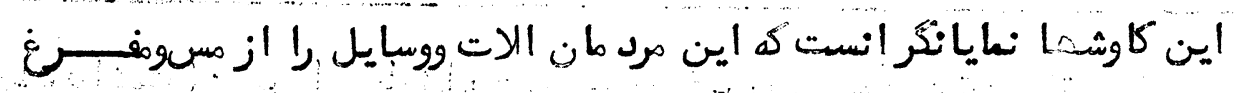


ميساختند •ولى اين مرد طان منوزبه اهن اشنايى نداشتند همه وسايل انها ازينـيكِ

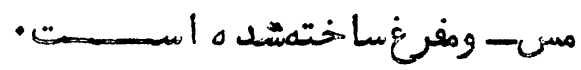

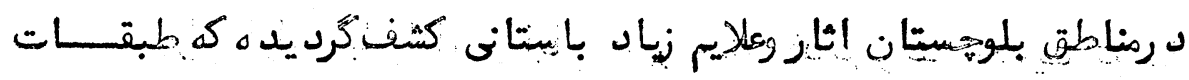

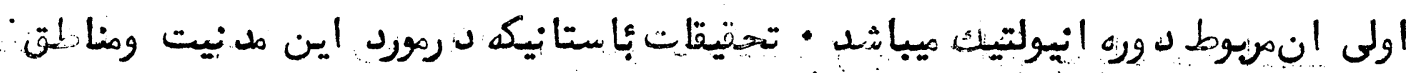

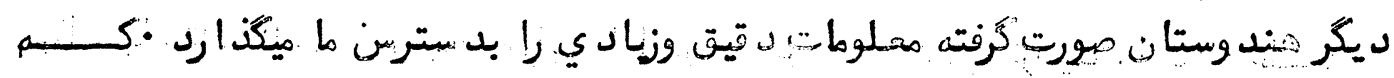

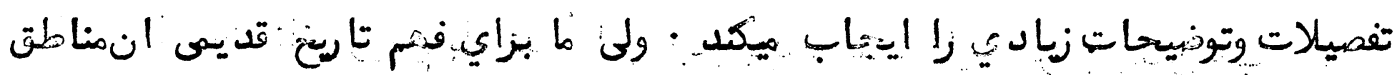

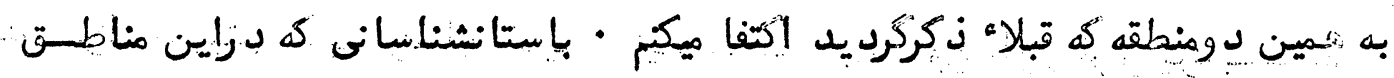

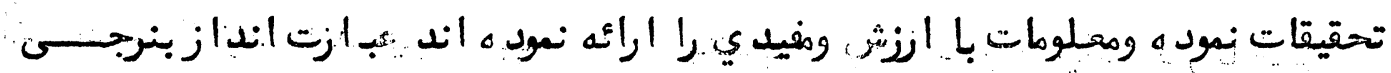

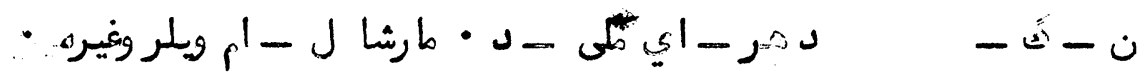

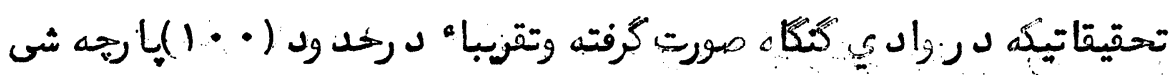

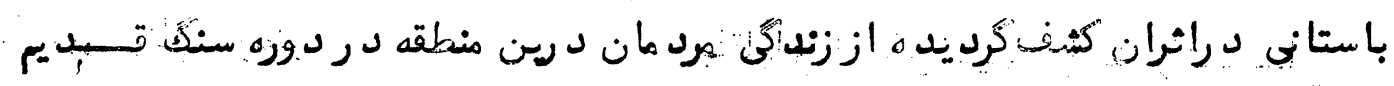

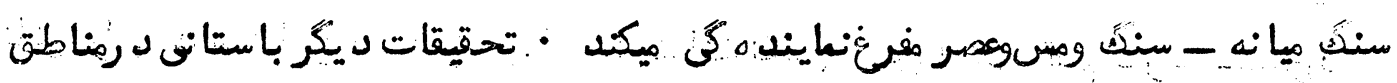
جند هودارا - جهاند ر - دز هوكر وفيره صورت كرفته است .

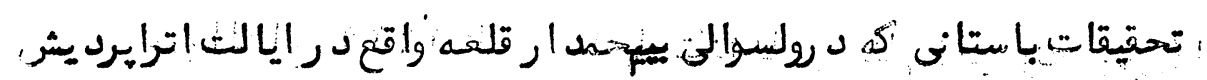

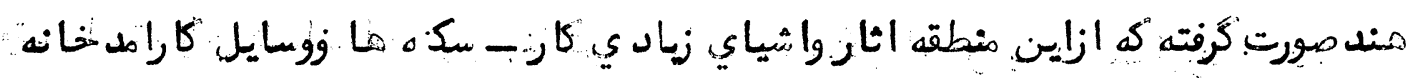

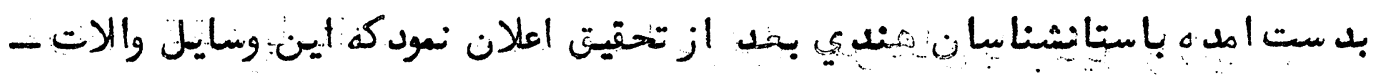

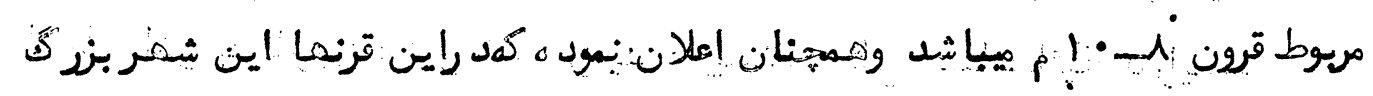

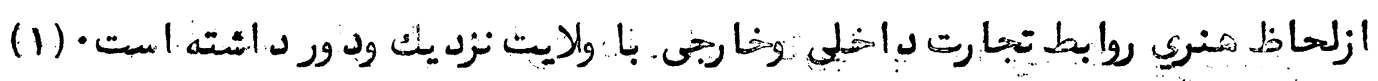

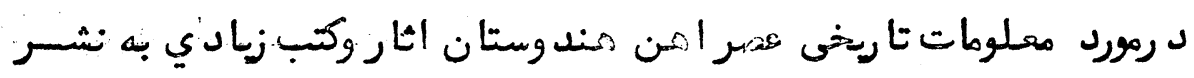

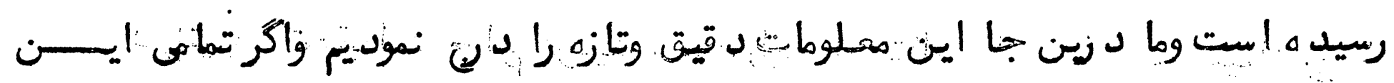

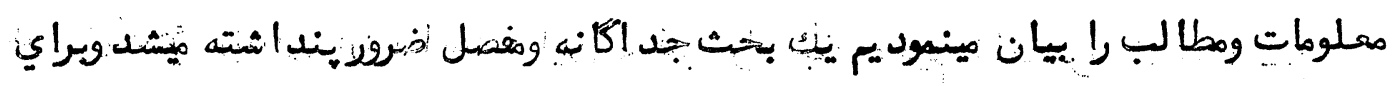

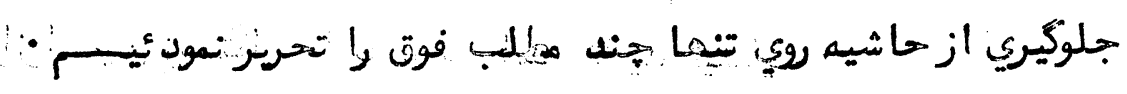

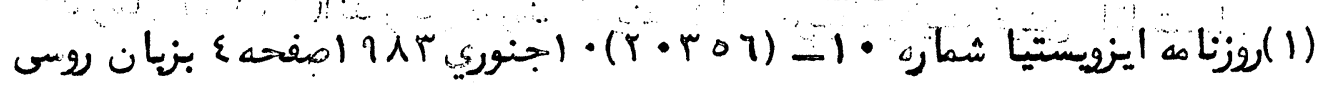




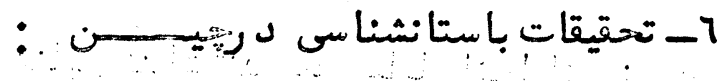

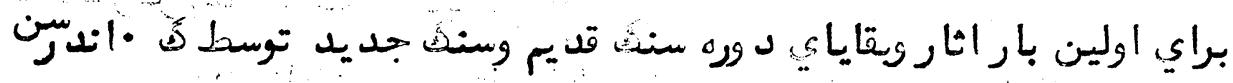

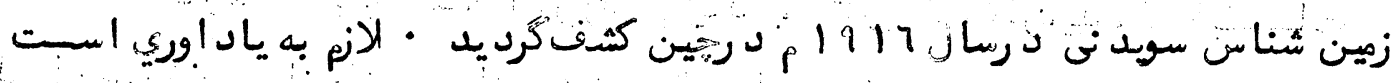

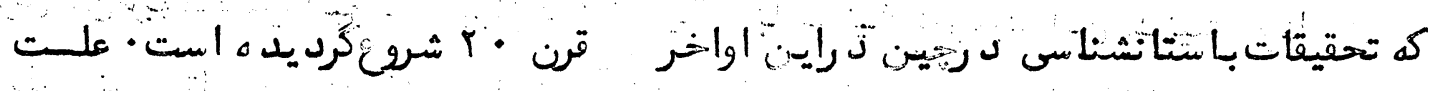

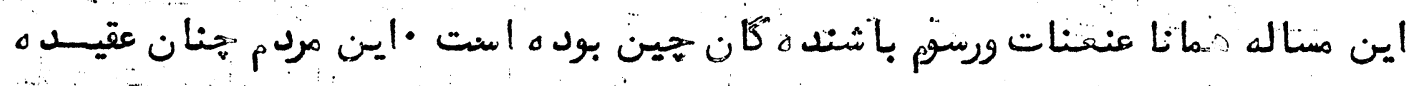

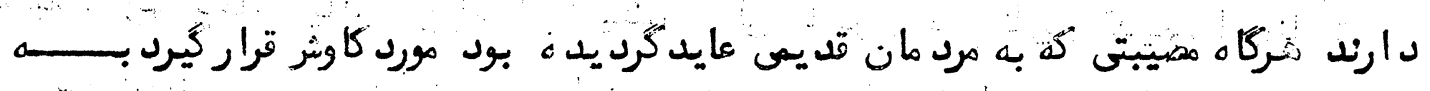

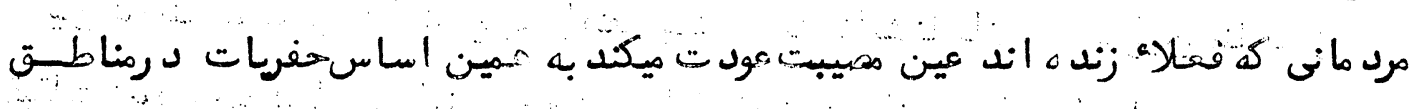

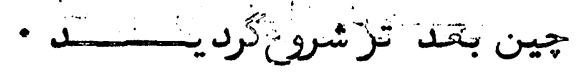

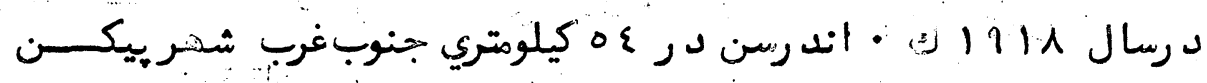

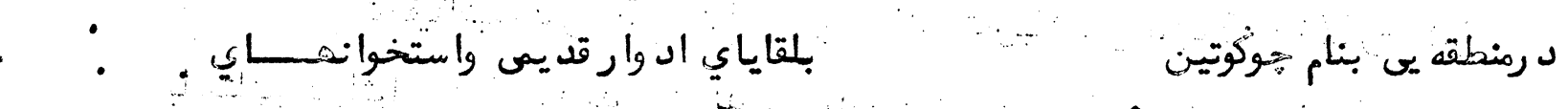

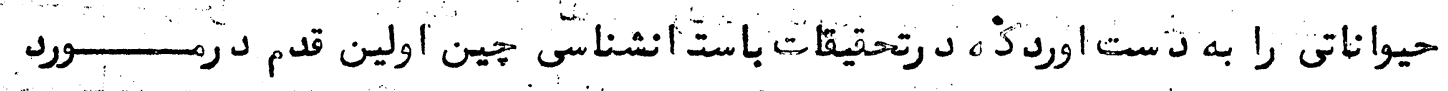

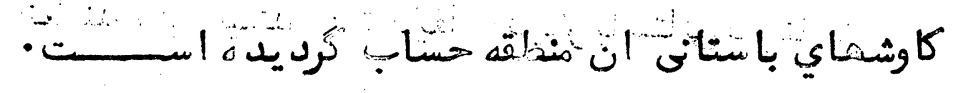

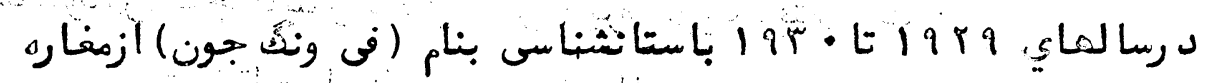

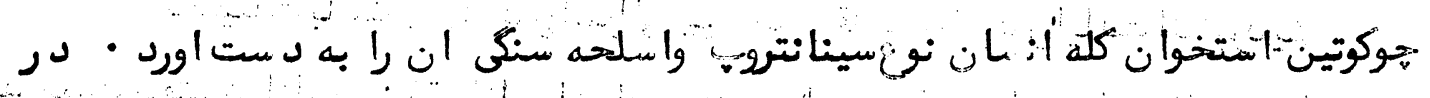

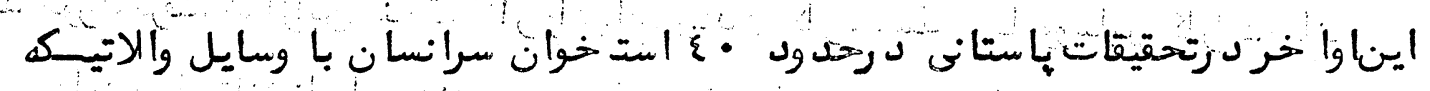

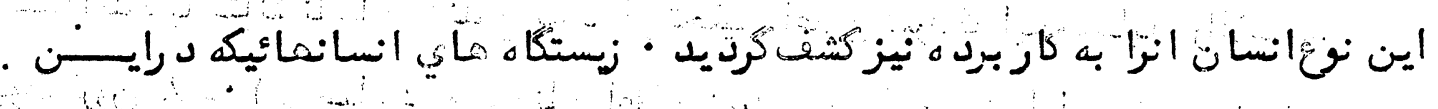

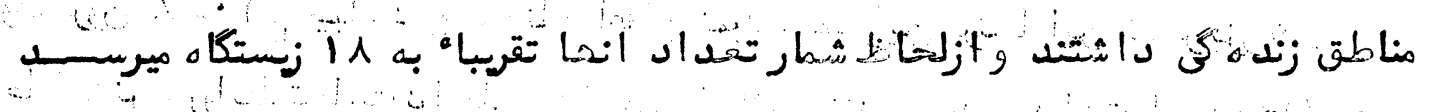

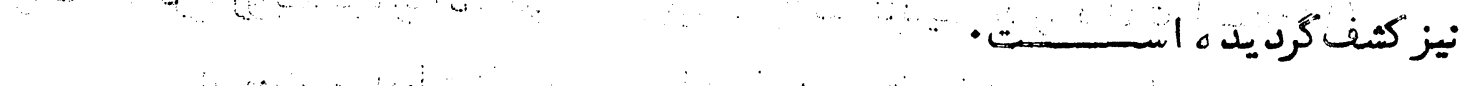

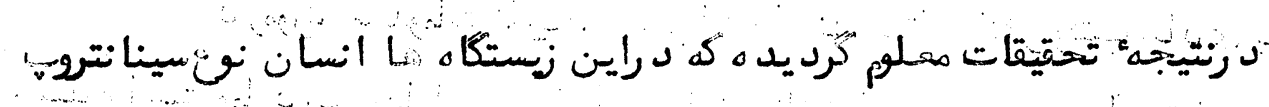

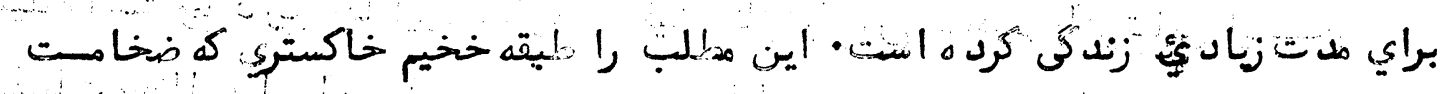

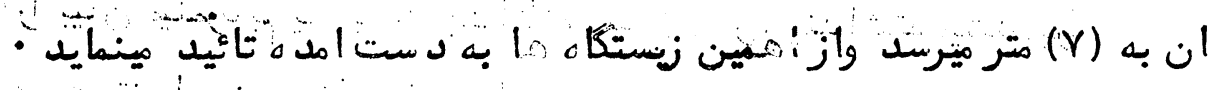

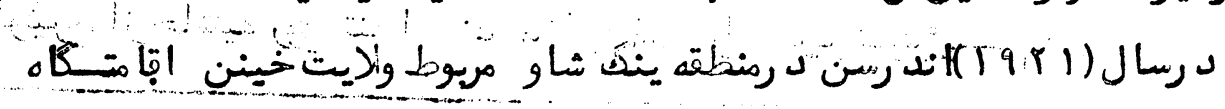




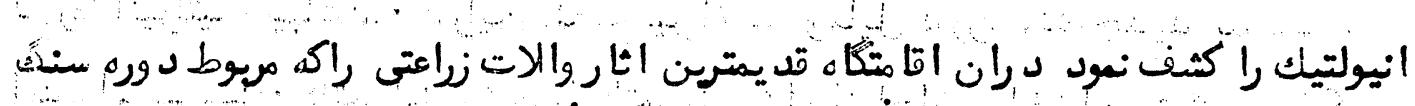

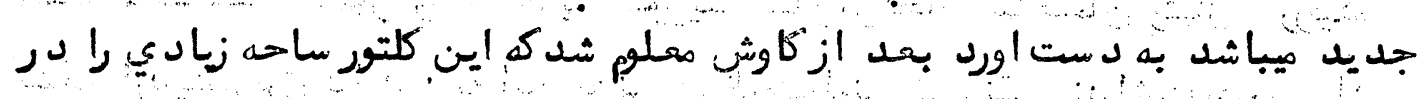

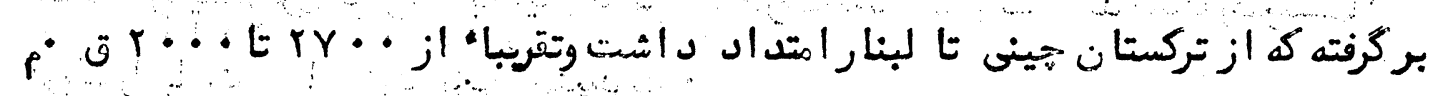

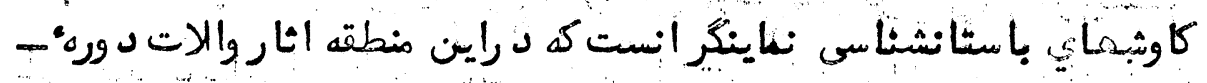

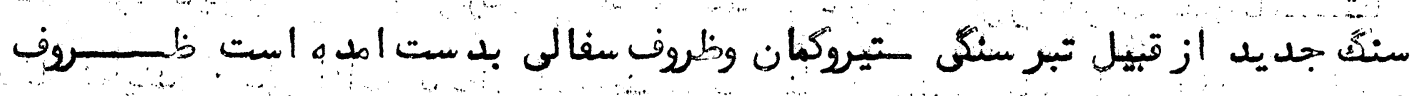

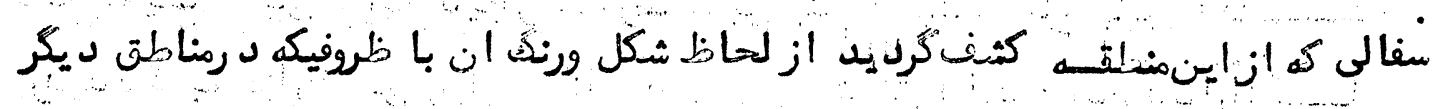

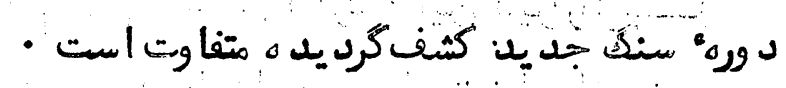

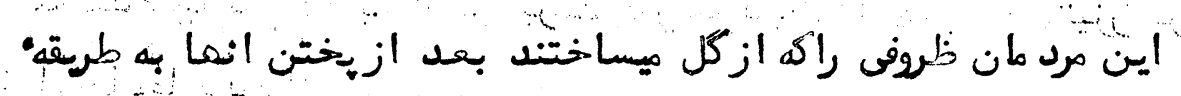

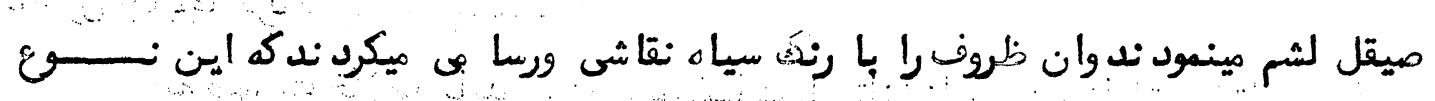

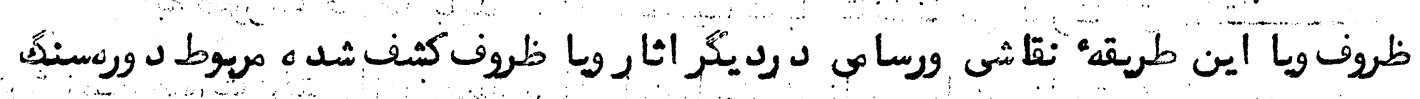

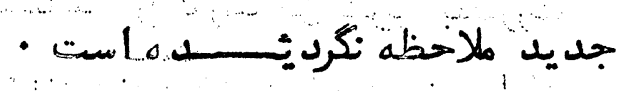

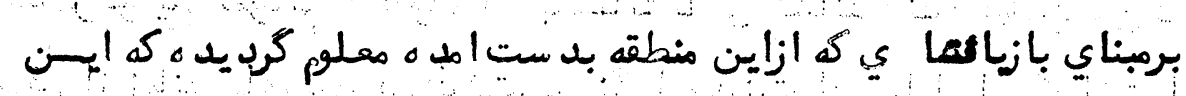

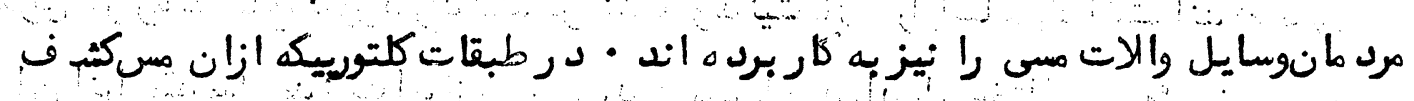

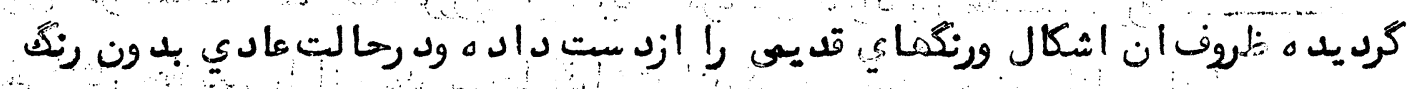

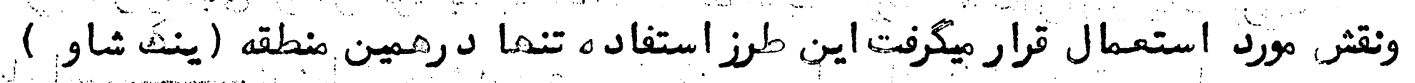

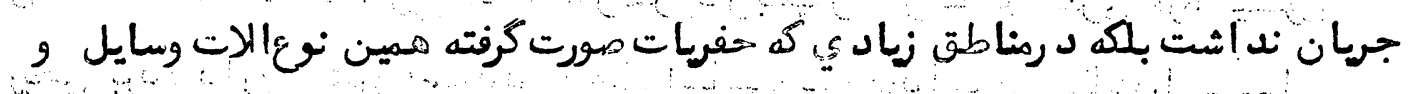

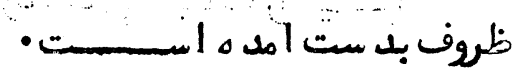

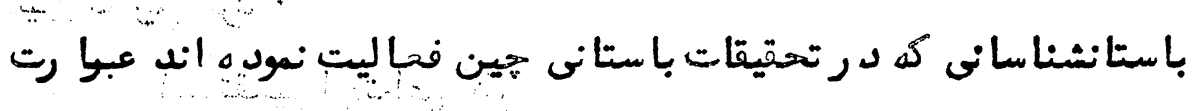

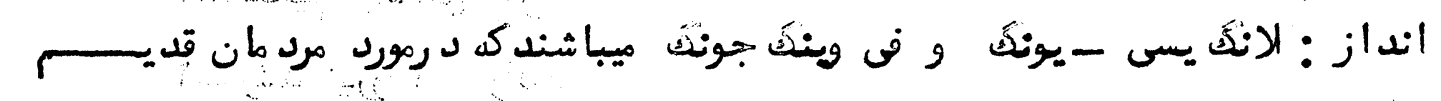

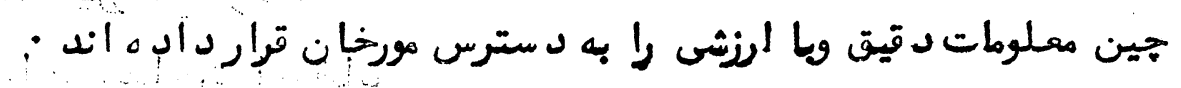

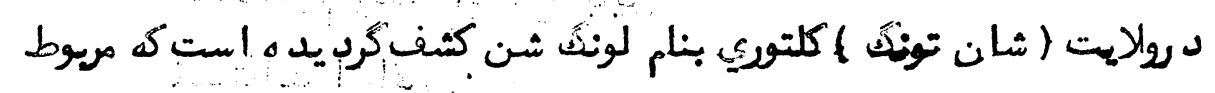




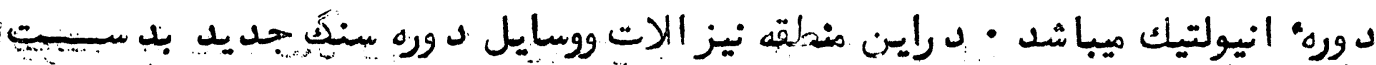

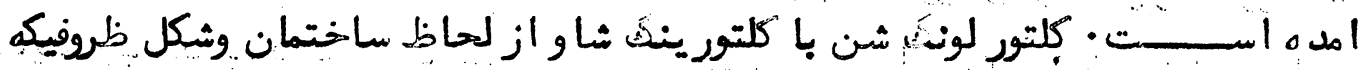

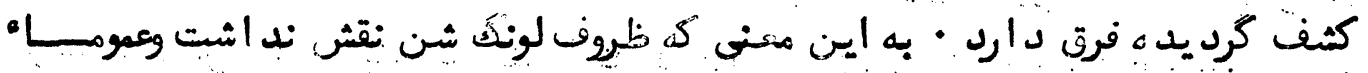

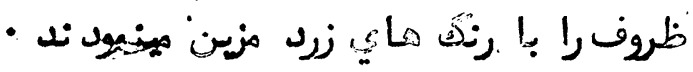

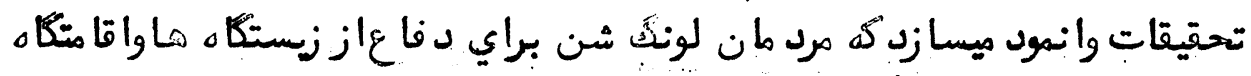

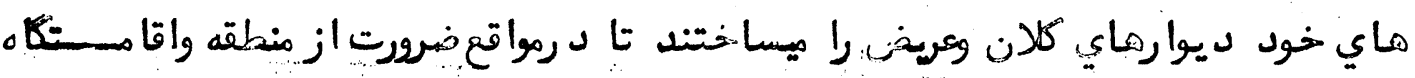

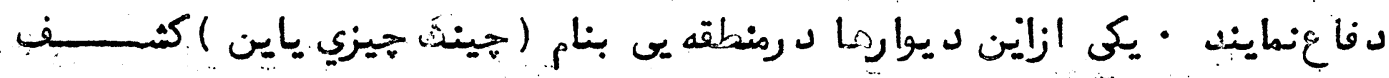

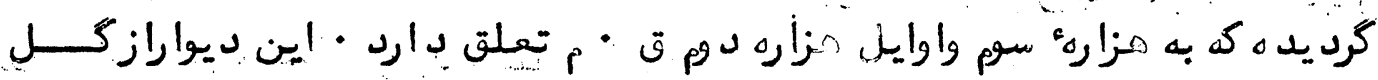

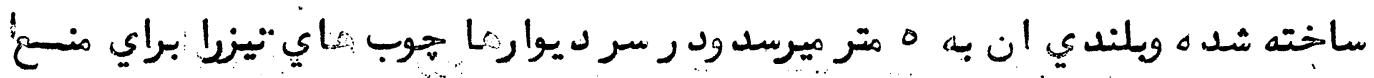

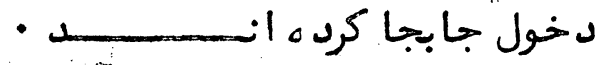

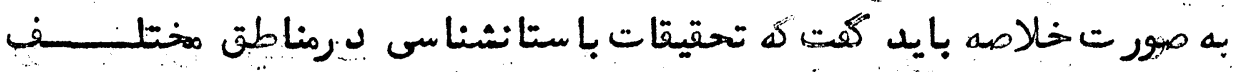

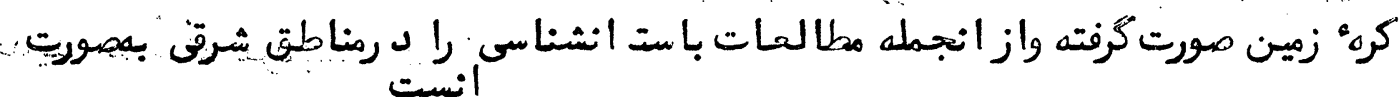

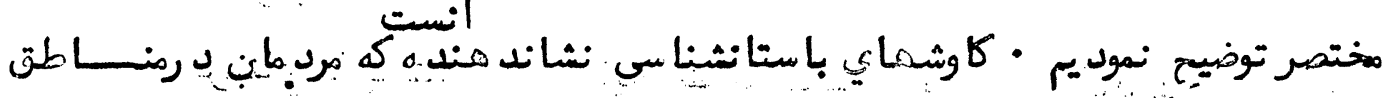

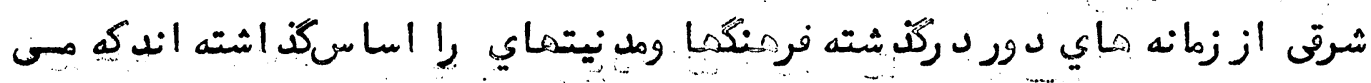

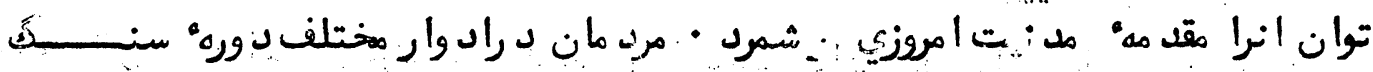

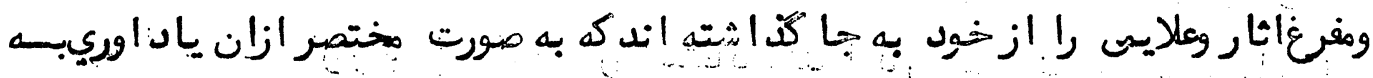

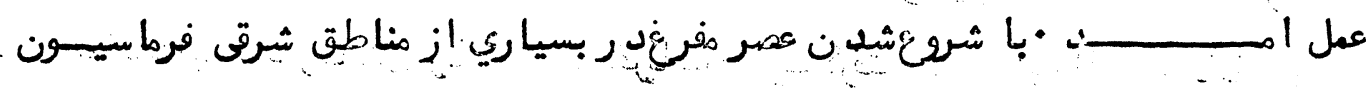

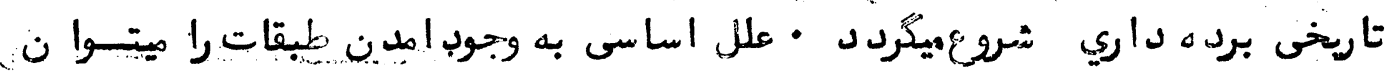

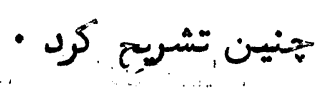
إ- تقسير اجتماعي كأر r رشد. نيروهايي مولد ه

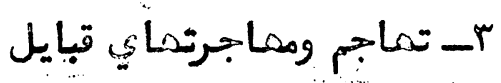
- عـ توليد اذافى 


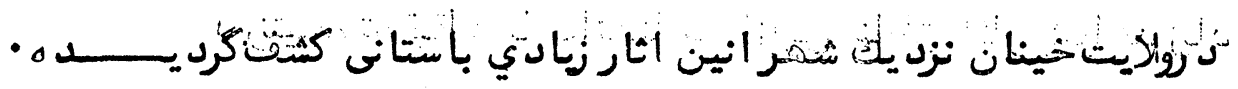

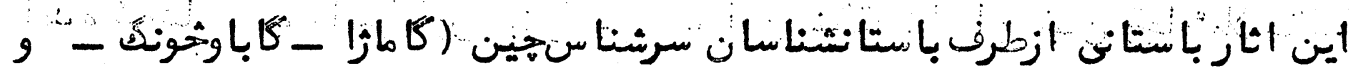

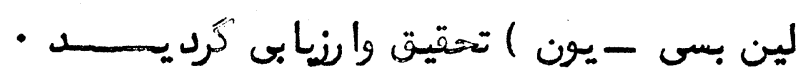

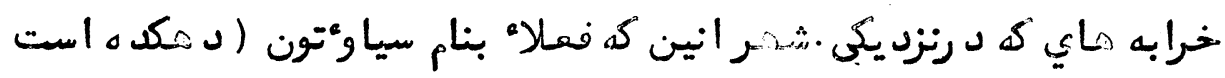

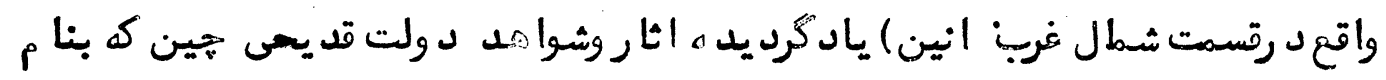

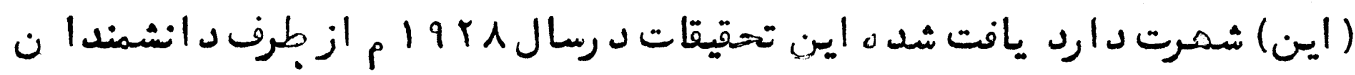

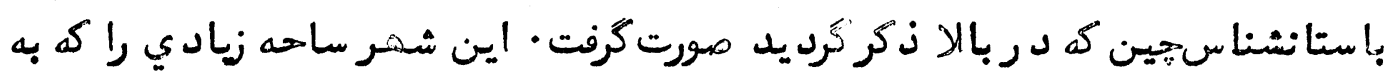

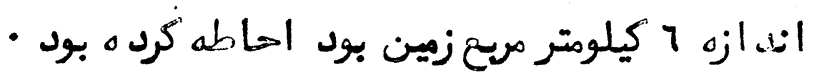

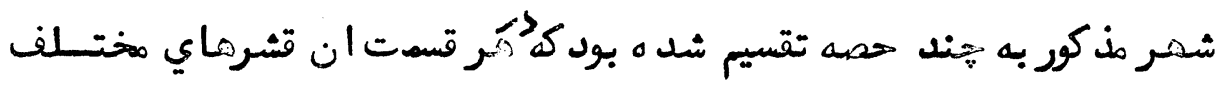

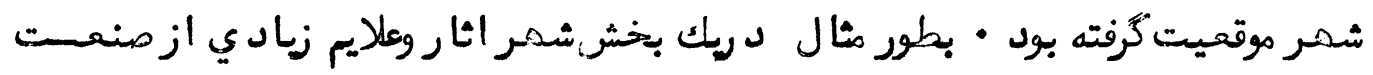

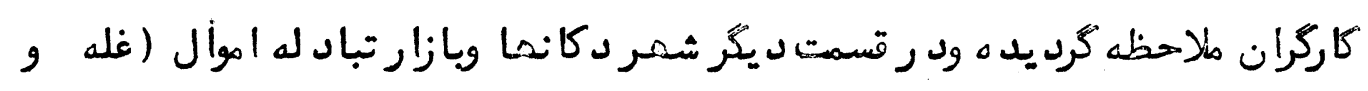

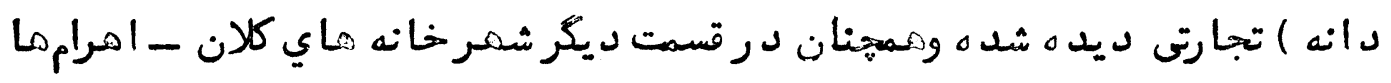

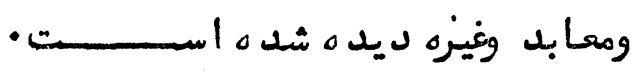

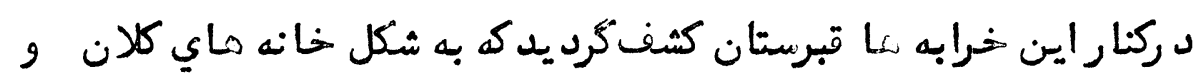

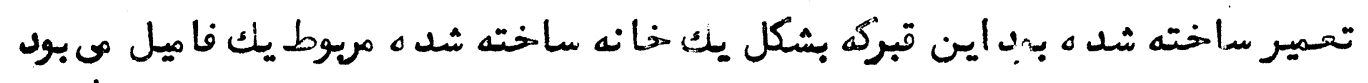

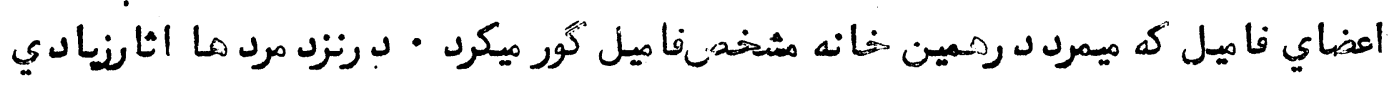

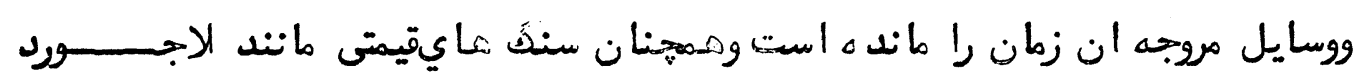

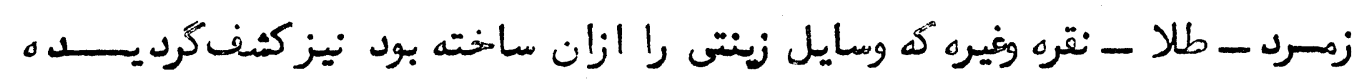

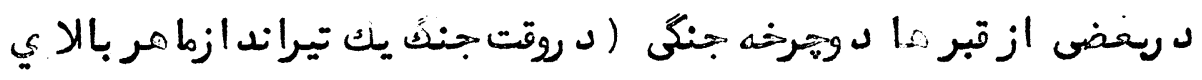

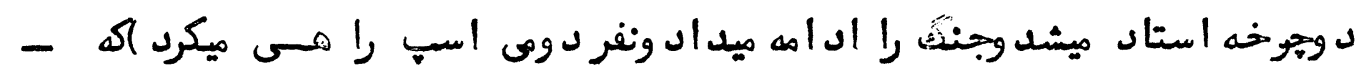

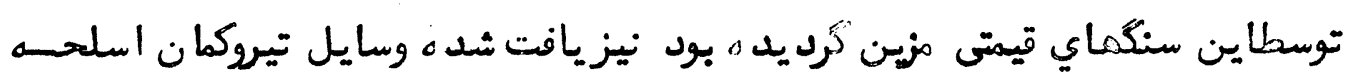

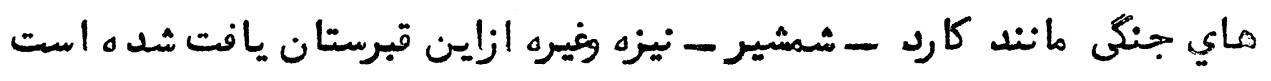


ITr

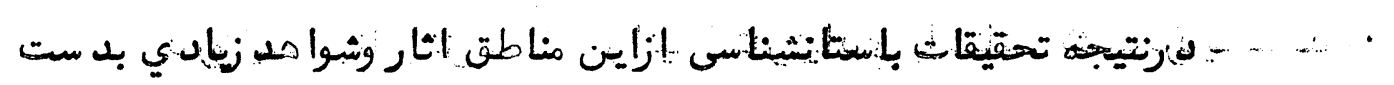

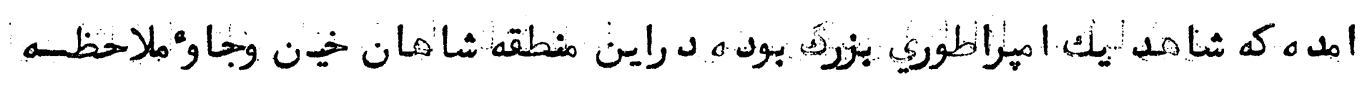

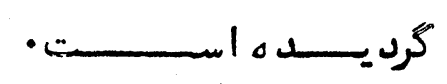


Y- تحقيقات باستانشناسى درسايبريسـا :

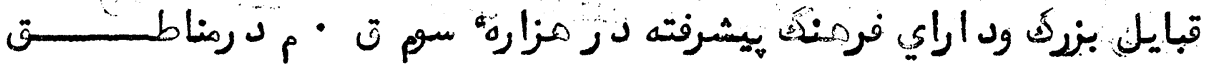

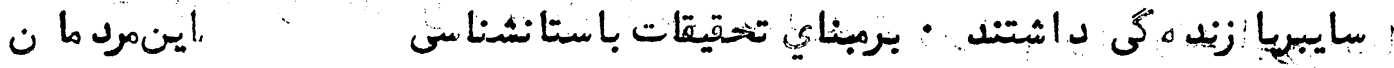

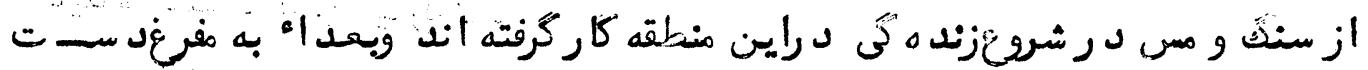

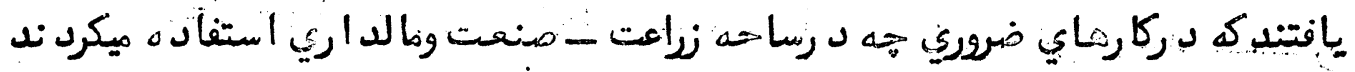

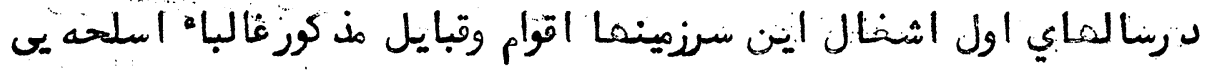

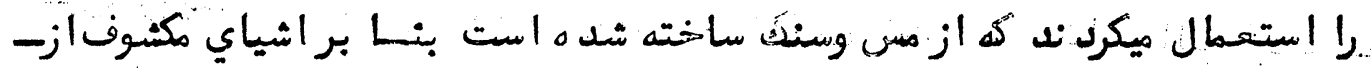

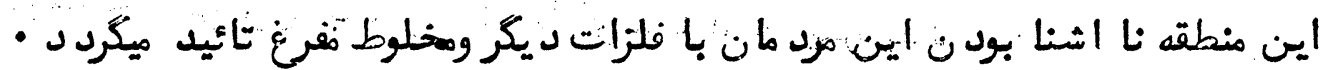

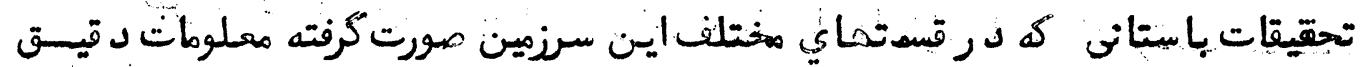

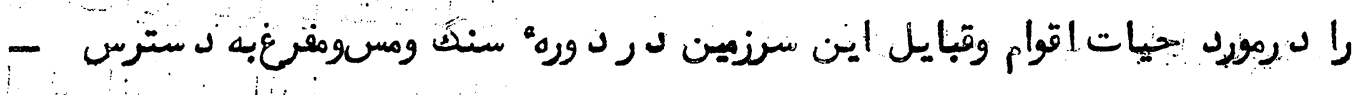

مورخان قرار ميـــــــد هد •

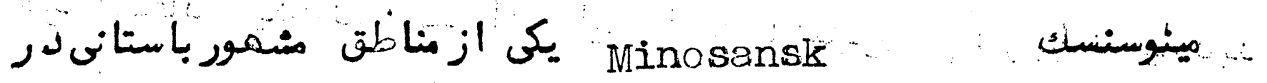

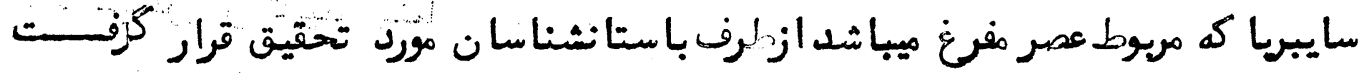

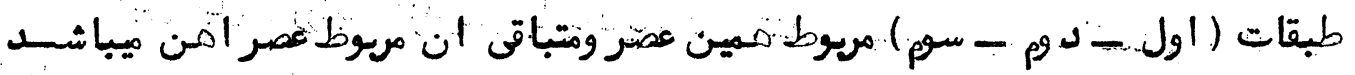

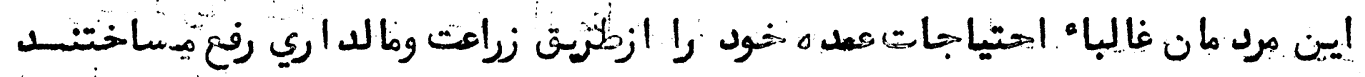

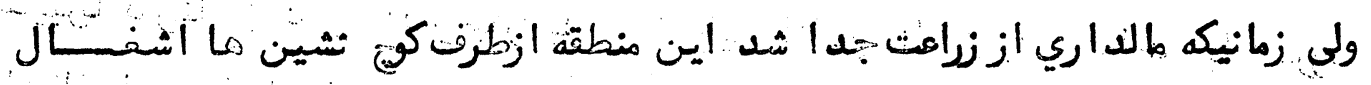

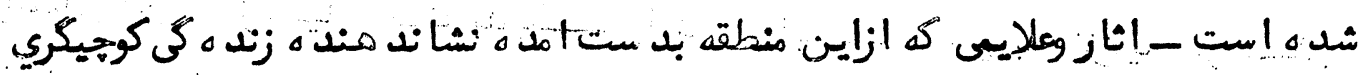

ومالداري استستصن

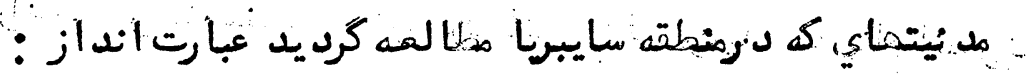

1 Afanscevi

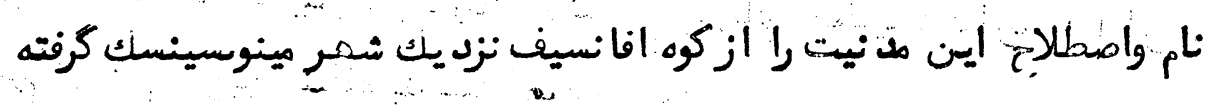

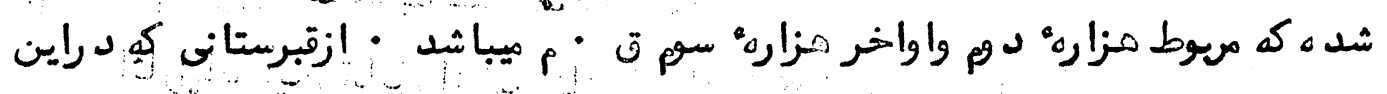




\section{Ir $r$}

منطقه مورد كاوشرقراركُرفته • اين مرد مان بالاي هر قبريك تيه خورد ساخته ود ر

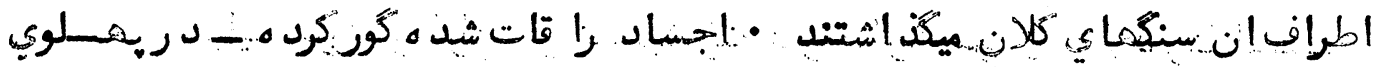

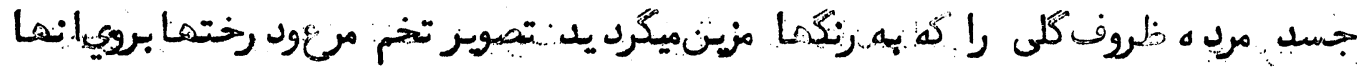

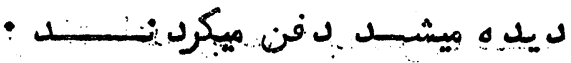

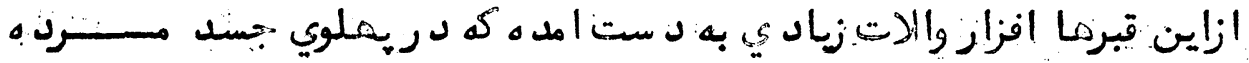

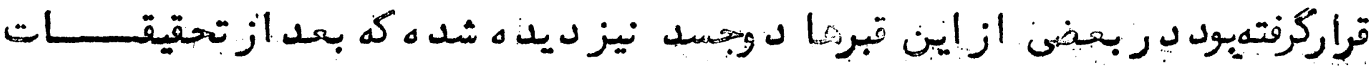

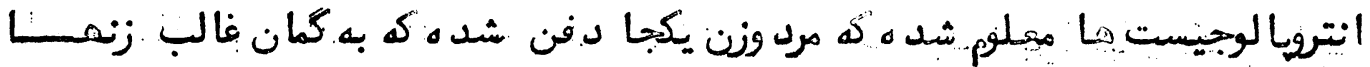

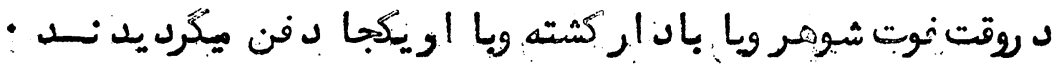

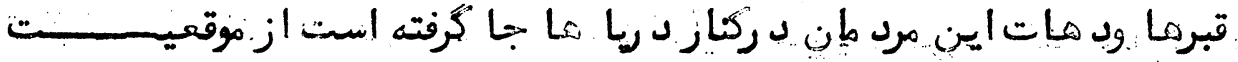

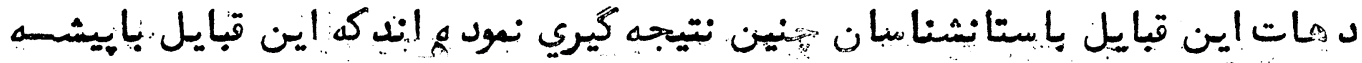
املى انها كه مالد اري بود تا اندازه يى ازماهيكيرينيزل رمورد زفع احتياجيات ألسى

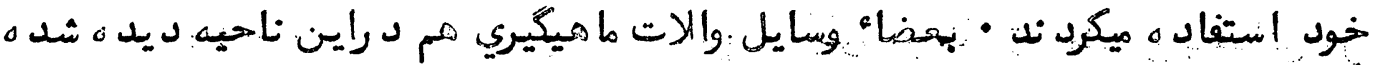

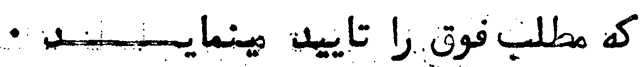

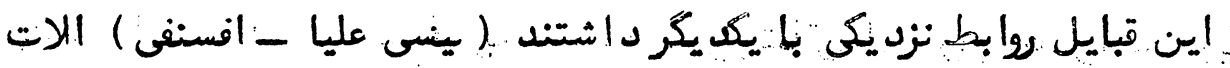

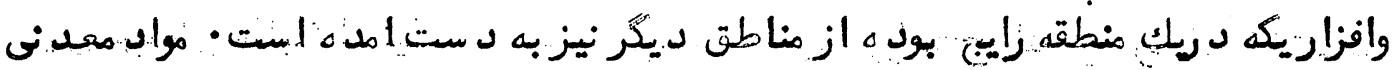

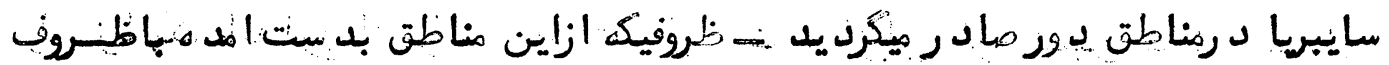

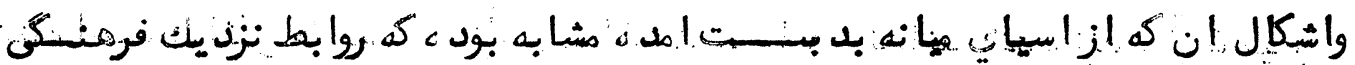

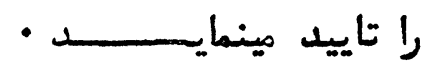

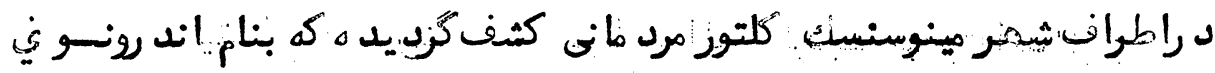

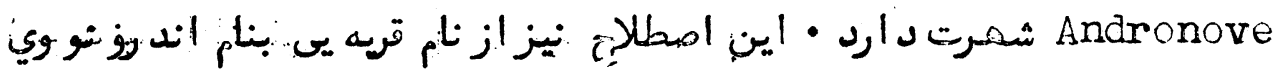

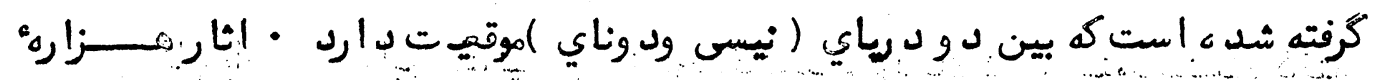

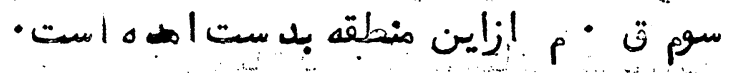

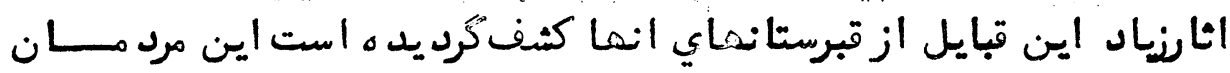


براي د فن مرده هاي يخود ازد وطريقه استفاد ه ميكرد ند د ر اول از قبرهاي نـــــــون

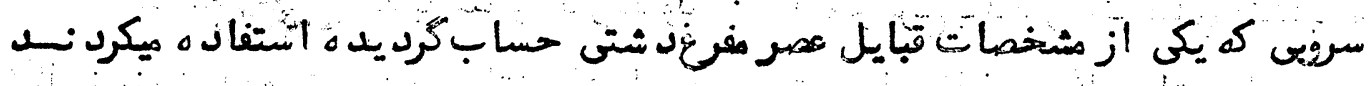

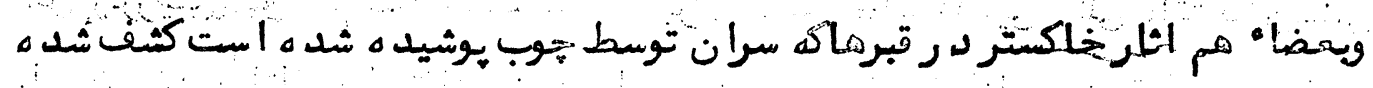

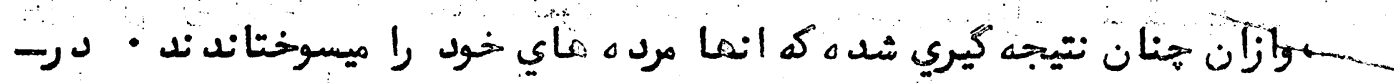

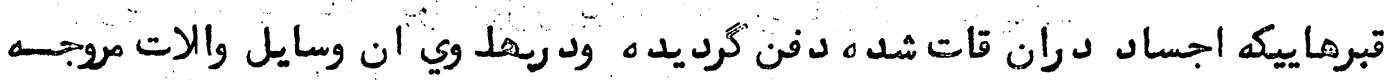

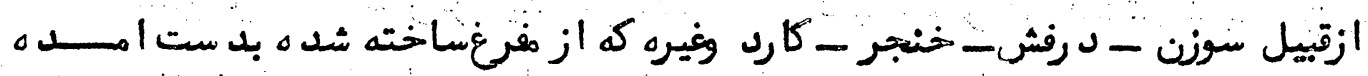

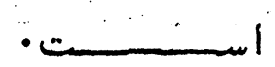

اين قبايل طريقه ذوب فلزات را به شكل ابتد ايى اب أموخته بود ند • الا ت

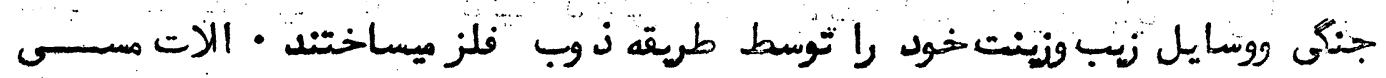

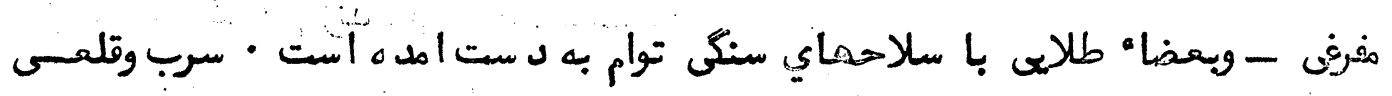
را شناخته بول ندوانرا استحصال ميكرد ند · د ر بعضى از طروق نقاشى طلايى نيسز

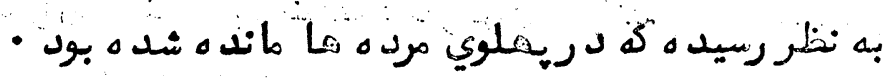

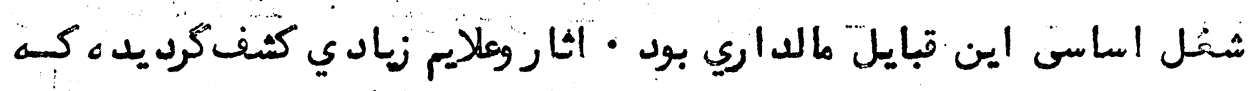

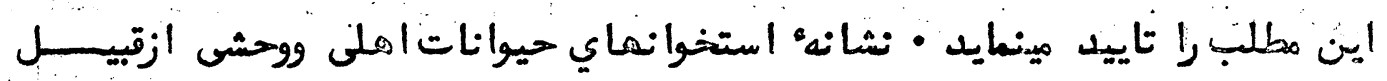

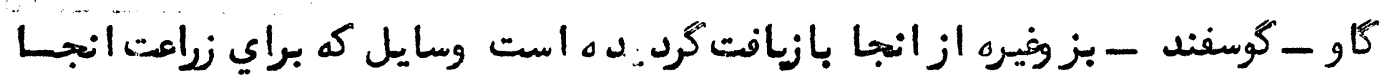

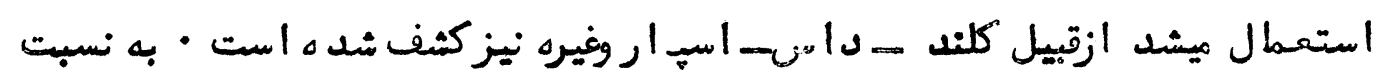

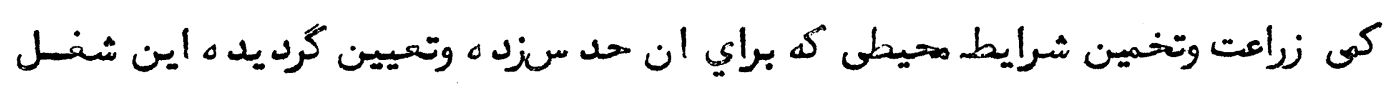

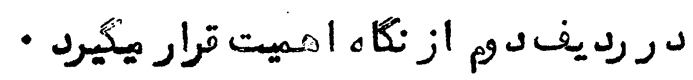

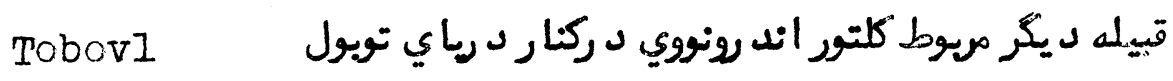

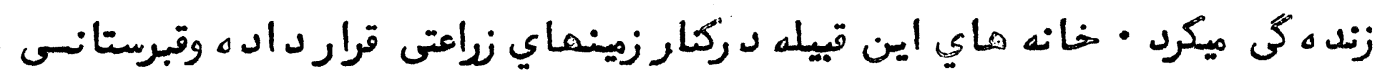

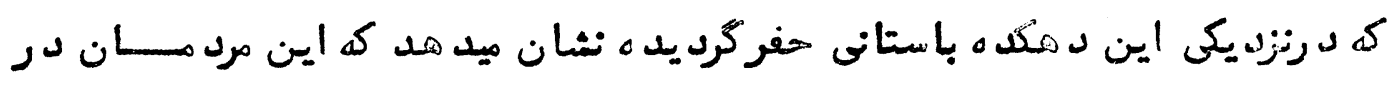

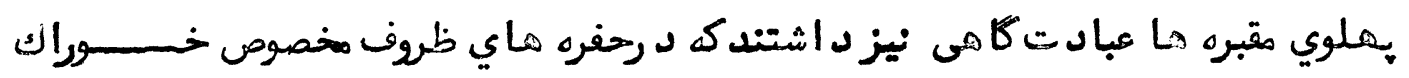

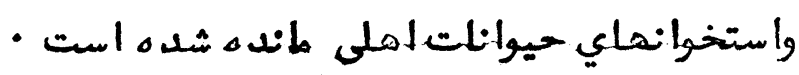




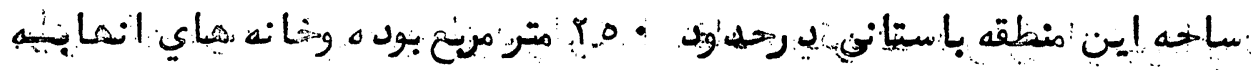

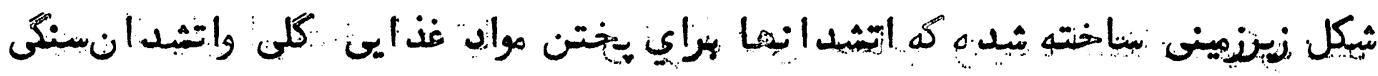

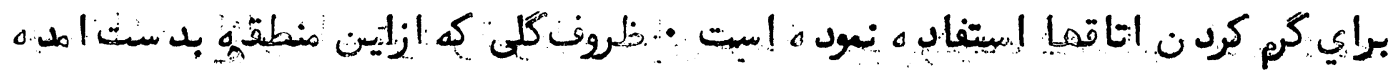

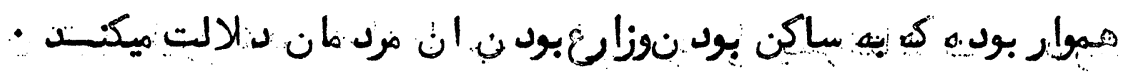

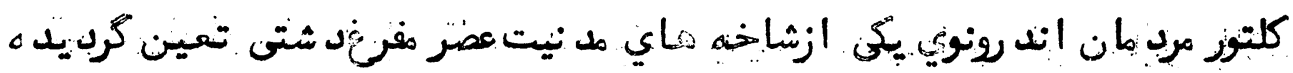

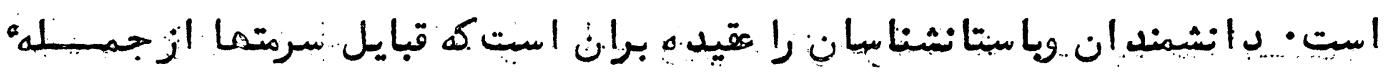

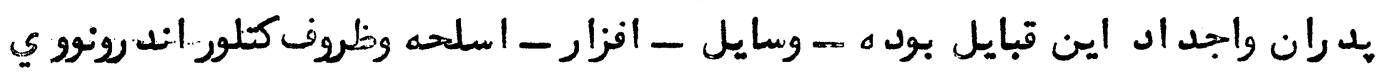

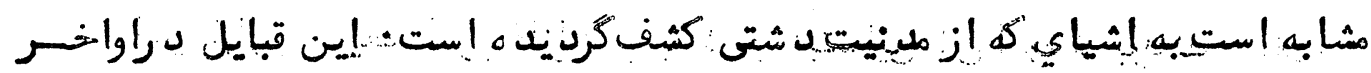

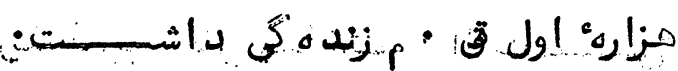

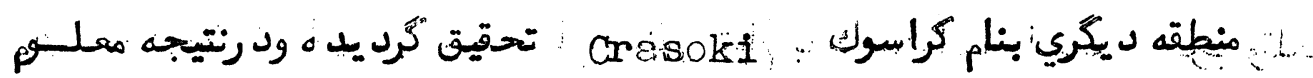

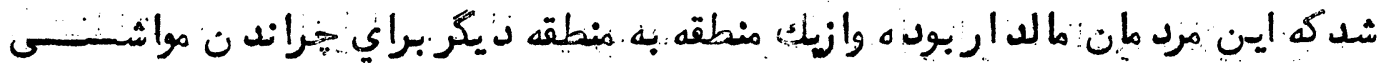

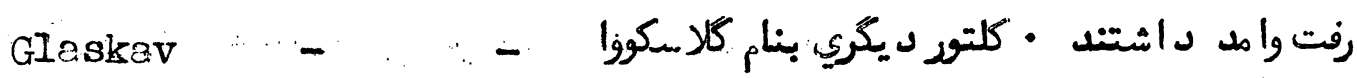

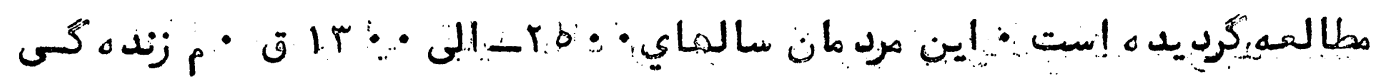

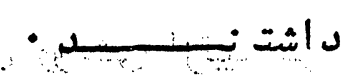




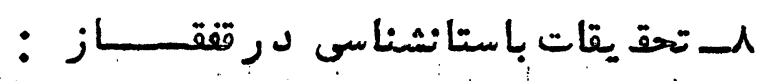

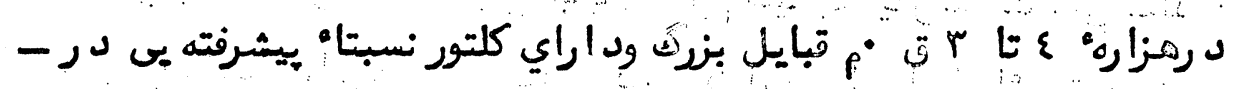

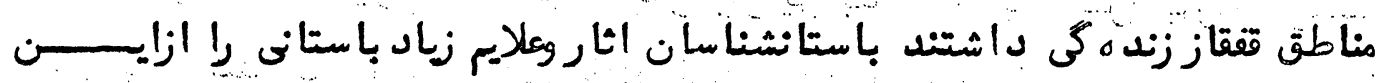

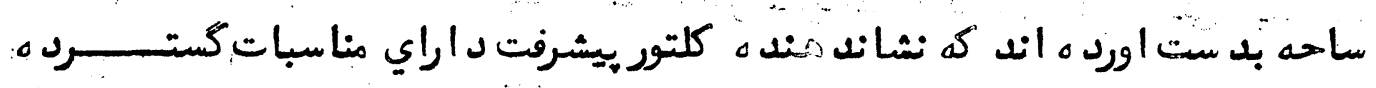

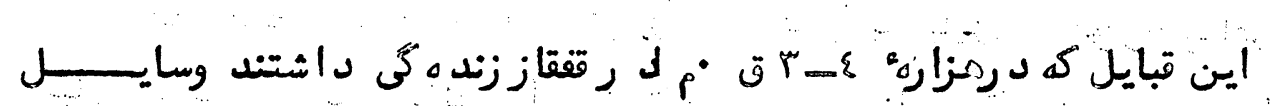

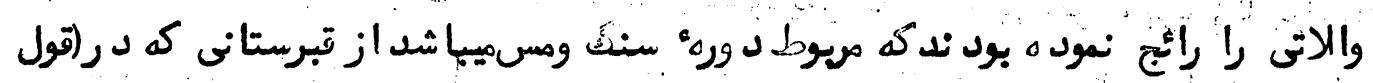

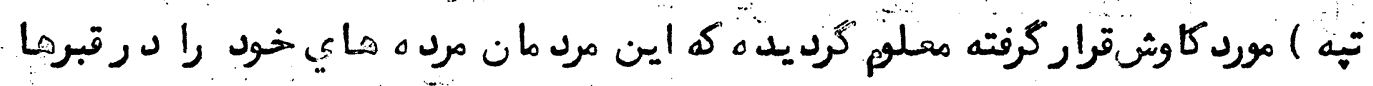

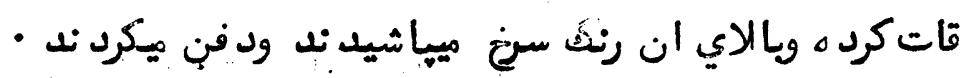

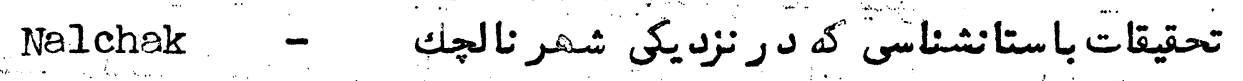

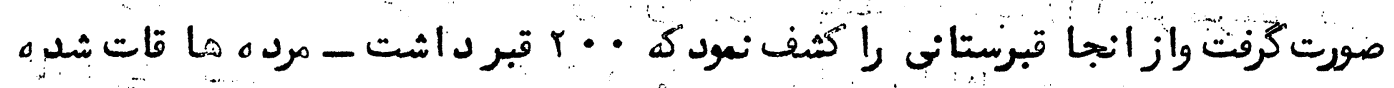

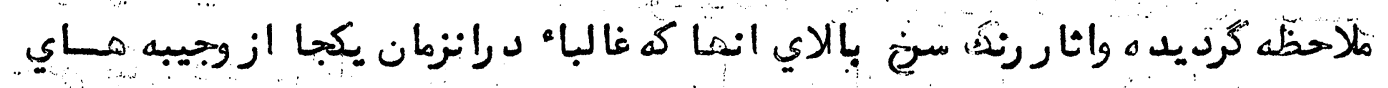

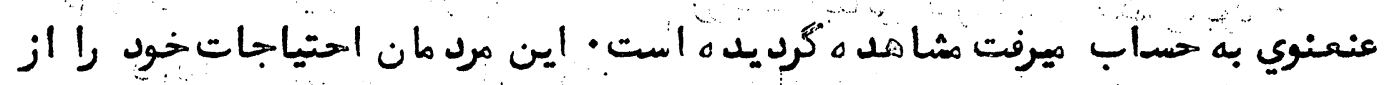

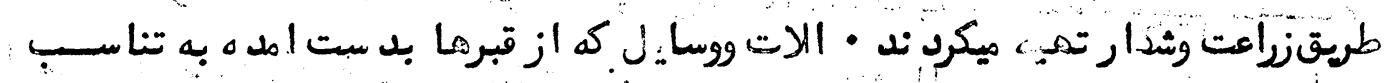

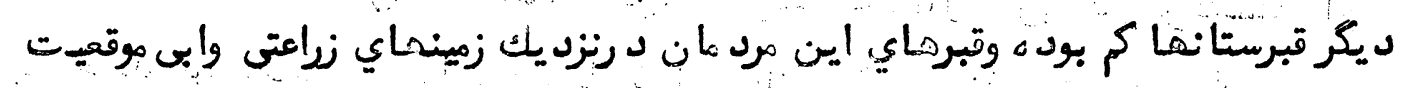

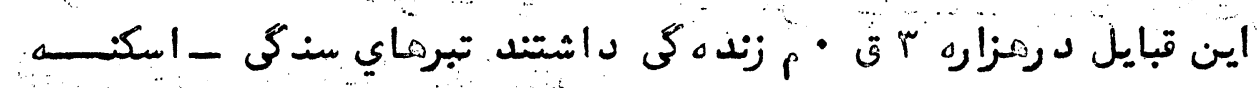

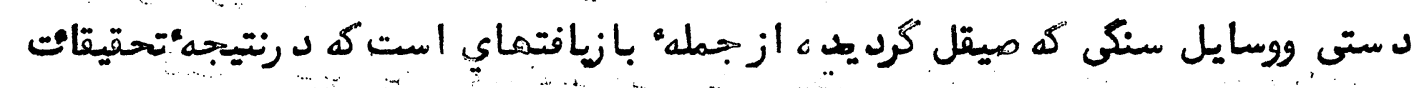

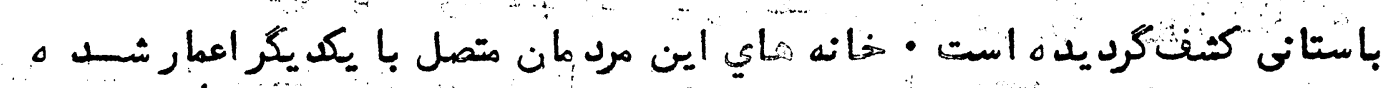

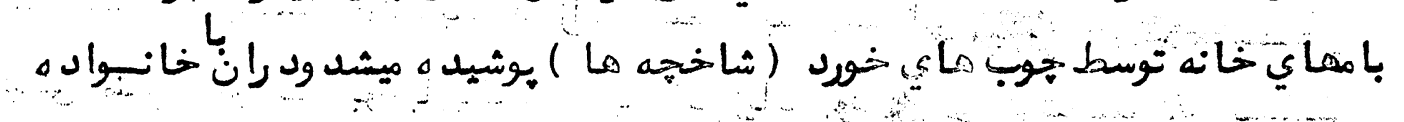

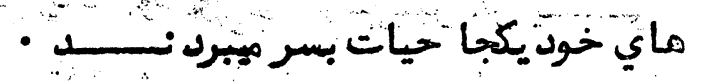
Shankawit لذرنتيجه تحق يقات وكاوشماي باستانى منطقه يى بنبام شنكاويت 


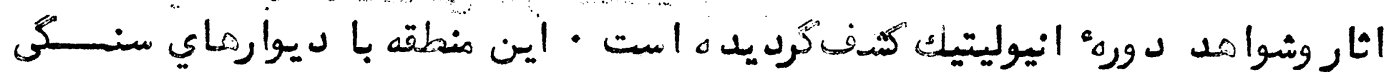

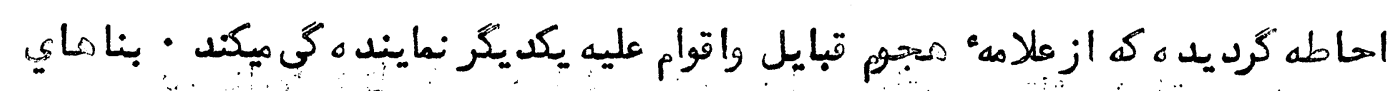

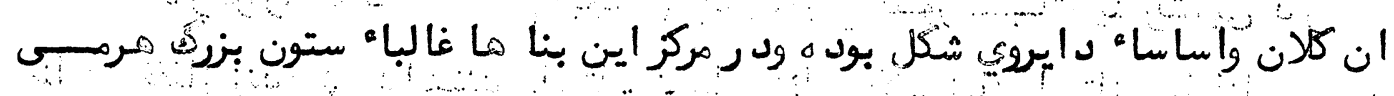

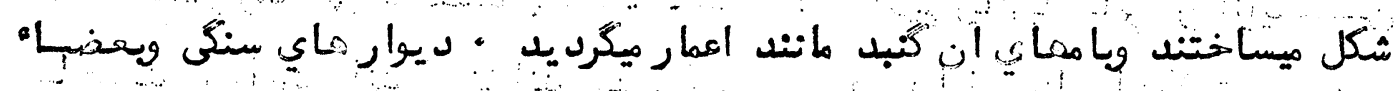

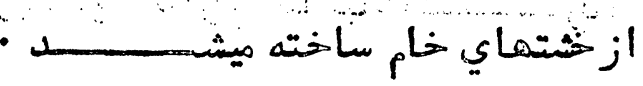

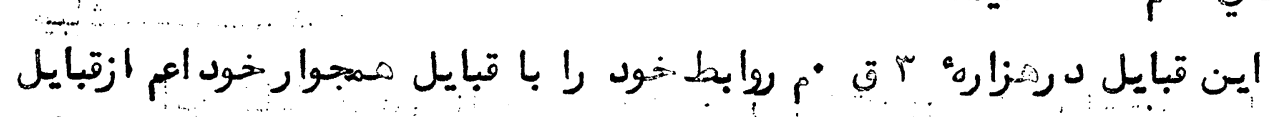

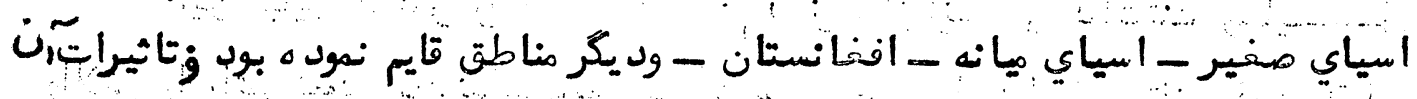

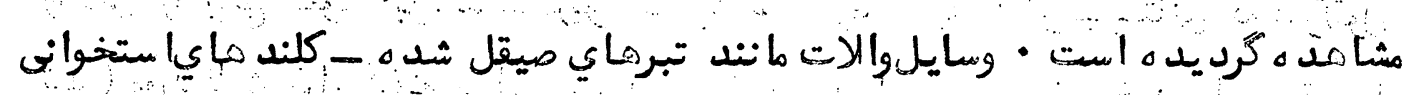

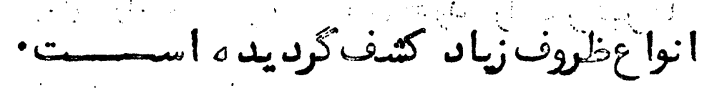

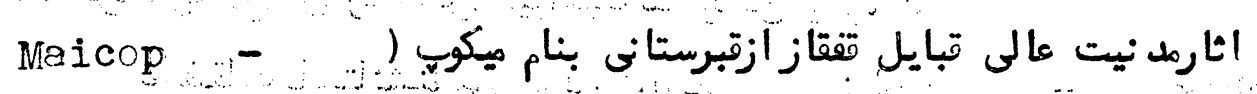

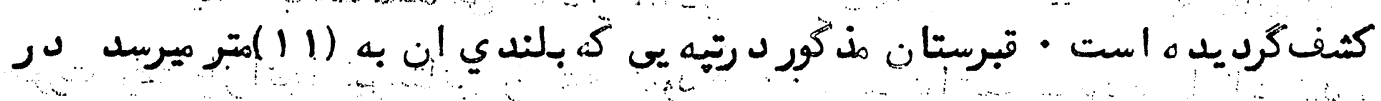

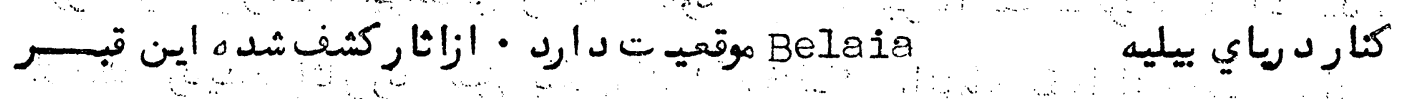

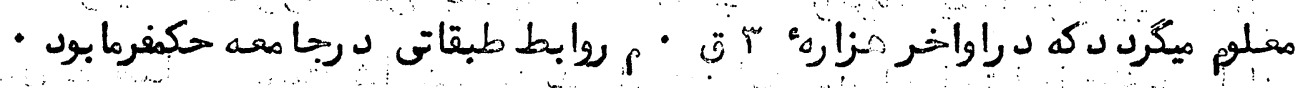

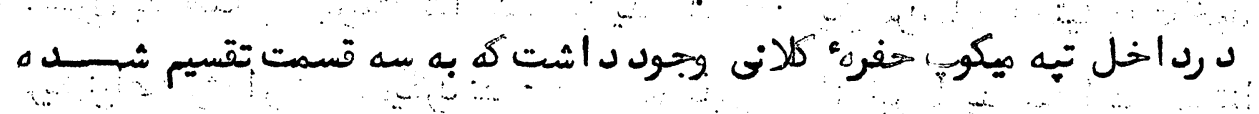

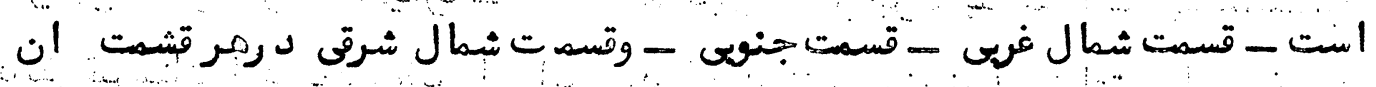

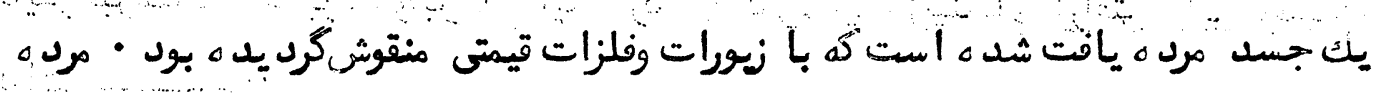

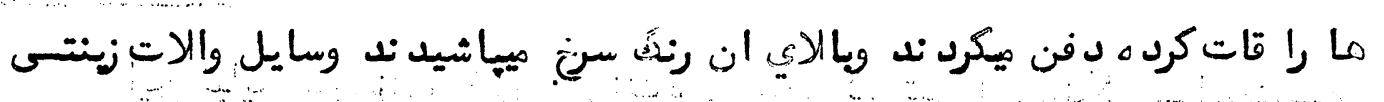

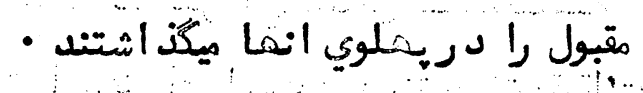

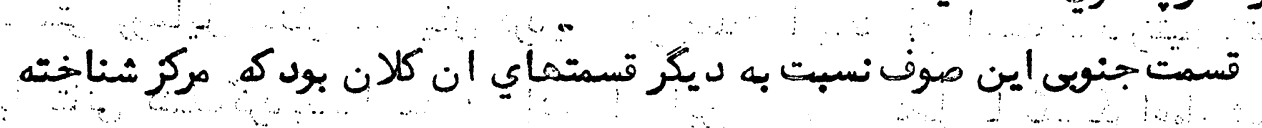

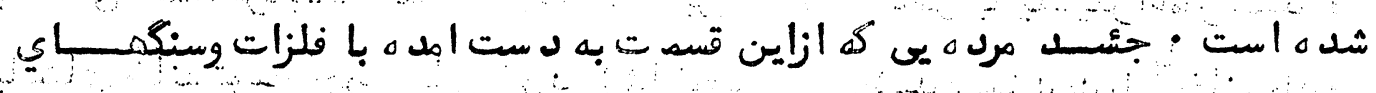

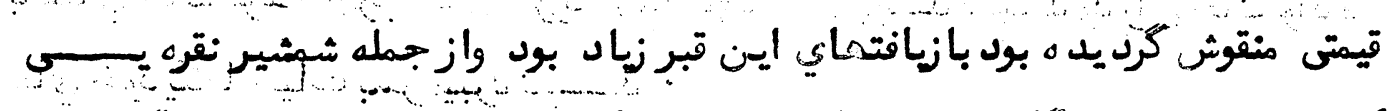

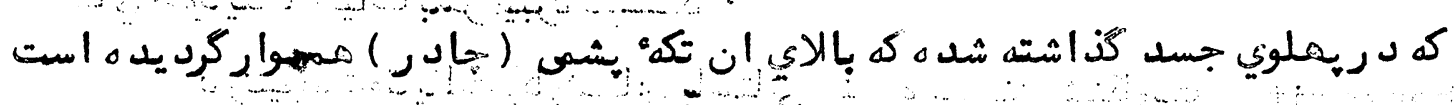

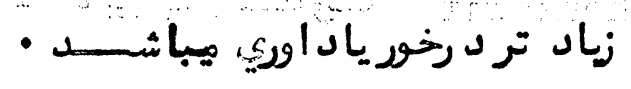




\section{5}

د رنتيجه تحديقات باستانشناسى اثارواشيايى كه ازاين تيه بل بت امســـــه

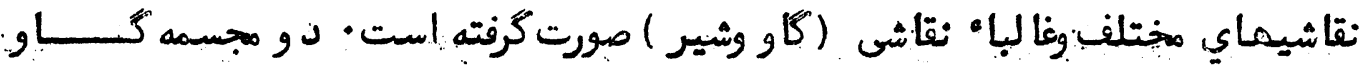
كه ازطلا ساخته شده ود ومجسمه د يخري كه از نقره سانته شده است نيز ازاينج

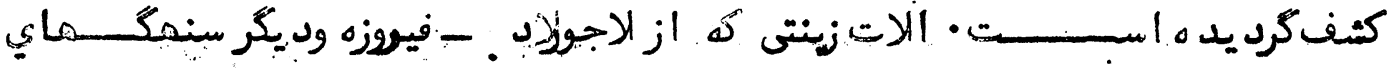

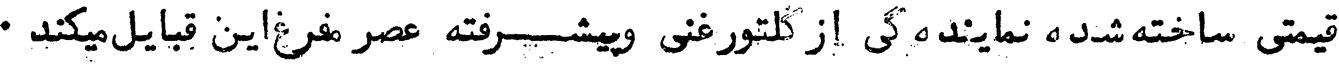

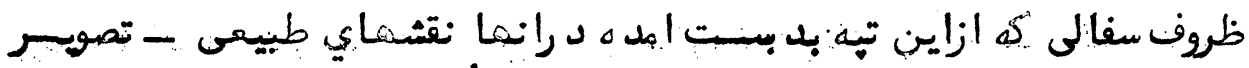

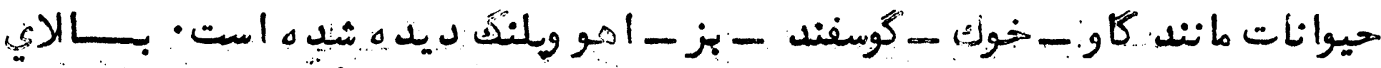

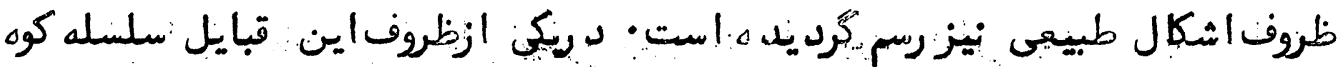

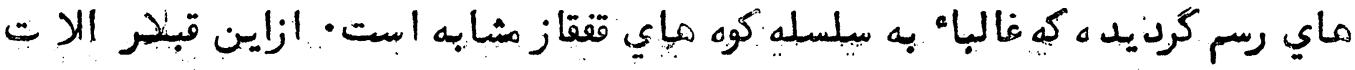

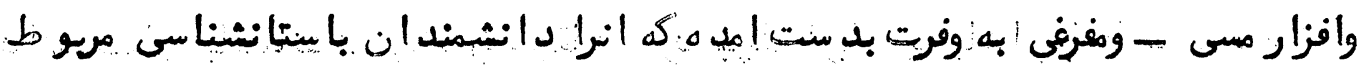

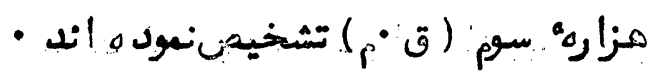

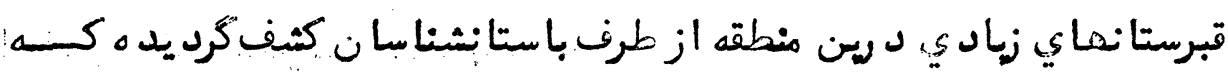

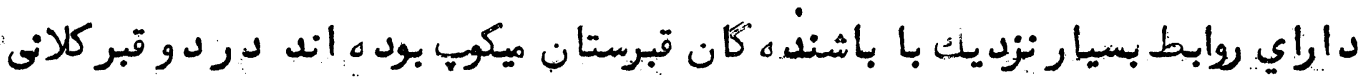

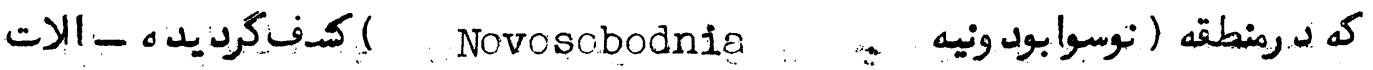

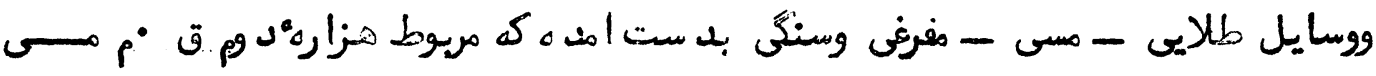

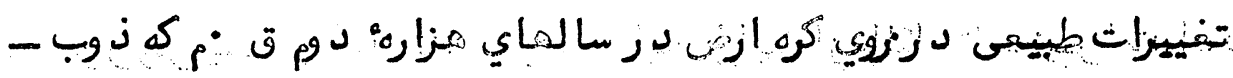

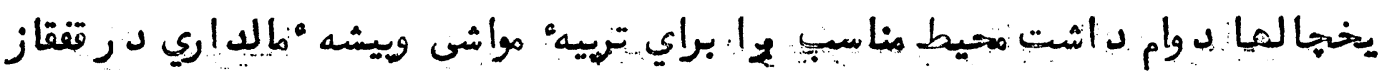

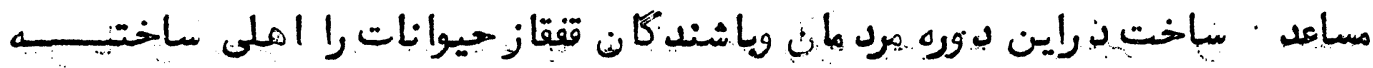

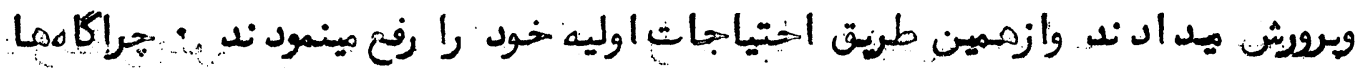

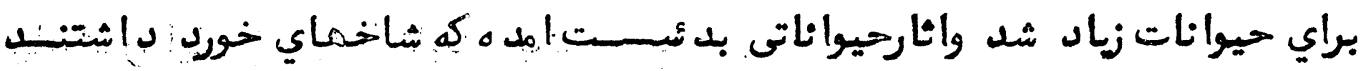

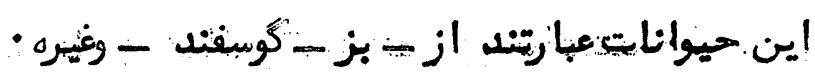

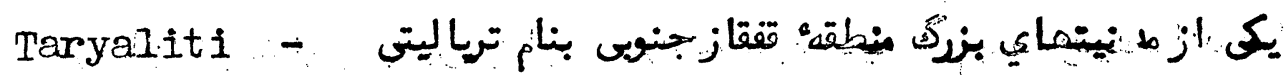

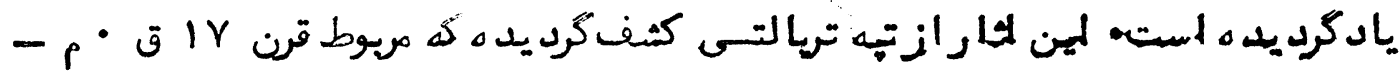




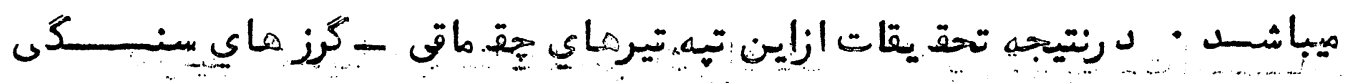

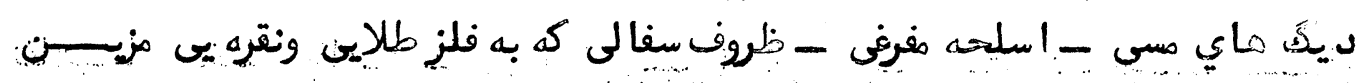

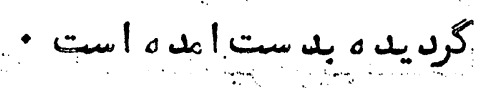

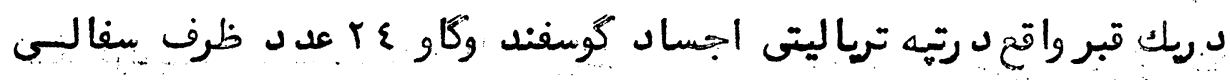

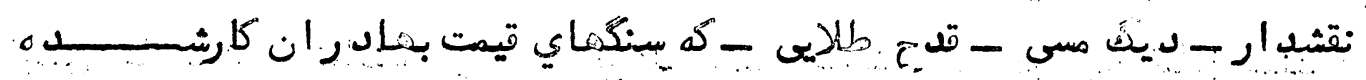

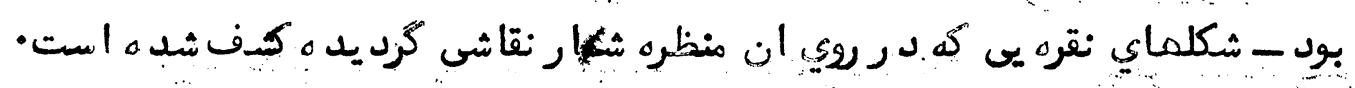

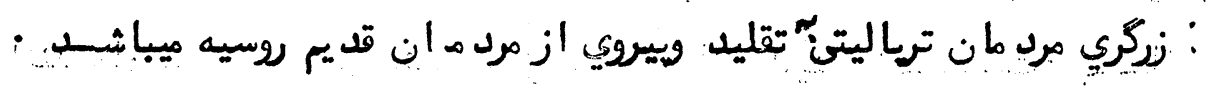

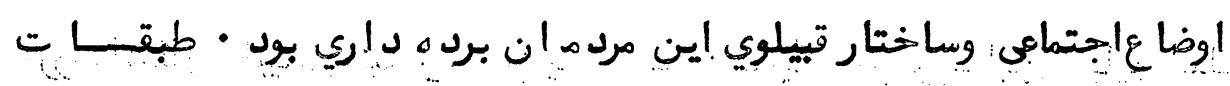

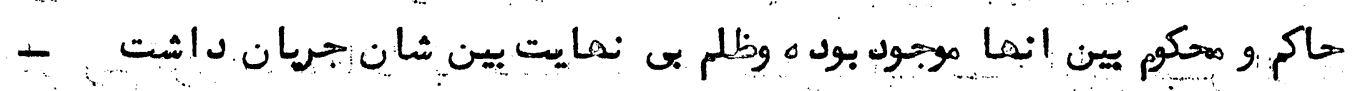

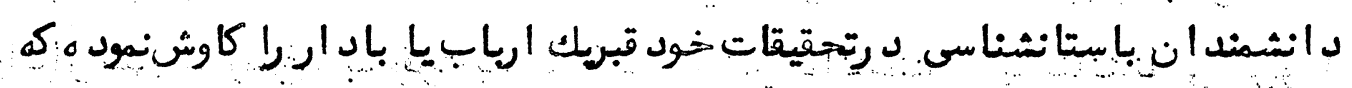

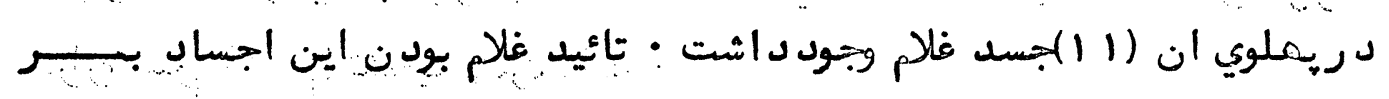

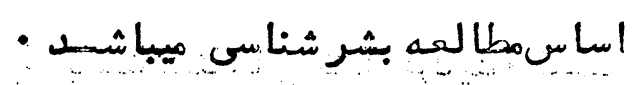

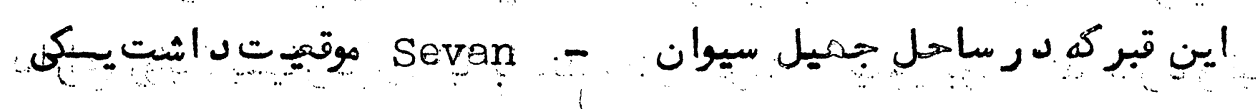

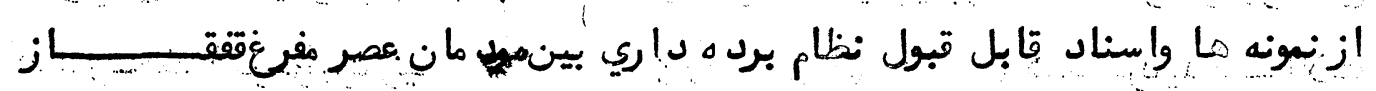

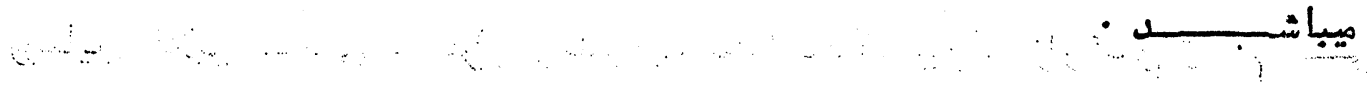

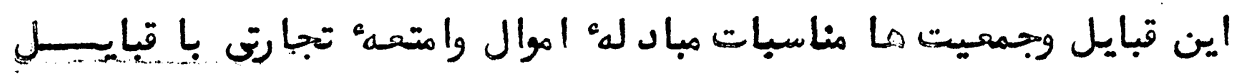

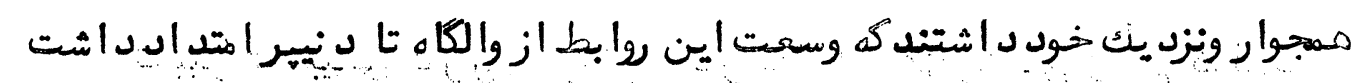

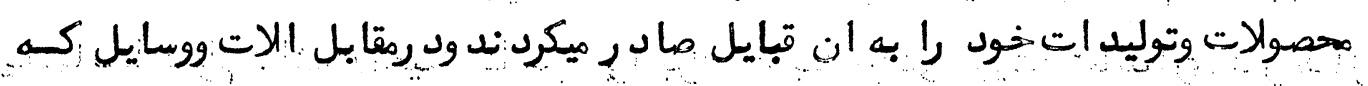

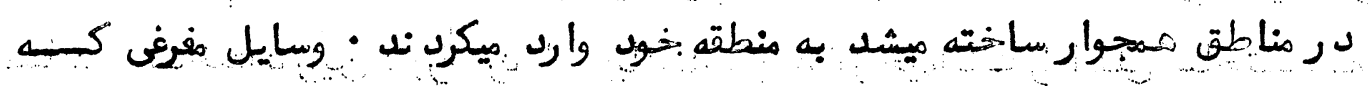

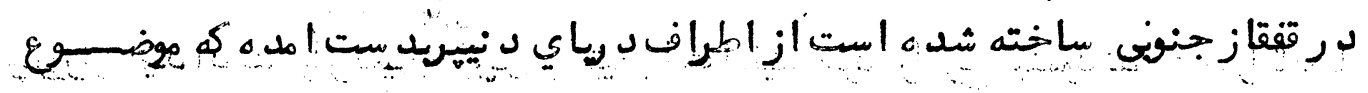

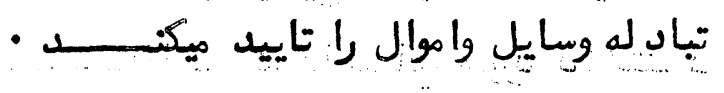

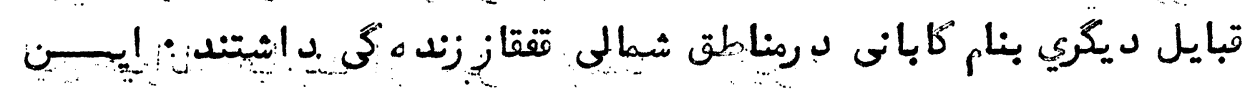

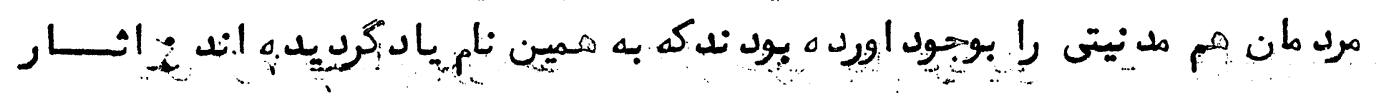




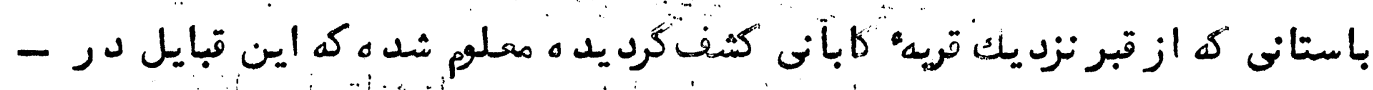

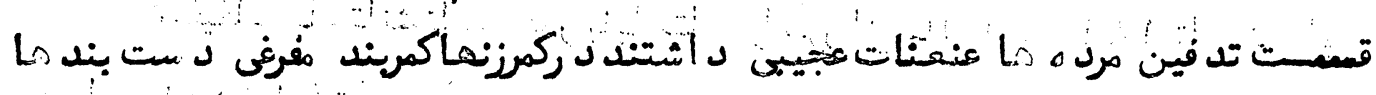

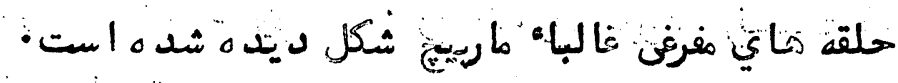

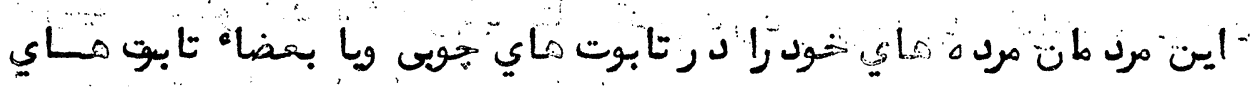

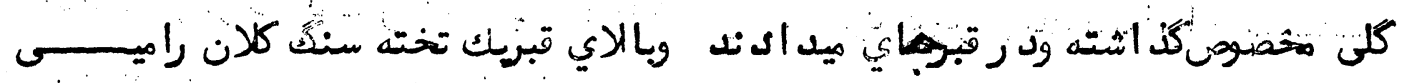

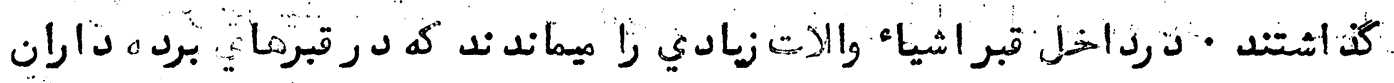

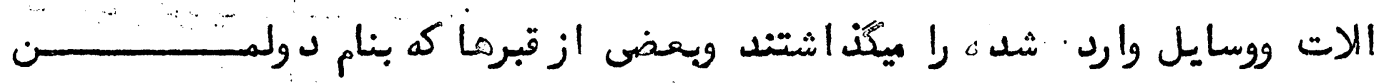
( DoIman : )

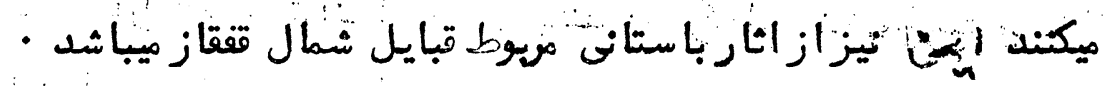

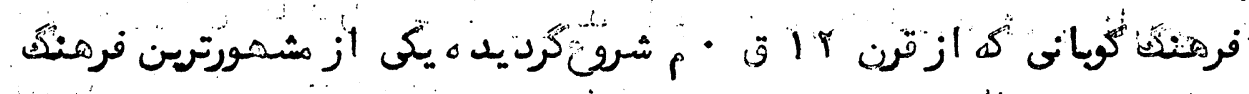

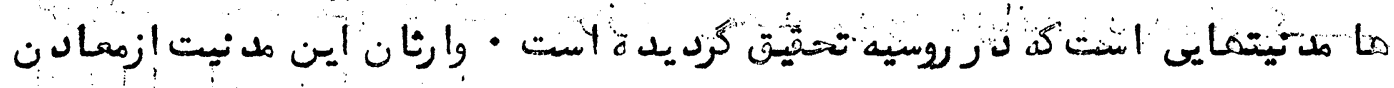

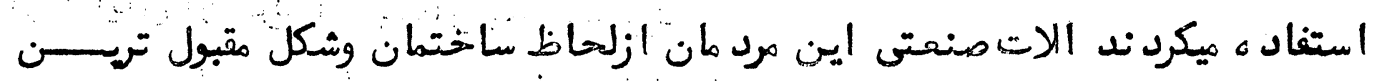

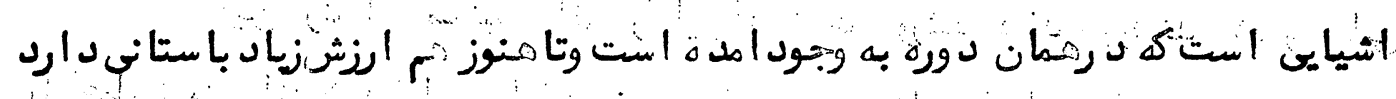

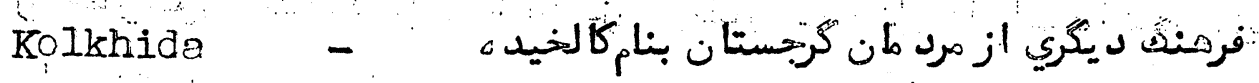

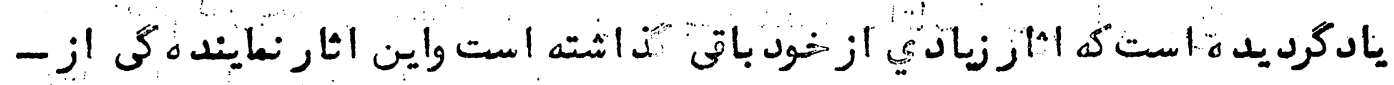

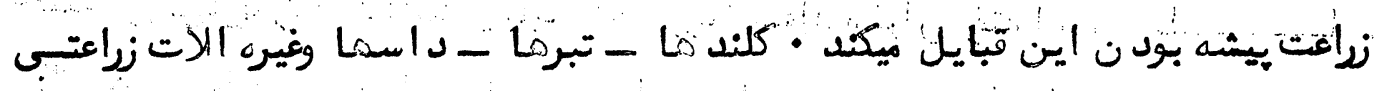

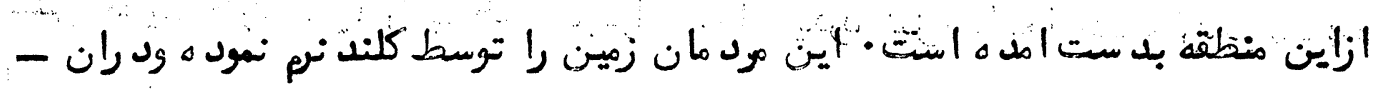

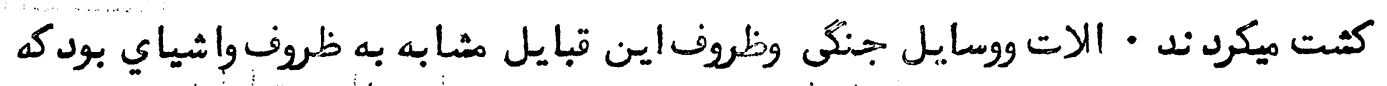

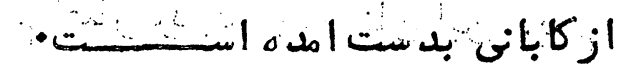


9- تحق يقات باستانشناسى درشرق نزليكُ؛ وشرق ميانه :

تحقيقات باستانشناسى د ربابلمتان واسور از سالماي و و

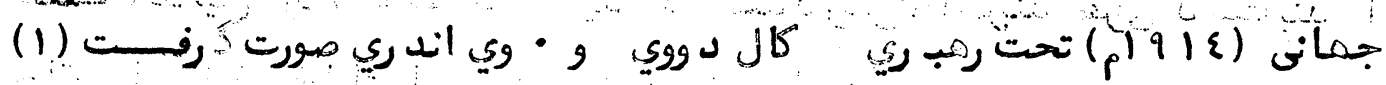

د رنتيجه معلوم شدكه شمَر با بلستان قديم د رد وطرف د رياي فرات موقعيت ت ارد •

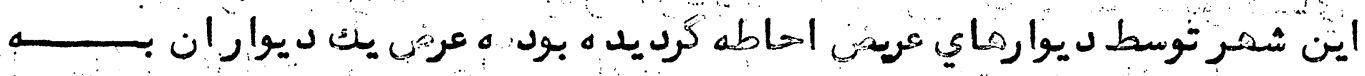

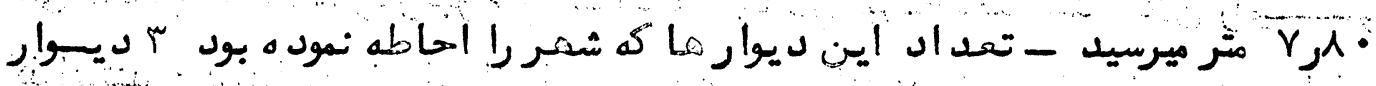

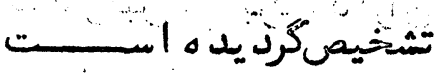
د رداخل شمر اثاروكلايم زيادي كثفكرد يده كه نماينده كى از منظا

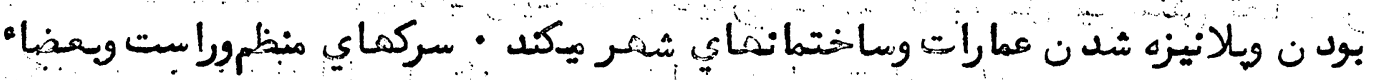

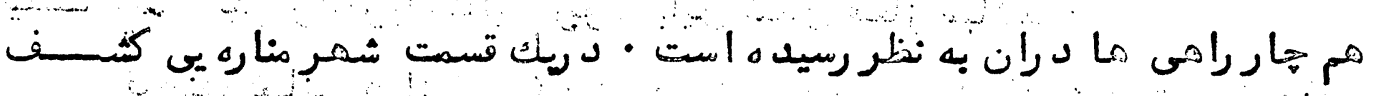

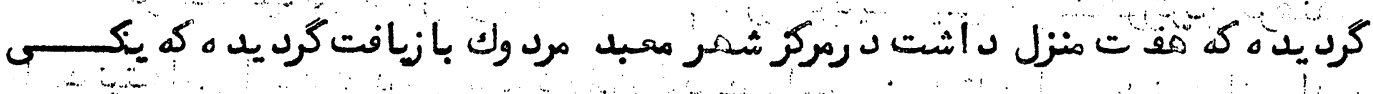

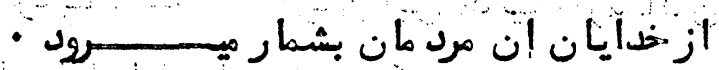

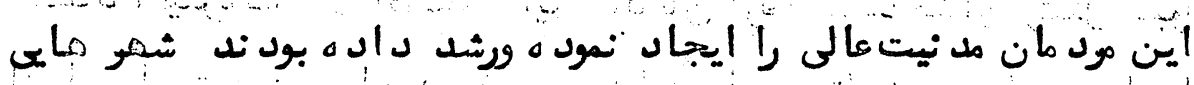

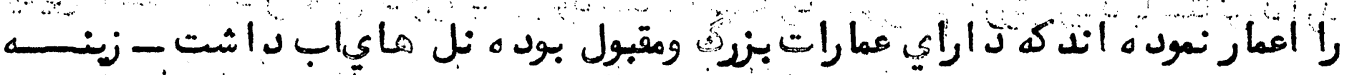

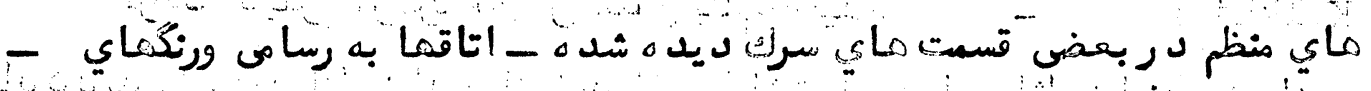

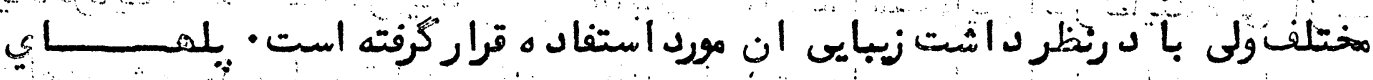

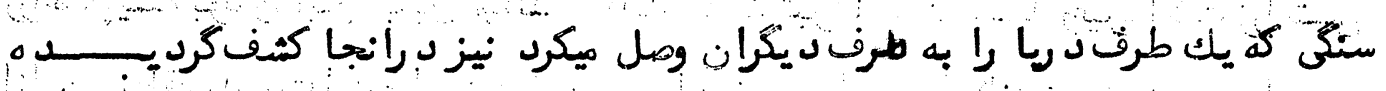

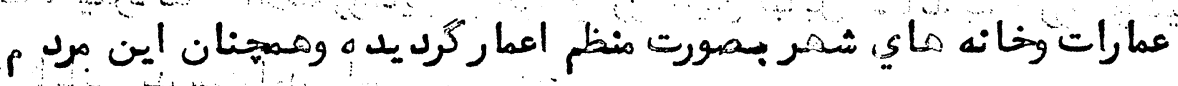

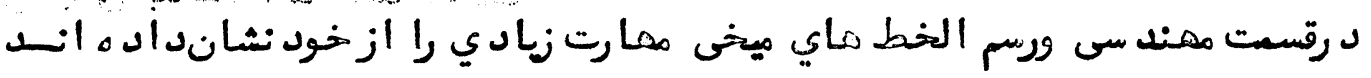

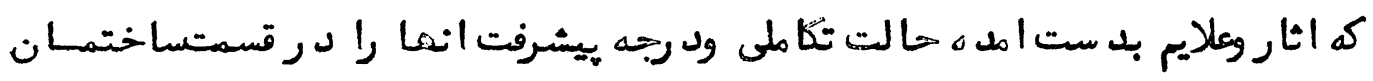

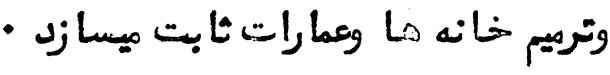

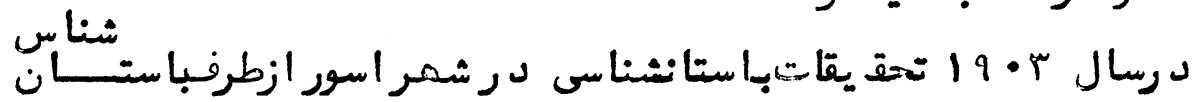

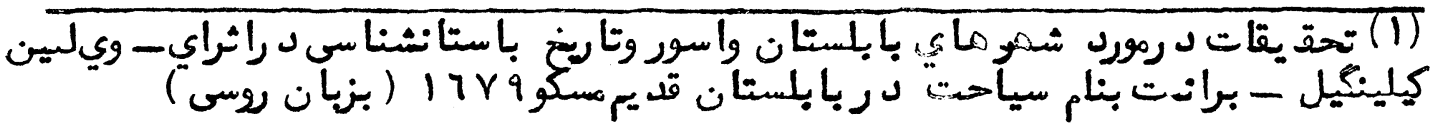




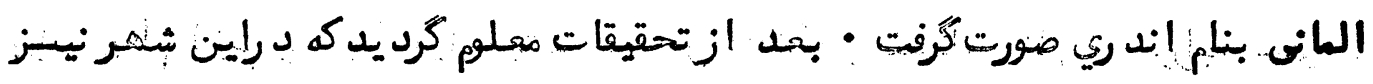

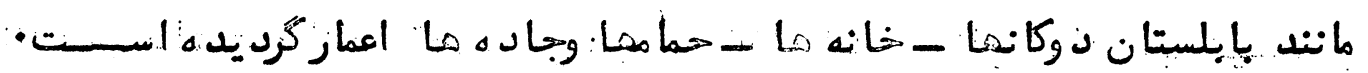

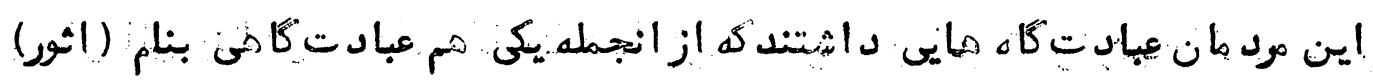

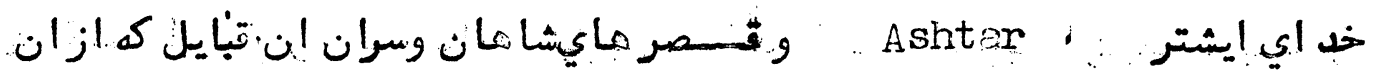

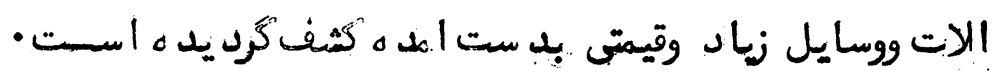

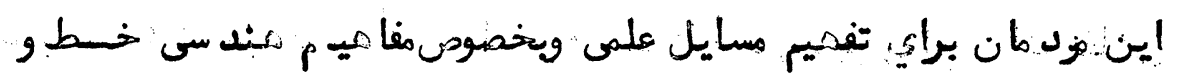

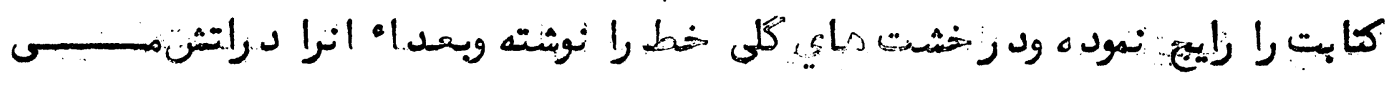

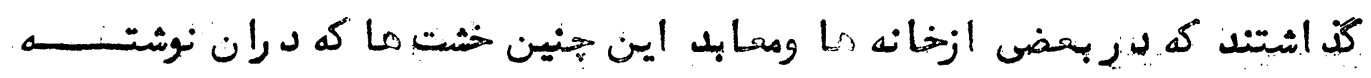

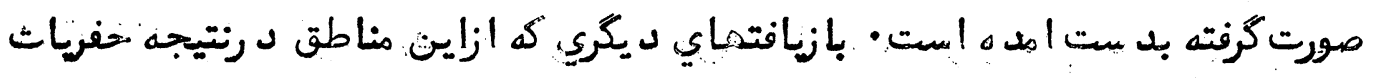

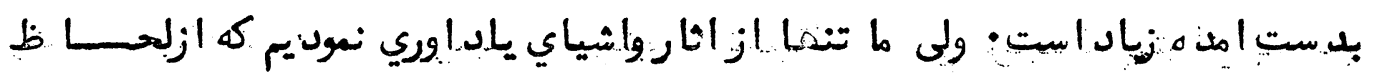

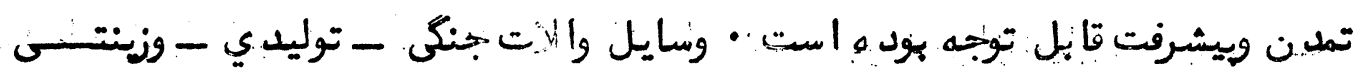

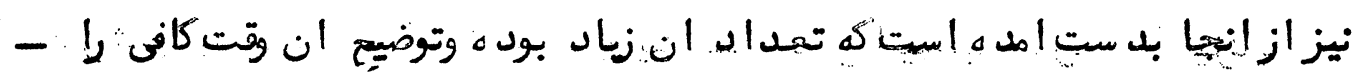

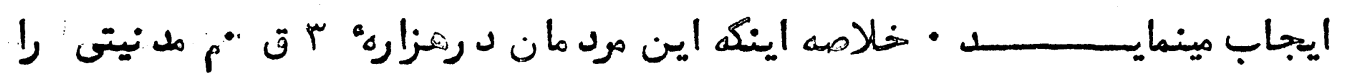

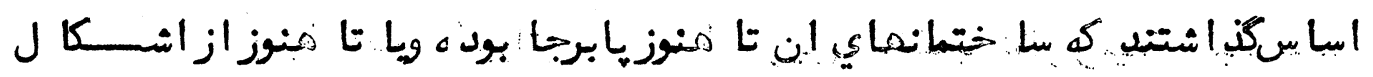

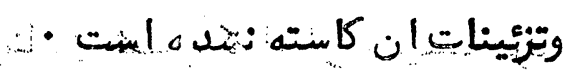

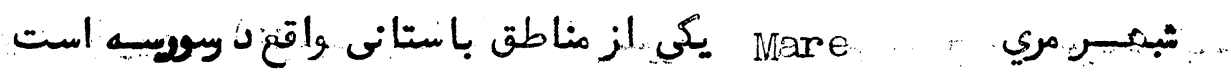

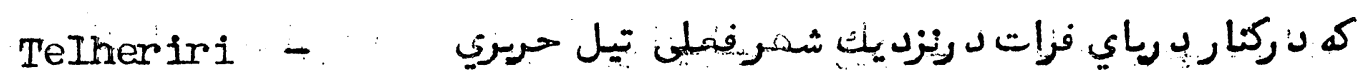

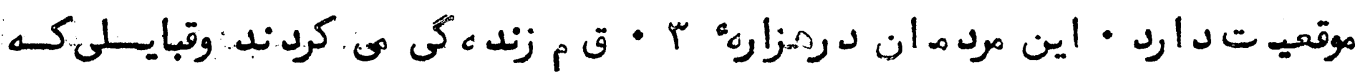

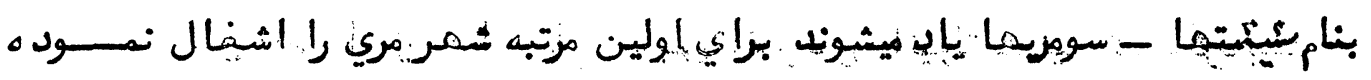

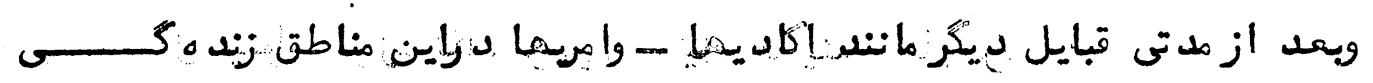

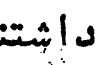

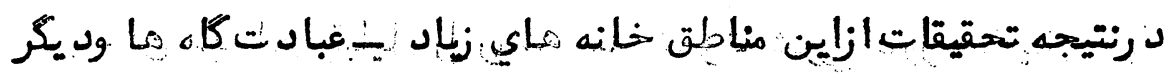

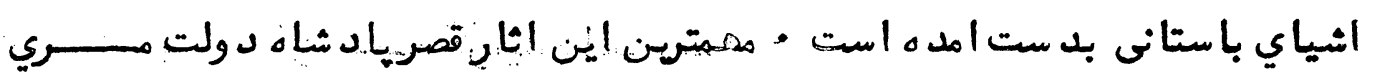




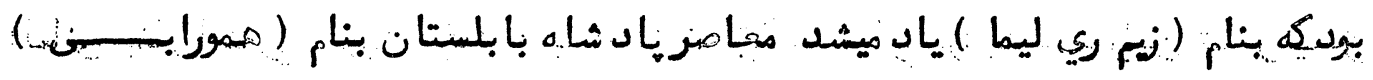

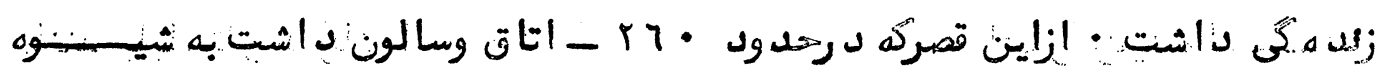

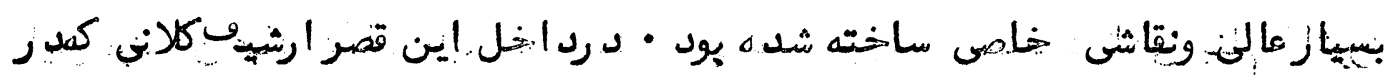

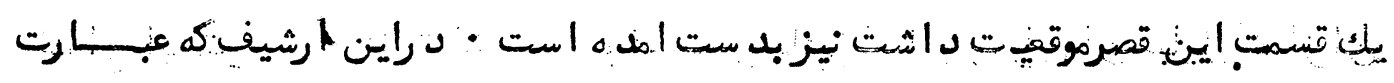

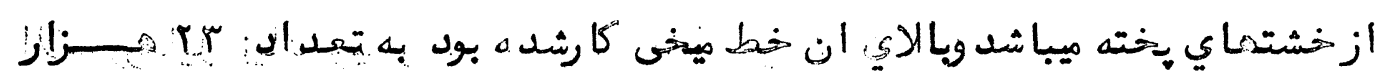

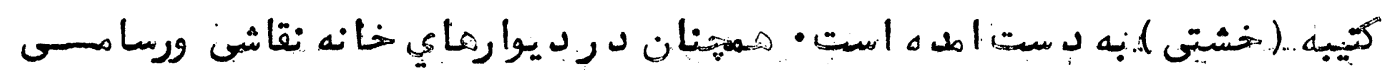

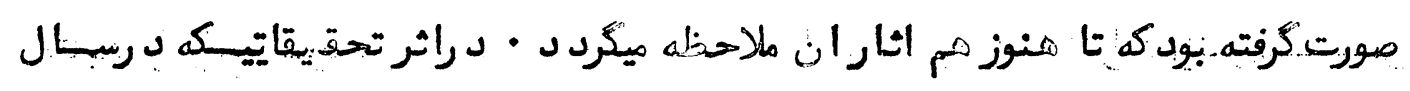

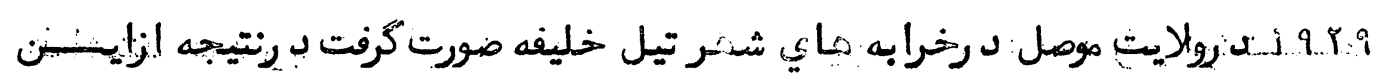

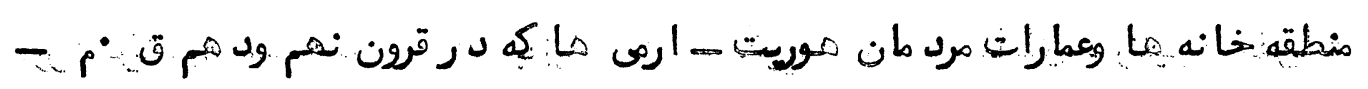

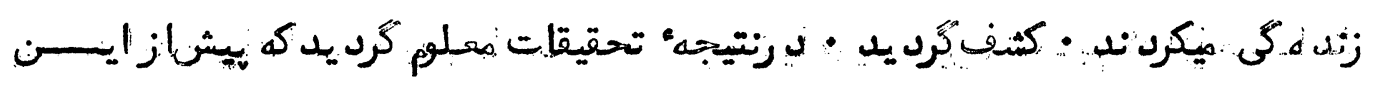

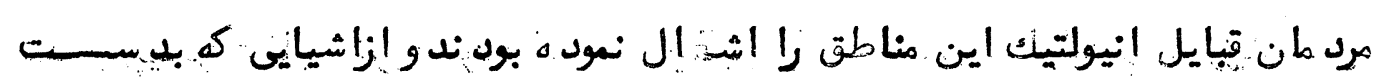

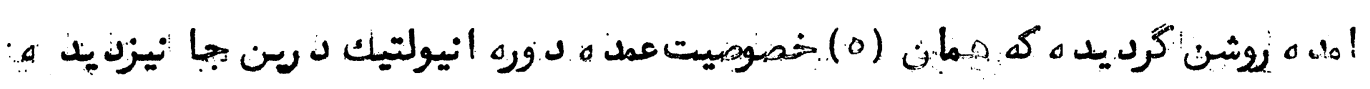
los.

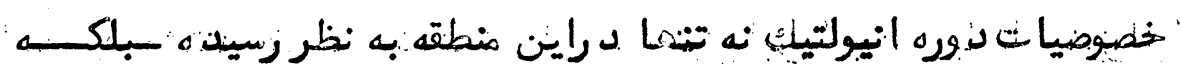

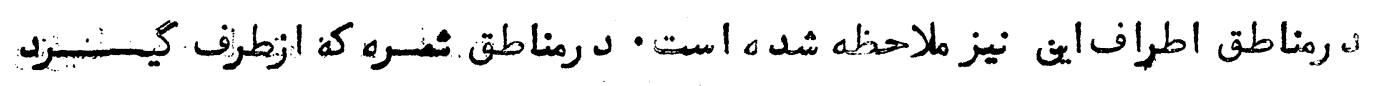

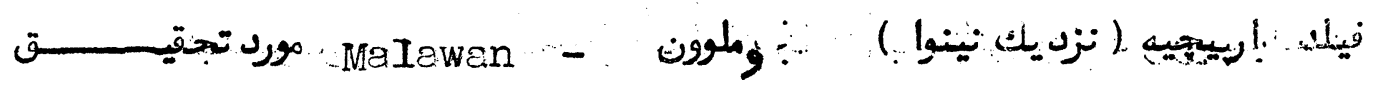

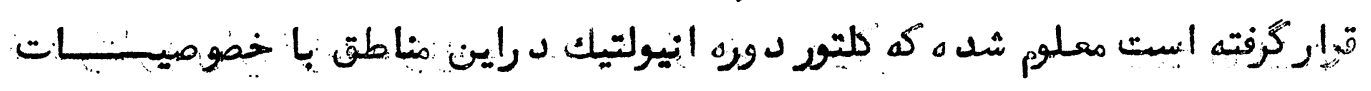

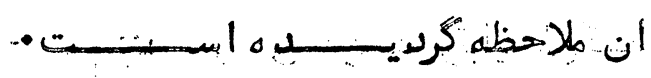

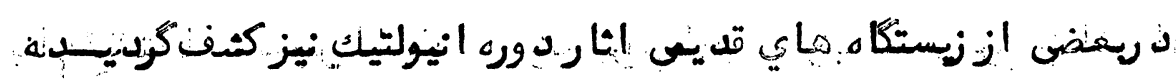

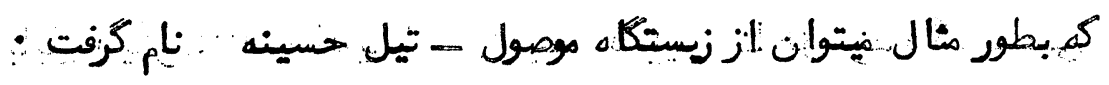

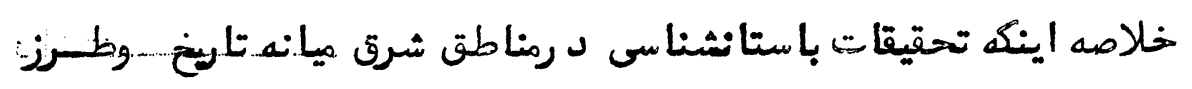

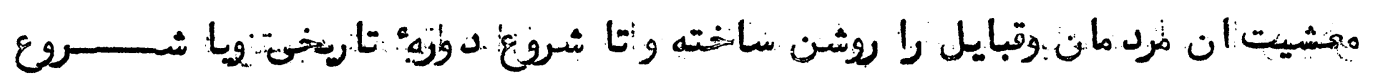

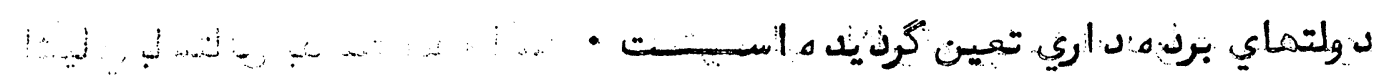


تحقيقات باستانشناسى دراين مناطق نمايانكر انست كه اين مد نيتما يسا

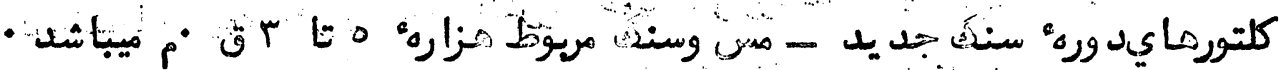

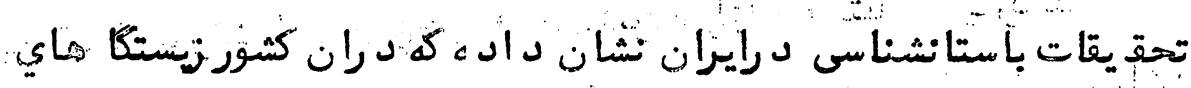

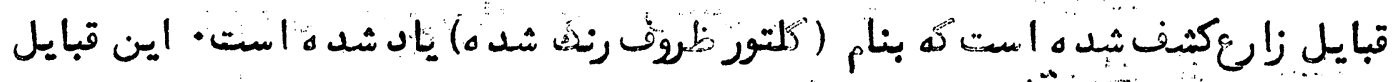

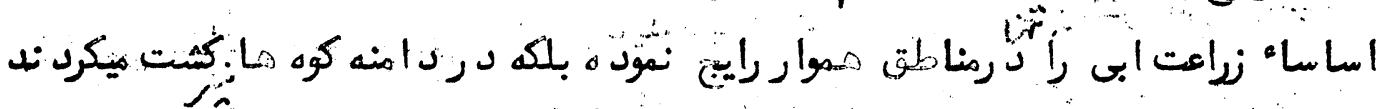

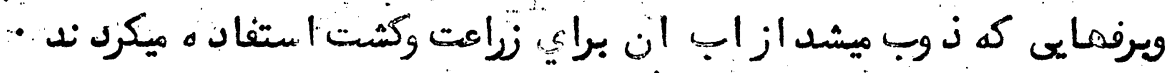

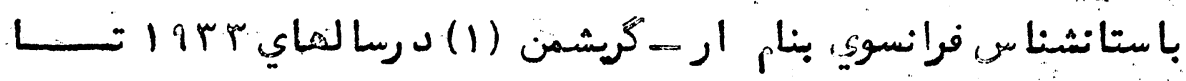

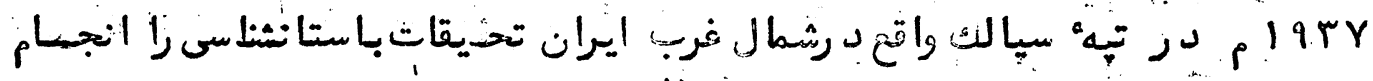

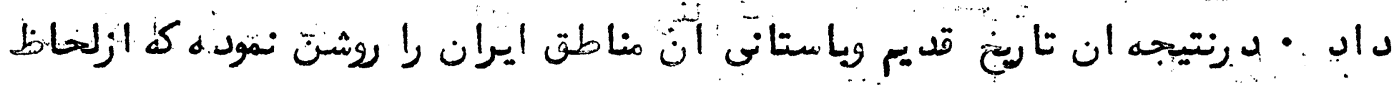

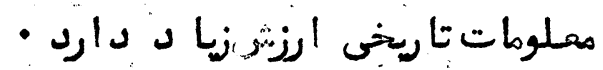

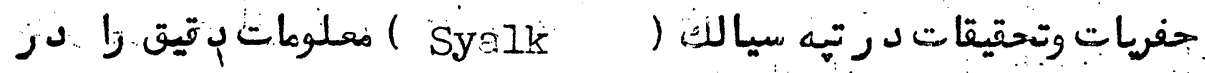

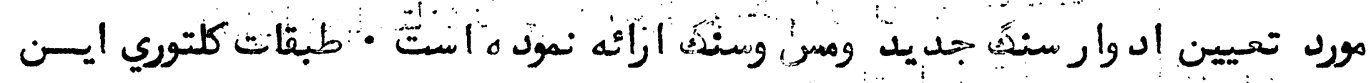

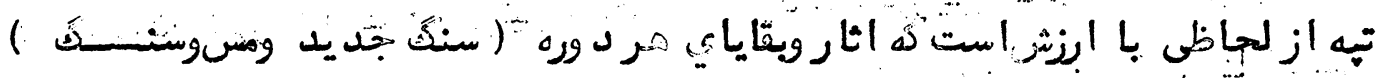

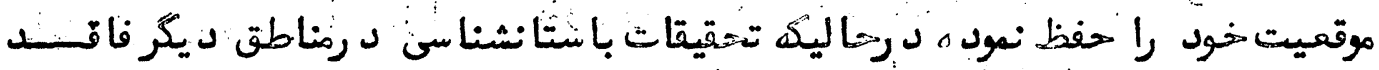

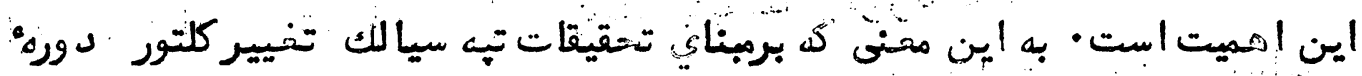

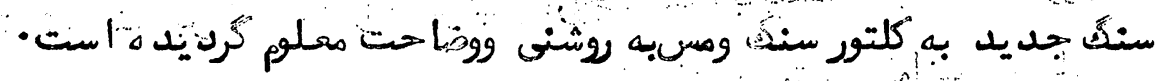

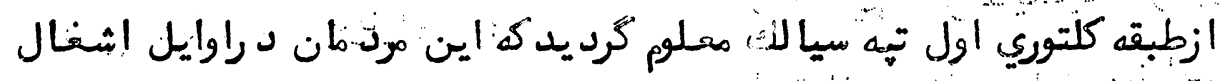

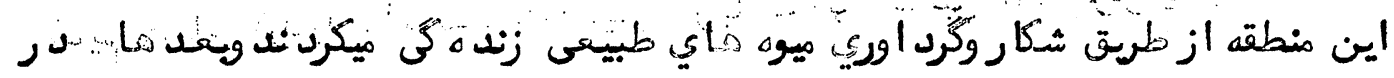

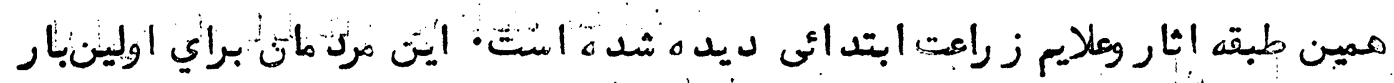

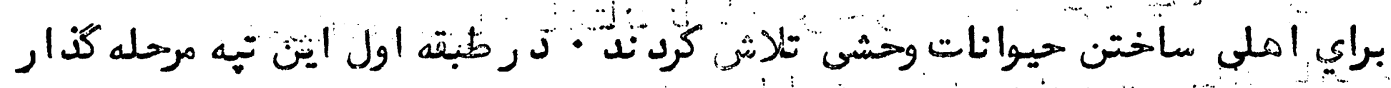

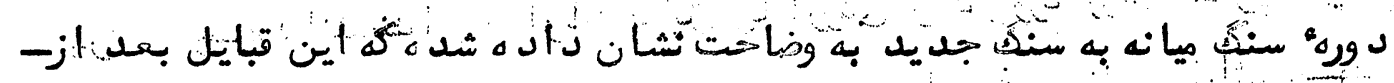

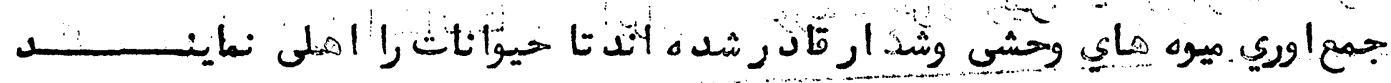

I- Ghirshman, Fouilles dé Sialk-V, VI, Paris, I939 . 


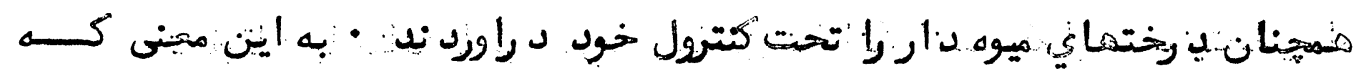

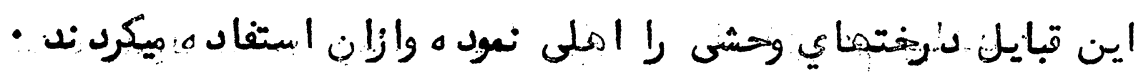

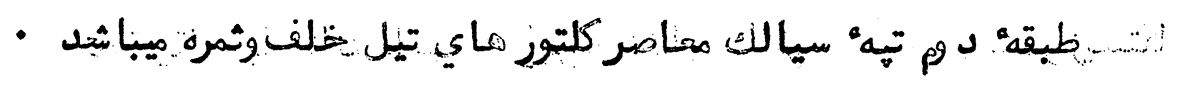

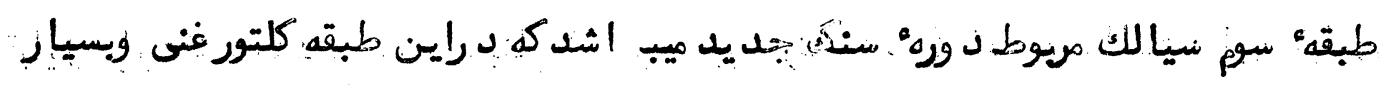

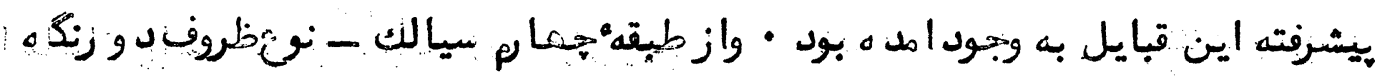

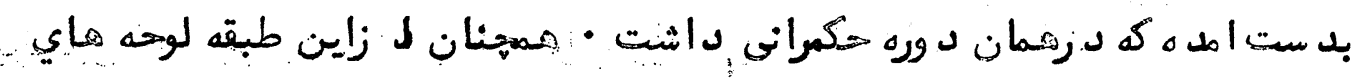

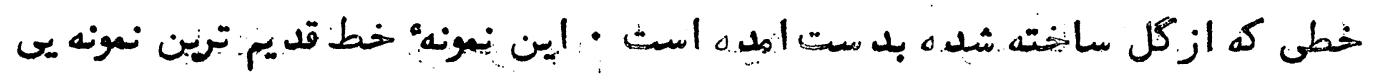

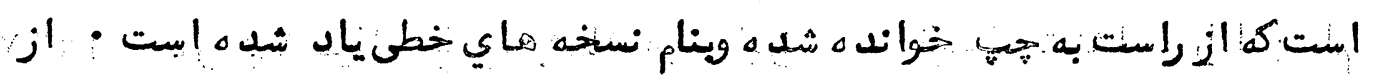

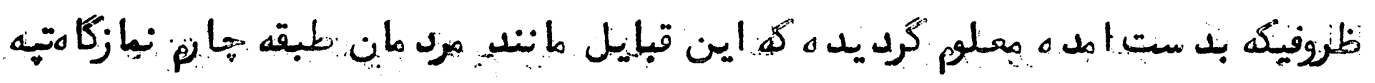

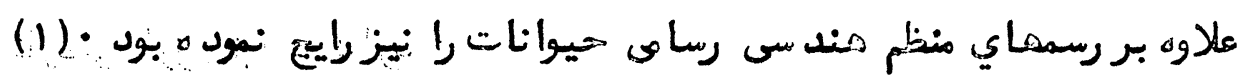

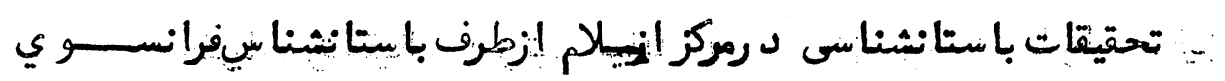

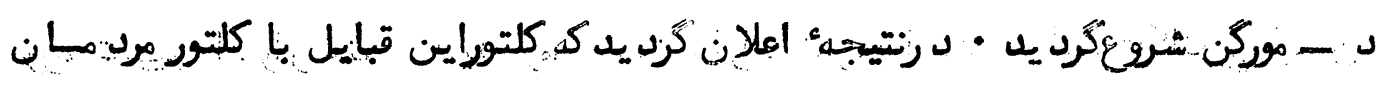

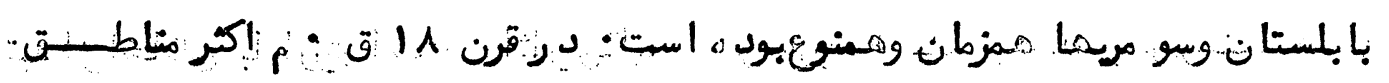

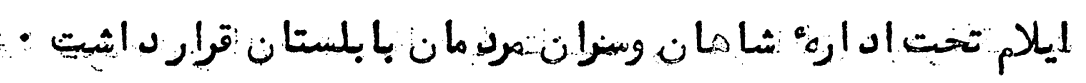

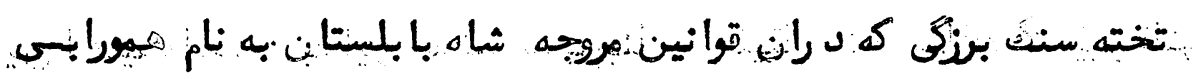

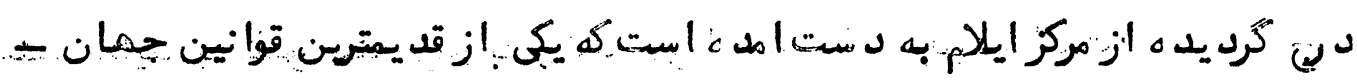

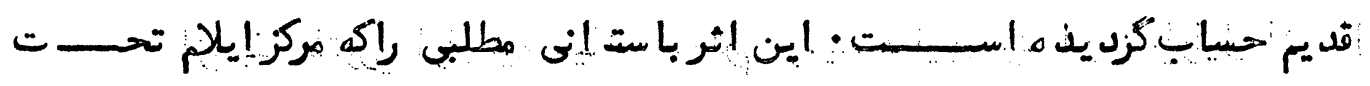
إداره؛ شاه بإبلستان بود تاييد ميد إرد -

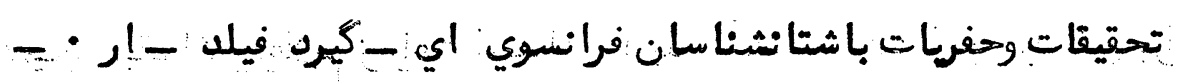

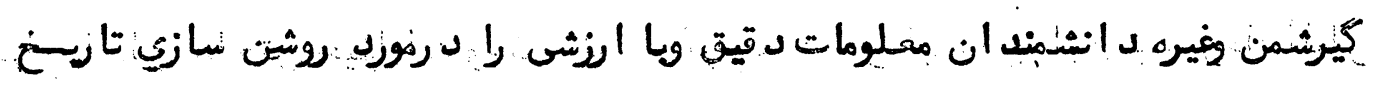

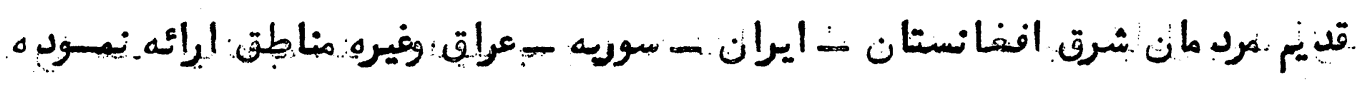

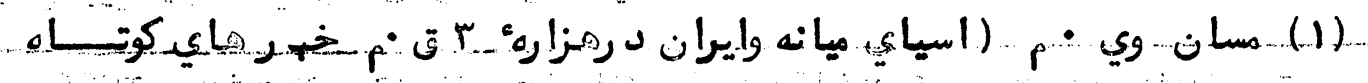

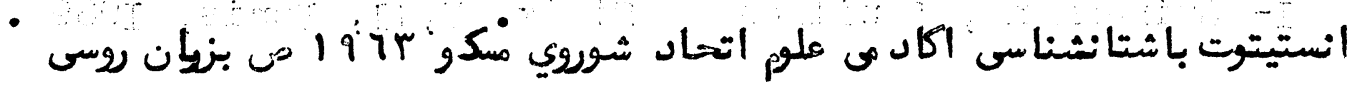




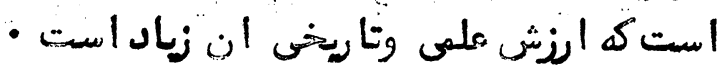

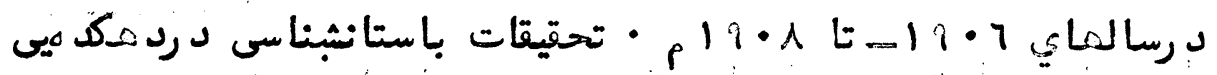

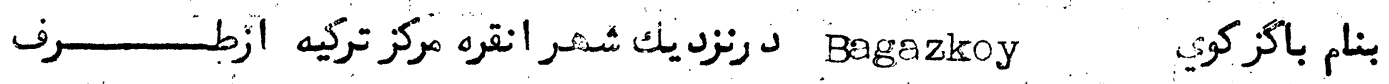

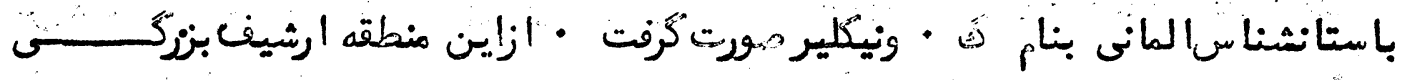

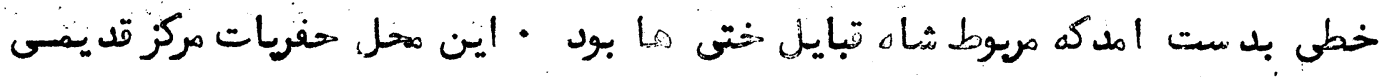

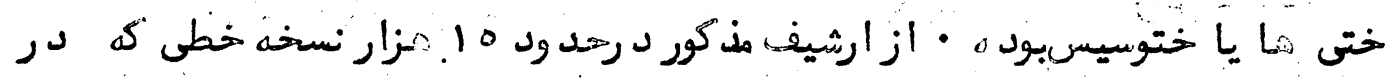

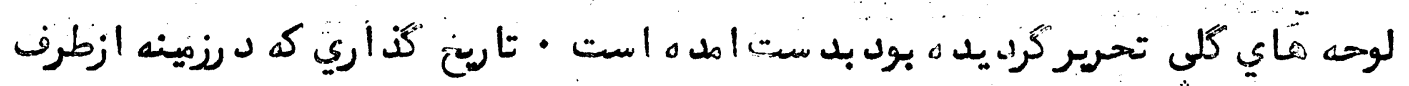

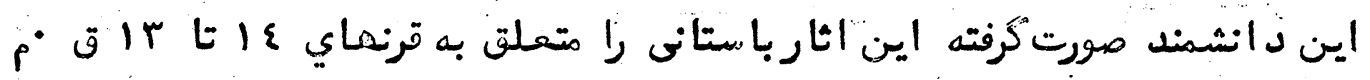

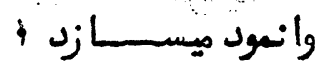

بايد ياد أورخرد يدك اشتباه اين باستانشناسد رين بودكبد ون اثارخطى

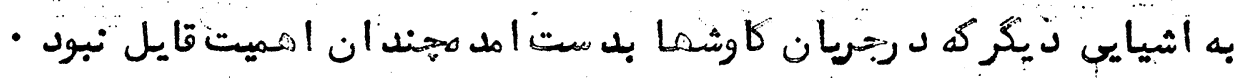

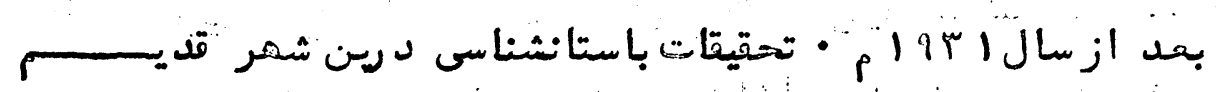

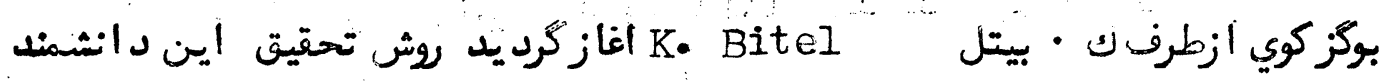

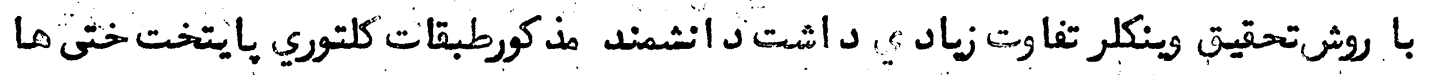

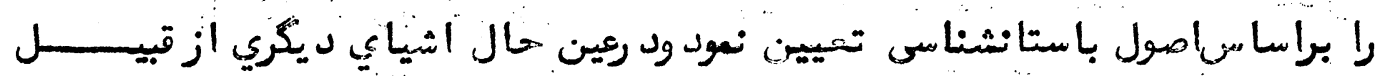

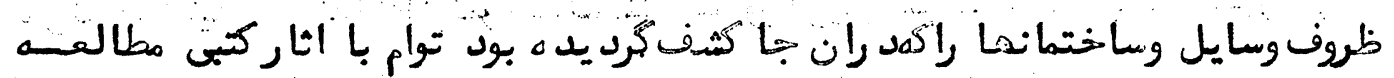

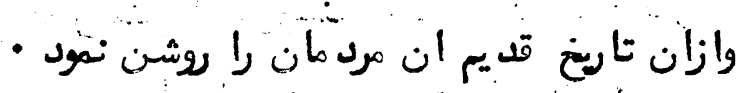

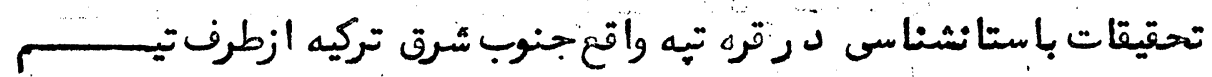

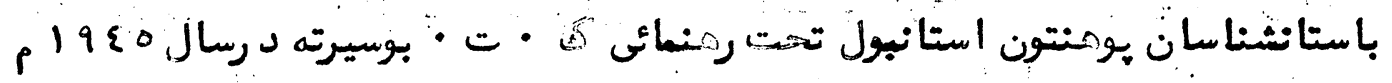

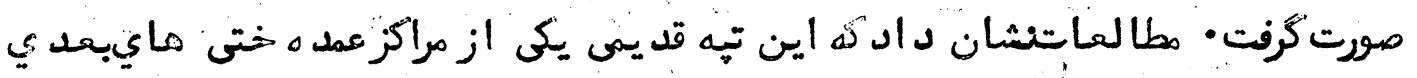

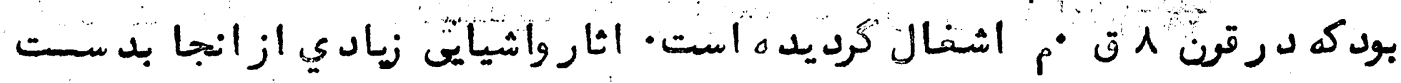

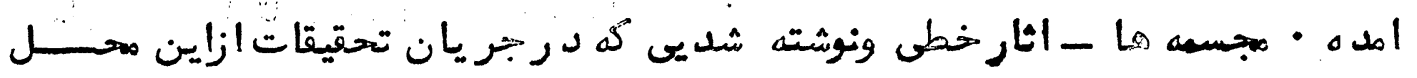

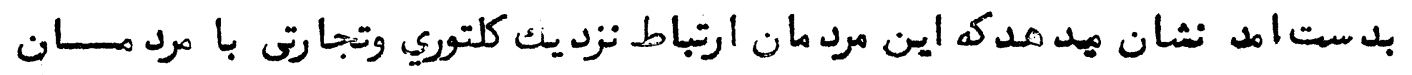




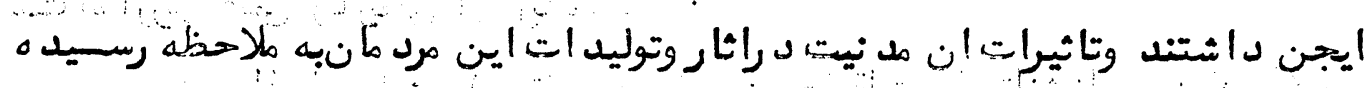
.

تجقيقات باستانشناسي لد رقلمور اهراتوري، خيتما كه ساحه إراضي ان ان

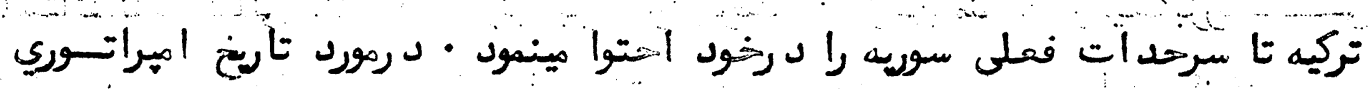

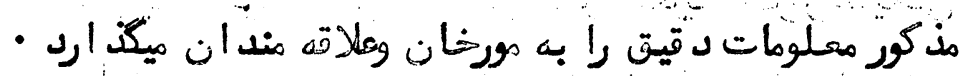

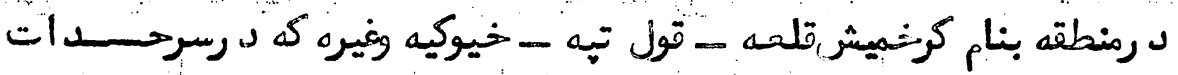

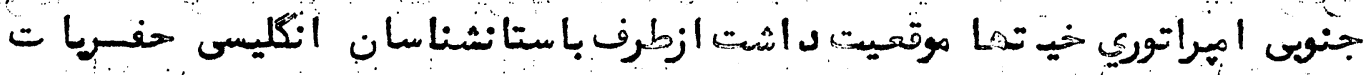

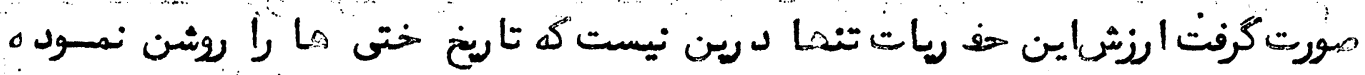

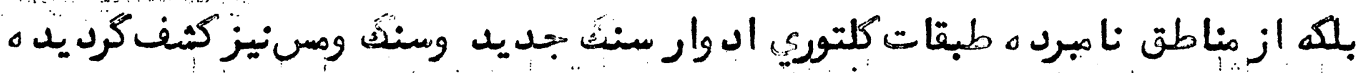
اسسـ الس إس

تحقيقات وكاوشماي باست انشناسى كه د راليه خيوكيه ازطرفكروباستان

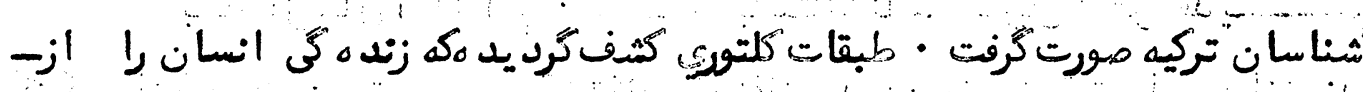

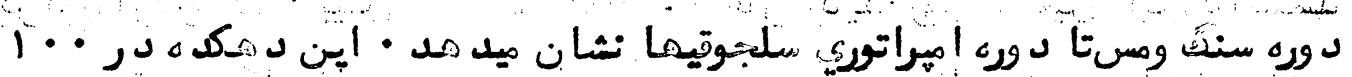

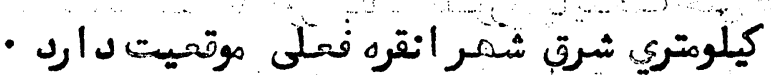

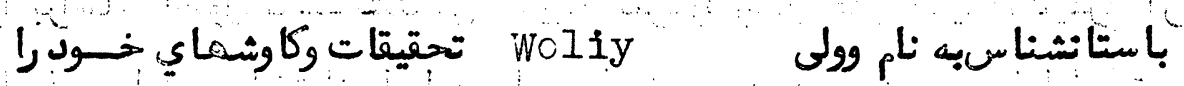

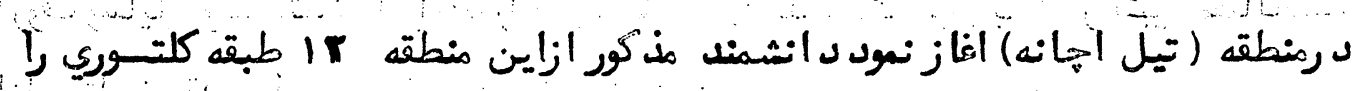

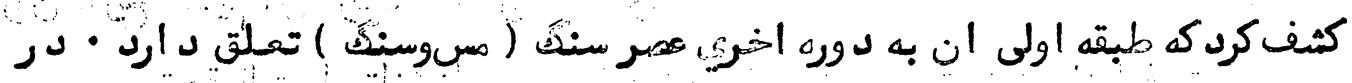

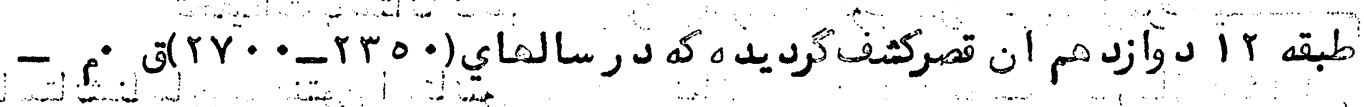
أعطاركرديد ه آست • ازطبقه هف تم اين همل باستانى لوحه هاي كلي يافت كرديده

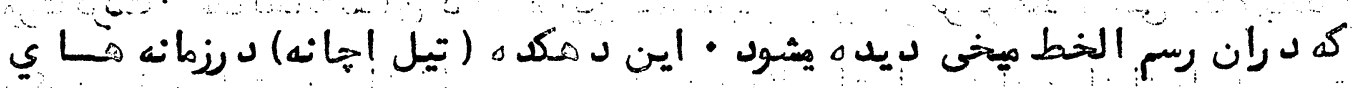

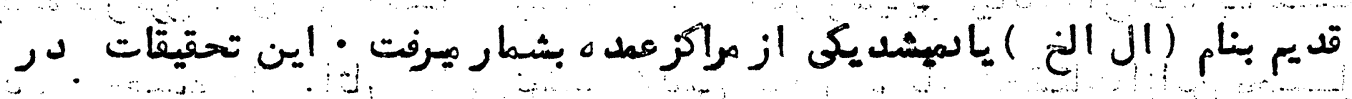

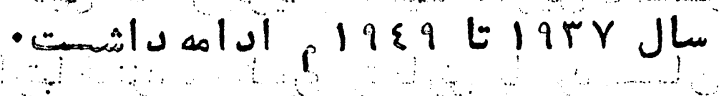


•

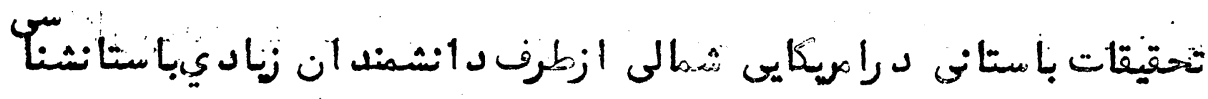

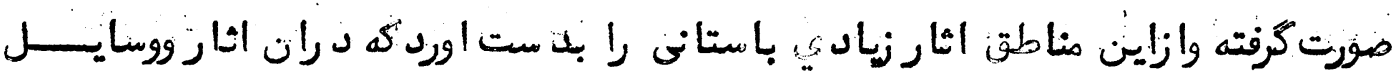

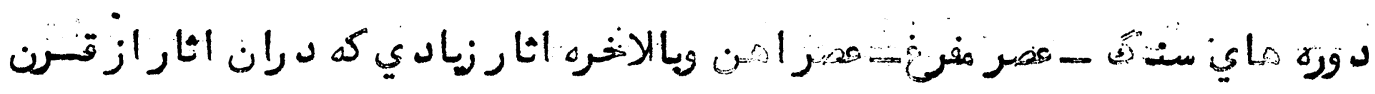

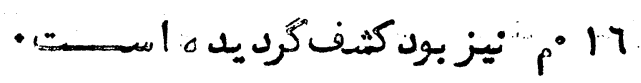

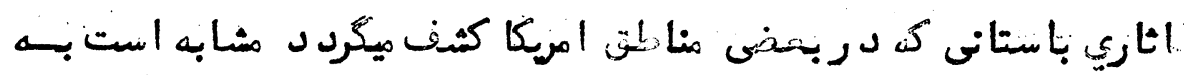

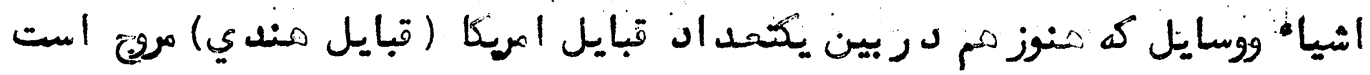

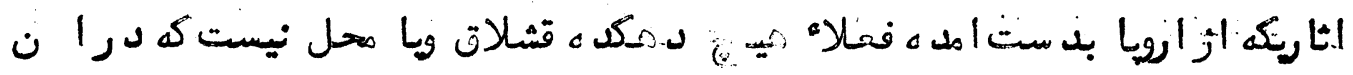

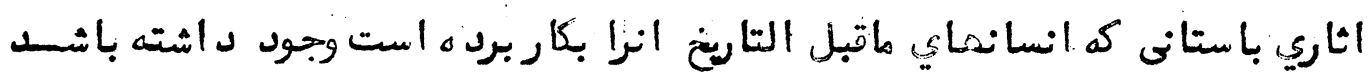

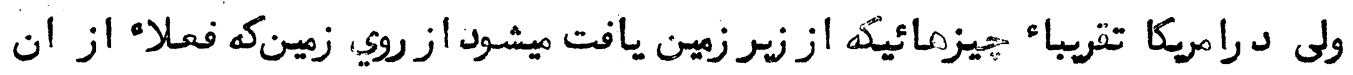

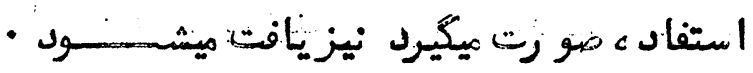

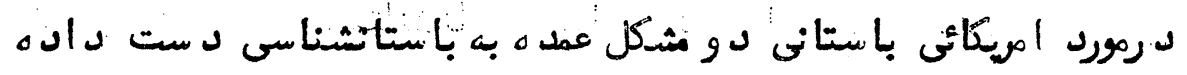

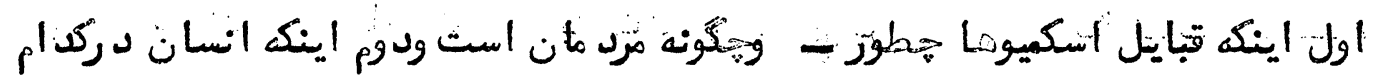

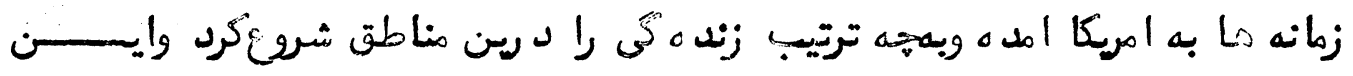

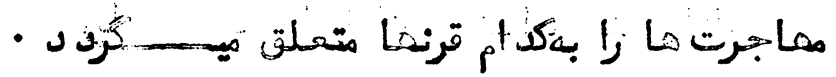

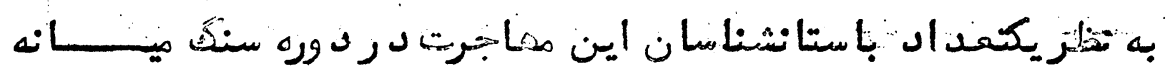

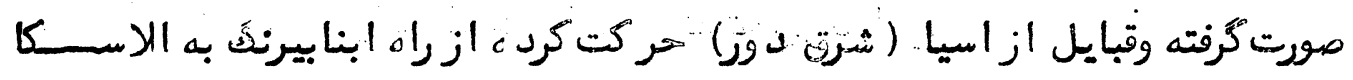

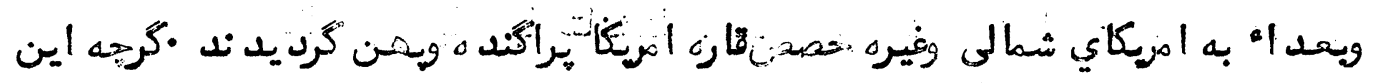

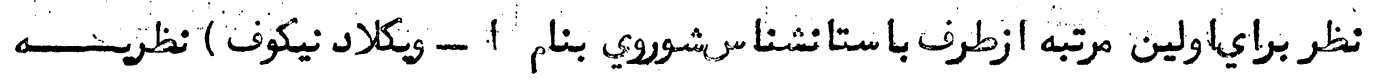

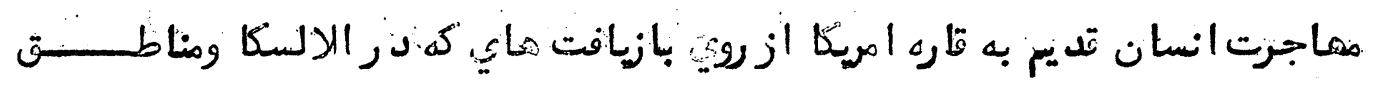

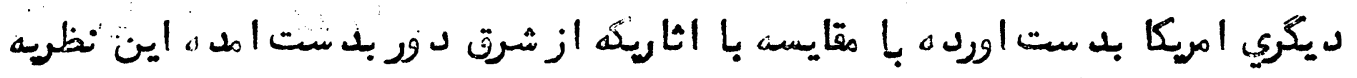

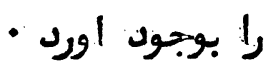


د رنزد يكى شـر فولس واقَ نيومكسيكو تهقيقات باستانى ضورت كرفته وازان

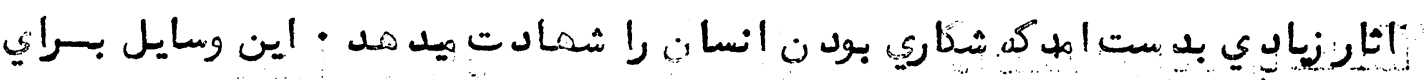

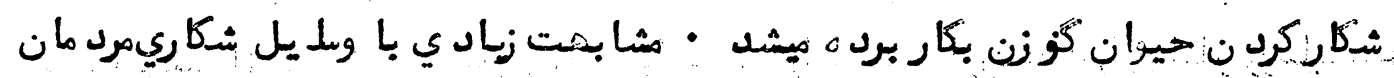

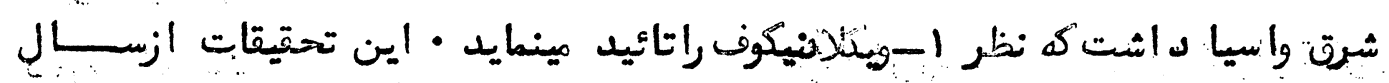

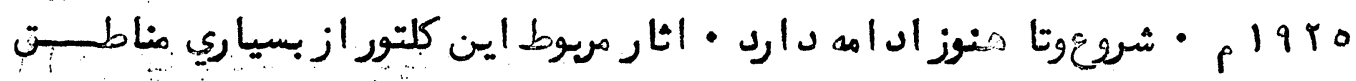
إمركا بد ست امد ه كه وسعت وزياد بود ن ساحه د اخل اين مد نيت شمبد ه ميشو د •

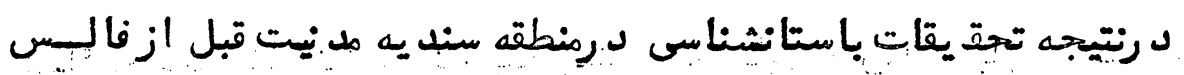

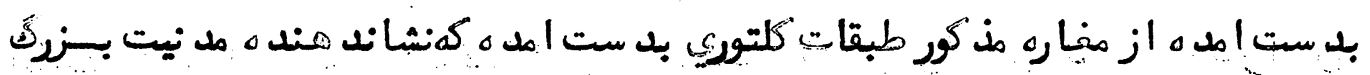

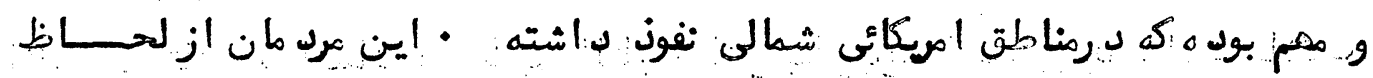

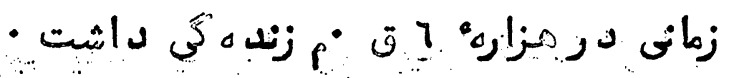

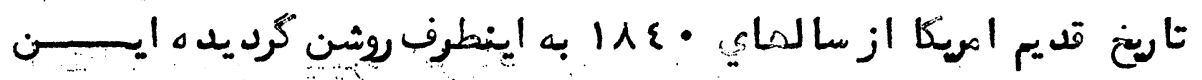

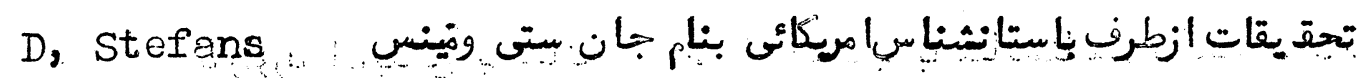

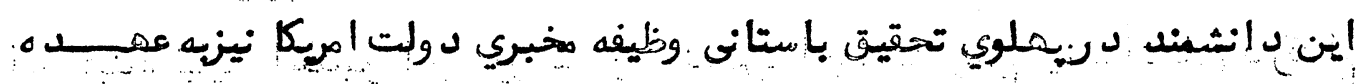

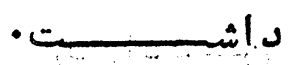
اين نويسنده فعاليت تجريات وكاويشها رإ انجام ند إده تنها اثاروخرابه

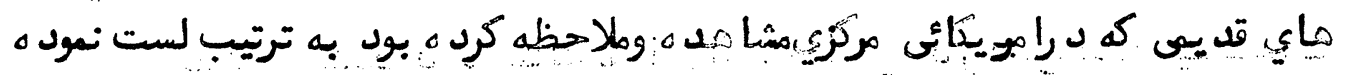

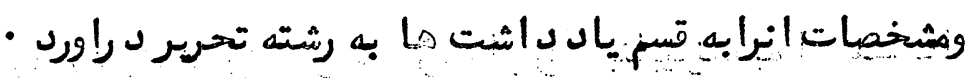
تحقيقات وحفريات ياستانثناسي به مورت منظم ازسال |

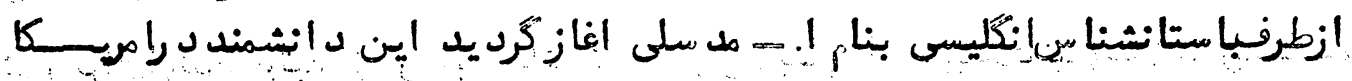

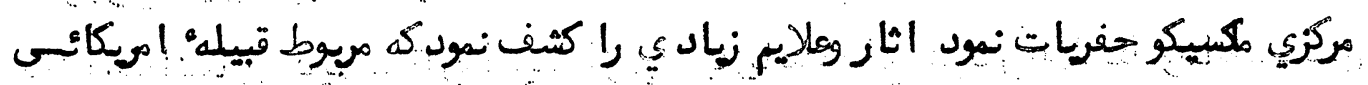

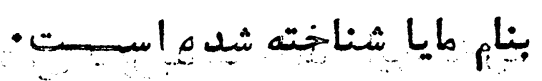

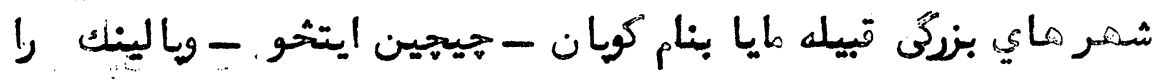

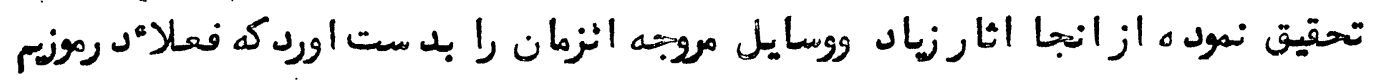




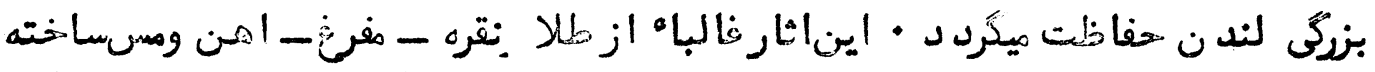

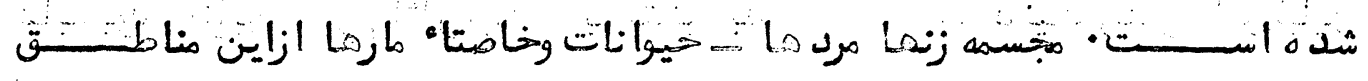

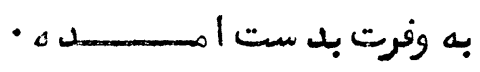

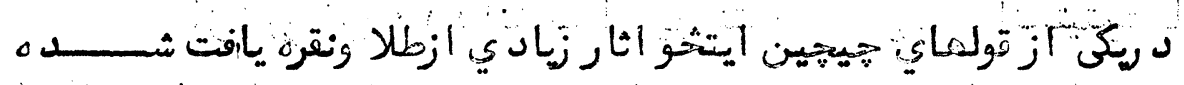

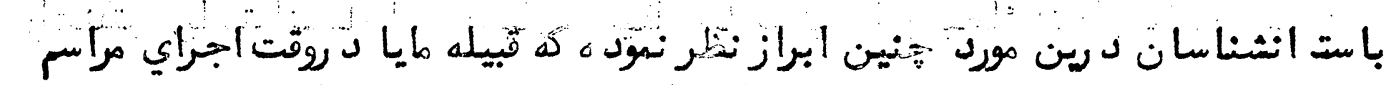

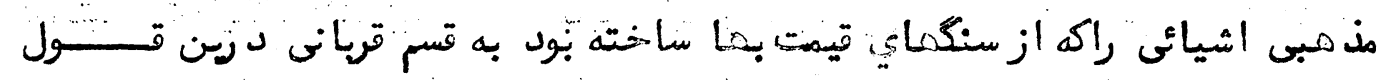

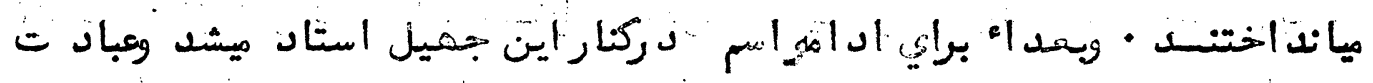

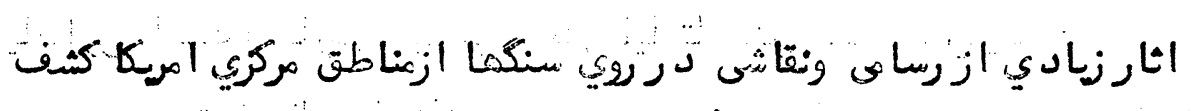

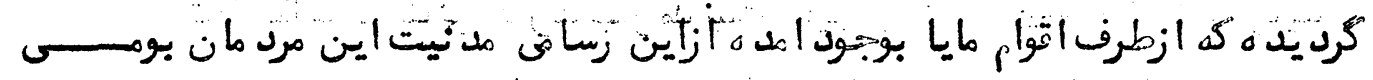

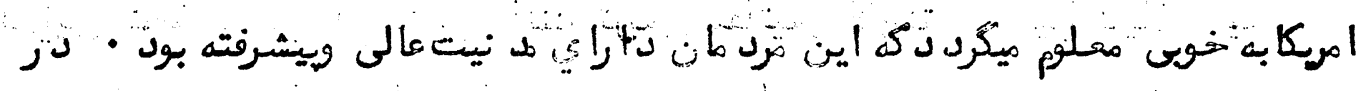

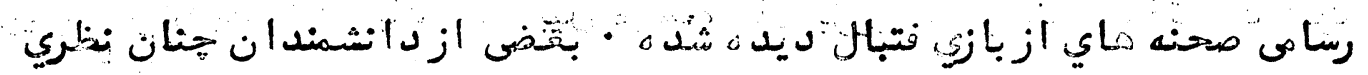

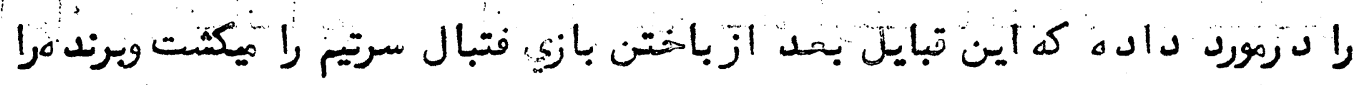

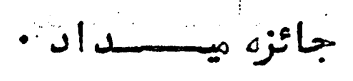

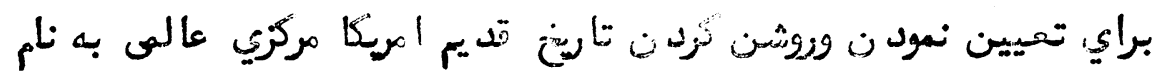

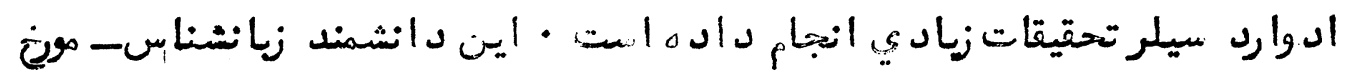

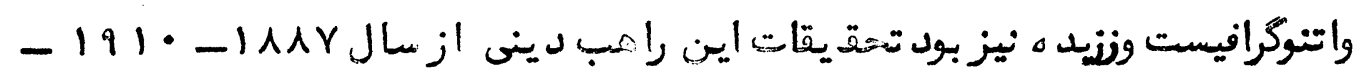

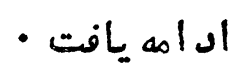

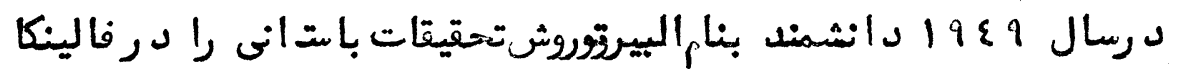

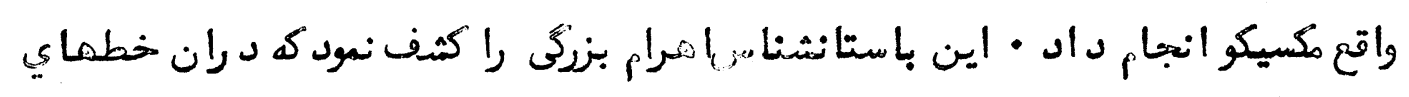

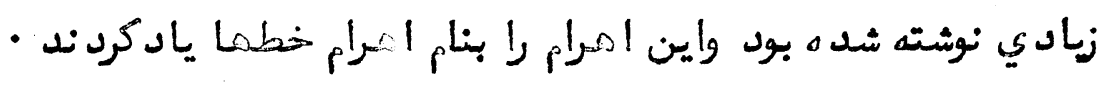

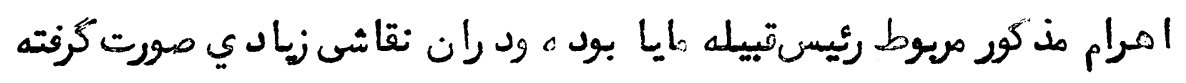

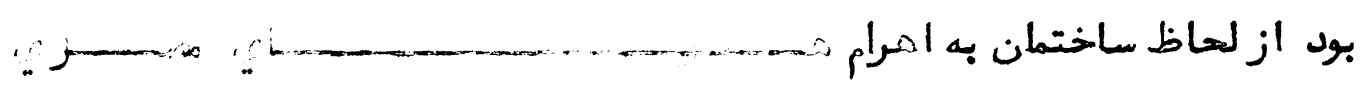


هشابه بوده ازاين أهرام الثارزيادي باستانى بد ست الهد كه مد نيت وقد رت اينبثايل

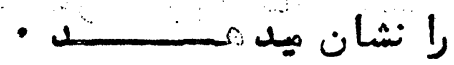

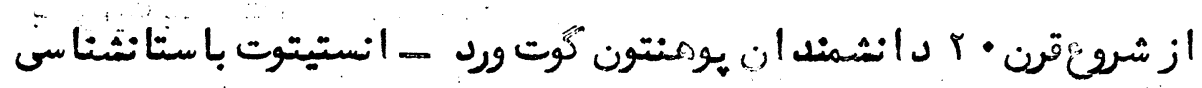

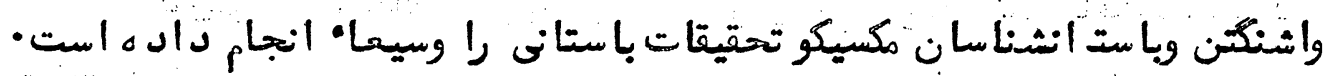

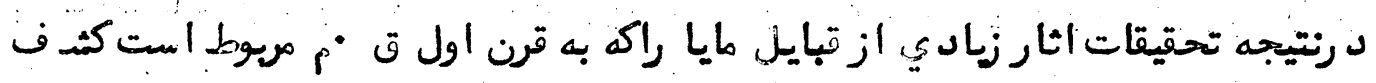

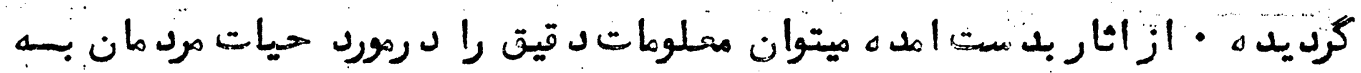

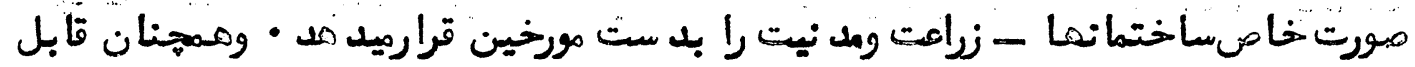

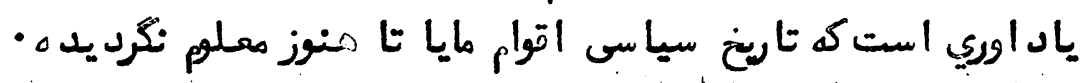

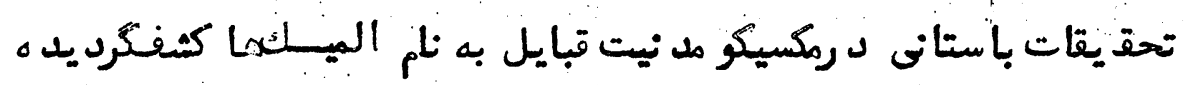

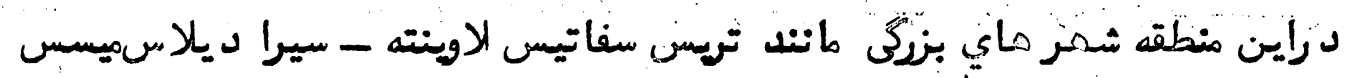

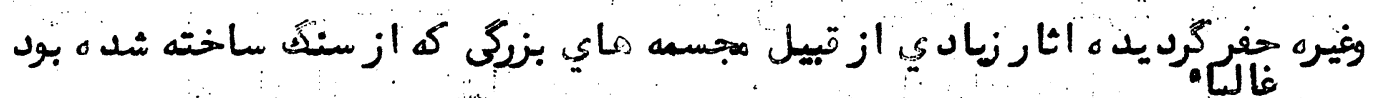

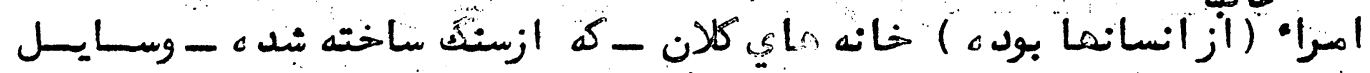

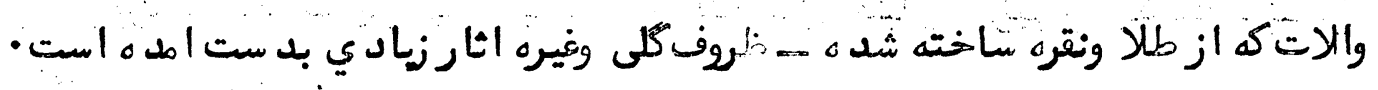


it
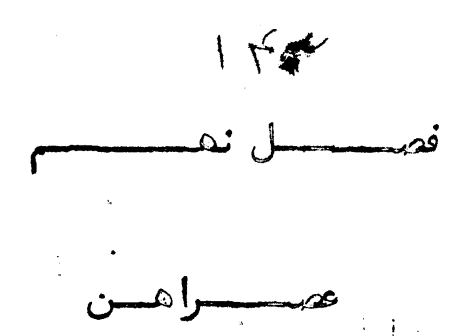

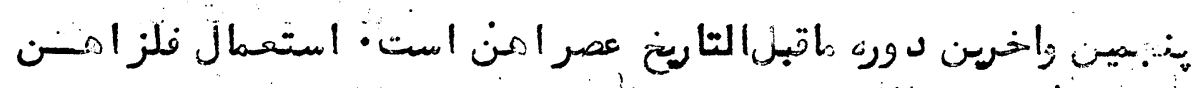

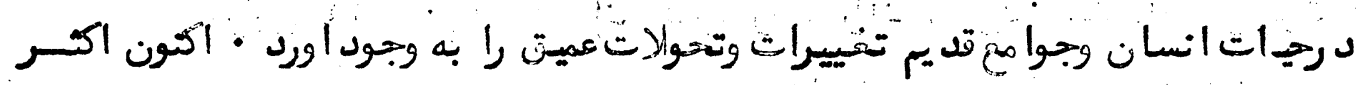

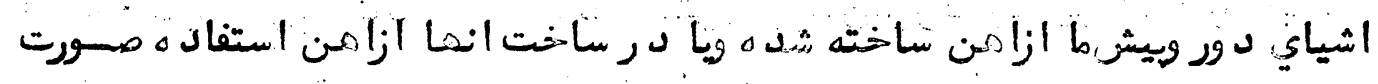

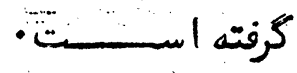

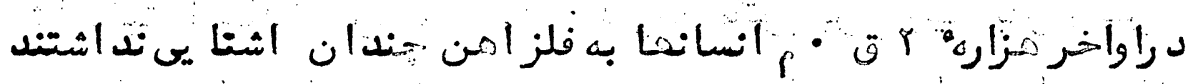

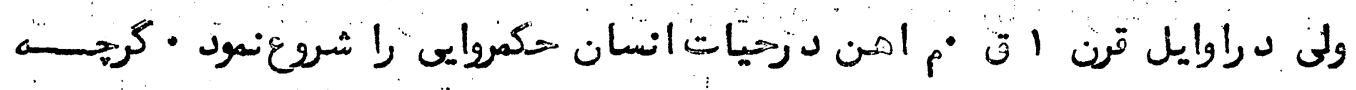

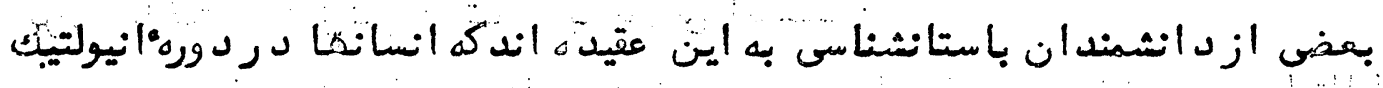

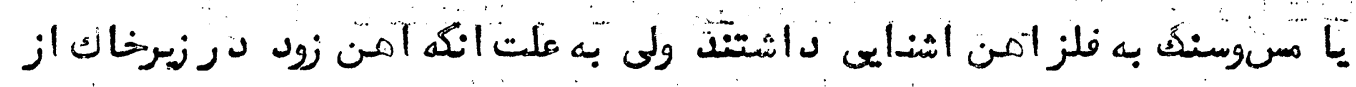

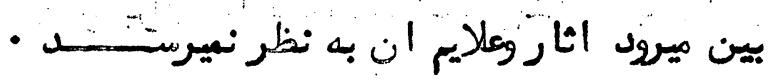

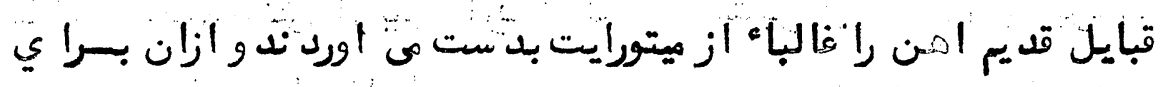

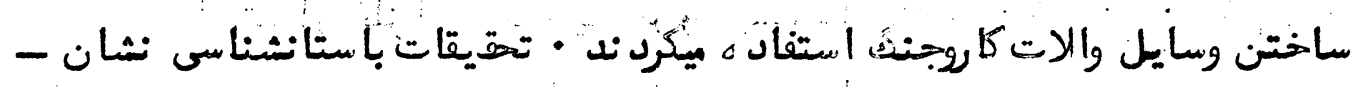

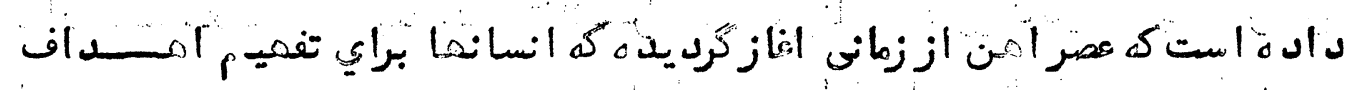

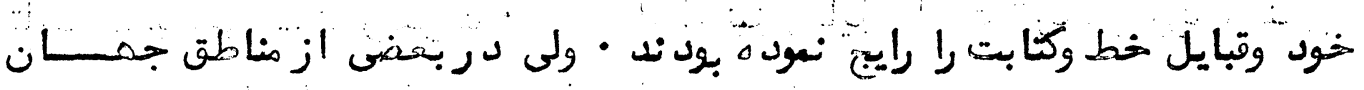

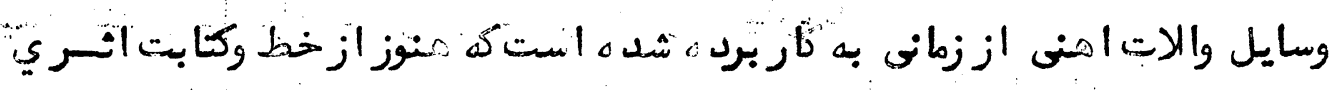

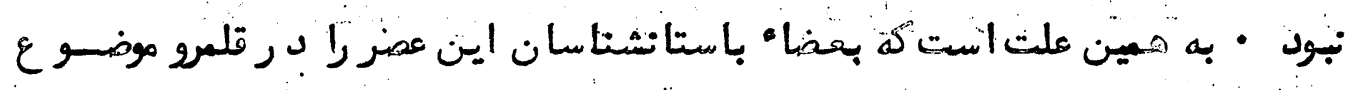
تحقيقات بلاستانشناس مطالعه ميكنيند

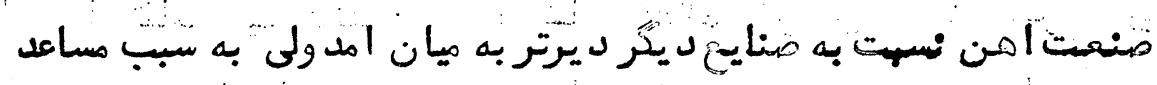

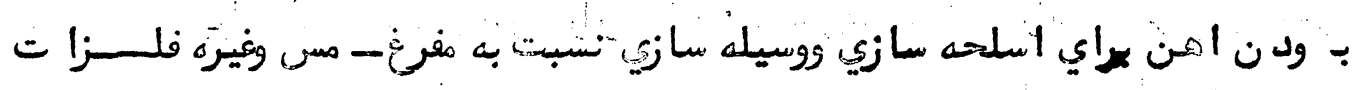

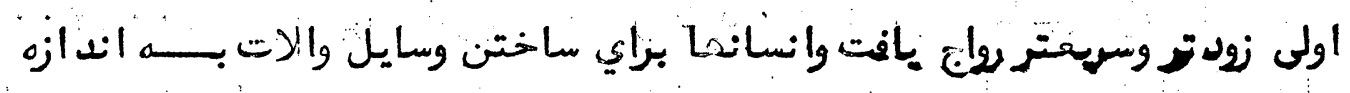




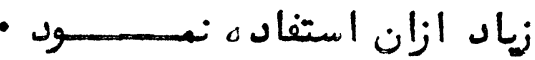

مرد مان وقبايلى كه براي اوأين مرتبه ازامن استفاده نموده اند تــــــــار

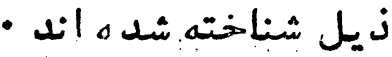

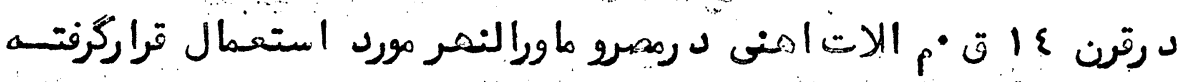

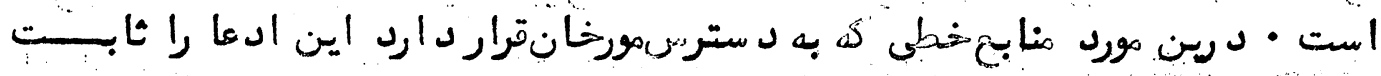

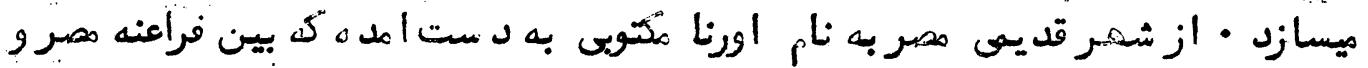

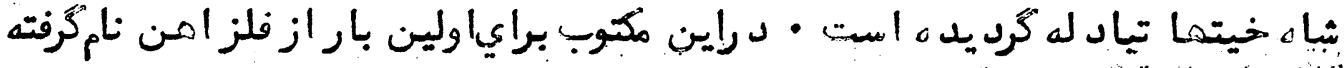

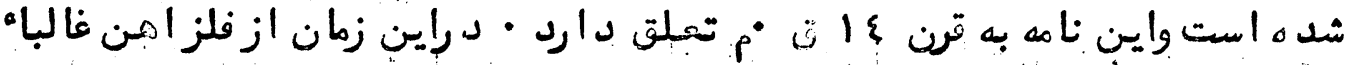

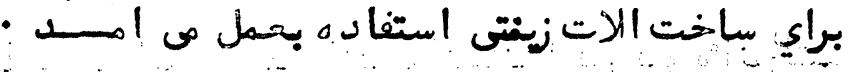

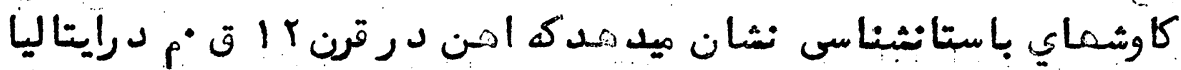

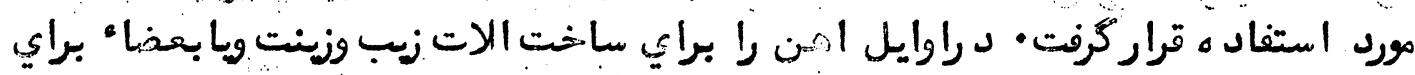

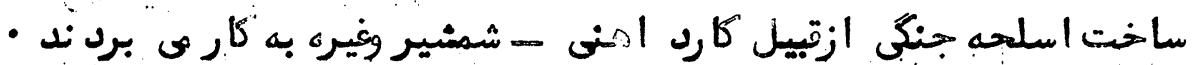

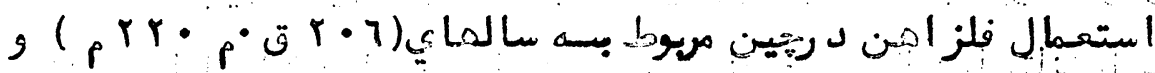

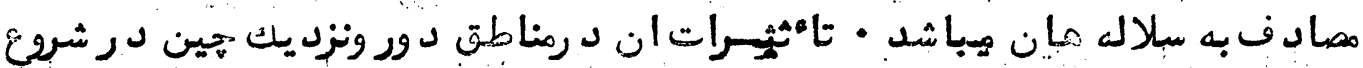

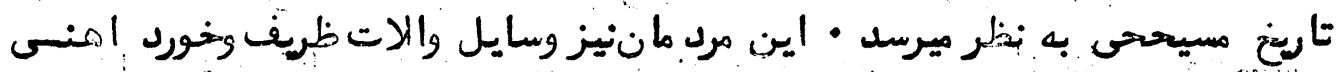

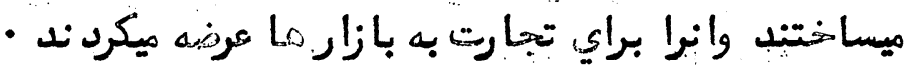

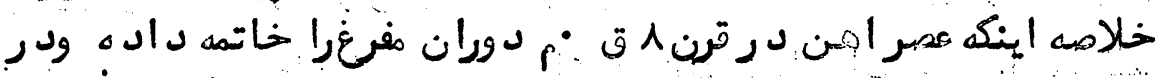

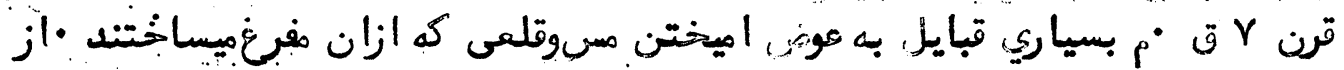

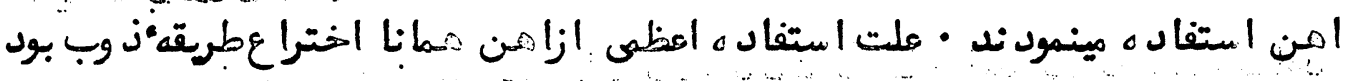

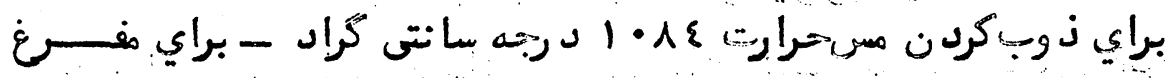

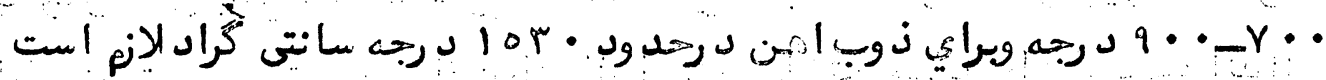

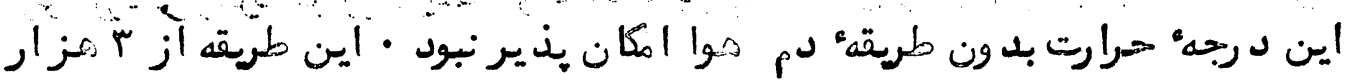

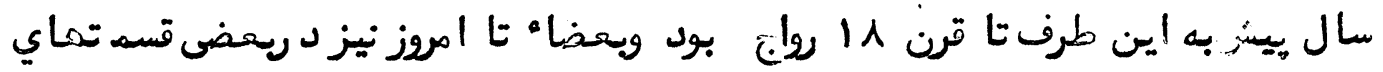




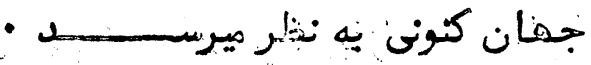

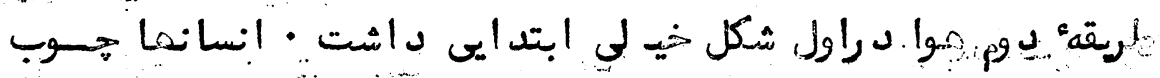

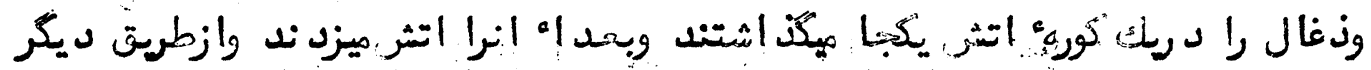
هوا را براي روشن نمود ن وتيز ساختز اتشرد اخل ميكرد ند اين عمليه را تا زمانسـى

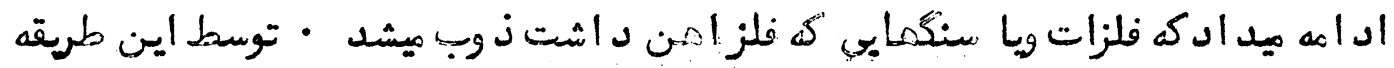
اهن را ازد يكرسنكها جد اكرد ه وبرائ ساختن وسايل والاتت ازان استفاد ه ميكرد ند -

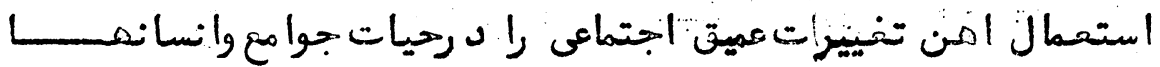

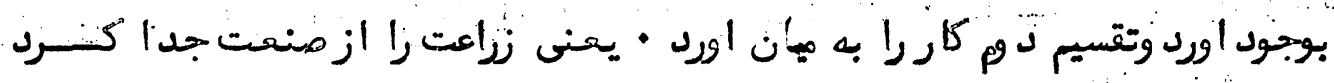

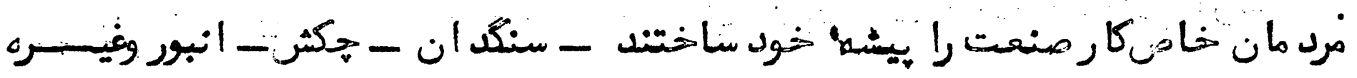

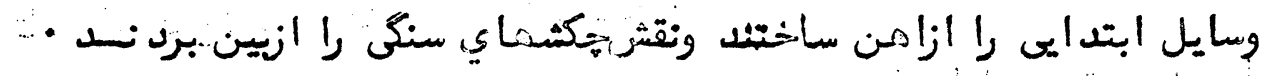

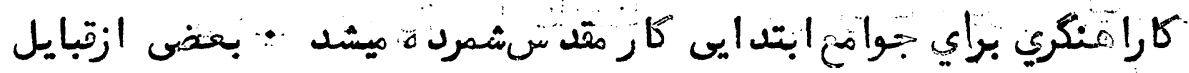

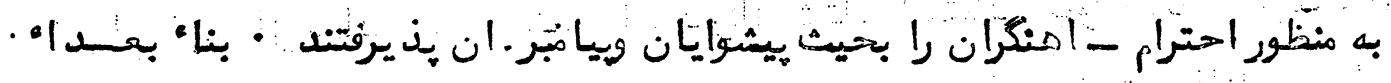

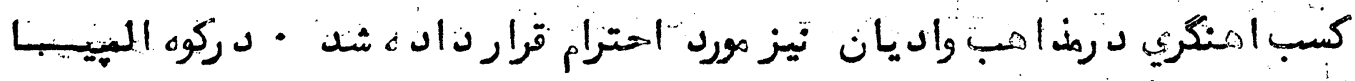

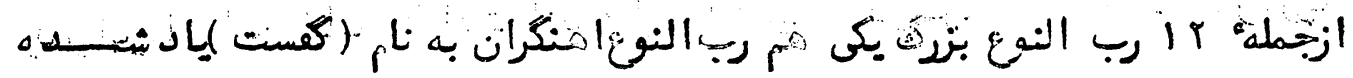

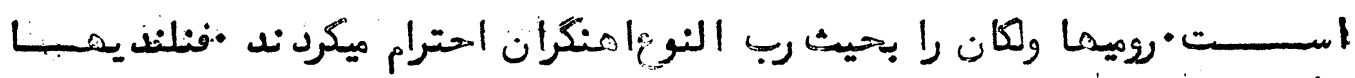

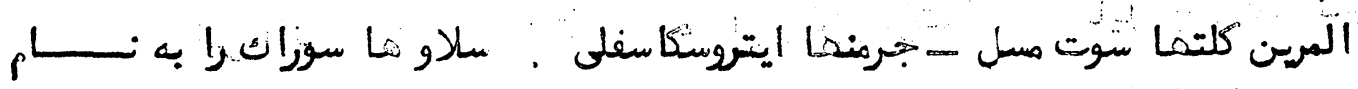
خد ايان المنكري احترام ميكرد ند ومسلمانان نيز داؤد عليه سلام را به يبشه المنكري

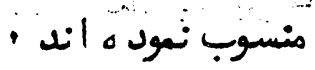

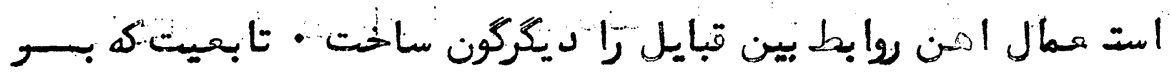

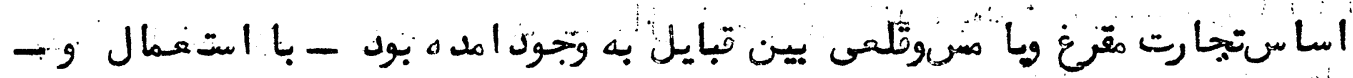

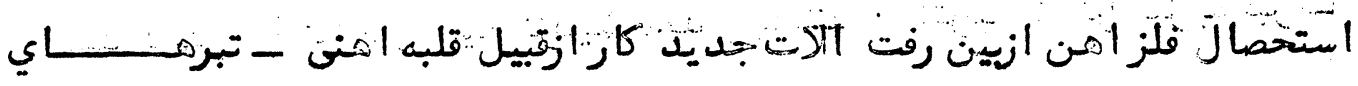

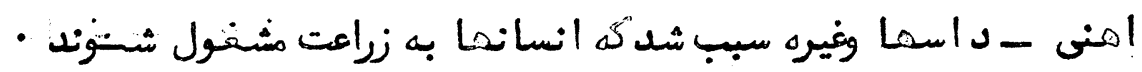

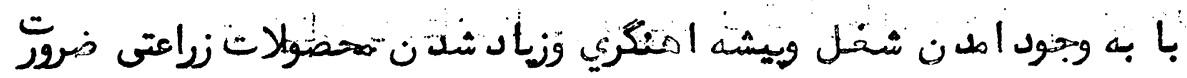




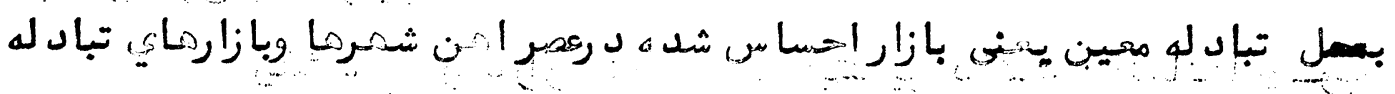

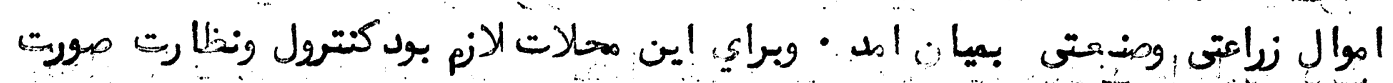

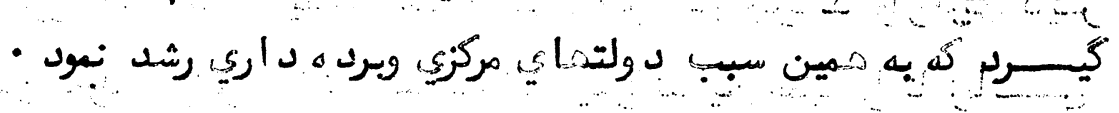

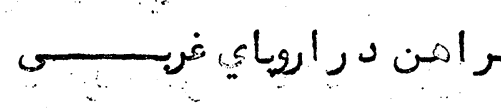

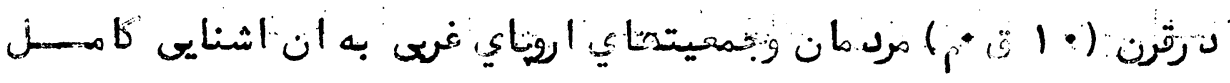

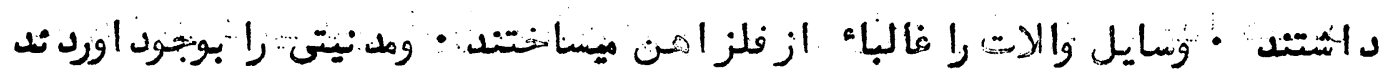

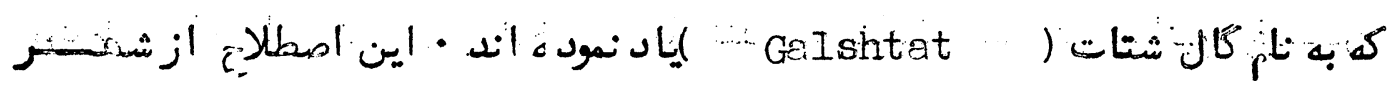

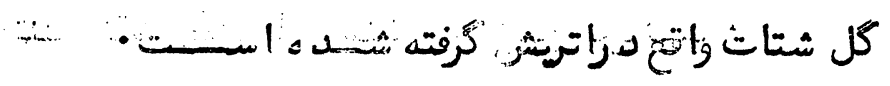

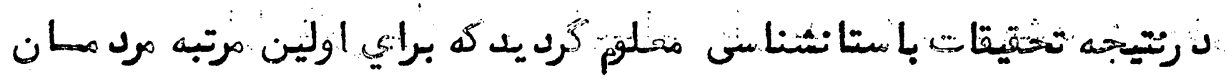

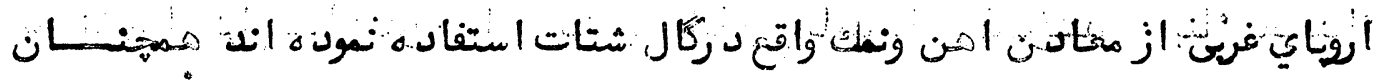

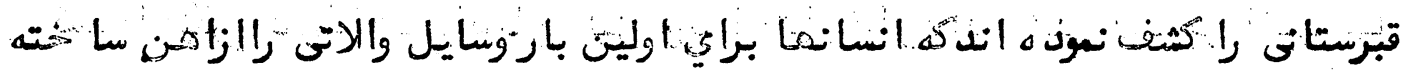

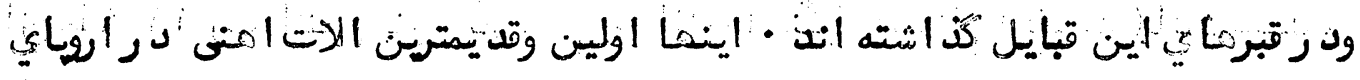

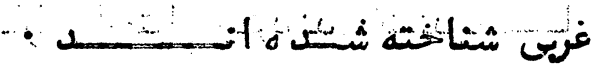

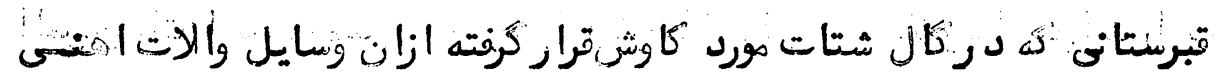

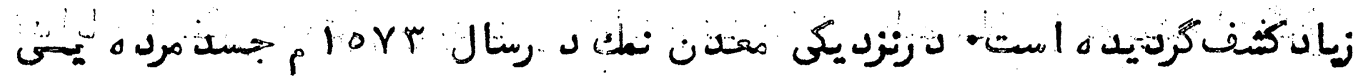

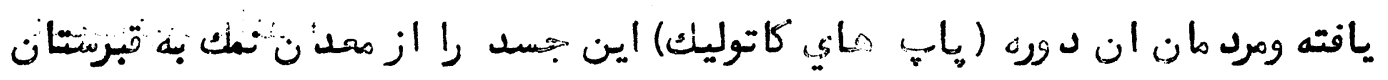

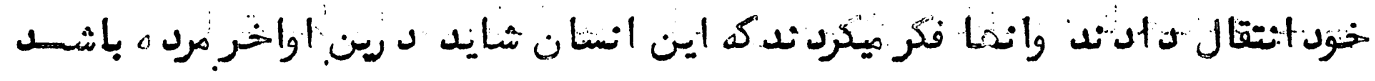

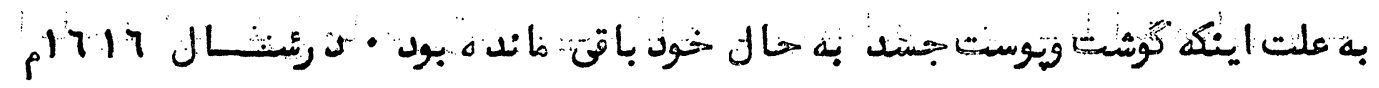

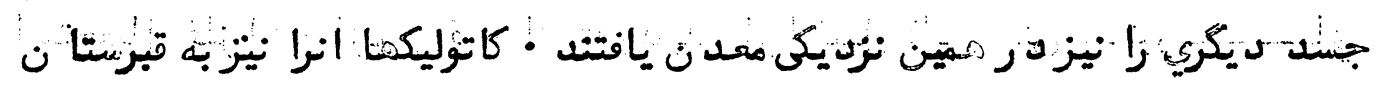

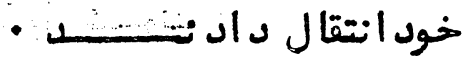

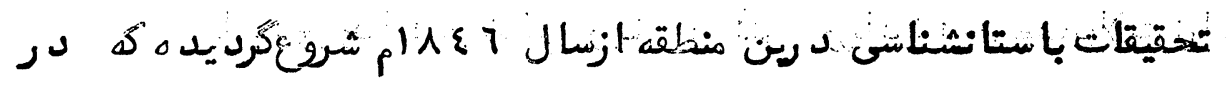




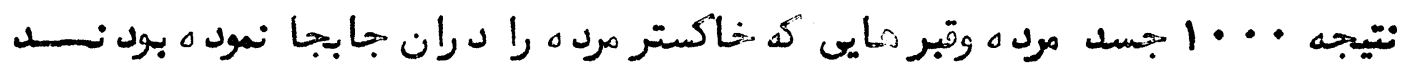

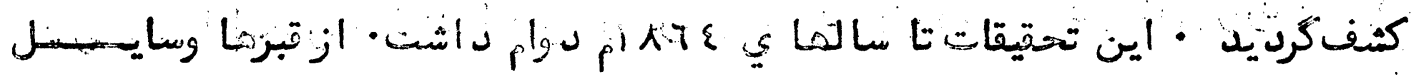

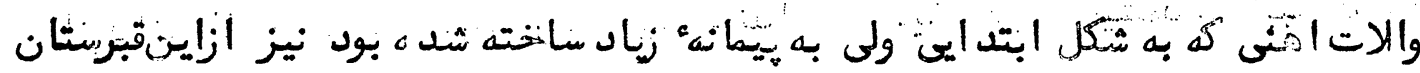

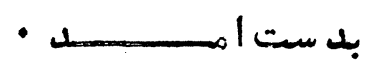

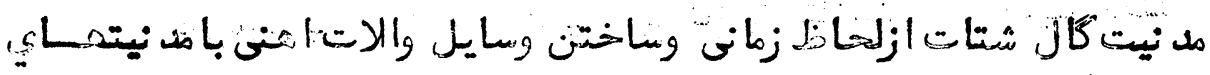

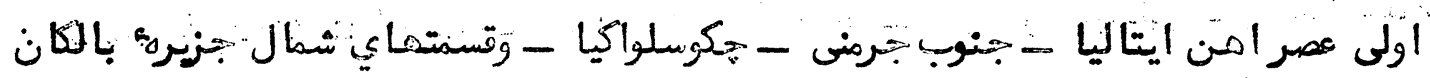

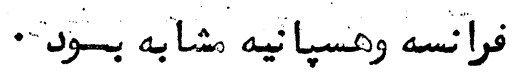

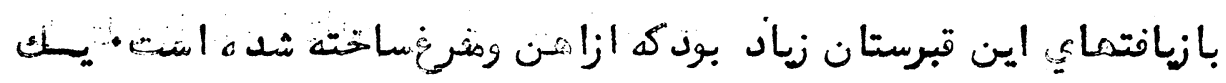

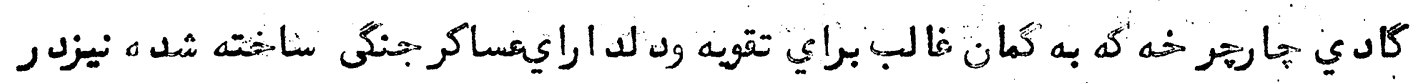

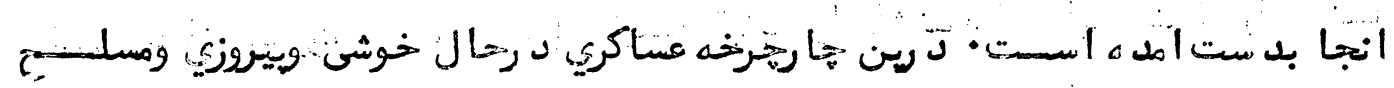

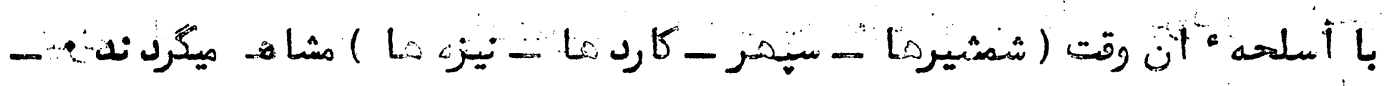

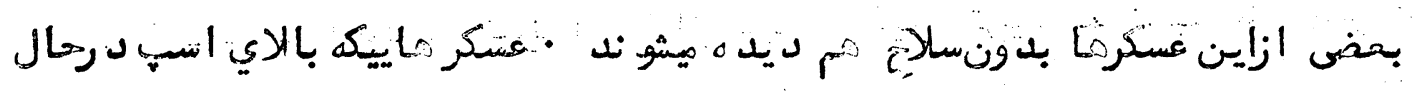

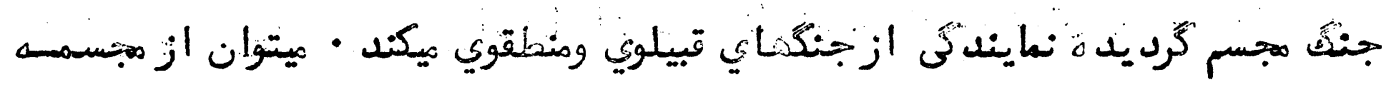

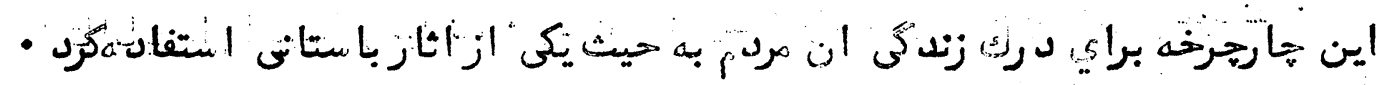

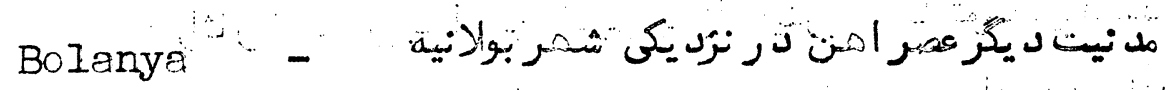

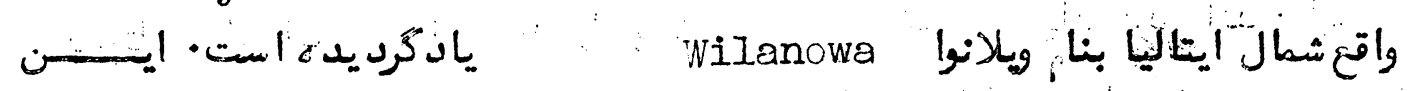

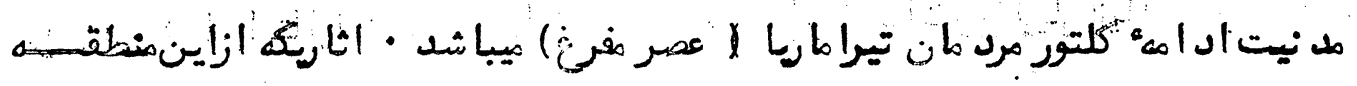

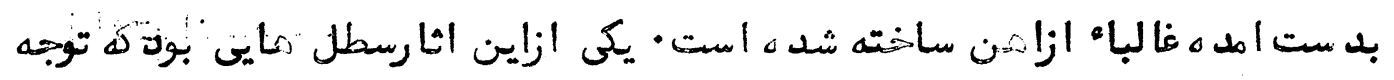

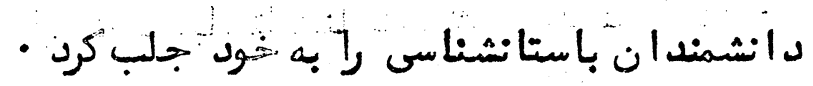

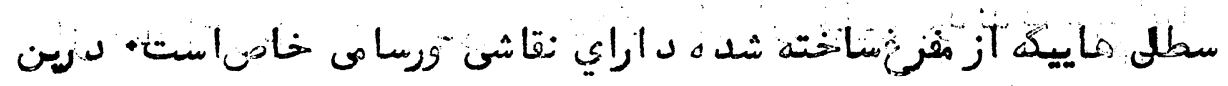

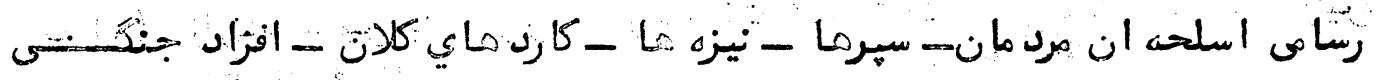

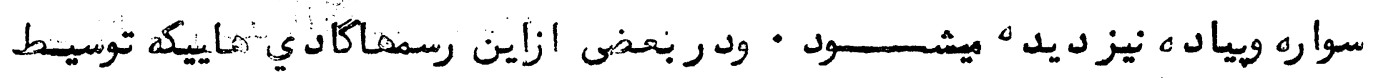

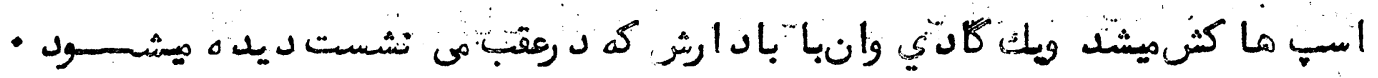




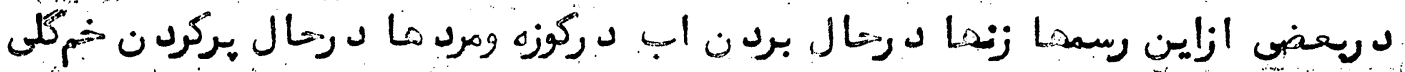

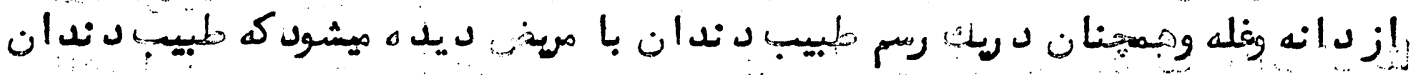

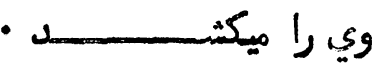

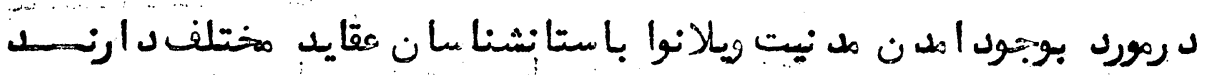

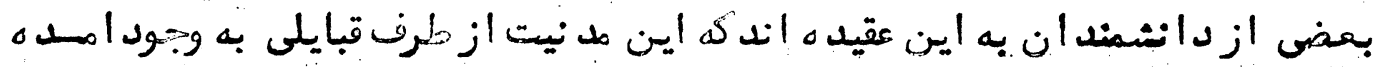

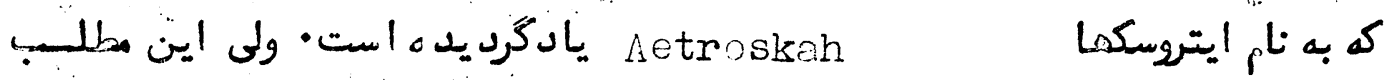

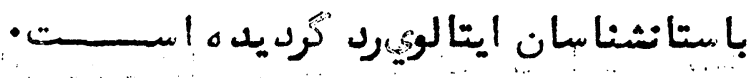

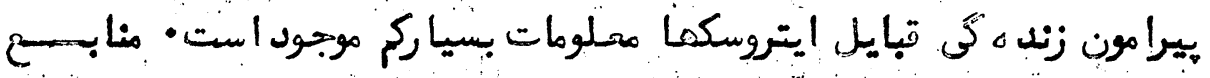
خطى كه از مي رود وت بد ست أمده ايسن قبايل يا باشند ه كان أين منطقه را به نسام

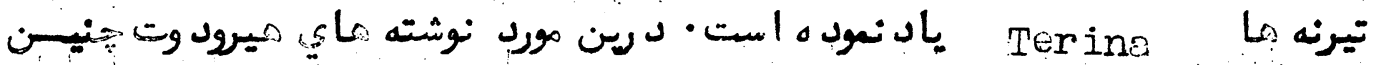

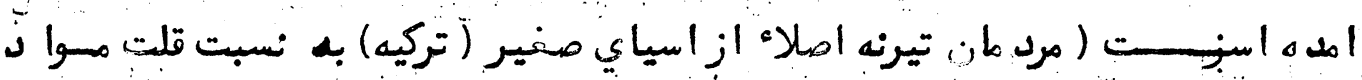

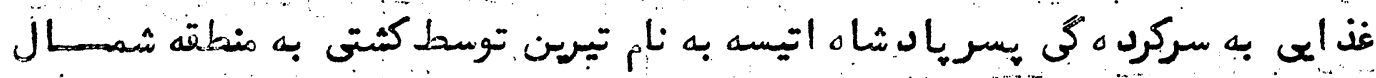

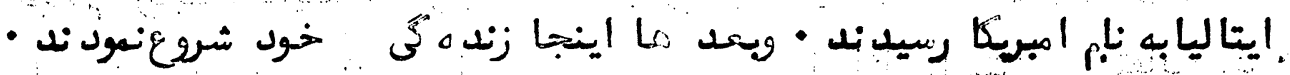

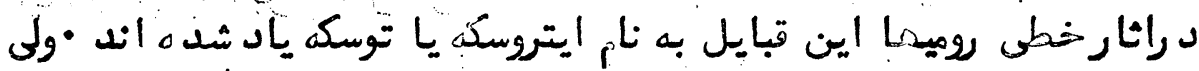

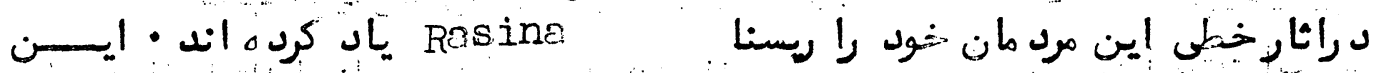

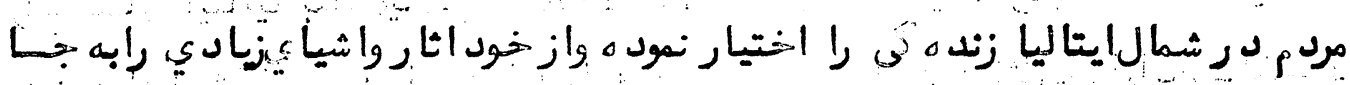

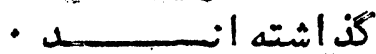

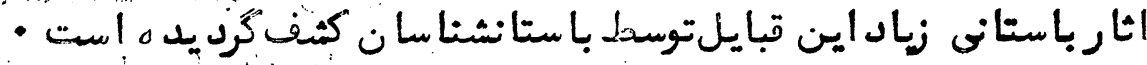

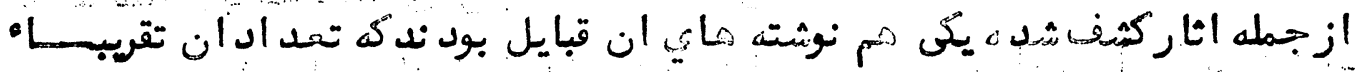

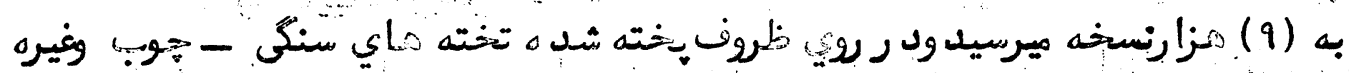

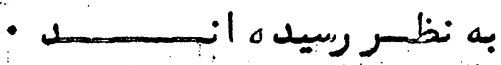
اثار خطلى اين قبايل ازلحاظ شكل به حروف يونانى نزد يك است : ولهى

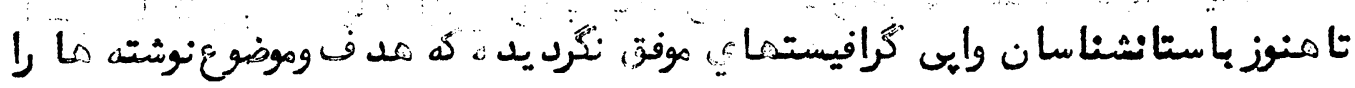




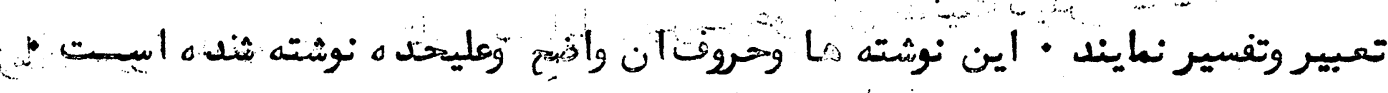

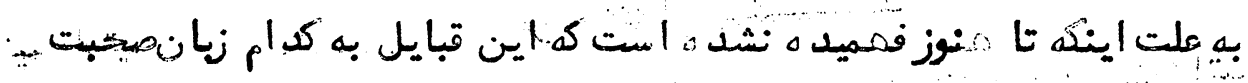

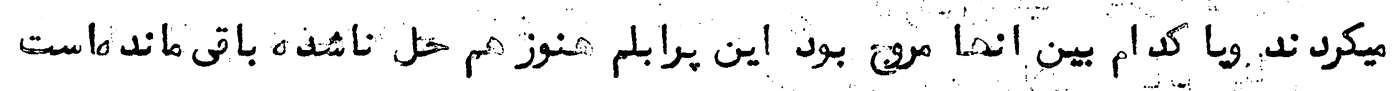

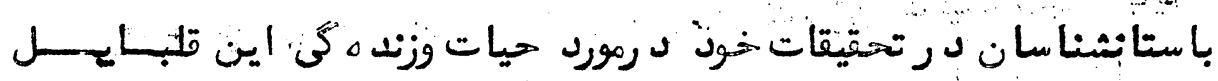

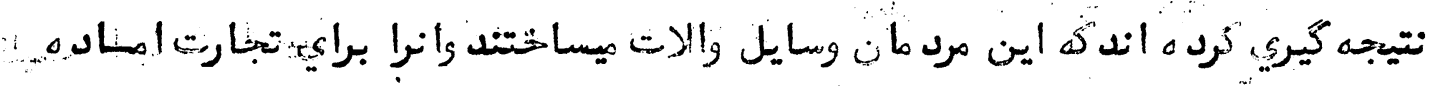

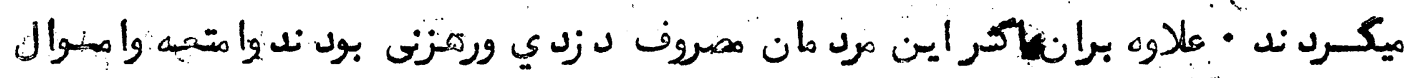

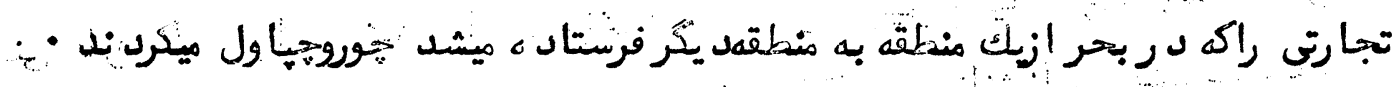

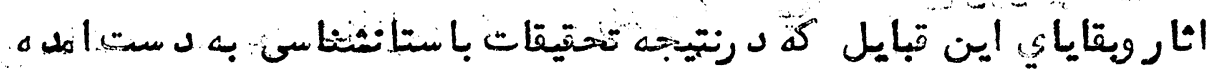

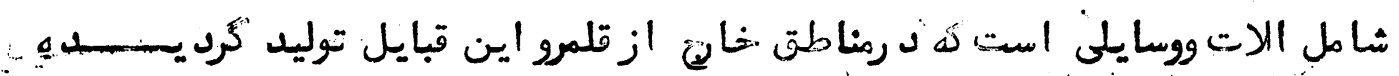

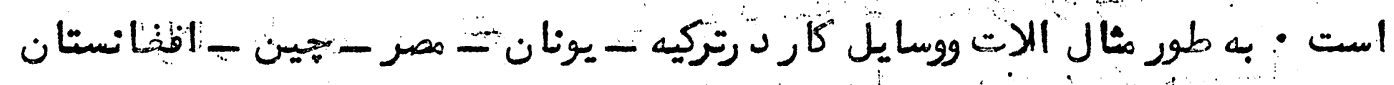

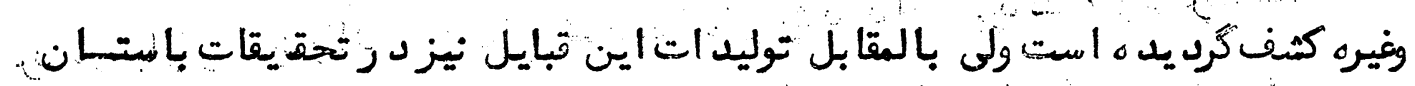
8

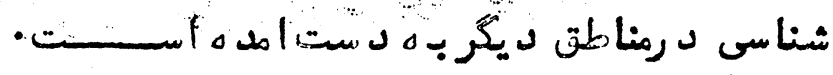

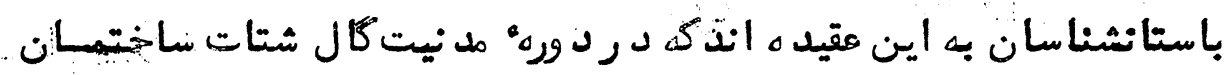

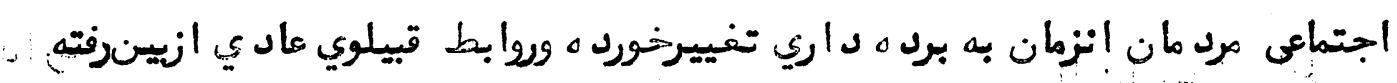

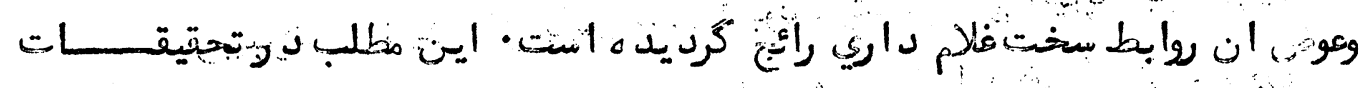

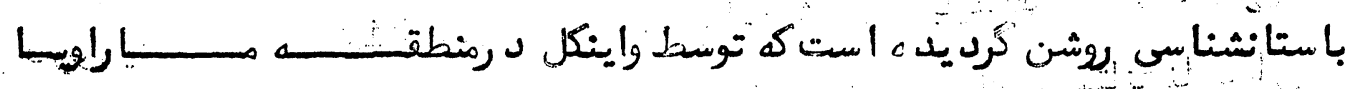

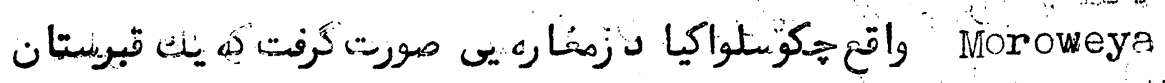

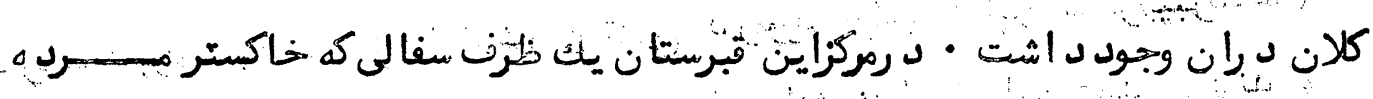

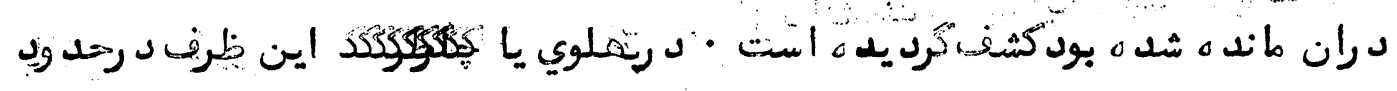

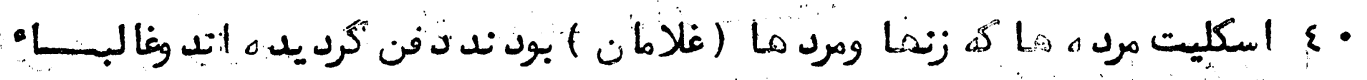

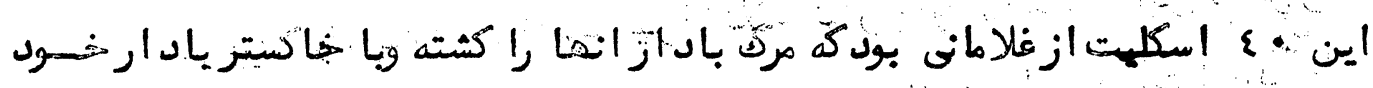

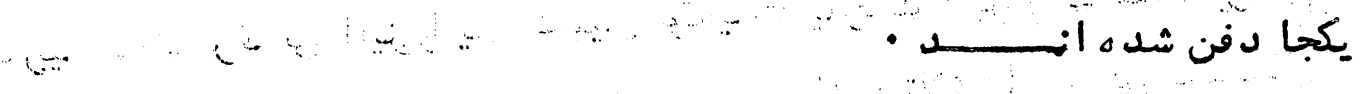

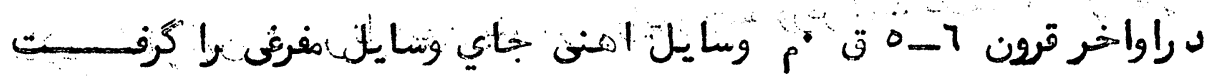




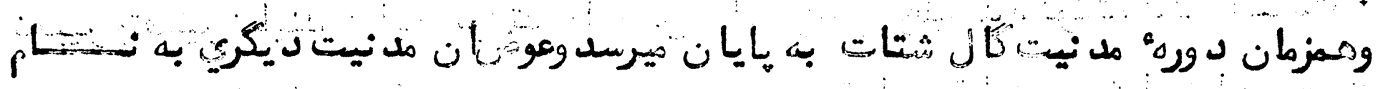

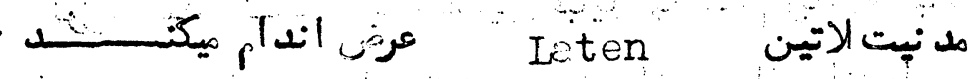

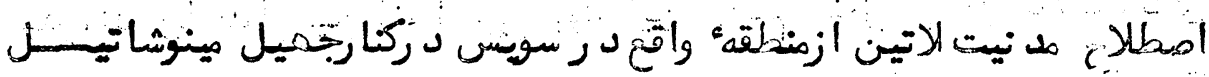
New Shatel

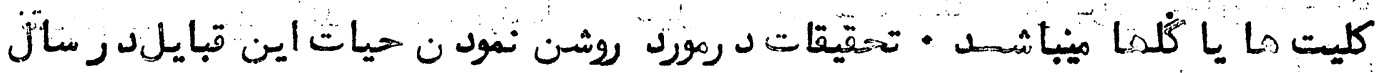

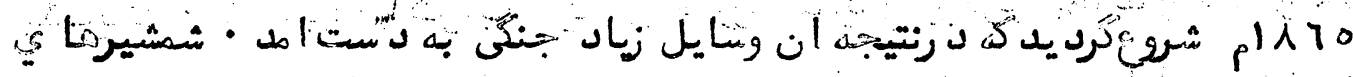

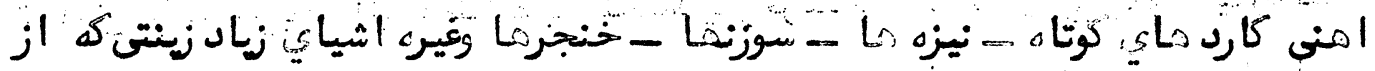

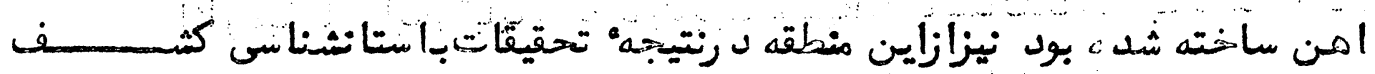

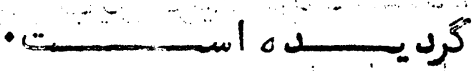

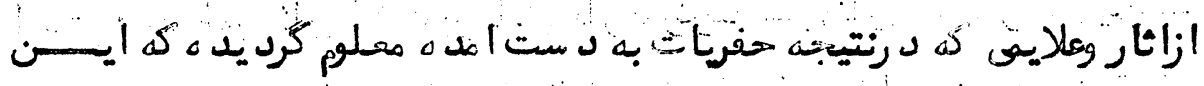

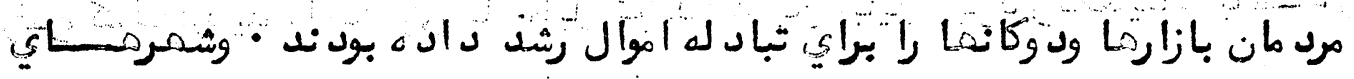

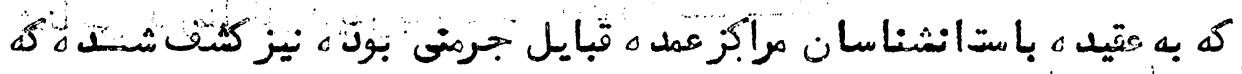
Bibrelkta

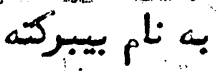
دارد

شهر بيبركته مركزيكى از قبايل كليتما بودة وشير دو "اليزيامزودا قبايل

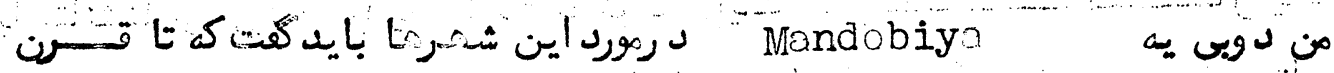

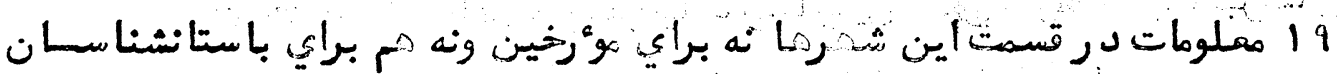

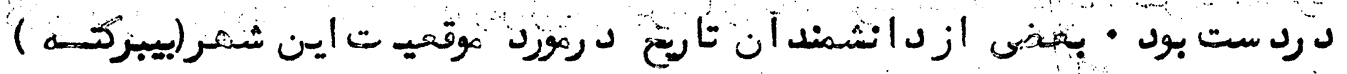

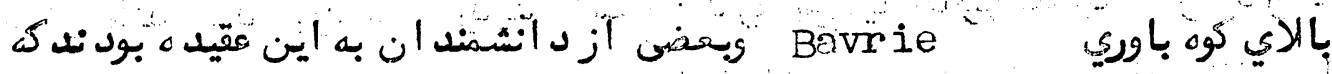

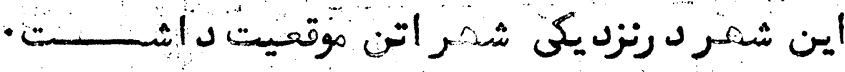

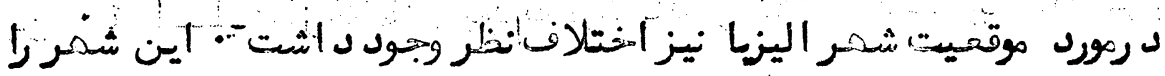

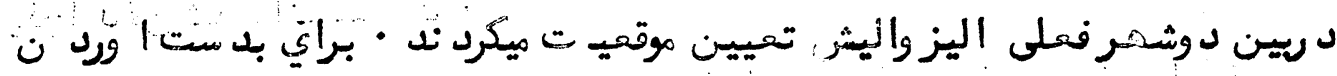

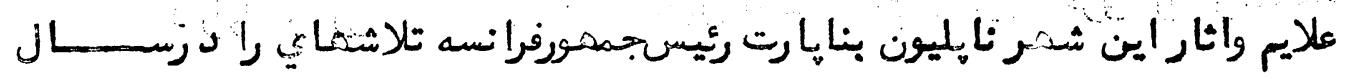


94

101

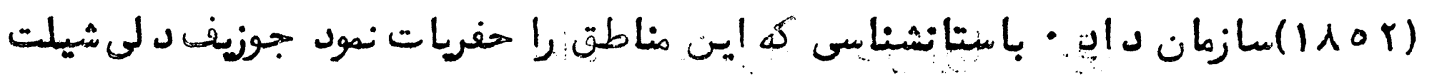

- نام دارد Jasef The Shilit

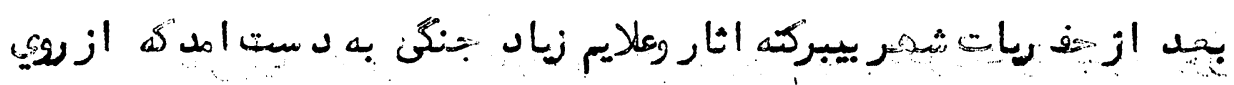

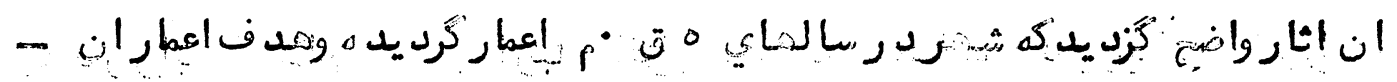

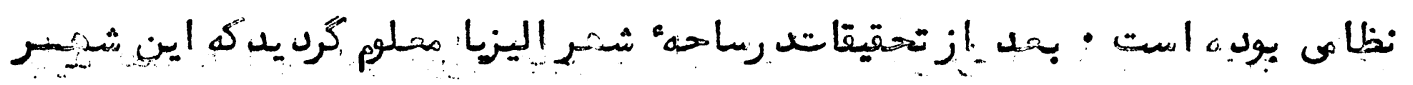

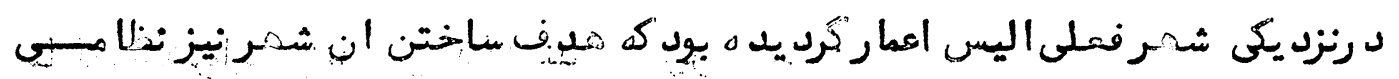

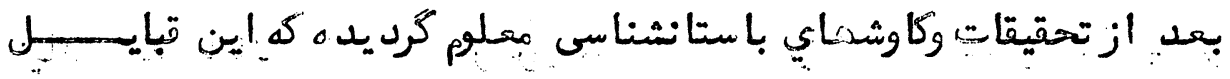

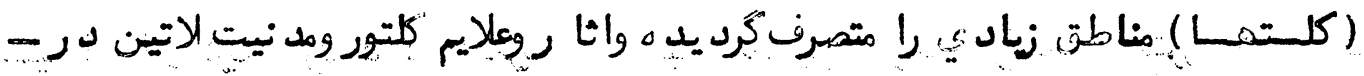

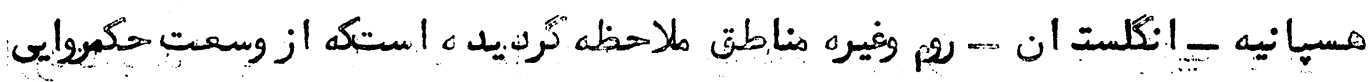

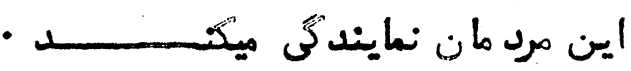




\section{5

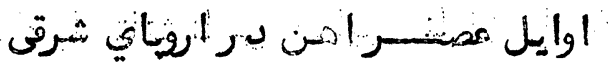

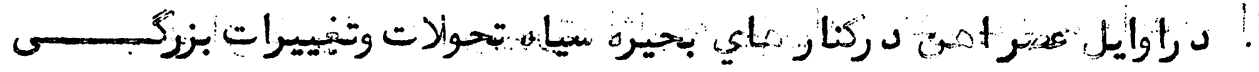

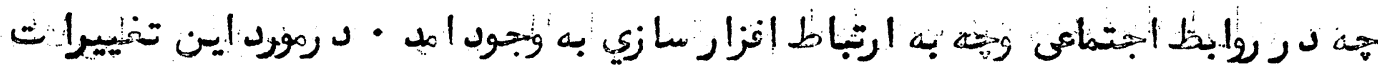

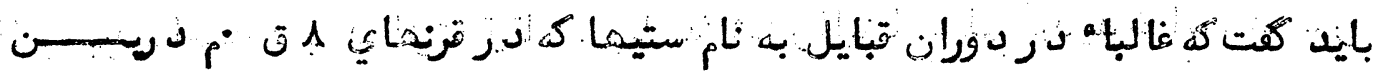

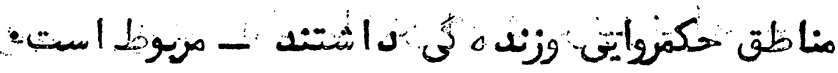

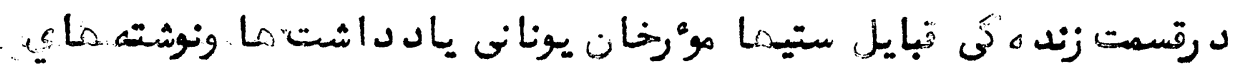

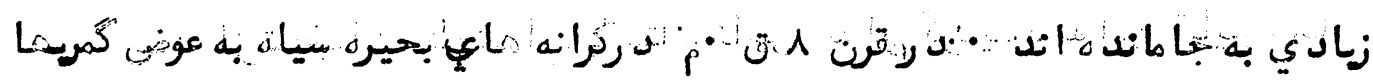

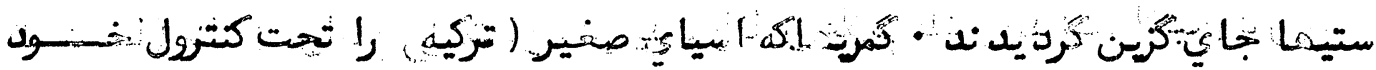

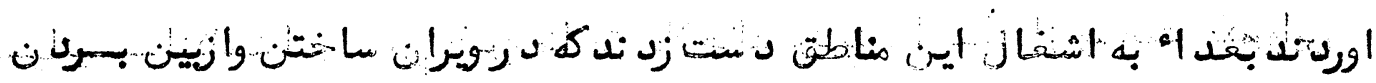

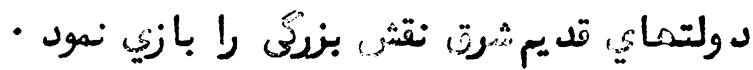

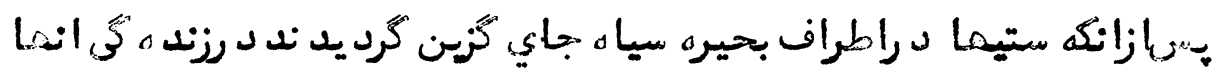

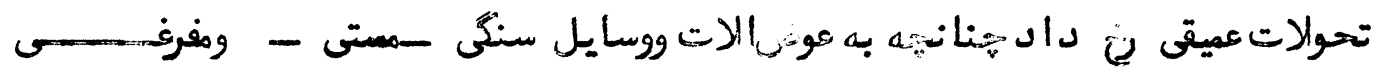

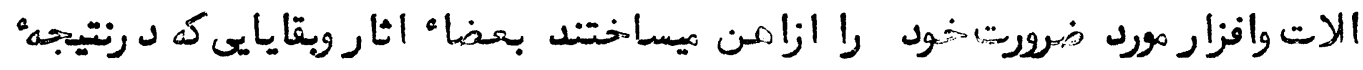

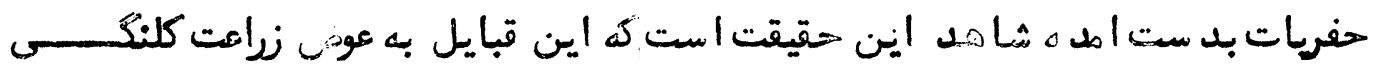

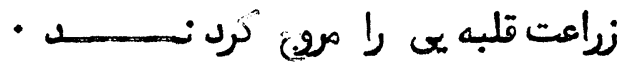

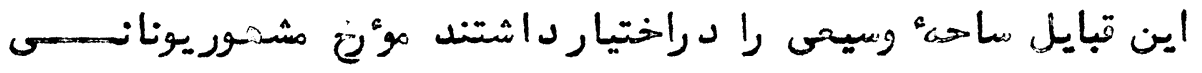
هيرود وت (قرن مت •م) د رورود سرحدات اين قبايل نجنين نكاشته كه اين قبايسل

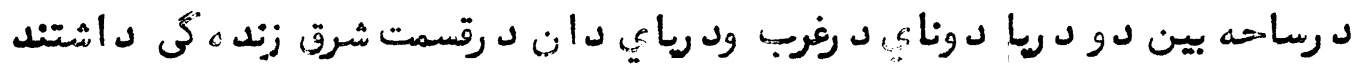

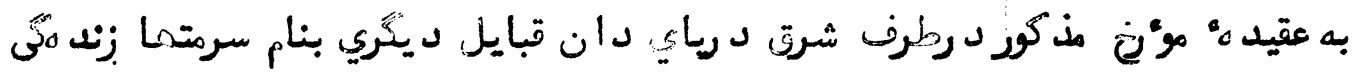

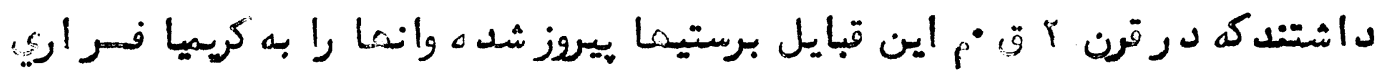

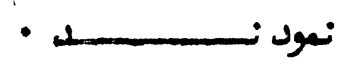
هب رودوت تبايل ستيى را به دود سته تقسيم نمود ه كه يك دسته ان 


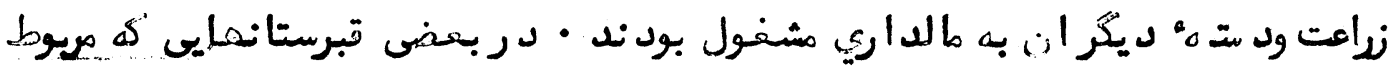

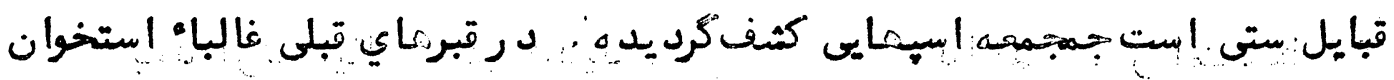

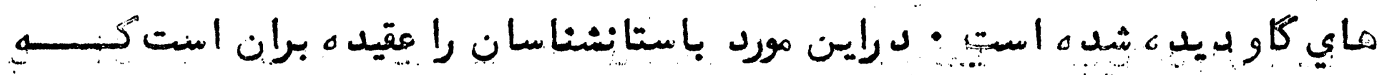

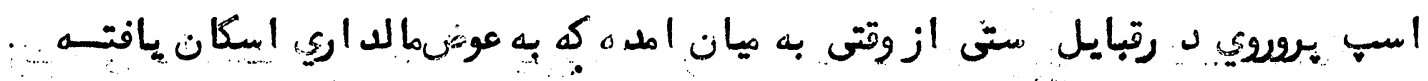

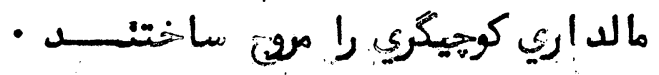

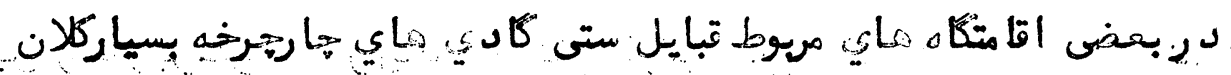

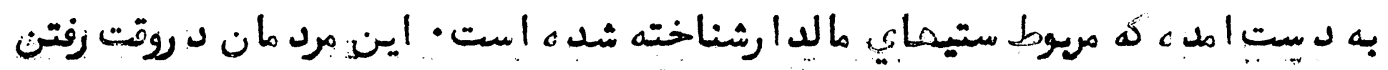

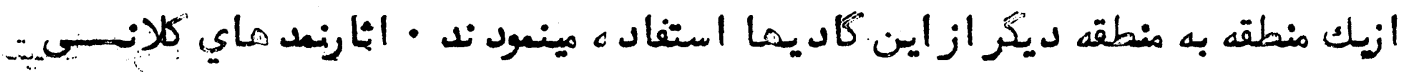

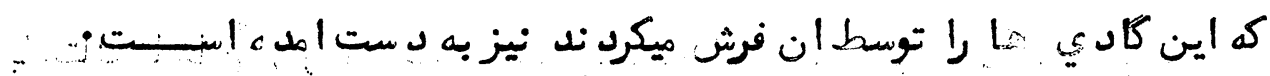

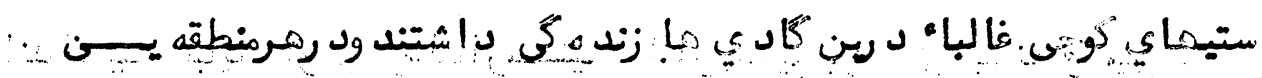

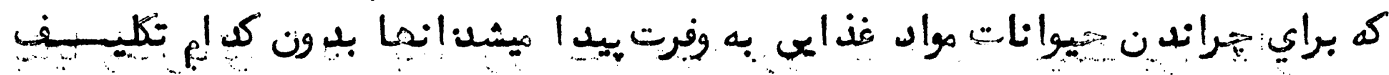

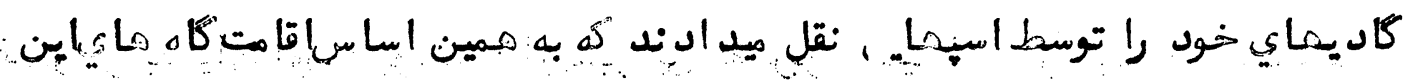

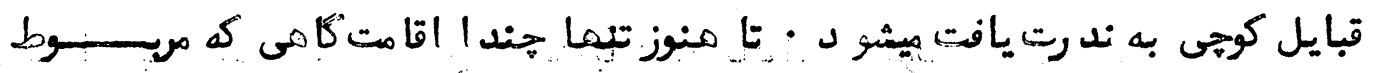

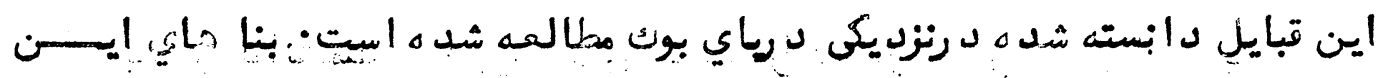

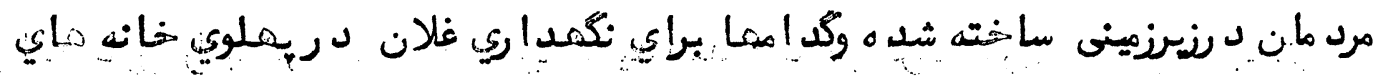

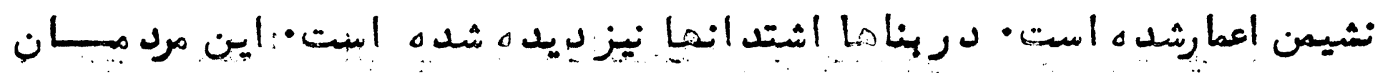

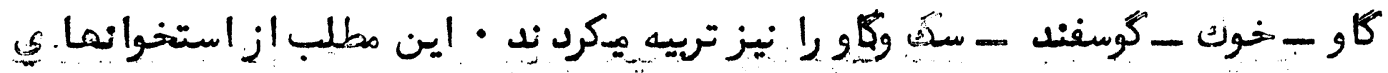

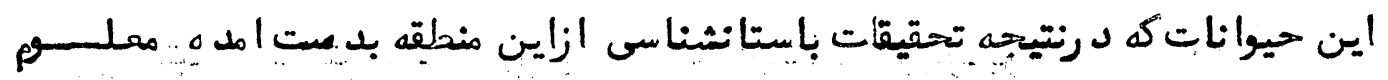

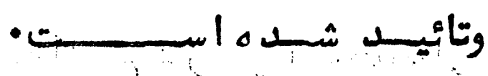

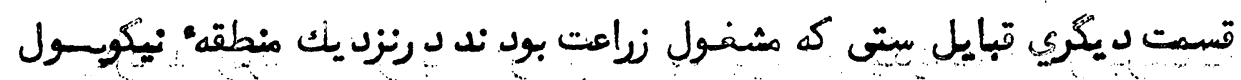

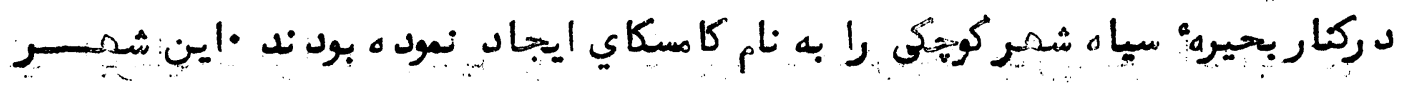

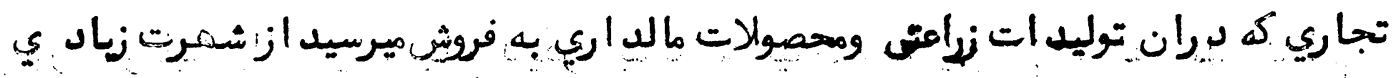

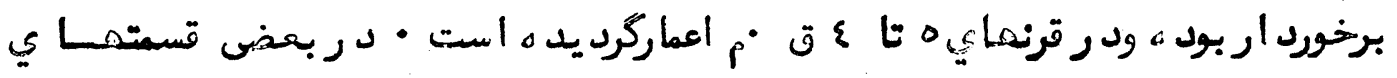




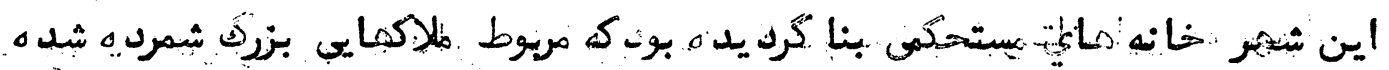

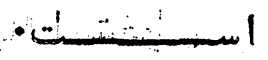

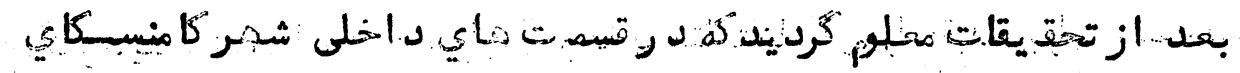

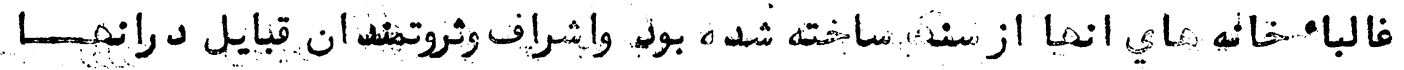

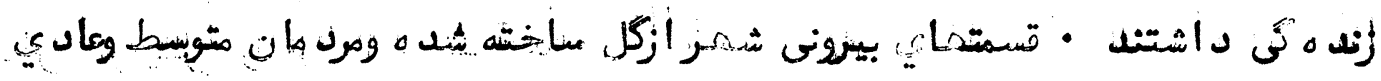

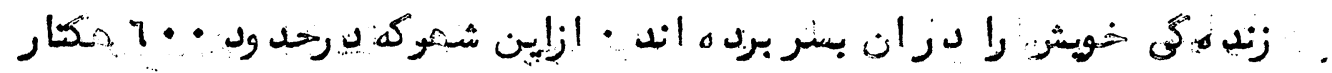

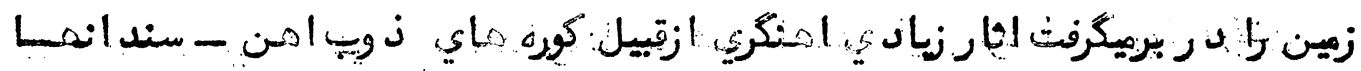

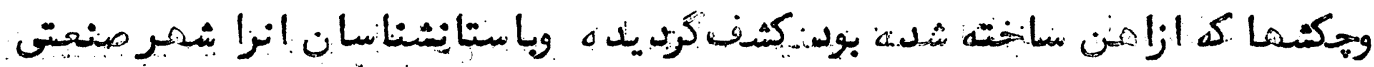

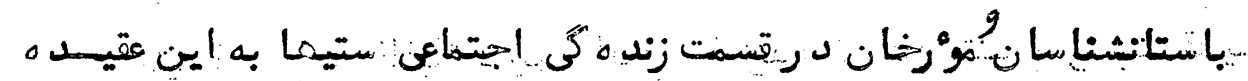

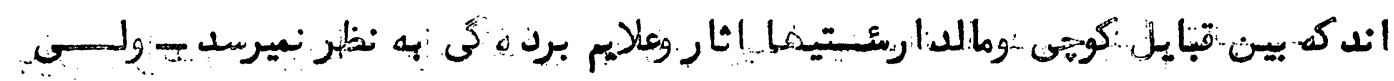

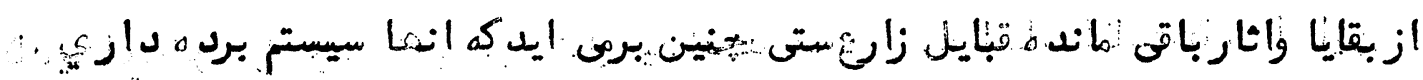

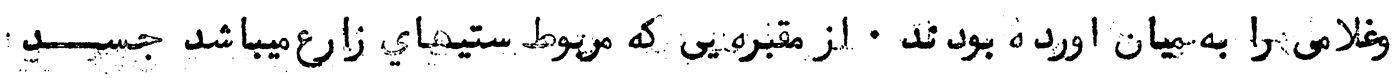

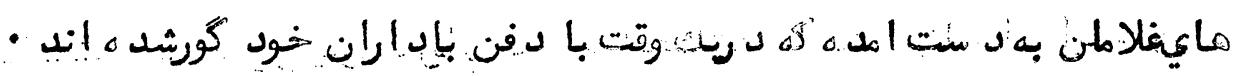

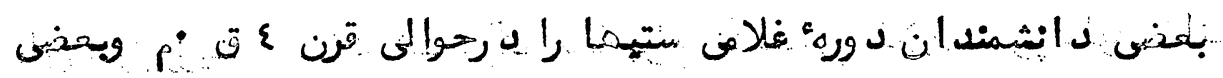

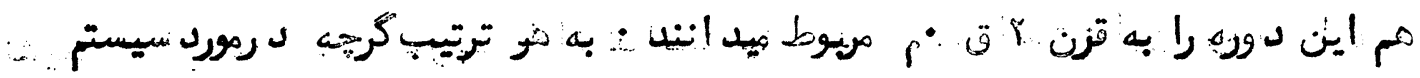

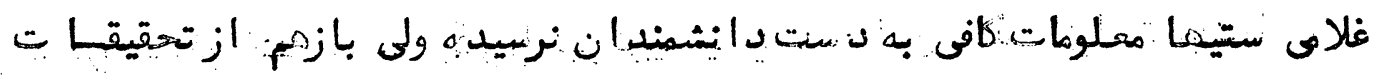

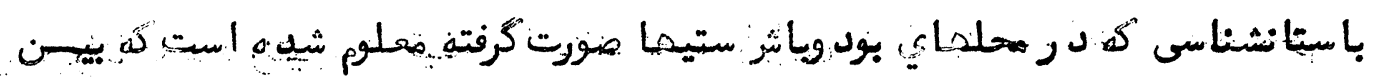

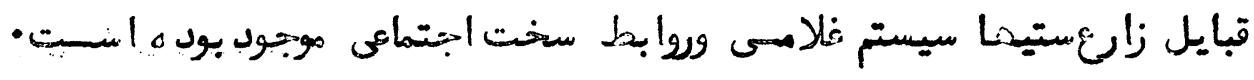

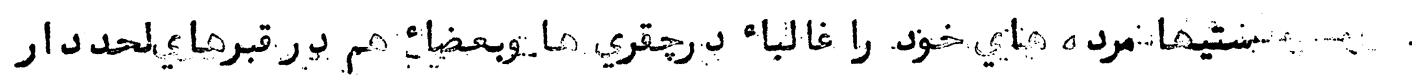

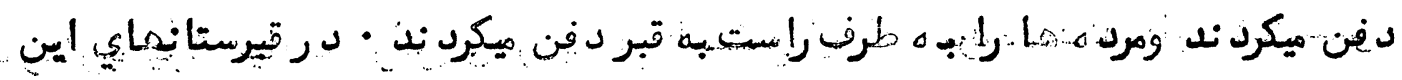

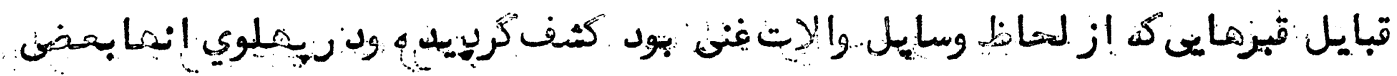

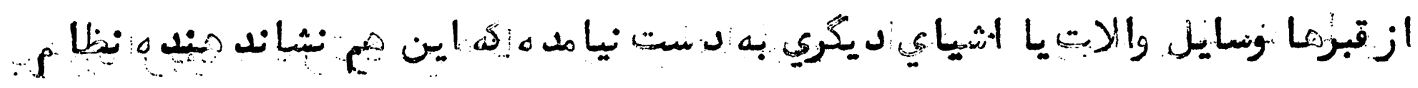




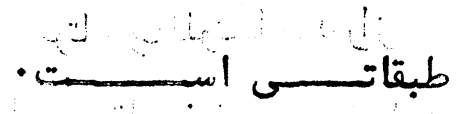

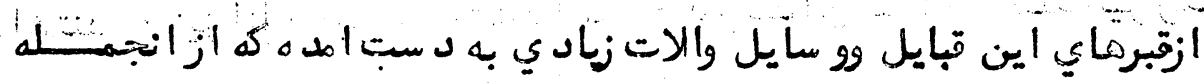

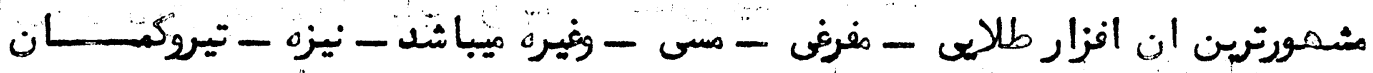

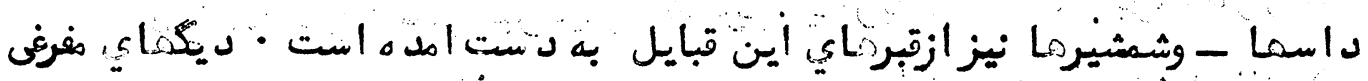

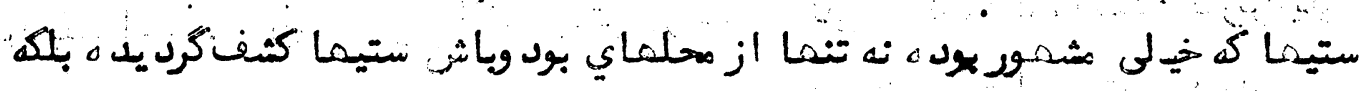

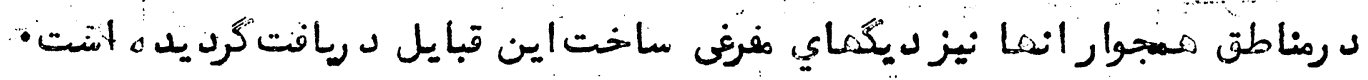

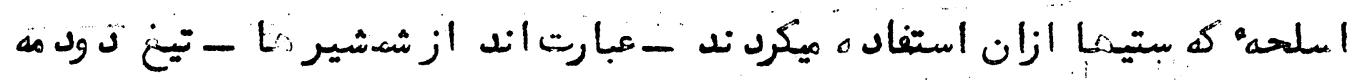

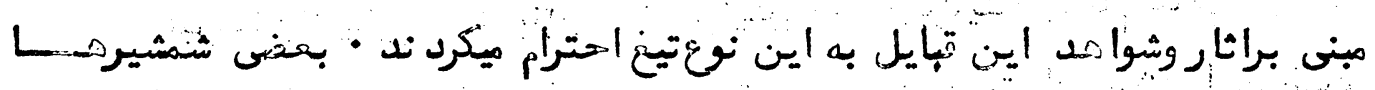

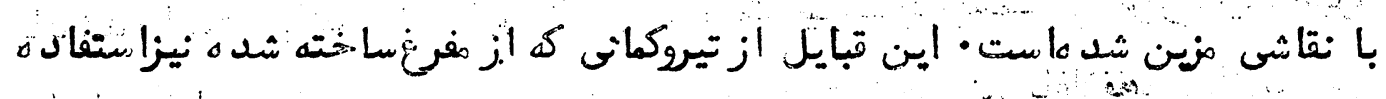

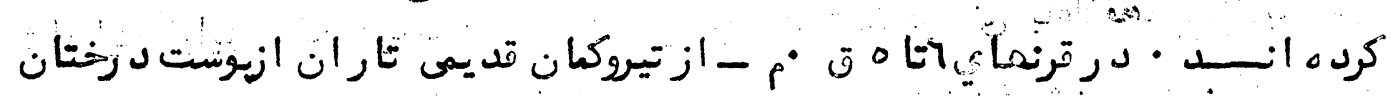

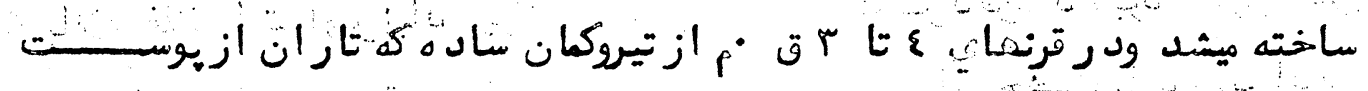

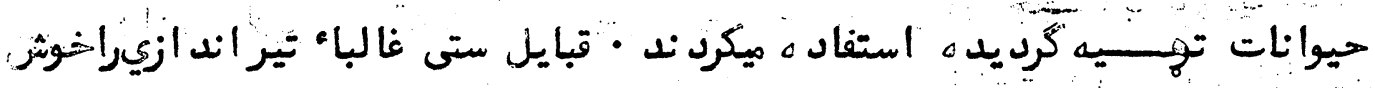

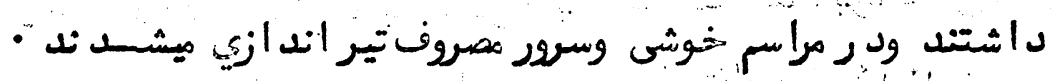

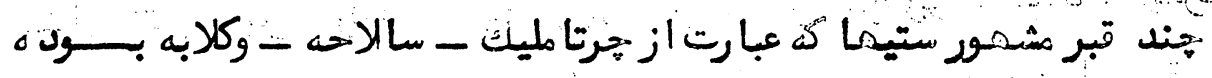

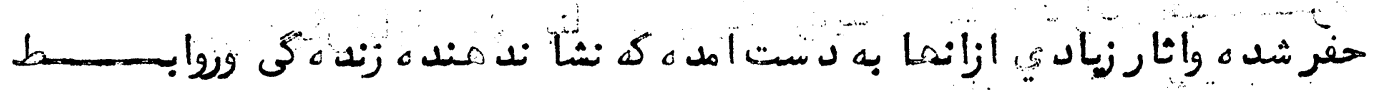

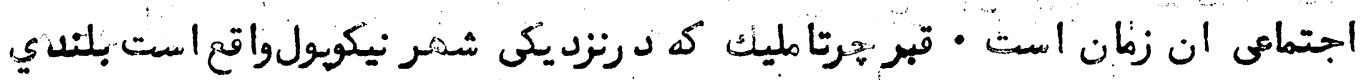

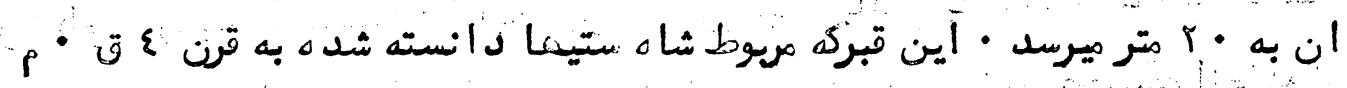

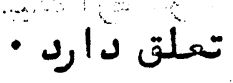

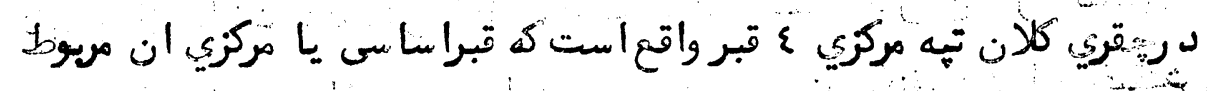

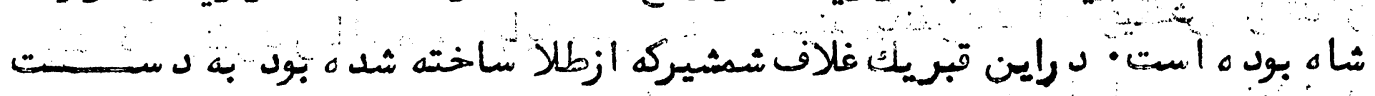

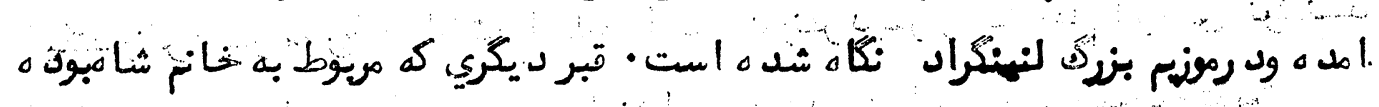

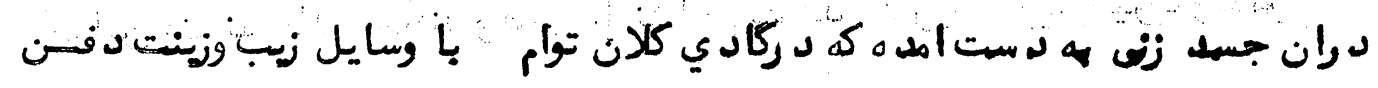

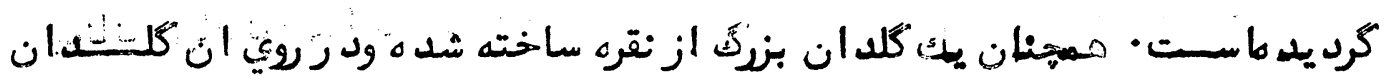




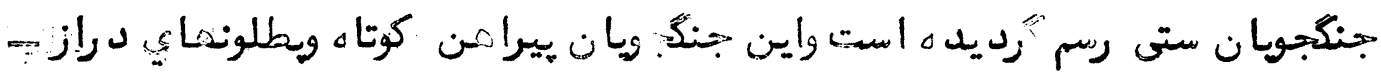

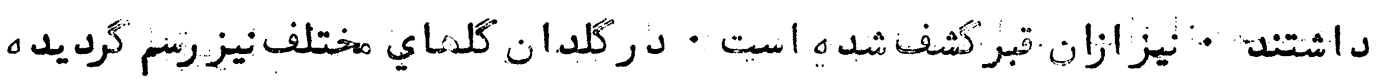

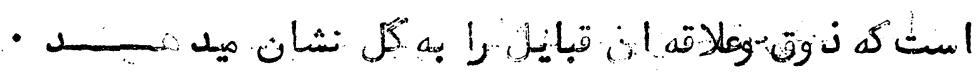

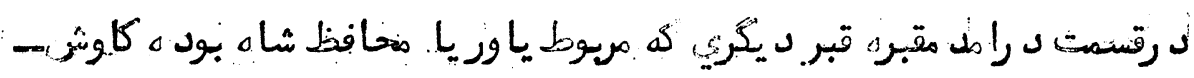

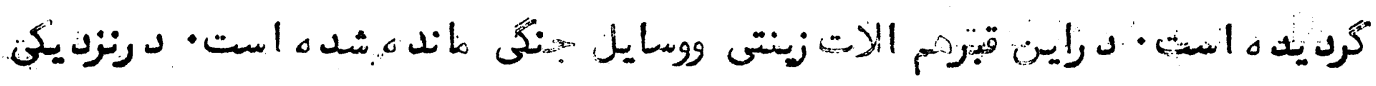

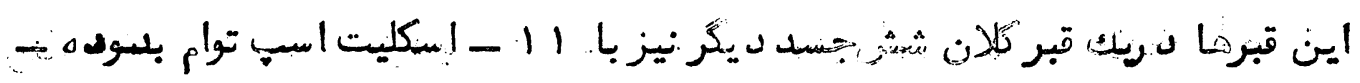

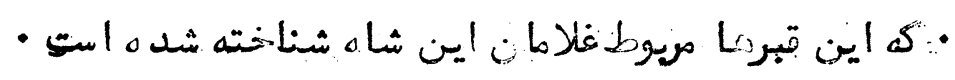

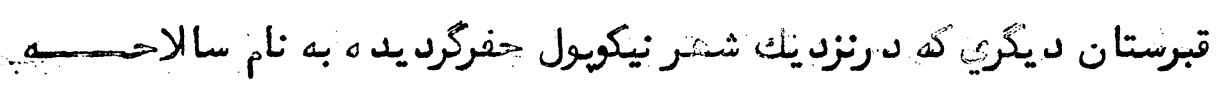

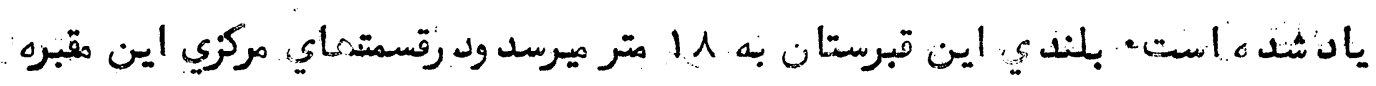

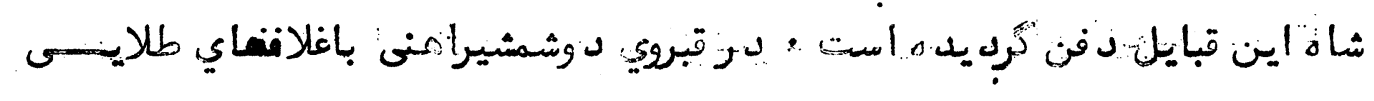

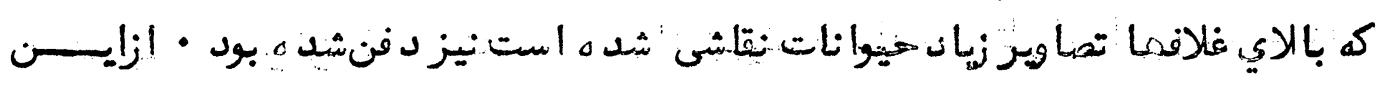

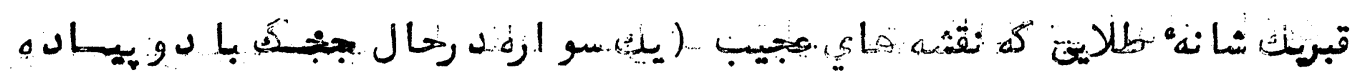

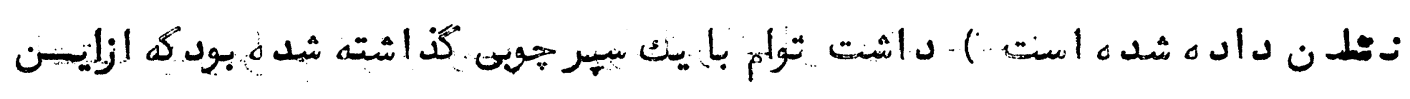

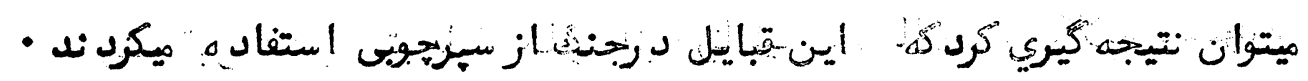

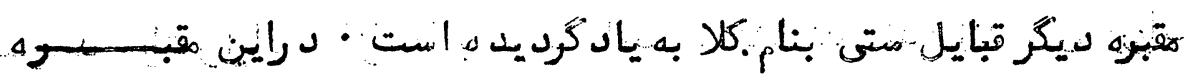

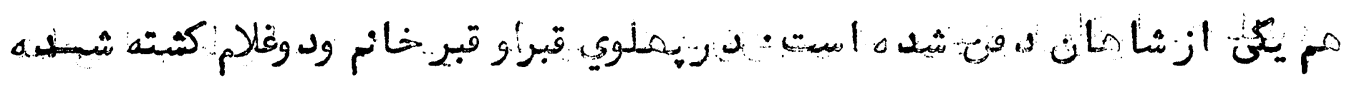

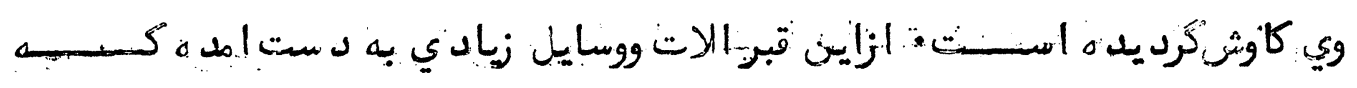

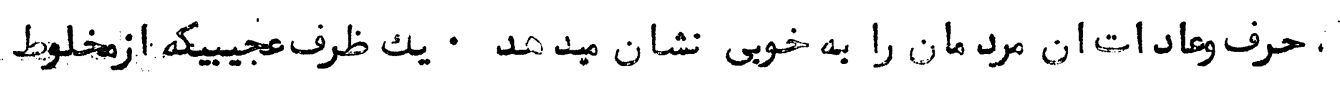

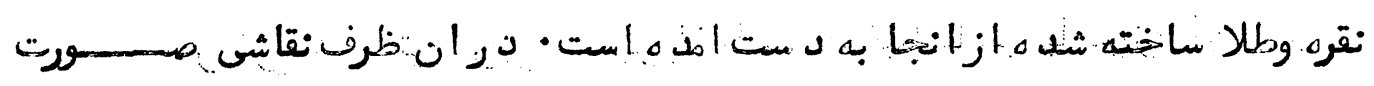

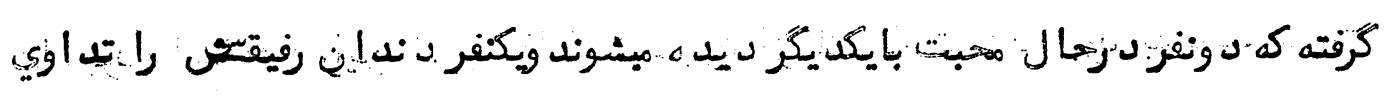

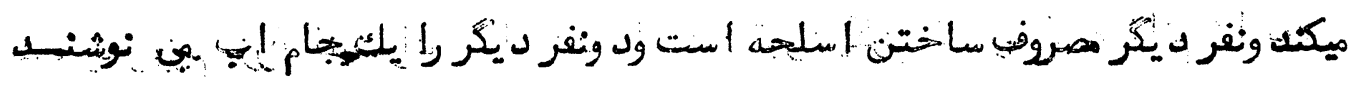

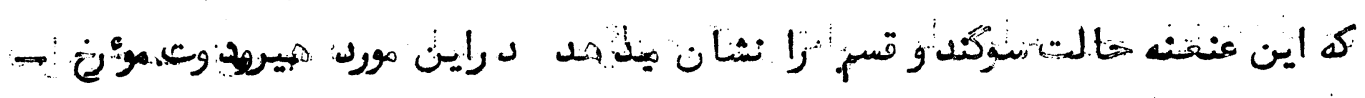

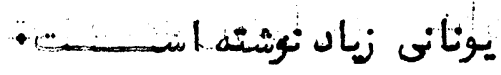




\section{$10 \mathrm{~V}$}

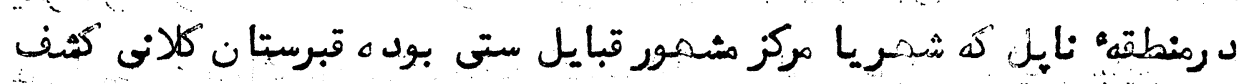

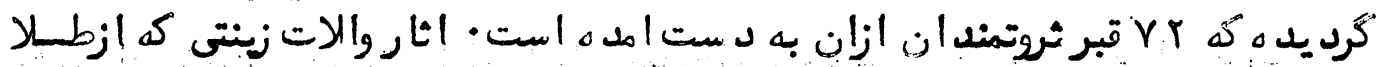

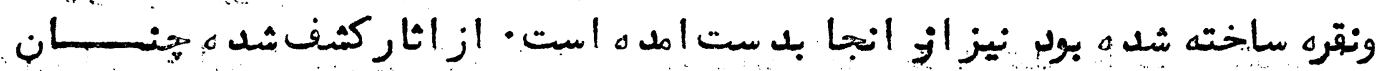

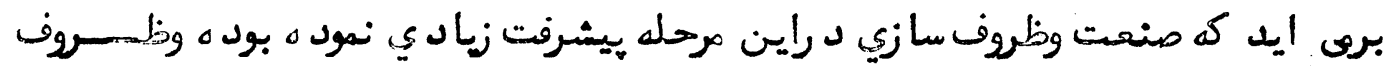

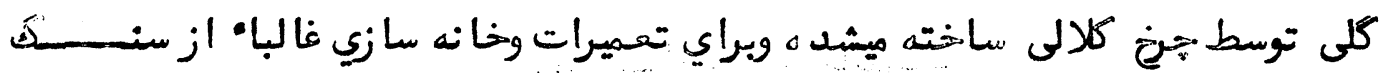

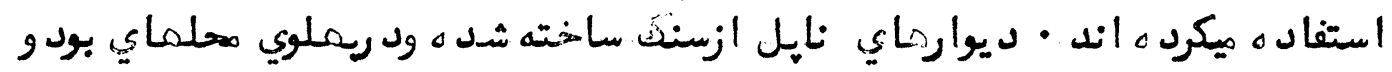

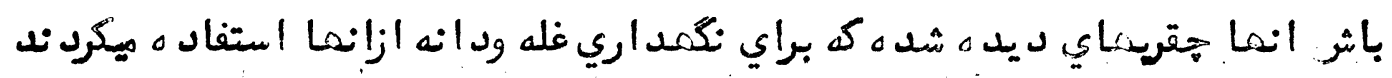

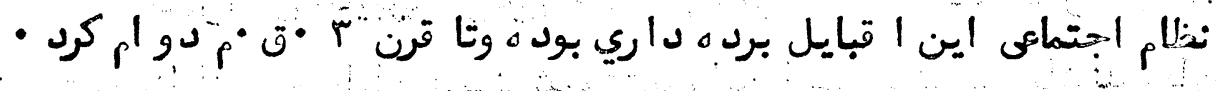

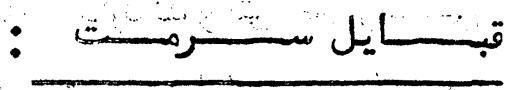

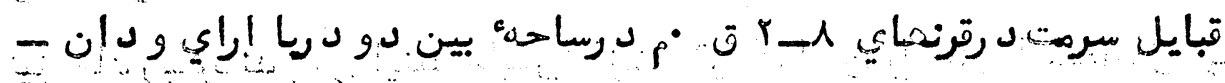

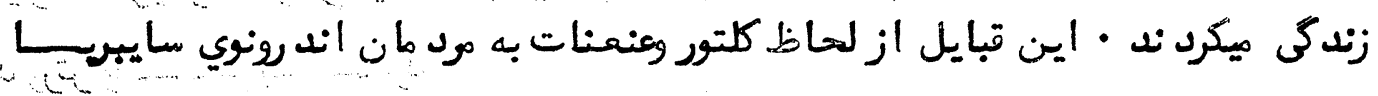

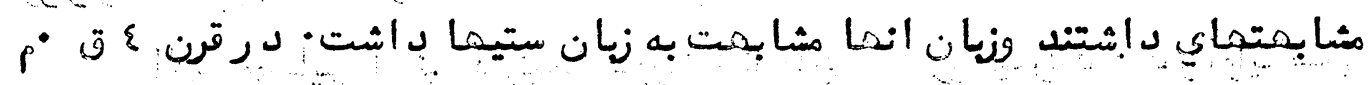

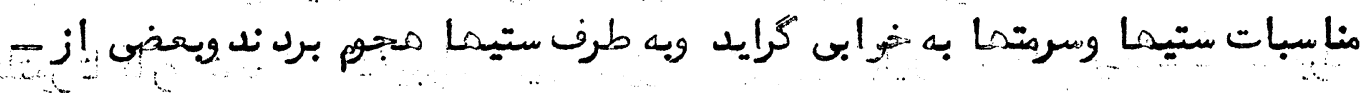

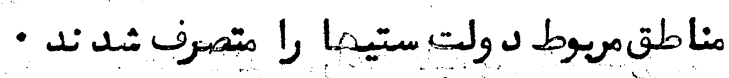

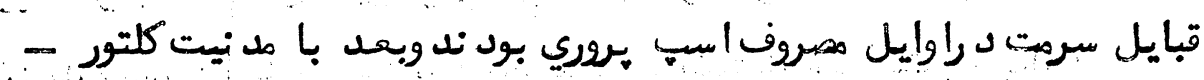

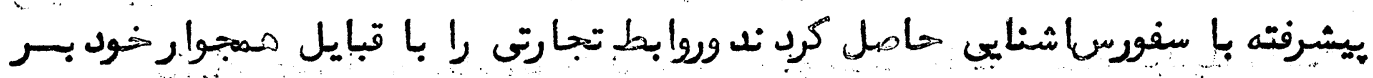

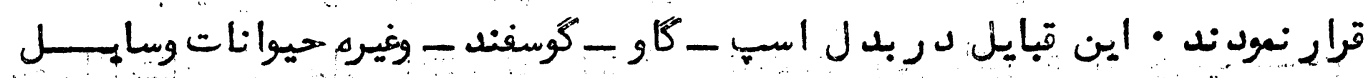

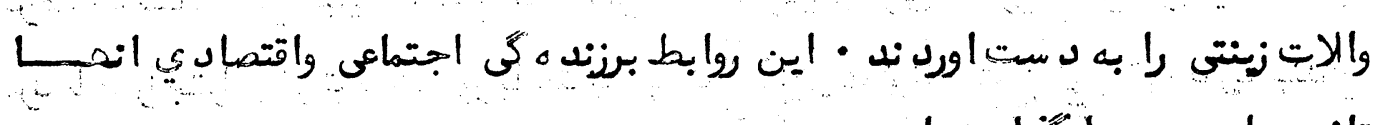

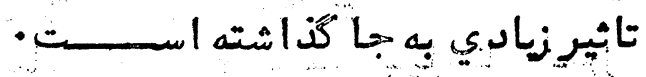

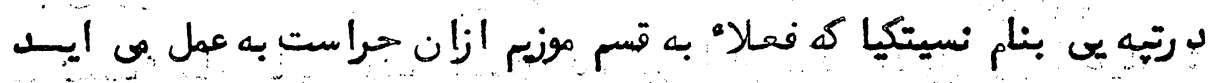

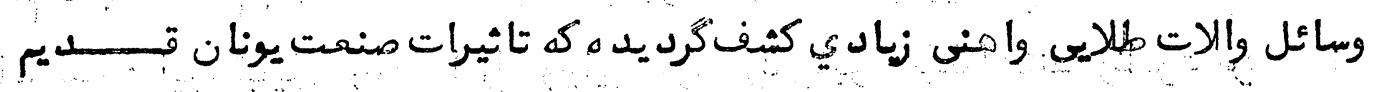

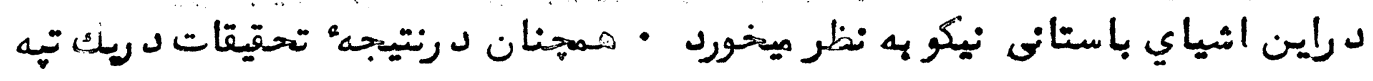


$(.94)$

$10 \wedge$

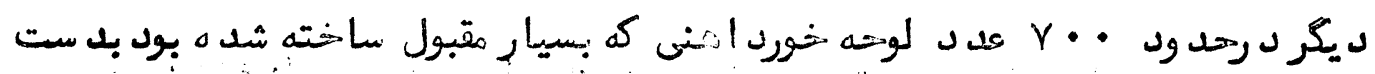

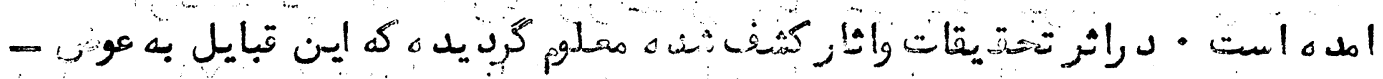

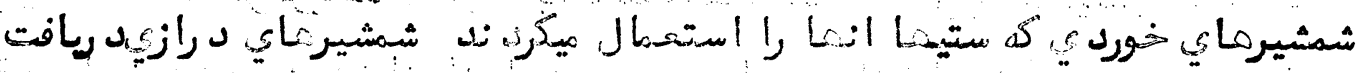

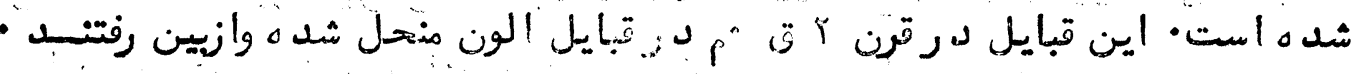

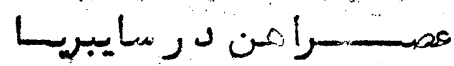

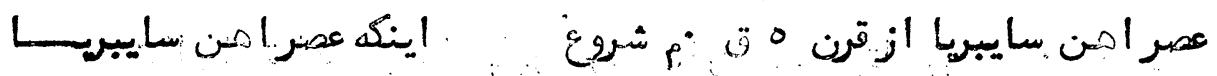

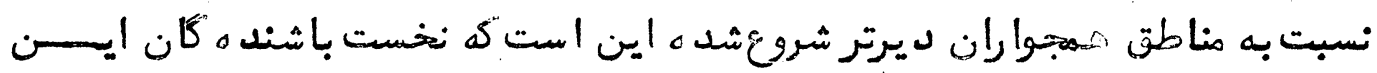

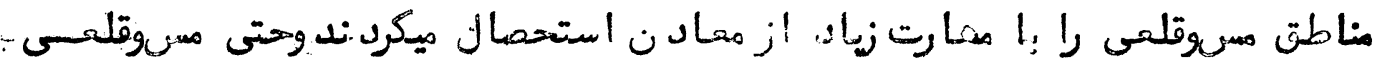

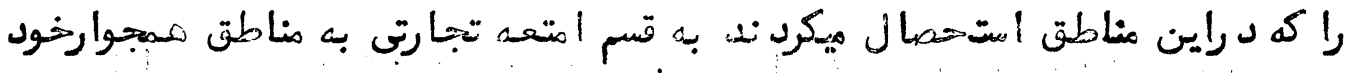

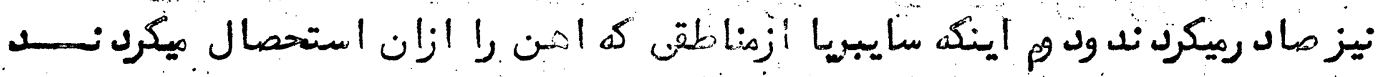

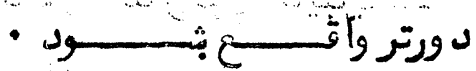

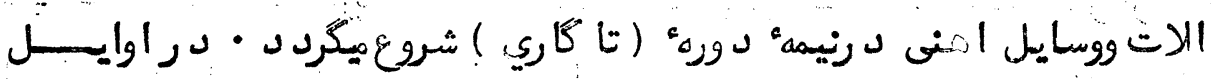

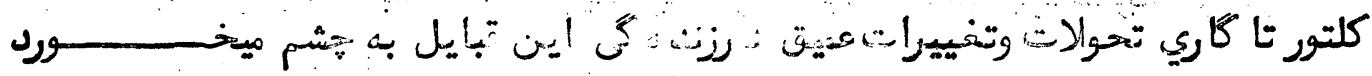

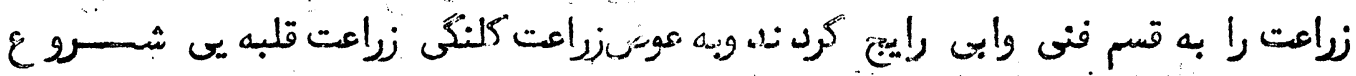

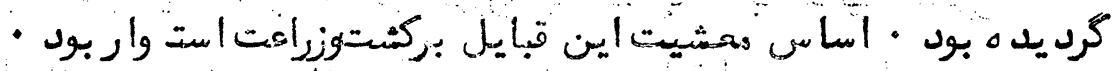

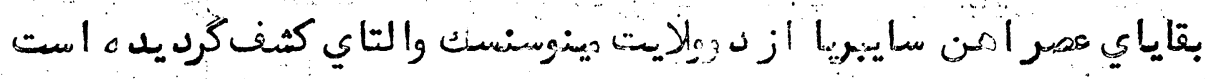

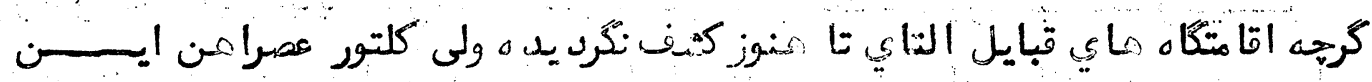

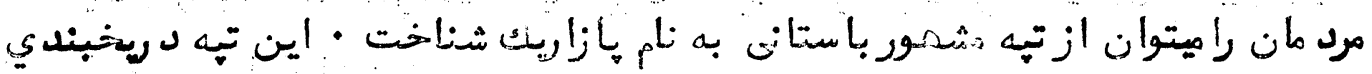

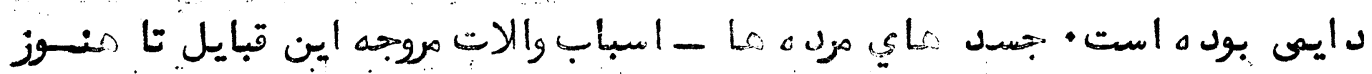

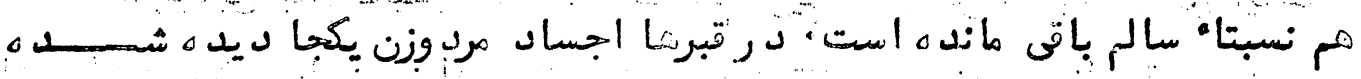

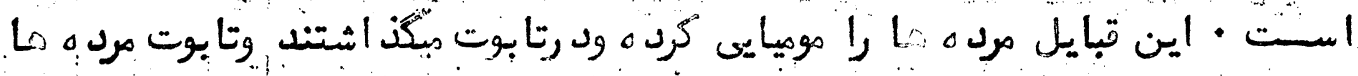




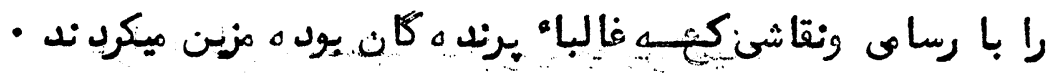

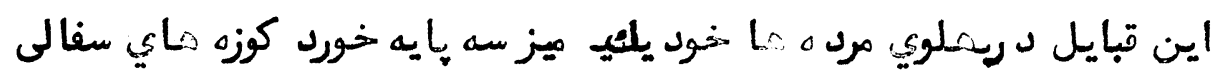

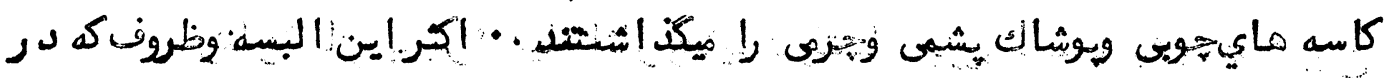

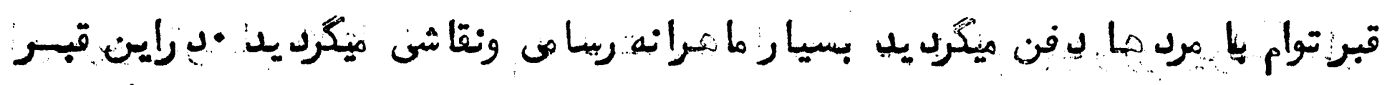

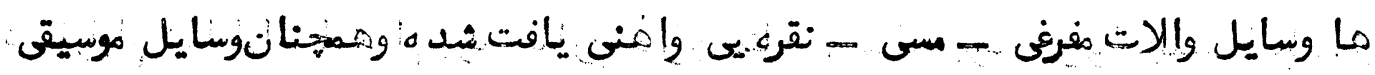

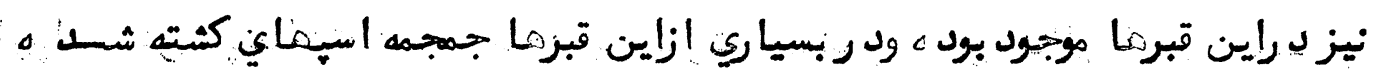

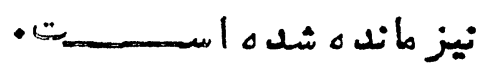

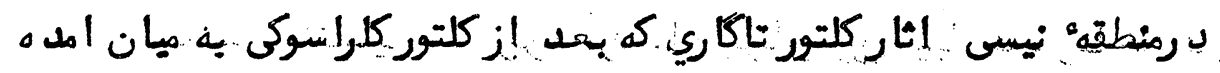

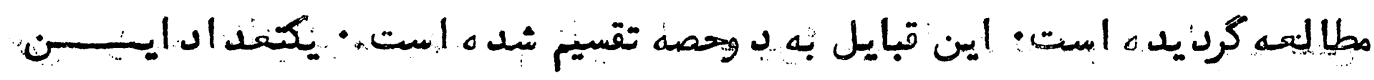

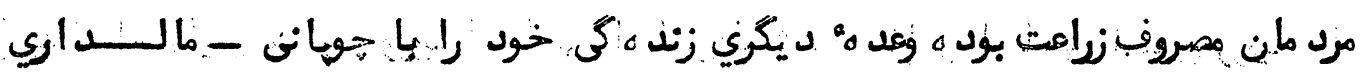

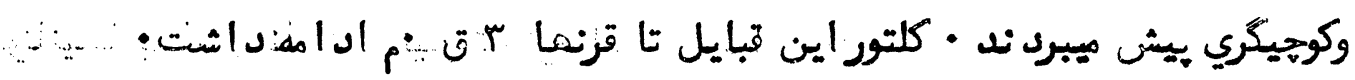

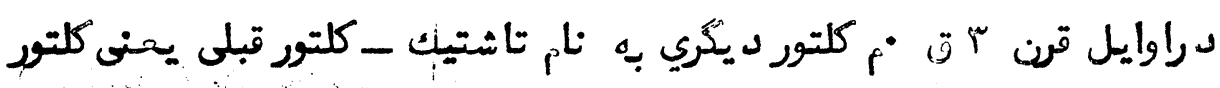

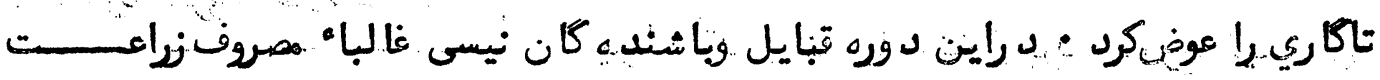

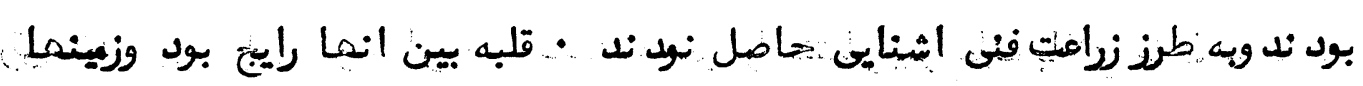

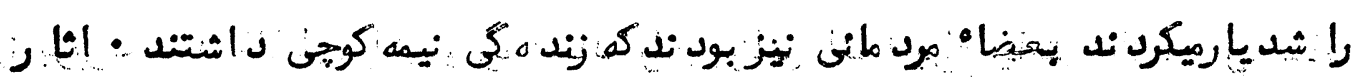

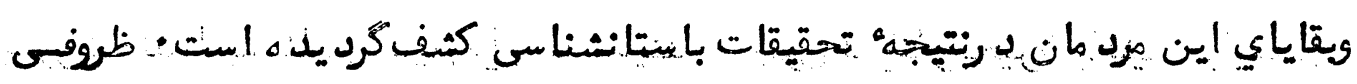

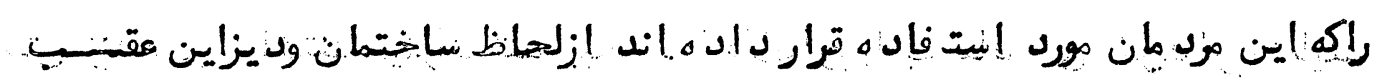

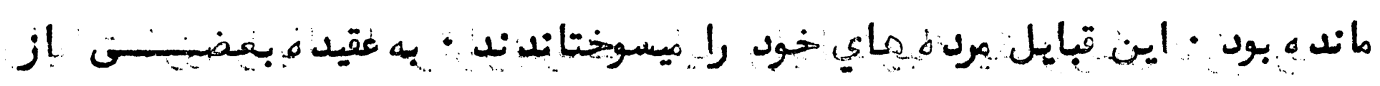

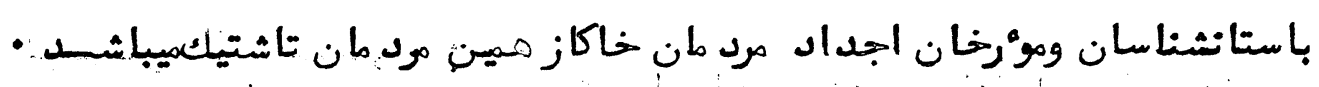




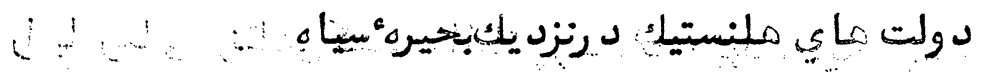

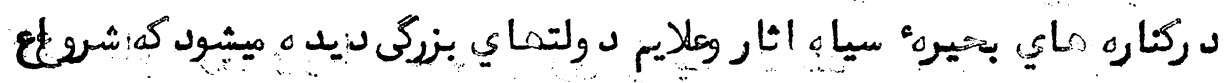

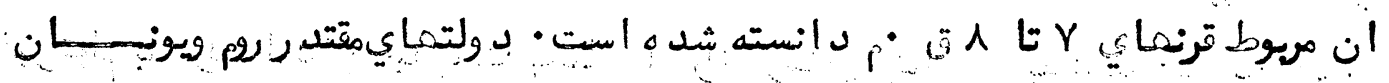

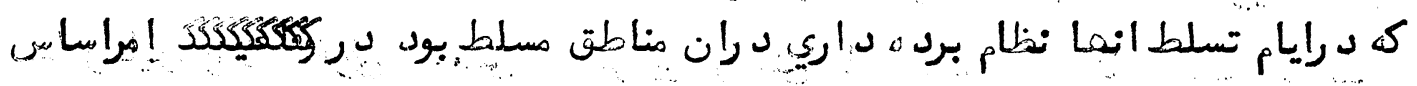

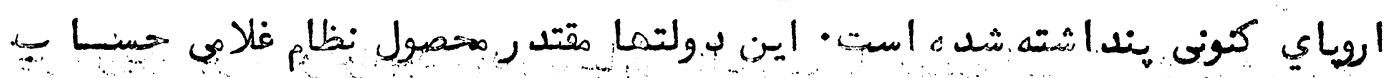

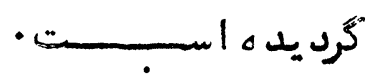

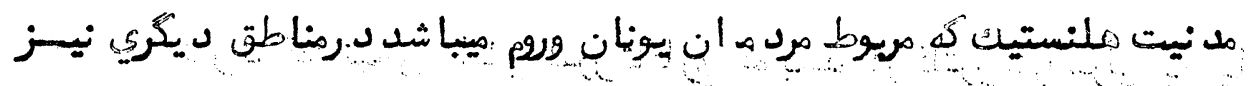

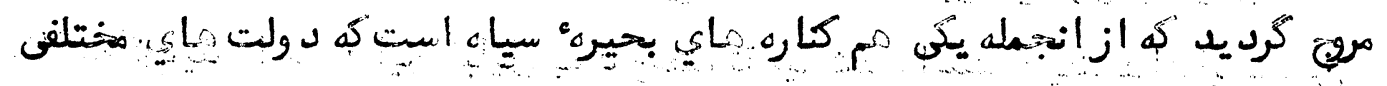

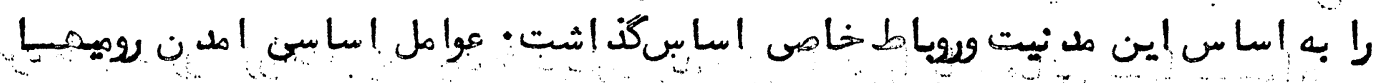

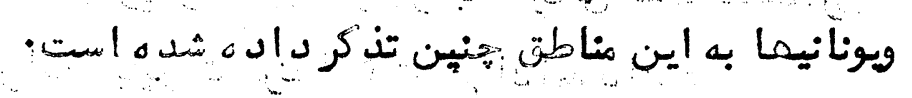

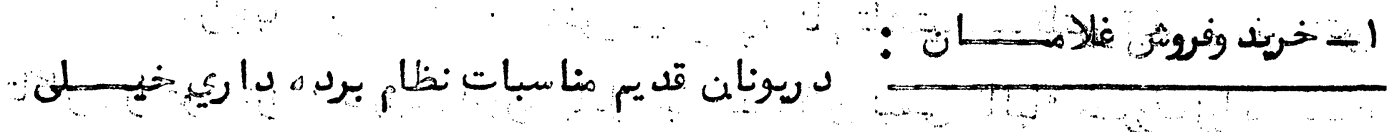

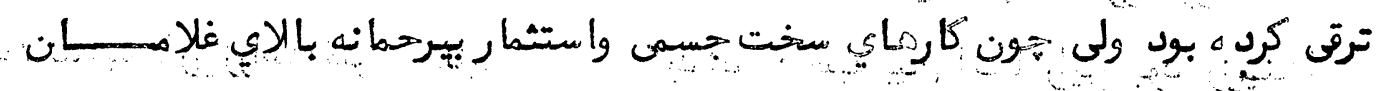

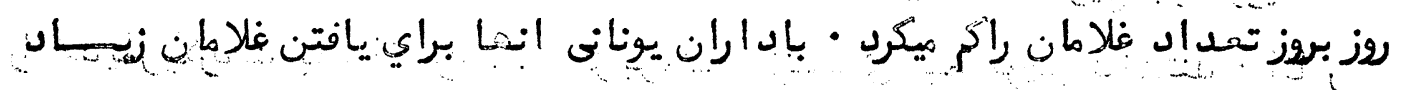

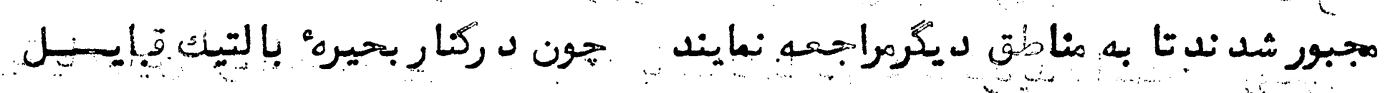

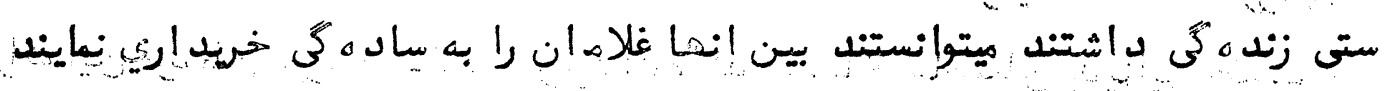

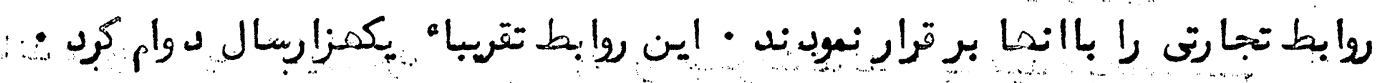

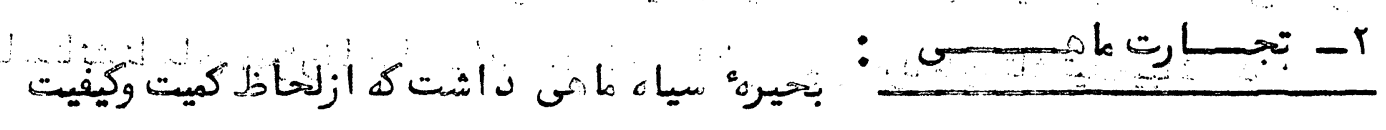

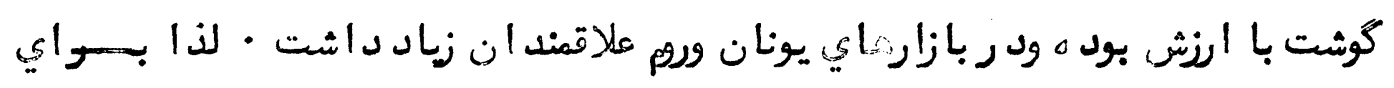

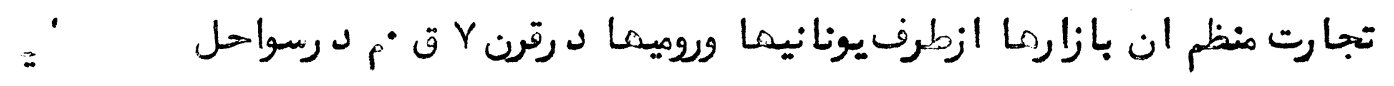

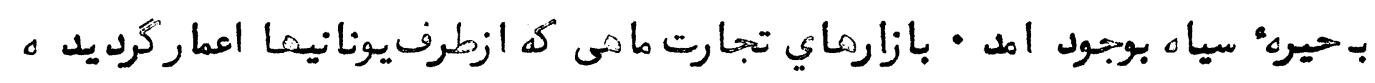

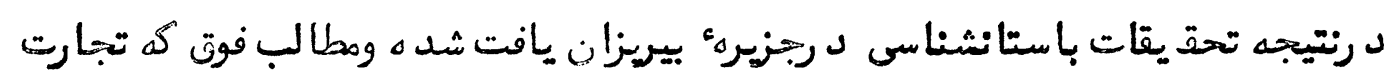


141

ماهى ازبحيره سياه :ه يونان بجريان داشت از اثار ورقاياي كثف شده إزاين جزيره

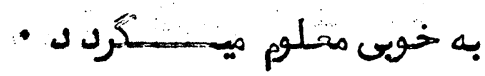

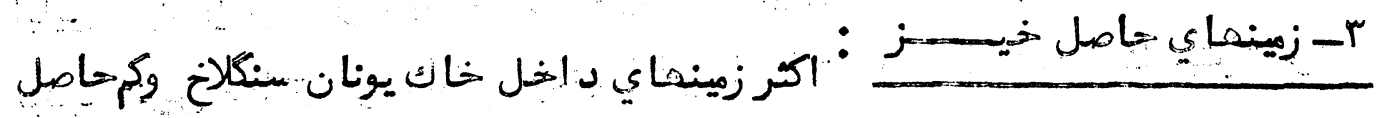

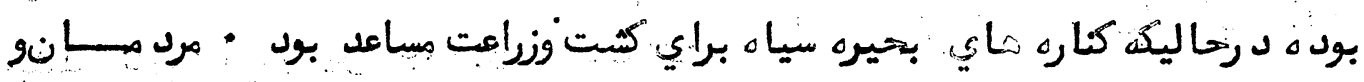

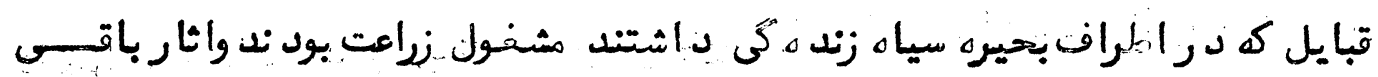

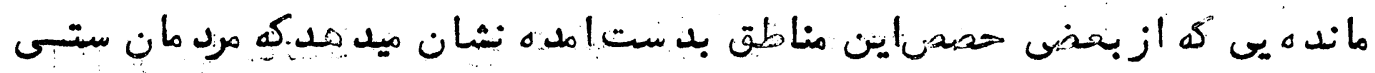

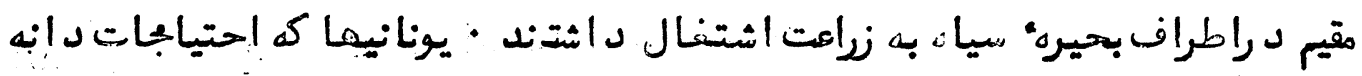
وغله خون را ازطريق تبارت با ستى مها ازاين مناطق رفع مينمود ند سـبب شدكه براي.

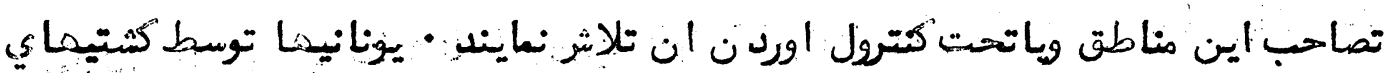

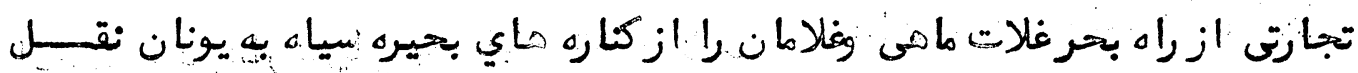

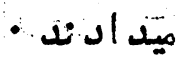

ساختن تعسيرات وخانه هاي ثبارتى در رنزديك بجيره بيـــــاه

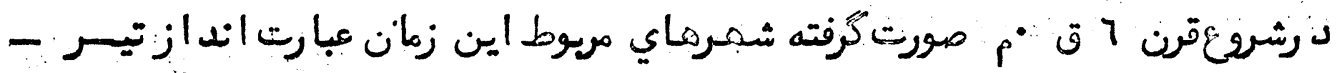

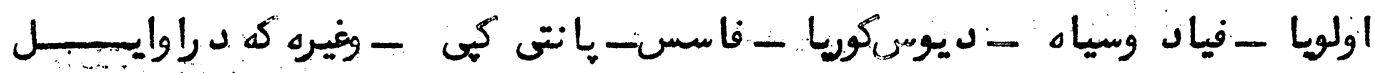
اين شهرها حكومتماي هنت قل داشتند وبحد ماه تحت كنترول يونانيهاي مهاجركي

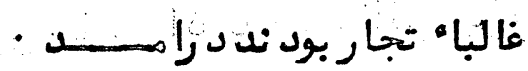

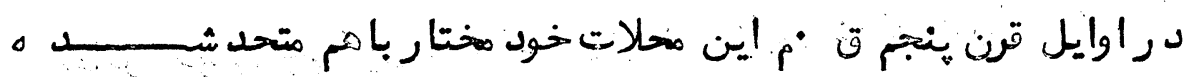

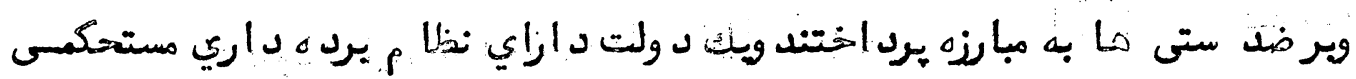

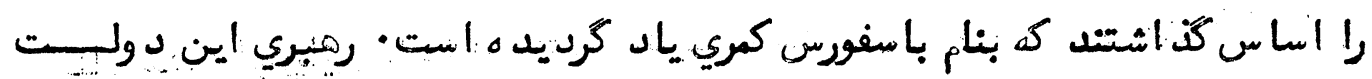

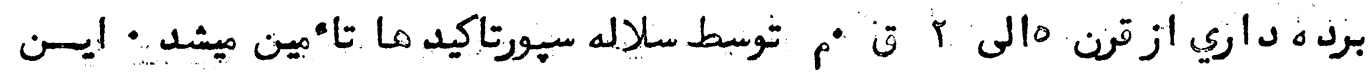

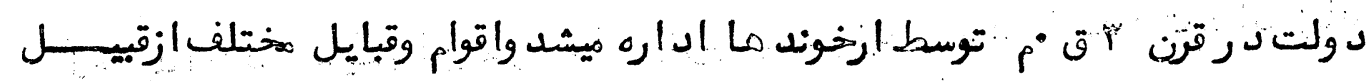

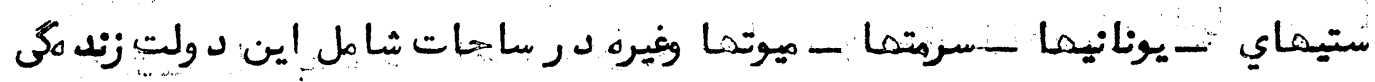




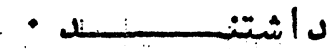

يونانيداي برد ه داريا باد اران يونانى كه نظر به تلت غلامان زميندهــاي

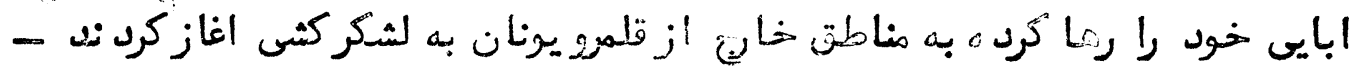

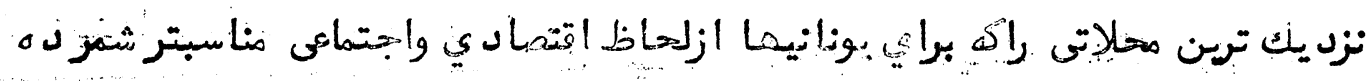

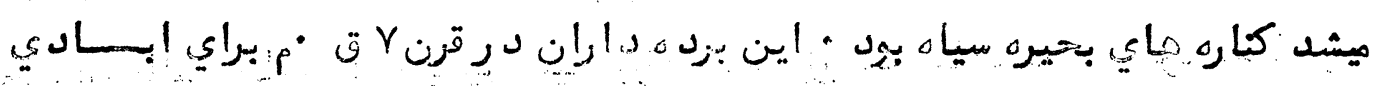

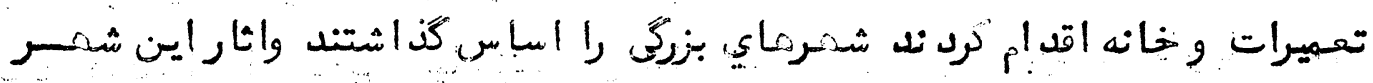

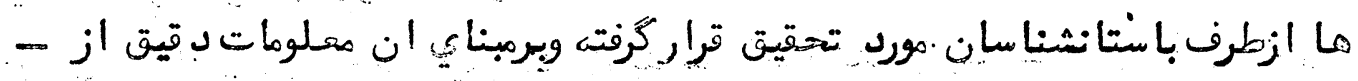

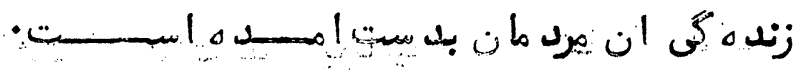

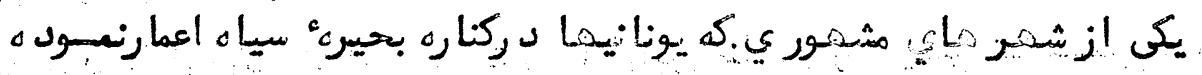

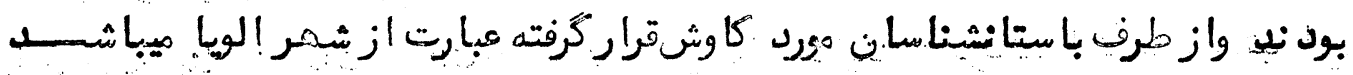

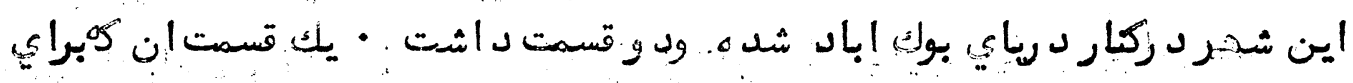

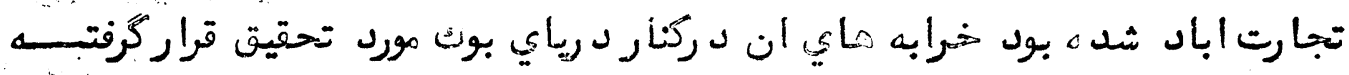

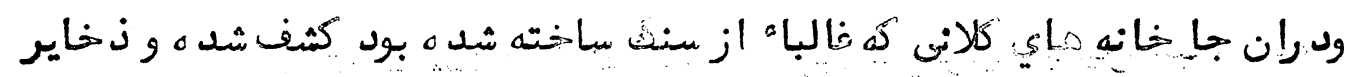

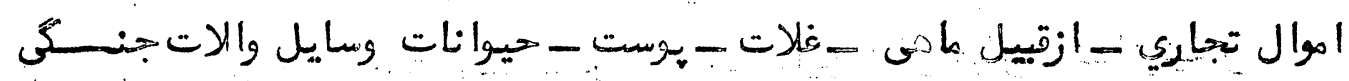

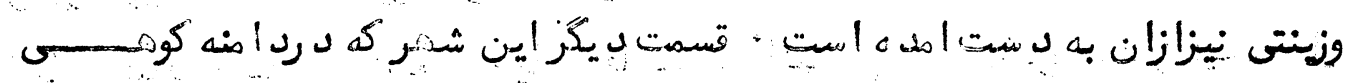

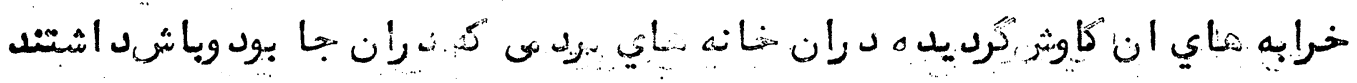

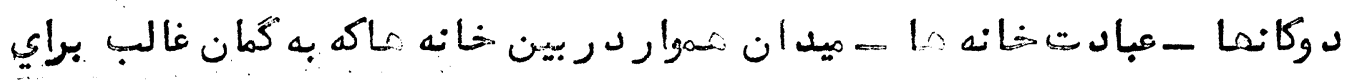

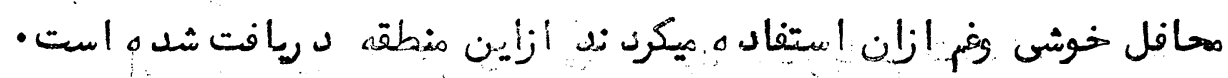

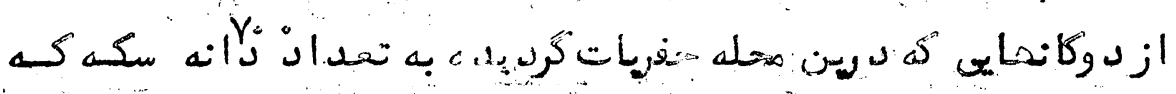

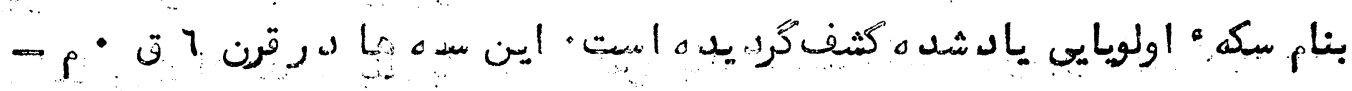

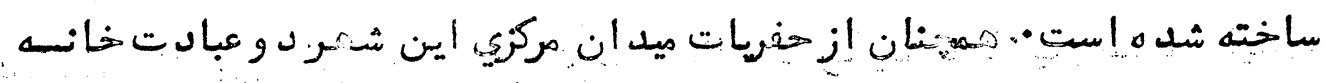

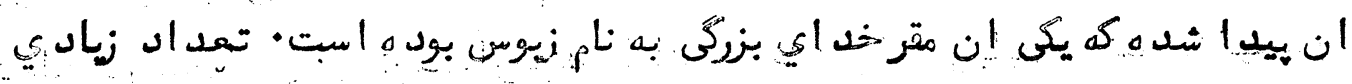

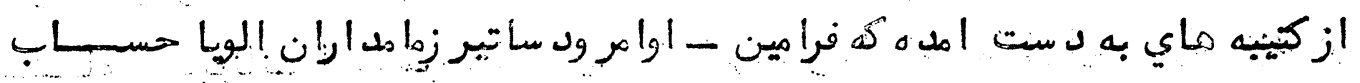




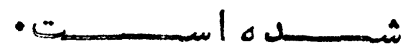

دربحضى ازتستهاي اين شهر - دوكانهاي نانوايان - كسبه كاران -

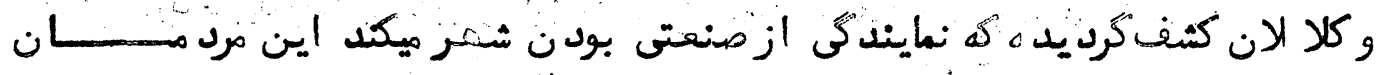

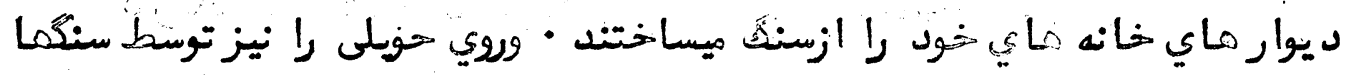

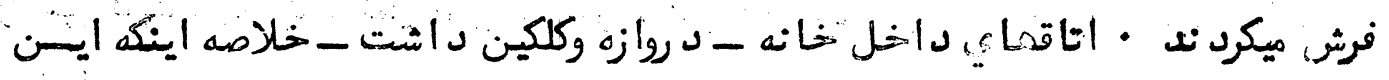

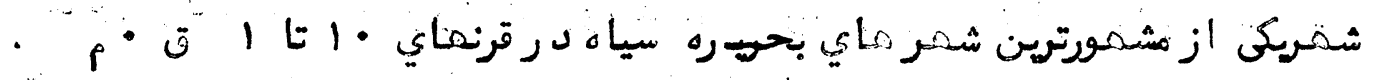

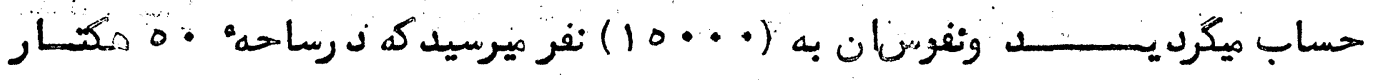

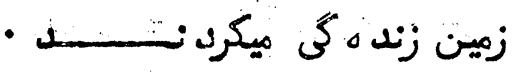

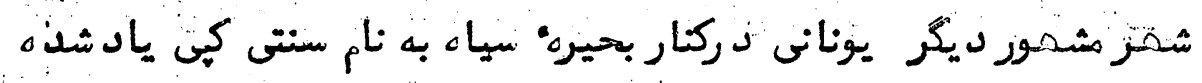

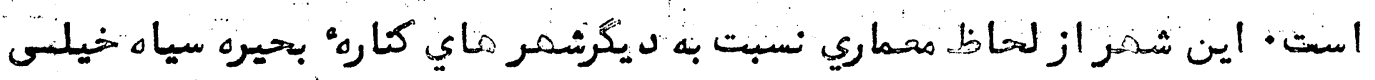

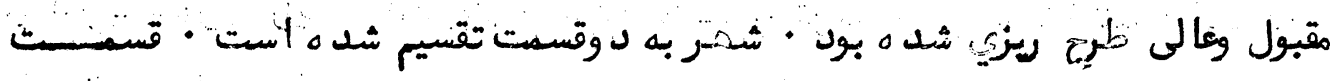

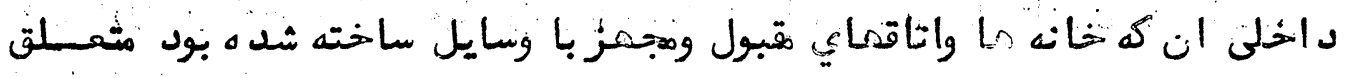

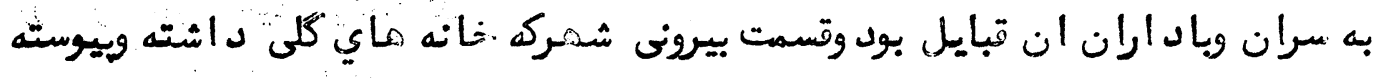

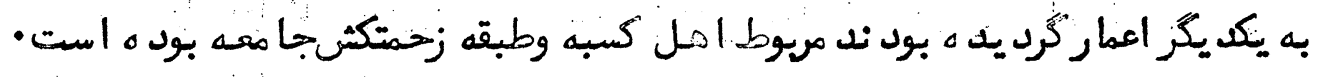

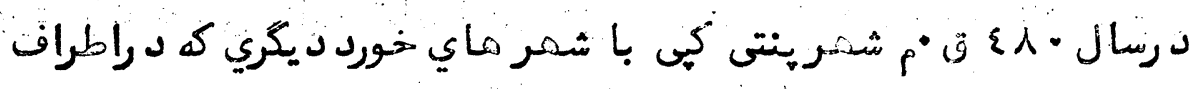

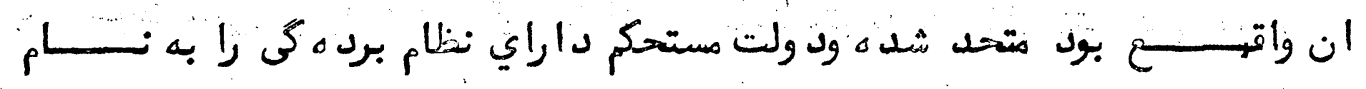

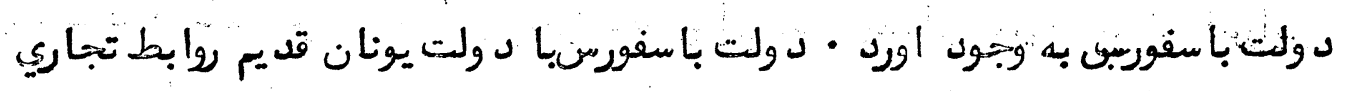

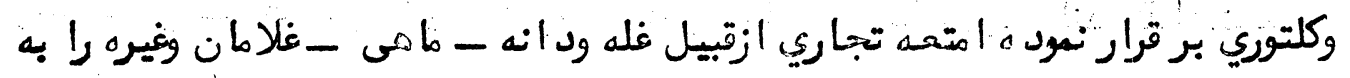

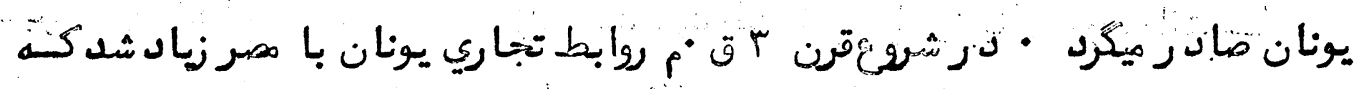

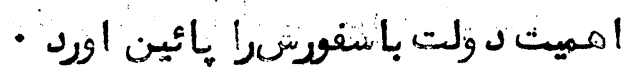

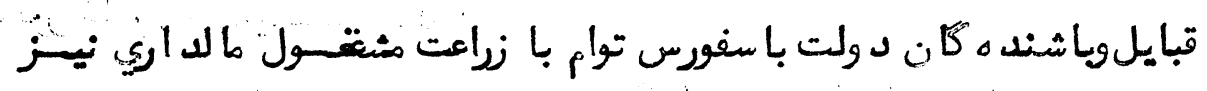

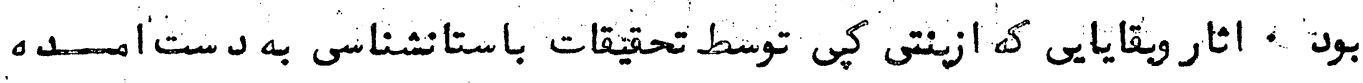

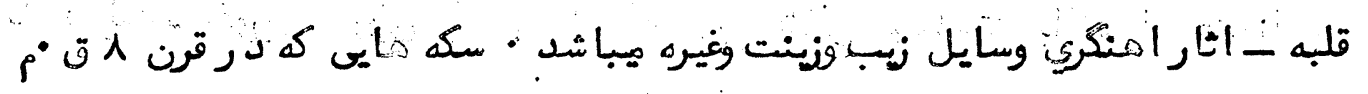




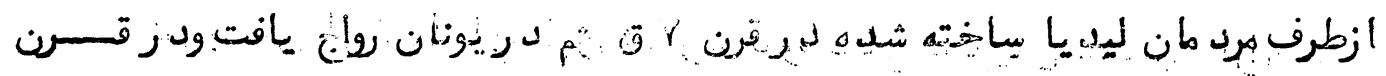

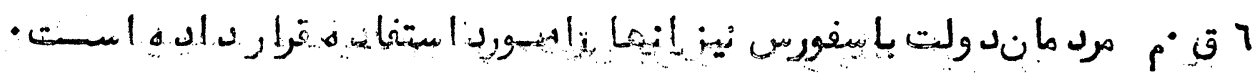

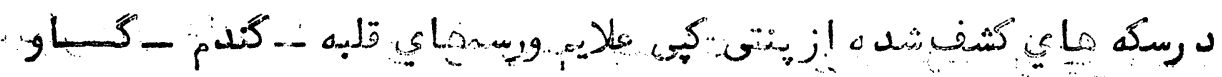

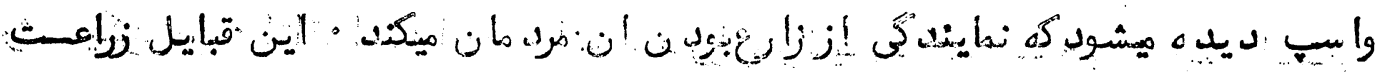

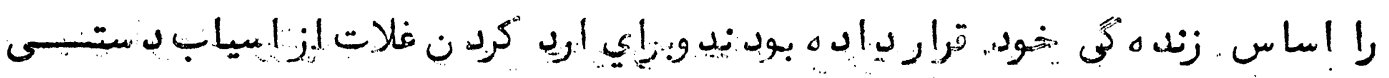

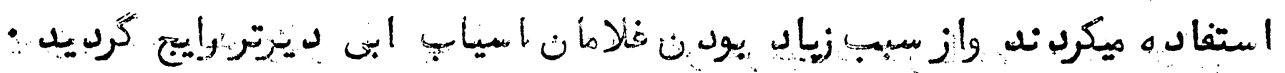

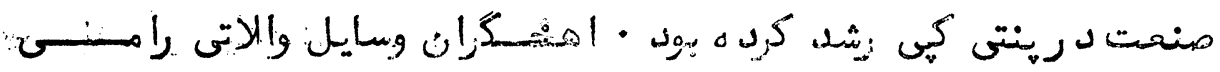

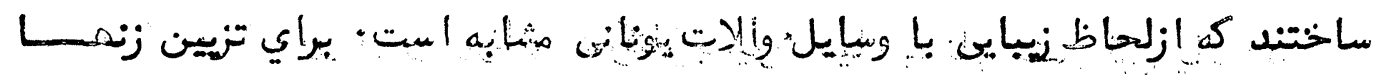

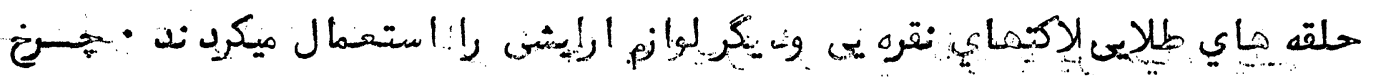

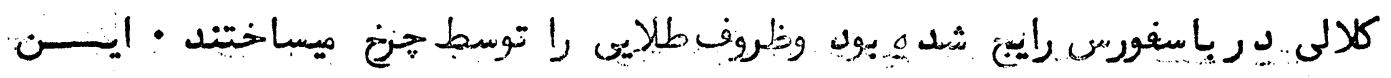

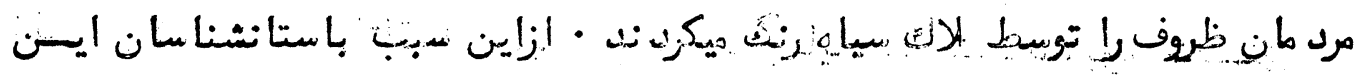

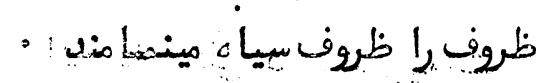

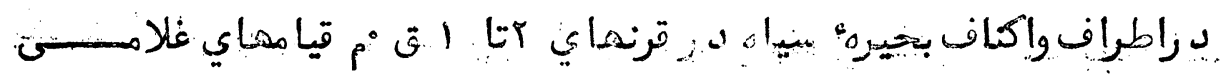

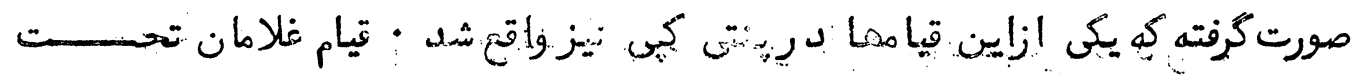

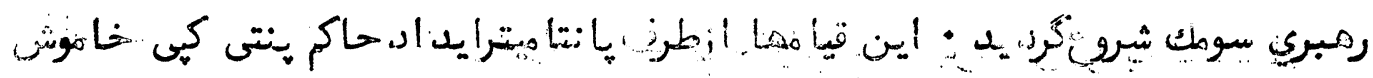

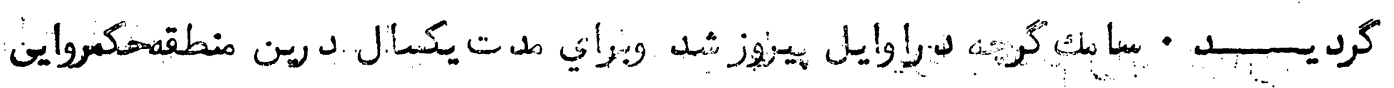

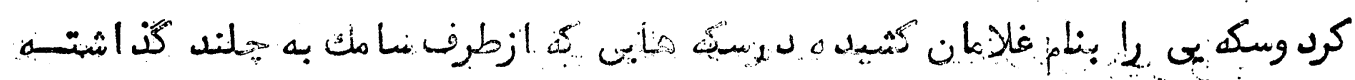

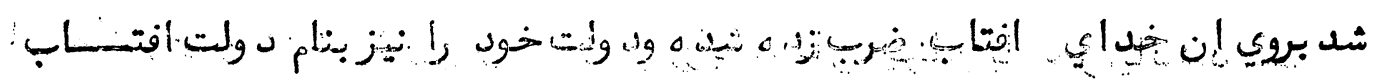

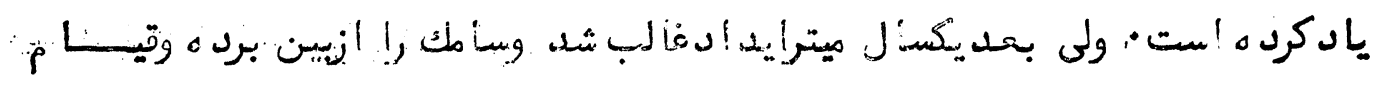

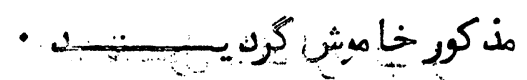

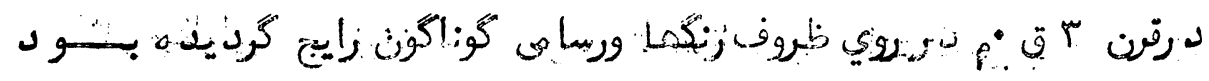

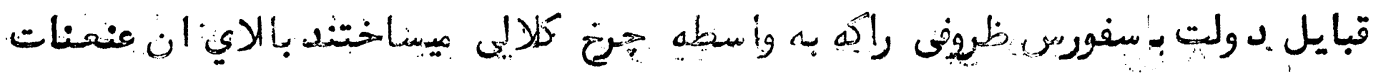

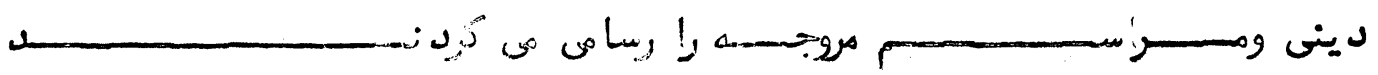


(r)

مدمترين ظروف إين مرد مان خم (هب ناز ) (1 ) وظروفكرد ن بلنيدي (انفره)

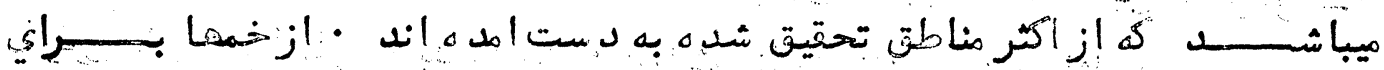

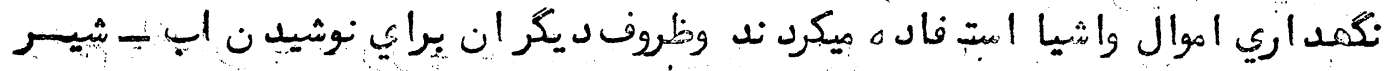

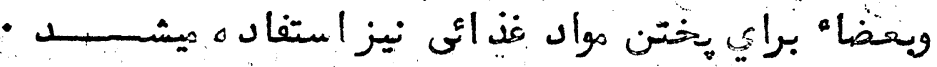

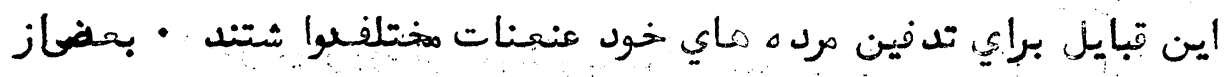

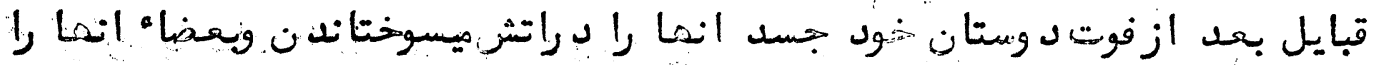

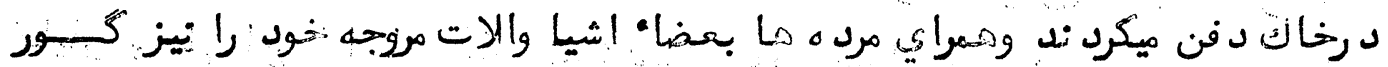

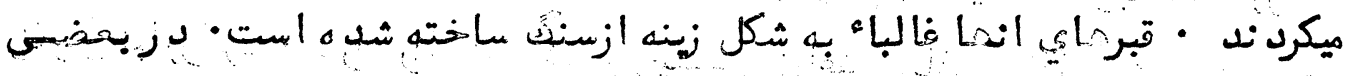

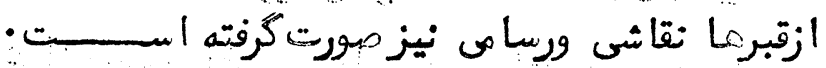

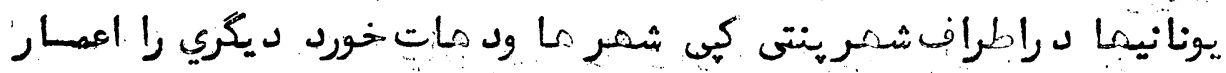

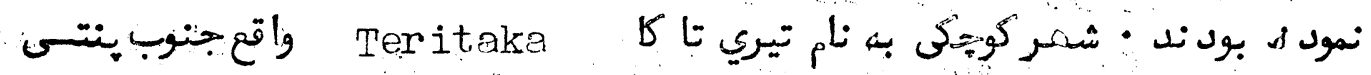

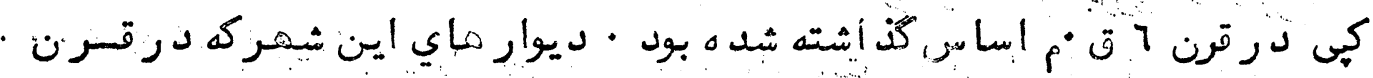

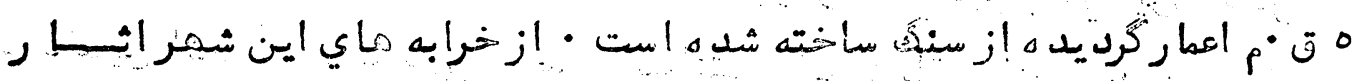

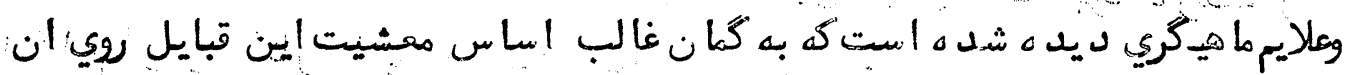

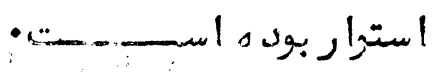

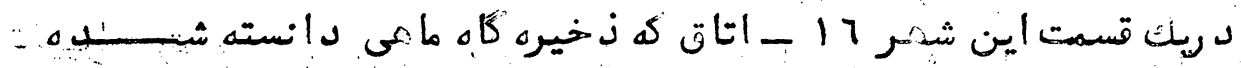

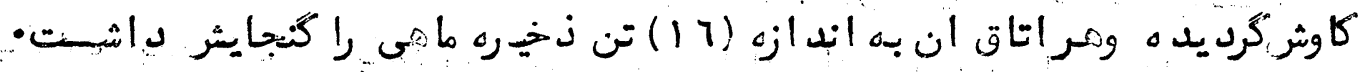

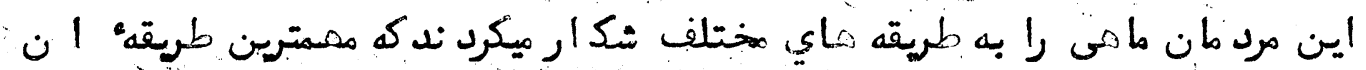

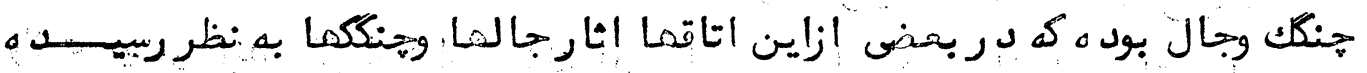

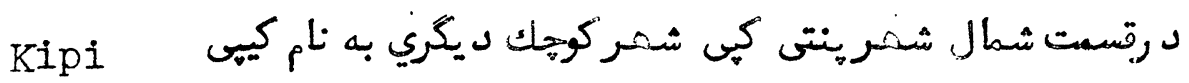

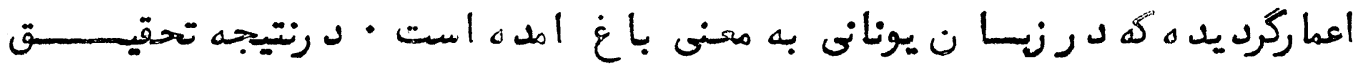

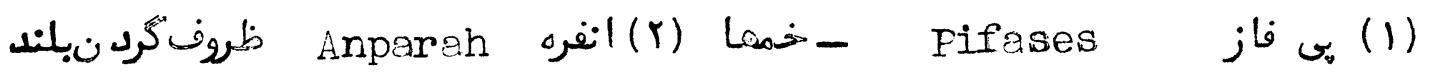




\section{4}

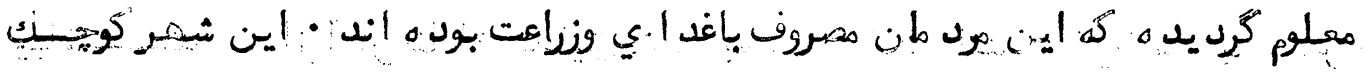

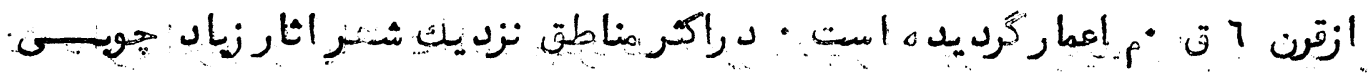

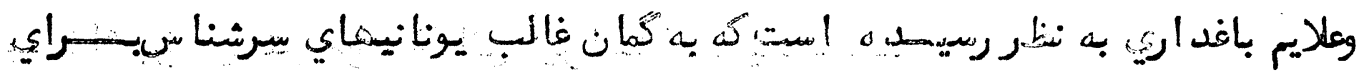

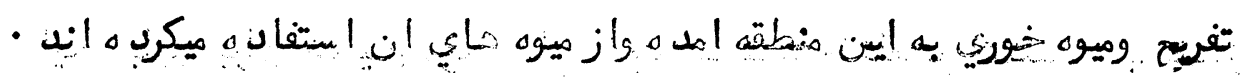

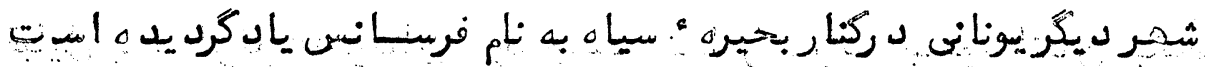

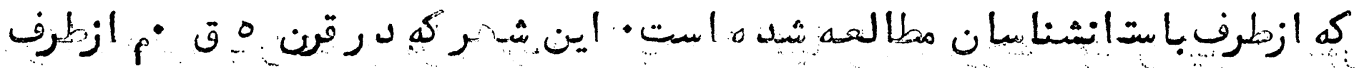

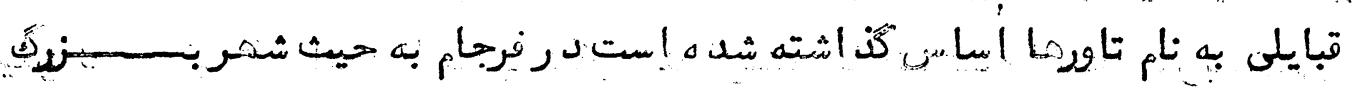
ويرنفوس تبانزكرد • دراطراف اين شمر زميندابي زراعتى وباغى منا لعه شده است.

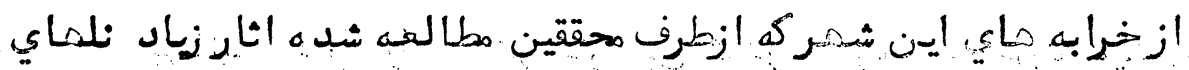

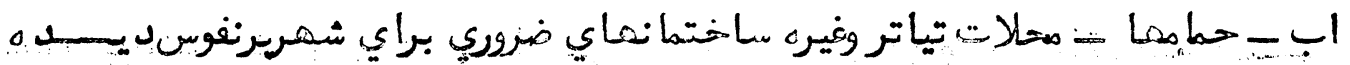

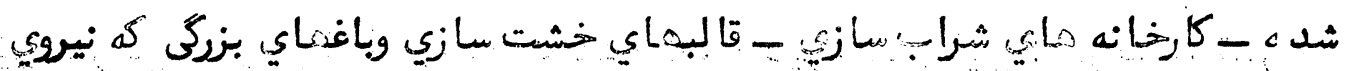

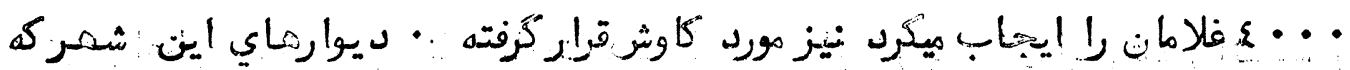

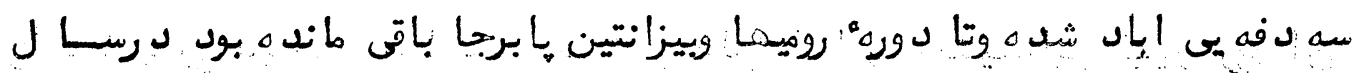

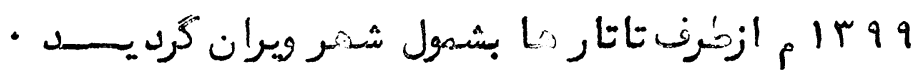

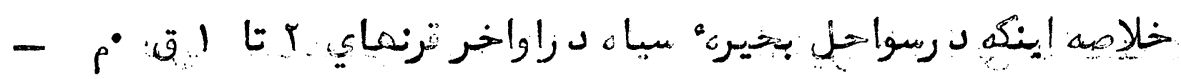

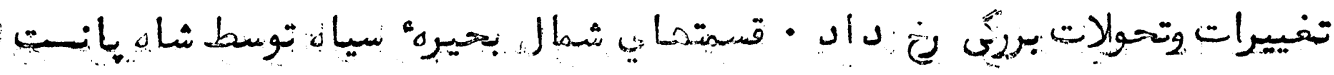

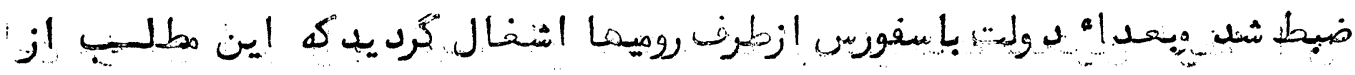

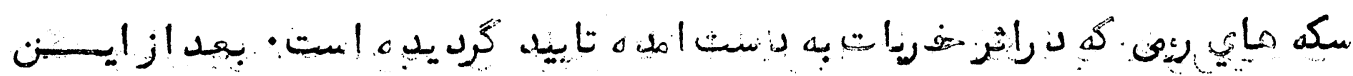

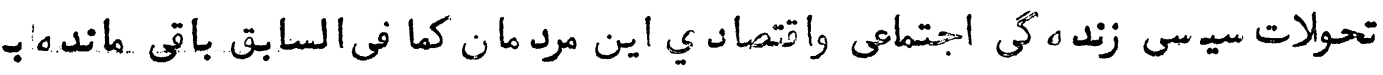


$14 v$

لدولت هاي برده د اري وفيود الىد رققاز

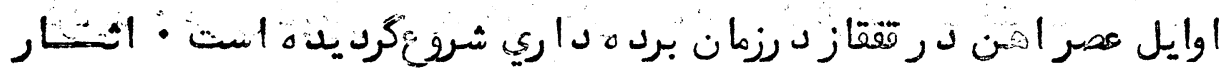

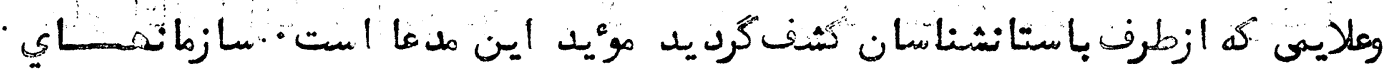

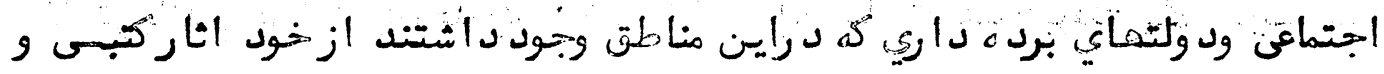

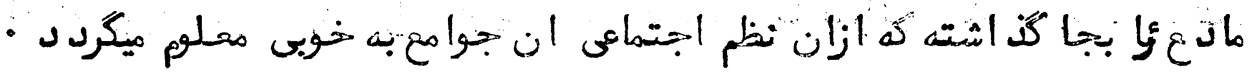

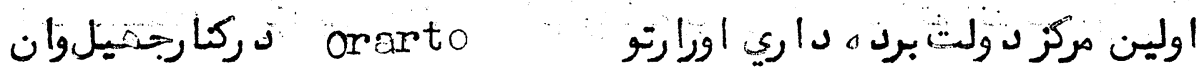

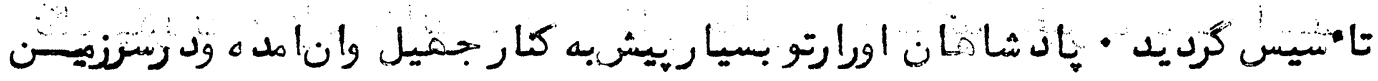

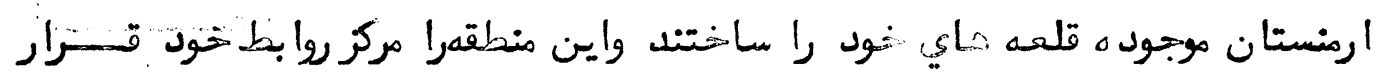
دان

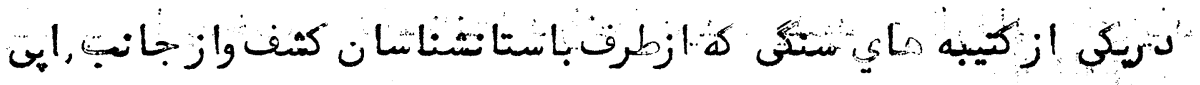

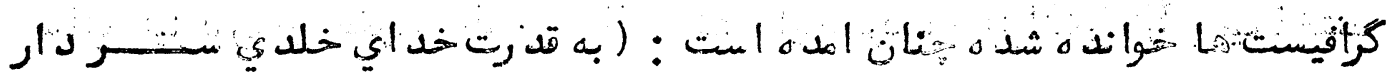

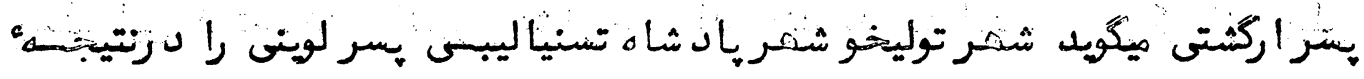

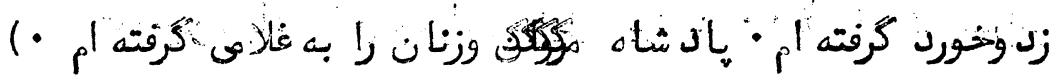

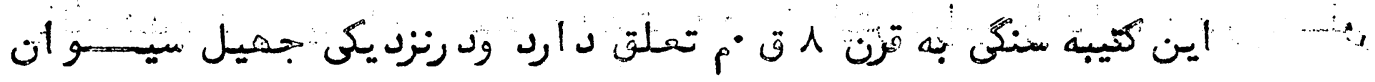

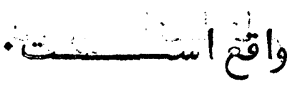

كيبه" ديكري كه د رنزد يكى جميل وان واقع است نيز مطالعة كرد يده ود رن

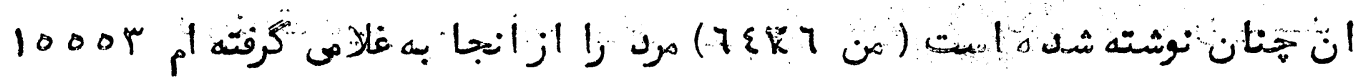

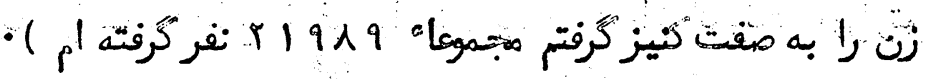

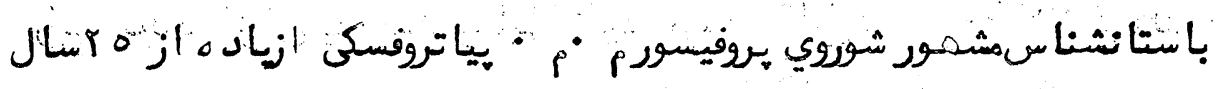

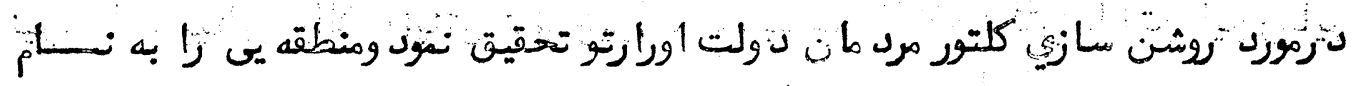

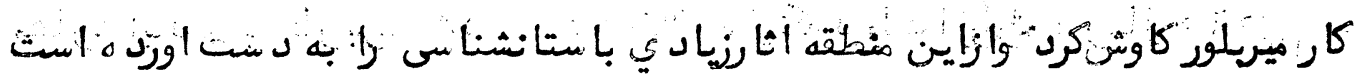

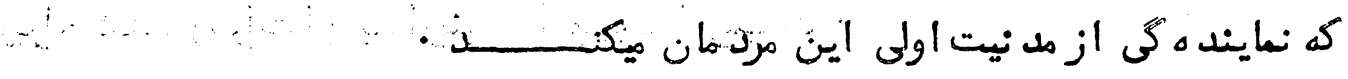




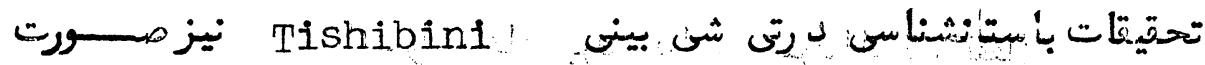

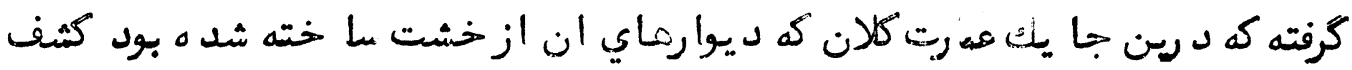

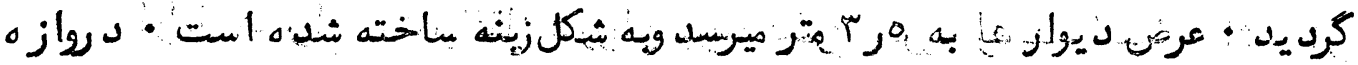

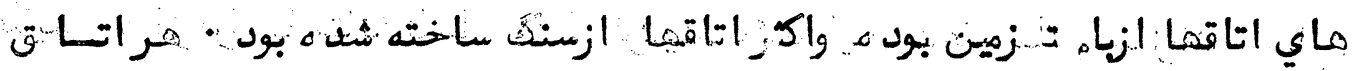

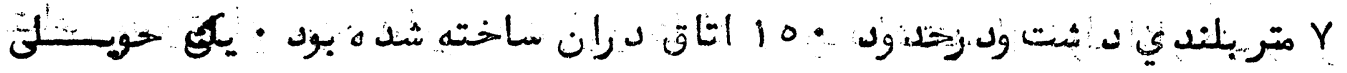

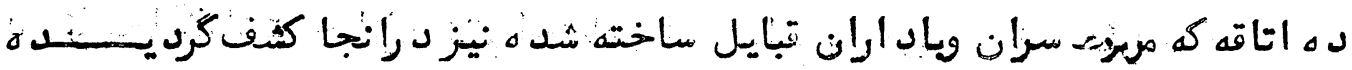

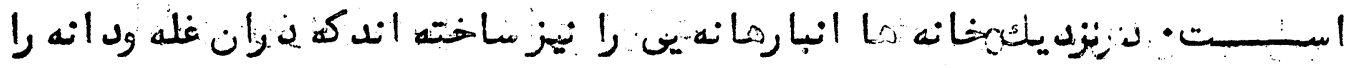

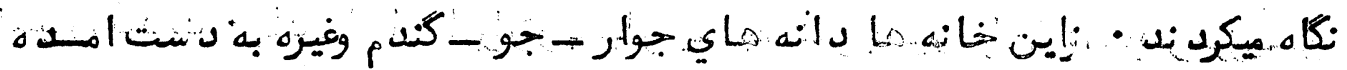

مرد مان لد وزت برده ه ا ري اورارتو به كثت وباغد اري مصروف بود ند · اثنار

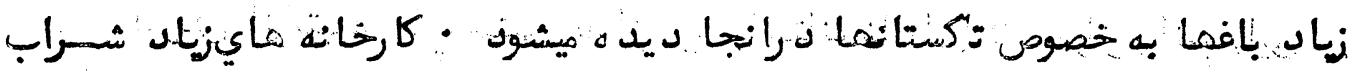

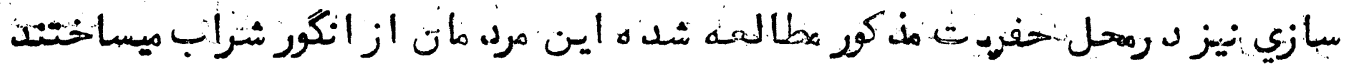

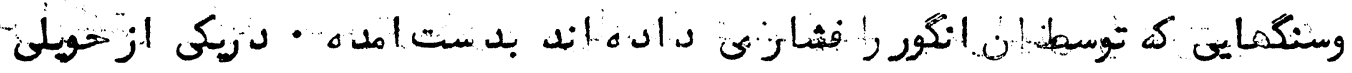

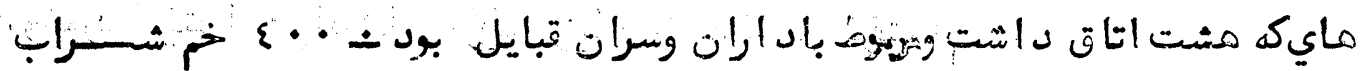

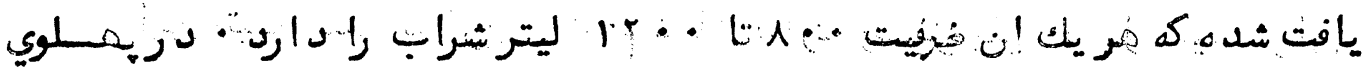

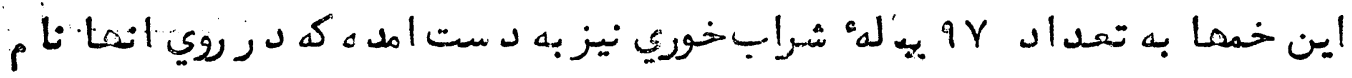

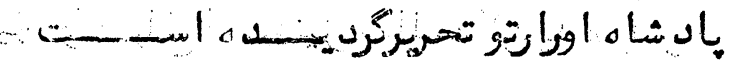

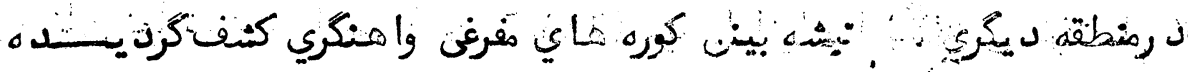

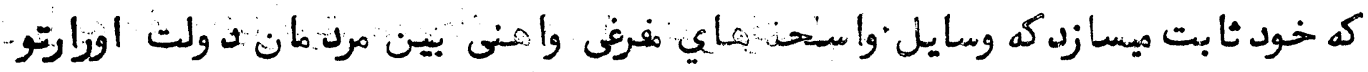

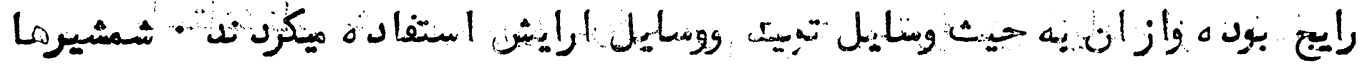

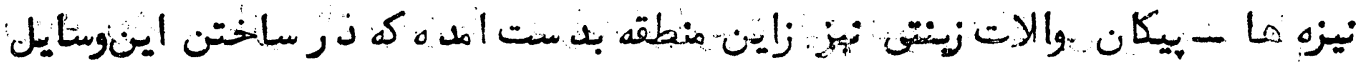

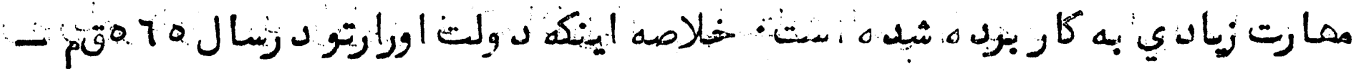

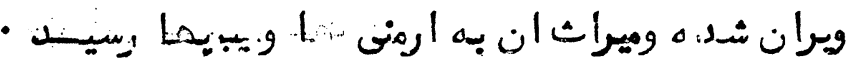




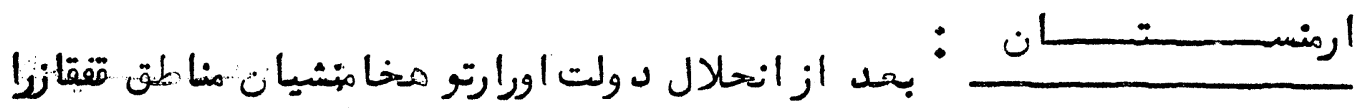

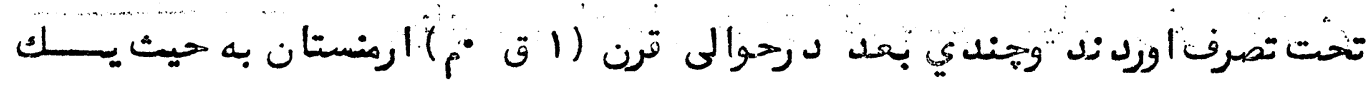

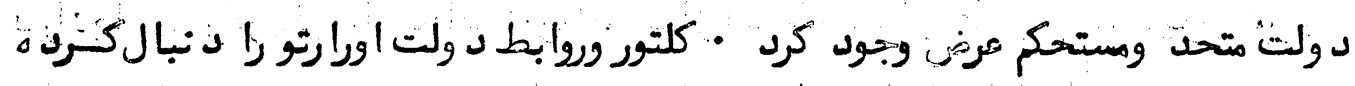

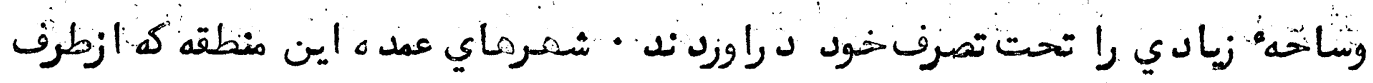

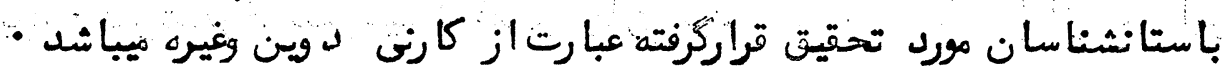

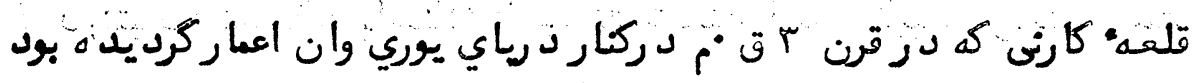

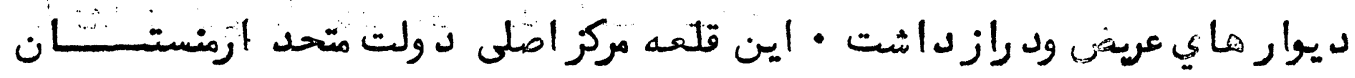

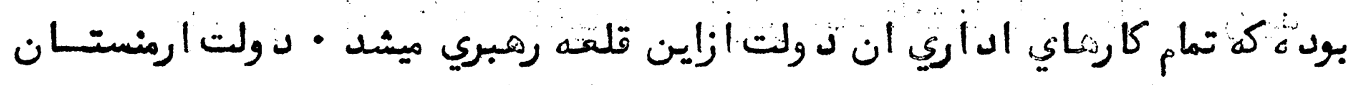

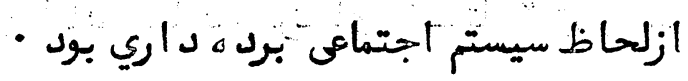

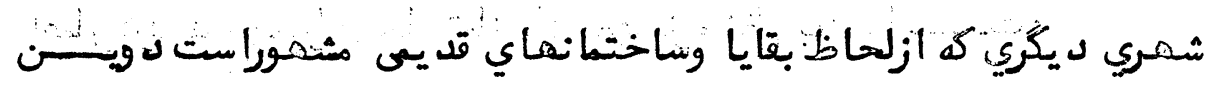
ثام دارد • اين شهرد ردوره ملنسنيك شهرخورد تجاري بود وبعد به حيثيك

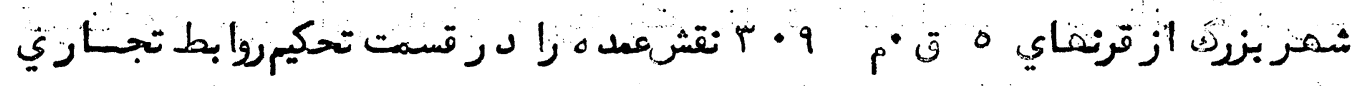

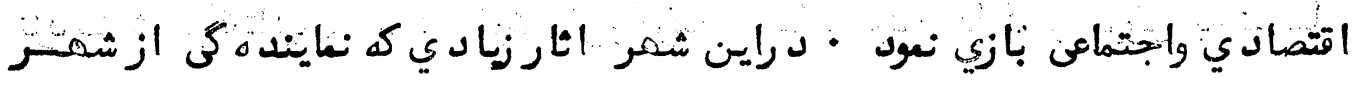

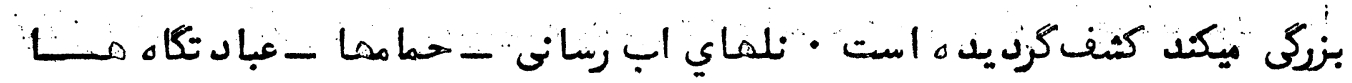

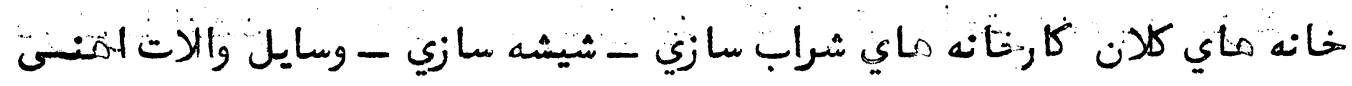

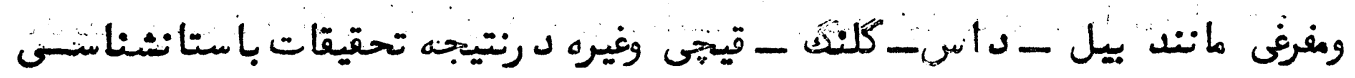

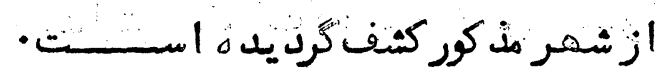

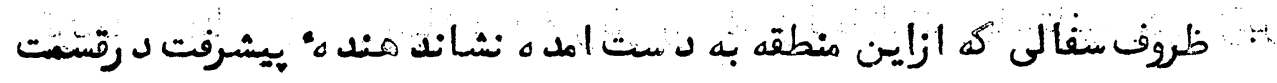

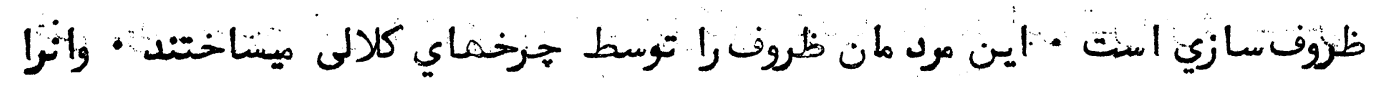

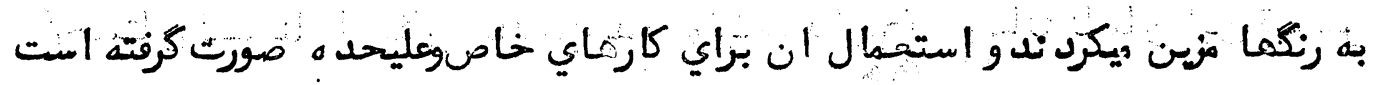

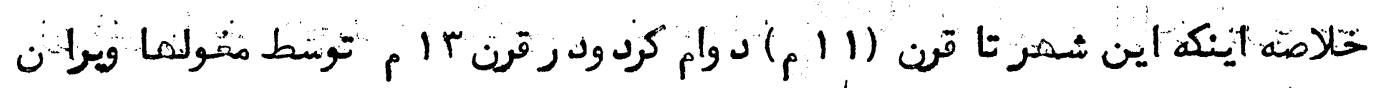

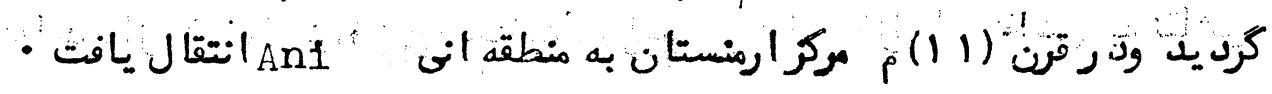




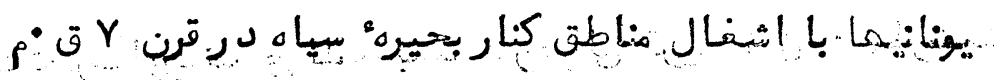

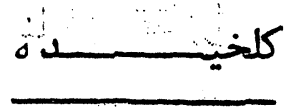

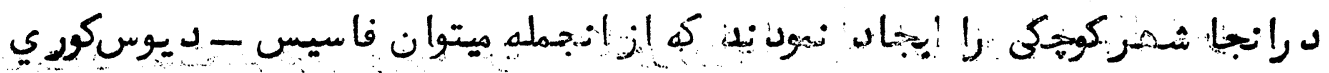

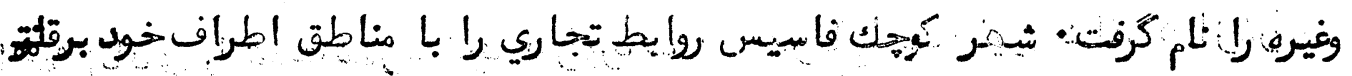

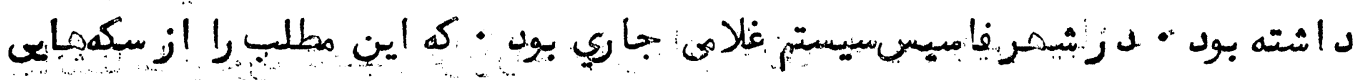

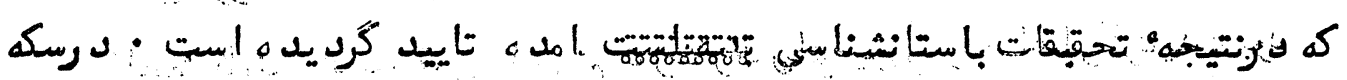

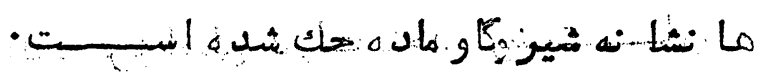

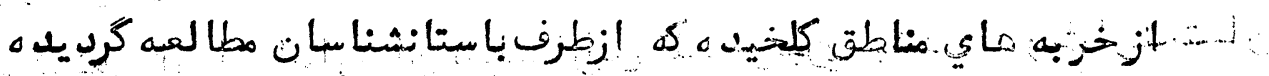

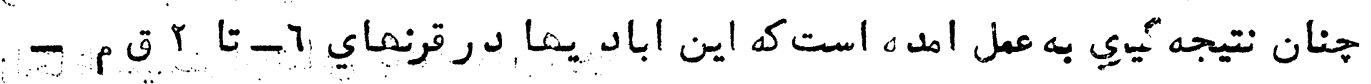

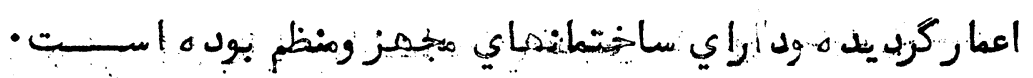

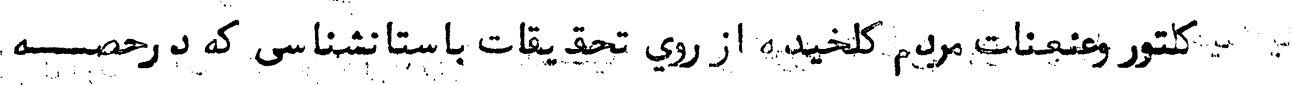

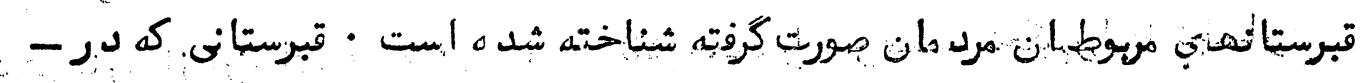

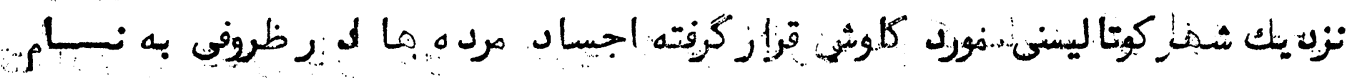

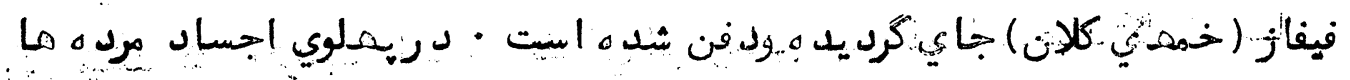

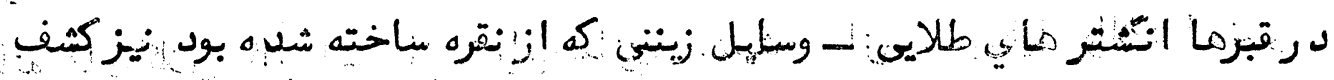

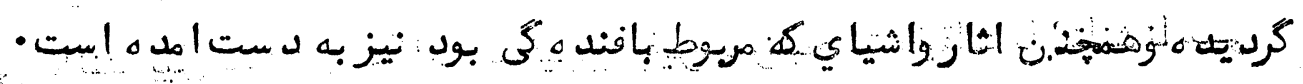

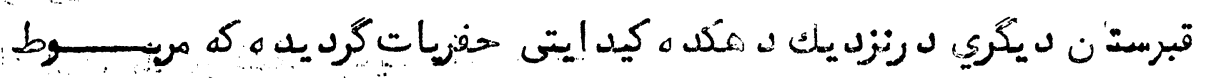

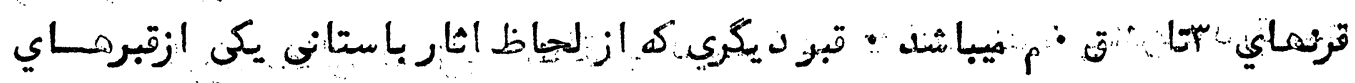

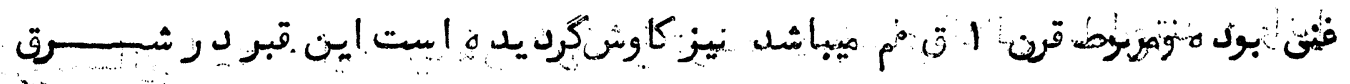

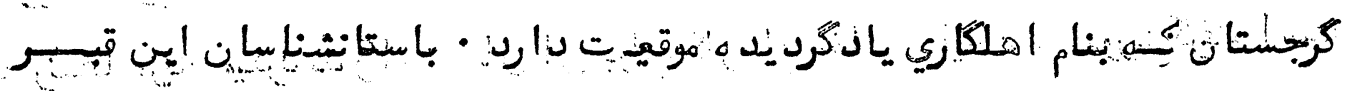

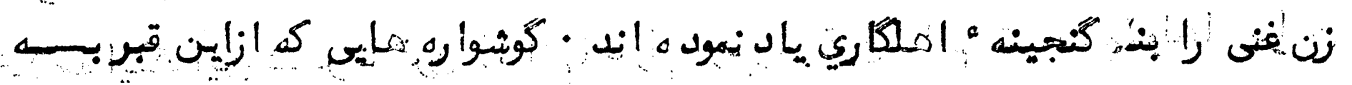

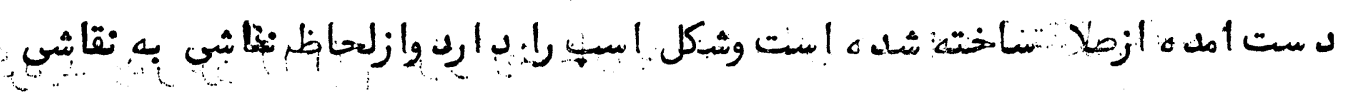

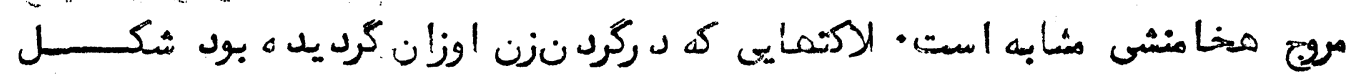


بقه داشت وازان باستا نشناسان حتنين نتيجه كرفته اندكه اين مرد مان به بقه احترام

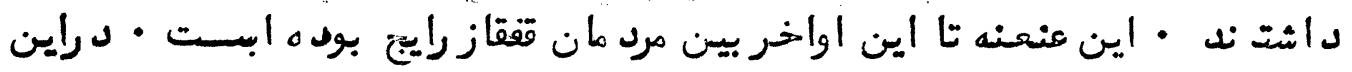

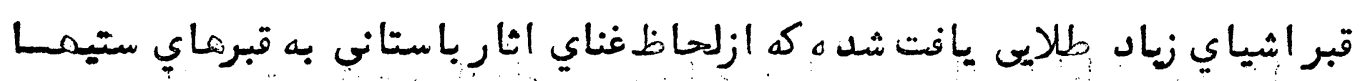

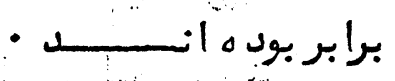

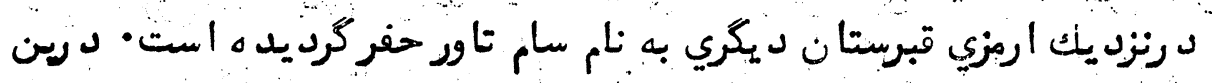

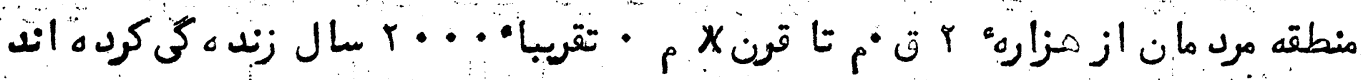

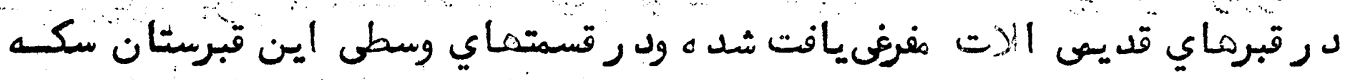

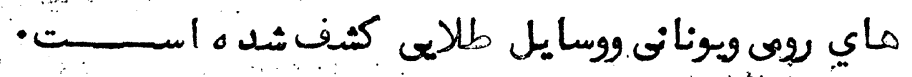
دركنار ب يكر شهر ارنري اقامتكاه سران وباداداران قبايل اليبري يافت شده

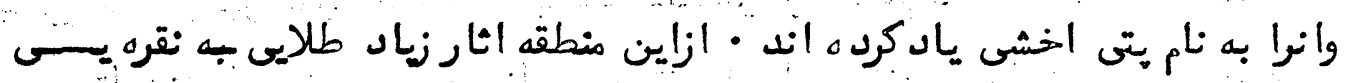

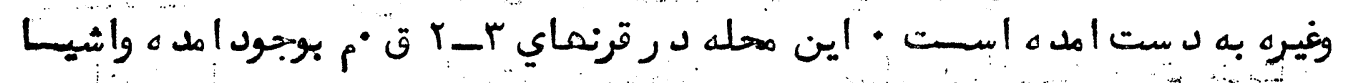

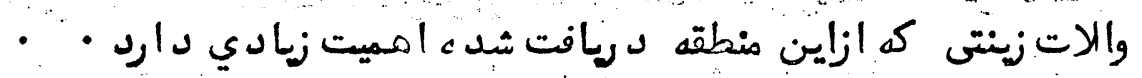

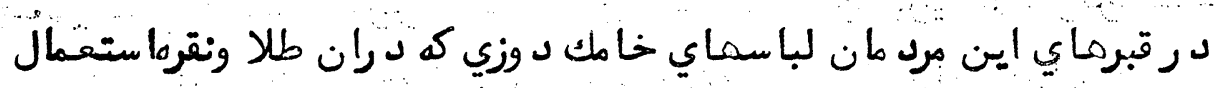

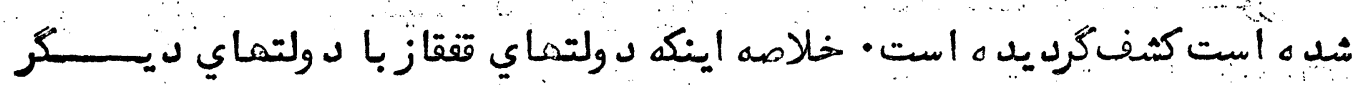

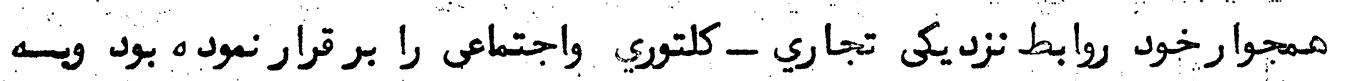

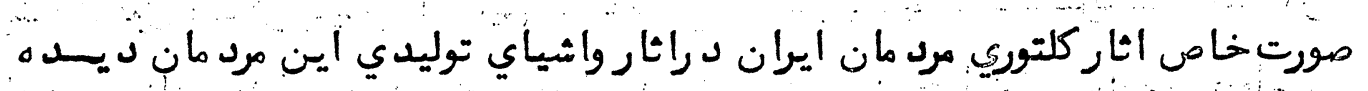

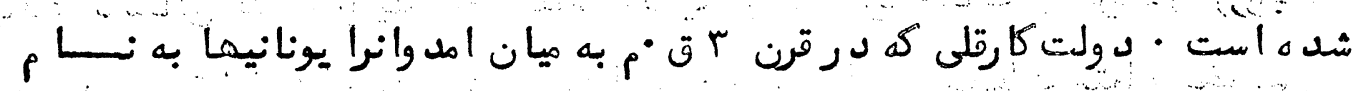

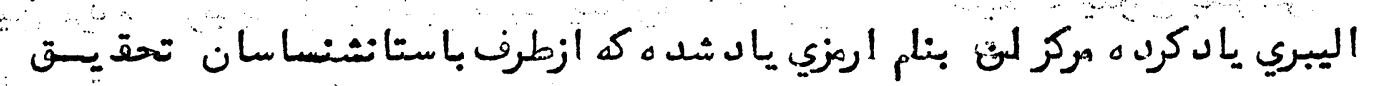

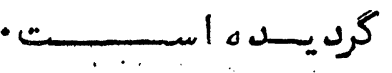




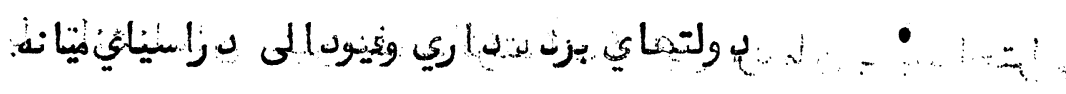

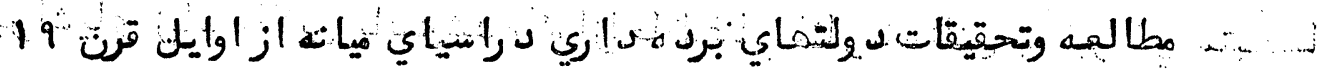

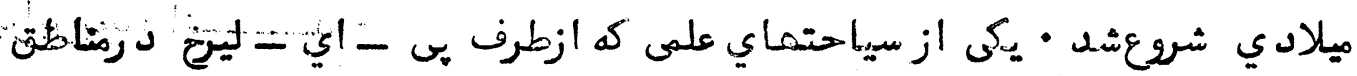

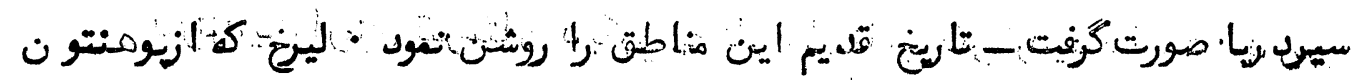

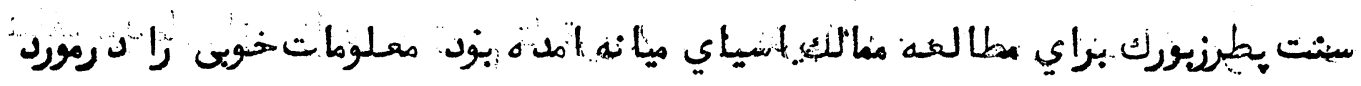

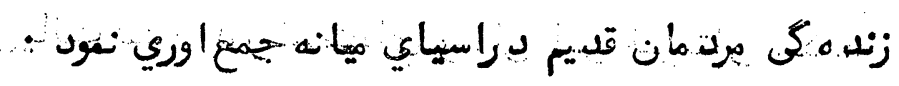

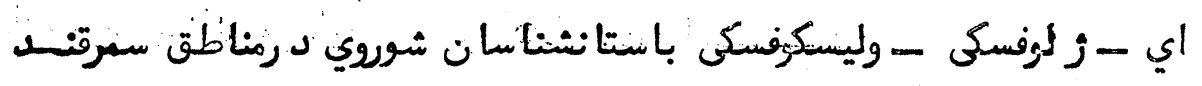

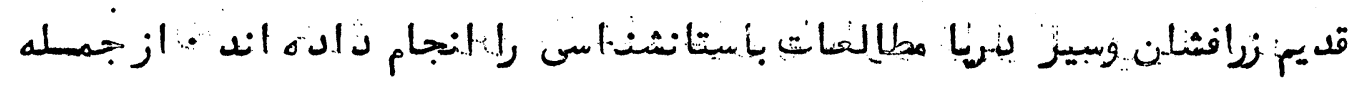

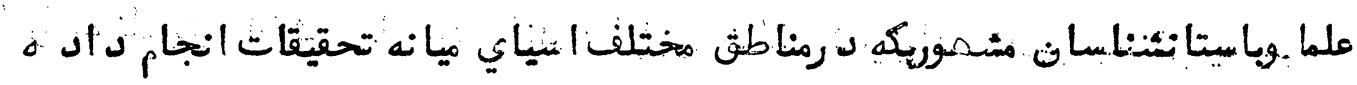

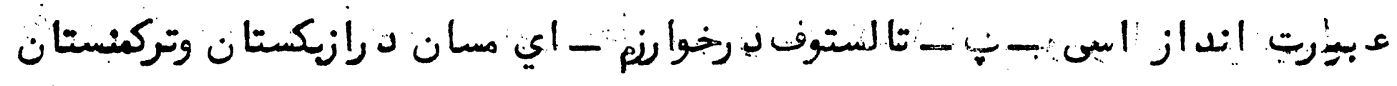

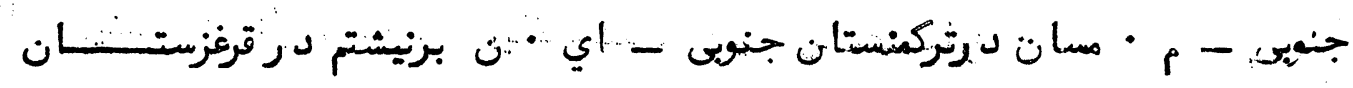

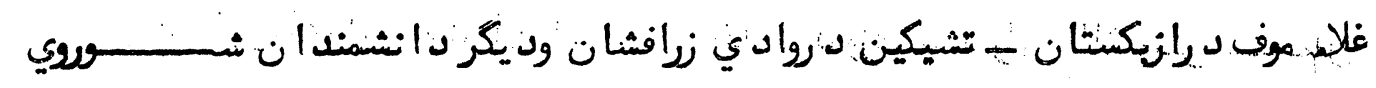

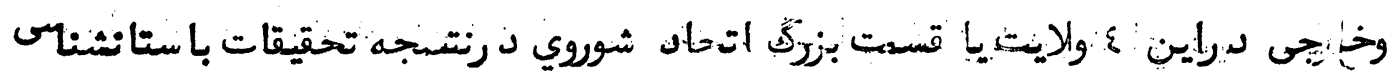

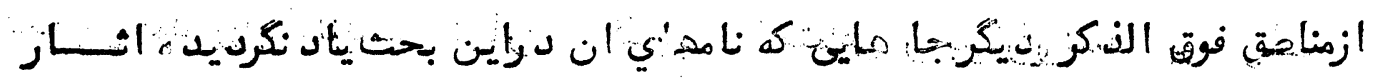

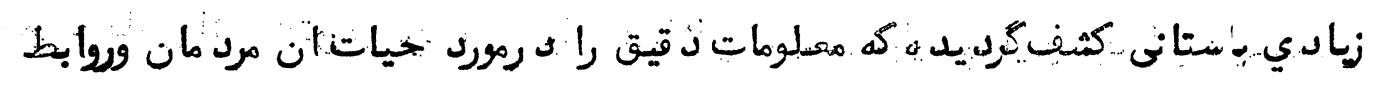

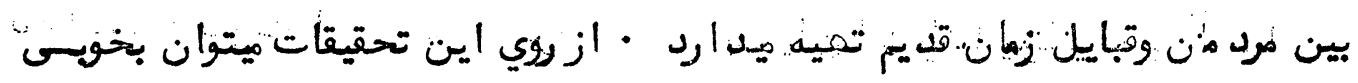

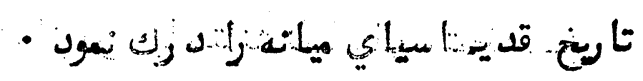

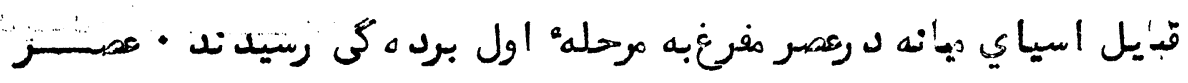

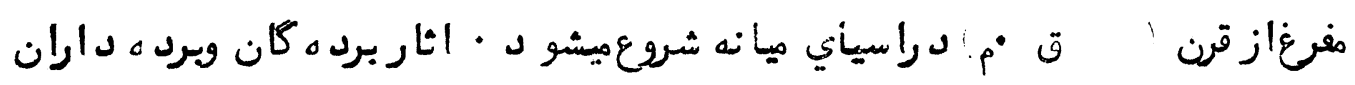

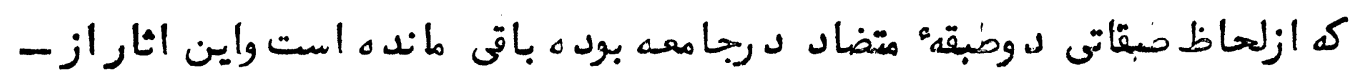

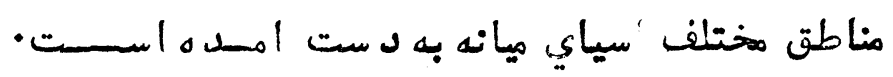
دراءيل هزاره اول ق •م د راسياي ميانه كروه ماي بزركَ واز لحاظ كلتوري 
$!(\xi)$

$1 \nu \mu$

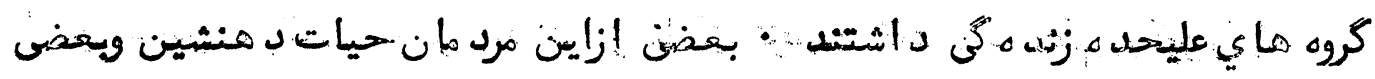

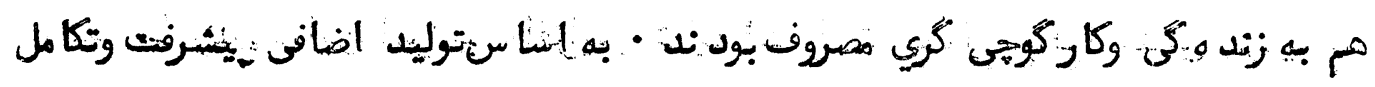

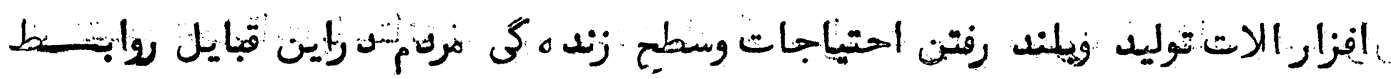

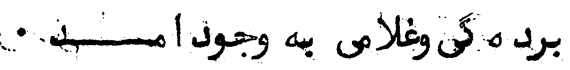

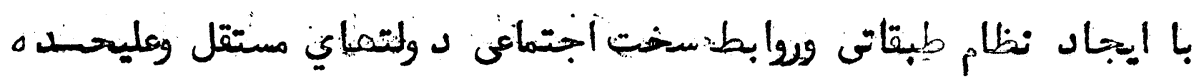

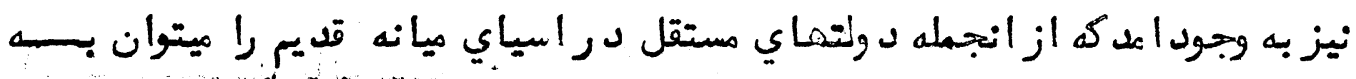

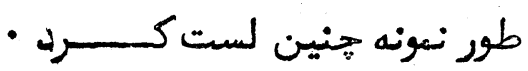

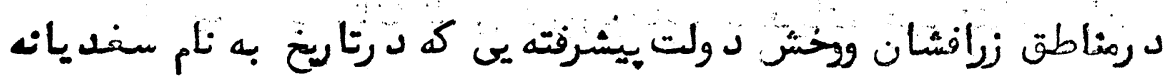

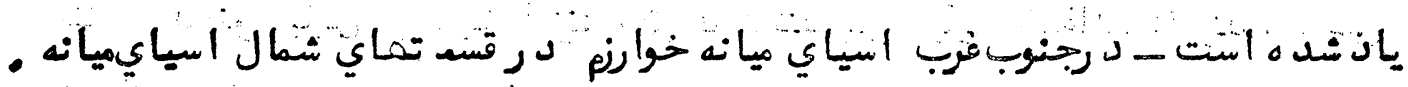

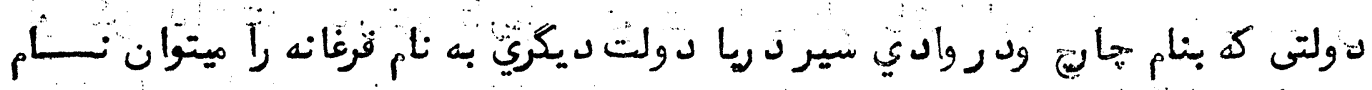

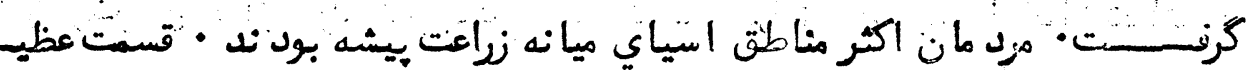

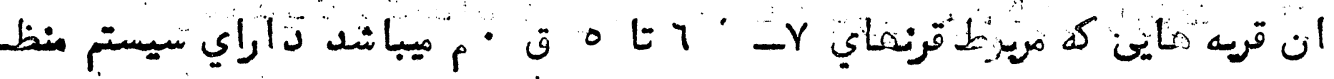

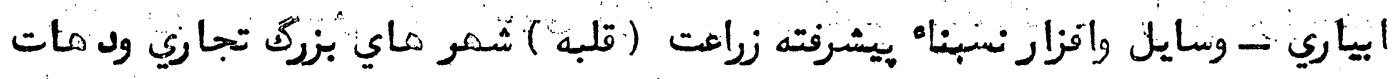

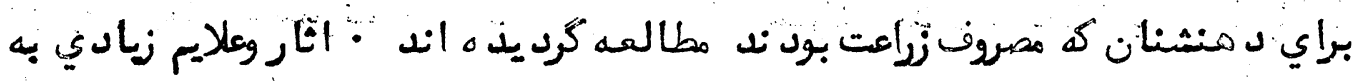

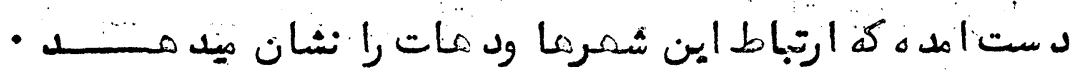

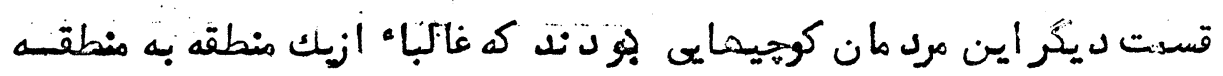

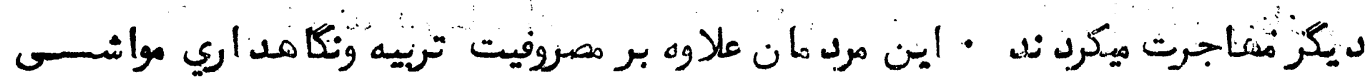

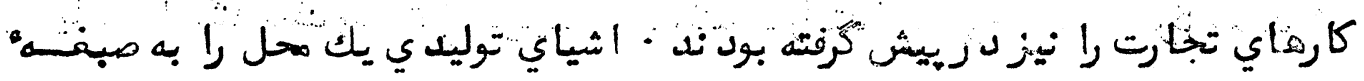

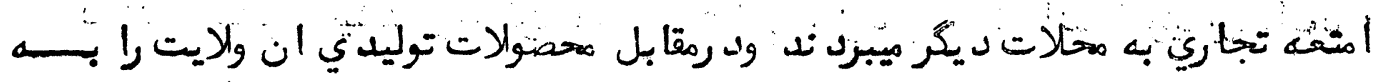

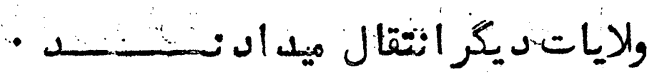

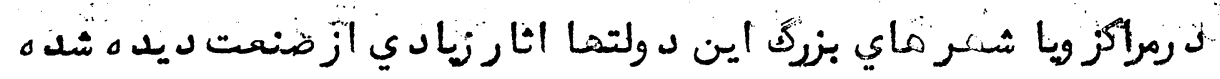

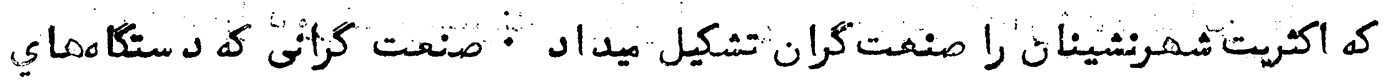

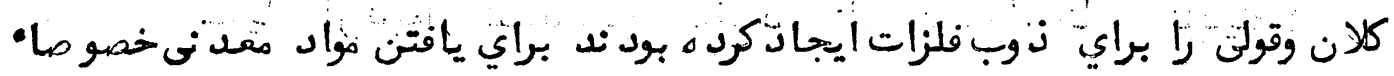


IV

اهن - مس- وقلعى هبجبور شد ند ازمناطق نزد يك خول مواد خام مذكور را بـــــــه

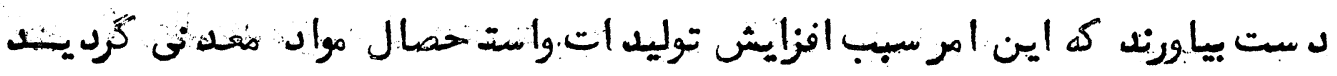

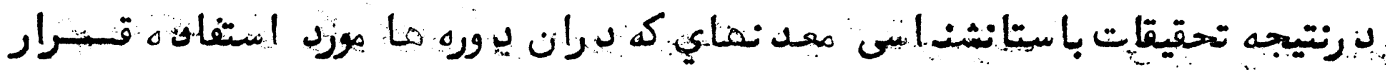

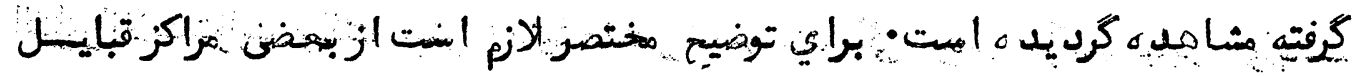

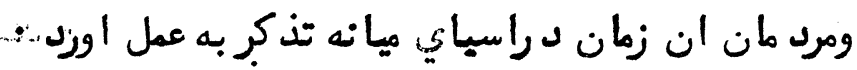

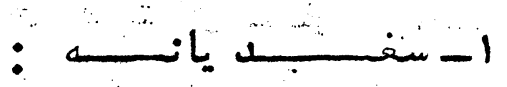

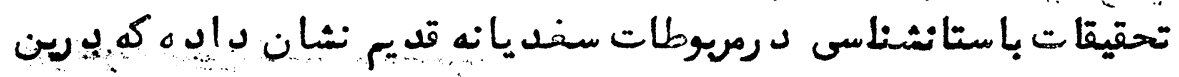

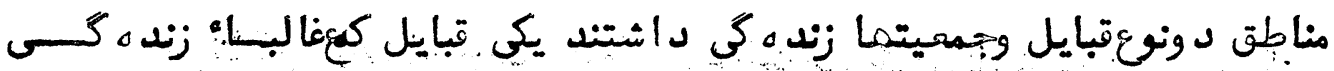

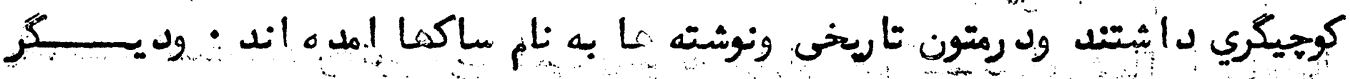

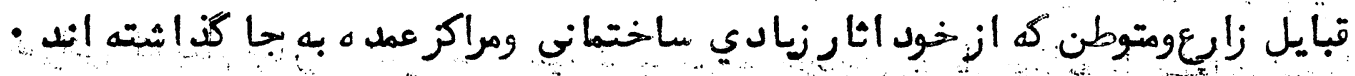

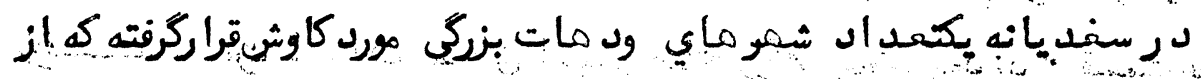

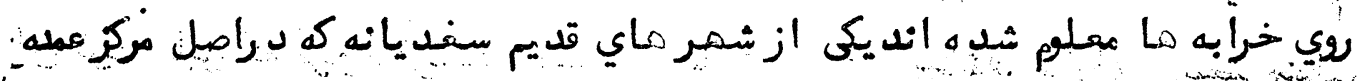

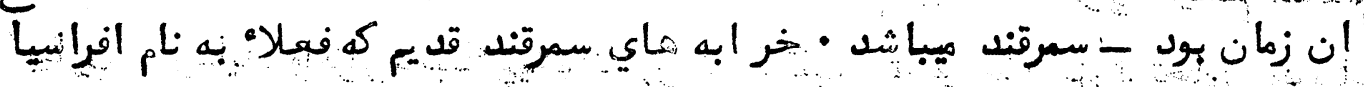

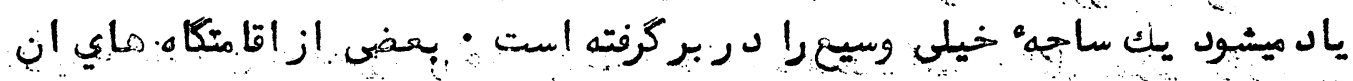

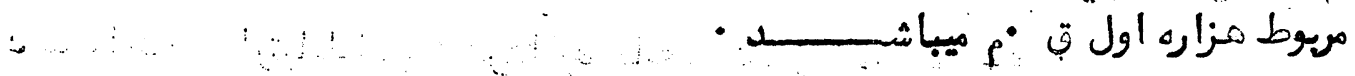

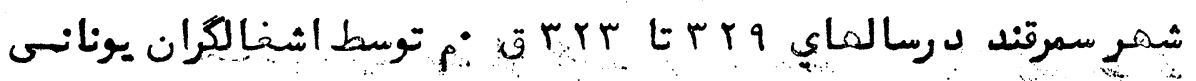

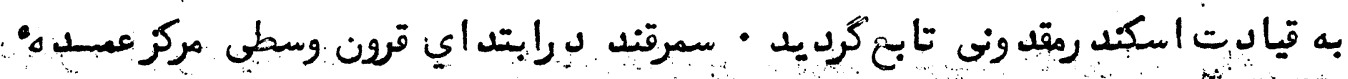

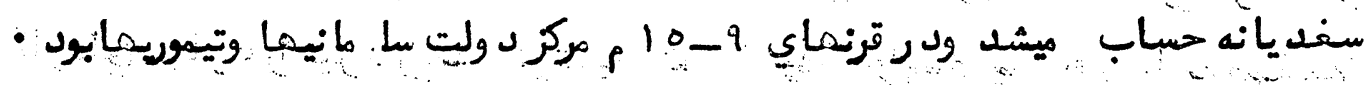

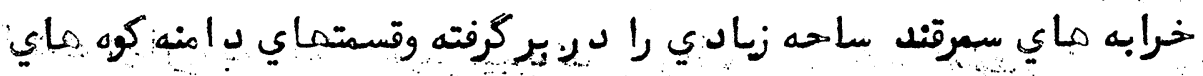

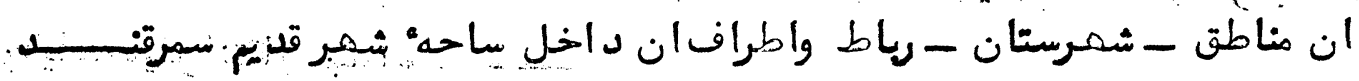

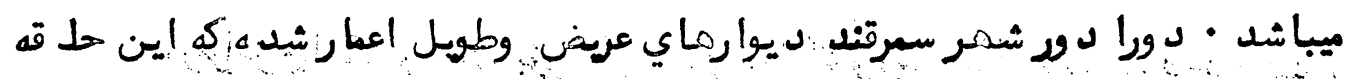

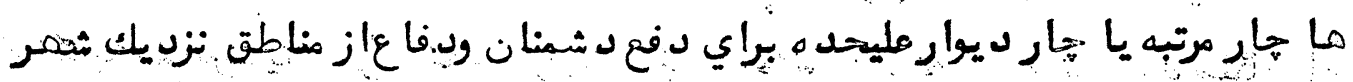




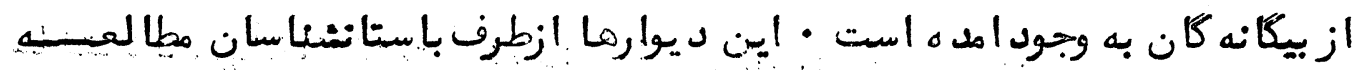

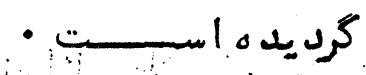

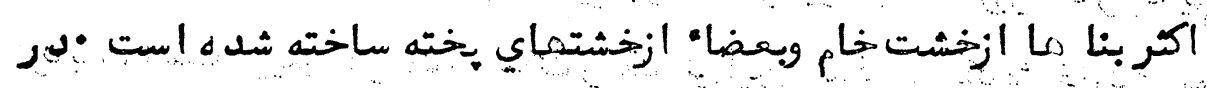

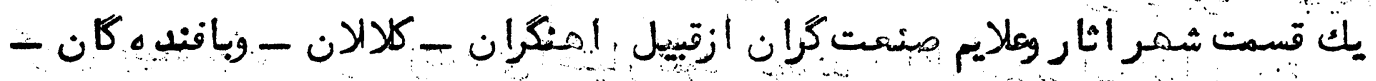

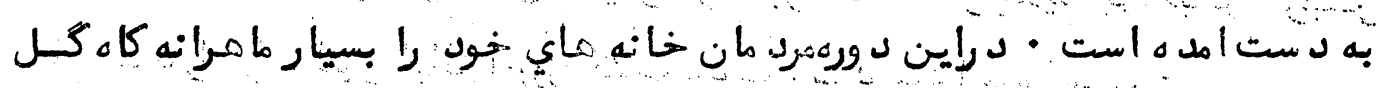
كرده وبعضى ازخانه ما توسط ريكماي مختلف ومقبول منين كرد يد ه انست.

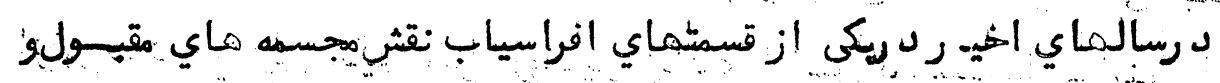

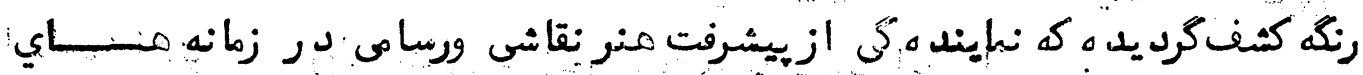

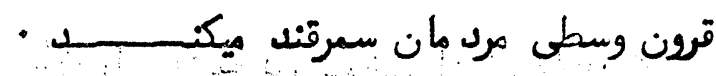

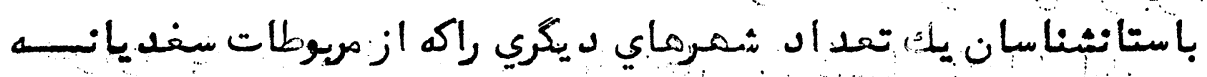

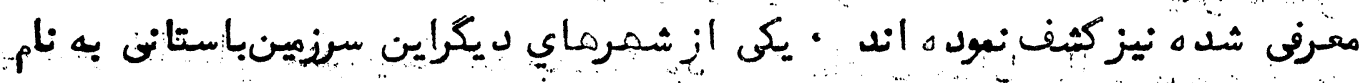

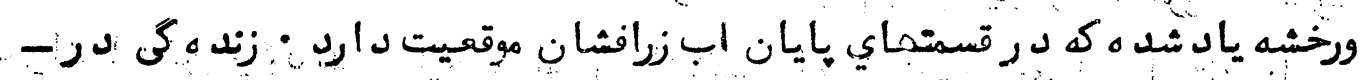

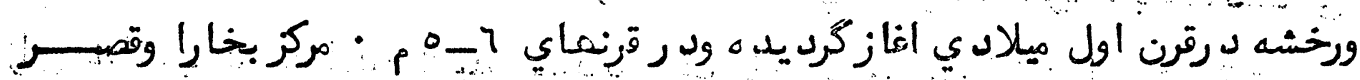

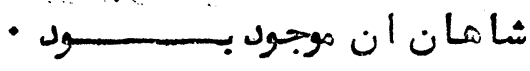

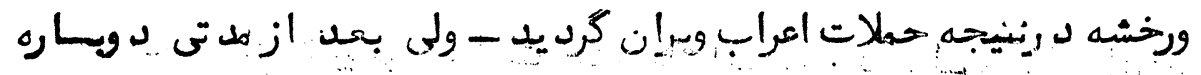

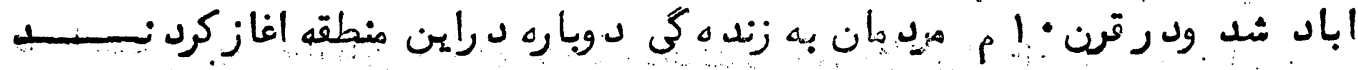

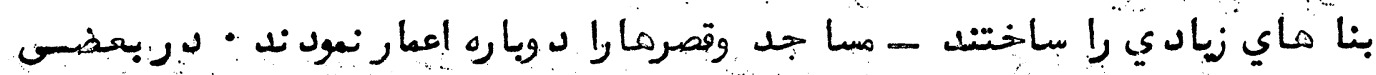

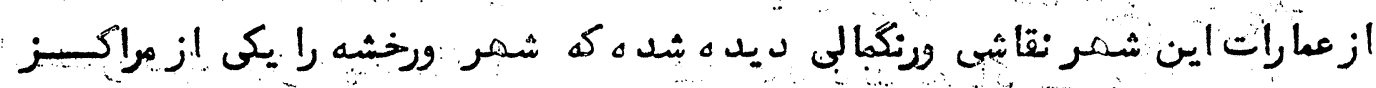

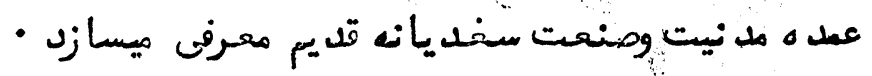

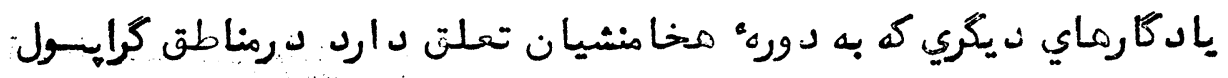

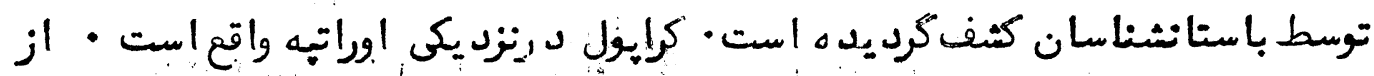
خرابه هاي اين منطقه محلفم كرد يذه كه اين شهبري است بسيا كلان كه د رزمانهماي

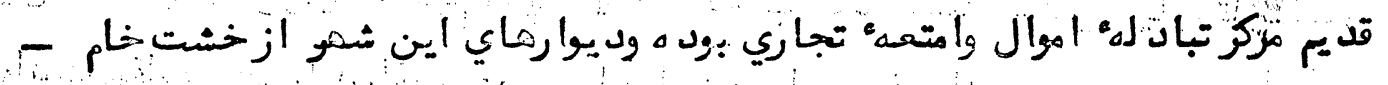




$$
14
$$

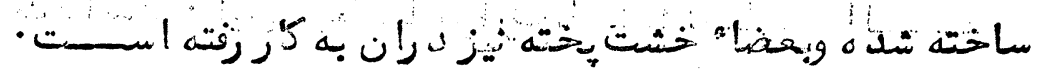

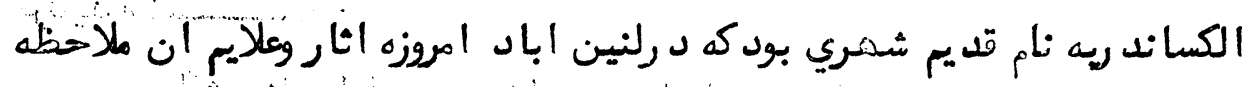

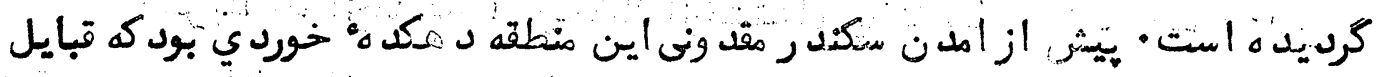

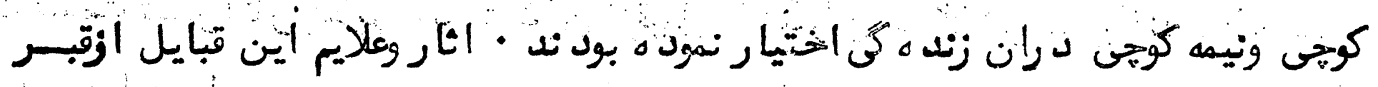

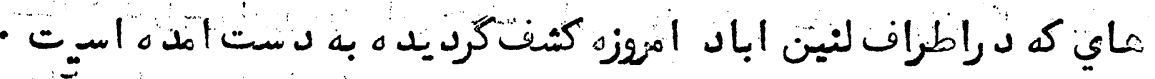

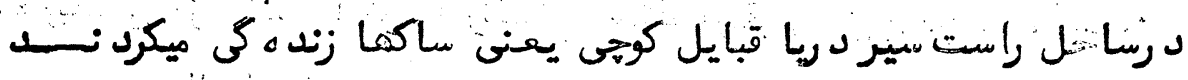

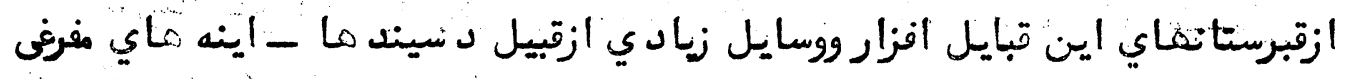

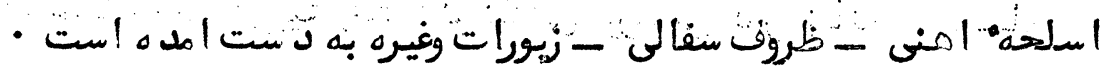

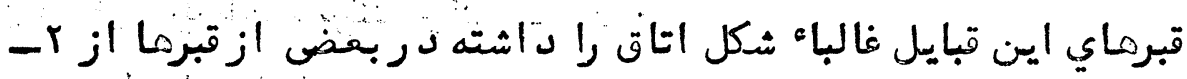

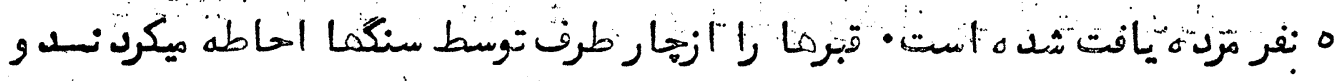

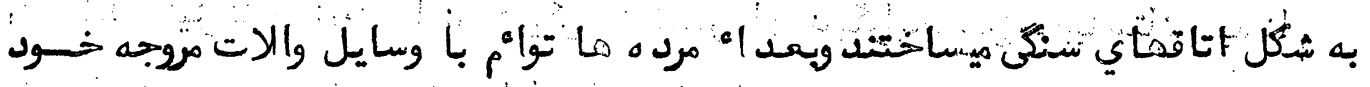

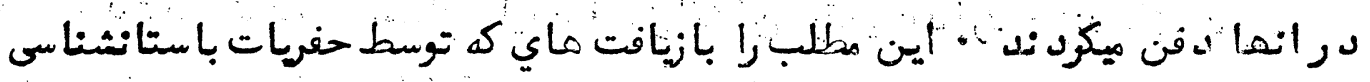

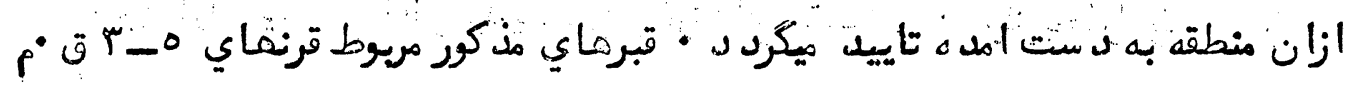
ميباشسد - مان

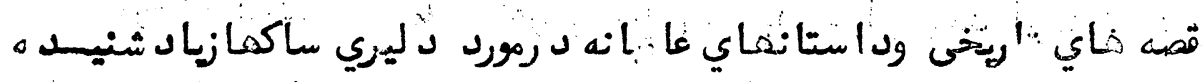

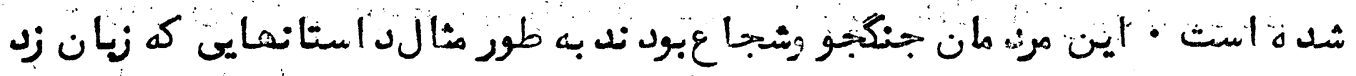

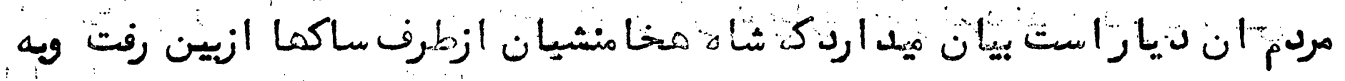

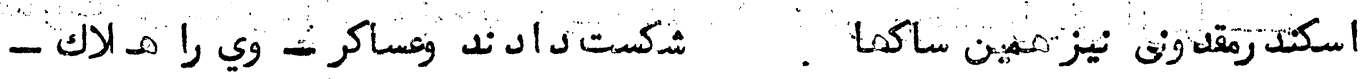

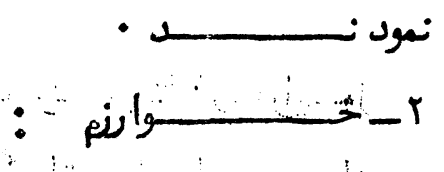

منطقه " بين هـايان أب سيرد ريا ويحيره اورال را به نام خوايني ياد نمود هاند.

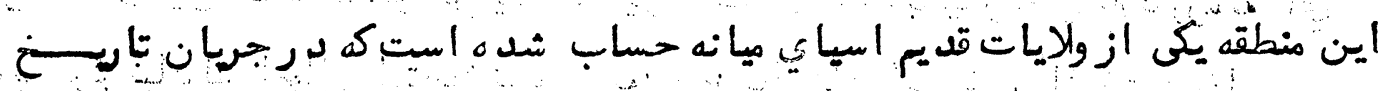

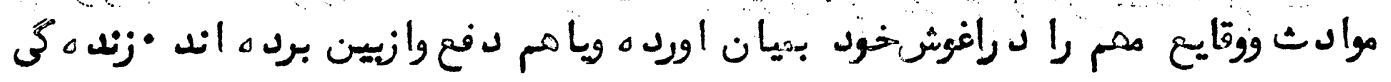




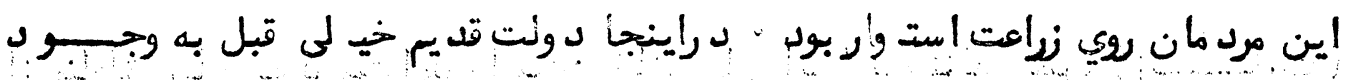

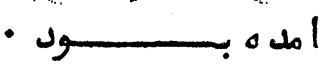

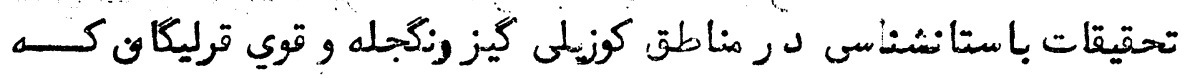

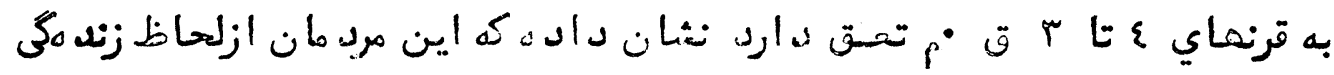

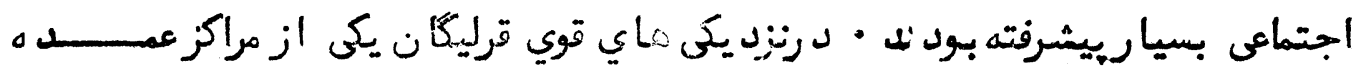

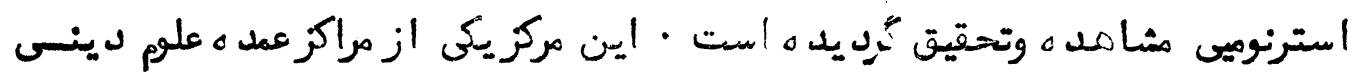

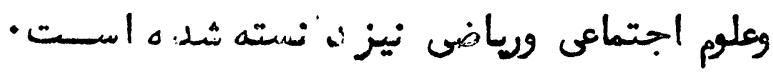

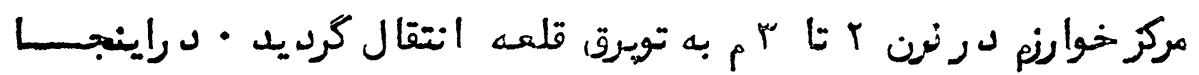

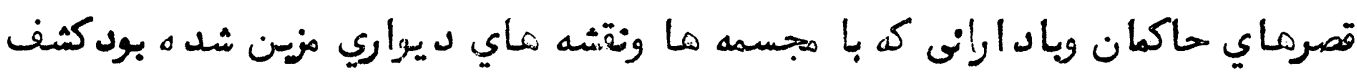

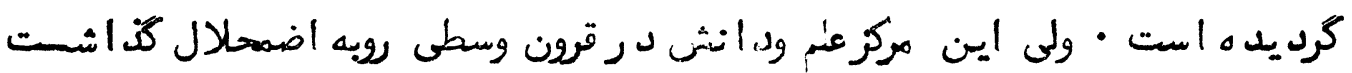

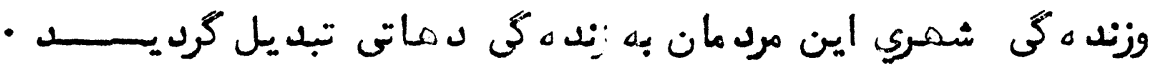

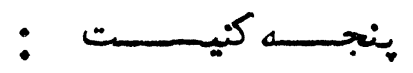

يكى ازشهر ماي قوون وسقى كه ازطرف باستا تشـناسشوروي به نـــــــام

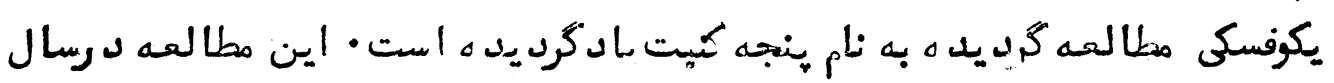

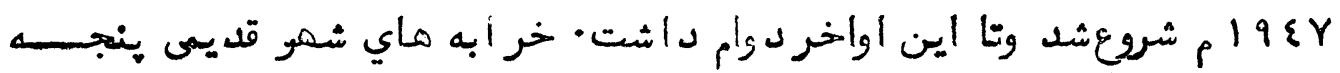

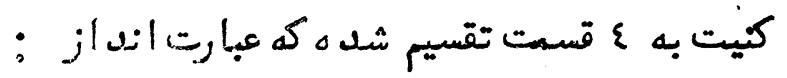
-

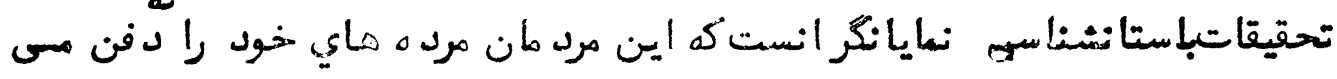

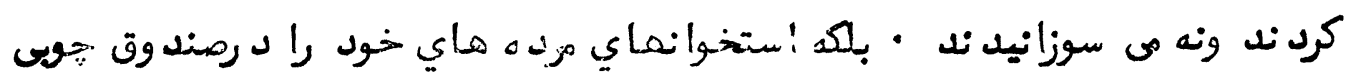

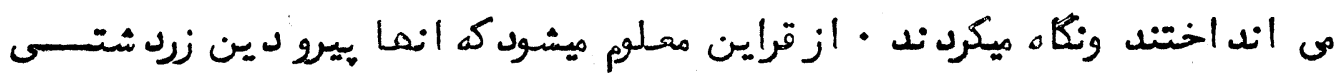

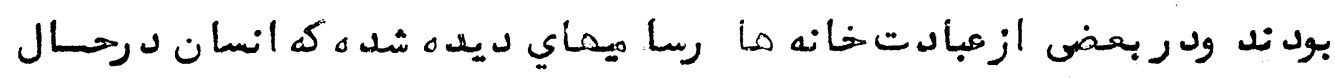
سجده به اتش نشان ميد مد كه علامه " دين اتش هرستى حساب شده هو واين رسام 
)

IVA

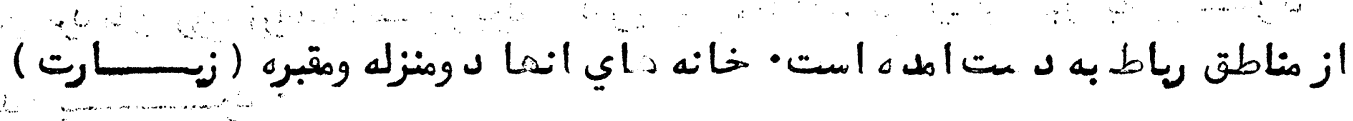

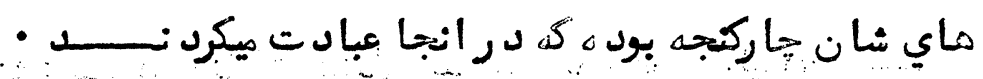

$\cdots$
$\therefore \cdots$ 


\section{تتيج}

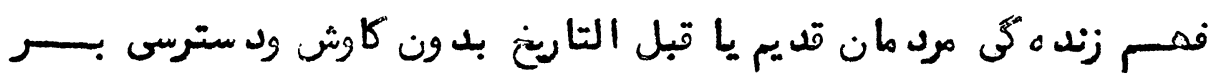

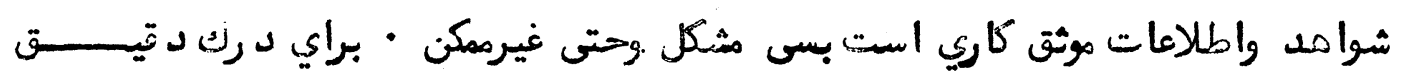

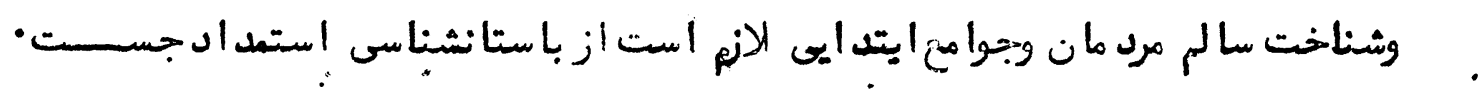

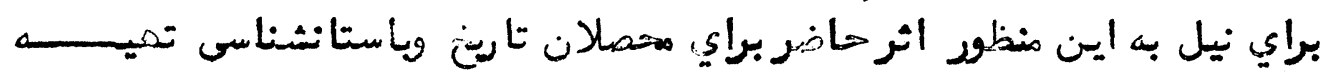

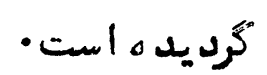

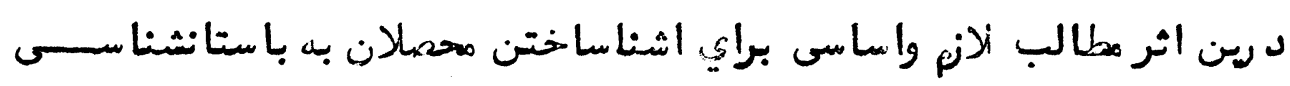

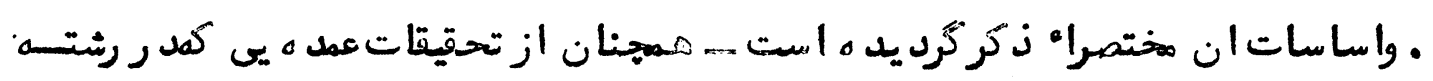

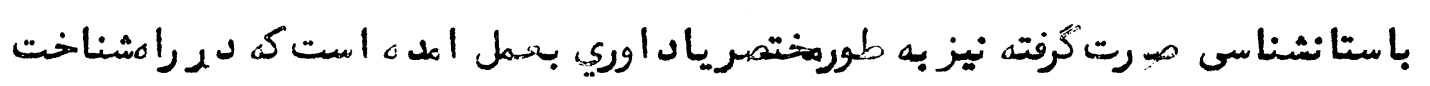

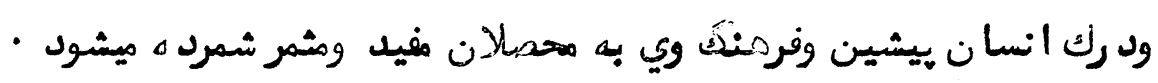

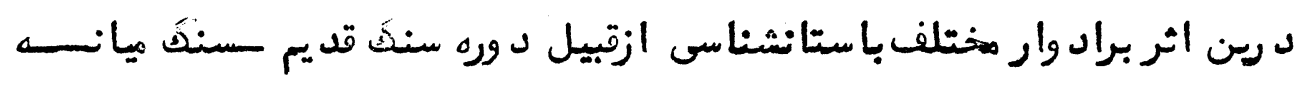

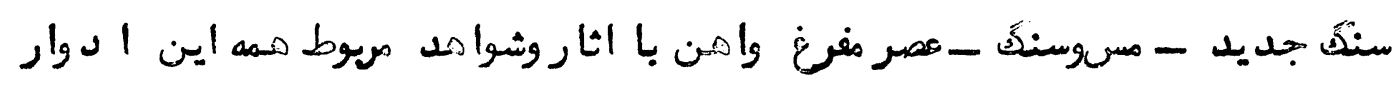

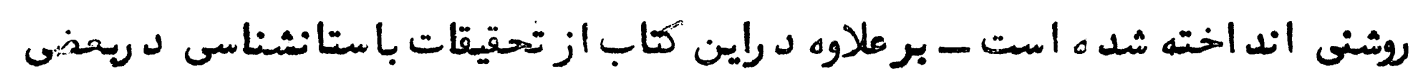

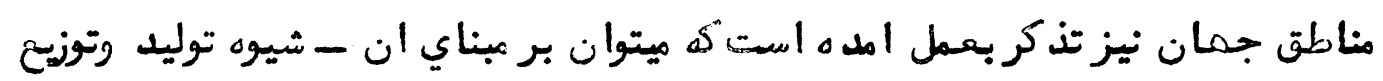

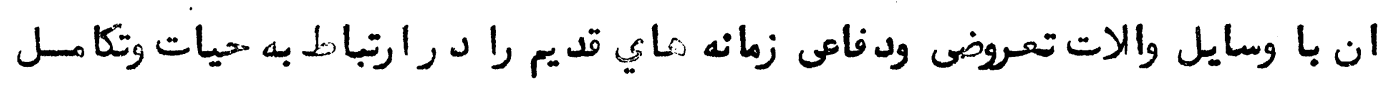

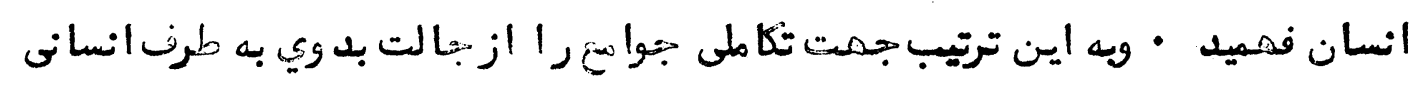

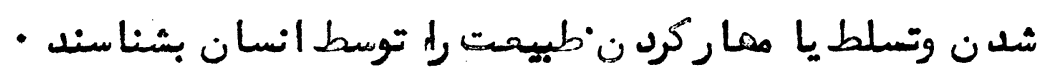




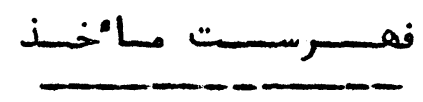

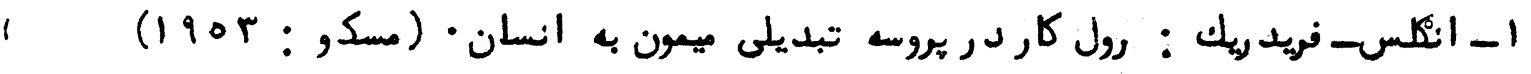

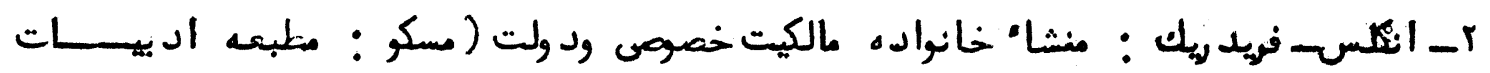

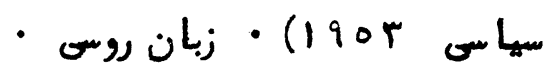

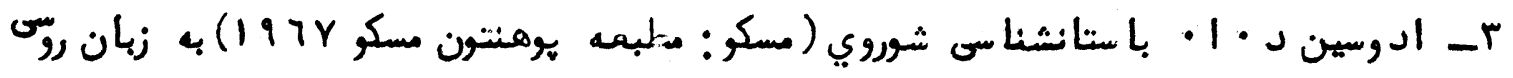

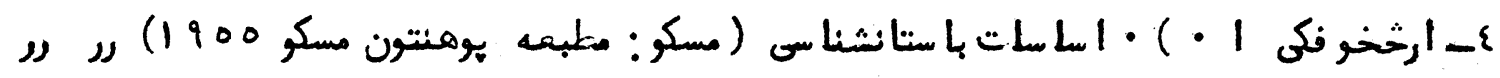

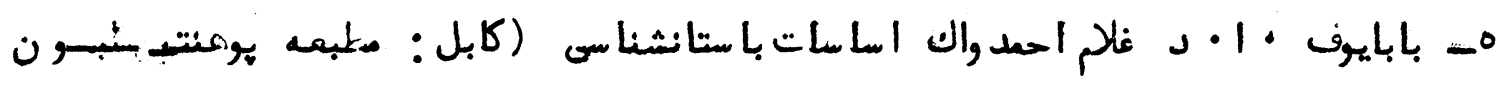

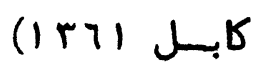

7- بابايون ا• د · ومحمد رسول باروي اعول وتحتيقات باستانشناسى (كابل : مطبعه هوهنتون

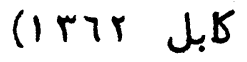

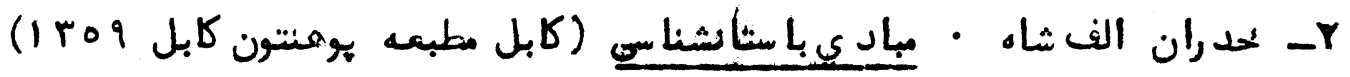

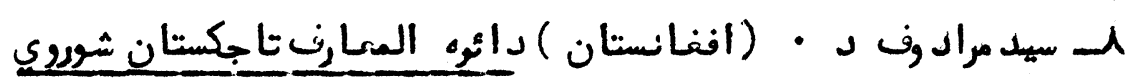

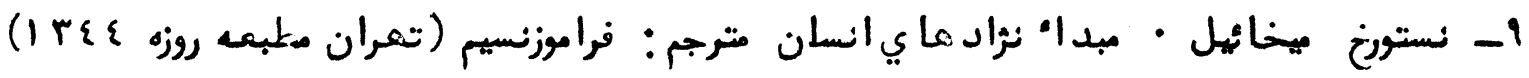

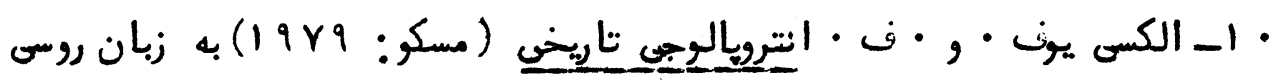

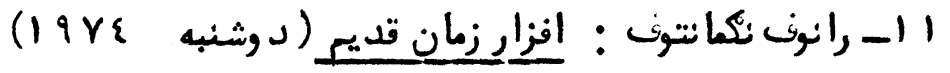

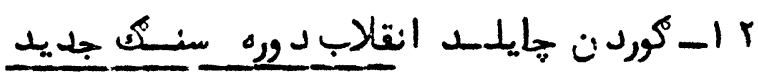

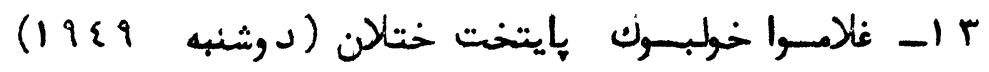

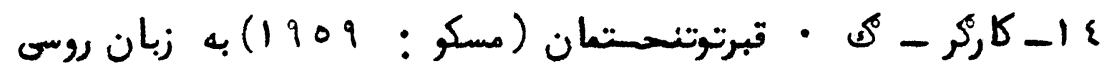

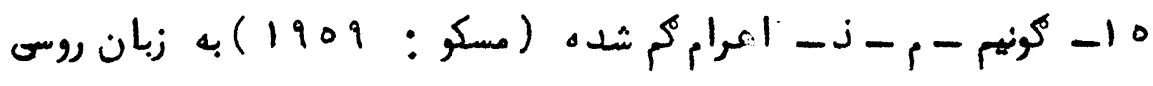

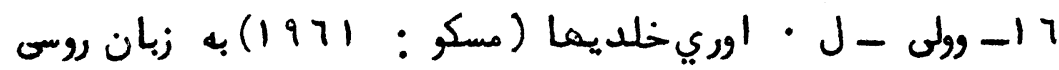

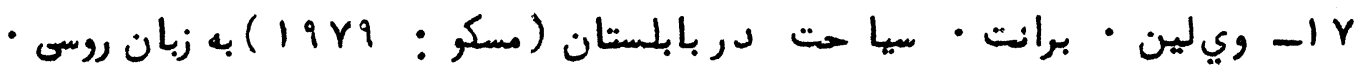

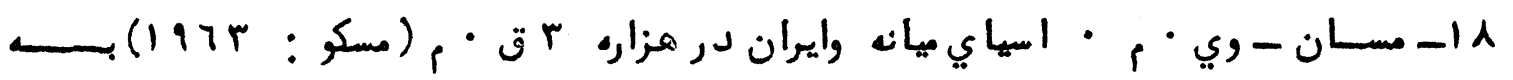
زبان روسى 


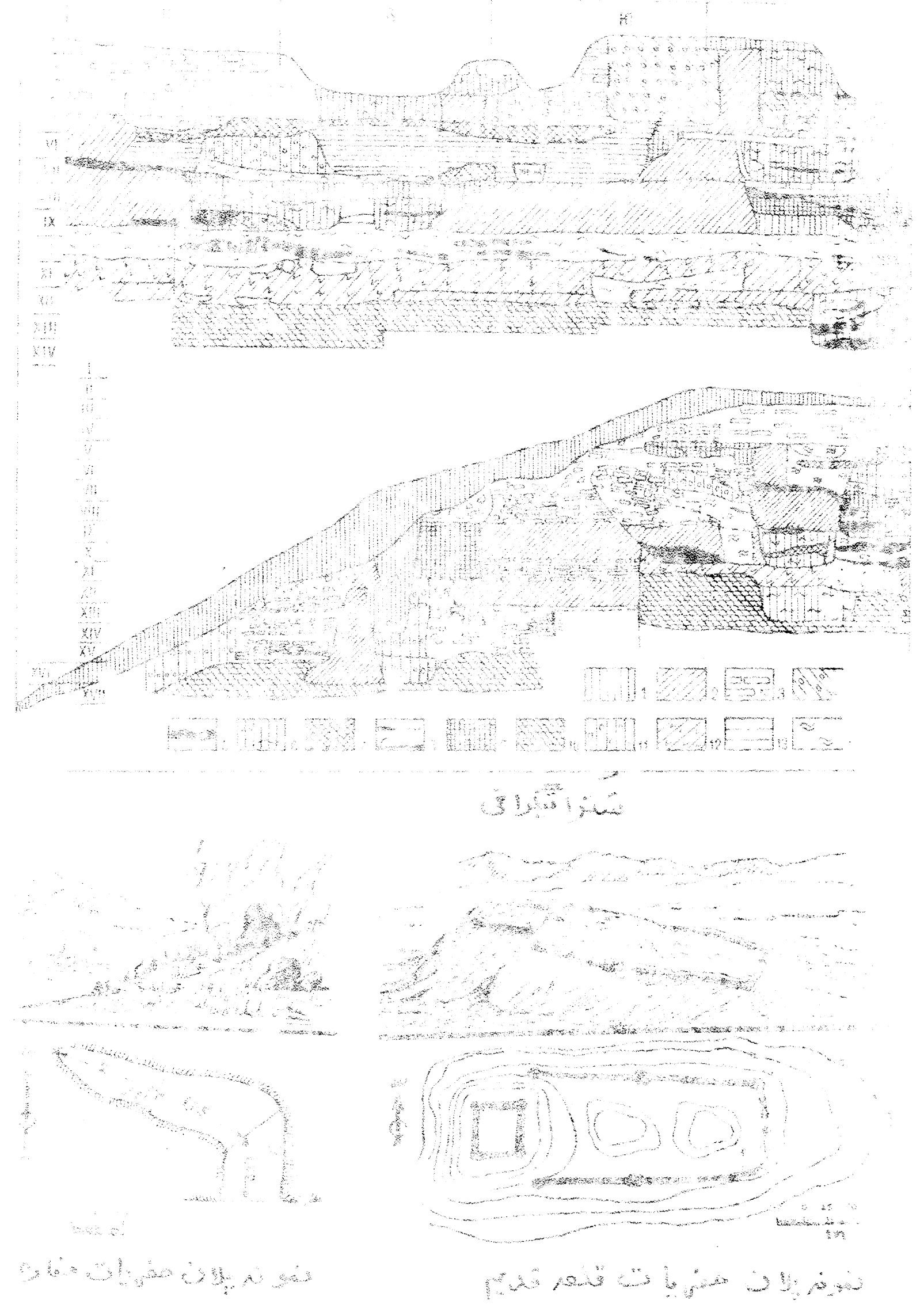




\section{$+182$}
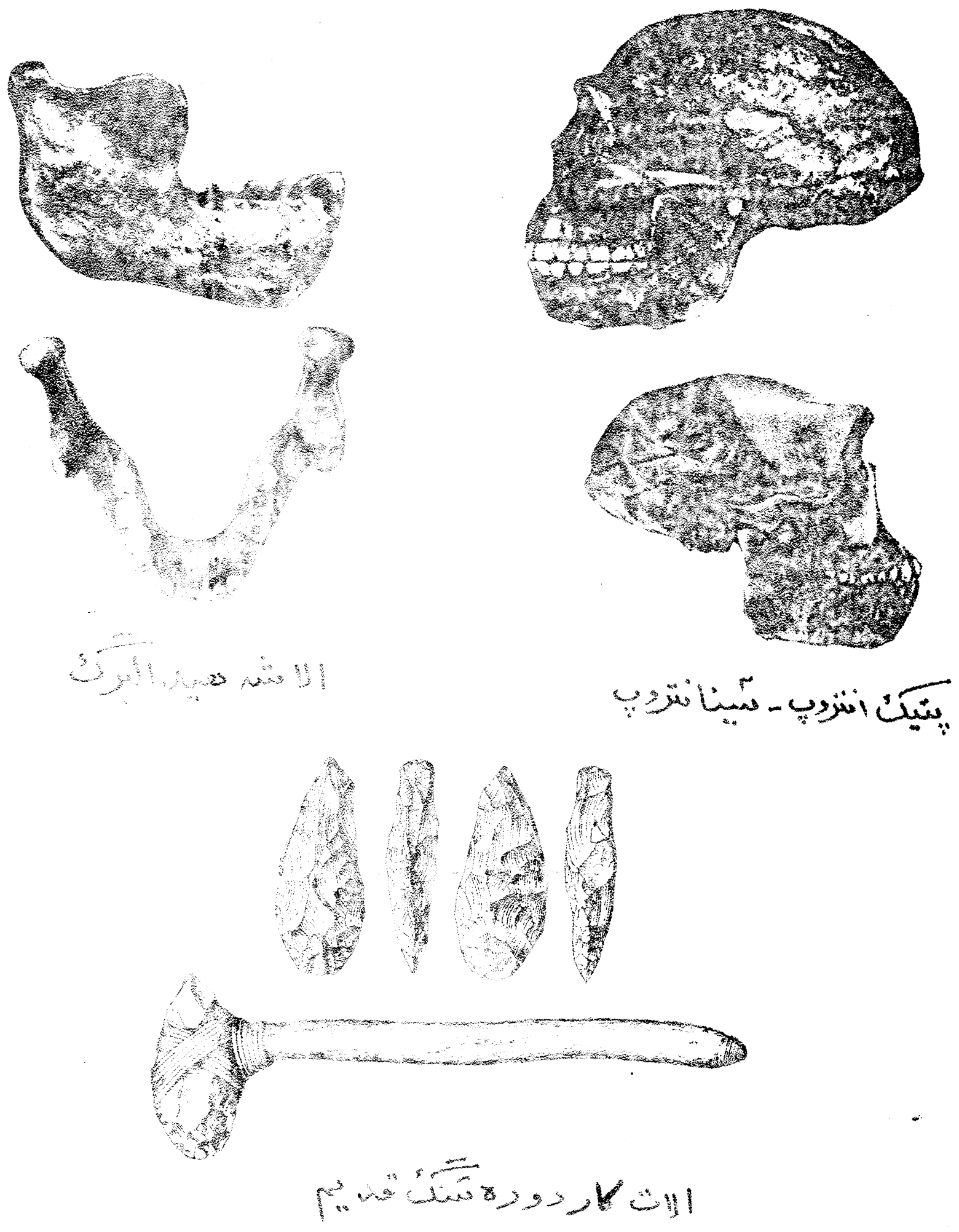
18

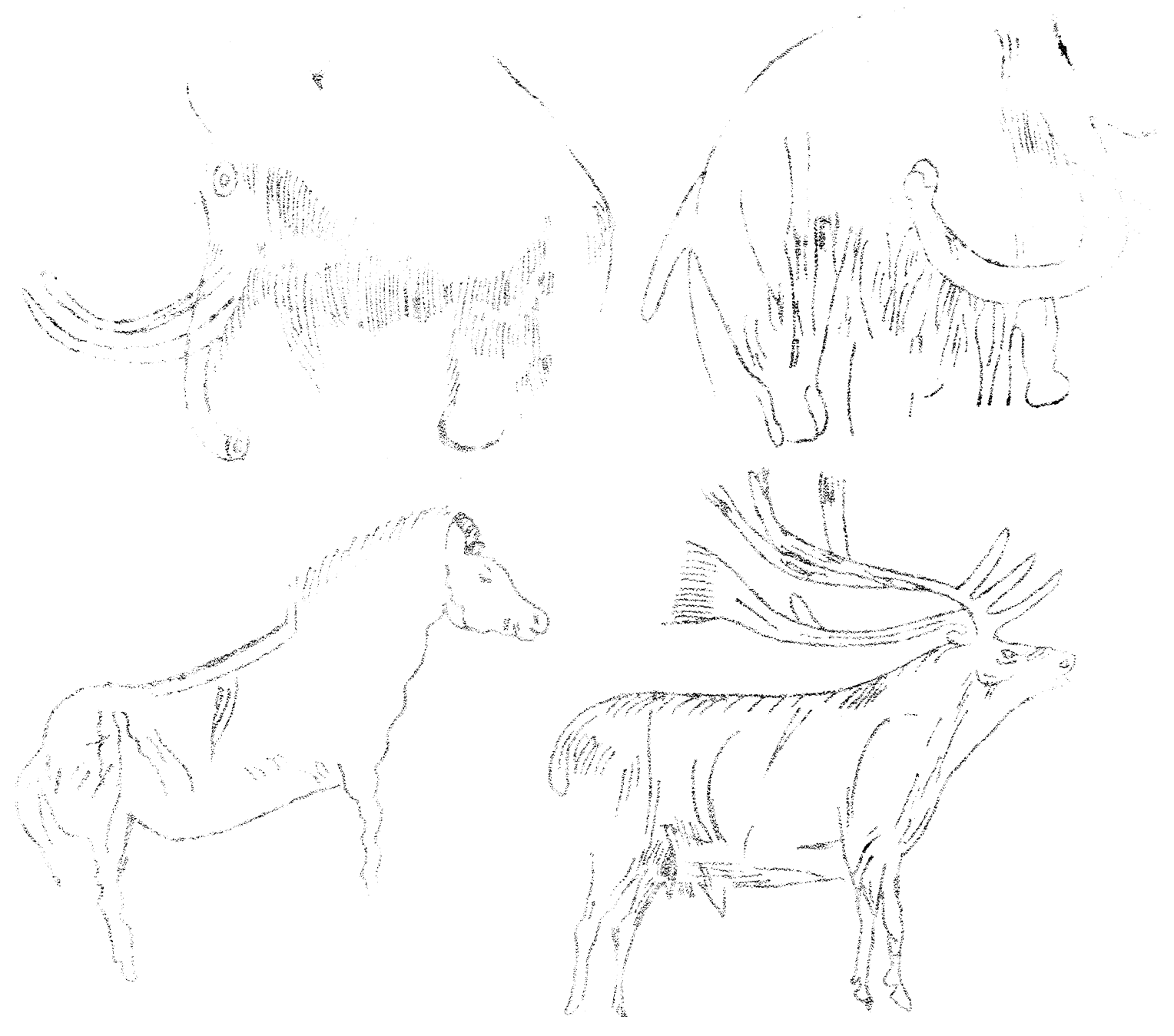

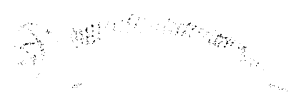

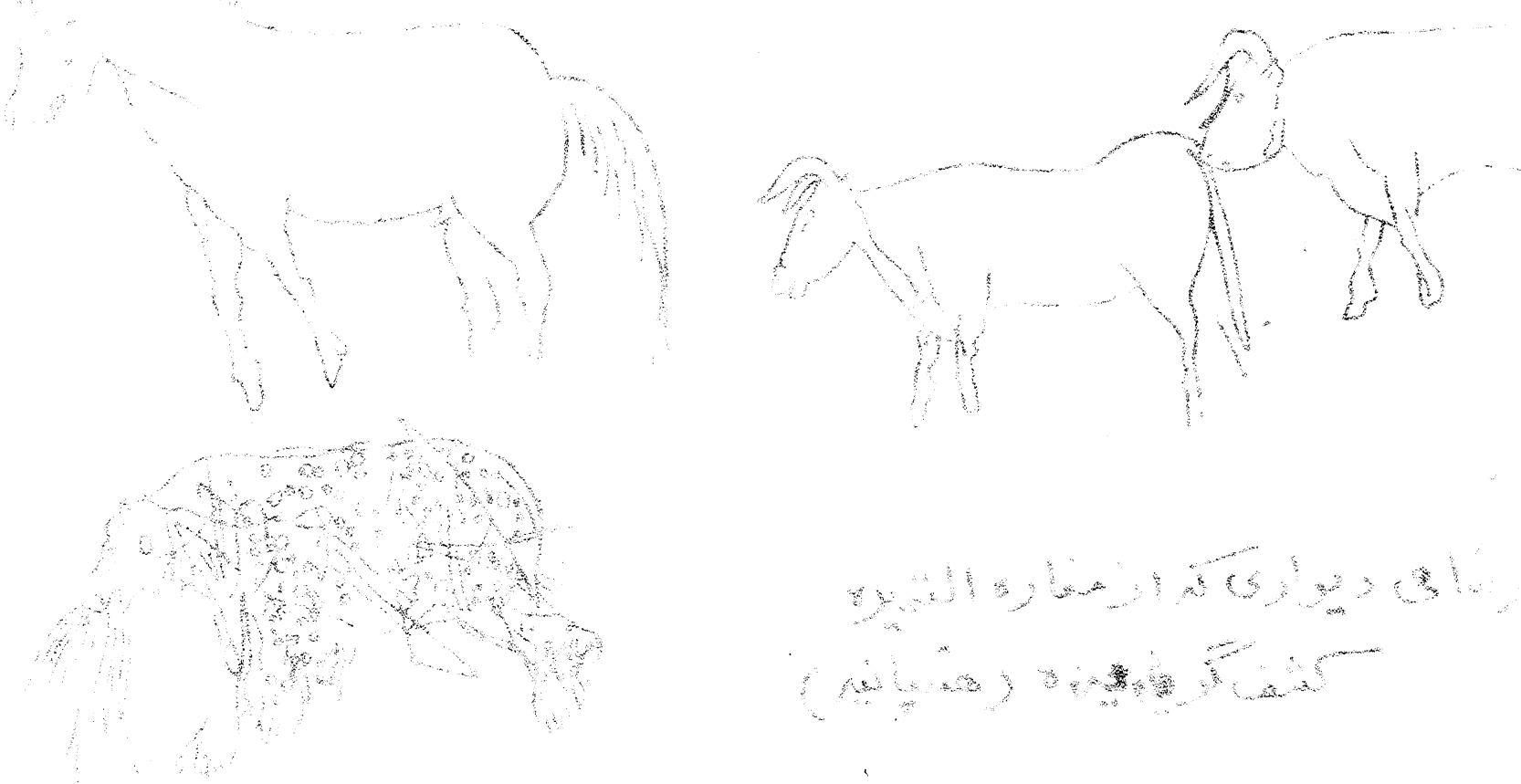


18
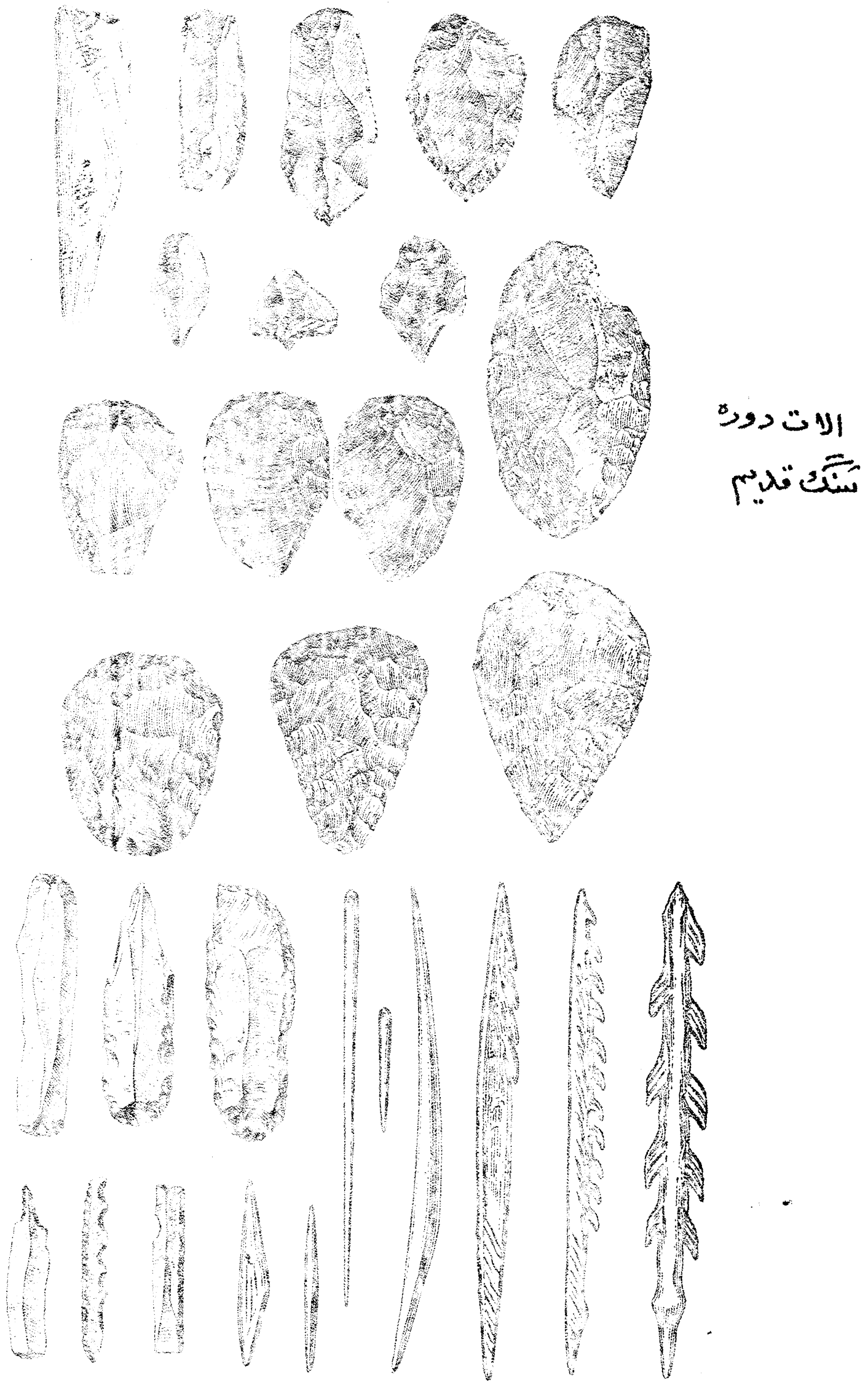


\section{5}

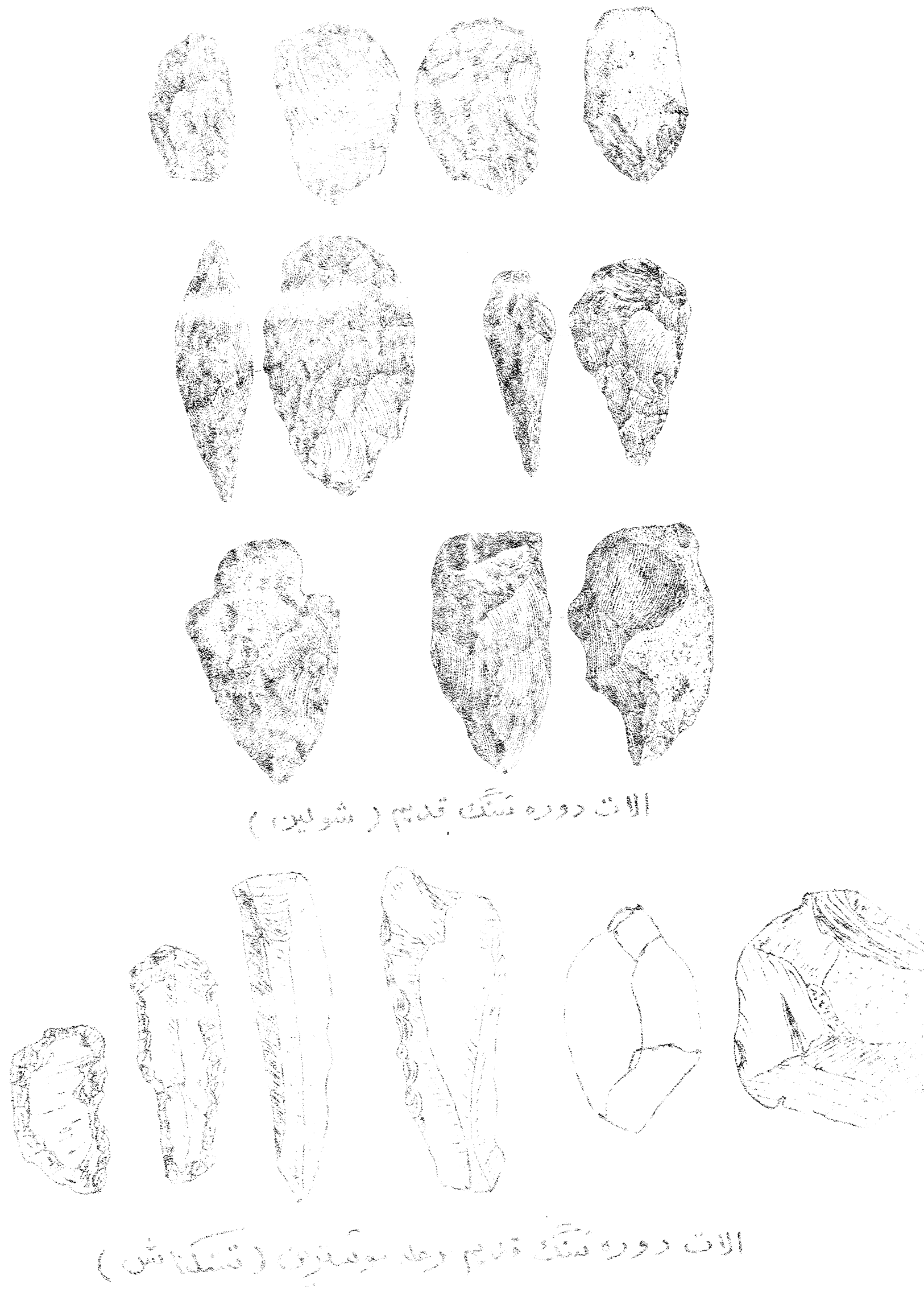


184

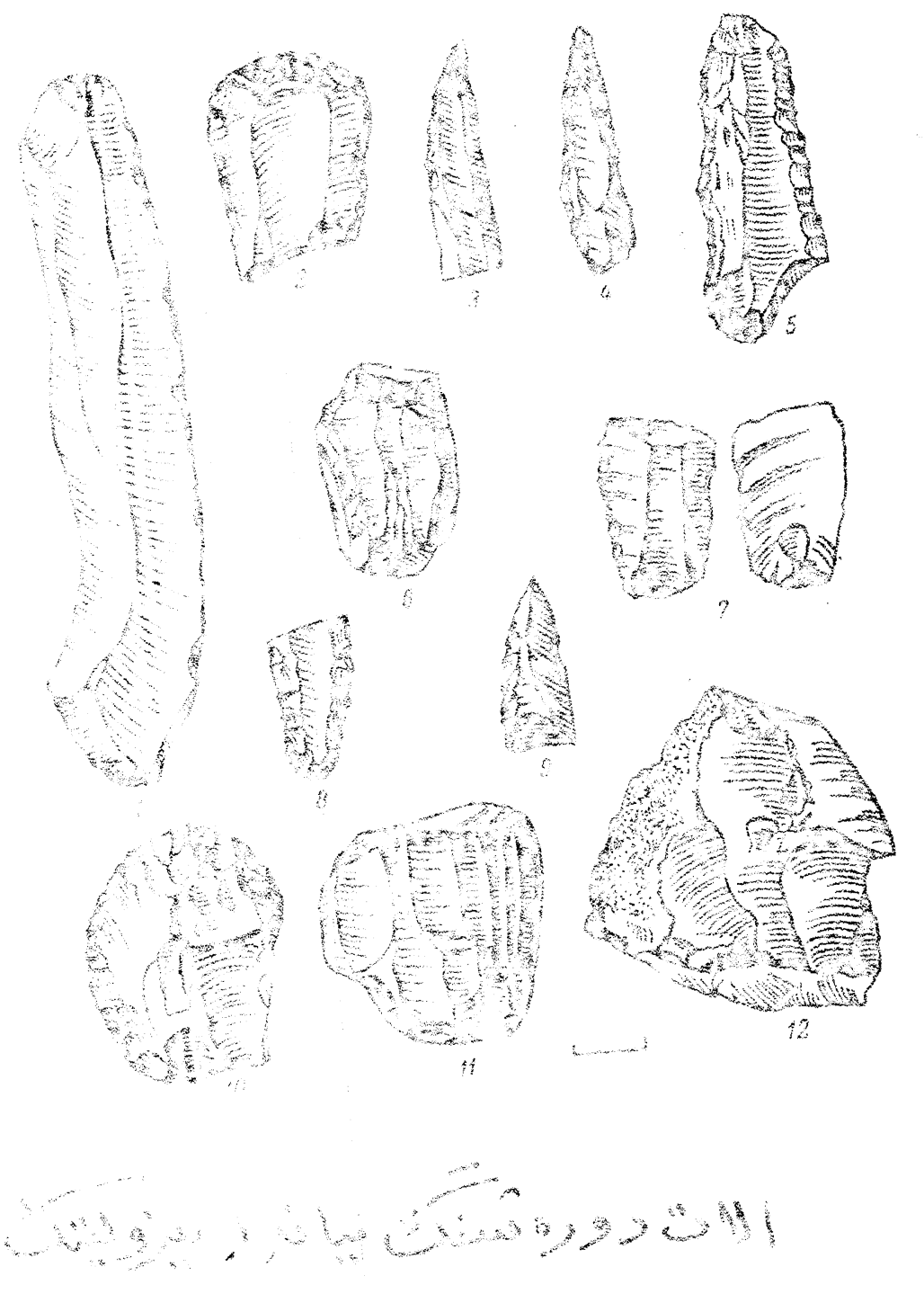




\section{7}

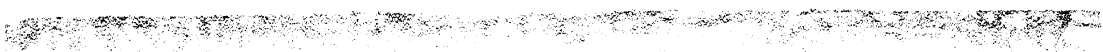

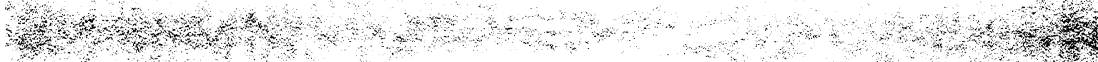

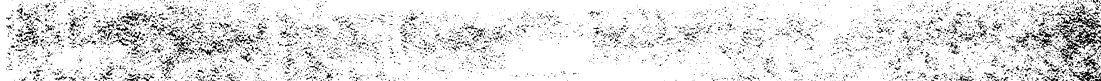

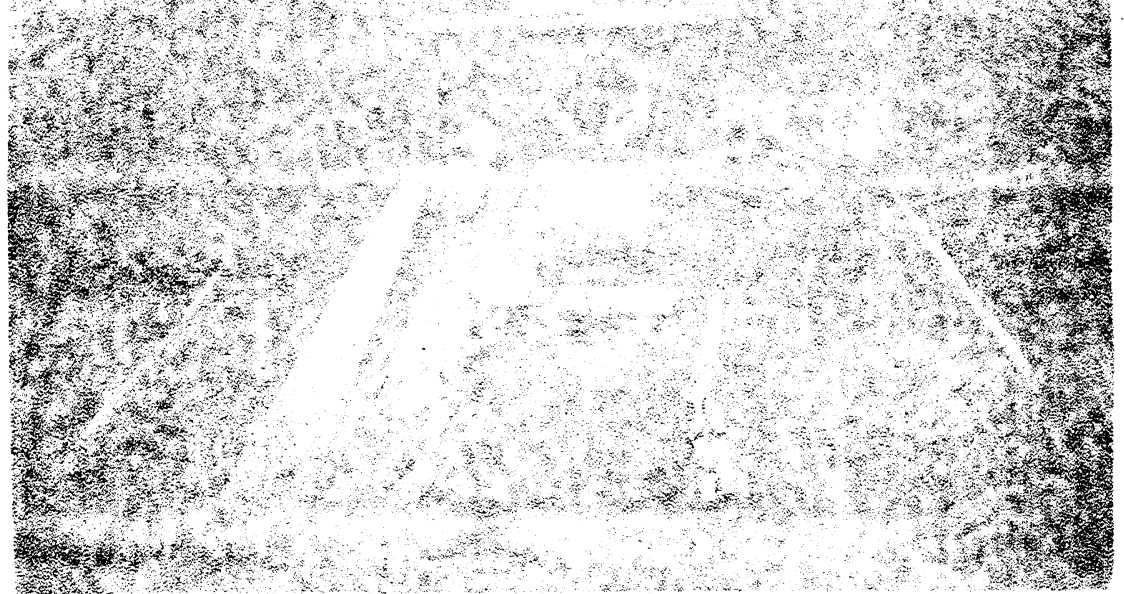

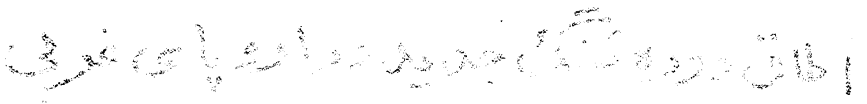
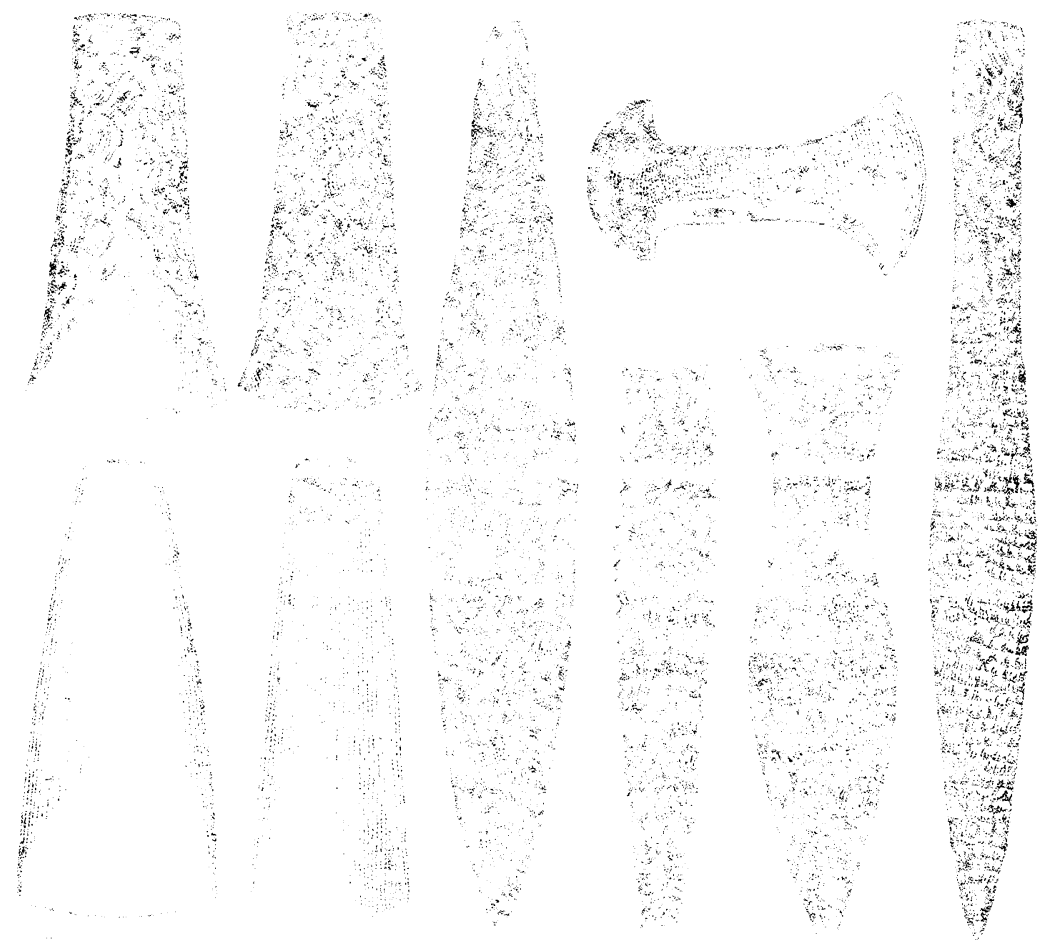

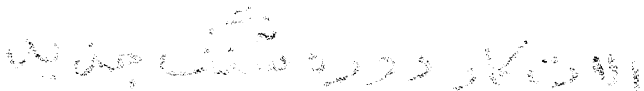



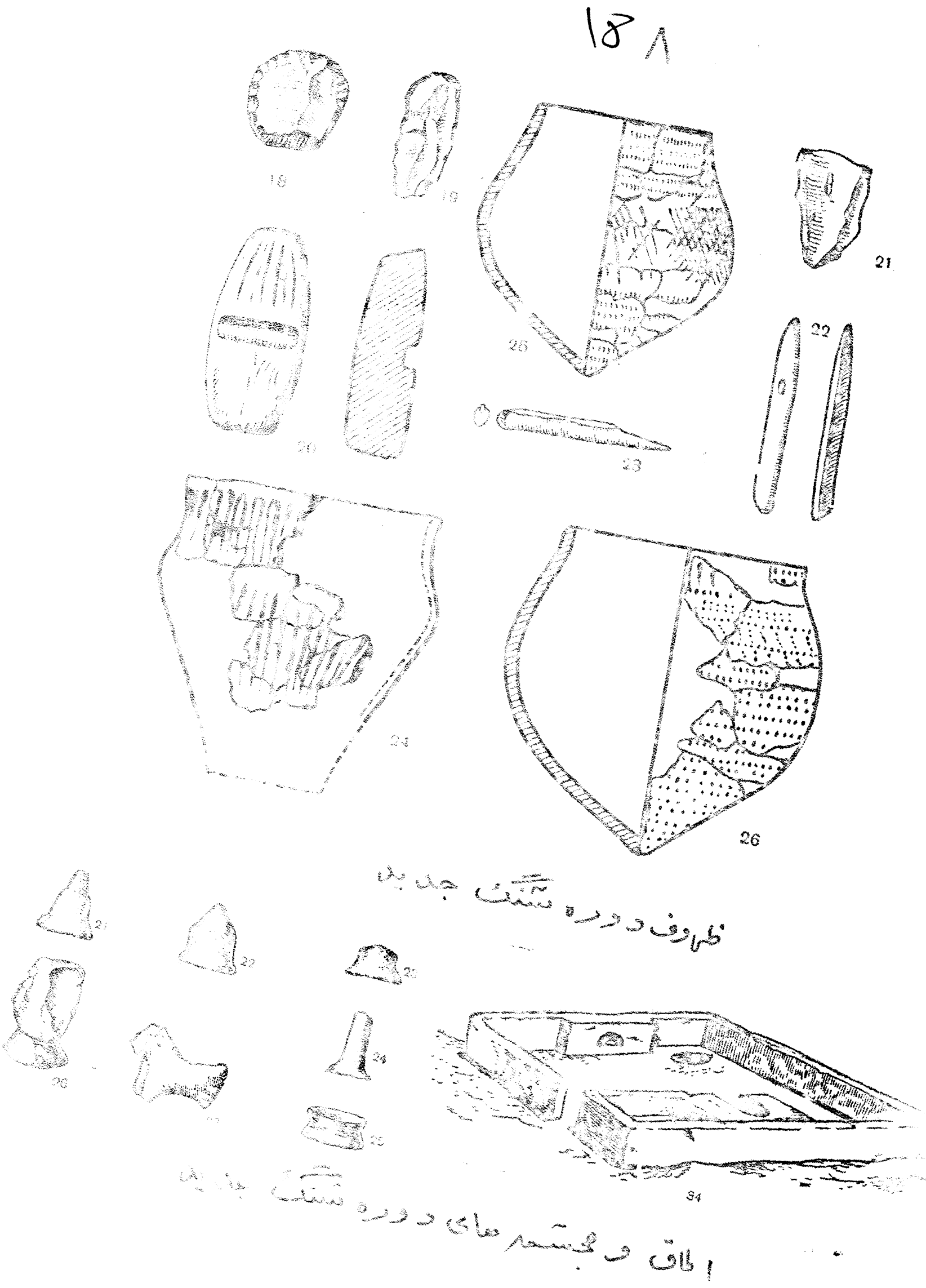

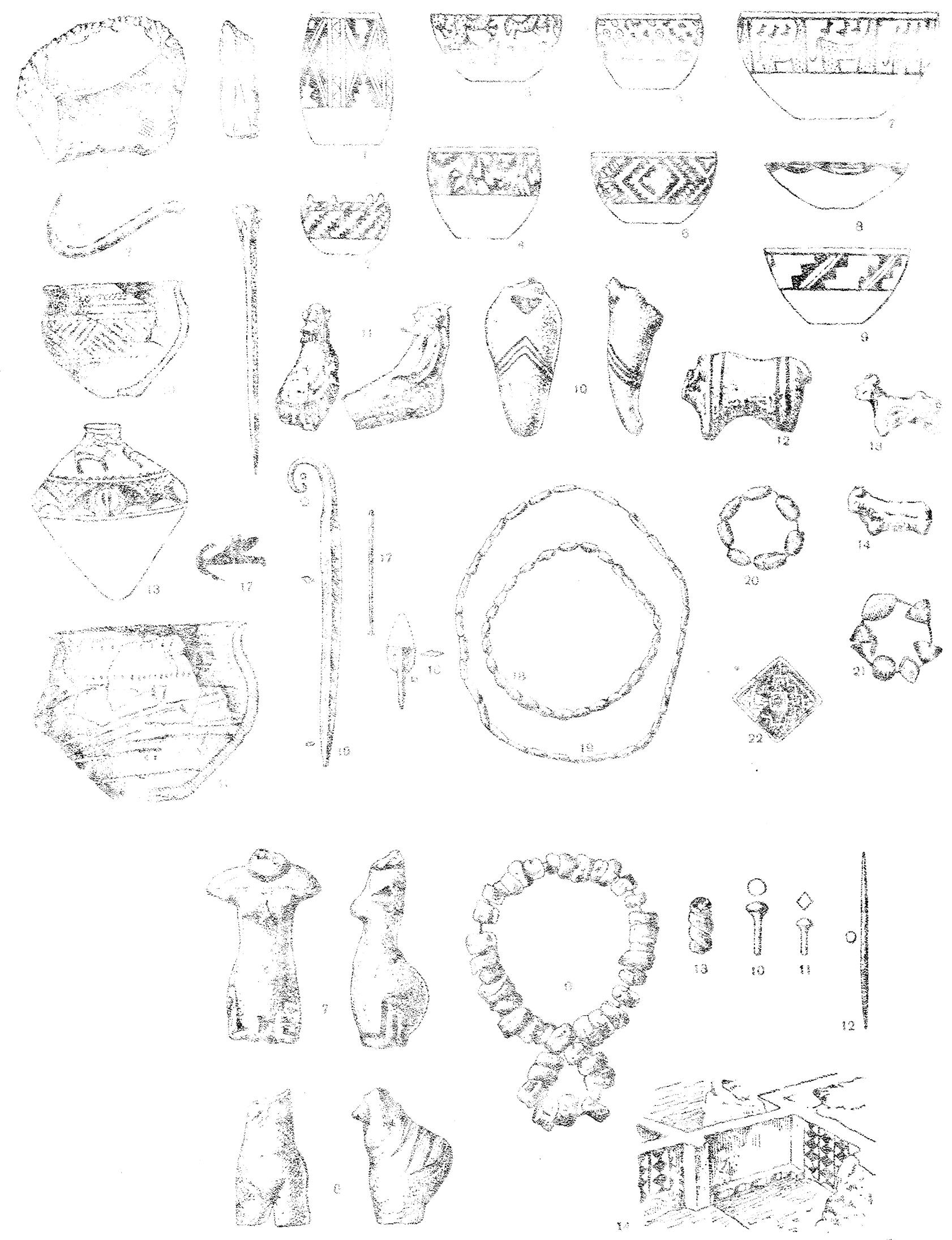

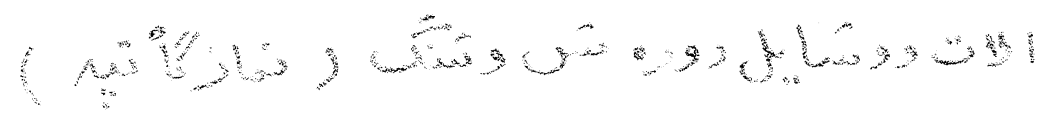




\section{0}
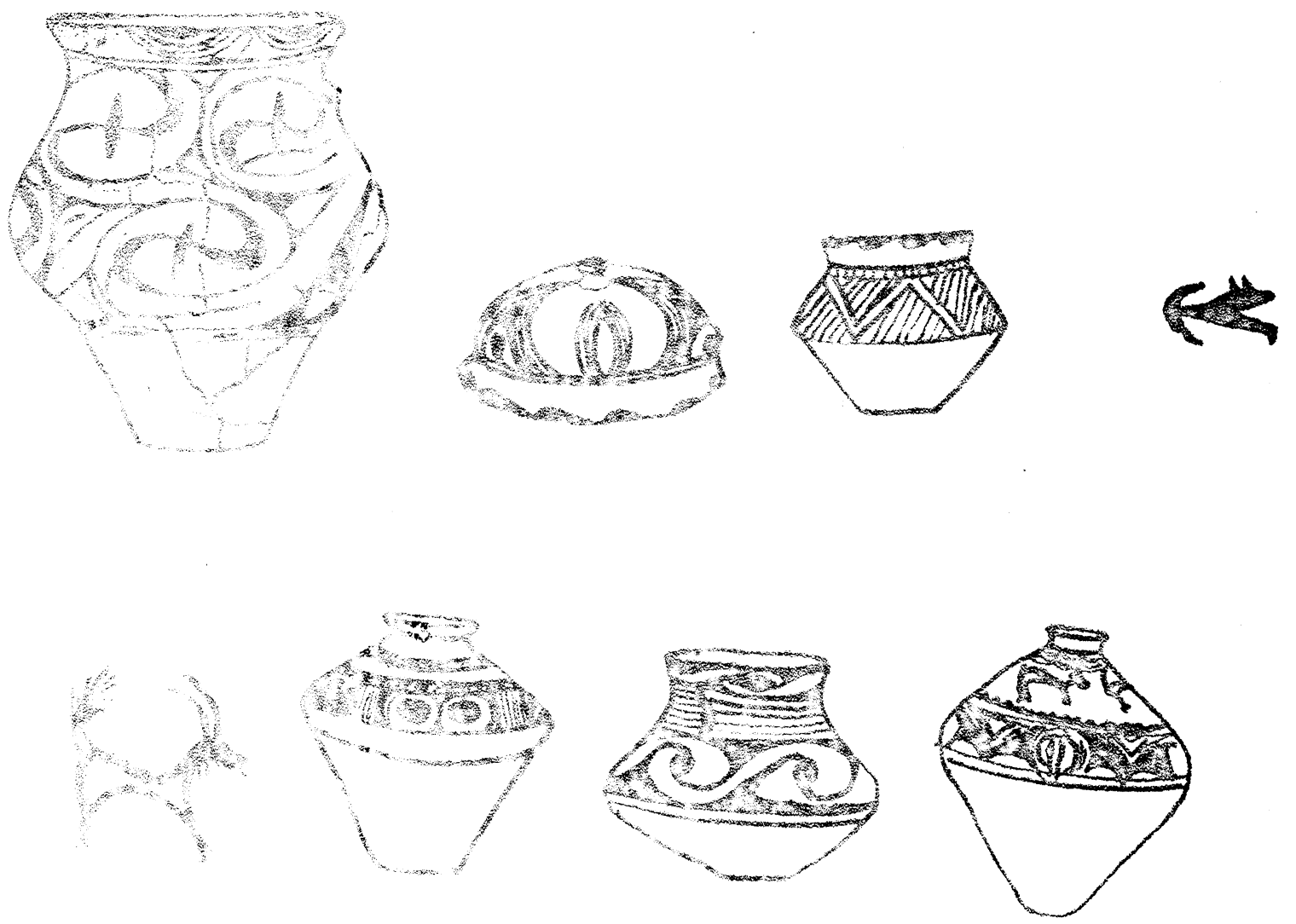

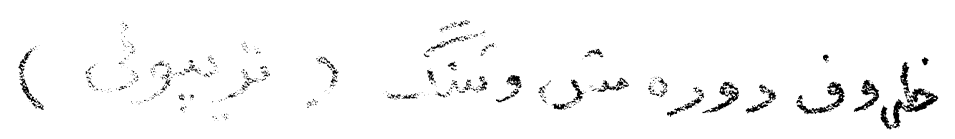



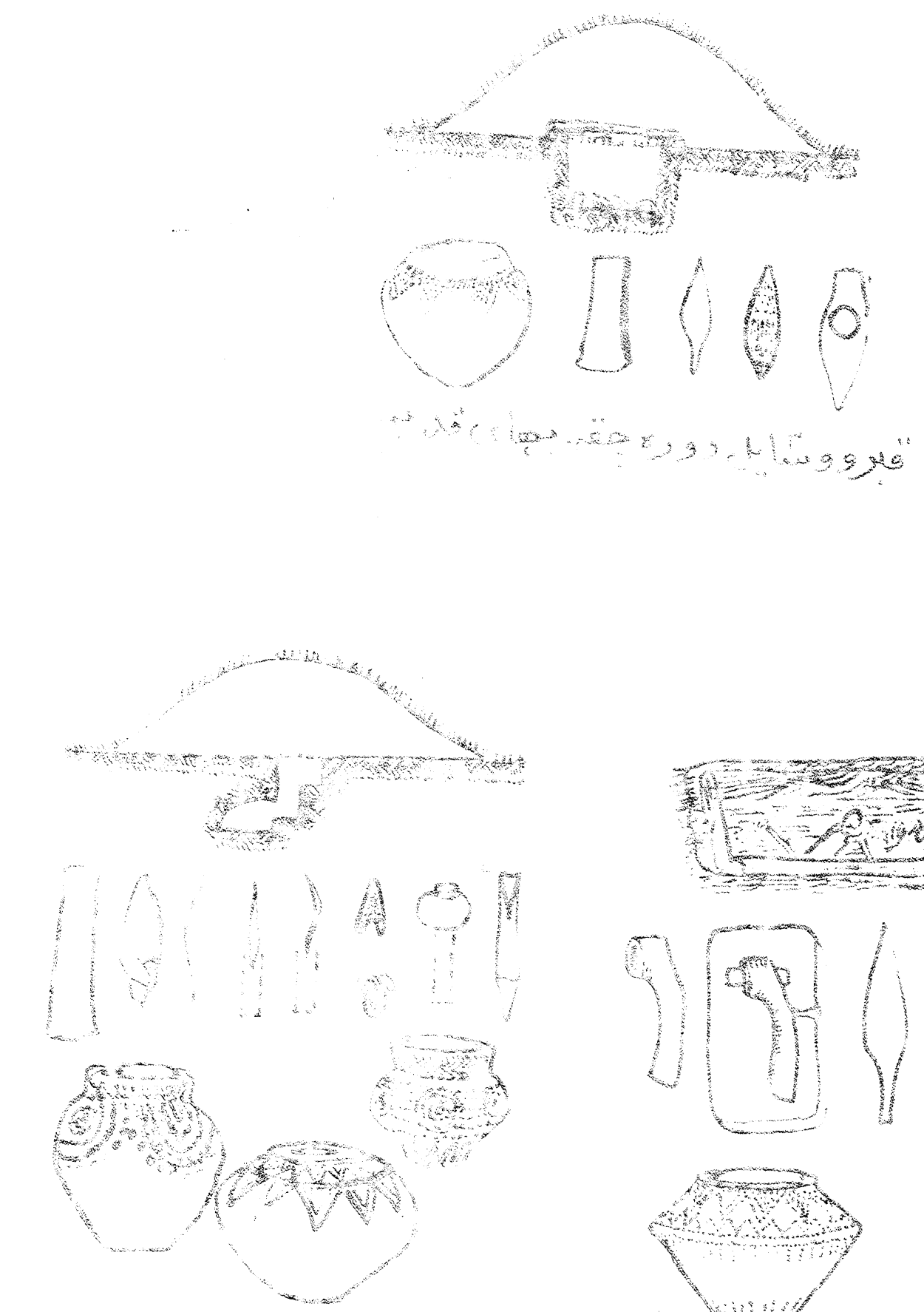

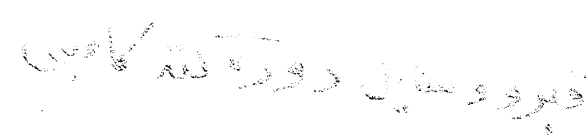

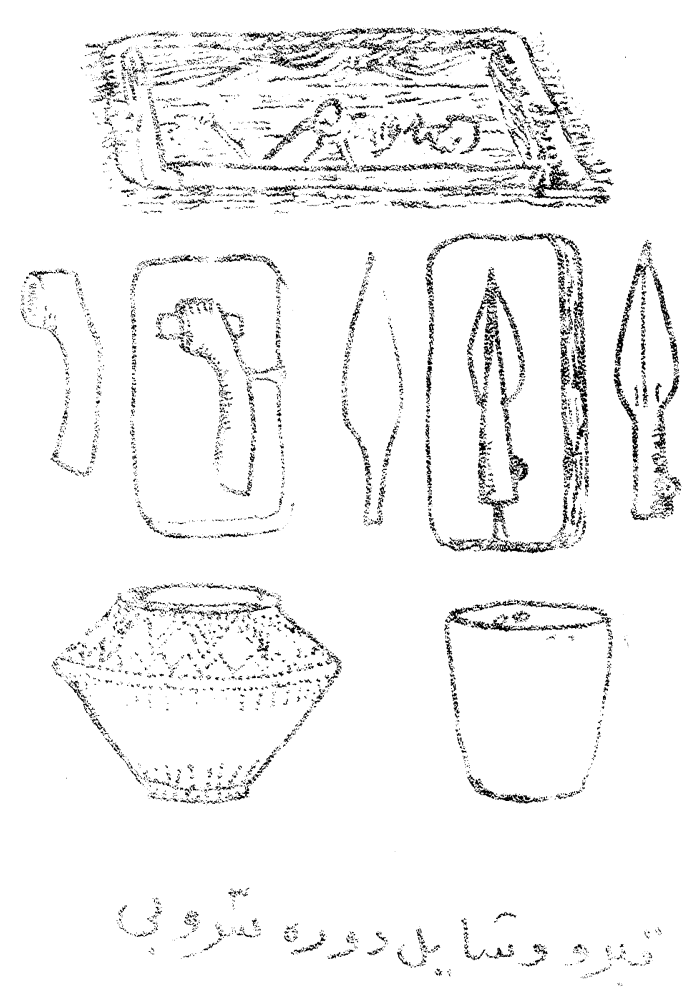


19
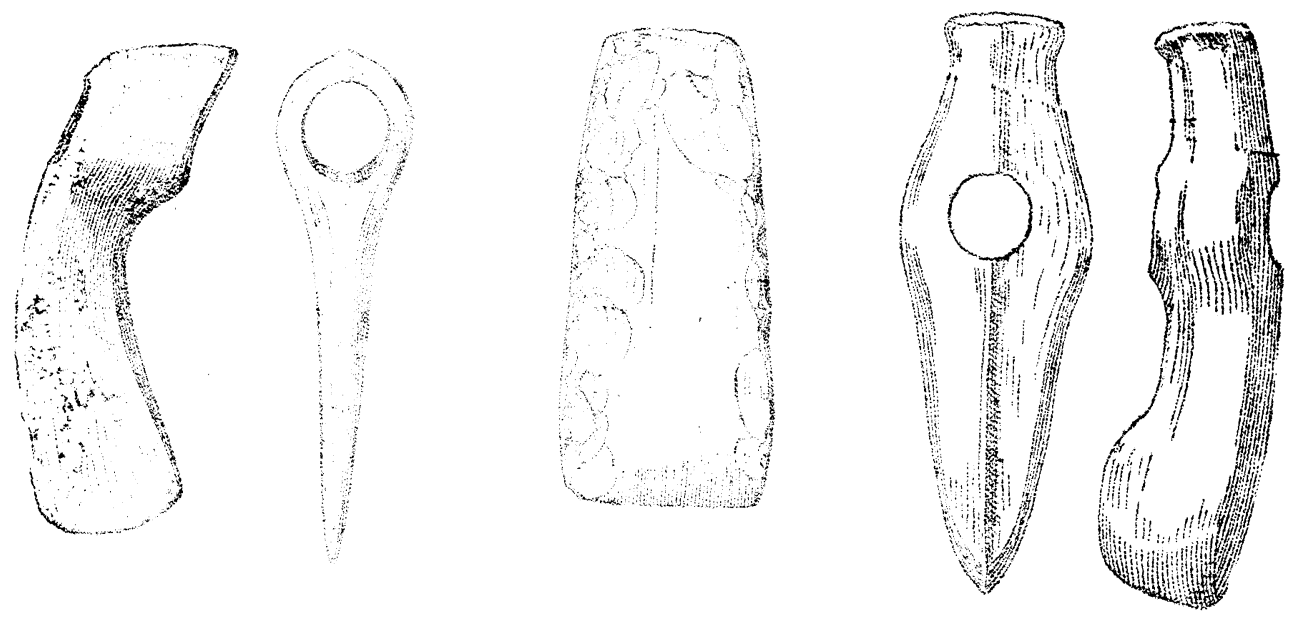

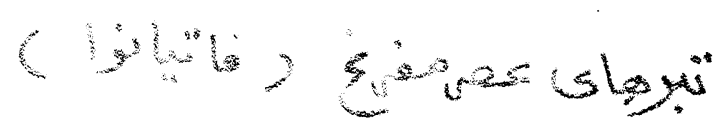

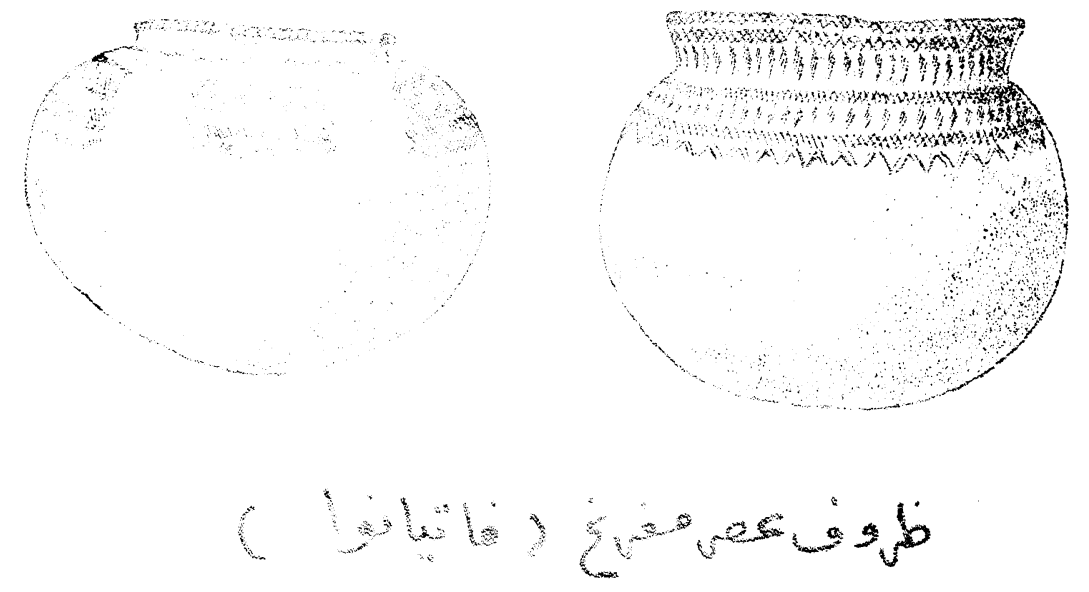




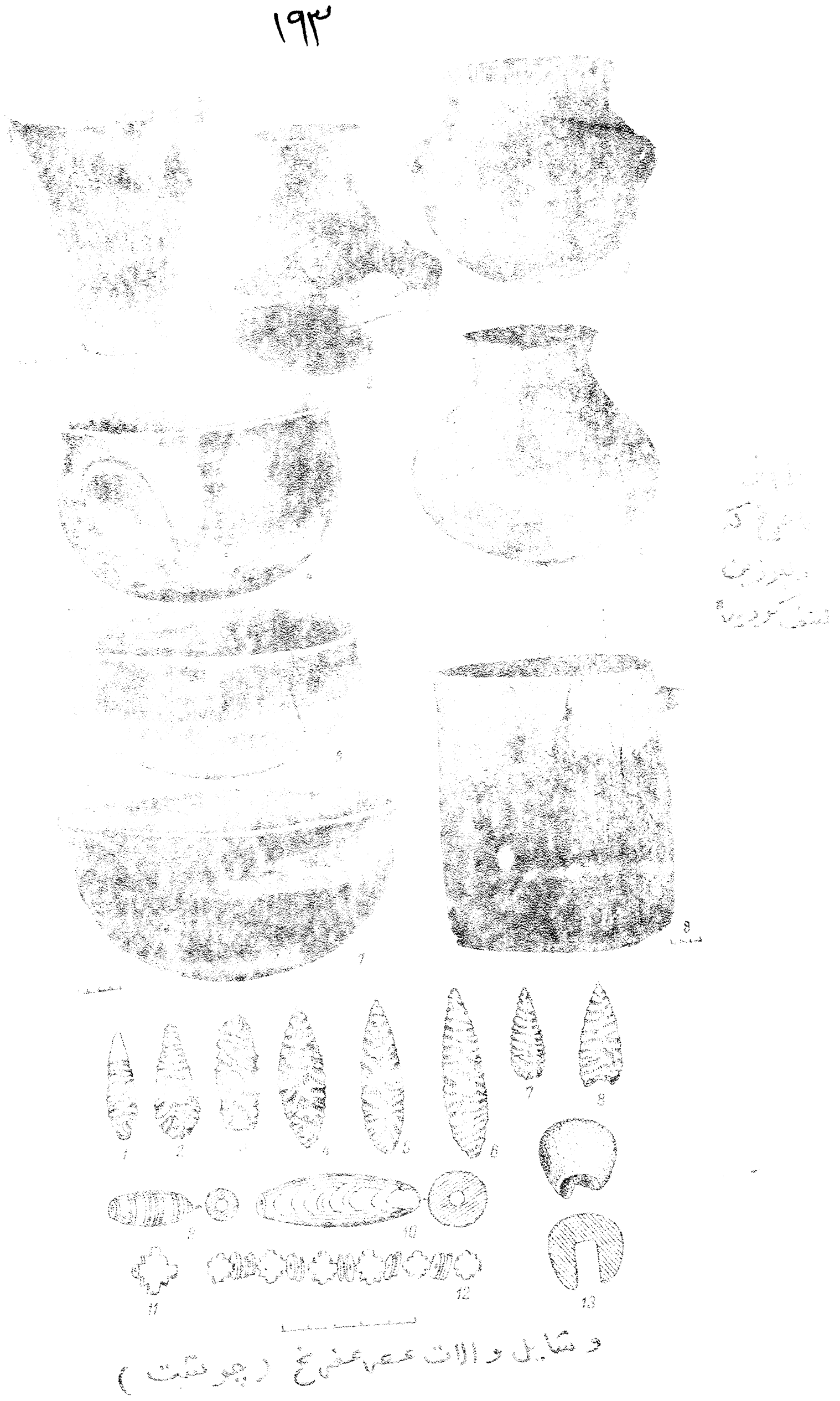




\section{5}

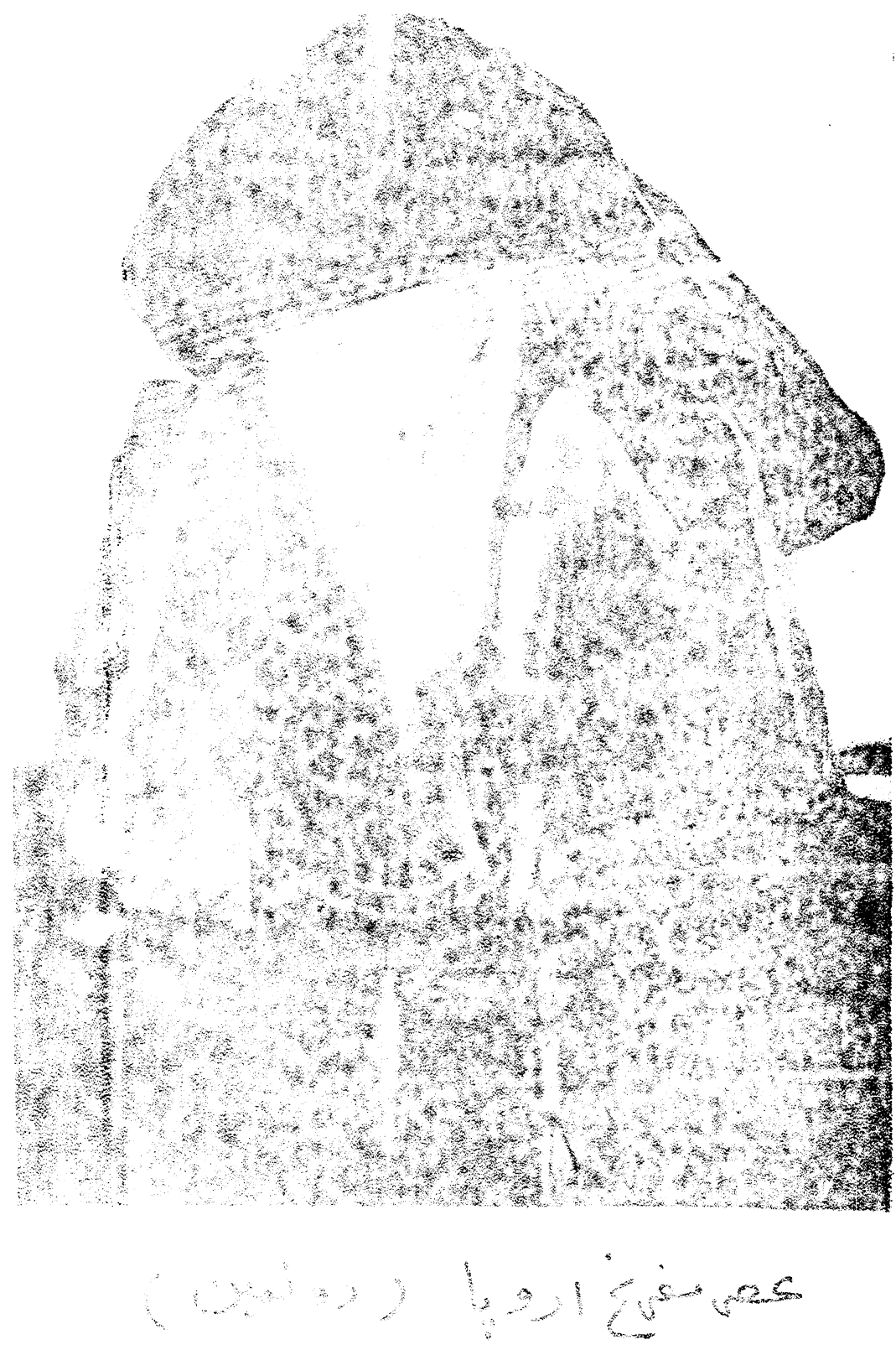




\section{0}

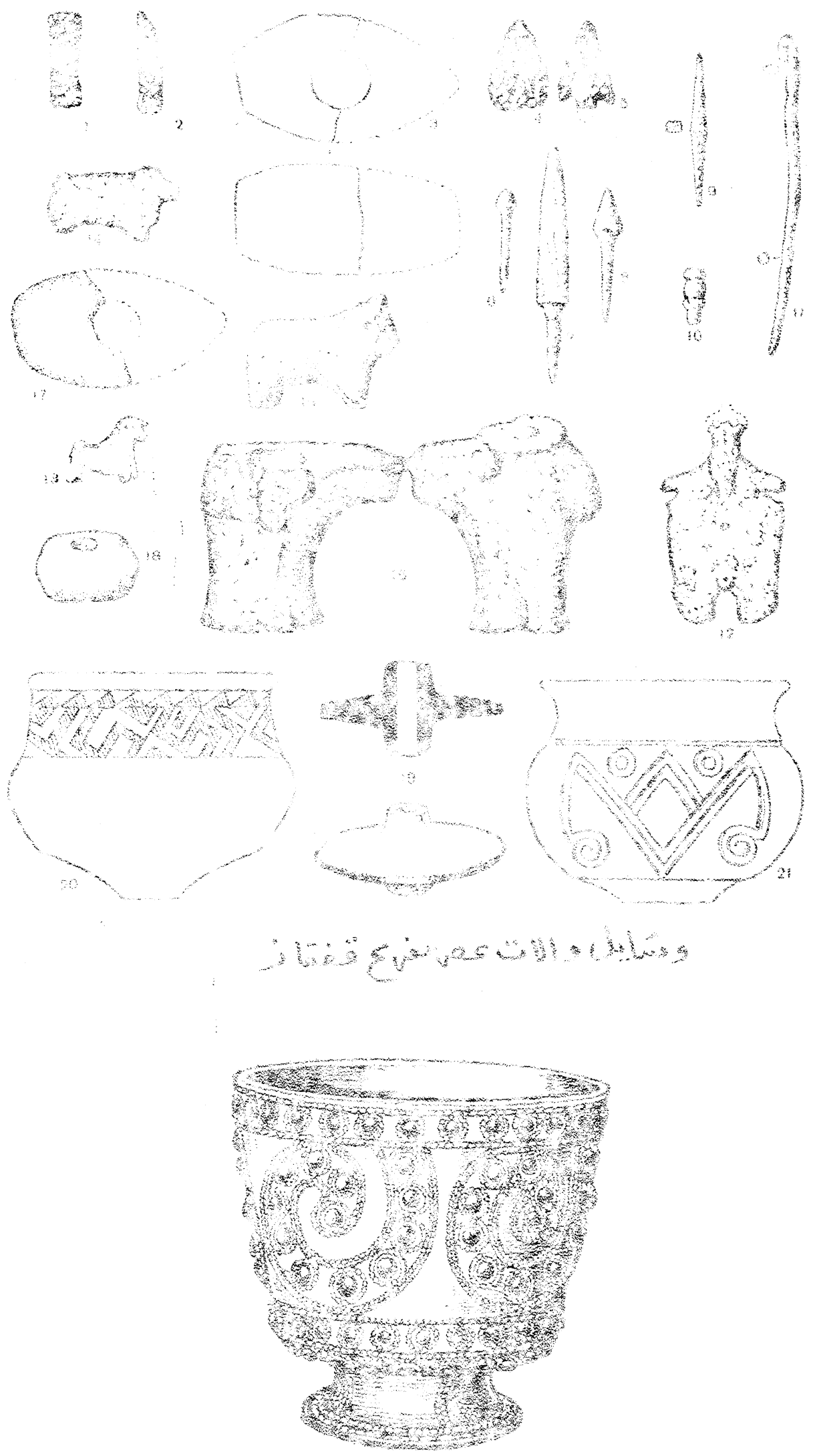




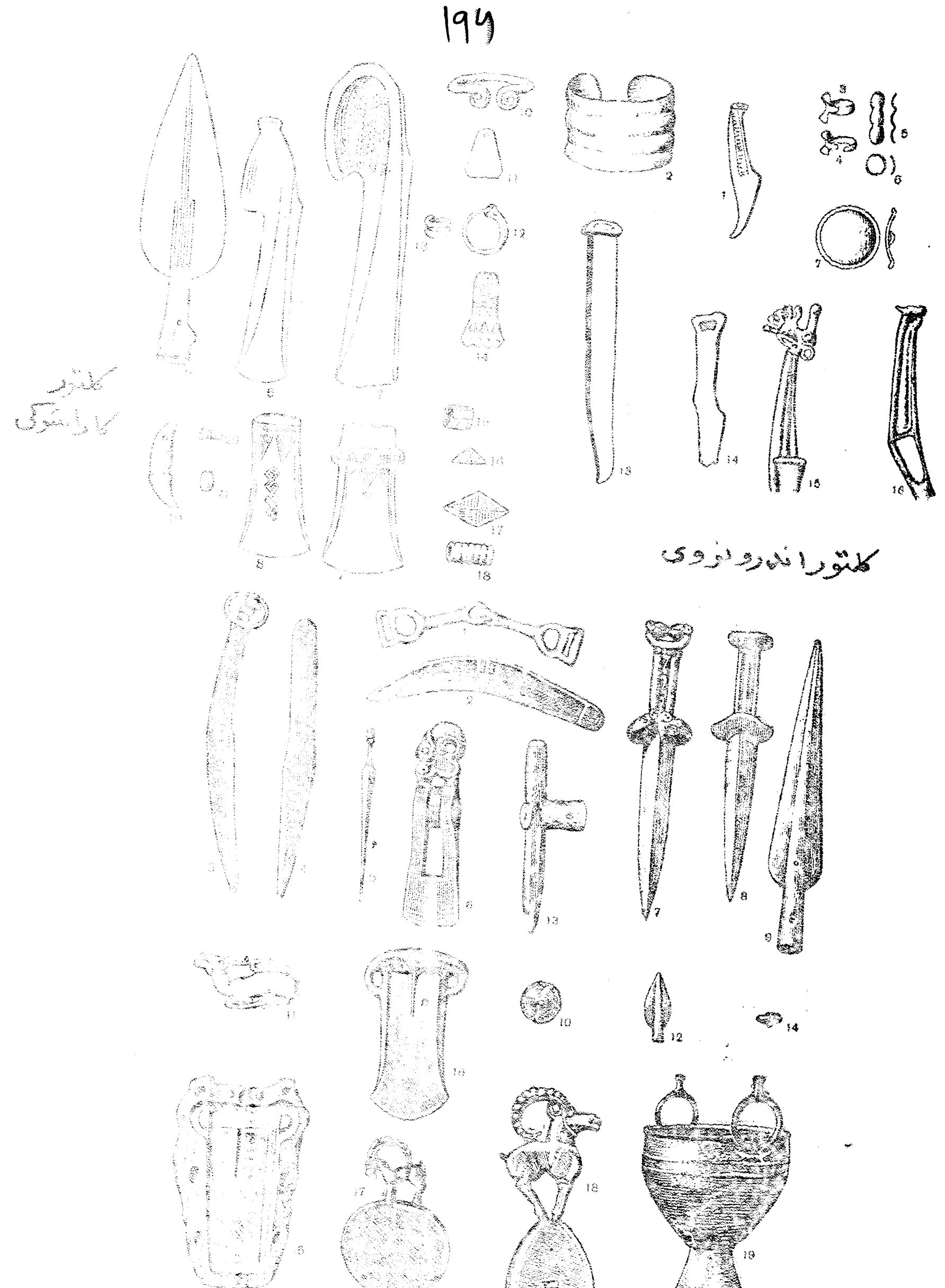


$19^{\prime}$

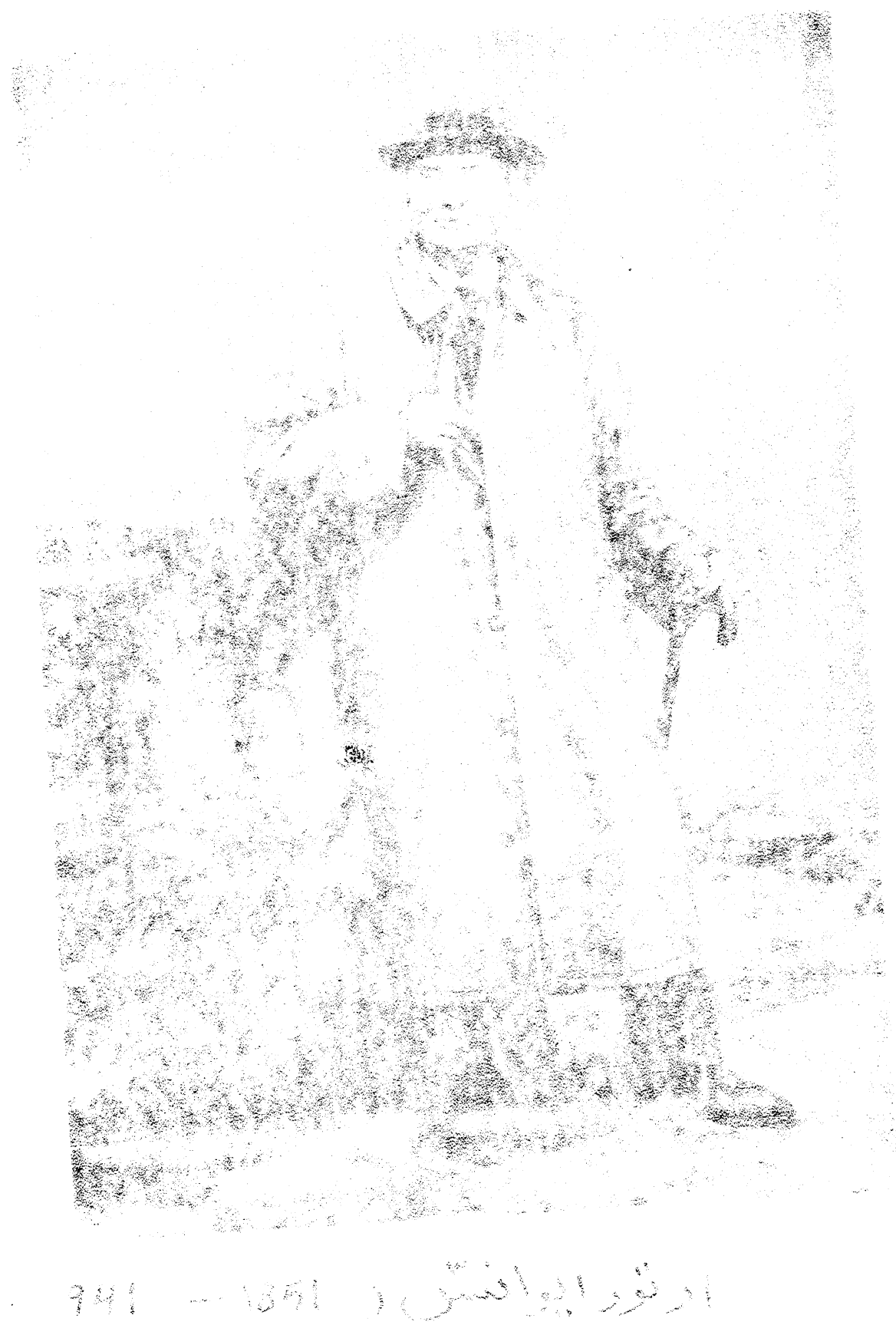


191

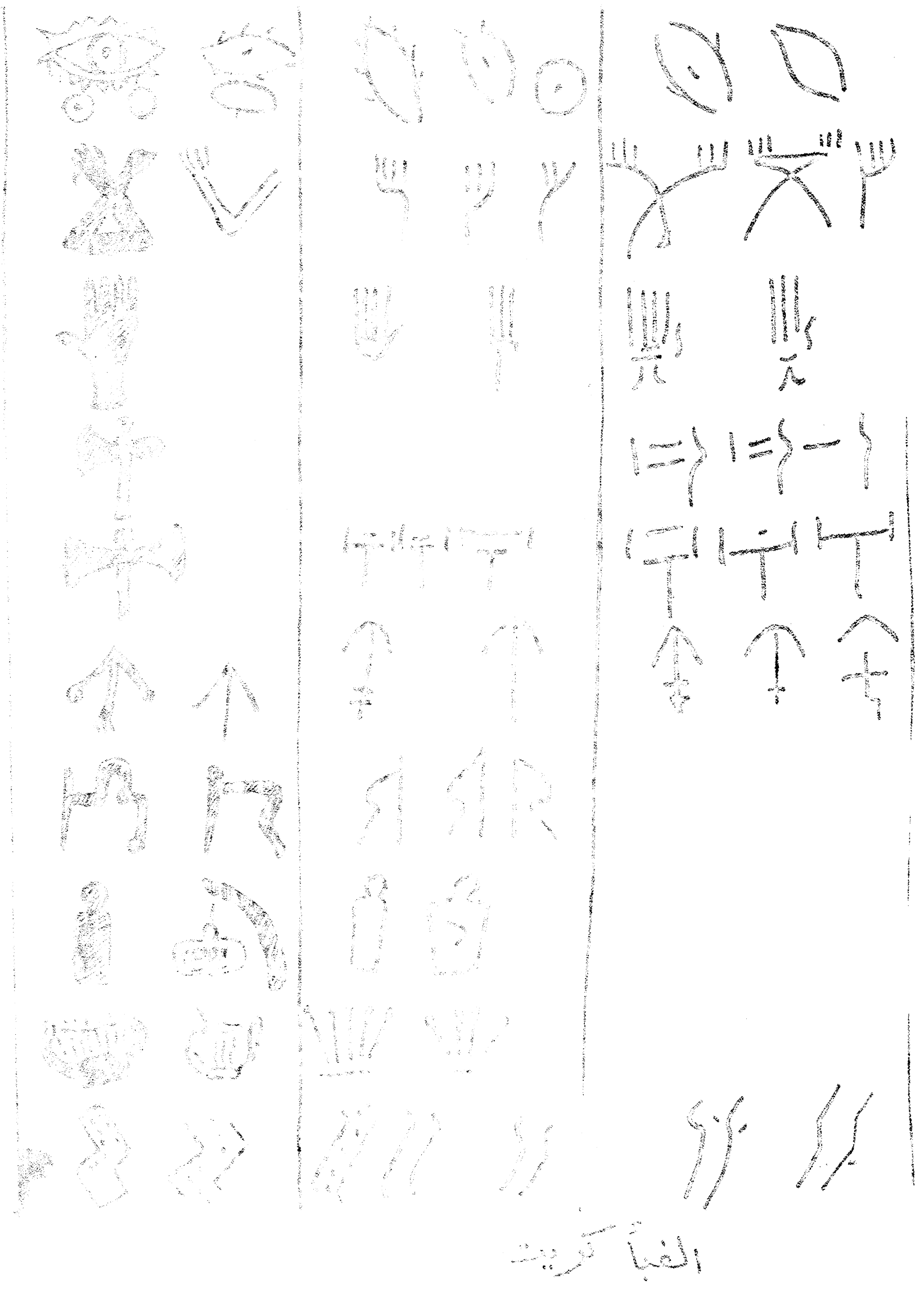




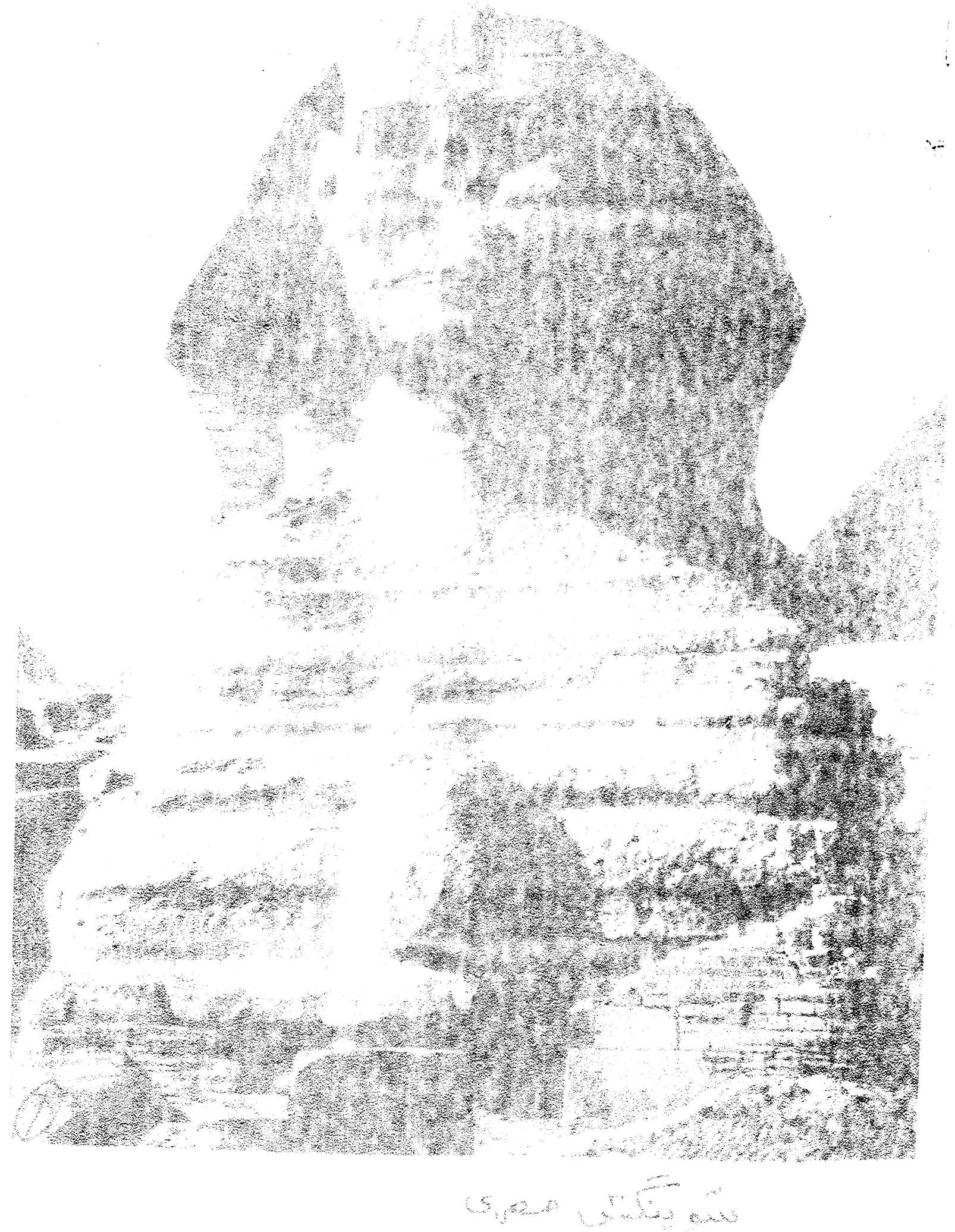




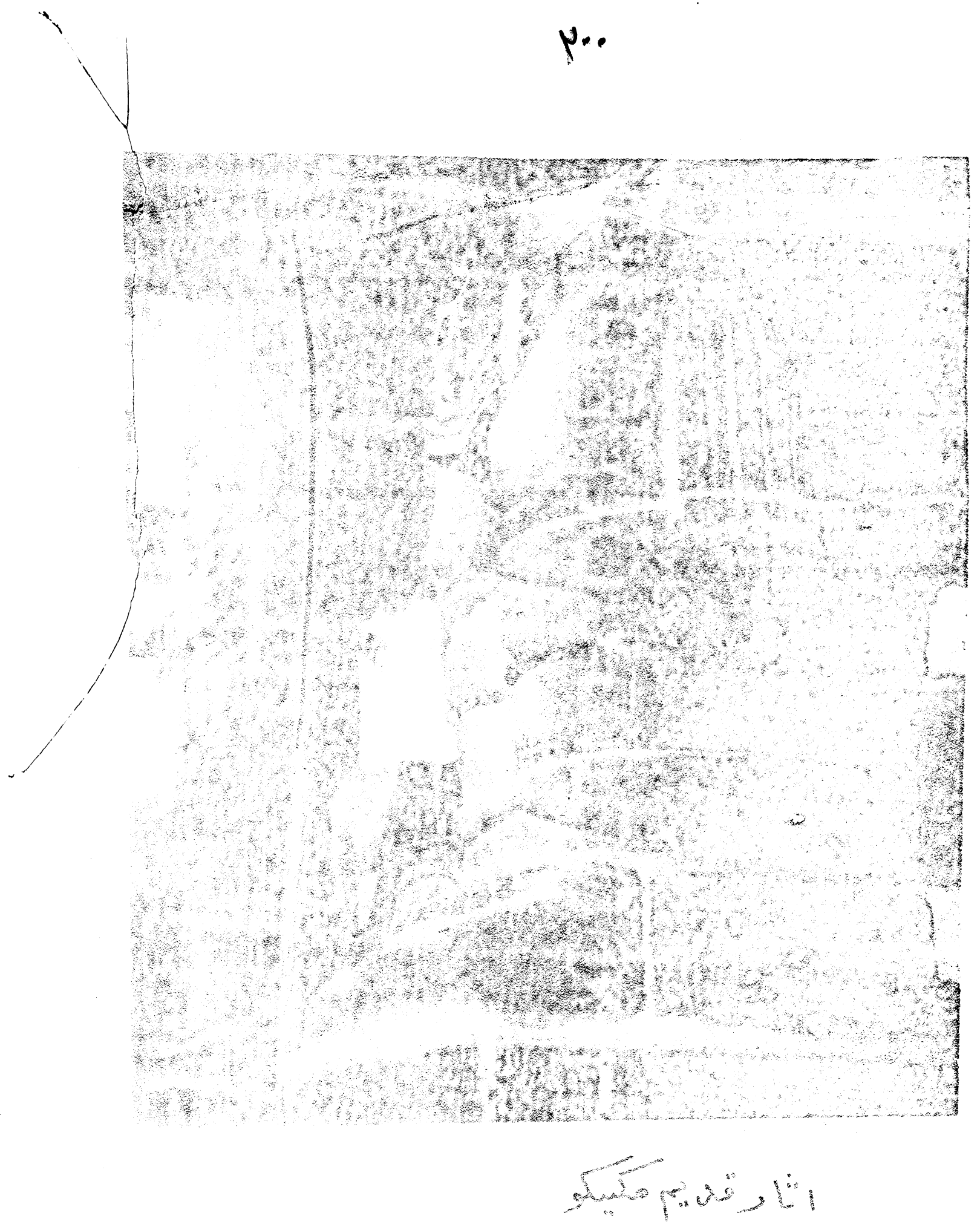


POI

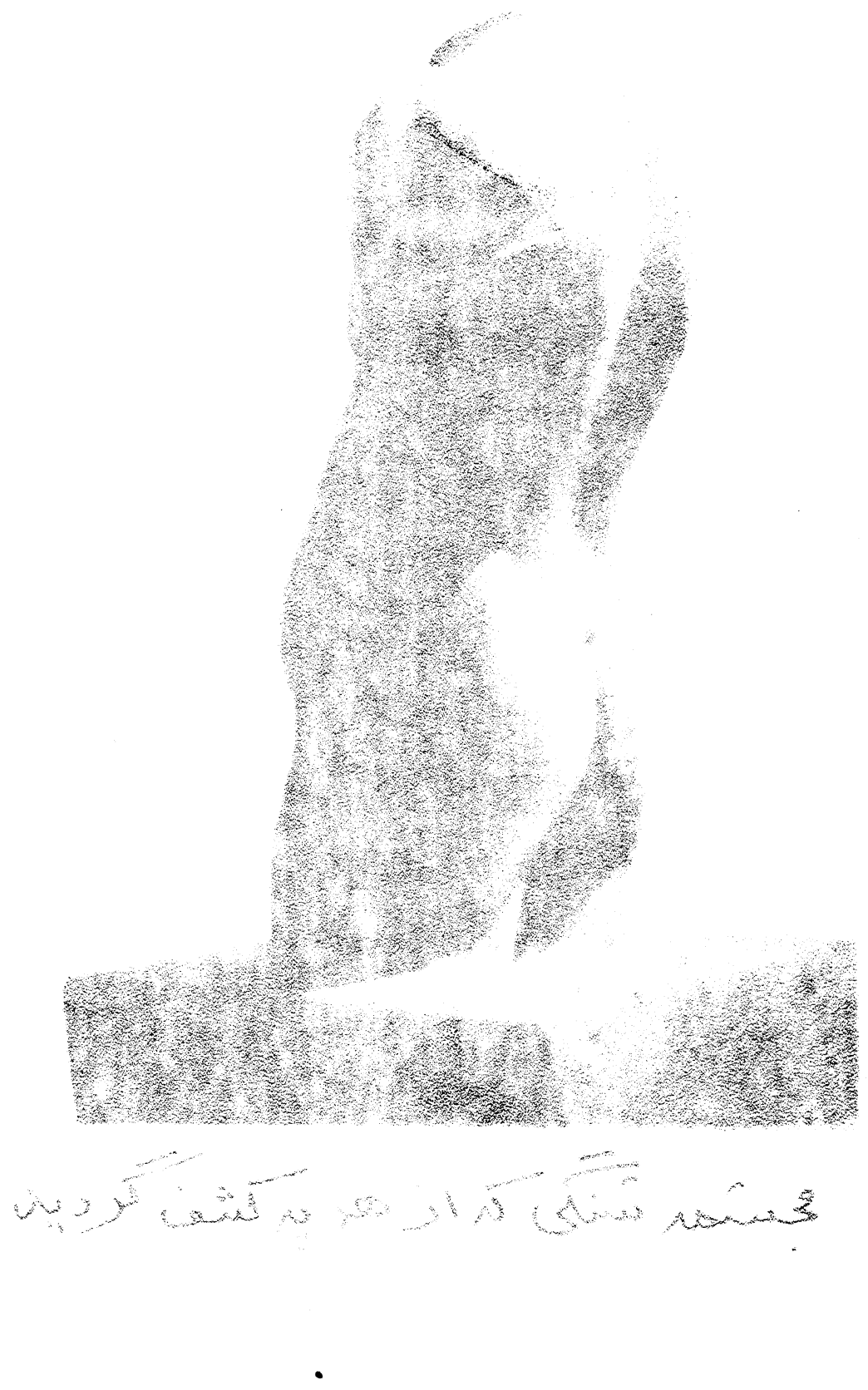




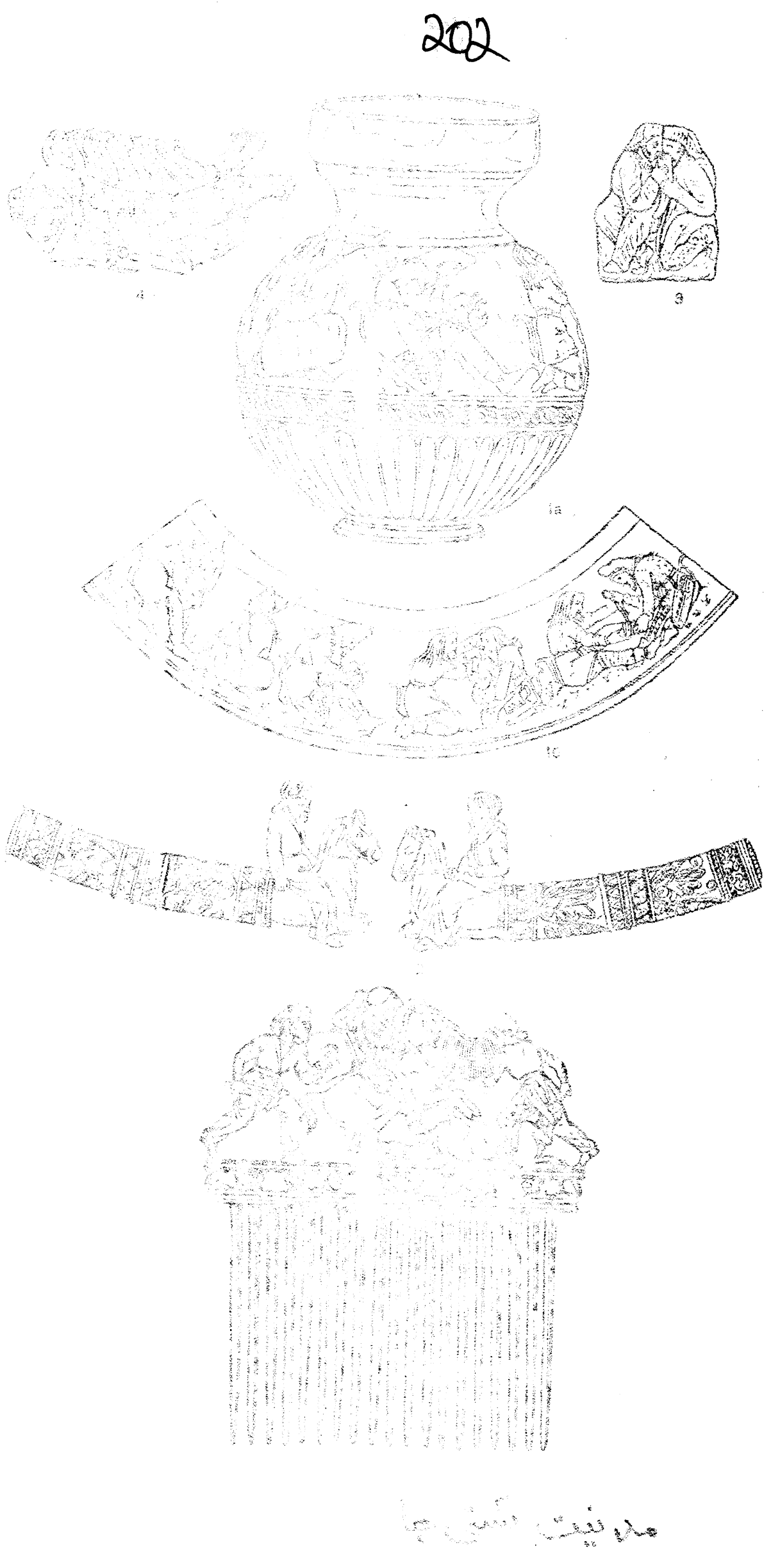



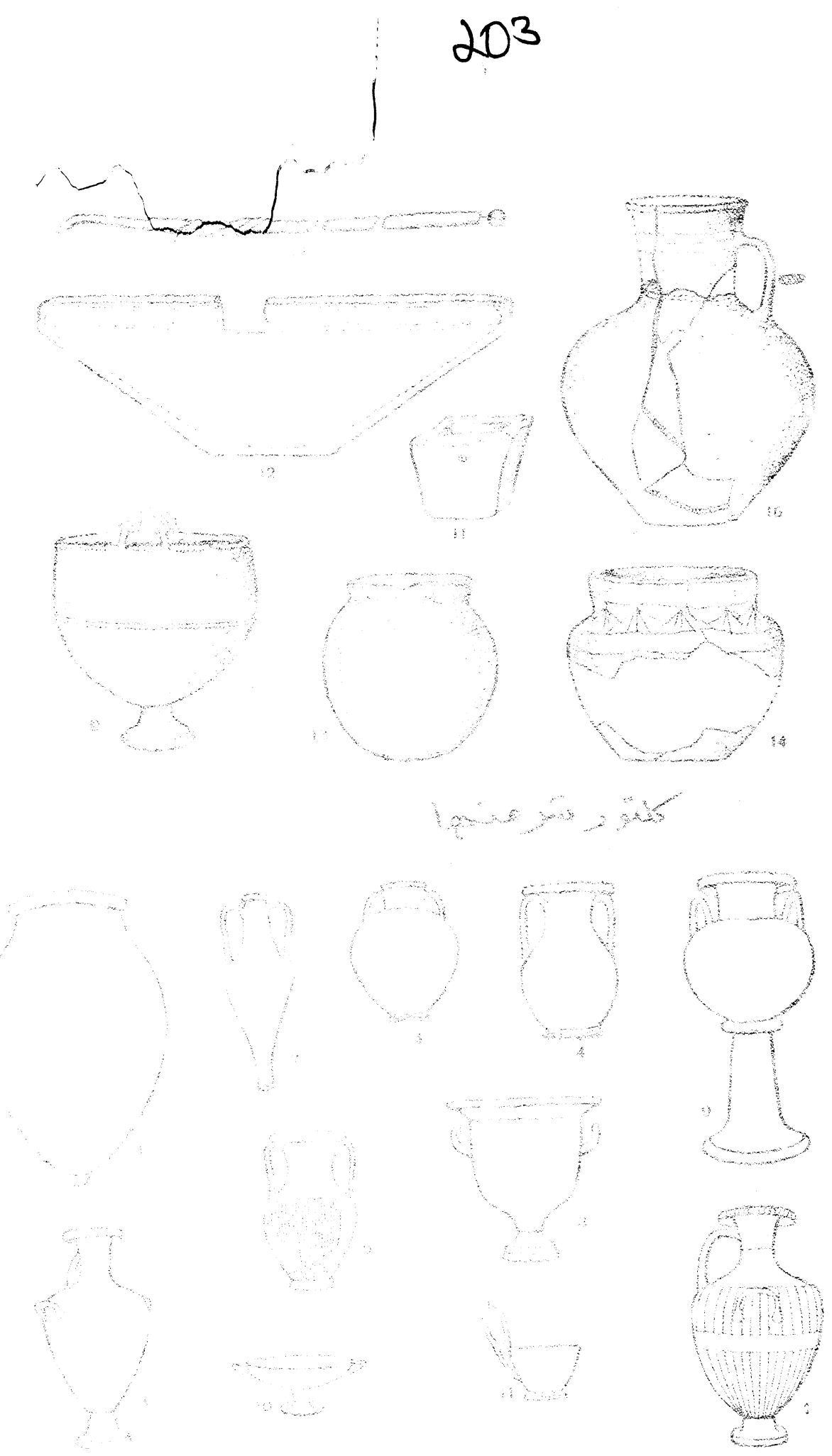

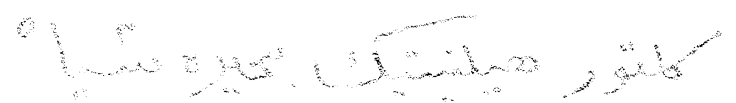




$$
204
$$

munumb

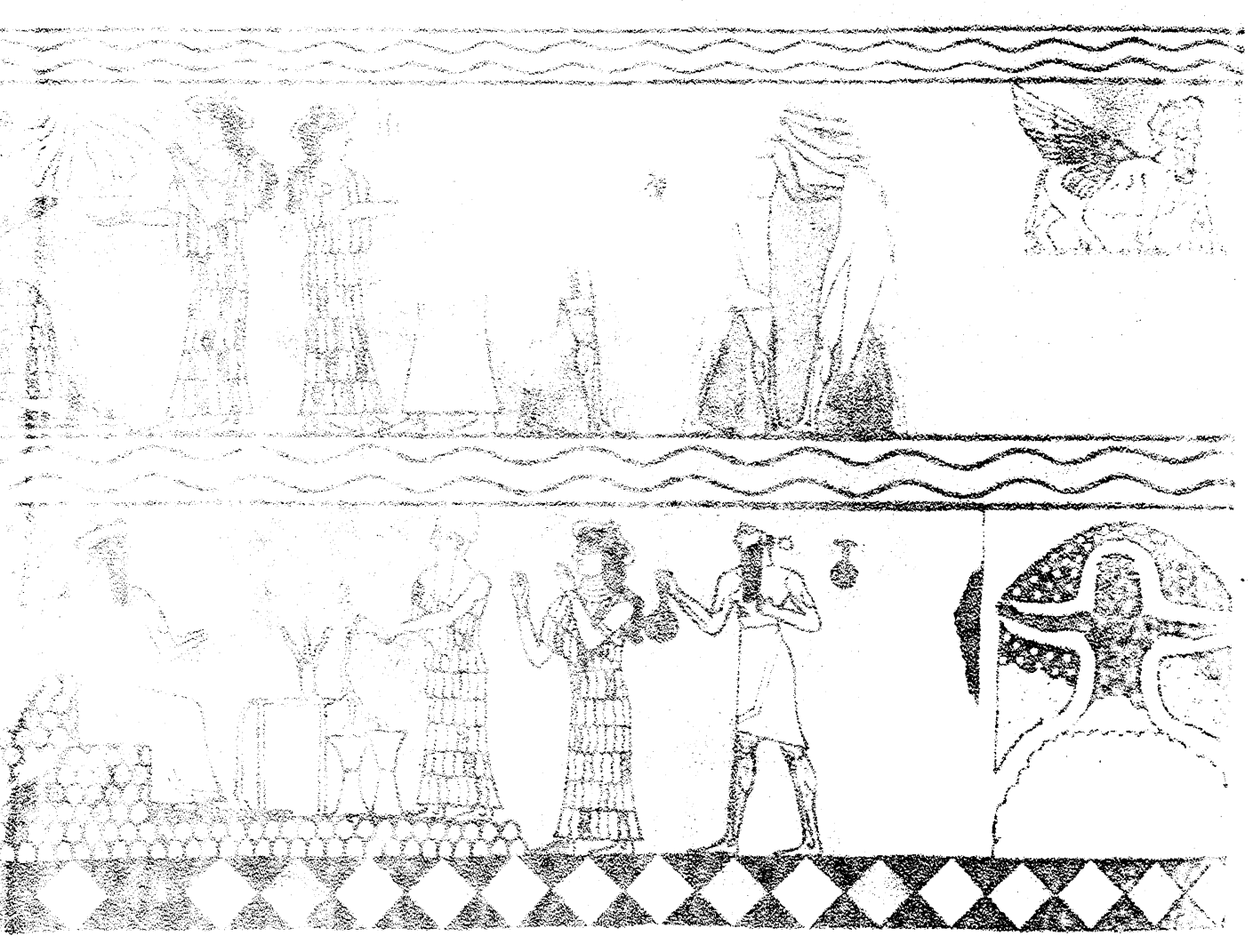

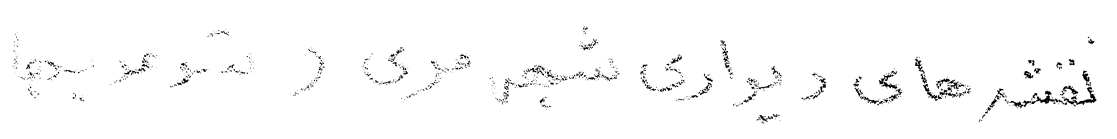




\section{5}
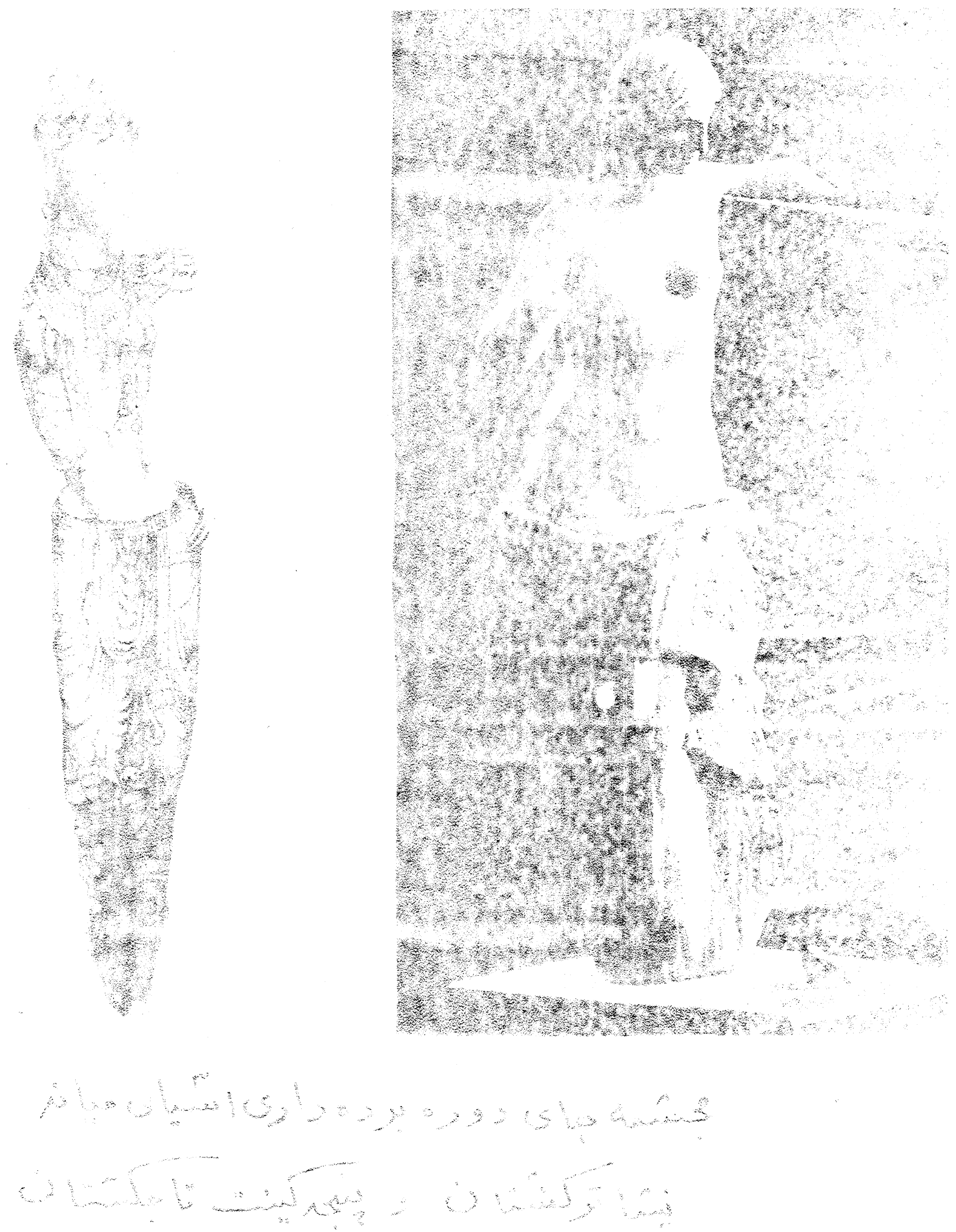


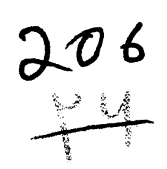

i

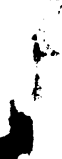
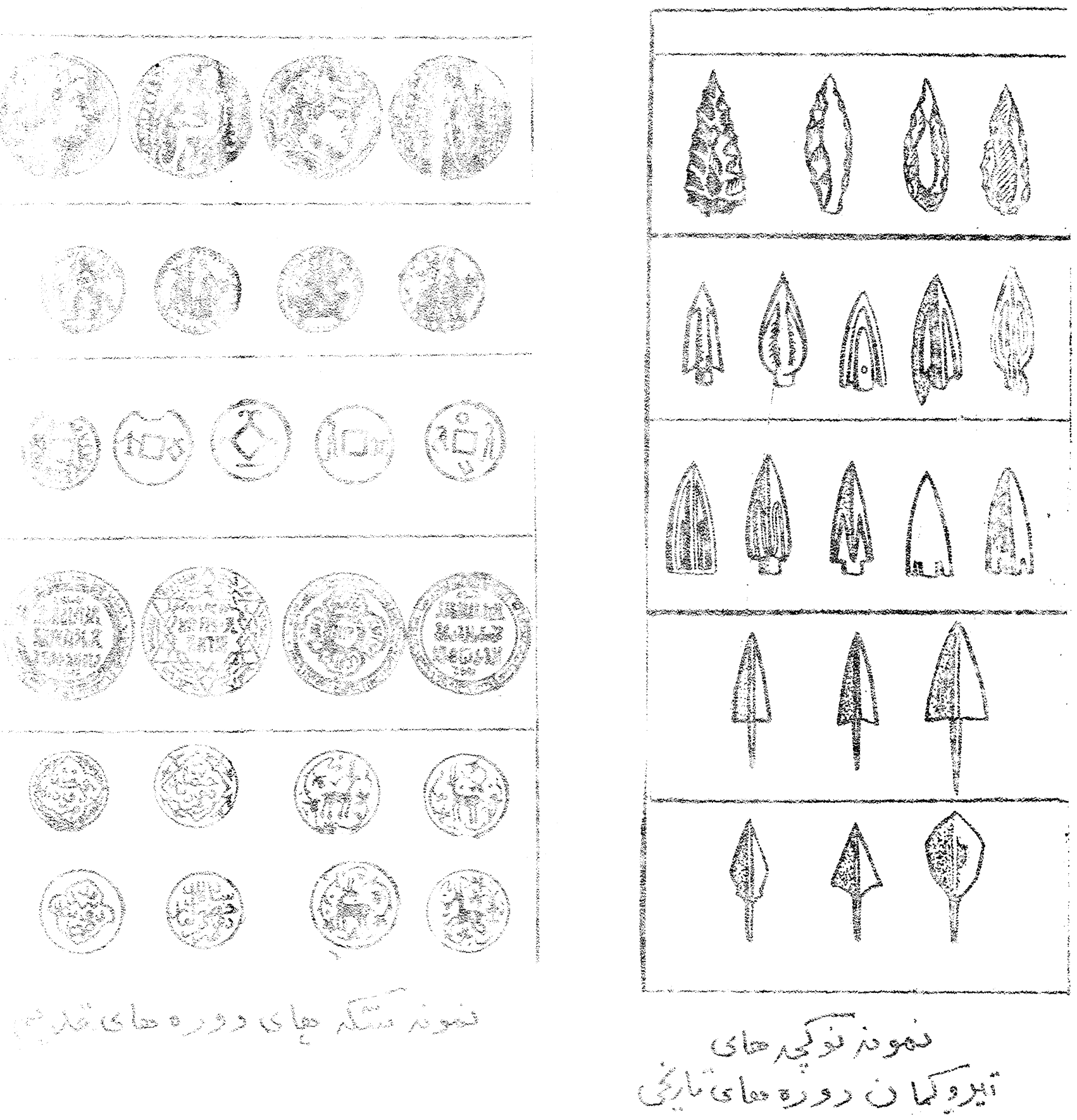


\section{Introdution to Archaeology}

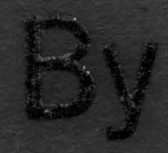

D5. Artem Babavy

Pobialai M. Rasool Bawari

Posialai G Abusd Wast

The Departmeat of Arobsasology and Anthropology

Fazsity of Soelai Soientes

Kaำ! Univerbily

Alghaniatan

1363 